\title{
PREHISTORIC SCOTLAND
}

\author{
RObERT MUNRO \\ M.D. F.R.S.E
}




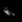


<smiles>[CH]C</smiles> 


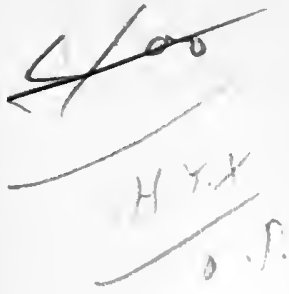

PREHISTORIC SCOTLAND 



\title{
PREHISTORIC SCOTLAND
}

AND I'TS PLACE

\section{IN EUROPEAN CIVILISATION}

\author{
BEING A GENERAL INTRODUCTION TO THE \\ "COUNTY HISTORIES OF SCOTLAND"
}

BY

ROBERT MUNRO, M.A., M.D.

AUTHOR OF

'PREHISTORIC PROBLEMS;' 'THE LAKE-DWELLINGS OF EUROPE;'

'RAMBLES AND STUDIES IN BOSNIA-HERZEGOVINA AND DALMATIA;' ETC.

\section{WILLIAM BLACKWOOD AND SONS EDINBURGH AND LONDON M D C C X C X}




\section{Digitized by the Internet Archive in 2007 with funding from Microsoft Corporation}




\section{P R E F A C E.}

THE primary object of this book is to lay before the public a short account of the methods and means by which archæologists are endeavouring to elucidate that obscure period in the history of Scotland vaguely defined as the prehistoric. From the very beginning I foresaw that this would be a labour of some difficulty, owing to the varied and comprehensive materials which had to be dealt with. A preliminary coup-d'ail of the subject disclosed a population occupying a small, but well-defined, geographical area amidst diversified surroundings. As soon, however, as the superficial crust was broken, it became apparent that both people and environments were subject to progressive changes not always emanating from causes inherent to the restricted locality under review. I had thus to look beyond the Scottish area, and to trace these exotic elements to their proper sources. At the present time direct 
evidence, either as regards the physical qualities of the people or the fluctuations and peculiarities of their environments during the earlier portion of the prehistoric period, is both scanty and fragmentary. Nor are the stray objects of the less perishable materials, such as stone and metal, altogether unimpeachable witnesses in the inquiry; for even these in many instances, betray their foreign origin. Moreover, the earliest inhabitants were themselves immigrants. These imperfections in the archæological record had therefore to be considerably supplemented from collateral sources. Thus on all hands the field of inquiry became enlarged in proportion as the materials were carefully scanned. Hence, in the compilation of this work the same ground had to be traversed as if I were engaged in writing an introduction to the prehistoric archæology of the whole of the British Isles. To bring such diffuse evidence within the narrow compass of one small volume is a kind of tour de force which is bound to disclose many shortcomings and errors of judgment.

From these inherent difficulties in connection with the selection and arrangement of the materials it is pleasant to turn my thoughts to those who have supplied me with so many beautiful illustrations, without which the work would be shorn of much of its value. On this score I have to thank the Councils 
of the following Societies: Society of Antiquaries of Scotland for most of the woodcuts illustrating the remains of the prehistoric fauna, as well as for a number of other objects, such as the massive bronze armlets, which are peculiar to the Scottish archæological area; Ayrshire and Galloway Archæological Association for a considerable number of the woodcuts of stone and bronze implements; Society of Antiquaries of London (figs. I66 and 175-177); Royal Irish Academy (figs. I23 and 162-164); Royal Society of Antiquaries of Ireland (figs. I4I, 2II, 213, and 257) I am also indebted (through my publishers) to Messrs Macmillan \& Co. for a few woodcuts from Sir Daniel Wilson's 'Prehistoric Annals of Scotland' (figs. 4, 89, I30, I38, 258, and 259), and to John Murray for the illustrations of Maeshowe and New Grange (figs. 192-196) from Fergusson's 'Rude Stone ,Monuments.' Of the large number of illustrations specially prepared for this work, many are mere sketches taken from objects in various museums, and have no claim to any artistic effect. But, as they are accurate in outline and reduced to a uniform scale, I preferred to retain them in their crude form rather than to have them touched up by a skilled artist. Indeed, a mere outline is all that is necessary for many of the objects which illustrate prehistoric archæology. On every occasion that I found it necessary or advisable to appropriate the results of other 
workers I have done so, when practicable, by quoting the ipsissima verba of the authors; and all such obligations are duly acknowledged in their proper place throughout the work, or in the list of illustrations.

Professor Sir William Turner, F.R.S., has kindly read the proof-sheets of the chapter on Ethnology; and James Macdonald, Esq., LL.D., has done the same for the other chapters. While cordially thanking these gentlemen for their valuable services, I have only to say of each of them, Nilil quod tetigit non ornavit.

48 Manor Place, Edingurgh, 3 ard Fuly 1899. 


\title{
CONTENTS.
}

\author{
CHAPTER I.
}

INTRODUCTION-THE HISTORIC BORDERLAND.

Allusions by classical writers to the British Isles-Voyages of Himilco and Pytheas-Julius Cæsar's invasion of Britain-Agricola in North Britain-Battle of Mons Graupius-The Emperor Severus marches as far as the Moray Firth-The Druids-Historic Borderland-Plan of work explained . . . . . . . . . . I-18

\section{CHAPTER II.}

\section{CLIMA't'IC AND TOPOGRAPHICAL FEATURES-ARBORESCENT GROWTHS AND PEAT-BOGS.}

The Glacial Period-Alterations in relative level of sea and land-Ancient sea-margins-Marl-deposits in lakes-Arborescent growths-Peatbogs-Great trees found in peat-Hatfield Moss and forest-Woods formerly in Orkney and Shetland-Chronological data-Destruction of the forests

\section{CHAPTER III.}

ALTERATIONS IN THE RELATIVE LEVEL OF SEA AND I.AND SUBSEQUENT TO THE APPEARANCE OF MAN IN SCOTLAND.

x. The MacArthur Cave and rock-shelter at Oban-Shell-heap of Caisteal-nan-Gillean, Oronsay. 2. Implements of deer-horn associated with the skeletons of whales in the Carse of Stirling. 3. Other relics of man in Carse-lands and alluvial deposits-Kitchen-niddens at Inveravon-Canoes and other relics found at Falkirk, Friarton brickclay-pit, Lochar Moss, and Moss of Cree. 4. Canoes in basin of the Clyde. 5. Evidence from raised beachcs, sand-dunes, caves, rock- 
shelters, \&c.-Flint factory and camping-ground at CampbeltownHoard of bronze axes at "The Maiden's"-Cave near the mouth of the North Esk-House and kitchelı-midden on Ghegan RockKock-shelier at Ardrossan-Chronology and the rock-shelter of Schweizersbild . . . . . . . . . . $45^{-83}$

\section{CHAPTER IV.}

\section{NOTES ON TIIE PREIISTORIC FAUNA.}

Reindeer-Elk-Irish Elk-Red-deer-Crus-Celtic Shorthorn-Beaver -Wild Boar-Great Auk-General remarks-Domestic animals $\quad 84-13^{6}$

\section{CHAPTER V.}

CULTURE AND CIVILISATION OF THE STONE AGE PEOPLE.

Prcliminary remarks-Prehistoric man already a toolmaker-The three ages : x. The Raw Materials-Flint, jade, ousidian, jet and cannelcoal, amber, bones, stones, and organic materials. 2. The Workshop and its Tools - Chipping, polishing, and boring of stones-Tubes not used in Scotland for boring holes-Anvils, fabricators, borers, \&c. 3. Implements, Weapons, and Ornaments-Axes, chisels, and hammers -Knives, saws, and scrapers-Weapons-Clothing and ornaments $137^{-176}$

\section{CHAPTER VI.}

PROGRESS IN CULTURE AND CIVILISATION DURING THE BRONZE AGE.

Axes, chisels, \&c.-Knives, saws, sickles, and razors-Weapons-Objects of toilet and personal ornaments-Art of the Bronze Age . $\quad 177 \cdot 225$

\section{CHAPTER VII.}

\section{GENERAL PHENOMENA OF TIE EARLY IRON AGE-LATE CELTIC PERIOD.}

The supersession of Bronze by Iron in cutting implements. LATE CELTIC PERIOD-Shields-Helmets-Swords and sword-sheaths-Daggers - Horse-trappings-Personal ornaments. Special Finds of the Late Celtic Period: Balmaclellan, Kirkcudbrightshire-Mount Batten, Plymouth-Trelan Bahow, Cornwall-Site of Esica on the Roman Wall-Gold hoard found in Ireland-Barrows at Cowlam, Yorkshire -Urn ficld at Aylesford, Kent-Hunsbury Camp, Northamptonshire - Military accoutrements at Lisnacroghera, Ireland-Caldron with iron implements from Carlingwark Loch, Kirkcudbrightshire General remarks 


\section{CHAPTER VIII.}

THE ABODES AND MEMORTALS OF THE DEAD.

More important than those of the living-Various methods of classifying sepulchres-Forms of Barrows - Cairn of Achnacree-Cairns at Largie, Kilchoan, and Kilmartin, Argyllshire-Stone circle at Ballymenach - Horned cairns of Caithness - Variety of structural remains in Orkney-Standing stones of Stennis-Maeshowe-The "Knowe" of Unstan - Chambers at Quanterness and WidefordChambers on Papa Westray, and at Quoyness on the island of Sanday - Stone circle of Callernish in the island of Lewis - Stone circles and chambered cairns at Clava - Cairn at Collessie, in Fife, and Gilchorn, near Arbroath-Bronze-Age cemeteries at Kirkpark and Magdalen Bridge, Mid-Lothian-Cenıeteries at Pitreavie, near Dunfermline-Mr C. E. Dalrymple's discovery of burials in stone circles in the counties of Kincardine and Aberdeen-Stone circles of Mauchrie Moor, Arran-Standing stones-Contents of gravesUrns, implements, ornaments, \&c.-General remarks . . 278-328

\section{CHAPTER IX.}

\section{ABODES OF THE LIVING-SOCIAL LIFE.}

Wooden huts-Beehive houses-Earth-houses in Scotland-Underground chambers in Ireland and Cornwall. Indications of Social Life: Factories for the manufacture of Flint implements-Division of labour-North Britons in time of 'Tacitus were a pastoral peopleCoracles and canoes--Civilisation of people indicated by the character of grave-goods .

\section{CHAPTER X.}

WORKS OF DEFENCE-FORTS, CAMPS, AND BROCHS.

I. Forts, CAMps, \&c.-The classification and distribution of FortsDivision into earthworks and stoneworks - Moats or Motes, and Moothills-The Caterthuns in Forfarshire-Barmekyne of EchtEast Fort of Bennachie - Midhill Head, Mid-Lothian-Forts of Abernethy, Forgandenny, Burghead, and Seamill-Fortifications on the Laws, Forfarshire-Dunbuie fort, relics from-Distribution of Hill-forts. Vitrified Forts-Discussion on their structure, age, and distribution. II. BRochs.-Peculiar structures found only in Scotland-A number of specimens examined-Secondary buildings attached to them-Relics point to post-Roman times as the earliest date of their construction-Discussion as to their origin-Recent investigations in Caithness . . . . . . 363-403 


\section{CHAPTER XI.}

\section{A K E - D WV E L LI NGS.}

1. Skctch of Lake-dwelling Researches: First discovery at Lagore-Discovery of Swiss pilc-dwellings at Ober-Meilen-Further discoveries in Europe-Discoveries in Loch of Dowalton-Researches of Ayr and Galloway Archrological Association-The more recent discoveries at Lochan Dughaill, Hyndford, and Ashgrove Loch-Discoveries in England-Glastonbury Lake-village. 2. Structure of Lake-dwellings : (1) Pile-dwellings, Pfahlbauten, Palafittes-(2) Cellular basements-(3) Crannogs. 3. Marine dwellings: Terpen in HollandStructures in Loch Crerar, Beauly Firth, Clyde (Dumbuck), and at Ardmore Bay, Ircland-Pile-dwellings still used in various parts of the world

\section{CHAPTER XII.}

\section{ETHNOLOGY.}

Inportance of the subject. I. Craniology: Modern researches-Kjökkenmöddings in Portugal - French archæologists on Neolithic crania in Gaul-Dolichocephalic and brachycephalic skulls. 2. General Anthropological Data: Linguistic researches and the Aryans-Religiosity and Funeral Rites-Cremation and the Bronze Age in Britain-Early Iron Age. 3. General Conclusions: Early people of the British Isles were non-Aryan-First Aryan immigrants (Goidels) were Bronze-Age people-Second wave of Aryans (Brythons) were the importers of Late Celtic Art-Non-Celtic speechGoidelic and Brythonic tongues were Celtic-Huxley on dark whites and fair whites-A monopoly of intellectuality not peculiar to any form of skull 


\section{ILLUSTRATIONS.}

\section{II.LUSTRATIONS IN THE TEXT.}

FiGs.

1-3. Bronze caldrons, found in Scotland . . . . 38-40

4. Bronze beaded torque and bowl, Lochar Moss . . . $\quad 4 \mathrm{I}$

5, 6. Bone pin and borer, MacArthur Cave, Oban . . . 49

7-9. Implements of bone and deer-horn, MacArthur Cave, Oban . 50

10-r2. Bone implement and harpoons of deer-horn, MacArthur Cave, Oban . . . . . . . . . 5 . 5

I3-I7. Harpoons from different localities . . . . 55

18, 19. Hammer-axe and implement of deer-horn found with whales' skeletons, Carse of Stirling . . . . . $\quad .58,63$

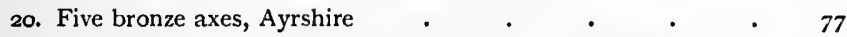

2I-23. A needle, a comb, and an ornament of bone, Ghegan Rock . 80

24-26. Portions of reindeer horns found in brochs a . . $\quad$. 87, 88

27. Skull of elk, Whitrig Bog, Berwickshire . $\quad$. 92

28. From a painting in oil of elk's skull, Forfarshire . . 94

29. Elk's horn, Strath Halladale, Sutherlandshire . • . 95

30. Skull of elk, Willie Struther's Loch, Roxburghshire . $\quad 97$

3x. Elk's horn, river Cree, Wigtownshire . $\quad$ • $\quad$. 98

32. Irish elk (from Prof. A. Nicholson's 'Palæontology') . . 100

33, 34. Horns of red-deer found in "The Meadows" and at Ashkirk 106, I07

35, 36. Skull of Bos primigenius, Fifeshire . . . . II3, II4

37. Two teeth of Bos primigenius . . . . . . $\mathrm{II}_{4}$

38. Portion of skull and horns of Bos longifrons . . . 118

39. Bronze implement, Kinleith . . . . . 119

40. Axe-hammer, West Kilbride . . . . . 149

4I, 42. Stone anvil and hammer-stone, Skelmuir . . . I5I

43. Hammer-stone, with circular depressions . . . I52

44. Fabricator of flint from the cairn of Unstan . . . $\quad{ }_{53}$ 
45, 46, Flint borers or drills . . . . . . . 154

47. Axe-hammer-head, Ardrossan . . . . . 155

48. Axe-hammer-liead, Crichie . . . . . 156

49. 50. Stone hammer and urn, from cairn at Glenhead . . 157

51. Stone axe-hend, Tarbolton . . . . . . 158

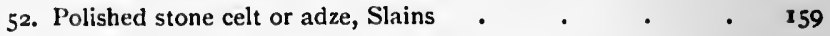

53. Whetstone with stone axe, Stoneykirk . . . 160

54. Polygonal grinding-stone, Lamberton Moor . . . 160

55. Virious methods of mounting stone implements . . 16I

56.58. Trimmed flint knives, Wigtownshire . . . . 162,163

59. Flint knife with ground edge, Butterlaw . . . $16_{3}$

60-63. Flint saws from Glenluce and Culbin . . . . 164

64.67. Flint scrapers, Wigtownshire . . . . . 165, 166

68.74. Flint arrow-heads, Wigtownshire and Ayrshire $\quad$. 167,168

75, 76. Stone bracers, Wigtownshire and Ross-shire . . . 169

77. Flint javelin-head, Wigtownshire . $\quad$. $\quad$. 170

78. Ornamented stone ball, Aberdeenshire - . $\quad$ I7I

79, 80. Buttons of jet, Lanarkshire and Forfarshire . . . 173

81. Portion of knitted fabric, Yorkshire . . . . 175

82, 83. Flat bronze axe-heads, Ayrshire . . . . 182, 183

84, 85. Bronze axes, winged type, Ayrshire . . . $\quad 184$

86. Socketed bronze axe, Ayrshire. $\quad$ - $\quad$. $\quad 185$

87. Ornamental bronze axe in miniature, Wigtownshire . $\quad$ I86

88. Bronze knife-dagger . $\quad$. $\quad$. $\quad$. $\quad 188$

89. Bronze knives . $\quad$. $\quad$. $\quad$. $\quad$. $\quad$. $\quad$. 188

90,91 . Bronze sickles, Scotland and Ireland . $\quad$ • _ . $\quad$. 189

92.95. Ornamented bronze blades, Scotland . . . . 190

96-100. Various kinds of bronze weapons, Scotland . . . I9I

101-105. " " " $"$. . . 192

106. Knife dagger of bronze, Forfarshire . . . . 193

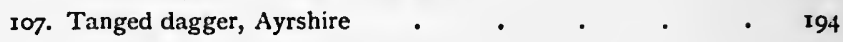

108-115. Bronze swords, found in Scotland . . . . 195

II6. Rapier sword-blade, Ayrsbire . $\quad$ - . $\quad$ - 197

I17. Bronze dagger-blade, Ayrshire $\quad$ - . $\quad$ • 197

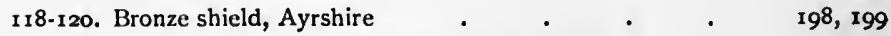

12r. Portion of a side-blast trumpet, Wigtownshire . . 201

122. The Caprington bronze horn, Ayrshire . . . 202

123. Ornamental disc of a bronze trumpet, Ireland . . 203

124, 125. Head of a bronze pin, and a bronze button, Edinhurgh : 204

126, 127. Bronze armlets of penannular and ring forms, Scotland . 206

128. Bronze armlet of a peculiar type, Argyllshire . $\quad$ - 207

129. Penannular ring of bronze with cup-shaped ends, Ross-shire 208

130. " gold " Inverness-shire 209 
131. Coiled armlet of gold, Mid-Lothian . . . . 210

132. Gold arnlet or torque, Perthshire . . . . 2rI

133-r35. Necklace of jet beads, and urn, and portion of a trepanned

skull, found in a Bronze Age burial, Bute .

212,213

136. Gold ear-ring, one of a pair found in a stone cist, Morayshire $2 \mathrm{I}_{4}$

137. Entrance to great cairn at New Grange, Ireland . $\quad 220$

138. Cover-stone of a cist at Coilsfield, Ayrshire . . . $22 \mathbf{r}$

139. " " Carnwath, Lanarkshire . . 222

r40. Sculptured stone at Monzie Castle, Perthshire $\quad$ - 222

r4r. Sculptured stone in Knockmany Cairn, Ireland . 223

142, r43. Cup-marked rock surface at High Banks, Kirkcudbrightshire 224, 225

r44. Bronze with horns, supposed to be a helmet or mask, Torrs,

Kirkcudbrightshire (now at Abbotsford) . • $\quad 239$

145. Bronze sword-sheath found at Hunsbury Camp, Northampton 242

146. Bronze sword-sheath, Ayrshire . . . 243

r47. " " Lisnacroghera, Ireland . . 244

148. " " Pentland Hills . . . 245

149. Iron dagger with bronze sheath from the river Witham . 246

r5o. Enamelled ring, Westhall, Suffolk . . . . 248

151. Enamelled ornament, Norton, Suffolk . $\quad$. 249

152. Ornament with trumpet-shaped spaces, Loch of Dowalton . 249

153. Bridle-bit, ornamented with enamel and Late Celtic ornamen-

tation, Birrenswark . . . . . 250

154. Portion of a supposed beaded torque, Hyndford Crannog - 253

155. Bronze collar, Stitchel, Roxburghshire . • . 253

156. Bronze armlet, Borgue, Kirkcudbrightshire . • . 254

157. " . . . 255

158. " Seafield Tower, Fife . . . . 256

159. " Castle-Newe, Aberdeenshire . . . 257

r6o. Bronze spiral armlet, Grange of Conan, Arbroath . $\quad 25^{8}$

161. Bronze snake-headed armlet, Wigtownshire . . . 259

162-164. Bronze fibulæe found in Ireland . . . $\quad 260$

165. Bronze fibula, Falkirk . . . . . . 261

166. Late Celtic ornament, Northamptonshire . . . 262

167. Upper stone of a quern, Balmaclellan, Kirkcudbrightshire . $\quad 263$

168, 169. Bronze mirror and crescent, Kirkcudbrightshire . . 263

I7o. Ornamented plate on mirror, Kirkcudbrightshire . $\quad 264$

I7 I. Back and side views of a bronze fibula, Mount Batten . 264

172. Bronze armlet opening by a hinge, Mount Batten - $\quad 265$

173. Two handles of bronze mirrors, Mount Batten. (Last three are after drawings in 'Archreologia,' vol. 40) . . 265

174. Bronze nirror from St Keverne, Cornwall. ('Arch. Journal,' vol. $\mathrm{xxx}$.) . $\quad$. $\quad$. . . 
175, 176. Fibula from Aylesford . $\quad$. $\quad . \quad$. 270

177. Tankard with bronze mounting, Elveden . • • $27 \mathbf{r}$

178. Fragment of pottery, Hunsbury Camp • • • 272

179. Iron dagger and saw, bone combs, and fibula, Hunsbury

Camp. . . . . . . . 273

180. Bronze caldron, Carlingwark Loch . . . $\quad 274$

181. Objects found in caldron, Carlingwark Loch . . $\quad 275$

182. Ornamented bronze ball, Walston, Lanarkshire . $\quad 277$

183. Section of the cairn of Achnacree. (After plan by Dr Angus

Smith, 'Proc. Soc. A. Scot.,' vol. ix., Pl. xxiii.) • . 284

184. Urn from cairn at Largie, Argyllshire $\quad$. $\quad$. $\quad 287$

185, 186. Urns found at Ballymenach and Kilmartin . . . $\quad$. 289

187-191. Ground-plans of cairns in Caithness. (Reduced from plans accompanying papers by Dr Joseph Anderson and others in

'Proc. Soc. A. Scot.,' vol. vi., Pl. 27, and vol. vii., Pl. 60-62) 292-297

192. View of the central chamber, Maeshowe . . 299

193. Ground-plan and section of Maeshowe . . . 300

r94, 195. Dragon and "Wurm-knot" in Maeshowe . . . 30

196. View of the great cairn at New Grange . . . 302

197. Ground-plan of cairn at Unstan. (Reduced from plan by $\mathrm{Mr}$

Clouston, 'Proc. Soc. A. Scot.,' vol. xix. p. 343) . 303

198. Ground-plan of cairn at Quanterness. (Reduced from plan in 'Scotland in Pagan Times,' p. 288) . . . 305

199. Ground-plan of sepulchral chamber in Holm of Papa Westray.

(From plan by G. Petrie, ibid., vol, ii., Pl. iii.) . .

200. Ground-plan and section of stone circle at Crichie. (After

plan by C. E. Dalrymple, ibid., vol. xviii. p. 320) . . 317

20r-208. Specimens of urns, various localities . . . . 319.323

209. Dolmen at Ballymascanlan, Ireland . . . . 326

2ro. Spinsters' Rock, Chagford, Devonshire . • . 327

211. Clochan-na-Carraige, North Island, Aran . • . 337

212. Ground-plan and section of beehive house (restored) in South

Uist. (After Captain Thomas, R.N., ' Proc. Soc. A. Scot.,' vol. vii. p. I66)

*.$\quad 339$

213. Oratory of Gallerus, Ireland . $\quad \cdot \quad \cdot \quad \cdot 34^{2}$

214. Ground-plan and sections of earth-house, Forfarshire. (After Mr Jervise, ibid., vol. iv. p. 493) . . . . 350

215. Ground-plan and sections of earth - house, Berwickshire.

(Ibid., vol. viii. p. 2x) . . . . . 352

216. Currach or coracle used on the Boyne . . . 360

217, 218. Bronze finger-ring and fibula, Abernethy fort . . . 372

219, 220. Ring of lignite and stone axe, Abernethy fort . . - 373

221-224. Objects of shale, bone, and bronze, Seamill fort . 376-378 
225. Ground-plan and sections of broch of Ousdale, Caithness. (After plans by Mr James Mackay, 'Proc. Soc. A. Scot.,' vol. xxvi. p. 352) $\quad$. $\quad$. $\quad . \quad$. $\quad$. $\quad$. 392

226. Bone comb from the Knowe of Saverough, Orknty . . 399

227. Bronze object, broch of Harray . . . . 400

228. Quartz pebble from the broch of Kintradwell . . 40t

229. Bronze patella, crannog in the Loch of Dowalton . . 4 ro

230. Glass beads, crannog in the Loch of Dowalton . . 4 II

231. Bronze brooch, crannog in the Loch of Dowalton . . 411

232. Portion of leather shoe, crannog in the Loch of Dowalten . $44^{12}$

233. Two spiral finger-rings of gold, Buston crannog . . $4^{12}$

234-236. Gold coin (Buston), glass bead, and ornament of rock-crystal,

Lochspouts crannog . $\quad$. $\quad$. $\quad$. $\quad$. $\quad$. $4 \mathrm{I} 3$

237. Stone with cup-and-ring markings, Lochlee crannog _ $\quad 4^{113}$

238. Jet ornament, Lochspouts $\quad$. $\quad$. $\quad$. $\quad$. $\quad$. 413

239. Fringe of moss, Lochlee . . . . . . $44^{14}$

240. Bridle-bit, Lochlee . $\quad . \quad$. $\quad$. . . $44^{\mathrm{I} 4}$

24t. Bone comb, Buston . . . . . . . 415

242. Bronze fibula, Lochlee . . . . . . 415

243. Bronze ornament, Lochspouts . . . . . 4 4I5

244-247. Flint scraper, jar, handle, and crucible, from crannog of Lochan Dughaill . • • • . . 417

248. Stone axe from Hyndford crannog . . . . $4^{18}$

249-254. Various objects, Hyndford crannog • • • • . $4^{19}$

255, 256. Fibulæ and handle of mirror, Glastontury lake-village . 425

257. View of piles at Robenhausen, Switzerland . . . 429

258,259 . Views of prehistoric skulls $\quad$. $\quad . \quad$. $\quad 446$

260-262. Views of a skull from MacArthur Cave, Oban . 453-455

\section{PLATE ILLUSTRATIONS.}

I. VARIOUS FORMS OF BRONZE RAZORS FOUND IN WESTERN EURope

I. South Lodge Camp, Rushmore Park (after General PittRivers, 'Excavations in Cranborne Chase,' vol. iv., Pl. 238, fig. 4). 2. Wor Barrow, Hudley Down, found along with RomanoBritish remains (ibid., Pl. 258, fig. 16). 3. Bowerhouses, Dunbar, associated with sepulchral urns ('Proc. Soc. A. Scot.,' vol. vi. p. 36r, and 'Scotland in Pagan times,' p. 26). 4. Terramara (Museo Civico di Reggio d'Emilia). 5. Found in 'Thames near Wallingford (Ancient Bronze Implements, fig. 269). 6. Found in the Shannon (Cat. R. I. Acad., fig. 433). 7, rr. Lake-dwelling of Moeringen (Keller's 7 th Rep., Pl. vi., figs. 3 and 6). 8. Basin 
of the Saône (M/useum of St Germain). 9, 1o. Iake of Bourget ('Lake-Dwellings of Europe,' fig. 20, Nos. 22 and 23). 12, I4. Scandinavian types (Bronzealderen zed S. Muller, figs. 294 and 188). 13. Lake Garda (see 'Lake-Dwellings of Europe,' fig. 63 , Nos. I to 6). 15. Found with an iron sword in a tumulus in Lorraine (Barthélemy, 'La Lorraine avant l'Histoire,' p. $13^{2}$ and fig. 60).

II, III. These are photographic illustrations by Mr R. Welch of the late Canon Grainger's collection of Irish antiquities (now in the Belfast Museum). They were taken shortly before his death, and the author was among those privileged to receive copies . . . . . . . . . . . 196, 197

IV. VARIOUS FORMS OF PREHISTORIC ROCK-SCULPTURING IN WESTERN EUROPE . . . . . . . .

Nos. I to to are mere diagrammatic illustrations after Sir James Simpson's types of the more common cup-and-ring markings. 11. Stone found at Bakerhill, near Dingwall, Ross-shire (Simpson, op. cit., Pl. xiv., fig. r). I2. Stone at Cargill, Perthshire ('Proc. Soc. A. Scot.,' vol, xviii. p. 314). 13. Stone in the dolmen of "Mané er Hroêg," about $3 \frac{1}{2}$ feet in length. I4. Stone in dolmen at Locmariaquer with incised figure like a fort, size $\frac{1}{2}$ (L. de Cussé, 'Des signes sculptés sur les monuments megalithiques du Morbihan,' Vannes, I886). I5, I6. Sculptured on the chalk walls of the Neolithic caves of Petit-Morin (Baron de Baye, 'Archéologie prehistorique'). 17. Stone in Loughcrew cemetery ('Proc. Soc. A. Scot.,' vol. xxvii., fig. 39). 18. This figure, reproduced from Fergusson's 'Rude Stone Monuments' (fig. 149), has done duty for many years as the representation of a mounted stone axe on the roof of the dolmen called "Table des Marchands." The original is about 4 feet in length, rudely carved and very unlike this outline (see phot. illustration of the stone in 'Revue Mensuelle,' 1899, p. 164). 19. On a stone in the dolmen of Petit Mont (Arzon). The foot-marks are about $9 \frac{1}{2}$ inches long (De Cussé, op. cit.)

V. Bronze Shifld found in the Thames (Britisil Museum) 236

VI. OBjects Found iN the Bog of LisNacroghera • 274

Nus. 1, 2. Iron swords. 3. Iron spear-head. 4, 5. Axe and adze of iron. 6-9 and 17. Bronze rings. 10. Bronze dish. 11, 12, and 14. Glass beads. 13. Amber bead. 15, 15. Bronze objects. 18, 19, 20, and 22. Bronze ornaments. 21. Top of a bronze rivet. 23-25. Bronze ferrules. 26. Bronze rivet serrated. 27. Bronze ornament for handle. 28-30. Bronze knobs for the butt-end of spear-handles.

Vli. The Ring of Brogar, Okkney . . . . . 297

VIII. The Circle of Stennis, Orkney . . . . . . 298

IX. The Tumulus of Maeshowe, Orkney . • . . 299 
X. Stone Circle of Callernish, Leivis . - . 309 XI, XII. Chambered Cairns at Clava . . . . 3io, $3 \mathbf{I}$

(From sketches by Cosmo Innes, 'Proc. Soc. A. Scot.,' vol. iii., Pl. vi. and vii.)

XiII. Stone Circle of Auquhorthies, near Inverury - 3 I8

It contains eleven stones-one lying horizontally, called the altar stone.

XIV. Gian't's Ring and Dolmen, near Belfast • . 328

The ring is an earthen circular mound 580 feet in diameter.

XV. Broch of Mousa, Shetland • • . . . 389

XVI. Broch of Clikamin, Near Lerwick . . . 398

XViI. Edenshall, Cockburn Law, Berwickshire • · 399

(From 'Proc. Berwickshire Nat. Club,' 1879-8r.)

XViII. General View of Pile-dwellings near Singapore 44I 



\title{
PREHISTORIC SCOTLAND.
}

\author{
CHAPTER I.
}

INTRODUCTION-THE HISTORIC BORDERLAND.

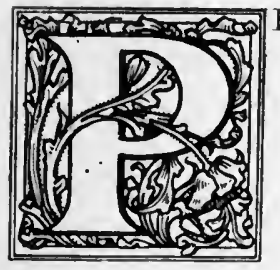

RIOR to the occupation of Britain by the Romans vague reports of the British Isles had found their way into the literature of Greece and Rome, but of these only a few have come down the stream of time to our day. Such historical data are now valuable chiefly for comparison with deductions derived from archæological and other sources. The Phœnicians, as early as the twelfth century B.c., founded colonies on the western shores of the Mediterranean, as well as on the coast of the Atlantic beyond the Pillars of Hercules; and after the conquest of Phœnicia by the Assyrians, about the middle of the ninth century B.c., these colonists acquired greater influence, more especially the Carthaginians, who organised commercial enterprises to distant lands. They sent expeditions in quest of tin, then so much in demand in the East, to the Cassiterides, or Tin Islands, identified by some authorities as the Scilly Isles, and by others as a group of islands on the north coast 
of Spain. Herodotus candidly confesses his ignorance of the whereabouts of the Cassiterides, "from whence," he says, "our tin comes." During the last few years there seems to be a consensus of opinion among English scholars that there is no evidence that the Phcenicians ever traded for tin as far as Britain. But, however this may be, there can be no question that they held for a long time a monopoly of navigation and trade in the Mediterranean, so that they must have played an important part in the early civilisation of Europe.

At a subsequent date (600 B.c.) the Phocæans founded Massilia (Marseilles), which speedily became an important station for the tin trade of Britain by means of a land-route across France. It was through this source that the Greeks became first aware of the existence of the British Isles, and henceforth we find the two largest of the group incidentally referred to by various classical writers under the distinctive names Albion and Ierne. Much of their information appears to have been derived from the narratives of the voyages of Himilco and Pytheas, but, unfortunately, only a few fragmentary passages of these narratives have survived to the present day as extracts incorporated in other works.

Himilco was a Carthaginian who, about 500 B.c., set out from Gades, beyond the Pillars of Hercules, on a voyage of discovery. Coasting along the shores of Spain and Portugal, he crossed the Bay of Biscay and arrived at the islands of the Estrymnides, described as rich in tin and lead, and inhabited by a numerous population who were in the habit of using skin boats (coracles). It would appear from 'Ora Maritima' of Festus Avienus that Himilco knew of the plains of the Britons, the distant Thule, the grass-green "Insula Sacra" inhabited by the race of the Hibernians, and the adjacent island of the Albiones. 
About 150 years later the Romans, then aspiring to be rivals to the Carthaginians in the tin trade, but unable to procure any definite information in regard to the Cassiterides, instigated the merchants of Marseilles to fit out an expedition to ascertain the whereabouts of these mysterious islands. Pytheas, an eminent mathematician of that town, and a contemporary of Aristotle and of Alexander the Great, accompanied the expedition, and on his return home published an account of his adventures. His story, though received both at the time and by subsequent classical writers with the greatest distrust-Strabo, indeed, going so far as to characterise him as a charlatan and his statements as utterly untrustworthy-is now recognised to be singularly accurate.

Entering the Atlantic by the Straits of Gibraltar, Pytheas sailed round Spain to Brittany, and thence crossed over to the neighbouring shores of Britain and the estuary of the Thames. From Britain he sailed to the mouth of the Rhine, and after coasting along the shore northwards, rounded Jutland and entered the Baltic, going as far east as the mouth of the Vistula. Here he turned back and proceeded along the coast of Norway as far as the Arctic circle and the island of Thule. On his return journey he touched at the north of Scotland, and finally reached Brittany and the mouth of the Garonne, whence he travelled to Marseilles by land. Although Pytheas does not appear to have visited the tin districts of Cornwall, his statements made known, for the first time, the three promontories of Cantium (Kent), Belerion (Land's End), and Orcas (North of Scotland). From his time the overland traderoute to Britain was permanently established, a fact which satisfactorily accounts for the earliest coins struck in the island being modelled after Greek coinage, especially the gold stater of Philip II., king of Macedonia.

It was not till the invasion of Britain by Julius Cæsar, 
in 55 B.C., that the Romans came into actual contact with the tribes inhabiting that mysterious and, hitherto, to them inaccessible island. The reasons which induced Cæsar to fit out this expedition at such an advanced season (August) are thus stated in his Commentaries (book iv. chap. xx.) :-

"During the short part of summer which remained, Cæsar, although in these countries, as all Gaul lies towards the north, the winters are early, nevertheless resolved to proceed into Britain, because he discovered that in almost all the wars with the Gauls succours had been furnished to our enemy from that country; and even if the time of the year should be insufficient for carrying on the war, yet he thought it would be of great service to him if he only entered the island, and saw into the character of the people, and got knowledge of their localities, harbours, and landing-places, all which were for the most part unknown to the Gauls. For neither does any one except merchants generally go thither, nor even to them was any portion of it known, except the sea-coast and those parts which are opposite to Gaul. Therefore, after having called up to him the merchants from all parts, he could learn neither what was the size of the island, nor what or how numerous were the nations which inhabited it, nor what system of war they followed, nor what customs they used, nor what harbours were convenient for a great number of large ships." 1

With the military exploits of Cæsar in Britain during that and the following year we are not here concerned, beyond the glimpses of British civilisation which they disclose-thus summarised in the Commentaries (book v. chaps. xii.-xiv.):-

"The interior portion of Britain is inhabited by those of whom they say that it is handed down by tradition that they were born in the island itself; the maritime portion of those

1 Bohn's Classical Library. 
who had passed over from the country of the Belgæ for the purpose of plunder and making war; almost all of whom are called by the names of those states from which being sprung they went thither, and having waged war, continued there and began to cultivate the lands. The number of the people is countless, and their buildings exceedingly numerous, for the most part very like those of the Gauls; the number of cattle is great. They use either brass (bronze) or iron rings, determined at a certain weight, as their money. Tin is produced in the midland regions; in the maritime, iron, but the quantity of it is small; they employ brass, which is imported. There, as in Gaul, is timber of every description except beech and fir. They do not regard it lawful to eat the hare, and the cock, and the goose ; they, however, breed them for amusement and pleasure. The climate is more temperate than in Gaul, the colds being less severe. . .

"The most civilised of all these nations are they who inhabit Kent, which is entirely a maritime district, nor do they differ much from the Gallic customs. Most of the inland inhabitants do not sow corn, but live on milk and flesh, and are clad with skins. All the Britons, indeed, dye themselves with woad, which occasions a bluish colour, and thereby have a more terrible appearance in fight. They wear their hair long, and have every part of their body shaved except their head and upper lip." 1

Cæsar bears testimony to the courage with which the Britons fought against his troops, sometimes fearlessly encountering them in the open in war-chariots, and at other times rushing upon them from their places of concealment in woods and fortifications.

Strabo (book iv. c. v.) supplies some additional particulars as to the manners and customs of the Britons. According ${ }^{1}$ Bohn's Classical Library. 
to him their country produced corn, cattle, gold, silver, iron, skins, slaves, and dogs sagacious in hunting. The natives carried on a trade in these commodities with the Kelts, who exported ivory bracelets and necklaces, amber, vessels of glass, and small wares. The manners of the Britons were in part like those of the "Kelts" of Gaul, but more simple and barbarous; insomuch that some of them, though possessing plenty of milk, had not skill enough to make cheese. They were also unacquainted with horticulture and other matters of husbandry. Strabo informs us that there were four passages commonly used for crossing over into Britain-viz., from the mouths of the rivers Rhine, Seine, Loire, and Garonne; but for such as sailed from the parts about the Rhine the passage was not exactly from its mouths, but from the country of the Morini, in which also was situated Itium, which Cresar used as a naval station when about to pass over into the island.

Diodorus Siculus makes mention of the tin-miners near the promontory of Belerion, and characterises them as more civilised than the other inhabitants, owing to their intercourse with strangers. Those who were regarded as the aborigines are represented as living in mean dwellings made of reeds or timbers, and leading a simple, frugal, and virtuous life. With regard to the method of harvesting, he makes the curious statement that they merely cut off the ears of corn, which were stored in underground cellars till required to be dressed for food. This suggests a speedy method of preparing a meal-a method which was probably the same as that practised on emergencies in Scotland up to recent times. ${ }^{1}$

Not till the year 79 A.D. did the Romans extend their conquests as far north as the borders of Scotland. In

1 See 'The Past in the Present,' by Sir Arthur Mitchell, pp. 46, 238. 
that year the famous commander, Julius Agricola, moved his forces northwards through the territories of the Brigantes in the direction of the Solway Firth, with the intention of carrying out his deliberately formed plan of subjugating the warlike tribes of North Britain, who had hitherto maintained their independence. The story of his invasion of Scotland, embracing a period of five years, is concisely told by the historian Tacitus. Sir Herbert Maxwell ${ }^{1}$ has already so well and thoroughly reviewed the Roman operations in the south of Scotland during that period that nothing remains to be done. And as other writers of the County Histories Series may probably do the same for the other provinces occupied by the Romans, it is unnecessary for me to enter on this part of the subject. I shall therefore restrict myself to giving a few extracts from the narrative of Tacitus illustrative of the topography of the country and the methods of warfare adopted by the natives.

During the two succeeding years Agricola continued his victorious career northwards. Penetrating the hilly regions north of the Solway, he reached the valleys of the Forth and Clyde. Struck by the narrowness of the neck of land which separates these two estuaries, he seemed to regard it as the most natural boundary of the new province, and so he erected a chain of forts along its entire length as an effective means of defence. Having thus secured the parts of the country already subjugated, Agricola transferred his operations to the regions on the north of the Firths of Forth and Clyde. In this enterprise he was assisted by his navy, which entered the Firth of Tay. The appearance of the fleet, as it were in the heart of the country, caused great consternation among the Caledonians, and so they resolved to take up arms, with the view of compelling the

'Dumfries and Galloway, chap. $i$. 
Romans to retire from that part of the country. Tacitus thus describes the events which led to this rising :-

"In the summer which began the sixth year of Agricola's administration (A.D. 83), extending his views to the countries situated beyond Bodotria, as a general insurrection of the remoter nations was apprehended, and the enemy's army rendered marching unsafe, he caused the harbours to be explored by his fleet, which, now first acting in aid of the land-forces, gave the formidable spectacle of war at once pushed on by sea and land. The cavalry, infantry, and marines were frequently mingled in the same camp, and recounted with mutual pleasure their several exploits and adventures; comparing, in the boastful language of military men, the dark recesses of woods and mountains, with the horrors of waves and tempests; and the land and enemy subdued, with the conquered ocean. It was also discovered from the captives that the Britons had been struck with consternation at the view of the fleet, conceiving the last refuge of the vanquished to be cut off, now the secret retreats of their seas were disclosed. The various inhabitants of Caledonia immediately took up arms, with great preparations, magnified, however, by report, as usual where the truth is unknown; and by beginning hostilities, and attacking our fortresses, they inspired terror as daring to act offensively; insomuch that some persons, disguising their timidity under the mask of prudence, were for instantly retreating on this side the firth, and relinquishing the country rather than waiting to be driven out." 1

To prevent being surrounded Agricola distributed his army into three divisions, an arrangement which induced the Britons to make a sudden attack in the night-time on the $9^{\text {th }}$ Legion, it being the weakest. So skilfully was this

1 Life of Agricola, chap. 25 (Bohn's Classical Library). 
mancuvre carried out that, having killed the sentinels, they were actually fighting inside the camp when Agricola, who had received information from his scouts of the movement of the enemy, came up just in time to save his friends. The enemy was routed ; and, according to the historian, "had not the woods and marshes sheltered the fugitives, that day would have terminated the war."

This victory completely restored the drooping spirits of the Roman soldiers, and henceforth they became eager "to penetrate into the heart of Caledonia."

In the beginning of next summer (A.D. 84) both armies prepared for the impending struggle. Agricola, having sent his fleet to various parts along the coast in order to cause alarm among the natives, advanced northwards as far as a hill called "Graupius," where the enemy, to the number of upwards of 30,000 , was already encamped. There being no description of Agricola's march, nor of the locality in which the hostile armies met, we have no clue to the precise situation of the field of conflict, beyond the vague topographical allusions in the account of the battle. We need not be surprised, therefore, to find that historians differ on this point. General Roy places Agricola's headquarters at the camp of Ardoch, while Dr Skene contends that they were at Cleaven Dyke, on the peninsula formed by the junction of the Isla with the Tay.

Agricola arranged his troops as follows: 8000 auxiliaries occupied the centre, supported right and left by 3000 horse, while the legions were stationed in the rear before the intrenchments. "The British troops, for the greater display of their numbers, and more formidable appearance, were ranged upon the rising grounds, so that the first line stood upon the plain, the rest, as if linked together, rose above one another upon the ascent. The charioteers and horse- 
men filled the middle of the field with their tumult and careering."

The following extract is interesting as showing that the Highland broadsword dates to pre-Roman times: "The Britons, armed with long swords and short targets, with steadiness and dexterity avoided or struck down our missile weapons, and at the same time poured in a torrent of their own. Agricola then encouraged three Batavian and two Tungrian cohorts to fall in and come to close quarters-a method of fighting familiar to these veteran soldiers, but embarrassing to the enemy from the nature of their armour; for the enormous British swords, blunt at the point, are unfit for close grappling, and engaging in a confined space. When the Batavians, therefore, began to redouble their blows, to strike with the bosses of their shields and mangle the faces of the enemy, and, bearing down all those who resisted them on the plain, were advancing their line up the ascent, the other cohorts, fired with ardour and emulation, joined in the charge, and overthrew all who came in their way."

Professor Rolleston, ${ }^{1}$ in narrating a somewhat similar incident $^{2}$ in a contest between the Romans and the Gauls, makes the following remarks on the Gaulish method of fighting with their long pointless broadswords: "The same tactics succeeded at Culloden, as the tactic of thrusting and giving point always will succeed when masses of men in rows, not isolated individuals merely, are pitted against each other on the thrusting versus the slashing plan, though the slashing sword at Culloden was of good steel enough." That the Caledonians should be defeated at Mons Graupius and Culloden-the first and last of their battles since they appeared

1 "On the Iron, Bronze, and Stone Ages," p. 3 : reprint from 'Trans. of the Bristol and Gl. Arch. Society.'

2 Polyb., Hist. ii. c. 33 
in history-through a peculiarity of their celebrated claymore is certainly very remarkable.

The actual result of the memorable battle of Mons Graupius was that Agricola withdrew his entire army to winter quarters south of the line of forts which he had erected between the Firths of Forth and Clyde, thus relinquishing all the fortresses previously held by his soldiers to the north of this line. It does not therefore appear that the victory was such a crushing defeat of the Caledonians as might, prima facie, be inferred from the words of the narrative. Whatever may have been the motive for abandoning the garrisons north of the firths, it is only natural that Tacitus, being the son-in-law of Agricola, would give as much renown and éclat to the battle as possible. The recall of Agricola, shortly after the defeat of the Caledonians became known in Rome, owing, according to his biographer, to the jealousy of the Emperor Domitian, was quickly followed by the abandonment of all the fruits of his northern victories. How the Caledonians settled their affairs is not known, but we do know that when Hadrian became emperor, thirty-three years afterwards, he had to resort to the construction of a wall across the island, from the Solway to Newcastle, in order to check the ravages of the northern barbarians: nor was it till about the year I42 A.D. that the Roman frontier was extended to Agricola's original line of forts between the Forth and Clyde.

The remarkable march of the Emperor Severus (208 A.D.), in the course of which he penetrated as far north as the shores of the Moray Firth, appears to have been on so large a scale as to preclude the natives from contesting the progress of his army in any pitched engagement; but yet, according to Dio, he lost 50,000 men during that expedition. He explains, however, that this loss was caused by the hewing of woods, the building of bridges, the draining 
of marshes, and especially by the ambuscades of the natives, who kept up a kind of guerilla warfare against the parties so engaged. The same author also states that the Romans were often entrapped into the lifting of cattle which had been purposely put in their way by the Caledonians themselves; and while the former were thus occupied the latter fell upon them from their ambuscades, so that the Romans, rather than become a prey to these people, often entreated their own companions to slay them.

At this time we read of the North Britons being divided into two tribes, the Mieatce and Caledonii, the former inhabiting the parts near the Roman IVall and the latter the regions beyond. It was a century and a half later before the Picts and Scots made their first appearance in history.

As to the religion of the Britons, little is said directly by any of the earlier classical writers. Cæsar (book vi. chaps. xiii.-xvi.) informs us that throughout Gaul there were two orders among the people of rank and dignity - viz., the Druids and the Knights - the commonality being held in the condition of slaves. The institution of the Druids he regarded as devised in Britain and brought over from it into Gaul; and he states that those who desired to gain a more accurate knowledge of the system were generally in the habit of going to Britain for the purpose of studying it. $\mathrm{He}$ represents these Druids as having great influence, both in religious and civil affairs. They conducted public and private sacrifices, gave decisions in all controversies, decreed rewards and punishments, and had the power of excommunicating criminals and law-breakers from all social and religious privileges.

'The description given by Tacitus ${ }^{1}$ of an attack, made by the Roman army under Suetonius Paulinus, on the Isle of

1 Annals, book xiv. chaps. xxix., xxx. (Bohn's Classical Library). 
Mona, and the destruction of the Druids who accompanied the native forces, throws a lurid light on the ceremonies of this mysterious cult :-

"He therefore prepared to attack the Isle of Mona, remarkable for the valour of its inhabitants, and a common receptacle for fugitives; he built, for that end, boats with flat bottoms, to meet the difficulties of a sea abounding in shallows and subject to variations; in these the foot were embarked; the horse followed, partly by fording and partly swimming by the side of their horses, where the water was deep.

"On the shore stood the forces of the enemy, a dense array of arms and men, with women dashing through the ranks like furies; their dress funereal, their hair dishevelled, and carrying torches in their hands. The Druids around the host, pouring forth dire imprecations, with their hands uplifted towards the heavens, struck terror into the soldiers by the strangeness of the sight; insomuch that, as if their limbs were paralysed, they exposed their bodies to the weapons of the enemy, without an effort to move. Afterwards, at the earnest exhortations of the general, and from the effect of their own mutual importunities that they would not be scared by a rabble of women and fanatics, they bore down upon them, smote all that opposed them to the earth, and wrapped them in the flames themselves had kindled. A garrison was then established to overawe the vanquished, and the groves dedicated to sanguinary superstitions destroyed; for they deemed it acceptable to their deities to make their altars fume with the blood of captives, and to seek the will of the gods in the entrails of men."

That the Britons practised mystic ceremonies of a religious character is also stated by Pliny, as may be seen from the 
following passage: 1 "There is a plant in Gaul, similar to the plantago in appearance, and known there by the name 'glastum'; with it both matrons and girls among the people of Britain are in the habit of staining the body all over, when taking part in the performance of certain sacred rites; rivalling hereby the swarthy hue of the Ethiopians, they go in a state of nature."

The result of the above clippings from historical sources is to show that the whole island of Britain was thickly populated, prior to the Roman invasion, by the descendants of different races of people distinguished, even then, from each other by racial and physical characteristics. From the small swarthy Silures to the large red-haired Caledonians there was a wide gap, which may have been since filled up by cross-breeding, and may thus account for the intermediate physiognomic shading of the present day. There appears also to have been a difference in degree in their culture, the people of the south and east being more refined than the aborigines. Their villages are described as wooden huts, located within woods, and rudely fortified with stakes and felled trees. The Caledonians depended for their living on finding pasturage for cattle rather than on the cultivation of the soil. On the whole, the British people were brave, proud, and superstitious. They fought in chariots with shield, sword, spear, and dagger, and painted or tattooed their bodies, especially when going to battle. The stories about canuibalism and laxity of morals are probably mere gossip, deriving at any rate little or no support from archæological evidence.

Within the historic borderland the historian and the archæologist meet on a common platform, and their respective researches become for a short time contemporary; and as

1 Nat. Hist., book xxii. chap. ii. (Bohn's Classical Library). 
the methods of the historian do not conduct him beyond the historic fringe, the archæologist is bound to bring his general conclusions into harmony with the most approved interpretations of the historical materials. Both investigators are virtually dealing with one and the same subject-viz., the story of the culture and civilisation of the people of Scotland since their arrival on its shores up to the present time - the only break in the narrative being due merely to the different means by which the information is gathered. But with the advent of written records-the true startingpoint of the historian-the methods of the archæologist are not necessarily to be discarded, and, indeed, they may be continued profitably, pari passu with the former, a long way down the stream of human progress.

Having thus parted from my fellow-workers-the historians -it may be well to cast a coup-d'xil on the special work before us. Half a century ago the unwritten records of man were scarcely recognisable through the impenetrable mists which had settled on the prehistoric horizon. Now, through the industry, researches, and scientific methods of modern archæologists, this happily is no longer the case. Numerous explorers have made incursions into the domain of prehistoric archæology, with the result that its highways and by-ways are being rapidly opened up. Already much of its materials has been gathered together, carefully surveyed, and parcelled out into the pigeon-holes of progressive civilisation. Definite landmarks in the various phases of culture have been laid down as on a chart; and the chronological sequence in the evolution of primitive tools and weapons is steadily pursued with increasing means of precision.

Although the prehistoric materials collected and annotated within the Scottish area do not comprise objects of any striking or exceptional character-such as hieroglyphs, archi- 
tectural ornamentation, art products like those of the Dordogne Troglodytes, \&c.-yet, rude and commonplace as many of them are, they have yielded some deductions of the greatest importance to the history of Scottish civilisation. During the centuries covered by the prehistoric period that portion of Britain now known as Scotland differed greatly as regards the social condition of its inhabitants, and even in its physical features. The vegetative garb which clothes its more permanent skeleton of mountain-ridges and winding river-valleys, has varied from time to time with the vicissitudes of climate and other changes in the environments. The low-lying plains of sedimentary deposits which stretch along the shores of our river estuaries, and the numerous filled-up lake basins, are comparatively recent additions to the cultivable soil. Immense fields of heath and peat-bogs have taken the place of equally extensive areas of primeval forests. Between the flora, fauna, and physical conditions of all these successive panoramas there has always been a close relationship. To such fluctuations of his environment man, being the most adaptable of all animals, readily accommodated himself. But, en revanche, the environment affected him most powerfully, not only partially moulding his organic constitution but to some extent regulating his actions. Scotland is only part of an island, and that the most distant from the old-world civilisations on the eastern shores of the Mediterranean; hence it is manifest that many of the physical and social changes which have taken place within its area were common to the whole island. The southern portion of Britain having been first occupied by the Neolithic immigrants, it took them some time to extend their hunting expeditions to the primeval forests and mountain recesses of its northern extremity. No description of the prehistoric inhabitants of Scotland which excludes their previous 
wanderings and relationship to contemporary races can, therefore, be regarded as adequately dealing with the ethnological problems involved. And this remark applies a fortiori to their handicraft products and racial characteristics. There is, therefore, no alternative but to treat the whole subject in its wider aspects. Accordingly, the first few chapters of this volume are devoted to a review of the physical phenomena which obtained in North Britain when the first Neolithic wanderers appeared on the scene. Concurrent and subsequent changes, such as the natural decay of forests, the growth of peat, and the alterations in the relative level of sea and land, are briefly described. After a few notes on the contemporary fauna we pass on to the more important subject of the culture and civilisation of the people who, by degrees, settled in these regions. Both in the inception of the work and in the filling in of the details, the twofold object of describing the salient features of the archæological materials found within the present Scottish border, and of showing their connection with analogous remains in outside areas, has been steadily kept in view. Western Europe was partitioned in Neolithic times among various races and nationalities, whose spheres of influence may, still be traced by their well-defined antiquarian remains; but the areas thus defined do not correspond with the political divisions of the present day. Also within the range of these wider influences there were often smaller archæological areas, whose characteristics depended on local developments. From the latter point of view it is possible that a few Scottish relics may present some local peculiarities; but, in their tout ensemble, they cannot be separated from the wider area of early British civilisation. This volume is not, therefore, intended to be a handbook to Scottish archæology, nor does it encroach on the domain of special treatises on that subject. 
It goes further afield, and deals with the antiquarian debris of a bygone civilisation and the sources from which its culture elements were derived. The picture which exhibits the prehistoric people of Scotland in the foreground is not less instructive because we have also figured in the background those from whom they inherited their culture and civilisation.

Antiquaries who restrict their investigations to mere local relics may look askance at the wide range thus extended to the field of our inquiry. But let me remind such critics that the unwritten records of man have no defined limitations, for they spread their absorbent radicles into all departments of knowledge. Consequently, no evidence bearing on any of the past phases of human civilisation can be of permanent value until it has been subjected to, and tested by, the sidelights and methods of comparative archæology. 


\section{CHAPTER II.}

CLIMATIC AND TOPOGRAPHICAL FEATURES-ARBORESCENT GROWTHS AND PEAT-BOGS.

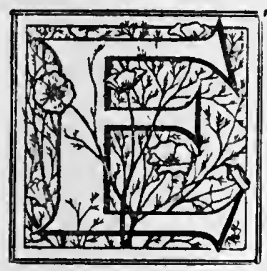

TYMOLOGICALLY, the word prehistoric includes the entire past of a country prior to the starting-point of the historian; but, practically, it has come to be regarded as only that portion of the indefinite past during which the country has been inhabited by man. Had the Romans found Scotland in the possession of wild beasts, without any evidence of the presence of man then or previously, the phrase "Prehistoric Scotland" would have no relevancy in the sense in which it is used in these pages. The physical and topographical features of a country do not, per se, contain the elements with which the archæologist concerns himself, but upon the faintest indication that man moved on the scene they become invested with the highest interest. In following up the trail of prehistoric man, we have to investigate not only his ordinary haunts-rocks, caves, woods, mountain recesses, \&c.-but also his entire environments, - the flora and fauna, climatic changes, \&c.-in short, everything capable of influencing or of modifying the conditions of human life. 


\section{Climatic and Topographical Features.}

There is one notable landmark which, as it fixes an $a b$ initio limit to archæological researches in Scotland, must be here briefly touched upon-viz., the Glacial period. The extension of a vast sheet of ice over the entire surface of the country, during the Quaternary period, excludes the possibility of its having been then the abode of man. The extreme and fluctuating climatic changes which accompanied this remarkable phenomenon gradually supervened on a subtropical climate, and as gradually disappeared, not, however, without leaving profound traces on the contour of the country. The breaking up and final dispersion of the subtropical world of North Britain, by the intervention of what may truly be called an Ice Age, and the subsequent reversion to a more genial climate, together with the incoming of a new flora and fauna, are phenomena of absorbing interest to those who study the civilisation and environments of Palæolithic man. But they lie outside the scope of this work. Scotland was not a congenial home for prehistoric man until its icy mantle had given place to a covering of herbaceous growths, and its primeval glens and forests had become stocked with a numerous and varied fauna. Nor, on the supposition that the Ice Age consisted of a succession of alternately cold and genial periods, is this statement likely to be modified; for, among the organic remains hitherto found in its interglacial deposits, there are no indications of the presence of man. The gradual shrinking backwards of the ice-sheet is the most probable explanation of the fact that in Scotland and Scandinavia-localities where the ice lingered longest - remains of Palæolithic man have not been found. ${ }^{1}$ But

1 The Rev. Fred. Smith, Cromlix, claims to have discovered stone im. plements of Palæolithic types, manufactured from the ordinary quartzite 
although the field of our inquiry is thus lightened and limited by the exclusion of palæolithic controversies, we have still to go hand-in-hand with the geologist, whose deductions are often essential in determining the relative position of sporadic finds in the scale of chronological sequence. Thus, at both ends of the prehistoric period, the materials and methods of archæology interdigitate with those of the collateral sciences.

When the last ice-sheet dissolved, under the effect of a more genial climate, its nourishing rootlets remained as a series of local glaciers, at first filling the great glens, but gradually diminishing, till finally they disappeared altogether. This transformation carried in its train corresponding changes in the fauna of the surrounding seas, as well as of the land surface. So long as Scotland was enveloped in an ice-sheet, whose limits extended far beyond its present area, it is impossible to say what might have been the relative level of the land to the surrounding sea; but when the diminution of the ice allowed the water to come into contact with the land, we find the country submerged at least roo feet more than it is at the present time. The waters of this sea were inhabited by an arctic fauna, remains of which can still be detected in the marine clays then deposited on the shores. Icebergs, shed by the glaciers which protruded into the estuaries, and other floating ice, deposited morainic débris over the submerged area. As the lands in the interior became exposed to atmospheric agencies arctic plants took root on them, and the numberless hollows which studded the moraine profonde became converted into and schistose rocks of the district, in the river and coast gravels of the Tay, Forth, Clyde, \&c. The most suggestive specimens are water-worn pebbles which, he thinks, were used as implements, and subsequently transported from above the 50-feet sea-margins. See 'Brit. Association Report,' 1892, p. 896 ; and 'Phil. Soc. Glasgow,' 30th November 1898. 
lakelets, whose flora and fauna tell the same story of arctic conditions.

Concurrent with the amelioration of climate which followed the gradual disappearance of the ice, there is now a new element to be considered-viz., a process of land elevation which henceforth became an important factor in determining the physical environments of man. The result of this movement was that the land rose much above its present level. The British Isles became part of the Continent, and the arctic climate gave place to a temperate one-probably more genial than that of the present day. Great forests of oaks, pines, and other trees covered the country, and extended to latitudes and altitudes far above those in which a similar vegetation is now to be found. The extent to which the land rose is not accurately known, as it is difficult to make researches below the sea; but judging from the evidence supplied by the submerged forests, and the wide distribution of the post-glacial flora and fauna, it must have been adequate not only to join Britain to Europe, but to connect it with Ireland, the Hebrides, and other islands in the Atlantic.

While these changes were in progress, the deposits of clay, sand, silt, shells, \&c., which were left in the estuaries as the sea retired from the Ioo-feet level, became exposed to the ordinary disintegrating and denuding agencies. The large rivers and frequently flooded streams cut through them, washing away the finer ingredients and strewing the coarser gravel here and there at lower levels. As already mentioned, organic life was equally active in its varied manifestations, and culminated in the great forests of oaks and pines. How long this arborescent age continued it is almost impossible to say. The first check to its development seems to have been coincident with the commencement of another oscillation in the 
land the reverse of the former. The sea now again began to encroach on the land, and continued to do so until it reached 45 or 50 feet higher than it stands at present. This movement seems also to have been concurrent with a cold humid climate, favourable to the growth of peat and injurious to forest-trees; the upshot of which was the reappearance of valley-glaciers, which extended in some parts of Scotland down to the sea, as we find terminal moraines deposited on the 50-feet raised beach. The cold of this period was, however, not excessive, nor had it induced any marked change in the flora and fauna of the country. A partial destruction of the forests, caused chiefly by the increased growth of peat and a diminution of the altitudes at which they formerly flourished, are the principal changes to be noted. Professor James Geikie, to whom we owe so many advances in this department of research, makes the following remarks on the period in question: "That many of our mountain - valleys contained glaciers at this time cannot be doubted; but, had it not been for the fortunate circumstance that some of these glaciers reached the sea and deposited their moraines on the beaches of the period, we should probably have assigned all the valley-moraines to the closing stages of our epoch of district ice-sheets. We should, in short, have considered these later moraines to have been dropped during the final retreat of the valleyglaciers of the earlier epoch. . . . But the intercalation of the beach-deposits shows clearly that we are dealing with the detritus of a later and less important glaciation." 1

The 50-feet raised beach, which marks the turning-point of this post-glacial submergence, coincides with the maximum cold of the period. As the sea again began to retreat the country passed through climatic conditions analogous to those

${ }^{1}$ Great Ice Age, 3rd ed., p. 312. 


\section{4 CLIMATIC AND TOPOGRAPHICAL FEATURES.}

which obtained during the previous period of forest growths. I'hether this re-elevation of the land to the extent of 50 feet has been effected at a uniform rate, it is difficult to say, as about half-way in its progress there appears to have been a prolonged period of stagnation, now indicated on the land by the 25 -feet raised beach. Professor Geikie maintains that this beach was due to another cycle of depression and elevation, with corresponding changes in climate and forest growths. ${ }^{1}$ On what grounds he comes to this conclusion I am unable to ascertain. According to his own description of the successive geological phenomena observed in the estuaries of the Forth and Tay, I find no data for such an interval. The carse-clays, beneath which lies the forest-bed, correspond with the submergence which left behind it the "mud silt, clay, and sand, with beds of recent shells," which constitute the 50-feet raised beach. "When these carse-beds," he writes, "are followed down the valleys to the shores of the present estuary, the level of the carse-lands falls more or less gradually away to a height of 25 or $30 \mathrm{feet}$, and still lower terraces succeed down to the more recent alluvium." 2 I cannot see where in this sequence the deposits and phenomena of a still later glacial epoch come in, or how they are to be distinguished from the former? In my opinion the upheaval corresponding to the 25 -feet raised beach was due to a local earth-movement which had probably nothing to do with glacial phenomena. I have elsewhere ${ }^{3}$ attempted to prove that it took place during the interval since Neolithic man appeared on the scene, and some time prior to the occupation of the country by the Romans, and that it was contemporaneous with an opposite movement in the south of England and other localities.

1 Great Ice Age, 3rd ed., pp. 313, 61 2.

2 Prehistoric Europe, p. 400

${ }^{3}$ Arch. Journal, September 1898. 
In tracing more minutely the successive changes in the appearance of the country since the ice-sheet vanished, down to the development of the arborescent growths and their peculiar fauna, two sets of concomitant phenomena have to be observed. First, the change from an arctic to a temperate climate, with corresponding changes in the flora and fauna; and second, the alteration in the relative level of sea and land which transformed the British Isles from a series of semisubmerged islands of arctic sterility into part of a vast continent with a luxurious inland vegetation. At the beginning of this transformation, clays, sands, and gravels would be washed into all the hollows left on the surface of the moraine profonde; but as the ice melted away, and the surface-water became diminished, the rivers and streams would also become less muddy. The smaller lakes thus became stagnant pools of clear water, and even those fed by the streams had much less sediment washed into them. The vast reservoirs of spongy peat which now supply a perennial flow were as yet in an incipient stage. Such topographical and meteorological conditions were favourable to the development of a peculiar fresh-water fauna, which have left their remains to this day as shell-marl in most of the lakes of Western Europe. Ever since I began to study the phenomena of lake-dwellings, I have been struck with the number of settlements which had been founded immediately over the marl-deposits (zeisser Grund, blanc fond) of the Swiss lakes. Such was the case with the settlement of Moosseedorfsee. Mr Lee states that Dr Uhlmann, one of its investigators, informed him that many of the specimens of Limnaa palustris and L. stagnalis in the shell-marl were larger than those of the present day; and that it contained $L$. auricularis, and a species of Paludina now extinct in the smaller lakes. ${ }^{1}$ Immediately above the shell-

${ }^{1}$ Lake-Dwellings, 2nd ed., p. 36. 
marl deposits in Scotland, as well as on the Continent, comes the peat, often without any appearance of a transition stagea fact which may be partly accounted for by the latter spreading over the bottom of the lake from its margin. As a rule, the stratigraphical succession of lake-deposits, especially in the smaller lakes of this country, is first clay, then shell-marl, and finally peat-all reposing on glacial till or bare rock. Doubtless, we have in these successive strata a record of the climatic conditions which obtained in post-glacial times. The suggestion that the period of maximum development of the fresh-water testacea which produced the shell-marl deposits in Scotland correspond, chronologically, with that of the forest growths, is not, therefore, unreasonable. Small stagnant lakes of clear water, fed by calcareous springs, appear to have supplied the most favourable conditions for their development. The icy water of glaciers was too muddy, and probably too deficient in calcareous matter, to be a congenial habitat to these organisms. Nor do they appear to have successfully held ground against the steady increase of peat in the succeeding ages. Sir Charles Lyell states that marldeposits do not occur in countries whose geological formations consist of granite, gneiss, mica, slate, clay-slate, and greywacke, but are most numerous in sandstone districts, such as Forfarshire, where they are exceptionally abundant. ${ }^{1}$

From geologists we learn that in its main outlines Britain has not greatly altered since prehistoric times, and that its mountains, valleys, and river-courses have retained nearly the same relative positions during the whole of the post-glacial period. But it is the minor elements and their ever-changing combinations that furnish the most striking features in a landscape. The view from the Abbey Craig, when the school of whales got stranded on the slimy mud of the inland sea (see

${ }^{1}$ Geological Transactions, 2nd series, vol. ii. p. 79. 
chap. iii.) which then occupied the site of the present carselands, to the west of Stirling, would be as great a contrast to the primeval forest which subsequently took possession of the bed of the vanished sea, as either scene would be to the present condition of the Forth valley. Such variations in Scottish scenery are always more or less in progress, owing to the unceasing activity of their natural causes; but since man appeared on the scene still greater changes have taken place. One thing is certain, that without the hand of man these carse-lands would have still been covered with a vast peat-bog, such as they were a few centuries ago. The scenery which met the gaze of prehistoric man when he first wandered as far north contained neither stone-built houses, nor cultivated fields, nor trimmed hedges, nor roads, nor dykes. Human interference had not yet set bounds to the primeval forests which clothed the lower hills and the banks of the meandering rivers, nor fettered the roamings of their wild animals. Nature alone regulated the outcrop of the organic world, and the only check to the exuberance of life was the internecine contests of the various animals and plants which there struggled for existence.

\section{Arborescent Growths and Peat-bogs.}

The actual extent of surface covered by arborescent growths at any given time must always remain a matter of uncertainty. It is probable that it was long before man became an inhabitant of Scotland that the first great post-glacial forests spread over the country, as no human relics, to my knowledge, have ever been identified as belonging to that period. By the time man took possession of the country it would appear that the age of great forests had already passed its zenith, and that the trees were getting into a death- 
struggle with the peat which ultimately entombed many of them.

Since the last glaciers disappeared extensive surface changes have taken place in the valleys and river-courses. The areas of lake-basins have become contracted, and many of the smaller ones are now entirely obliterated, in consequence of aquatic growths and the amount of disintegrated materials carried into them through the agency of streams and floods: upland plateaux and hillsides have become carpeted with the decayed remains of successive crops of heather and other plants : the prostrate trunks of trees, which had succumbed either to storms or to the inevitable natural decay, initiated peat-bogs, and so transformed the soil that it no longer formed a suitable habitat for the recurrence of the same species. This is an important point in considering the phenomena of successive vegetations, as it partly explains the frequent changes that take place in this respect. In the fresh morainic débris of a glacier the Pine at once finds a congenial home, but with a slight amelioration of climate the Oak would as readily take possession of the same ground. Oak does not grow on peat, and when the peat-cutter encounters its roots he finds them invariably implanted in the virgin soil. But birch, hazel, alder, and Scotch fir are found in the upper deposits of peat, in succession to the buried oaks. Thus nature may be said to work on the system of rotation of crops, so universally practised by experienced farmers of to-day. On these principles the Danish antiquaries have shown that there has been a regular chronological sequence in the forests of their country, beginning with the Pines, which sprung up on the wane of the glaciers, then the Oaks, and lastly the Beeches. Nay more, they have attempted to correlate these successive forests with the three ages of Stone, Bronze, and Iron. ${ }^{1}$

1 See 'Lyell's Antiquity of Man,' p. 9. 
As evidence of the scenic and organic changes thus effected we can still point to the stools of huge trees, at the bottom of extensive tracts of moorland peat, in localities where not a vestige of a living forest is now to be found. Early in June 1897, while staying at the Carrick Hotel in the west of Donegal, I became greatly interested in the remains of one of these ancient forests which had been exposed by peat-cutters on the hillside to the east of the hotel, and overlooking the Atlantic Ocean. Here the stumps of huge trees in situ, chiefly pines and oaks, could be counted in hundreds, and were as fresh looking as if they had been of a comparatively recent growth. The peat reposes on the original glacial débris of the metamorphic rocks of the neighbourhood, in which these widespreading roots had taken a deep hold. I could find no evidence of two forests, an upper and a lower, but occasionally the contorted roots of stunted shrubs were to be seen half-way up in the sections. Similar remains of forests may be seen in nearly all the glens of that neighbourhood. At the present time small shrubs and willows grow in the district, but only in the vicinity of houses.

Those who are conversant with phenomena of this kind, so abundantly met-with over the British Isles, especially in districts where peat-cutting is still carried on, as between Shapwick and Glastonbury in England, Lochar Moss in Scotland, and the Bog of Allen in Ireland, may regard further evidence on this subject as superfluous. However, for the benefit of those who are denied these outdoor privileges, the following extracts from old documents, selected almost at random from a large number of similar records, may be interesting :-

"It may be a matter of surprise," says a writer on North Uist," 1 that though no trees now grow at present in this 1 Sinclair's Stat. Account of Scotland, vol. xiii. p. $3^{2}$ I. 
parish, the time has been when the whole face of it was covered with wood. The truth of this assertion is evident from the circumstance that the roots of trees are found in peat-mosses in different parts, and even below high-water mark : where the sand is washed away by the sea or blown away by the wind they plainly appear in a kind of black soil, or rather moss. This is the case particularly in the island of Vallay." After expressing the opinion that the spray of the ocean prevents the growth of forests at the present time, he continues thus: "Though it is evident that the island was once covered with trees, it must have been at a period when the ocean was at a greater distance -that is to say, when the land extended a great deal farther to the westward."

The topographical conditions, on which this writer so judiciously comments, existed when Great Britain, Ireland, and all these western islands, formed part of the continent of Europe. The presence of deer-bones in the peat, as mentioned in an unquoted portion of the same article, and of most of the present flora and fauna of the island, can only be accounted for on the supposition that the British Isles were formerly the central parts of an extensive land area now submerged.

Another writer describes analogous phenomena on the mainland of Scotland as follows: "Of old in the parish of Croy, Inverness-shire, and before the records of the kingdom, there were extensive forests of oak, birch, fir, and hazel, which have been converted into moss, in some places upwards of 20 feet deep. In a moss 400 feet above the level of the sea, oaks of extraordinary size are dug up, some of them measuring from 50 to 60 feet. Where the parish joins the Strathdearn hills large blocks of fir are found, where now, from cold and storm, the 
dwarf willow can scarcely raise its downy and lowly head." 1

A moss in the parish of Kilbarchan, Renfrewshire, from 7 to 9 feet in depth, is thus described: "The soil below is a deep white clay, where has formerly been a forest. The oak is perfectly fresh; the other kinds of timber are rotten. The stumps in general are standing in their original position. The trees are all broken over at about the height of 3 feet, and are lying from south-west to north-east. So, whenever you see a stump, you are sure to find a tree to the northeast. How an oak-tree could break over at that particular place I never could understand. But we may be allowed to form a conjecture, that before the tree fell the moss had advanced along its stem and rotted it there." 2

Sir John Clerk ${ }^{3}$ in one of his letters thus refers to magnificent oaks found at Drumcrief: "Here in a mosse of small extent, I believe 40 or 50 fathoms at least above the level of the sea, I saw the finest oak my eyes ever beheld. It lay 6 feet under the surface, straight, and above 70 feet in length, all fresh from the root to the top, though it no doubt had lain there $\mathrm{I} 500$ years; near to it were a great many other oaks, and above, near the surface, a whole wood of birch trees, which have grown up after the catastrophe of the oaks."

Mr Aiton, ${ }^{4}$ in an excellent introduction to his treatise on moss earth, says: "Trees of enormous dimensions have grown spontaneously in many parts of Britain where it would baffle the ingenuity of man to rear a tree of the tenth part of the size. The mosses in all parts of the island

1 New Stat. Account, vol. xiv. p. 449.

2 Old Stat. Account, vol. xv. p. 484 .

3 Reliquiæ Galeanæ, p. 333.

4 A Treatise on the Origin, Qualities, and Cultivation of Moss Earth, I8I I. 
abound with trees of much greater dimensions than any now to be found growing in this country." In support of this statement he instances a number of huge trees dug up from peat-bogs in various localities throughout Scotland.

In a letter dated November 19,1701 , in the 'Philosophical Transactions' (vol. xxii. p. 980), describing a buried forest exposed when Hatfield Moss (Chace), Yorkshire, was being reclaimed, the author, Mr Abraham de la Pryme, after mentioning various trees, firs and oaks, from 20 to 35 yards in length (one oak was 120 feet long, 12 feet in diameter near the root, and II feet in the middle), thus writes :-

"It is very observable, Sir, and manifestly evident, that many of those trees of all sorts have been burnt, but especially the Pitch or Firr trees, some quite through, and some all on a side; some have been found chopped and squared, some bored through, otherwise half riven with great wooden wedges and stones in them, and broken ax-heads, somewhat like sacrificing axes in shape, and all this in such places, and at such depths, as could never be opened from the destruction of this forest, until the time of the drainage. Near a great root in the parish of Hatfield were found 8 or 9 coins of some of the Roman Emperors, but exceedingly consumed and defaced with time; and it is very observable that upon the confines of this low country, between Burningham and Brumby in Lincolnshire, are several great hills of loose sand, which, as they are yearly worn and blown away with sand, are discovered under them many roots of great Firrs or Pitch trees, with the impresses of the ax as fresh upon them as if they had been cut down a few weeks, which I have several times with pleasure taken notice of, as I have rid that way.

"Hazle nuts and acorns have frequently been found at 
the bottom of the soil of those Levels and Mores, and Firr or Pitch tree apples or cones in great quantities by whole bushels together. And at the very bottom of a new river or drain, that the drainers cut, were found old trees squared and cut, rails, stoups, bars, old links of chains, horse-heads, an old ax somewhat like a battle-axe, two or three coins of the Emperor Vespatian, one of which I have seen in the hands of Mr Cornelius Lee of Hatfield, with the Emperor's head on one side and a spread eagle on the other; but that which is more observable is, that the very ground at the bottom of the river was found in some places to lye in Rigg and Fur, manifesting thereby that it had been plow'd and tilled in former days.

"That which is also very strange, is that about 50 years ago, at the very bottom of a turf-pit, was found a man lying at his length, with his head upon his arm, as in a common posture of sleep, whose skin being as it were tann'd by the More Water preserved his shape entire, but within, his flesh and most of his bones were consumed and gone, an arm of whom one of the workmen cut off, and brought home to his master, which is now in the possession of my honoured friend and great antiquary Dr Nat. Johnson, whose antiquities of this county are earnestly expected by all ingenious men."

The opinion of the writer was that the Hatfield forest had been destroyed by the Romans, and that the prostrate stems and branches of the trees, by preventing the flow of water, had converted the locality into a peat-bog. Among other examples of great trees buried under peat and associated with the remains of human industry, he instances (loc. cit., p. 984) the following: "Dr Leigh (in his late learned and ingenious history of Cheshire) observes that in the draining of Martin Meer (which was performed but a 
few years ago) was found multitudes of the roots and bodies of great Pitch trees commonly called Firrs, in their natural postures, with great quantities of their cones, 8 canoes, such as the old Britons sailed in; and in another More was found a brass kettle, beads of amber, a small millstone, the whole head of an Hippopotamus, and human bodies entire and uncorrupted, - I suppose he means to outward appearance."

The Orkney and Shetland Islands are at the present time absolutely destitute of woods or trees of any kind; but yet we are informed, on trustworthy authority, that decayed timbers of considerable size are frequently found in the peat-bogs on these islands. In June 1896 , while on a short visit to Shetland, I made an excursion to an extensive peat-moor in the vicinity of Lerwick for the purpose of satisfying myself on this question. The peat-deposits in this locality have been utilised as fuel by the inhabitants of Lerwick from time immemorial, and so I had no difficulty in finding numerous sections exposing the structure of the peat down to the virgin clays. These showed two distinct layers, a lower and an upper, of nearly equal thickness. The former was a black, dense, heavy material, which, when cast into peats and dried, looked almost like a piece of coal ; the latter was a spongy, fibrous substance, of a brownish colour, with a tendency to lamination. Between these different deposits I noticed in several places an aggregation of the remains of shrubs, and also beneath the lower bed. The bogwood was much decayed, and looked like scraggy contorted stems and roots of stunted hazel or willow. The largest pieces I found measured only 14 and I 6 inches in circumference. I visited another peat-bog on the road to Scalloway, where peat-cutting was going on; but there I could find no trace of wood in the sections, 
although the two qualities of peat were much the same as in the former.

Mr George Low, ${ }^{1}$ more than a century ago, puts on record the following observations on this subject: "Crossed the Parish of Delting, thro' deep moss grounds, for Yell. Observed near the kirk of Scalsta, in the bank where the sea had wore away the earth, a continued stratum of large pieces of wood, in a horizontal position, a few inches above the hard gravel, covered with about ro feet of moss. This stratum is continued as far as I could search the whole length of this worn bank, and, probably, round the bay; it consists of pieces from 8 inches to half an inch in diameter, roots, stocks, and, in a word, all parts of a tree; seems Hazel and Aquatick woods, but so much rotten that no part can be moved. This, however, is a proof of trees having been here at some period, but this seems to have been very ancient, if we compute from the vast disproportion there is between the thickness of moss below the stratum with that above, and at the same time consider the length of time the latter would require to grow, both in height and solidity, both which it has in a great degree, particularly towards the bottom. The horizontal position seems to indicate that they have all fallen at the same time, or have subsided after some terrestrial convulsion, a partial or universal flood; but however this is, are a plain proof of wood having been here of old, and might be a lesson to the inhabitants to enquire what woods are fittest for, and would be most valuable in, their country."

While the existence of bogwood in the Outer Hebrides, and in the Orkney and Shetland Islands, demonstrates the wider geographical distribution of forests in former times, its presence in the peaty uplands of the mainland is equally

1 Tour thro' Orkney and Shetland, 1774, p. 146. 
conclusive as to the greater altitudes at which they flourished. The most stunted Scotch fir at the present time rarely grows above 1800 feet above sea-level, but in the peat-bogs its roots are found up to 3000 feet, as has been observed at Glenavon, ${ }^{1}$ Banffshire, and other localities.

The inferences to be derived from these and similar observations on peat-bogs and their buried forests, throughout Scotland, are somewhat conflicting. There can be no doubt that the climatic conditions which permitted oaks to flourish on the uplands of Scotland, and trees of considerable size to grow in the Orkney and Shetland Islands, where scarcely a stunted shrub is now to be seen in a wild state, were more favourable to the growth of forest trees than those which now obtain. On the other hand, the large pines found in some of the Lowland mosses would seem to indicate a colder climate. The probable explanation of this is, that the pines and oaks, though sometimes found associated in the same bog, belong to slightly different periods of time:

\section{Chronological Data.}

Nothing, in my opinion, can be more certain than that an extensive forest of oaks and other trees sprang up after the sea retreated from the valley of the Lochar and the Carse of Stirling, and that both of them subsequently succumbed to the growth of peat. In the south portion of Lochar Moss I have seen stems and trunks of oak-trees which grew on the subjacent marine clays. Farther inland, where the marine deposits are light and gravelly, the roots of the fir are said to be more abundant-a difference which is readily explained by the nature of the deposits, the oak preferring a clayey soil. These facts are in accordance with the experience of peat-

1 Old Stat. Account, vol. xii. p. 45 I. 
cutters and others who have recorded their observations from practical knowledge. Nor can there be any doubt that a forest preceded the formation of the Blair Drummond Moss in the Carse of Stirling. A wooden roadway, exposed in the early part of this century, is thus described: "The mosses preserved the remains of an ancient forest chiefly of oak-trees, which had occupied the plain but little above the surface of the river during ordinary floods, part whereof appears to have been lower and marshy, across which a road had been formed of trees laid longitudinally, with a second laid transversely. The depth of Blair Drummond Moss (in which this road occurs), prior to the operations, was 8 feet, extending to 14 towards the upper extremity. Some of the roots of the trees were very large, and occupied their natural position in the soil, their trunks being extended horizontally, many retaining distinct impressions of the axes employed in felling them-an operation commonly referred to the period of the Roman conquest." 1

The surmise that this wooden pavement was part of a Roman road is not at all improbable, and if this could be substantiated it would disprove the theory advanced by Sir Archibald Geikie and others, that the 25-feet raised beach had been formed since the Romans visited Scotland. ${ }^{2}$ That these peat-deposits in the Forth and Lochar valleys, as well as those of the Cree, Solway, and others within the 25 -feet zone of submergence, are comparatively recent, there can be little doubt from the evidence of man's presence in the localities long before their formation. A bronze caldron (fig. 1), now in the National Museum, was discovered in the Kincardine Moss in 1768 "upon the surface of the clay buried under the moss." It is made of thin plates of

1 Mem. Wern. Soc., vol. v. p. 426.

2 Edin. New Phil. Journal, vol. xiv. p. 102. 
bronze riveted together-the rounded bottom portion being shaped from one plate-and measures 25 inches in diameter and 16 inches in depth. The everted rim, which is formed of a couple of bands of sheet-bronze fastened to the upper edge of the vessel, bears marks of the rivets by which a pair of ring-handles had been attached. Another caldron

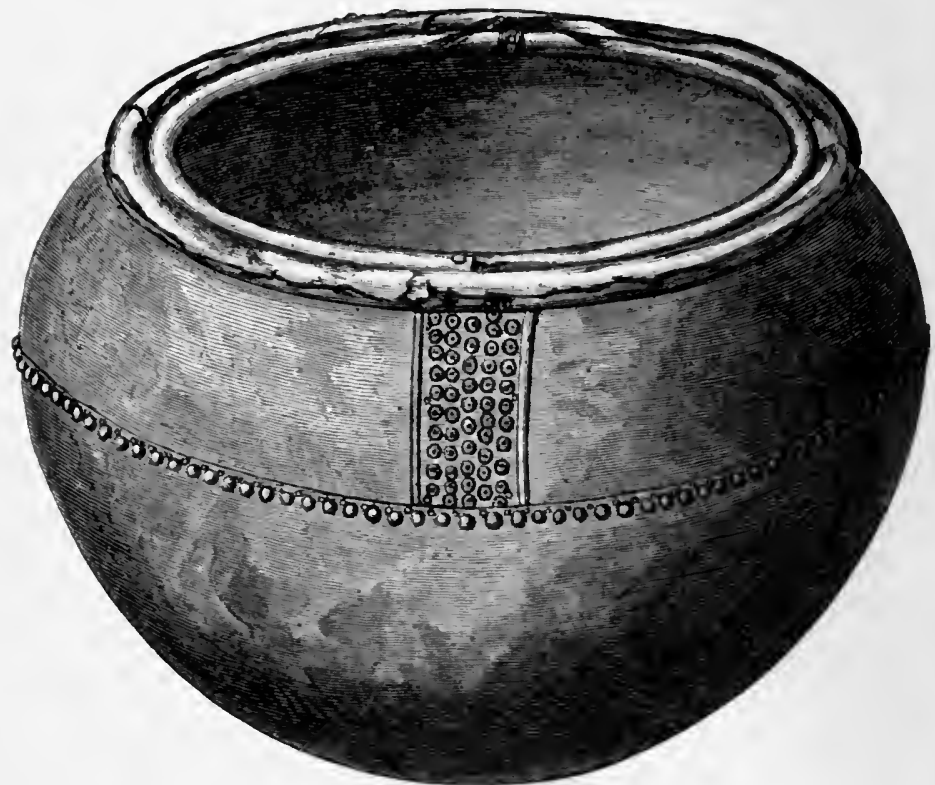

Fig. 1.-Bronze caldron found in the Moss of Kincardine $(25$ inches diameter).

(fig. 2) of the same type, said to have been found in the west of Scotland, is also in the National Museum. ${ }^{1}$ A third caldron (fig. 3), showing the same style of workmanship, but differing from the former in being bucket-shaped with a flat bottom, was found at Cardross, in a small camp on the north-west corner of Flanders Moss, in the valley of

${ }^{1}$ Proc. Soc. A. Scot., vol. xix. p. 315. 
the Forth. ${ }^{1}$ The globular- and round-bottomed forms are more commonly met with in the British Isles, whereas on the Continent the reverse of this is the case. Both kinds have, however, been found on the Oppidum La Tène. (See 'Lake-Dwellings of Europe,' p. 290, and fig. 92, Nos. I 8 and r9.) These vessels appeared in Britain in pre-Roman times,

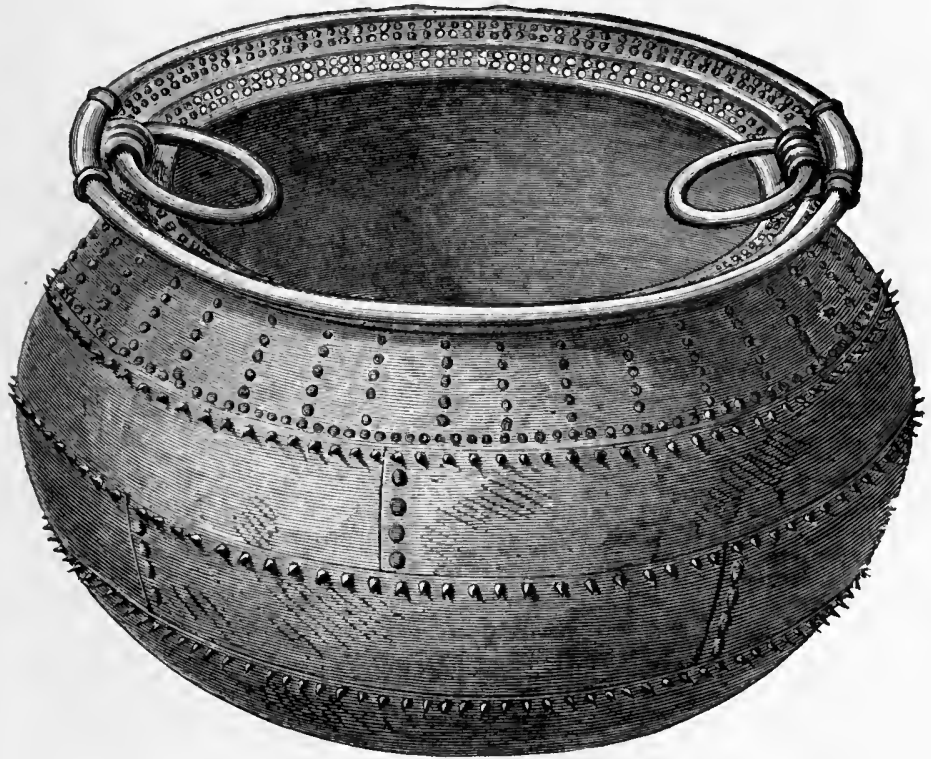

Fig. 2.-Bronze caldron from the West of Scotland (25 inches diameter).

probably in the late Bronze or early Iron Age; but nevertheless the Kincardine caldron might have been a "Roman camp-kettle," as described in the Museum list of 1782 . It was apparently abandoned in the depths of a forest, which had already shown symptoms of decay, and ultimately got covered over with the growing peat.

1 Proc. Soc. A. Scot, vol. xxii. p. 37. 
Another beautiful object of the Late Celtic period was found in Lochar Moss inside a bronze bowl (fig. 4). This is a beaded torque, consisting partly of ornamented beads and partly of a solid portion elegantly chased with. a pattern of "late Celtic" design.1 Other relics reported to have been found in buried forests have already been mentioned; and it may be observed that all of them, so far as the circumstances of their discovery can now be recalled, support the theory

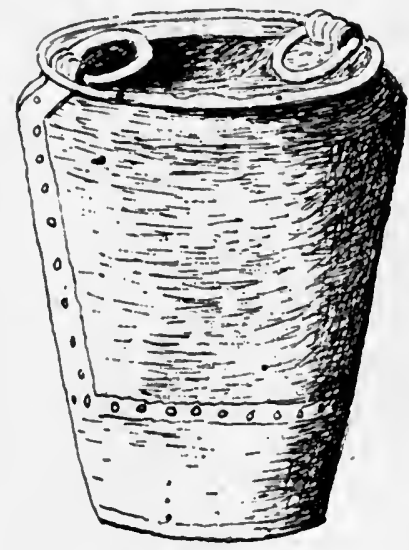

Fig. 3.-Bronie caldron (19 inches in height) found at Cardross. that man was an eyewitness of the successive transformations of sea, forest, moss, and wheatlands which have taken place in the Carse of Stirling. If the facts regarding the Culzean hoard (p. 77 ) be of any value, the sea had not retired in the early Bronze Age much beyond the 25 -feet level. But this evidence could be entirely negatived on the supposition that a severe storm would suffice to throw up gravel on a gently shelving beach to that height. That the relative level of sea and land during the Bronze Age was not much different from what it is at the present time is proved by the position of a small cemetery of the Bronze Age found at Magdalen Bridge, near Joppa, and described by $\mathrm{Mr}$ W. Lowson. ${ }^{2}$ The surface of the ground was only I 2 to I 4 feet above high-water mark. On the top was ordinary soil, and beneath that a layer of sea-sand, 4 to 8 feet thick (in which urns and a bronze blade were found),

1 Wilson's Preh. Annals, vol. ii. p. 140; Plate IX. vol. i. p. 465.

2 Proc. Soc. A. Scot., rol. xv. p. 419. 
resting on a bed of gravel. This conclusively shows that the sea had then retreated to near its present limits. During Roman times it would appear that the sea had forsaken the Carse of Stirling and Lochar Moss sufficiently

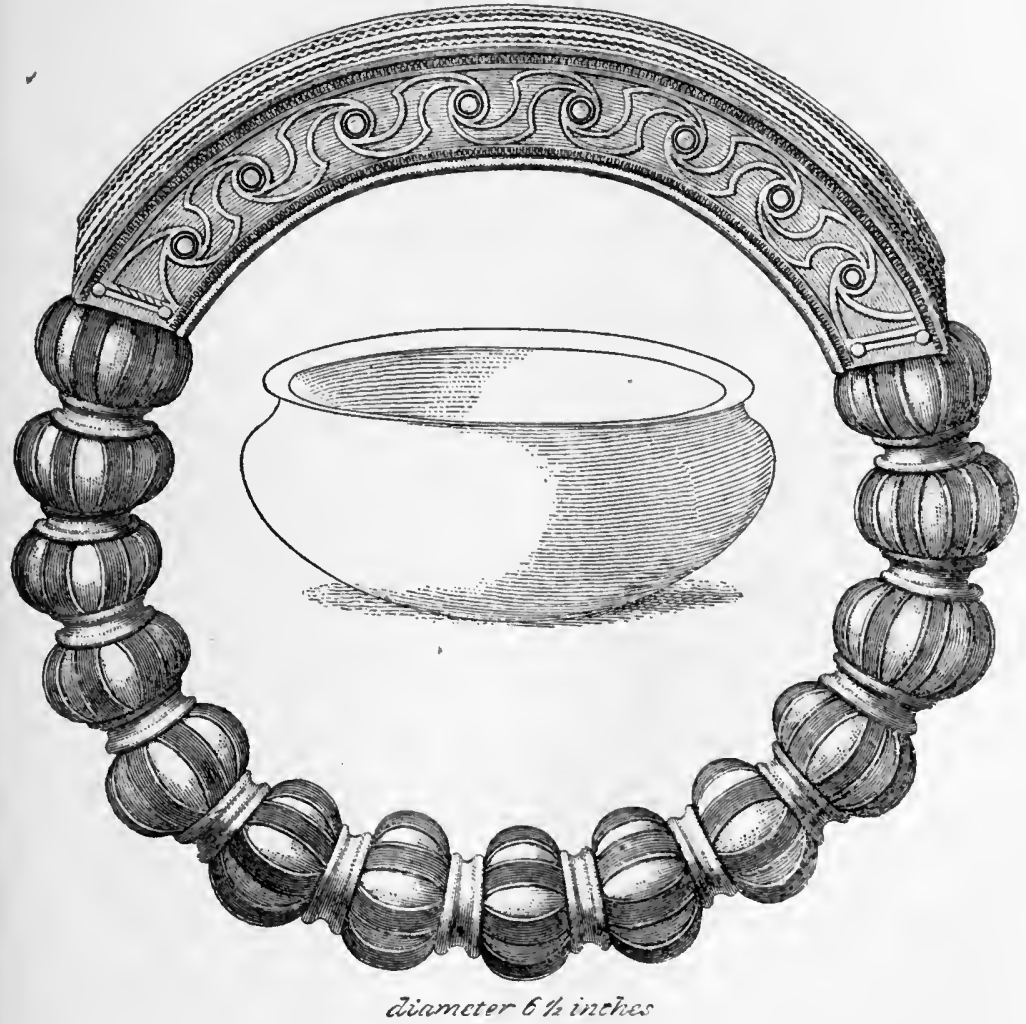

Fig. 4.-Bronze beaded torque and bowl found in Lochar Moss.

long to admit of forests to grow on areas which in Neolithic times had been sea.

Outside the 5 o-feet zone of submergence the older and newer peat-deposits cannot be readily distinguished, as the two periods are in a certain measure continuous; but within 
it they are often separated by beds of clay, as may be seen in the valleys of the Forth and Tay. ${ }^{1}$ It is possibly to the older forest-bed that many of the large trees found in the Cree, and described by Sir Arthur Mitchell, must be assigned. He has recognised their existence in "two distinct positions"-one "on the surface of the clay," and the other in the channel of the river, with "from ro to 15 feet of sandy clay" above them (see p. 69). It is also probable that many of the great oaks found in peat-bogs, as well as the pines in the higher altitudes, belong to the same older period.

Many of these consecutive changes on the earth's surface are as legible to the geologist as the seasonal indications of flowering-plants, autumn tints, and snowy wreaths are to the country peasant. They are indeed hour shadows on the dial of time. Like the dies and the annus, the intervals between one ice age and another were measured by precise movements of the heavenly bodies; and they had their consecutive phases - dawn, noon, and evening - distinguished in the book of Nature by concurrent phenomena in the physical and organic environments. The evolutionary phases, which preceded the vegetative garb, now clothing the rugged contour of our country, are also valuable factors in deciphering the history of past ages. But space will not admit of discussing this interesting subject at greater length.

To whatever causes the disappearance of the great forests may be assigned, there can be no doubt that North Britain was more extensively wooded in prehistoric times than at the present day. Roman historians agree in representing the climate of Britain as humid and favourable to luxuriant vegetation, and sufficiently mild to permit of the natives going about in a semi-nude condition. Cæsar states that all

1 Geikie, Great Ice Age, 3rd ed., p. 291. 
kinds of trees grew on it, with the exception of the fir (silver fir) and the beech, and that its climate was more temperate than that of Gaul. Tacitus also describes the climate of Britain as always damp with rains, and overcast with clouds, without, however, the cold being extremely rigorous. $\mathrm{He}$ speaks of cutting down woods and draining bogs; and represents the natives, when beaten, as flying for shelter to the woods and marshes. Another writer (Dio Cassius) describes the Caledonians as dwelling in tents, naked, and without shoes; enduring hunger, cold, and all manner of hardships with wonderful patience; and capable of remaining in bogs for many days immersed up to the neck, and without food. In the woods they lived on the bark of trees and roots, and had a sort of food always ready, of which, if they took but the quantity of a bean, they would be neither hungry nor thirsty for a long time after. Herodian describes them as going about partially naked to prevent the beautiful figures painted on their bodies from being hidden. According to him, they wore neither coat of mail nor helmet, to prevent them being encumbered in their marches through bogs and morasses-whence such a quantity of vapours was exhaled that the air was always thick and cloudy.

According to tradition and the annals, the Romans are credited with being the prime movers in the destruction of the British forests; and certainly the quoted extract, about the drainage of Hatfield Moss, supports that view. But however destructive they may have been on the forests, while clearing a way for their legions, it is impossible to assign to this agency more than a nominal value. Forests have equally disappeared in countries and districts never visited by the Romans. That the natives themselves partly contributed to the clearance of the woods and jungles, as they became habituated to the systematic tillage of the land, is 
probable. But whatever may have been the real agency of their destruction, - whether the growth of peat, the variation of climate, or the hand of man,-the change was not effected all at once. The numerous place-names, such as Woodlands, Woodend, Woodside, Linwood, Fulwood, Oakshaw-side, Oakshaw-head, Walkingshaw, \&c., \&c., prove that the south of Scotland was well wooded after the Saxon language had ousted the Celtic. On the other hand, in medieval times wood was becoming scarce. Cosmo Innes thus alludes to the subject: "At the earliest period illustrated by the Melrose Charters there is sufficient evidence that the southern division of Scotland was not a well-wooded country. On the contrary, the right of cutting wood was carefully reserved when pasturage or arable land was granted; and when that right was conceded for some particular purpose, such as for fuel for a salt-work, or for building, the use was limited in express terms. The high grounds of Ayrshire may be an exception, where there seems to have existed an extensive forest; but elsewhere wood was a scarce and valuable commodity." 1

1 Sketches of Early Scottish History, p. 100. 


\section{CHAPTER III.}

ALTERATIONS IN THE RELATIVE LEVEL OF SEA AND LAND SUBSEQUENT TO THE APPEARANCE OF MAN IN SCOTLAND.

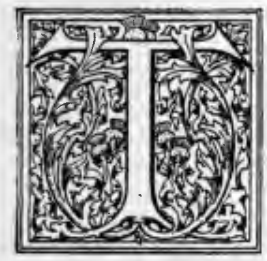

HAT there is a remarkable parallelism between the repeated land-submergences and the glacial epochs, as partially described in the last chapter, has been frequently pointed out by geologists. The most probable explanation of this coincidence of two apparently independent phenomena is that they were the effects of one common cause-viz., cosmic or astronomical cycles. But the operation of such causes would not destroy the effects of other agencies capable of altering the relative level of sea and land. The result of a local -i.e., terrestrial-element coming into play, synchronously with a cosmic movement, would be either to intensify the action of the latter, if they were acting in one direction, or to counteract it, if in opposite directions. The 25 -feet raised beach in Scotland may, therefore, be accounted for on the supposition that while the land was gradually rising in obedience to an astronomical cause, it became arrested by a terrestrial movement of depression, the apparent result being a cessation of all movement. But my object is not 
to explain the physical causes of land oscillations, but to chronicle their existence and effects on the career of man. Without, therefore, taking into consideration local volcanic disturbances, such as Sir Charles Lyell describes as having occurred at Puzzuoli since the temple of Jupiter Serapis was built, there are other obscure land oscillations whose effects have to be investigated. The first evidence of this nature which falls to be discussed is that which proves that the shore-lands of Scotland have risen some 25 or 30 feet since Neolithic man appeared in Central Scotland. As the facts on which this conclusion is based are derived from sources of investigation which have little or no connection with each other, there is no necessity for marshalling them in any particular order. Accordingly, I begin with one of the most recent discoveries bearing on this subject, viz. :-

\section{The MacArthur Cave and Rock-Shelter at Oban.}

The MacArthur Cave was discovered in December 1894 by quarrymen while removing stones, for building purposes, from a cliff facing the bay of Oban, long regarded by geologists as marking the line of an old sea-beach. In the course of these operations a cavity was exposed in the rock which turned out to be a cave 25 feet long (north to south) and from 16 to 20 feet broad. This opening was made near the back of the cave, but its natural entrance, which had been most effectually concealed by an old talus of earth and stones, was at the other or north end. Before the discovery came under the notice of the Society of Antiquaries of Scotland, the whole of the roof had been removed by the quarrymen; but as the floor, already ascertained to be an accumulation of relic-bearing débris, remained practically undisturbed, it was decided by the Council of the Society to have it thoroughly 
excavated. A full report of the investigation was read at a meeting of the Society- $r$ ith March 1895 -by Dr Joseph Anderson, who, with the co-operation of a number of local gentlemen interested in the antiquities of their neighbourhood, superintended the excavations.

The contents of the cave consisted, first, of a layer of black earth, the presence of which was accounted for by a slanting shaft filled with a similar material, which extended from the wall of the cave to the surface of the ground above. This shaft was formerly an open-air passage, by means of which, it was conjectured, surface-soil had been washed into the interior of the cave. In this layer, besides the bones of various animals, the following human remains were found, the relative positions of which are thus stated: "Towards the back of the cave, and under a projecting part of the roof which remained on the east side, a human skull was found on the surface of the black earth. A few feet farther north, on the same side of the cave, another skull was found embedded in the black earth, almost on the top of the shell-bed underneath. Still farther north, and only a few feet distant, were a good many other bones of a human skeleton. Two lower jaws were also separately found near these remains on the same side of the cave."

Professor Sir William Turner gave a report on these human remains, but it is unnecessary here to dwell on their special characters, as, from their superficial position in the cave, their owners had probably no relationship with the cave-dwellers who left the implements and weapons among the subjacent deposits.

The next deposits in descending order are thus described: "It was found that underneath the layer of black earth there was a bed of shells, varying from 27 inches to about 3 feet in thickness, extending over the whole floor of the cave, and 
showing little or no intermixture of black earth or gravel, but here and there patches of ashes mixed with wood-charcoal, and charred splinters of bone. Under this shell-bed was a bed of fine clean gravel, composed entirely of small waterrolled stones. In this gravel, at a depth of about 18 inches (where the section was first made), there was intercalated a deposit of shells, which we at first spoke of as the lower shellbed, but which proved to be of partial extent and unequal thickness, thinning out towards the sides and towards the mouth of the cave, and in several places presenting an irregular or patchy appearance in the section, as if the shells had been deposited in heaps or pockets in the gravel. Underneath this intercalated layer of shells the gravel extended for about 4 feet or more to the cave bottom, where it was mixed with large and small fragments of loose rock. The whole thickness of the gravel-bed under the upper deposit of shells was thus about 6 feet, including the intercalated lower deposit of shells."

Both the upper and lower shell-beds were composed of the shells of edible species found on the neighbouring shores and of the bones of land and marine animals, the entire mass being a true refuse-heap, evidently the result of a lengthened occupation of the cave by people who fed on the fauna represented in it. The bones were, for the most part, broken into splinters both for the purpose of extracting the marrow and of manufacturing bone implements, of which a large number was collected.

All the implements recovered were made of bone or deerhorn, with the exception of three hammer-stones, and twenty flints (three being natural nodules), mostly flakes and chips, "a few of which show secondary working, though none are really implements in the sense of being fashioned and finished." 
The bone and horn implements consist of three pins (fig. 5); three borers (fig. 6), together with a few bones of nondescript characters, being merely pointed or flattened at the end; I 40 " round-nosed, chisel-ended implements having an extraordinary likeness to each other" (figs. 7, 8, 9, and Io); and seven harpoons (two being entire) made of deer-horn. The larger of the entire harpoons (fig. I I) (6 inches in length)

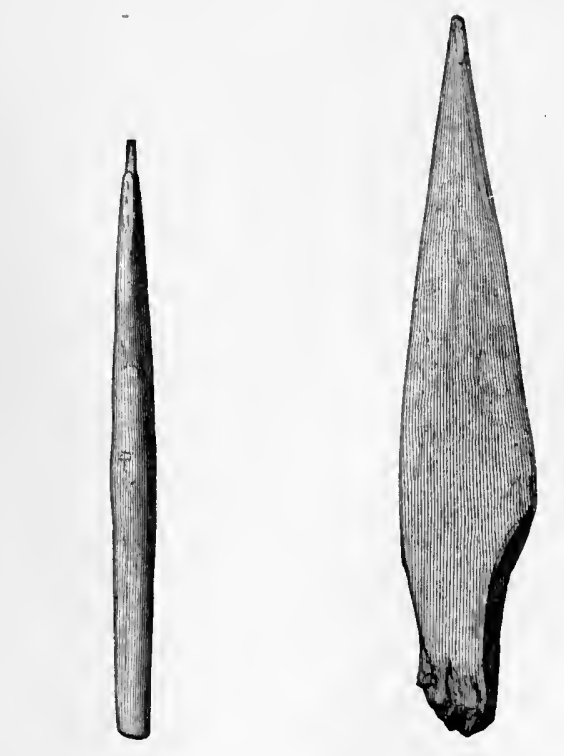

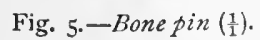

Fig. 6. - Bone borer (1).

has four barbs on each side and a perforation at the buttend. The other (fig. I 2) differs from it only in being smaller ( $4 \pi / 4$ inches in length) and having no perforation at the butt-end.

The animal remains from the respective deposits were identified by $\mathrm{Mr}$ James Simpson, assistant to Sir William Turner, as follows:-

"(I) In the upper layer of black earth were bones or teeth 
of the red-deer and of a species of ox, also of the pig, dog, and badger (Meles taxus). Some bones of birds, fish, claws of crabs, and shells of patella, solen, and whelk were recognised.

"(2) In the shell-bed underneath the black earth, in addition to bones of badger, red-deer, and ox, a part of the jaw of a roe-deer ( $C$. capreolus) was recognised; also bones of small

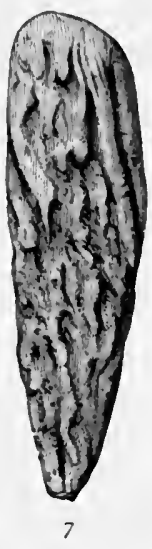

Figs. 7, 8, 9. -Implements of bone and decr-horn (1).

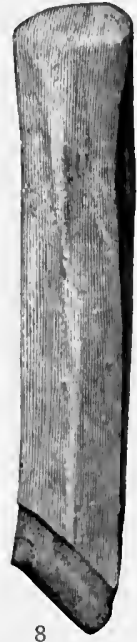

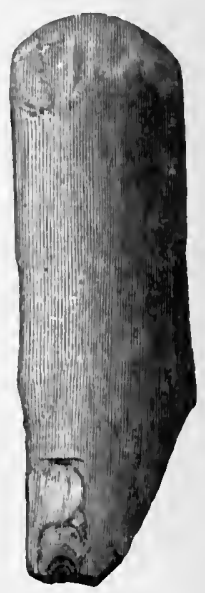

9

birds and of fish, claws of crabs, and shells of patella, pecten, and solen.

"(3) In the deeper shell-bed and pockets underneath the gravel below No. 2 were portions of two frontal bones of an ox, probably Bos longifrons, antlers, and bones of red-deer, one of which had been a large stag, the burr being $80 \mathrm{~mm}$. (about 3 inches) in diameter, bones of roe-deer, the humerus of an otter (Lutra vulgaris), the humerus of a cat, the lower jaw of a young pig, the upper jaw of a badger; also bones of small birds, jaw and vertebra of fish, crabs' claws, and shells of 
molluscs. Some of the bones were blackened and calcined from the action of fire."

It is fortunate that the record of archrological phenomena

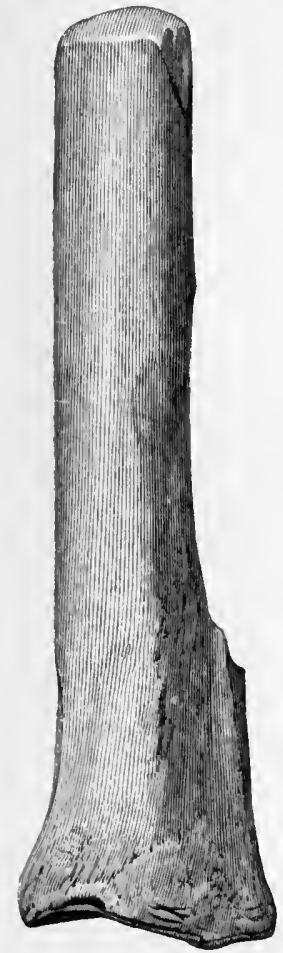

Fig. 10.-Bone implement made of the leg.bone of a $\operatorname{deer}\left(\frac{3}{4}\right)$.
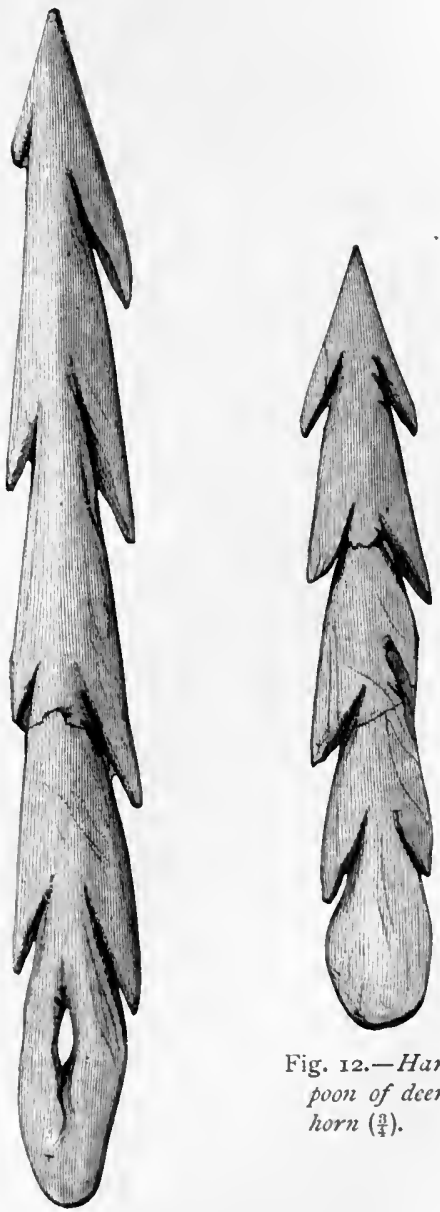

Fig. 12. - Har. poon of deer.

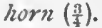

Fig. II.-Harpoon of deer-horn (多).

found in this cave fell to be described by such experienced and accurate observers as Sir William Turner, Dr Anderson, 
and $\mathrm{Mr}$ J. H. Cunningham, C.E. (the last having made a plan of the cave and determined its height above the Ordnance datum line), as the conclusions arrived at with regard to the relative level of sea and land, then and now, are of exceptional importance.

Dr Anderson, after discussing with great clearness and precision the possibilities as to how the upper and lower shell-beds became separated by a layer of sea-gravel, leaves it undecided whether it was deposited by the action of the waves after man had taken up his abode in the cave, or, as he suggests, was due to that of man himself incidentally treading down the gravel previously heaped up in it. "There is," he writes, "no absolutely decisive evidence for either of these suppositions : and even though my objection be found to have little value, there is no escape from the conclusion that, if the upper gravel was washed into the cave after its occupation by men, it must have been during or subsequent to Neolithic times, for archæologically the fauna and implements of the cave must be classed as Neolithic at the earliest." I need hardly observe that the acceptance of Dr Anderson's. hypothesis, as an adequate explanation of the phenomena in question, would entirely eliminate the chronological problem from the field of discussion. But in my opinion this hypothesis is untenable, for the very cogent reason that it fails to explain the facts. Morever, the alternative view, so forcibly described by Dr Anderson that in reality he is its advocate, is not only consistent with archæological deductions derived from other sources, but offers a natural and probable explanation of the entire set of phenomena.

With respect to the inadequacy of the treading-down process to account for the presence of the upper layer of gravel, it is only necessary to make an effort to picture to the mind's eye any conceivable modus operandi by which this could be 
effected to be convinced that the hypothesis must be abandoned as unpracticable. When the upper shell-bed was cleared off we are told that there was exposed beneath it " a layer of clean washed gravel or small-sized pebbles extending over the whole floor of the cave," underneath which, at a depth of from 6 to 18 inches, was embedded a lower shell-bed. Now is it probable, or indeed possible, that this intermediate layer of clean washed gravel had been so placed by the tread of the people who from day to day frequented the cave, and here cooked and ate their food, throwing the refuse anywhere around them? This treading process must have gone on, even to a greater degree, from the very beginning of the occupancy of the cave, and consequently the gravel would become mixed more or less uniformly with the shells; but we have no evidence to show that any intermingling of this kind had taken place in the upper gravel. Again, while we would expect to find the gravel largely mixed with the shells at the bottom, and becoming less so as the accumulation increased, it is inconceivable that any unintentional treading would spread over the whole shell-heap a clear bed of gravel, nowhere less than 6 inches in depth. Besides, we must bear in mind that this lower shell-bed "was mixed with broken bones of animals," and contained "the same shells and bones of the same animals," as well as "the same varieties of bone implements," as the upper shell-bed. The only distinction between them was that the shells and bones of the former "were more decomposed and friable" than those of the latter. Also the "patches of shells intercalated in the gravel still retained among them the smaller and lighter shells as well as the heavier, and occasional deposits of charcoal and ashes."

To me it seems obvious that this layer of clean washed gravel, which so completely separated these two shell-beds, 
was the result of some sudden coup, some specific action, which came into operation a considerable time after the people had taken possession of the cave. The facts would be quite consistent with the idea that the Troglodytes abandoned the cave for a time, and that, on coming back, they purposely spread this layer of gravel over the former refuseheap, so as to start, as it were, with a clean floor and hearth. There is, however, no natural process which, to my mind, accounts for it more satisfactorily than the supposition that during a severe storm the waves were forced into the cave, carrying with them a certain amount of shingle, which henceforth became the floor of the cave, and over which the cave-dwellers, after the abatement of the storm, again took up their quarters as formerly.

If this opinion be correct, the importance of the Oban cave cannot be exaggerated, as it proves that man was an inhabitant of the district when the opening to the cave was on the seabeach, and sufficiently near the water to permit the waves to enter it during a storm. But the beach of to-day is 100 yards distant, and the lower shell-bed lay fully 30 feet above the present high-water mark. ${ }^{1}$

At the beginning of May i 898 another discovery was made at Oban which yielded similar remains of human industry, associated with a refuse-heap of shells and broken bones precisely analogous to those from the MacArthur Cave. This was a rock-shelter, situated at the base of a steep rock called Druimvargie, and overlooking a marsh in which, some years ago, the remains of a lake-dwelling were found. The area of the shelter was some ro feet square, and the dibris which lay in it had been covered over for ages by a deep talus. It was while clearing away this talus, preparatory to laying the

1 In addition to Dr Anderson's Report, see 'Proc. Soc. A. Lond.,' May 2I, 1896. 
foundations of a house, that the shell-heap became exposed. Among the relics were a few stone implements of water-worn pebbles of an elongated shape and slantingly abraded at one end, two or three bone borers, a portion of a deer-horn broken across a circular perforation, a number of " roundnosed" chisels of bone, and the front portions of two harpoons (figs. 13 and I4) made of deer-horn, and of the same
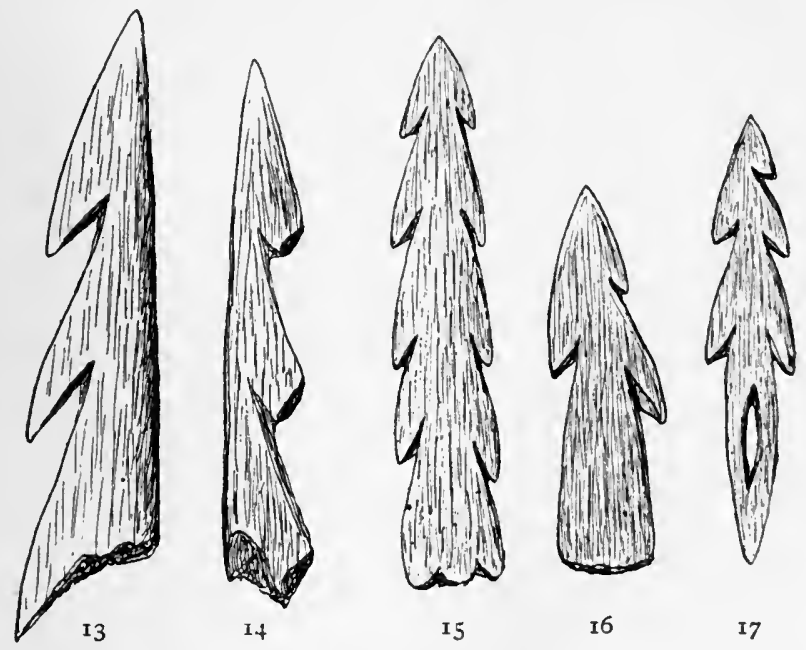

Figs. 13-17.-Harpoons from Druimvargie, Caisteal-nan-Gillean, and Nerucastle-upon-Tyne $\left(\frac{2}{3}\right)$.

character as those found in the MacArthur Cave, differing from them only in having the barbs-three in each caseon one side. M. Piette also records unilateral barbed harpoons from the cave of Mas-d'Azil in France. Hence the discovery of this variety at Oban only strengthens the remarkable analogy between these relics in the French and Scottish caves, the significance of which I have elsewhere fully discussed. ${ }^{1}$

1 Prehistoric Problems, pp. 60-77. 
Bone harpoons and implements of bone and stone, similar to those from the MacArthur Cave and the rock-shelter of Druimvargie, have also been found at Caisteal-nan-Gillean, Oronsay, explored by $\mathrm{Mr}$ Symington Grieve and the late $\mathrm{Mr}$ William Galloway. These investigations have been described by Mr Grieve in his work on 'The Great Auk or Garefowl,' and recently by Dr Joseph Anderson in the Proceedings of the Society of Antiquaries of Scotland, vol. xxxii. Caistealnan-Gillean is a sand-hill, about 150 feet in diameter, with an average height of 25 feet. Its surface was covered with grassy turf, having blown sand underneath to a depth of from I to 5 feet. "Below this covering," writes Dr Anderson, "an accumulation of shells and bones, in a series of layers mingled with sand and ashes, extended downwards for a total depth of about 8 feet. Underneath this refuse-heap the substance of the mound consisted of blown sand in layers, the upper part of each layer defined by a thin line of dark mould, with a few sea and land shells intermixed, but no implements or other remains of human occupancy." The bone and horn implements found in this shell-heap consisted of eleven harpoonheads (figs. I 5 and 16 ), three bone awls, and I 50 "roundnosed," chisel-like implements, similar to those from the caves at Oban. The stone implements, which numbered over 200, were elongated water-worn pebbles worked at one end into "round-nosed" endings precisely similar to the bone chisels. They are supposed to have been utilised by the people who formed this midden as "limpet hammers." Besides the above-named objects there were eight fragments of perforated implements of deer-horn, and others roughly cut round the circumference and then broken across; two small anvil-stones measuring about 4 by 3 inches and $1 / 2$ inch thick; fifty chips and splinters of flint, but none which can be characterised as a worked implement. With the exception of bones 
of the Great Auk, the organic remains were those of the existing fauna of the West Coast.

Two other shell-heaps in Oronsay were excavated by $\mathrm{Mr}$ Galloway, whose contents were apparently similar to those of Caisteal-nan-Gillean. Also Dr T. B. Sprague exhibited at a meeting of the Scottish Natural History Society, in 1898 , a large quantity of broken bones found in a shell-heap or kitchen-midden on the island of Inchkeith, among which I observed a few round-nosed chisels similar to those of Oban and Oronsay.

Recently, when on a visit to the Antiquarian Museum at Newcastle-upon-Tyne, I saw a bone harpoon labelled as having been picked up on the shore at Whitburn in $185_{2}^{2}$. As will be seen from figure $\mathbf{I} 7$, it is very similar to the Oban specimens. Another of the same class of weapon was found in the Victoria Cave, Yorkshire, ${ }^{1}$ which has the peculiarity of having two reverse barbs, one at each side, for the purpose of fastening the string, instead of a hole as in the Whitburn specimen.

2. Implements of Deer-horn associated with the Skeletons of Whales in the Carse of Stirling.

On the 17 th September 1889 Professor Sir William Turner read a paper at the British Association, then held at Newcastle-upon-Tyne, "On Implements of Stag's horn associated with Whales' Skeletons found in the Carse of Stirling." In this paper the author describes a perforated horn implement shaped like a hammer-axe head, I I inches long and $6 \mathrm{I} / 2$ inches in its greatest girth (fig. I 8 ). It was found in 1877 , resting on the skull of the skeleton of a Balrnoptera exposed in the course of drainage operations on the estate of Meikle-

1 Cave Hunting, p. II 2. 
wood, a few miles west of Stirling. In 1819 and 1824 it is recorded that implements of deer-horn, two of which are described as being perforated with a round hole about an inch in diameter, were found also associated with whales' skeletons, but they appear to have been lost. ${ }^{1}$

In his introductory remarks Sir William writes as follows: "Those who are acquainted with the valley of the Forth know that the river Forth winds for many miles through an extensive plain called the Carse of Stirling. This plain is a raised sea-beach, which reaches from 5 or 10 to 30 feet above the present level of high-water. Geologists regard this beach

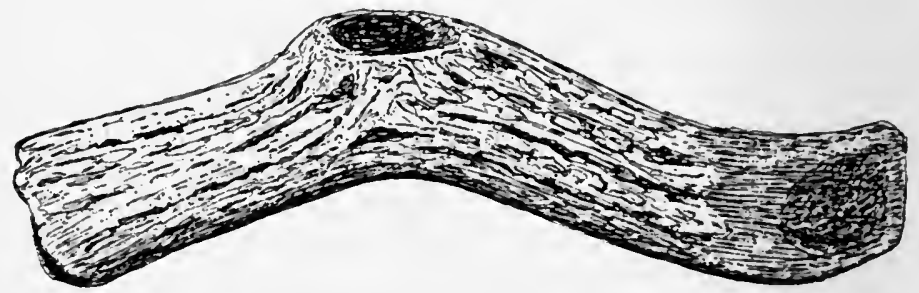

Fig. 18.-Hammer-axe head of stag's horn found with a whale's skeleton at Meiklezeod, near Stirling (1).

as a post-glacial accumulation of marine origin, for the shells which it contains are not Arctic but those of molluscs now extant in the seas of Scotland. In the subsoil of the raised beach the skeletons of large whales have from time to time been found, and as many as seven well authenticated specimens have been recorded. They were all got under almost similar conditions imbedded in a blue silt which underlay a former peat moss, at a depth of usually 3 to 5 feet below the present surface of the ground, and at levels varying, it is said, from 5 feet to 25 feet above the present high-water mark. At the time when those whales were stranded the estuary of the Forth would have extended some 8 or 10 miles to the 
west of the site of the town of Stirling, and there must have been a sufficient depth of sea to permit, with a flowing tide, large whales to swim many miles farther west than is now possible, with the risk, however, of becoming stranded as the tide receded. It has been customary to speak of these whales as Greenland whales; by which term, I presume, has been meant the right whale-Balana mysticetus - which is an Arctic species. But the skeletons which I have examined did not belong to the genus Balæna, but to the genus Balænoptera, or the Finner whales, several species of which now frequent the British seas. I have identified one skeleton as that of Balcenoptera musculus."

The deer-horn implement is here figured from a drawing kindly made for the author by Miss Turner. It consists of a portion of the beam, II inches in length and $6 \mathrm{I} / 2$ inches in greatest girth. It is perforated by a hole, oval on one side and round on the other, the former orifice measuring $\mathrm{I} 3 / 4$ by $3 / 4$ inch, and the latter $3 / 4$ inch in diameter. When found there was a portion of a wooden handle in the hole. The implement is truncated at one end and bevelled into a flat cutting edge at the other, and the perforation is not in the middle but about 2 inches nearer the truncated extremity than the cutting edge. Sir IVilliam sums up his report of these discoveries as follows: "The discovery of those horn implements proves that, when the fertile land now forming the Carse of Stirling was submerged below the sea-level, the surrounding highlands were inhabited by a hardy Caledonian race, who manufactured from the antlers of the red-deer useful tools and weapons. I have already stated that there is nothing in the form of these implements to lead one to suppose that they could be used in the chase of the whale as lances or harpoons. It is probable that the whales, by the side of which they were found, had been stranded during the ebb of 
the tide, and that the people had descended from the adjacent heights, and, with the aid of their chisels of horn, had spoiled the carcass of its load of flesh and blubber. In support of this view, I may state that the three skeletons along with which the implements were found were lying in proximity to the edge of the Carse-land, where it approached the adjacent high ground."

One of the previously recorded whale skeletons was found in July 1819 immediately adjoining the east gate to Airthrey Castle. The following account of this discovery was given at the time by $\mathrm{Mr}$ Robert Bald in the 'Edinburgh Philosophical Journal' for I 8 I9 (vol. i. p. 393): "The skeleton is evidently that of a whale, and the animal appears to have been about 72 feet in length. The greater part of the bones were found at the depth of about $4 \frac{1}{2}$ feet, but some were nearer the surface. The head was lying across the march ditch, the jawbones projecting a few feet over Sir Robert Abercromby's march-line into the estate of Powis. The tail lay in a westerly direction from the head. Though the bones were a little disjoined, yet they lay, upon the whole, in a regular position. The bones which have been preserved consist of the cranium, numerous vertebræ, several ribs, the jawbones, and the bones of the swimming paws, with some smaller bones; likewise some bones of the ear, particularly the mastoid process, which is remarkably hard, and somewhat of the shape of a large shell of the genus Cypræa, for which it was at first mistaken. Some of the ribs are 10 feet in length; and it is remarkable that one of them had been broken and healed again, being, as usual, much thicker at the place of fracture. The bones are in general firm, and in a state of good preservation, excepting the jawbones. These last were immured chiefly in the dry bank upon the side of the ditch, and upon exposure to the air the cellular 
structure speedily fell to powder. Bones of equally open structure which lay in the sludge remain very entire. There were found close by the skeleton two pieces of stag's horn, one perforated. The lovers of natural history are under great obligations to Sir Robert Abercromby for the attention he paid in searching for and securing the bones of the skeleton. It may be added that he has in the most polite and handsome manner presented the whole to the Museum of the University of Edinburgh, where they are now deposited."

The other recorded ${ }^{1}$ whale skeleton, which had associated with it perforated implements of stag's horn, was unearthed in 1824 in the barony of Burnbank, about three-quarters of a mile from Kincardine Church. The ground was originally covered with peat, which had been artificially removed for improving the land, and it was while digging a ditch in the underlying clay that the bones were encountered. The clay here was only 4 feet thick, and beneath it there was a stratum of peat, which cropped up to the surface at the edge of the carse. It was on this peat layer, but imbedded in the clay above, that the skeleton lay. "It is a very singular circumstance that, along with these bones," says the writer (Mr H. H. Drummond), "there should have been found a fragment of a stag's horn similar to that found along with the Airthrey whale, and having a similar round hole bored through it. This piece of horn is also deposited in the Museum [of the College of Edinburgh]. The peat stratum was 6 feet thick, and contained wood, particularly alder, and various water-plants."

The limits of this work prevent me from continuing the history of these stranded whales further; but to those who have a desire to do so $I$ heartily recommend an article by 
Mr David B. Morris on the subject, ${ }^{1}$ in which he gives the records of ten other well authenticated whale remains, in addition to the three above described. To the writings of $\mathrm{Mr}$ Morris ${ }^{2} \mathrm{I}$ am indebted for the following facts in regard to a recent discovery, in these Carse-lands, of whale remains associated with at least one primitive implement.

It appears that in May and June 1897 the County Council of Stirlingshire carried out a scheme of drainage for the village of Causewayhead. A drain track leading from the village to the river Forth was cut into the clays of the Carse to a depth of 13 or I 4 feet, and in it the following relics were found :-

I. Portion of a rib of a whale, 3 feet long, which was unfortunately broken into three pieces after being found.

2. Several bones, which are in the possession of $\mathrm{Mr}$ Morries Stirling at Gogar. These have not been identified, but they are probably bones of a whale.

3. Portion of a rib of a whale, measuring $29 \frac{1}{2}$ inches along its convexity, and split in two in the greater part of its length.

4. Fragment of a rib of a whale, $61 / 2$ inches long, and the same in circumference, which corresponds to the whole thickness of the rib. This is an interesting specimen, as it is supposed to show traces of human workmanship.

5. Portion of horn of red-deer (Cervus elaphus), which had been used by man as an implement for boring (fig. I9).

6. Right horn core attached to fragment of the frontal bone of a small ox of an extinct species, Bos longifrons.

7. Similar right horn core of a smaller animal of the same species.

8. Numerous marine shells, of which a selection is placed in the Smith Institute.

1 Stirling Nat. Hist. and Arch. Soc., $x \$ 92 . \quad 2$ Ibid., 1897. 
In the course of cutting the drain the following sections were noted, the first by $\mathrm{Mr}$ Morris and the second by Mr

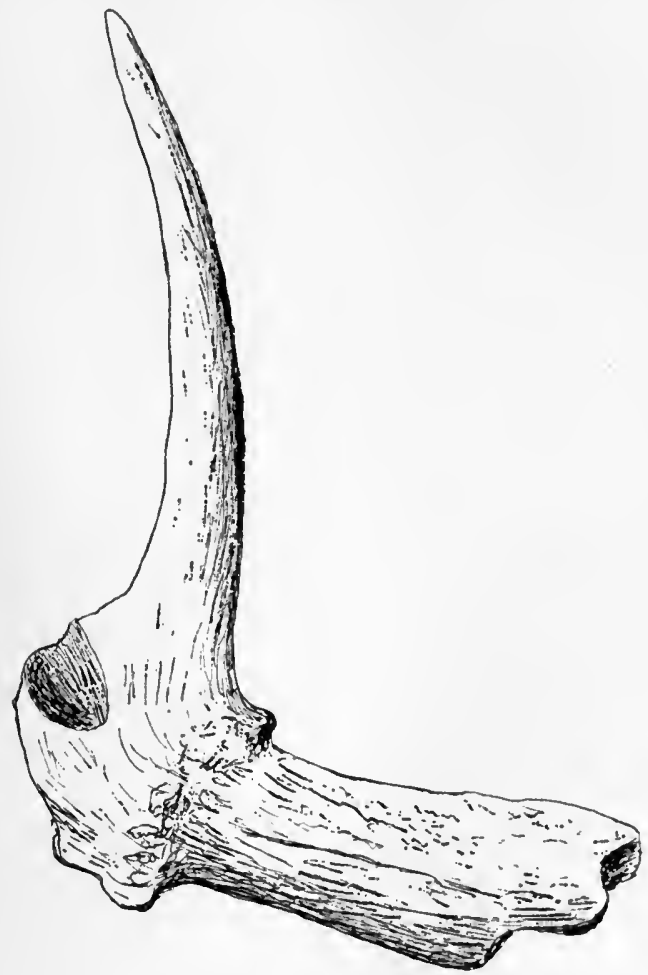

Fig. 19. - Implement of deer-horn associated with whale remains in Carse of Stirling (?

Kidston, but, unfortunately, the position of the relics in the different layers is only occasionally given :-

Section I. - 4 - bout 300 yards east from Cansewiryhead Inn.

$\begin{array}{lllr}\text { Soil } & & & \text { Fee } \\ \text { Yellow "brick clay" } & . & \cdot & \text { I } \\ \text { Blue mud or "sleech" } & . & \cdot & 4 \\ \text { Sand . } & \text {. } & \text { depth unknown }\end{array}$


Section II.-In the village.

Road metal

Soil

Yellow clay

Blue clay

Sand with shells

Clay

$\begin{array}{ccc} & & \text { Feet. } \\ \cdot & \cdot & 1 \\ \cdot & \cdot & 2 \\ \cdot & \cdot & 4 \\ \cdot & \cdot & 2 \\ \text { depth unknown }\end{array}$

"Sir William Turner states that the ribs are thicker than the ribs of Balcenoptera rostrata and B.borealis, and are more of the size of $B$. musculus or $B$. Sibbaldii, which had not reached full growth. The whale remains were not all found together, but were scattered over a distance of 100 yards. The locality is on the public road, from 300 to 400 yards east of the inn. This is just at the old coast-line of the 50 -feet raised beach, where a whale would readily become stranded in the shallows. The carcass would in time be broken up by the prehistoric men who inhabited the shore, and by the beating of the waves, and so the bones, being scattered over a space and cast up on the beach, would be left in just such a position as that in which we have found them now."

The deer-horn borer was found "within a short distance of the fragments of the whale's ribs, and at the junction of the blue clay and the subjacent sand. It is the right frontal process broken off from the frontal bone, with the burr and nearly two inches of the beam of the antler continuous with it. Springing from the beam, close to the burr, is the curved pointed tine of the brow antler, five inches long, following the convexity."

With regard to a portion of a whale rib, Sir William Turner, to whom these interesting relics were submitted for examination, writes as follows: "One end of this fragment showed an irregular fractured surface; the opposite end was cleft, and the lateral boundaries or lips of the cleft were formed by the 
inner and outer surfaces of the rib. The surface of bone forming each lip was smooth as if from rubbing. When the clay was picked out of the cleft, its depth varied from $\mathbf{2} 2$ to $26 \mathrm{~mm}$., and in its deepest part the cancellated tissue of the bone was exposed. The appearance presented by this end of the bone was not natural to the rib, but was obviously due to some artificial process. It is difficult to account for it on the supposition that it was produced by accidental friction in the soft mud or blue carse clay in which the bone was found; rather it gives one the impression that it had been artificially fashioned into shape by the hand of man, so as to adapt it for use as a rude bone implement."

Such are the main points of interest in the Causewayhead discoveries, as described by Mr Morris and Sir IVilliam Turner. I have seen the larger portion of the relics, and find no reason to differ from the opinion of these two experienced observers that the stag-horn was used as an implement by the whalehunters of the period; but as to the portion of the whalerib the evidence of human workmanship seems to me more doubtful. The position of the former, at the junction of the blue clay and subjacent sand, points to a time long before the tidal waters ceased to flow over the Carse-lands.

3. Other Relics of Man in Carse-Lands and alluvial Deposits.

But the association of implements with cetaceous remains is not the only evidence we have that prehistoric man wandered about the shores of these old inland seas. Accumulations of sea-shells in conjunction with fireplaces have been observed along the bluff of the old coast-line on both sides of the Avon, just where it enters the Carse-a locality which, singularly enough, is still called Inveravon, although the present mouth of the river is several miles distant. The following extract from 
the Memoirs of the Geological Survey (sheet $3 I$ ) is quite explicit on this point. "A section," writes Mr Peach, F.R.S., " across a heap 50 yards long by 20 wide was exposed in a road cutting, and showed many successive layers of shellsprincipally oysters - to a depth of 3 feet without the bottom being visible. The remains of fireplaces were plentiful among the shells. Oysters seemed to have been preferred by the makers of the midden, though they had also used the Anomia, the big 'horse-mussel' (Modiola), the common mussel (Mytilus edulis), the whelk (Buccinum undatum), and periwinkle (Littorina littorea). Fragments of the large edible crab (Cancer Pagurus) were also present. All the valves of the oysters were separate except such as had been empty, and which still had barnacles or zoophytes in their interior. The mussel and other shells were found in separate nests, and not indiscriminately throughout the mound. Layers of sand were also found among the shells. All the middens observed occur on the bluff itself or just at its base, as if, when it was the limit of high water, the people who formed the middens, after searching the shores during low water, had retreated thither to enjoy their feast while the tide covered their huntingground. Few or no oysters are now found in the Forth above Borrowstounness."

The finding of canoes in the Carse-lands is well authenticated. Sir John Clerk in 'Reliquiæ Galeanæ'1 informs his correspondent that "a very ancient curiosity" was found in the Carse of Falkirk in the month of May 1726 . "The washings of the river Carron discovered a boat, 13 or 14 feet underground; it is 36 feet in length and $4 \frac{1}{2}$ in breadth, all of one piece of oak. There were several strata above it, such as loam, clay, shells, moss, sand, and gravel; these strata demonstrate it to have been an antediluvian boat.

1 Bib. Top. Brit., No. II., p. 24. 
The tree of which it was made was, no doubt, very big, but still no bigger than one which is yet alive not far from that place, which is about 12 or 13 feet in diameter." To this he adds a cutting from a contemporary newspaper, in which the boat is described as finely polished and having a pointed stem and a square stern. At a later period another writer ${ }^{1}$ mentions that a canoe was found near Falkirk, 5 fathoms deep in the clay, and that anchors were dug up in the ground between Alloa and Stirling. These instances are given as a proof, in the opinion of the writer, that these lands were formerly under sea.

Professor James Geikie gives a description of a canoe made of pine-wood found in a brick clay-pit at Friarton, Perth. It lay on its bottom over a bed of peat, underneath 10 or I I feet of clay, and measured 15 feet in length, $3 \frac{1}{2}$ in breadth, and 3 feet in depth. This clay, according to the Professor, belongs to the second series of terraces forming the raised beaches in the carse-lands of the valley of the Tay, rising from 25 to 45 feet above mean-tide mark. ${ }^{2}$

Another locality which has yielded evidence of the same nature is Lochar Moss, in Dumfriesshire, long utilised as a storehouse of fuel for the neighbouring inhabitants. This moss extends to the Solway, over an area of twelve miles in length and in some places three miles in breadth, with a fall of only about $3 \circ$ feet. A couplet from an old rhyme, quoted by Sir Daniel Wilson, ${ }^{3}$ -

\footnotetext{
"First a wood, next a sea,

Now a moss, and ever will be,"-
}

reveals the facts, as they appeared to the unsophisticated

1 Beauties of Scotland, vol. iii. p. 419 .

${ }^{2}$ Scot. Naturalist, vol. v. p. 167.

${ }^{3}$ Prehistoric Annals of Scotland, vol. i. p. 44. 
peat-cutter's mind, long before they became the subject of geological investigation.

The Rev. James Laurie, writing in Sinclair's 'Statistical Account' (vol. i. p. I60), thus describes the opinion current about this moss in the end of last century: "There is a tradition universally credited, that the tide flowed up this whole tract above the highest bridge in the neighbourhood. In the bottom of the moss sea-mud is found; and the banks are evidently composed of sea-sand. A few years ago a canoe of considerable size, and in perfect preservation, was found by a farmer when cutting peats, 4 or 5 feet below the surface, about four miles above the present flood-mark; but it was destroyed before any antiquarian had heard of it. Near the same part of the moss, and about the same depth, a gentleman found a vessel of mixed metal, containing about an English quart. . . . Antiquities of various kinds are found in every part of this moss where peats are dug, even near its head, such as anchors, oars, \&c.; so that there is no doubt of its having been navigable near a mile above the highest bridge, and fully twelve miles above the present flood-mark. Near the manse there is a narrow gut, between two sandy hillocks, called Collyveat, supposed to be a corruption of Collin's boat, where it is thought there was a ferry, which indeed would be very necessary, on the supposition of the tide flowing there."

Previous to this Pennant ( 1772 ), while passing through the country, took notice of these boats, which he thus describes: "Near a place called Kilblain I met with one of the ancient canoes of the primeval inhabitants of the country, when it was probably in the same state of nature as Virginia when first discovered by Captain Philip Amidas. The length of this little vessel was 8 feet 8 inches, of the cavity 6 feet 7 inches, the breadth 2 feet, depth I I inches, 
and at one end were the remains of three pegs for the paddle. The hollow was made with fire in the very manner that the Indians of America formed their canoes. Another was found in 1736 with its paddle, in the same morass. The last was 7 feet long, and dilated to a considerable breadth at one end; so that in early ages necessity dictated the same inventions to the most remote regions." 1

Sir Arthur Mitchell ${ }^{2}$ has put on record some interesting observations on the ancient forest of Cree, in Galloway. According to him the mosses of Cree, Carsegown, and Borrow, cannot cover less than 1500 to 2000 acres, and average 7 to 8 feet in depth. The peat lies immediately over the clay, the line of separation being sharply defined. But I cannot do better than quote Sir Arthur's own words :"These trees, which, as far as I know, are all oak, are found in two distinct positions-first, in the channel of the Cree, or projecting into its channel from the banks at the side, many of these last having 10 to I 5 feet of sandy clay above those parts of them which are on the bank, and an unknown number of feet of clay below; and secondly, under the peat, on the surface of the clay.

"The existence of this ancient Cree forest does not rest on our finding some half-dozen trunks. You may count them by the hundred, exposed in the bed of the river, between Newton-Stewart and Barsalloch; and you may reckon roots by the score where the moss has been cleared away, near the mouth of the Lorne Burn. I say roots in this case, because such trunks as are discovered in peat-casting are carted off at once."

These trees are described as of great size, and specimens measuring ${ }_{5} 5$ feet in girth and 50 feet in length are not uncommon. The objects which are found with them, or

1 Tour, vol. ii. p. 107.

2 Proc. Soc. A. Scot., vol. v. pp. 20-29. 
"in such positions as lead to the possible conclusion that they are coeval with the trees," are the following: Two canoes, a quern, a Roman battle-axe, a couple of stone celts, and one bronze celt, together with horns of deer and several heads of the extinct Urus. A very large deer-horn was found under I 2 feet of clay, along with "some human bones said to have been of great dimensions." Unfortunately the precise localities where the heads of the Urus were found, whether in the clay or in or beneath the moss, are not given. In commenting on these discoveries Sir Arthur makes the following remarks: "It thus appears that very interesting remains are found in close association with the vestiges of this forest. The country appears to have been peopled when these trees were living. On the margins of this forest man paddled in his canoe, and under the shade of these mighty trees he pursued the red-deer and the Urus. $\mathrm{He}$ cultivated corn in the neighbourhood, and ground it; he was of goodly stature, and carried formidable weapons of war. These things at least are possible, if not probable, inferences from the facts I have detailed."

\section{Canoes found in the Basin of the Clyde.}

It would be too great an encroachment on my space to describe the number of old canoes, and the circumstances in connection with their discovery, which have been disinterred from the basin of the Clyde, in localities now far from the sea and at elevations considerably above its present level.

Mr John Buchanan describes the finding of not less than eighteen in the environs of Glasgow prior to $1854 .^{1}$ The first recorded specimen, dating as far back as 1780 , was

1 See Appendix to Smith's Newer Pliocene Geology, 'I862. 
found, in the course of digging the foundations of old St Enoch's Church, lying in a horizontal position and at a depth of 25 feet from the surface. In its interior lay a polished stone celt, figured in Wilson's 'Prehistoric Annals' (vol. i. p. 53). Since 1854 seven additional canoes have been recorded from the bed of the Clyde, five before the and of February I 869, as we find $\mathrm{Mr}$ Buchanan referring to them in an address to the Archæological Society of Glasgow of that date (vol. ii. pp. 77 and $12 \mathrm{I}$ ). In this address he said: "The last of the five canoes was found also last summer, a little below Milton Island, near Douglas. It is $\mathbf{2 2}$ feet in length and about 2 feet 10 inches in breadth. The interior is well scooped out. Some interesting relics were got inside. These consist of six stone celts, an oaken war-club, and a considerable piece of deer's horn."

In discussing the chronological problems suggested by these Clyde canoes, we must bear in mind that, as boats may be submerged in any depth and become afterwards silted up, their positions afford no reliable data for determining the relative level of sea and land at that time. It is only when they are found deposited in marine beds, now above highwater mark, that they have a bearing on this problem. The "dug-out" does not necessarily carry us back to prehistoric times, as canoes are invariably found associated with crannogs and other medieval remains, so that it is quite probable that some of those found in the Clyde basin may be comparatively modern. ${ }^{1}$ But after discounting all such objections, there is no escape from the conclusion that some of them foundered when the sea was 20 or 30 feet higher than it is at present. This was the opinion of Mr Buchanan and other geologists, who had better opportunities than we have of examining the exact details of each discovery.

"See notice of the Dumbuck "Crannog" and Canoe, p. 438 . 
In ${ }^{1848} \mathrm{Mr}$ Robert Chambers ${ }^{1}$ makes the following pertinent observations on the evidence to be derived from the canoes discovered in the Clyde basin up to that time :-

"The situation of the boats found under the Tontine and Trades' Lands (places within a pistol-shot of each other) is 21 or 22 feet above high-water in the river. It forms part of that extensive plain which rises from the river's brink to the height of 26 feet above tide-mark, forming the site of the Trongate and Argyle Street, and the numerous streets to the north and south of that line. This plain is composed of sand, as appears whenever the foundation of an old house is dug up. . . .

"The question arises, Are the deposits such as the river, while pursuing in general its present level, could have laid down? The situation, be it remembered, is a quarter of a mile from the river; its superficies is $2 \mathbf{I}$ feet above tidemark, while Mr Robert Stevenson has determined the greatest recorded river floods as only $\mathbf{1}_{5}$. The laminated sands do not, moreover, appear such a deposit as a river flood would bring to the spot, even if it could reach it. It therefore appears that we scarcely have an alternative to the supposition that, when these vessels foundered, and were deposited where in modern times they have been found, the Firth of Clyde was a sea several miles wide at Glasgow, covering the site of the lower districts of the city, and receiving the waters of the river not lower than Bothwell Bridge. We must suppose this to have been a time when already a people instructed to some degree in the arts of life occupied that part of the island. Taken in connection with the whales' bones and perforated deers' horns of the Carse of Stirling, the boat and other relics said to have been found near

1 Ancient Sea-Margins, p. 206. 
Falkirk, the human skull at Grangemouth, and the various particulars already cited with respect to the Carse of Gowrie, those Glasgow canoes are objects of much greater interest than any one seems yet to have thought of attaching to them."

\section{Evidence from Raised Beaches, Sand-Dunes, Caves, Rock-Shelters, \&oc.}

Important information bearing on the problem we are now discussing is occasionally derived from a careful in. spection of the sand-dunes, raised beaches, \&c., along our shores, which yield flint implements of Neolithic types. I am informed by experienced collectors that such relics are not found on or near the present sea-level, but always at some distance inland, which, in flat districts, may be far from the actual shore. Certainly this is in accordance with the little practical experience I have gained by a few visits to the sand-hills of Irvine in Ayrshire, and Glenluce in Wigtownshire. At the former locality the flint-bearing ground is several hundred yards from the shore, and at the latter the distance is still greater.

Mr Alexander Gray has communicated to the Society of Antiquaries of Scotland (vol. xxviii. p. 263) some notes on a discovery of urns and flint implements in sand-pits within the town of Campbeltown, in Argyllshire, which I claim as strong evidence in favour of the theory of land elevation within the Neolithic period. This town, it appears, is built on deposits of sand and gravel which gradually rise to the old 50 -feet beach, and sand for building purposes is continually being excavated at about $3 \circ$ feet above present sealevel. Reports of finding urns and other relics in these pits induced $\mathrm{Mr}$ Gray to keep an eye on the excavations. In the beginning of 1894 a new pit was opened in which an 
urn containing some bones was found, withoút being protected by any cist. While he and others were collecting the fragments of the urn they discovered that the finely stratified gravel, beneath the position in which the urn stood, contained numbers of worked flints, cores, and splinters; from which they concluded it had been the site of an old flint factory.

Subsequently, at Millknowe, in another part of this old sea-beach, and 300 or 400 yards south-west of the sand-pit, similar flint implements were discovered in the beach shingle which was being cleared away to make room for a new bonded warehouse at Albyn Distillery.

"The section," writes Mr Gray, "as exposed at present, consists of about 3 feet of rich black loam; beach shingle, with a very little sand, 2 feet; a thin dark-coloured band which extends along the face of the section for about 7 yards, and is from 3 to 6 inches thick, thinning out and disappearing on both sides. Below this is about 2 feet of shingle similar to that above. The dark seam is not a former landsurface, as might at first be supposed, but the site of the old flint-working encampment. It is in reality a dirt-band, composed of litter and refuse of all sorts, such as bits of charred sticks, burnt bones, and innumerable chips and splinters of flint, the latter all quite sharp and unworn. In some spots the dirt has actually a greyish, pepper-and-salt appearance, from the great number of minute bone fragments which exist in it, in the last stages of decay. To separate them from the other material is generally quite impossible, as they are mostly so small and so far gone that a good lens is necessary to convince one that they really are bone. From this dirt-band I took the full of a large zinc bucket, not selected, but filled with the shovel, and carefully washed it out. I found that at least 80 per cent of the total bulk was made up of 
the ordinary shingle, and from the remainder I picked out 498 pieces of flint, mostly very small chips and scales, such as fly off during the process of breaking. A few were between $I$ and 2 inches long, and seemed to be broken or spoiled arrow-points, knives, or flakes which had been rejected. Besides the flints, I succeeded in finding about eighty fragments of bones, in a sufficiently sound condition to stand washing, among them being two of what I took to be the vertebræ of a small fish. The others seemed to be the bones of larger animals, but are, I am afraid, too small for recognition. The better-preserved fragments look as if they had been burned; the mouldering bits which fall away on being touched have no such appearance. Of small bits of burnt sticks I picked out ro4, but a great deal of this material went to mud in the washing, so that the quantity found bears an insignificant proportion to the total amount which must have been present. A number of those picked out seem to be parts of very small twigs or branches. The evidence here adduced, together with the fact that the dirtband is not continuous-as it would be were it a former landsurface-but a mere isolated though large patch, in the midst of the ancient beach, proves beyond a doubt that this is the spot on which the Palæolithic (sic) men camped for a time, and dressed the flints, the refuse of which still remains mixed up with the general camp debris to attest their presence there. The flint-bearing gravel above the dirt-band shows that the site was probably that of a summer encampment, over which the storms of winter had washed the layer of flint-strewn gravel, and thus preserved to us the old campfloor, which otherwise might have been entirely obliterated. All through the beach which has been cleared away, and at frequent intervals, the workmen found little nests of a similar black material, generally with a few larger stones lying in 
and around them. A good many of these stones were angular lumps of the ordinary vein quartz from the schist of the neighbourhood, which have lost their natural glassy semi-transparency, and taken on that opaque dull-white appearance, with all their natural seams opened up, and of that peculiar rusty-red colour, which indicates severe burning. It is quite evident that they had been built up to form the backs and sides to the old camp-fires, of which the black sooty material in which they now lie is the only remains. The total absence of even the smallest bit of pottery is very remarkable; and still more remarkable is the absence of shells, of which not a fragment has yet turned up, and no recognised article of human manufacture except the flints has yet been found."

It is impossible not to recognise the force of Mr Gray's arguments in support of his opinion, that this was an encampment of people of the Stone Age, who here congregated for the purpose of manufacturing such implements and weapons as were required in their various social or warlike duties.

Evidence of similar encampments - fireplaces, flint chips, and other refuse of occupancy - has been observed on Shewalton Moor, freshly exposed by the shifting sands. ${ }^{1}$

After discussing the various theories to account for the presence of flint nodules in the gravels of the district, $\mathrm{Mr}$ Gray comes to the conclusion that these flints could not have been obtained from local sources, and that consequently they must have been imported in canoe-loads.

But the significant feature of Mr Gray's discovery as regards this inquiry is that, while the settlement was in existence, the waters of the Campbeltown bay washed the

${ }^{1}$ Annals of Kilmarnock Glenfield Ramblers, 1893-94; and Ayr and Gal. Arch. Assoc., vol. vi. p. 77. 
surrounding shores some 30 feet higher than they do at the present time.

In I 883 I contributed to the collections of the Ayr and Galloway Archæological Association (vol. iv. p. I) notes on the discovery of five bronze celts, of an early type (fig. 20), found in an excavation near the shore of a little bay called the "Maidens," in the vicinity of Culzean Castle, Ayrshire. While clearing out the foundations for building a shipyard the workmen had to slice away a portion of a whinstone rock which projected into the area of the proposed building, and at the lowest part of the trench they came upon the celts and a bronze ring which had apparently bound them together. They had been inserted into a cleft in the rock facing the sea; and this cleft had been subsequently covered by 2 feet of sea-gravel, apparently thrown up against the rock by the ac-

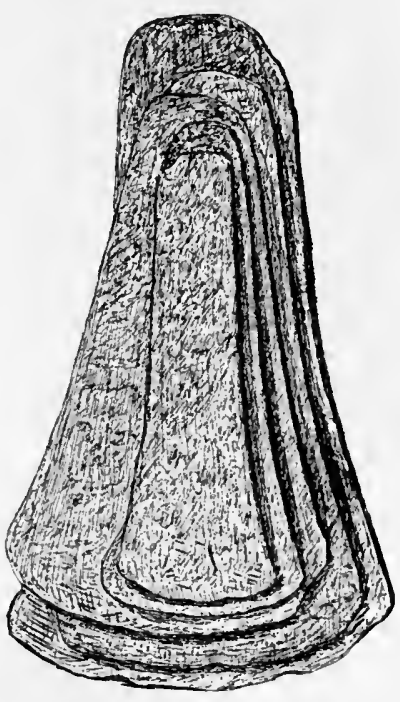
tion of the waves. Over this Fig. 20.-Five bronse celts found gravel there was a deposit of together at the "Maidens," Ayr-

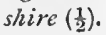
surface-earth also 2 feet thick.

The present high-water mark was ascertained by measurements to be roo yards distant from the spot where the bronze implements had been concealed, and 25 feet lower in level. I visited the locality along with the Marquis of Ailsa and Mr Smith, his factor, a few days after the discovery; but before this, and indeed before the implements were found, the soil and gravel in front of the rock, as well 
as a portion of the rock itself, had been removed. After a careful inspection of the spot and inquiries of the workmen into all the circumstances, the conclusion to which we came was thus recorded: "Unless, therefore, there had been a vertical slit in the rock, of which there was no indication whatever, it is difficult to form any other opinion than that the ledge of rock under which the celts were concealed was, at the time of their deposition, open towards the shore; and that the waves subsequently dashed against it with sufficient violence to cover up the opening of the crevice with a portion of this coarse gravel. Since then, however, the tide has gradually receded, either in consequence of the accumulation of detritus or of a general rising of the seabeach. Curiously enough, the position of this find coincides with the latest and best-defined of the ancient sea-margins or raised beaches, the remains of which are so conspicuous in the south-western districts of Scotland."

The interpretation of the phenomena of raised beaches is, however, so liable to error, owing to the number and variety of minor details which have to be considered, that great caution is necessary in accepting such conclusions as evidence of alteration in the relative level of sea and land.

To the caves along our shores, ascertained to have been occupied by man, we naturally look for some additional scraps of information on this subject. We know, however, of very few caves which have been so used, at least as early as Neolithic times. A cave becomes habitable by man only after the retreat of the sea, and such an incident as a storm causing the waves to enter it synchronously with man's occupation, as was the case in the MacArthur cave at Oban, must of necessity be a most unusual occurrence. Most of those which have hitherto been examined prove by their relics that they became inhabited in post-Roman times. 
Such was the case with the Borness cave in Kirkcudbrightshire. ${ }^{1}$ The floor of this cave stands 19 feet above the present high-water mark, but we have no means of associating the work of man with that of the sea.

In 1847 a cave near the mouth of the North Esk, in Kincardineshire, was discovered and reported on, first by $\mathrm{Mr}$ A. Bryson, ${ }^{2}$ then by $\mathrm{Mr}$ W. Beattie, ${ }^{3}$ and lastly by $\mathrm{Dr}$ Howden, in $1866 .{ }^{4}$ According to Dr Howden the entrance to the cave, which faces the south, is about half a mile from the estuary of the river, and i 5 feet above high-water mark. It contained a mass of débris, including bones of various animals, as well as some relics of man. Among the latter were an amulet formed of the leg-bone of an ox, four chain plate bolts, "evidently belonging to a small craft of about roo tons," and the remains of an iron harpoon or spear. An inner compartment of this cave contained only remains of marine mollusca - a fact which, says Mr Bryson, "seems certainly to indicate the presence of the German Ocean I 2 feet above its present highest spring-tide." Notwithstanding the preciseness of this statement, it is more probable that these shells were merely a portion of the refuseheap from the outer cave, so that no conclusion can be drawn from the facts as regards land elevation.

Mr J. W. Laidlay, in describing an early habitation and kitchen-midden on the "Ghegan Rock," near Seacliff, East Lothian, which yielded a few relics of late-Roman times, concludes by observing that this discovery goes against the supposed rise of the neighbouring coasts within the historical period. "Against this theory," Mr Laidlay writes, "the

1 Proc. Soc. A. Scot., vol. x. p. $48_{3}$.

2 Edin. New Phil. Journal, vol, 49, p. 253.

${ }^{3}$ Brit. Assoc., Aberdeen, I859, p. 99.

4 Proc. R. Phy. Soc., vol. iii. p. 368. 
dwelling on the Ghegan seems to me a cogent protest; a very inconsiderable depression of the rock would render habitation there simply impossible." The foundation of the dwelling stood 22 or 23 feet above sea-level, and the author assumed the relics to be of "an age not later than the Roman, possibly before it, but extending to it, as the large vase would seem to show." 1

The site of this habitation is interesting as showing the foundation of a rude rectangular building of undressed stones without mortar. It presented a front 39 feet long, and a breadth of 26 feet at one end - the other corner being

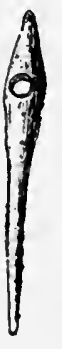

2 I

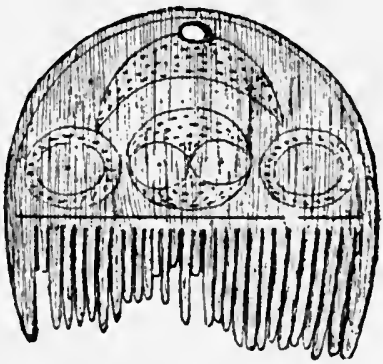

22

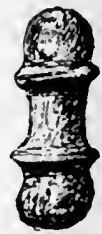

23

Figs. 21-23. - t neddle, a comb, and an ornament of bone found on

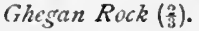

demolished. From its position at the base of the slanting side of the rock, it became covered up in the course of time with 3 to 4 feet of soil. The relics are of the kind usually found on Romano-British sites, comprising fragments of a large Roman jar, and of other pottery; a bone needle (fig. 2 I), and some bone pins and implements; fragments of toilet combs, one double-edged made of plates fixed with iron rivets, and another highly ornamented (fig. 22); a curious ornament of dark bone (fig. 23); a small crucible; a polished

${ }^{3}$ Proc. Soc. A. Scot., vol. viii. p. 377. 
disc of serpentine, one inch in diameter; the upper and lower stones of a quern-mill made of gneiss, \&c. Also teeth and bones of ox, horse, sheep, goat, pig, deer, dog, \&c., and a variety of sea-shells of the edible species.

Mr John Smith ${ }^{1}$ has excavated the debris of human occupancy in a rock-shelter close to the Ardrossan Railway Station, the result of which, he thinks, "demonstrates" a rise of "many feet" in the Ayrshire coast since the rockshelter was first frequented by man. The shell-heap rested on a raised beach of sand and gravel containing rolled shells. The evidence of alteration in the relative level of sea and land is thus stated by the investigator: "That this place had been occupied by man shortly after the waves left it was clearly evident, as there had only been time sufficient for a layer of earth, little more than half an inch in thickness, to form on the top of the gravel, nor had there been time for any talus of fragments from the rock-face to gather upon the gravel before the inhabitants began to throw down the shells and other débris upon it. In fact, the talus of rock-splinters was formed on the top of the mound, as will be seen from the crosssections, demonstrating at once its antiquity, and affording some guidance to the time of its commencement. Another point in favour of its antiquity is the fact that many specimens of a spiral mollusc, Trochus lineatus, were got in the mound, and must have been common on the then existing shore. This mollusc is now extinct in the Clyde and in the West of Scotland, and has only been found in the Clyde district before as a fossil, Mr David Robertson having got it in the Raised-beach strata of Millport."

The land animals represented in the food-refuse, all of which belong to the ordinary Neolithic fauna, are of no special interest beyond the fact that they include the beaver.

1 Ayr and Gal. Arch. Assoc., vol. vii. p. 60. 
It is somewhat startling to find that these people were not only cannibals but made implements of human bones. "A great many jaws with teeth," writes Mr Smith, "and bones were obtained, all the latter which had contained marrow having been split open. Under the ledge of rock at a point $a$, and imbedded in the mass of shells, was a human upper jaw without teeth, which had evidently been knocked out with a stone, splinters of the jaw having been broken off in the process. On finding this grim relic my first impression was that the people who lived here had been cannibals, the jaw having evidently been thrown in the most matter-of-fact way on the general shell-heap, while, probably, the teeth had been kept to make a necklace or other ornament. Further evidence, however, obtained during the exploration, showed that, although the mound-men had feasted, probably during ' hard times,' on their own species, they were not habitual cannibals, for the whole human remains obtained seemed to show that not more than two human beings had been devoured." Part of a human lower jaw was got in a mass of shells cemented together into a stalagmite "about a foot above the Raised-beach bed; it had three well-preserved teeth. Near the top of the same bed a well-made diamondpointed bone chisel, a rude implement made of a human bone, and several human vertebræ, were obtained." Of implements only a few bone pointers or awls are recorded.

From these and other considerations it is manifest that in attempting to account for land oscillations we have to deal with a complicated series of phenomena, probably due both to astronomical and terrestrial causes. It is therefore not impossible that while a submergence followed by a reelevation of the land has occurred over an extensive area corresponding with the glacial and interglacial epochs, other local disturbances may have been going on which would 
considerably modify the effects of the former. The hypothesis that the 50-feet raised-beach was contemporaneous with the last glacial epoch (an event which, according to the astronomical theory, occurred about 11,000 years ago) admirably harmonises with the recent chronological deductions founded on the archæological remains in the rock-shelter of the Schweizersbild in Switzerland. ${ }^{1}$ We have no means as yet, so far as I know, of dating the first appearance of Neolithic man in Britain. It is, however, a significant fact that the remains of his handiworks have been found in the submerged forests of the south of England (Quart. Jour. Geo. Soc., 1865 ; Early Man in Britain, p. 248) and in the raised beaches of Scotland; but, although it was probably the same land oscillation which depressed the one and elevated the other, we cannot at present identify this earth movement with any archæological phenomena which have been dated.

${ }^{1}$ See Journal of the R. Arch. Institute, vol. lv. pp. 259-285. 


\section{CHAPTER IV.}

NOTES ON THE PREHISTORIC FAUNA.

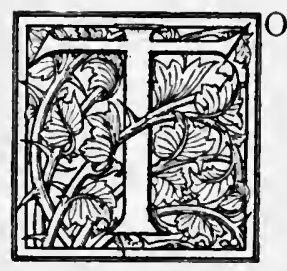

complete our survey of the environments of prehistoric man, a few remarks must now be made on the fauna of the period, especially on the larger animals with which he came in contact in the chase or otherwise. Our knowledge of these animals is derived mainly from the discovery of their bones in marl-pits, peat, and alluvial deposits, and also, but more rarely, associated with human remains on inhabited sites. My labours in this most interesting department of prehistoric archæology have been greatly lightened by the exhaustive monographs of the late Dr John Alexander Smith, nearly all of which have been published in the 'Proceedings of the Society of Antiquaries of Scotland.'

According to our definition of the word "prehistoric," which covers only that portion of man's existence in Scotland prior to Roman times, a distinction ought to be made between it and "post-glacial," which embraces a much longer period of time. Broadly speaking, Neolithic man was in possession of the domestic animals-ox, sheep (?), goat, and $\operatorname{dog}$-and acquainted with the art of cultivating plants 
and cereals. Perhaps, therefore, the best principle of classification to follow would be that which associates prehistoric man with the introduction of domestic animals into Britain, as advocated by Professor Boyd-Dawkins at the International Congress of Archæology, held at Norwich in $1868 .{ }^{1}$ But as the date of man's immigration into Scotland is unknown, it is evident that we must here act under a kind of roving commission, without assigning any precise limits to the commencement of the prehistoric period. Again, by treating of the remains of the prehistoric fauna, so far as they have been found within the Scottish area only, we are merely touching the fringe of a vast subject which embraces the whole Pleistocene or Quaternary period of Western Europe. It is therefore manifest that independent conclusions of any great value cannot be drawn from the Scottish specimens without, to some extent, correlating them with analogous discoveries over the wider area. Of the post-glacial fauna whose remains have been found in Scotland, some undoubtedly became extinct, or at least disappeared from Britain, before Neolithic man came on the scene; others, again, such as the domestic animals, have been introduced by him. Hence, for chronological purposes, it is almost as important to determine what animals were not contemporary with man, as it is to determine those with which he was actually acquainted.

Excluding the inter- and post-glacial mammalia which were the contemporaries of Palæolithic man-with the exception of the Irish Elk, which is surmised to have touched the horizon of Neolithic man in Ireland-the chief animals which are of archæological interest in the present inquiry are the Reindeer, Elk, Bos longifrons, Bos primigenius, Beaver, Brown Bear, Wolf, Wild Boar, and the Great Auk. As the limits of 
this work are absolutely prohibitory of discussing the remains of these animals on the basis of their geographical and geological distribution, I shall only bring before my readers as much of the collateral details from beyond the Scottish area as will enable them to grasp and appreciate the importance of the palæontological problems raised.

\section{REINDEER (Cervus tarandus).}

Dr Smith was induced to look for horns of the reindeer among Scottish archæological remains in consequence of having his attention directed, through an article by $\mathrm{Dr}$ Hibbert, ${ }^{1}$ to a passage in the 'Orkneyinga Saga,' to the effect that, in the twelfth century, the Jarls of Orkney were in the habit of crossing the Pentland Firth to chase the roe-deer and the reindeer in the wilds of Caithness. ${ }^{2}$ The following tabulated statement of localities which have yielded remains of this animal is compiled mainly from his researches :-

I. On the Morbhaich Mor, a sandy flat to the east of Tain, Ross-shire, the Rev. Dr Joass found, at a depth of 4 feet, "the skull of a young ox, several bones of a large deer, one tyne of a palmated stag's horn, and the jaw of a large canine animal. All these bones lay beneath the moss, and on a natural shell-bed in which occurred the Scaphander lignarius, believed, from its size and delicacy of structure, to indicate warmer conditions of climate during its existence in such a situation, as well as a considerable subsequent elevation of the sea-bottom. The coast-line is now three miles distant."

1 Edinburgh Journal of Science, 1831 .

2 Proc. Soc. A. Scot., vol. viii. p. 186 : see also Professor Boyd-Dawkins in 'Transactions of International Congress of Prehistoric Archæology,' I868, p. 287. 
Professor Owen subsequently identified the above-mentioned tyne as portion of a reindecr horn. ${ }^{1}$
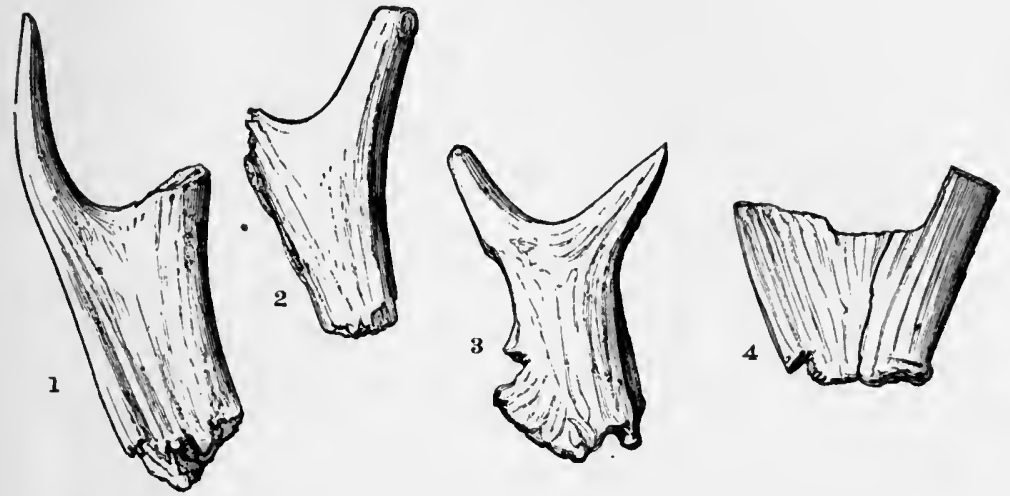

Fig. 24.-Portions of reinder's horns found at Cill. Trölla Broch, Sutherlandshire $\left(\frac{1}{5}\right)$.

2. Séveral pieces of reindeer horns (fig. 24) were found among a collection of bones, shells, and other débris of occu-

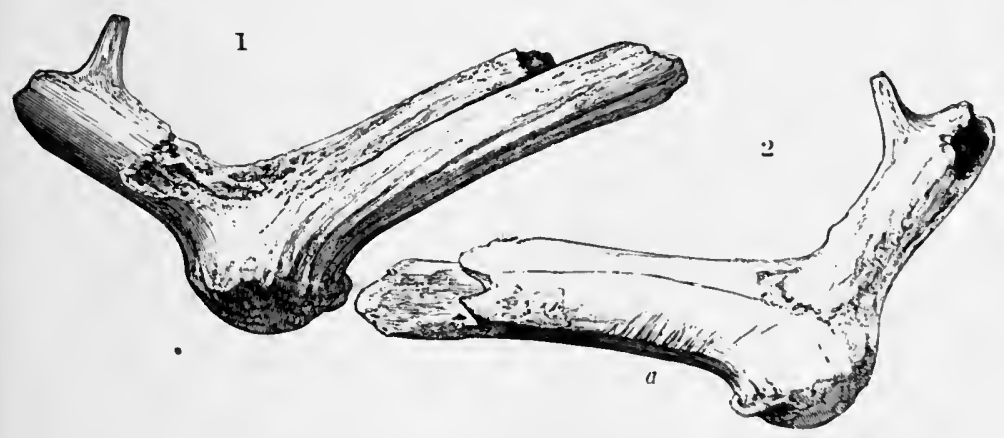

Fig. 25.-Front and back view of a portion of reindeer horn found in a broch at Keiss, Caithness (1).

pancy, while cleaning out the ruins of Cill-Trölla Broch, near Brora, in Sutherlandshire. ${ }^{2}$

1 Proc. Soc. A. Scot., vol. vi. p. 387 , and vol. viii. p. 187 .

2 Ibid., vol. viii. p. 188. 
3. In the course of the investigation of the Harbour Mound, Keiss, Caithness, by Mr Samuel Laing, several portions of reindeer horns (figs. 25 and 26 , No. I), some of which had

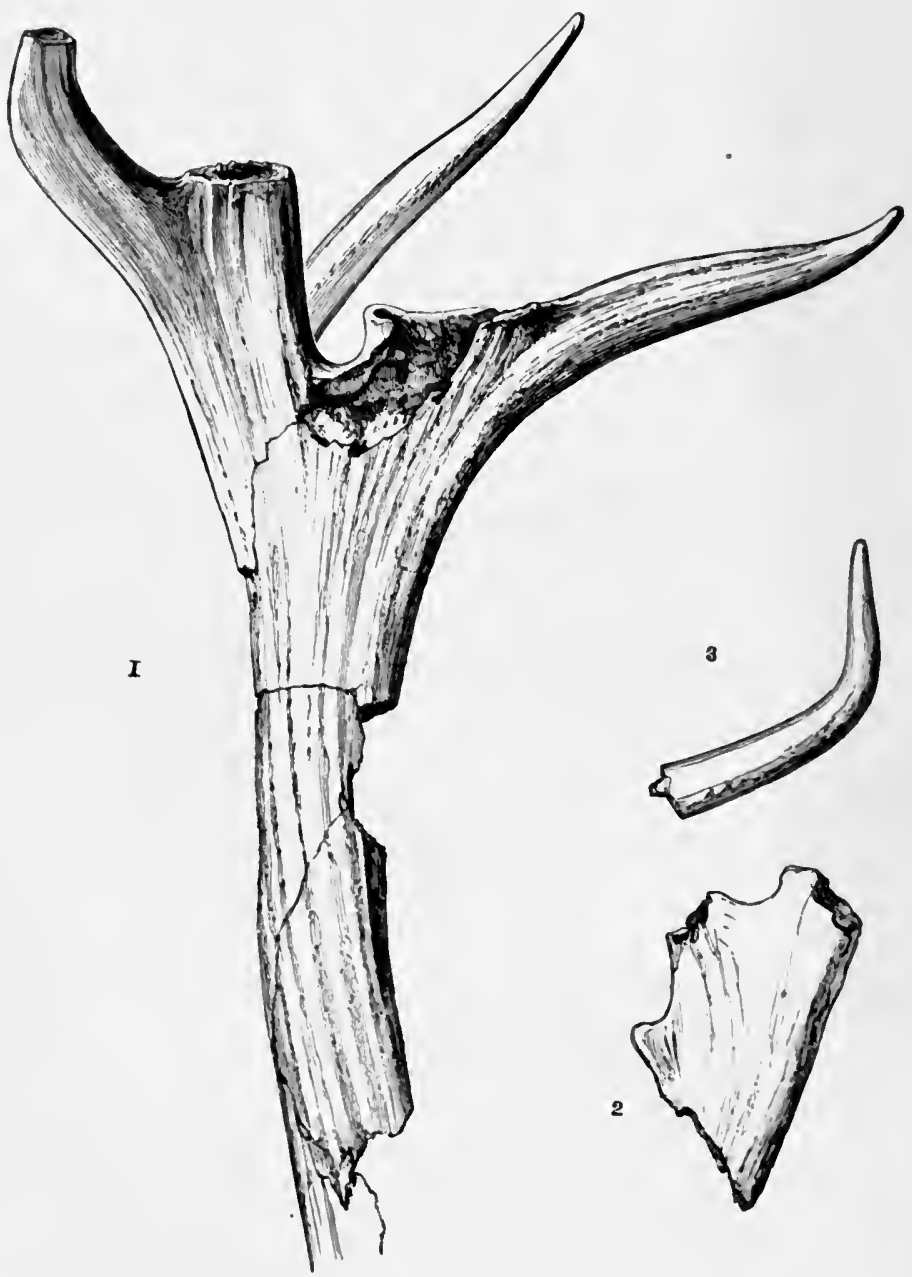

Fig. 26. - Portions of rindecr horns found at K'ciss (No. I), and at Yarhouse (.Nos. 2 and 3), Caithness (1). 
been sawn or cut, were disinterred along with numerous relics of man. ${ }^{1}$

4. Two small tynes, and a portion of third tyne showing workmanship (fig. 26, Nos. 2 and 3), were found by $\mathrm{Dr}$ Joseph Anderson and Mr J. Shearer in a broch at Yarhouse, associated with the bones of the ox, horse, pig, deer, sheep, and goat, as well as a vast quantity of the ordinary débris of human occupancy. This broch was situated on what was formerly an island in the Loch of Yarhouse, and had attached to it a number of outhouses, in one of which the fragments of horn, subsequently identified as those of the reindeer, were found. ${ }^{2}$

5. Pennant states that he was assured by Dr Ramsay, Professor of Natural History at Edinburgh, that the horns of the reindeer "were found fossil in 1775 , in a marl-pit, 5 feet below the surface, near Craigton, in the shire of Linlithgow." 3

6. In 1833 the skull of Bos primigenius and fragments of deer-horns were found in beds of laminated clay on the north bank of the river Clyde, below the junction of the Kelvin. These relics were sent to the Glasgow Museum, and afterwards the horns were recognised as those of the reindeer. ${ }^{4}$

7. A fragment of a reindeer horn in the Hunterian Museum, Glasgow, was traced to sub-glacial deposit at Raesgill, Lanarkshire. ${ }^{5}$

8. In one of the marl-pits sunk in the partially drained Loch of Marlee, Perthshire, the skeleton of a beaver was found, and in another the horns of a large species of deer, now supposed to have been those of the reindeer. ${ }^{6}$

1 Proc. Soc. A. Scot., vol, viii. p. 193.

2 Ibid., p. 200 ; also Scotland in Pagan Times, p. 230.

3 History of Quadrupeds, vol. i. p. 100.

+ Proc. Soc. A. Scot., vol. viii. p. 207. ${ }^{5}$ Ibid., p. 208.

${ }^{6}$ See Owen's Fossil Mammals, p. 482 ; Stat. Account, vol. xvii. p. 478 ; and Mem. Wern. Soc., rol. iii. p. 214. 
9. In 1856 a portion of a reindeer horn was found in a railway cutting at Croftamie, Dumbartonshire, embedded in blue clay underneath glacial till; and in its close vicinity arctic shells were detected. ${ }^{1}$

ro. Reindeer horns and a mammoth tusk were found while removing alluvium (till) over part of the Woodhill quarry, Kilmaurs, Ayrshire. ${ }^{2}$

I I. Sir W. Jardine describes the finding of the horns of a reindeer along with the remains of roe, red-deer, Bos primigenius, and the skull of a bear (Ursus arctos) under a peat-bog, while digging for marl on the Shaw property, Dumfries. ${ }^{3}$

I 2. Sir Arthur Mitchell fell in with a large horn of a reindeer nailed above the door of a house in Orkney, which, as he was informed, had been found deep below the surface of a peat-bog in the adjoining island of Rousay.

13. Professor Boyd-Dawkins states that "Sir Philip Egerton met with a small fragment of an antler in the peat-bogs of Ross-shire, which, beyond all doubt, belongs to this animal" (reindeer). ${ }^{5}$

14. Professor Rolleston identified, among the animal remains sent to him from the Lochlee crannog, two fragments of reindeer horns. ${ }^{6}$

15. Mr James Simpson read a paper at the Edinburgh Geological Society (March I 8, I 886), "On Reindeer and other Mammalian bones discovered by Mr Macfie of Dreghorn in a rock-fissure at Green Craig, Pentland Hills." These bones are deposited in the Anatomical Museum of the Edin-

${ }^{1}$ Proc. R. Phy. Soc., vol. i. pp. 163, 247.

2 Trans. Geo. Soc. Glasgow, vol. i. p. 7 I.

${ }^{3}$ Proc. Soc. A. Scot., vol. viii. p. 216, and vol. xiii. p. 360.

4 Ibid., vol. viii. p. 216.

5 International Cong. Prehistoric Arch., Norwich, p. 276.

${ }^{6}$ Ancient Scottish Lake-Dwellings, p. 142, and Proc. Soc. A. Scot., vol. xiii. p. 244. 
burgh University, and the animals represented include the reindeer, horse, dog, and deer.

r6. Pieces of reindeer horn have recently been found in a broch excavated by Sir F. T. Barry, M.P., on his estate of Keiss, Caithness. They were associated with painted pebbles, part of the antlers of an elk, and the canine tooth of a bear. ${ }^{1}$

\section{The ElK (Cervus alces).}

The elk, like the reindeer, inhabits northern regions, being at the present time met with in Finland, East Prussia, Lithuania, and some parts of Russia. Essentially a forest animal, its geographical range must at all times have been largely governed by the distribution of the primeval forests. The spread of Neolithic civilisation, which entailed the clearing of woods for tillage, curtailed the haunts of the elk. Partly for this reason, and partly on account of the change in climate, it would appear that in Roman times it had become virtually extinct in Western Europe. Cæsar merely mentions it as one of the three wild beasts peculiar to the Hercynian forest - viz., Reindeer, Elk, and Urus. During the Quaternary period the elk roamed over Europe from the Pyrenees to the Altai Mountains, and from the northern fringe of the forests to the south of France and North Italy. ${ }^{2}$

Its remains have been found on the sites of several of the Swiss lake-dwellings, and in numerous localities throughout the British Isles. The following are the instances of its discovery in Scotland :-

In 187 Dr J. A. Smith recognised the skull and horns of a reported large species of deer recently found in the Whit-

1 Proc. Soc. A. Lond., vol. xvii., 2nd series, p. I9I.

${ }^{2}$ Hamy, Paléontologie Humaine, p. I 5 t. 
rig Bog, Berwickshire, as those of the elk (fig. 27). Whitrig has been an old lake basin of considerable size, but it is now entirely filled up and superficially occupied with a thick deposit of peat.

"Below the peat," writes Dr Smith, "there is an extensive bed of shell-marl; for 3 feet in thickness you have pure marl, then over a part at least of the bog there is a bed of blue clay about 3 feet in thickness, and below this again there are other 3 feet of marl. Under the marl is a bed of brick clay, averaging 6 feet in thickness, and underneath this clay you come at last to the hard till, or boulder-clay.

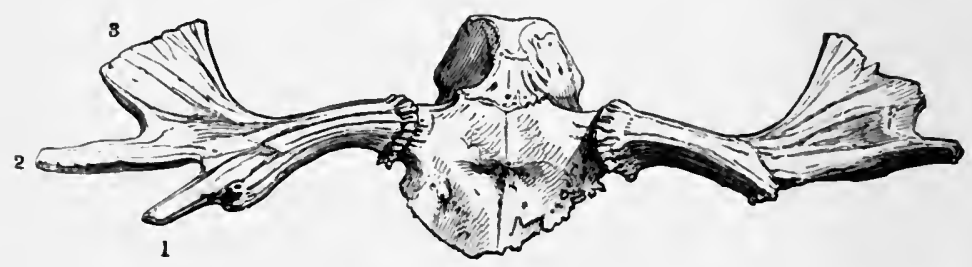

Fig. 27.-Skull of the elk, found in Whitrig Bog, Berwickshire.

"Mr Hogarth told me the elk's head was found about two months before my visit, at about 150 or 200 yards from the northern margin of the bog. They were cutting peat at the time, and there was a great abundance of water in the peat; the wall of peat, I may mention, is not cut down to its very bottom, to avoid the marl, and Mr Hogarth cut a drain through the bottom or remaining peat and part of the marl, towards the open side of the bog, to let the water escape. It was while cutting this drain in the peat, and before he reached the marl, that the skull was discovered." 1

This discovery induced Dr Smith to hunt up all the scattered notices he could find of the remains of this animal

1 Proc. Soc. A. Scot., vol. ix. p. 298. 
throughout the British Isles. Of those recorded in Scotland ${ }^{1}$ the following is an epitome :-

I. In a printed list of the first donations made to the Museum of the Society of Antiquaries of Scotland, the horns of the elk are four times included among the gifts, but unfortunately none of them have been preserved. These donations are thus recorded.

(a) By Sir Alexander Dick of Prestonfield ( $178 \mathrm{r}$ ). "A quantity of Roman arms, consisting of twenty-three pieces of the heads of the hasta and jaculum; twenty pieces of the blades and nine of the handles of the gladius and pugio; a ring, 3 inches in diameter, fastened to the end of a staple; and a mass of different pieces of these arms, run together by fire, all of brass; skulls and other human bones, together with the horns of animals of the deer and elk species, dragged out of the middle of a bed of shell-marl at the bottom of his loch of Duddingston." This remarkable hoard of the Bronze Age was presented, at the time, to the Antiquarian Museum.

(b) By Mr James Muirhead (1781). "A skeleton of a palmated head, with very large horns, projecting both before and behind, dug up lately on the farm of Greycrook, near Cramond, occupied by Mr Henry Sawers, and found buried 8 feet below the surface, covered with 5 feet of marl, above which was 3 feet of moss."

(c) By Mr George Aitkenhead ( 1783 ). "The broad upper part of the horn of an elk, dug up anno 1779,76 feet below the surface of the ground, in Trinity Muir [Brechin], in the heart of a marle bed, which, besides being covered with several strata of earth, clay, and sand, each between 6 and 8 feet in thickness, had over them all a covering of moss to the height of 30 feet."

(d) By Mr William Mabon," cutler in Dunse ( 1783 ). "A

${ }^{1}$ Proc. Soc. A. Scot., rol. ix. pp. 297-345, and vol. xvii. p. 325. 
large palmated horn, 27 inches in length, and 9 inches in breadth."

2. A donation to the Royal Society of Edinburgh by the Honourable Lord Dunsinnan, in $\mathbf{1} 788$, is " a painting in oil of the head and horns of an elk, found in a marl-pit, Forfarshire" 1 (fig. 28).

3. In the account to the parish of Kinloch, Perthshire, the Rev. J. Brodie states: "A pair of very large deer's horns

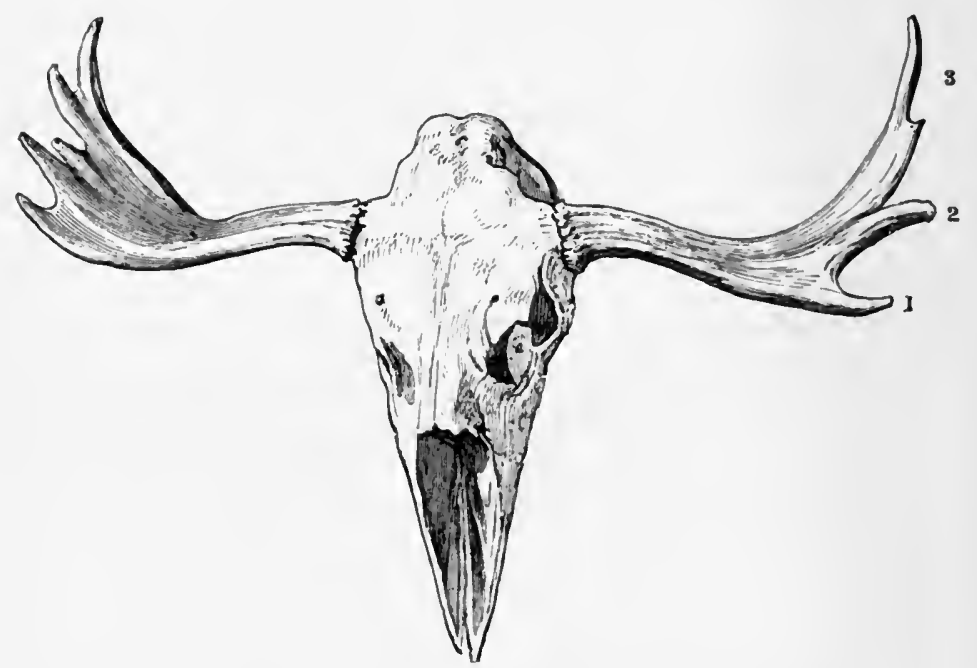

Fig. 28.-From a painting in oil of elk's skull found in Forfarshire.

were found a few years ago, in a bed of marl, in Mr Farquharson's marl-pit at Marlee. From their superior size and palmated form they appear to be the horns of the elk-deer, anciently the stately inhabitant of the Caledonian forests." 2

4. The circumstances in which a head and horns of the elk from a marl-pit at Airleywight, Perthshire, preserved in the Hunterian Museum, Glasgow, were found, are thus de-

1 Proc. Soc. A. Scot., vol. ix. p. $3^{15}$.

2 Old Stat. Account, vol. xvii. p. 478 . 
scribed: "They were got in the mossy hollow ground to the north of this house in digging for marl. The first section was moss of from 10 to 12 feet in depth; then 2 or 3 feet of an inferior kind of marl; then a bed of rich plastic red clay of about I or I $\mathrm{I} / 2$ foot in thickness; and last, the rich marl for which the work was done. It was between the moss and inferior marl strata, and partly in both, that the head and

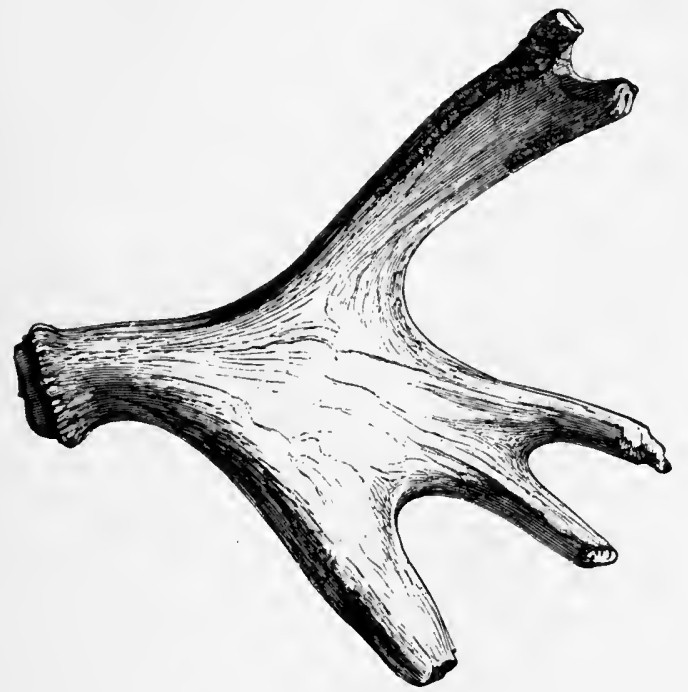

Fig. 29. - Elk's horn found in Strath Halladale, Sutherlandshire.

bones were found. The heads were pretty perfect when got, and the horns almost entire, showing distinctly the species to which each belonged, the one evidently of the elk kind; the other just like our present red-deer heads, but of rather larger size than we now see. The bones found along with the elk's head showed it to have been a very large animal; it must have been, at least, as tall as a good-sized ox." 1

5. A shed palmated horn (fig. 29) of the left side of 1 Proc. Soc. A. Scot., vol. ix. p. 320. 
the head of an elk "was found about forty years ago in the formation of a cutting made for diverting the course of the river in Strath Halladale (a river valley running north through the eastern part of the country, and opening to the shores of the North Sea at the bay of Melvich), and was preserved by $\mathrm{Mr}$ Robert Rutherford, Helmsdale, in whose possession it remained until it was recently presented, through the Rev. Dr Joass, to the Duke of Sutherland's Museum at Dunrobin. . . The horns of a very large red-deer, Cervus elaphus, were also found in the course of the same cuttings, and are now in the museum at Dunrobin; they display no less than some twenty-five or twenty-six points."

On the above discovery Dr Smith makes the following comments: "This horn has almost the look of the horn of a recent elk, having apparently lost little or nothing of its animal or mineral constituents. So that, judging from its appearance, we are led to consider it must either have belonged to a recent elk, or that the elk lived down to a comparatively late period of time in this most northern part of Scotland, and perhaps to a still later period here, than in the more southern localities in which its remains have been discovered." 1

6. Besides the skull and horns of the elk discovered in Whitrig Bog, already noticed, Dr Smith considers that a portion of a palmated horn, found at Coldingham in Berwickshire -described and figured by the late Mr James Hardy, in the 'Proceedings of the Berwickshire Naturalist's Club for 1 860,' as belonging to the Irish elk-has a much closer resemblance to the horns of the elk. Mr Hardy, in a footnote, refers to another instance of the discovery of what he supposed to be the Irish elk in the neighbourhood of North Berwick. In vol. i. of 'Hillside and Border Sketches,' by W. H. Maxwell,

${ }^{1}$ Proc. Soc. A. Scot., vol. ix. p. 324. 
London, 1847 , at p. 317 , it is stated that "a medal of Trajan, a fibula, a patera, and a horn of a moose-deer" were discovered.

7. According to Dr Smith, the finest specimen of the true elk that had yet been discovered in the British islands was found, in 1828 , " in a peat on the edge of a small loch called Willie Struther's Loch, in the valley of the river Slitrig," in Roxburghshire (fig. 30). Some other bones, including the skull of a Bos longifrons, were found in this moss. ${ }^{1}$

8. Another specimen of the cranium of an elk with its

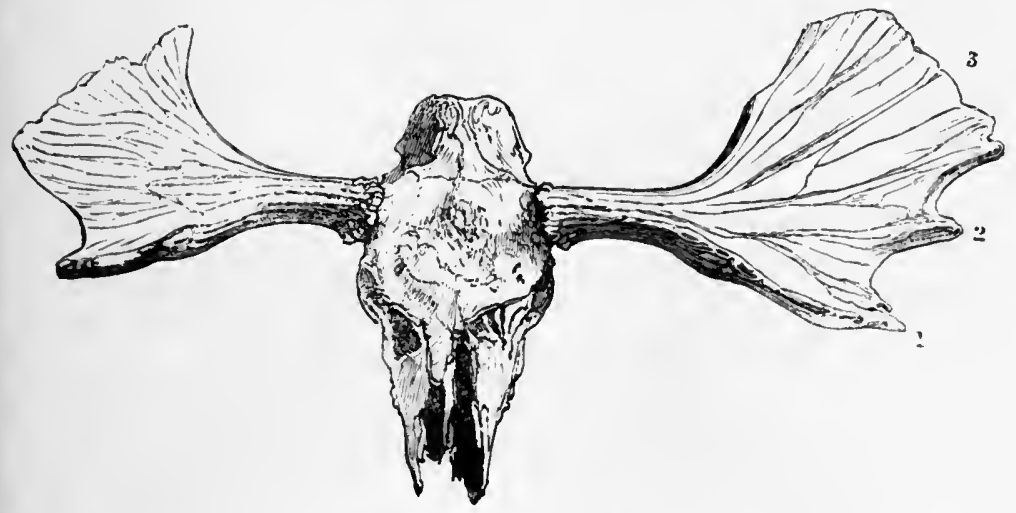

Fig. 3o.-Skull of elk found at Willie Struther's Loch, Roxburghshire.

horns was discovered in a bog at Oakwood, "a few miles up the river Etterick, above the town of Selkirk, and was brought upwards of thirty years ago by the Hon. Francis Scott to Mertoun House, Roxburghshire, where it is still preserved." 2

9. In the 'Edinburgh Encylopædia' ( 1830 ) the following statement occurs under the description of Selkirkshire: "It is likely that in ancient times the urus had been common, for skulls of that animal have frequently been found in the

${ }^{1}$ Proc. Soc. A. Scot., vol. ix. p. 326.

${ }^{2}$ Ibid., p. 33 I. 
marl mosses along with those of the stag, and another extinct species of deer with palmated antlers, of a size which seems to indicate the bearers to have been as large as a blood horse." (Probably the same as the deer of Saomme of Cuvier.)

The Rev. James Russell, in his account of the parish of

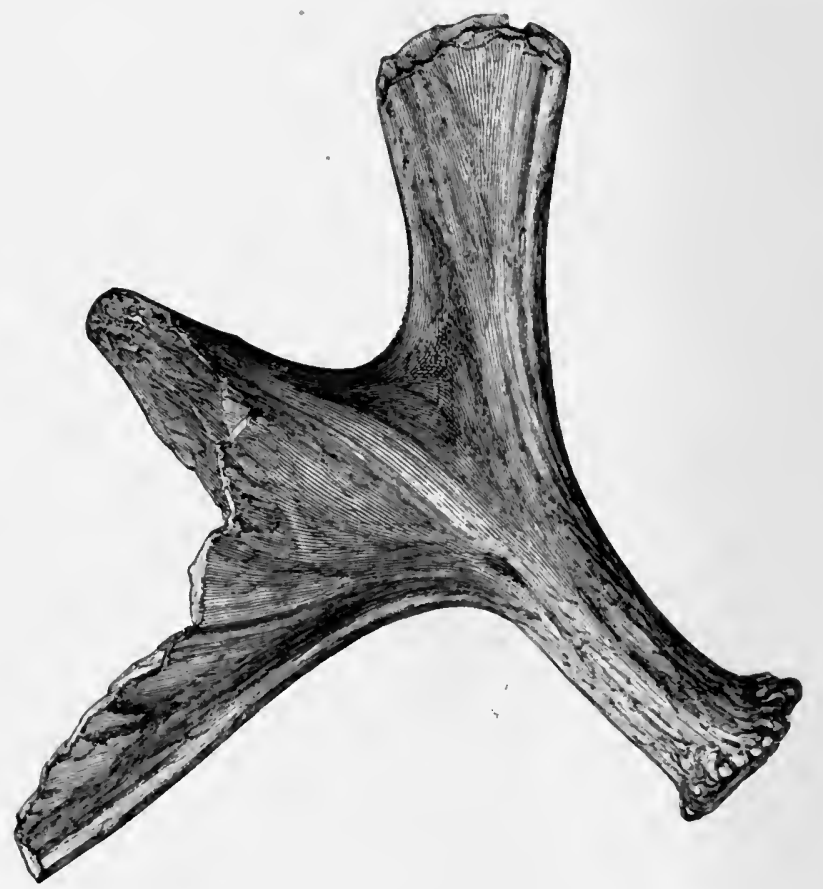

Fig. 3r.-Horn of the elk found in the river Cree, Wigtownshire.

Yarrow, states that "the skulls of the urus, described by Cresar, and an extinct species of deer with large palmated antlers, have been found embedded in the marl mosses." 1

I0. In the account of the parish of Kirkurd by the Rev.

1 New Stat. Account. of Scotland, Selkirkshire, p. 3 S. 
David Anderson, it is stated that " not long ago, in digging for marl in the Mount bog, several horns of the elk, in a high state of preservation, were found." 1

I I. In $1883 \mathrm{Dr}$ Smith records the finding of the horn of an elk (fig. 3I) in Wigtownshire. It and a fragment of a large deer-horn were drawn out of the estuary of the river Cree, "somewhere between Newton-Stewart and Creetown, in a salmon net," and given to the Rev. George Wilson, of Glenluce, by the man who got them. ${ }^{2}$

I2. Part of the antler of an elk (Cervus alces) was found recently by Sir F. T. Barry, M.P., in underground buildings attached to a broch at Keiss, excavated by him. ${ }^{3}$

\section{England and Ireland.}

The remains of the elk have also been recorded from various localities throughout England and Ireland, among which the following may be mentioned: Chirdon Burn, Northumberland ; ${ }^{4}$ Walthamstow, Essex $;^{5}$ in a RomanoBritish settlement at Wetton, Staffordshire $;{ }^{\circ}$ Hartlepool, Durham; ${ }^{7}$ Thorpe Hall and Carnaby, Yorkshire ; ${ }^{8}$ Isle of Man $;^{9}$ in a cave at Llandebie, Caermarthen $;^{10}$ and at Stewartstown, Tyrone, Ireland. ${ }^{11}$

1 New Stat. Account of Scotland, Peeblesshire, p. 128.

2 Proc. Soc. A. Scot., vol. xvii. p. 325.

${ }^{3}$ Proc. Soc. A. Lond., vol. xvii., 2nd series, p. I9I.

4 Trans. Tyneside Nat. Field Club, vol. v. p. $111,1863$.

${ }^{5}$ Geo. Mag., vol. vi. p. $3^{89}$.

6 Bateman's Ten Years' Digging, \&c., 1861, pp. 202, 29 S.

7 Trans. Tyneside Nat. Field Club, vol. v. p. 121.

8 Proc. Geo. and Polytech. Soc. of the West Riding of Yorkshire, I86c.

9 Proc. Soc. A. Scot., vol, ix. p. 339.

10 Ibid.

11 Proc. Zool. Soc., London, part v. p. 52, $1 \$_{37}$ 


\section{Gigantic Irish DeEr (Megaceros hibernicus).}

The Irish elk (fig. 32) is remarkable, among all the species of deer both living and extinct, for the great proportional size of its horns. Dr Molyneux, ${ }^{1}$ to whom we owe the first ac-

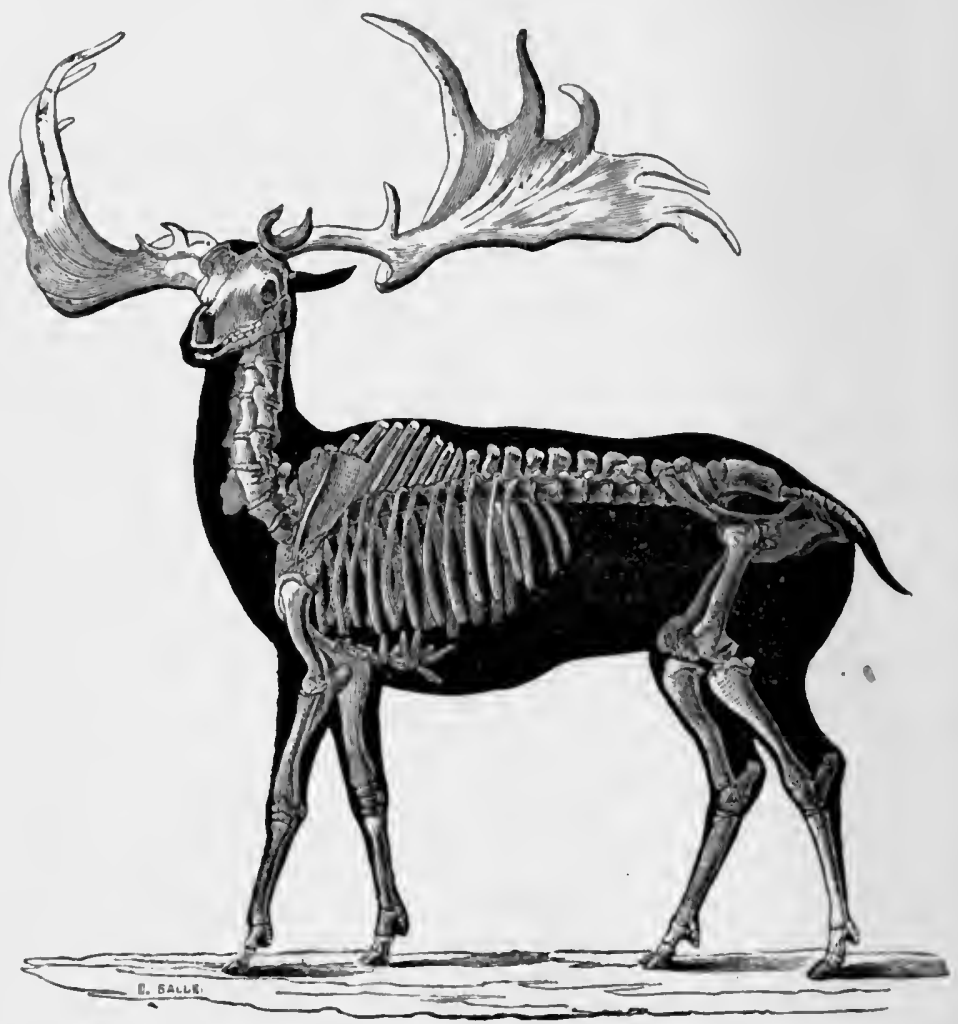

Fig. 32.-Irish elk.

count of this fossil animal, gives the length, from the extreme tip of the right to that of the left antler, as ro feet 10 inches; the length of each antler from the burr to the I Phil. Trans., vol. xxx. p. 485 . 
extreme tip, 5 feet 2 inches; and the breadth of the palmated part I foot $10 \mathrm{x} / 2$ inches. From these data he infers the amount of the superiority of the bulk of the animal over ordinary deer. Further discoveries, however, have shown this conclusion to be erroneous, as the osteological modifications necessitated by the vast weight of the head consisted merely in the greater strength of the limbs and neck.

"The first tolerably perfect skeleton of the Megaceros," says Sir R. Owen, writing in 1846,1 "was found in the Isle of Man, and was presented by the Duke of Athol to the Edinburgh Museum; the figure in the 'Ossemens Fossiles,' tom. iv. pl. viii., is taken from an engraving of this skeleton transmitted by Professor Jamieson to Baron Cuvier. Another skeleton was composed and set up by Dr Hart, in the Museum of the Royal Dublin Society, from a collection of bones found at Rathcannon, in Ireland, and this is figured in his 'Description of the Skeleton of the Fossil Deer of Ireland.' A third engraving of a foreshortened view, by Professor Philips, of the skeleton of the Megaceros, from Waterford, in the Museum of the Yorkshire Philosophical Society, was published, without description, by $\mathrm{Mr}$ Sunter of York; and this exhibits a more natural collocation of the bones than do either of the above-cited figures. Three very complete and well-articulated skeletons have since been added to English collections; one of those is in the British Museum, another in the Woodwardian Museum at Cambridge, and a third in the Hunterian Museum at the Royal College of Surgeons in London."

Remains of the Megaceros are sparingly found in Britain, but so abundantly in Ireland that about one hundred heads have been found, during the last thirty or forty years, in

' British Fossil Mammals, p. 447. 
the small bog of Ballybetagh alone. ${ }^{1}$ Besides Britain and Ireland, it inhabited the largest part of the Continent, where its remains are met with in caverns and Pleistocene deposits. Like the Bos primigenius, it is represented in the Cromer forest-bed, so that it existed throughout the entire glacial period. It probably found its way into Scotland during the first great forest growths in post-glacial times. It is maintained by some writers that the Megaceros was the contemporary of man in Ireland, on the ground that its remains have been found associated with the works of man in caves and crannogs. ${ }^{2}$ Mr Kinahan, in his notice of the crannogs in Loughrea, states that from Shore Island 300 tons of bones were procured, among which "were perfect heads of oxen, sheep, goats, deer, pigs, and what seemed to be large dogs or wolves. There was also exhumed the head of a Megaceros hibernicus which measured over 13 feet from tip to tip of its horns." 3 Horns of the animal were also found on the crannog of Cloonfinlough.* In the cave of Ballynamintra, County Waterford, explored by Messrs A. Leith Adams, F.R.S., G. H. Kinahan, M.R.I.A., and R. J. Ussher, ${ }^{5}$ numerous bones of the Irish elk were found, associated with a number of hammer-stones and pounders, and so broken as to suggest to the authors that it had been done by the hand of man. "Taking, therefore, into consideration," they write, "the oblong and rounded stones, battered and chipped at the ends by blows, also other stone tools bearing traces of man's handiwork, and strewn about among the Irish elk's remains, one can scarcely doubt but that the regularity in the mode of

${ }^{1}$ Geo. Mag., vol. viii. p. $35^{8}$.

2 Scientific Transactions of R. Dublin Society, vol. i., 2nd series, p. 222.

3 Proc. R. I. Acad., vol. viii. p. 424.

5 Scientific Transactions of R. Dublin Society, vol. i., 2nd series, p. 200. 
fractures was the result of his ingenuity for the extraction of the marrow, and possibly also for other objects."

It may also be observed that these Irish elk bones were associated with the remains of a Neolithic fauna, among them being the bones of horse, pig, ox (Bos longifrons), grizzly bear (Ursus ferox), goat, red-deer, badger, wolf, fox, dog, \&c. Among the relics of man were human bones, a polished stone celt, various implements of bone, an amber bead, two bone plates of the handle of a knife ornamented with incised concentric circles, charcoal, \&c., showing that the cave had been frequented by man up to early.medieval times.

The remains of the Megaceros hitherto discovered in Scotland are very few. The Rev. George Gray ${ }^{1}$ gives an exceedingly interesting notice of a find in the parish of Maybole, Ayrshire, in which the head and horns of the animal were found associated with bones of the ox and the red-deer. In this report he writes as follows :-

"Towards the southern boundary of the parish there are a series of hollows between the undulations of the sandstone, some of them still in the state of lochs, and others of marshes. On draining some of them, it has been found that, after penetrating a bed of soil and moss of about 8 to ro feet in thickness, great deposits of marl occur, containing an immense number of organic remains. It is to be regretted that at the time the marl was excavated no greater attention than what curiosity prompted was directed towards these interesting relics. Portions of different animals have, however, been preserved; and for the following notice of the heads of the elk and Bos in the possession of Mr Kennedy of Drummellan I am indebted to Dr M'Tyer of Redbrae.

" "The fossil head of the Cervus megaceros differs from the

1 New Stat. Account, vol. v. p. 353. 
specimen in the Museum of the Royal Society of Dublin in the head being larger and the horns a little less, probably from the Drummellan animal having been aged.' [Then follow the dimensions.]

"The other head appears to have belonged to a variety of Bos taurus, the forehead being concave. It measures ro inches between the horns, and $13 \frac{1}{2}$ inches round the hole of the horn. Horns of the Cervus elaphus were also found."

Two portions of the horns of the Megaceros, consisting of the left beam of a shed horn of average size, and the brow snag of another horn, were found in a cutting on the Crofthead and Kilmarnock Railway; but geologists differ as to the nature of the deposits, some assigning them to an interglacial period. ${ }^{1}$

In September 1897 an almost complete skeleton of the Irish elk was dug out of a bed of marl at Close-y-Garey, parish of German, Isle of Man. The marl bed lay under 3 feet of disturbed soil and peat, and extended downwards to a depth of about 10 feet. The skeleton was found about 9 feet from the surface, lying "on its right side, the head towards the bank and the legs drawn up to the body." From the interim report of the Committee conducting the investigation, I extract the following notes on this interesting discovery.

"The bones were nearly in juxtaposition, and in a fair state of preservation. Unfortunately, however, the skull was badly decayed, having probably broken, as suggested by Professor Dawkins, under the weight of the antlers, of which the left one had fallen over the lumbar vertebrr, the right dropped down by the cervical vertebræ and shoulder-blades. The latter was in almost perfect preservation; the tines, how-

2 Trans. Geo. Soc. Glasgow, vol. iv.; Geo. Mag., rol. v. p. 393, vol. vi. p. 390 , and rol. vii. p. 137 . 
ever, dropped off in lifting it out of the marl. The left antler is the larger, measuring across the palm $\mathbf{I}_{5}$ inches, allowing for a small piece of the front edge which has decayed away; the right measures 13 inches. With tines restored, they are respectively $561 / 2$ inches and 53 inches long. Curiously, the beam was missing in both; this would probably have been another Io inches. They have each six points or tines besides the brow tines which had fallen off, the part of the beam to which they were attached having decayed away.

"The size and shape of the antlers show the animal to have been an adult male; the teeth which remain are in excellent preservation, showing no sign of weakness or decay. The limbs are perfect, all the small bones having been recovered; the vertebræ are sound, but, unfortunately, the atlas is missing, having probably been turned over and reburied in the wet clay without being observed. The right shoulderblade, which lay beneath the other, is badly decayed, as are many of the ribs and the pelvic bones; but we hope that, with a little piecing out and patching, the bones, when articulated and mounted, will make a perfect skeleton."

RED-DEER (Cervus elaphus) and RoE-DEER (C. capreolus).

Red-deer had formerly a wide distribution throughout the temperate regions of Europe and Asia, and they are still to be found in some of the European forests, though in greatly diminished numbers from what they used to be even in early historic times. The great range of this animal in time is attested by numerous discoveries of its antlers, teeth, and bones, throughout England, Scotland, and Ireland, in ossiferous caves, in the newer fresh-water deposits of the Pliocene period, and in intermediate formations up to the 
growth of the existing peat-bogs. "The chain of evidence of the existence of this species of deer in Britain," writes Sir R. Owen, "from the Pliocene tertiary period to the present time, seems to be unbroken. This at least is certain, that a deer, undistinguishable by the characters of its enduring remains from the Cerous elaphus, coexisted with the Megaceros, the spelæan Hyæna, the tichorhine Rhinoceros, and the Mam-

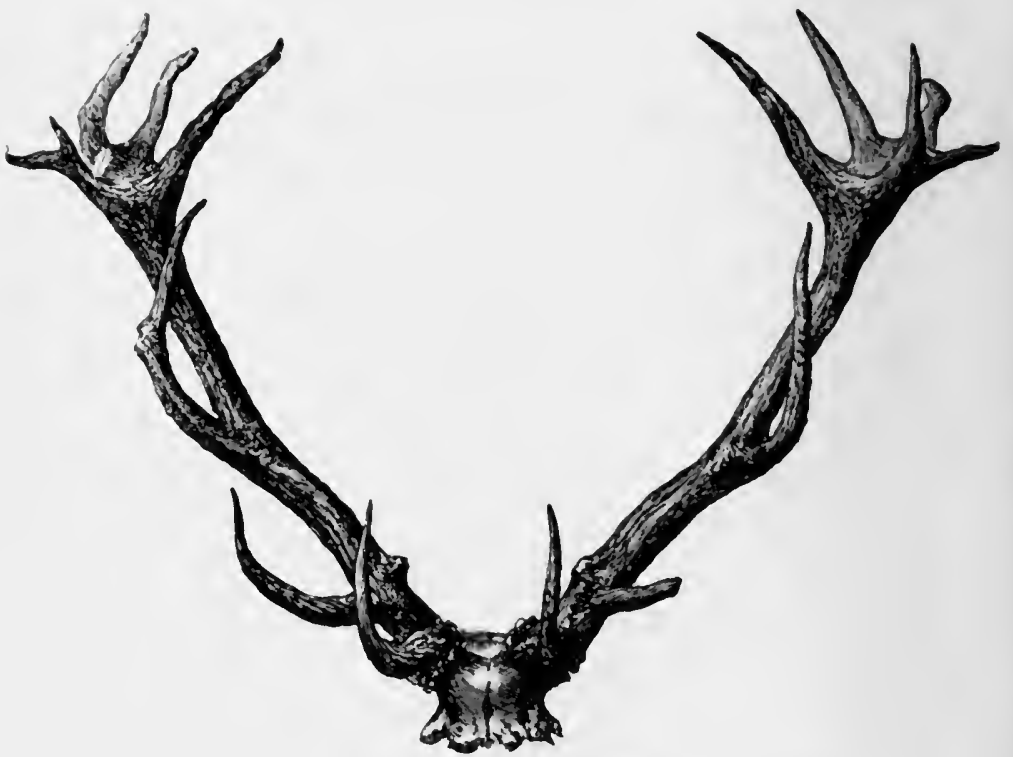

Fig. 33.-Horns of red-deer found in the Meadows, Edinburgh.

moth, and has survived, as a species, those influences which appear to have caused the extinction of its gigantic associates, as well as of some smaller animals-for example, the Trogontherium, the Lagomys, and the still more diminutive Palcospalax." 1

No animal, among the prehistoric fauna of Britain, comes more frequently before the eye of the archrologist than the

1 British Fossil Mammals, p. 478 . 
red-deer. Indeed from the very dawn of Neolithic civilisation it was sought after, not only as food, but also for its horns and bones, which were utilised as implements, weapons, and ornaments, \&c. The frequency and abundance with which its remains have been found on ancient inhabited sites, such as crannogs, brochs, earth-houses, caves, rock-shelters, \&c., is positive evidence that in those times great herds of

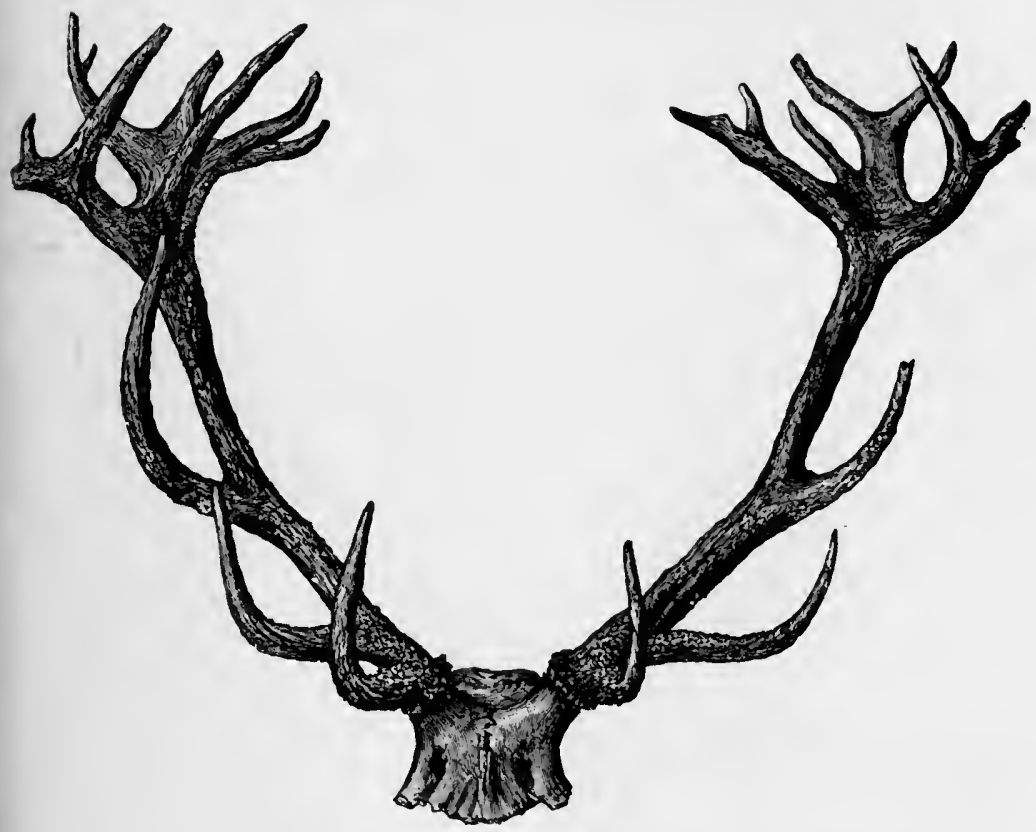

Fig. 34.-Horns of red-deer found in a moss, Ashkirk, Roxburghshire.

deer roamed over the country. Although the area of their existence in Britain has now dwindled down to a few protected forests in the north of Scotland, where some herds enjoy a kind of wild life, there is ample historical evidence to show that deer abounded in the south of Scotland in medieval times. Thus, by order of Edward I., dated I 8th August I 291, "Simon Fresel (Frazer), Keeper of the forest of Sel- 
kirk, is enjoined to bestow upon the venerable fathers, William Frazer, Bishop of St Andrews, thirty stags; Robert (Wishart), Bishop of Glasgow, twenty stags and sixty oaktrees; and the Bishop of Caithness for himself, ten stags; James the Steward of Scotland, twenty stags," \&c. ${ }^{1}$ For further historical notices of the red-deer, and the specified localities throughout Scotland which have yielded the remains, I would refer my readers to the valuable article of $\mathrm{Dr} J$. Alexander Smith, in the $1^{\text {th }}$ volume of the 'Proceedings of the Society of Antiquaries of Scotland.' I will only further remark that the horns disinterred from marl-pits, and the older turbaries, appear to indicate animals decidedly larger than those of the present day. At any rate, nowhere throughout Europe could we find, at the present time, a stag's head to match with the two here illustrated (figs. 33 and 34), one found in the Meadows, Edinburgh, and the other in a moss at Ashkirk, Roxburghshire.

The history of the roe-deer, as well as its distribution in space and time, may be paralleled with that of the red-deer, and, as obtains at present, at no time was it so numerous as the latter. The antler of the roe-buck requires very little to convert it into a convenient hand-dagger; and $I$ have found weapons or implements of this description in various crannogs. ${ }^{2}$

\section{URUS (Bos primigenius).}

Of the two wild oxen, the Bison and the Urus, stated by Pliny to be, in his time, inhabitants of Germany, ${ }^{3}$ the remains of the former have not yet been discovered among the superficial deposits of the prehistoric period in Britain; but its

1. Quoted in Proc. Soc. A. Scot., vol. xv. p. 61.

2 See Ancient Scottish Lake-Dwellings, fig. 174.

3 Nat. Hist., book viii. chap. 15. 
presence in earlier times, as a contemporary of the mammoth, tichorhine rhinoceros, and cave hyæna, is unequivocally established. "A characteristic cranium with horn-cores of the Bison priscus," says Professor Owen, "obtained by $\mathrm{Mr}$ Warburton from the fresh-water newer Pliocene deposits at Walton in Essex, is suspended in the Hall of the Geological Society of London." 1

In France and Germany its remains are frequently met with, being indeed among the fauna of the lake-dwellings of Robenhausen and Wauwyl ; and, in more eastern parts, it is still extant as the auroch of the Lithuanian forest. "Its absence from Britain," says Professor Boyd-Dawkins, "may perhaps be accounted for by our island having been cut off from the mainland of Europe before the commencement of the prehistoric period, and by the animal having been consequently exposed to the craft of the hunter in an area too small for its concealment." 2 On the other hand, the urus continued to live in Britain during the prehistoric period (probably longer in Scotland than elsewhere in the island). The discovery of its remains in marl-pits, in the newer tertiary deposits, and in the Cromer forest-bed, proves that the animal had a wide geological range, embracing the entire glacial period. Cæsar gives a good account of the uri of the great Hercynian forest : "There is a third kind, consisting of those animals called uri. These are a little below the elephant in size, and of the appearance, colour, and shape of a bull. Their strength and speed are extraordinary; they spare neither man nor wild beast which they have espied. These the Germans take with much pains in pits and kill them. The young men harden themselves with this exercise, and practise themselves in this kind of hunting, and those who have slain the

1 British Fossil Mammals, p. 494.

2 International Cong. Prehistoric Arch., Norwich, p. 283. 
greatest number of them, having produced the horns in public to serve as evidence, receive great praise. But not even when taken very young can they be rendered familiar to men and tamed. The size, shape, and appearance of their horns differ much from the horns of our oxen. These they anxiously seek after, and bind at the tips with silver, and use as cups at their most sumptuous entertainments" (Book ri. chap. 28).

The fossil remains of this great ox have been abundantly found throughout Scotland, as the following records will show :-

I. Five skulls were discovered in a marl-moss at Whitmuirhall, one of which was presented to the Museum of the Society of Antiquaries of Scotland by the Rev. Thomas Robertson, accompanied by a letter, in which the writer says: "Among other curiosities dug out of a marle moss at Whitmuirhall, in this parish, the skull and flints of an ox which I have sent you attracted my attention. You, I know, are fond of anything that tends to throw light upon the ancient state of this country, and therefore I used the freedom to transmit this, not merely on account of its uncommon size, but as a proof of the large breed of cattle with which this country abounded in the last century. I found five skulls, evidently larger, but not so entire. I found also several small axes, resembling those used by coppersmiths, but I did not think it worth while to trouble you with them." 1

Subsequently, in noticing this discovery, ${ }^{2} \mathrm{Mr}$ Robertson states that a Roman spear was found along with these skulls.

2. Another fine specimen of the head of the urus, labelled from Selkirkshire, is in the Museum of the Royal College of Surgeons, Edinburgh.

1 Proc. Soc. A. Scot., vol. ix. p. 643.

${ }^{2}$ Stat. Account of Scotland, rol. ii. p. 434. 
3. A fine large skull of Bos primigenius is preserved in the Abbotsford collection, said to have been found in a moss near Jedburgh. ${ }^{1}$

Dr J. A. Smith has put on record the fact that during a drive in the valley of the river Ale, near the town of Lilliesleaf, he saw two large skulls impaled one on each of the wooden posts of an old field-gate. ${ }^{2}$

4. In 1826 the bones of a large ox, described as the Bos primigenius, were got in the marl of Linton Loch, Roxburghshire, as well as those of deer. A perfect skull of the beaver (Castor fiber) was also found "below the peat and on the surface of the marl, now preserved in the Museum of the Tweedside Physical and Antiquarian Society at Kelso." 3

5. A skull of the urus was presented to the Museum of the Society of Antiquaries of Scotland, in $\mathrm{I}_{722}$, by Thomas Scott of Hapsburn. Also in the same year another specimen, from a moss in Galloway, by the Rev. David M'Robert. ${ }^{4}$

6. The Rev. G. J. Hamilton states, inter alia, that in a marlmoss on the estate of Synton, Ashkirk, "besides the horns of the stag already mentioned, the horns of the urus (Bos primigenius) were dug up from the same moss." 5

7. A portion of the skull of the urus was found by Dr Henderson in the Whitrig Bog, and presented to the Hunterian Museum, Glasgow. ${ }^{6}$

8. Remains of Bos primigenius were found in Dumfriesshire associated with the bones of the bear and reindeer, as already described (p. 90). ${ }^{7}$

9. In the British Museum there is a skull, from a turbary

1 Proc. Soc. A. Scot., vol. ix. p. 656.

${ }^{3}$ Edin. New Phil. Journal, July 1858 .

4 Proc. Soc. A. Scot., vol. ix. p. 644.

${ }^{6}$ Ibid., vol. ix. p. 658 .
2 Ibid., p. 657 .

5 Ibid., vol. $x v$, p. 50.

7 Ibid., vol. viii. p. 216. 
in the county of Kirkcudbrightshire, presented by Lord Selkirk in 1859.1

I 0 . A skull of the urus is recorded as having been found in a marl-pit near Maybole, associated with remains of various other animals (see p. ro4).

I 1. A portion of the skull with a horn-core was found in a bed of clay in a railway cutting, near Crofthead, Renfrewshire, along with remains of Irish elk and horse. ${ }^{2}$

12. Professor J. Geikie describes the remains of Bos primigenius found in the valley of Cowden Burn in clay-beds, which he considers to be interglacial. ${ }^{3}$

I3. Mr William Lockhart, in his account of the parish of Lanark, states that, in 1785 , while digging a mill-lade, "there was found the skeleton of the Bison scoticus, or Urus, described by Cresar, lib. vi., which has been extinct in Scotland for above 300 years. The cores or flints of the horns are still preserved, one in the College of Glasgow, and another in my possession: the last, though not entire, is 2 feet in length, and next the head measures above 15 inches in circumference." 4

14. Remains of the urus were found on the north bank of the Clyde, associated with those of the reindeer, ${ }^{5}$ and also in an excavation in Greendyke Street, Glasgow. ${ }^{6}$

I 5. A large skull of a Bos taurus, described in Fleming's 'History of British Mammals,' is now preserved in the Museum of the New College, Edinburgh. A label, fixed on it in Dr Fleming's handwriting, is to the effect that it

1 Proc. Soc. A. Scot., vol. ix. p. 659.

2 Trans. Glasgow Geo. Mag., vol. iv., and Geo. Mag., vol. vii. p. 137.

${ }^{3}$ Geo. Mag., vol. v. pp. 393,486 , 535 ; vol. vi. pp. 73,390 ; vol. vii. p. 53 .

+ Stat. Account of Scotland, vol. xv. p. 34 .

5 Proc. Soc. A. Scot., vol. viii. p. 207.

6 Trans. Geo. Soc. Glasgow, vol. ii., I867. 
was found in a marl-pit at Newburgh, Fifeshire (figs. 35, 36 , and 37 ).

16. A large skull from near Athol, now in the British Museum, is figured and described by Professor Owen in his 'British Fossil Mammals,' p. 50r. At the end of his description he makes the following remarks, which show that his opinion was against the supposition that any of the domestic

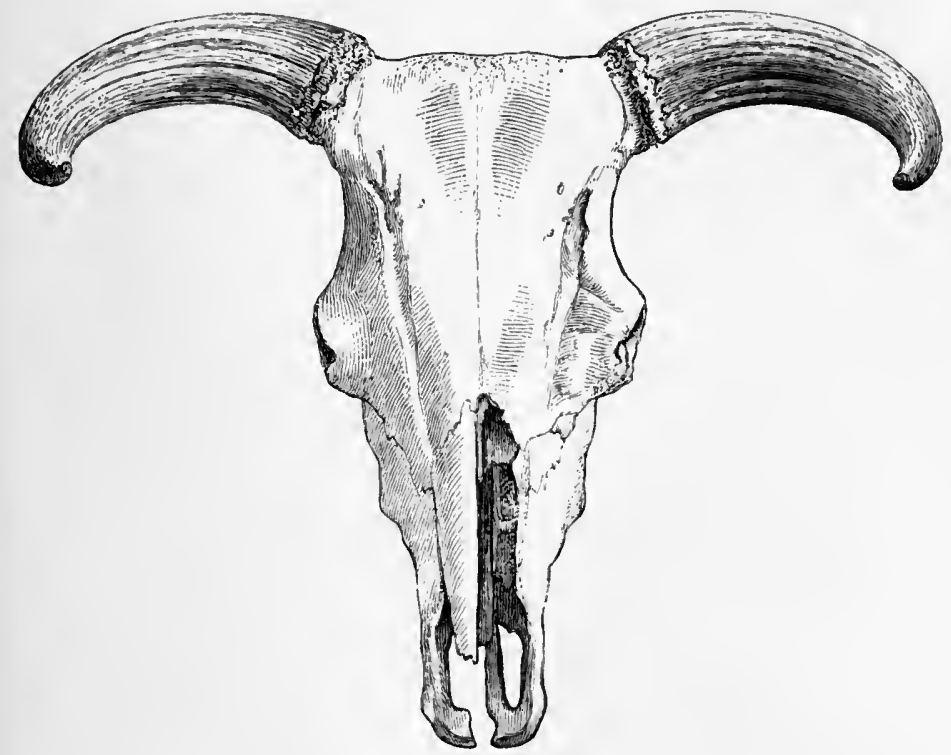

Fig. 35. -Skull of Bos primigenius found in Fifeshire (273/4 inches in length).

cattle of Scotland are descendants of the prehistoric wild ox: "In the manuscript catalogue of the British Museum this fine specimen is ascribed to 'the Caledonian Ox, Bos taurus, var. gigantea.' But the wild white variety with black muzzles, ears, and horns, the 'boves sylvestres' of Leslie, which are identical with the cattle preserved at Chillingham, are of very inferior dimensions, and differ particularly in the smaller proportional size, and finer and more tapering figure 
of the horns. The kyloes of the mountainous regions of Scotland, which are more likely to have been derived from an indigenous wild race than the cattle of the Lowlands, differ

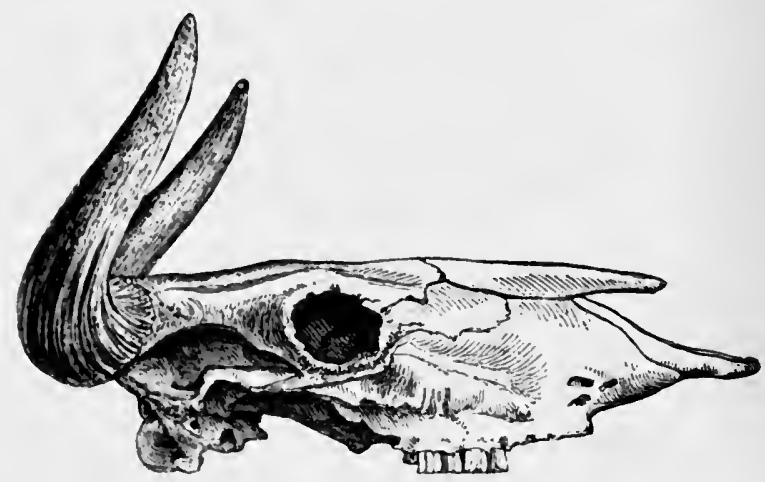

Fig. 36. - Side view of skull in fig. 35 .

still more from the Bos primigenius than does the Chillingham breed in their diminutive size, and very short horns."

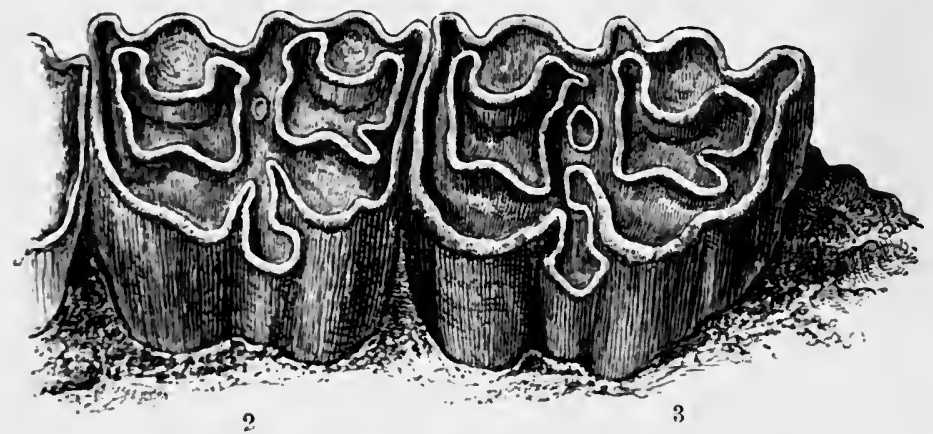

Fig. 37.- Tư last maxillary molar licth of left side of Bos primigenius (natural size).

i7. Another skull was found in the last century in a marlpit half a mile from Moulin, Perthshire. ${ }^{1}$

IS. The Rer. J. Scott, in his account of the parish of

' Stat. Account of Scotland, rol. v. p. 70. 
Muthil, ${ }^{1}$ writes as follows: "At this time (1793) there are no wild deer, but as the horns of both the elk and forest deer of very large size have of late been found in marl-pits, on both sides of the parish, and as the head and horns of the urus (Bos ferus of Linnæus) or mountain bull were lately dug up at the side of a small lake near Drummond Castle, it plainly shows that forest deer, and the other animals now so little known, once frequented this part of the country."

Another specimen, got in a marl-pit in the neighbourhood several years ago (one of several found at the same time), is preserved at Drummond Castle. ${ }^{2}$

1 9. A skull and bones found in Belhelvie peat-moss, a few miles north of Aberdeen, are now preserved in the Museum of the University of Aberdeen. ${ }^{3}$

20. Rev. Dr Joass found in a ruined broch at Kintradwell remains of the pig, reindeer, and other animals, along with the frontal bone, horn-cores, and other bones of a large animal of the ox tribe. ${ }^{4}$

21. Dr Joseph Anderson discovered in an ancient mound at Keiss the upper part of the skull, with the frontal bone and horn-core, of a large ox-now preserved in the Museum of the Society of Antiquaries of Scotland, which, in Dr Smith's opinion, corresponds more to that of the Bos primigenius than to any other species. ${ }^{5}$

22. Another specimen found in the marl of the Loch of Breckigo, along with antlers of the red-deer, was presented to that museum by Bentley Innes, Esq. of Thrumster, in June $1870 .^{6}$

23. Dr Smith records, on the authority of Dr Joseph Anderson, the two following instances of the finding of bones

${ }^{1}$ Stat. Account of Scotland, vol. viii. p. 487 .

2 Proc. Soc. A. Scot., vol. ix. p. 663.

3 Ibid.

4 Ibid., p. 665.

5 Ibicl.

6 Ibid. 
of the Bos primigenius in bogs: Two heads with the horns entangled, as if the animals had been fighting, were found in a bog in the parish of Bower when digging for marl on the estate of Thura. They were upwards of 3 feet in the ground, and in a high state of preservation. The second instance was also of two heads similarly locked, and buried about the same depth. They were found at Clayock, in the parish of Bower, by Alexander Ross, while digging a drain in the month of October 1840.1

24. Mr Samuel Laing recognised the horns of a large ox found in the "Underground House of Skaill," Orkney, as those of the Bos primigenius. ${ }^{2}$

\section{Celtic Shorthorn (Bos longifrons).}

Sir Richard Owen gave the name longifrons to a frontlet and horn-core of a small ox, which formed part of the original collection of fossils of John Hunter, recorded as having been obtained "from a bog in Ireland." " Had no other localities," he writes, "for the Bos longifrons been known than that of the Hunterian specimen, the species might have been held to be of later date than the Bos primigenius and Bison priscus, of whose existence, as the contemporaries of the Mammoth and tichorhine Rhinoceros, we have had such satisfactory evidence. I have, however, been so fortunate as to find, in the survey of the collections of Mammalian Fossils in the eastern counties of England, some indubitable specimens of the Bos longifrons from fresh-water deposits, which are rich in the remains of Elephas and Rhinoceros." 3

Professor Boyd-Dawkins denies the validity of the evi-

1 Proc. Soc. A. Scot., vol. ix. p. 666.

${ }^{3}$ British Fossil Mammals, p. 5 ro.

- Transactions of International Congress of Prehistoric Archxology, Norwich, 186S, p. 2S1. 
dence on which the Bos longifrons is thus made contemporary with the fauna of the newer Pliocene age. After critically reviewing the reported geological conditions in which the specimens on which Owen based his opinion were found, he comes to the following conclusion: "In fine, all the cases of its reputed occurrence, associated with post-glacial mammalia in Britain, may be resolved either into a mistaken identification of its remains with those of bison, or by the mixture of its remains with those of animals derived from a different formation."

The difference of opinion thus manifested is not yet satisfactorily disposed of, so far as I know; but as it can only be settled by an appeal to further discoverable materials, it would be useless to continue the discussion here.

There are no animal remains, with perhaps the exception of those of the red-deer, which come more frequently before the archæologist than those of Bos longifrons (fig. 38). They are constantly met with on the sites of the earlier constructions and habitations of man, such as lake-dwellings, earth-houses, Roman camps and villages, brochs, barrows, caves, and kitchen-middens; also in peat-bogs and alluvium. It is unnecessary to enumerate all the finds recorded; and I shall, therefore, notice only a few of the more instructive circumstances in which the bones of this animal have been found.

Crannogs.-On the crannogs in the loch of Dowalton, they were associated with Romano-British industrial relics, as well as with remains of pig and sheep or goat; ${ }^{1}$ and on the crannog of Lochlee, with the bones of the horse, tame pig, sheep, red-deer, roe-deer, and reindeer. ${ }^{2}$

Roman Station.-On the site of the Roman station at

1. Proc. Soc. A. Scot., vol. vi. p. I 8 .

2 Ancient Scottish Lake-Dwellings, p. I 39. 
Newstead, in Roxburghshire, sereral specimens were found along with Roman pottery. ${ }^{1}$

Brochs. - In the brochs of Cill Trölla, Kettleburn, Keiss, Yarhouse, ic."

Cires. - In the Mac.Arthur Care at Oban (see p. 50), and in the Borness Cave in Kirkcudbrightshire. ${ }^{3}$

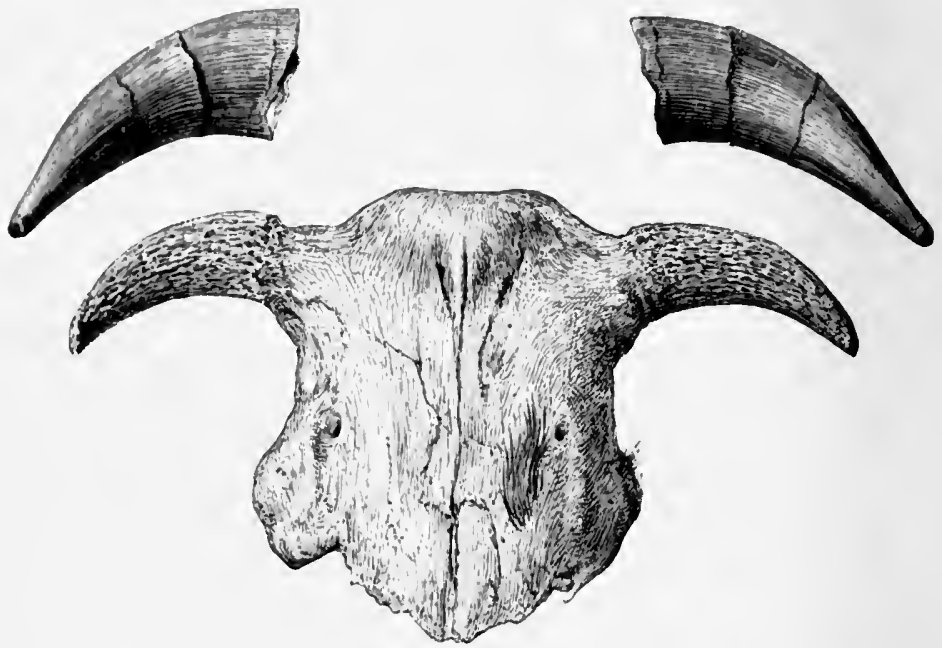

Fig. 38. - Portion of skull and horns of Bos longifrons found in a bog in Ireland 25 feet betow the surface, and now preserved in the Museum of the New Collegt, Edinburgh.

Kitchen-middens. - On the Ghegan Rock (see p. 80), associated with the goat, horse, pig, deer, roe, and dog. ${ }^{4}$

Forts. - Mr Hugh W. Young notes the remains of the bos longifrons along with those of the horse, sheep, and pig, at Burghead. ${ }^{5}$

Alininum. - At Kinleith, near Edinburgh, bones of the ox and $\operatorname{dog}$ were found in a gravel-bed, formed by the river in

'Proc. Soc. A. Scot, vol. ix. p. jSS.

2 Ibid., vol. ix. pp. $631-634$.

${ }^{3}$ Ibid., vol. x. p. 502.

4 llid., vol. viii. p. 372 .

${ }^{3}$ Ihid., vol. sxvii. p. 9 I. 
ancient times, at a depth of nearly I I feet from the surface, together with a remarkable bronze razor (fig. 39). ${ }^{1}$

Peat.-Near Drem, a skull with horn-cores was found I 5 feet under a peat-moss at Balgone; and also in BlairDrummond Moss its remains were found in several places. ${ }^{2}$ At Morbhaich Mor, Tain (see p. 86), its remains were associated with those of the reindeer and dog.

Professor Owen states that it has been found under peat in the neighbourhood of Bridgewater, Devon, and in various localities in Ireland "from sub-turbary shell marl." 3

I may observe that on the sites of the Swiss lake-dwellings remains of a small ox are everywhere noted. As Bos brachyceros it is recorded among the animal remains found on the great Neolithic settlement of Butmir, in

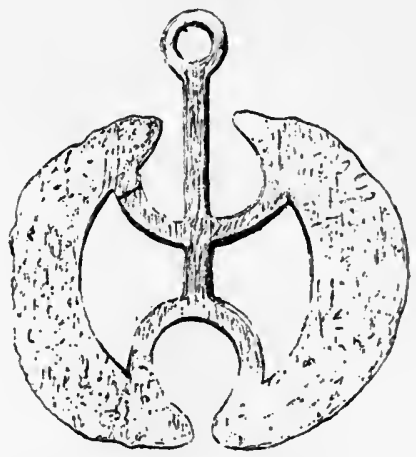

Fig. 39.-Bronse ruzor found at

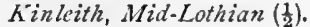
Bosnia, including the Urus, and other varieties of Bos, as well as the pig, sheep or goat, stag, and roe-deer. ${ }^{4}$

Remains of Bos longifrons have also been found in tombs of the Stone and Bronze Ages by numerous explorers, as Canon Greenwell, ${ }^{5}$ Mr Bateman, ${ }^{6}$ Sir R. Colt Hoare, ${ }^{7}$ and Mr Warne. ${ }^{\mathrm{s}}$

Sir Richard Owen, in combating the idea that our modern

${ }_{1}$ Proc. Soc. A. Scot., vol. v. p. 84 , and vol. ix. p. 625.

2 Ibid, vol. ix. pp. 627-629. ${ }^{3}$ British Fossil Mammals, pp. 511, 512.

4 Rambles and Studies in Bosnia, \&ic., p. 108.

5 British Barrows, pp. 168, 230.

6 Vestiges, p. 82 ; and Ten Years' Diggings, pp. 126-129.

7 Ancient Wilts, vol. i. p. 199.

${ }^{8}$ Celtic Tumuli of Dorset, p. 37. 
domestic cattle are descendants of the Bos primigenius, regards it as "more probable that the herds of the newly conquered regions would be derived from the already domesticated cattle of the Romans." To this, however, he adds the following: "But, if it should still be contended that the natives of Britain, or any part of them, obtained their cattle by taming a primitive wild race, neither the Bison nor the great Urus are so likely to have furnished the source of their herds as the smaller primitive wild species, or original variety of Bos, which is the subject of the present section." 1

On reviewing the whole circumstances, so far as I can gather the evidence in support of both sides of the question, I am inclined to agree with Professor Boyd-Dawkins that the Bos longifrons was part of the indispensable belongings of Neolithic man when he first entered Britain. It was indeed the possession of domestic animals that gave him the mastery over his Palæolithic predecessors in Europe.

I have already quoted Crsar's statement (p. 5) that the Britons possessed numerous herds of cattle. There can, therefore, be no doubt that the Bos longifrons was a domestic animal in the British Isles long before the Romans invaded the country.

\section{BeAver (Castor europaus).}

According to Sir Richard Owen, remains of the Beaver have been found, both in this country and on the continent of Europe, in Pleistocene fresh-water formations associated with those of the Mammoth, Hippopotamus, Rhinoceros, Hyæna, and other extinct mammalia. They are not, however, found in the bone-caves of this country belonging to that period. The most common situation in which they occur is in the 
sub-turbary deposits and the peat-bogs. At Newbury, Berkshire, bones of the beaver were discovered in a deposit of shell-marl, 20 feet below the surface, associated with those of the "wild boar, roe-buck, goat, deer, and wolf." Also at Hilgay, Norfolk, they were found at a depth of $81 / 2$ feet beneath peat, resting on a stratum of clay and associated with remains of the Megaceros. ${ }^{1}$

Among the débris of the Swiss lake-dwellings remains of the beaver are almost everywhere to be found. At the station of Laibach, in Carniola, so abundant were they that Dr Karl Deschmann calculated that over 140 individuals were represented. ${ }^{2}$ It is not, however, among the animal remains at Polada, and its bones are only sparingly found in the Terremare of Italy. ${ }^{3}$ Among the prehistoric remains recently discovered at Sobunar, near Sarajevo in Bosnia, portion of the under jaw of this animal has been identified by Herr Fiala - who also remarks on the frequency with which Daber (Beaver) occurs in place-names of the country. ${ }^{4}$ In England remains of the beaver have been found in the crannogs explored by $\mathrm{Mr}$ Thomas Boynton in the Holderness, Yorkshire $;^{5}$ and in the Glastonbury Lake-village they are associated with bones of the ox, goat, sheep, pig, horse, and domestic fowl. ${ }^{6}$ Canon Greenwell describes a sharppointed implement, made from a beaver's tooth, found in one of the Yorkshire barrows. ${ }^{7}$

Equally unequivocal is the evidence of the prevalence of the beaver in Scotland. On the I6th December I 788 , Dr Farquharson presented to the Society of Antiquaries of Scot-

1 British Fossil Mammals, p. 193.

2 Lake-Dwellings of Europe, p. 185.

3 Ibid., p. 274.

4 Rambles and Studies in Bosnia, Sic., p. $32 \mathrm{I}$.

5 Lake-Dwellings of Europe, p. 474.

6 Brit. Association Report, 1894, p. 433.

7 British Barrows, p. 138 . 
land "the fossil skeleton of the head and one of the haunch bones of a beaver" which had been dug up in a marl-pit in Perthshire. The locality was a partially drained loch (Marlee, in the parish of Kinloch), and the marl in which the bones were found was overlaid by a covering of peat-moss 5 or 6 feet thick. ${ }^{1}$ Another discovery was in October 1818 , on the estate of Kinmmerghame, parish of Edrom, near the head of that district of Berwickshire called the Merse. In the drained morass, known as Middlestot's Bog, the skeleton of a beaver was found partly embedded in a deposit of shell-marl over which 7 feet of peat had accumulated. ${ }^{2}$ In more recent times its remains have been found by Mr John Smith in a cave and rock-shelter, both in Ayrshire. ${ }^{3}$

Nor must we omit the historical notices of this animal, which show that in Wales and Scotland it continued to live down to about the twelfth century. From the article in the 'Memoirs of the Wernerian Society', already referred to, it would appear that the earliest written reference to the beaver is contained in a document of the ninth century, published in 'Leges Wallica,' or the Laws of Howel the Good (Hywel D'ha), book iii. sects. I I, I 2 , in which the prices of skins are regulated.

The Marten's skin is valued at . . . . 24d.

The Otter's (Ddyfrgi, or Lutra) at . . . . I Id.

The Beaver's (Llosdlydan, or Castor) at . . . 120 .

In the 'Itinerarium Cambria' of Giraldus de Barri, the beaver is said to be found only in the Teivi : "Inter universos Cambriæ seu etiam Llægriæ fluvios, solus hic castores habet"; to this he added, "In Albania quippe, ut fertur, fluvio similiter unico habentur, sed rari." But this is not the only his-

I Mem. Wern. Soc., vol. iii. p. 207.

2 Ibid.

See chap. iii. 1. S1; and Trans. Geol. Soc. Glasgow, vol. vii. p. 309. 
torical evidence of the existence of the beaver in Scotland. Hector Boece (Boethius), at the end of the fifteenth century, states that beavers were in Loch Ness in Scotland. "Ad lacus latera, propter ingenta nemora ferarum ingens copia est, cervorum, equorum indomitorum, capreolorum ; ad hæc, marterellæ, fovinæ ut vulgo vocantur, vulpes, mustelæ, fibri lutreæque, incomparabile numero, quorum tergora exteræ gentes ad luxum immenso pretio coëmunt."1

Bellenden in his translation uses the words: "Mony wyld hors, and among yame ar mony martrikis, bevers, quhitredis, and toddis, the furrings and skynnis of thayme are coft with great price amang uncouth merchandis." 2

Mr Patrick Neill, the author of the article in the "Memoirs of the Wernerian Society,' states that Dr Walker, Professor of Natural History in the University of Edinburgh, used to mention in his lectures that the beaver was known among the Highlanders by a peculiar Gaelic name, which name, he ascertained, through Dr Stuart of Luss, to be Dobran losleathani.e., the broad-tailed otter. ${ }^{3}$

\section{WiLd BOAR (Sus scrofa).}

Sir Richard Owen informs us that when Cuvier communicated his memoir on the fossil bones of the hog to the French Academy in 1809 , he had met with no specimens from formations less recent than the mosses or turbaries and peat-bogs, and knew not that any had been found in the drift associated with the bones of the elephant. There can, however, now be no doubt that this animal was contemporary with the extinct

1 Boethius, Scot. Hist.

2 Bellenden, Croniklis of Scotland.

3 See also Edinburgh Philosophical Journal, vol. i. p. 177 ; and Owen's British Fossil Mammals, p. 198. 
mammalia of the Quaternary period. ${ }^{1}$ Although the present range of the Wild Boar extends over certain portions of Europe, Northern Africa, and Western and Central Asia, it is by no means so abundant as it was in the prehistoric period. Its prevalence throughout the British Islands in pre- and proto-historic times is attested, not only by the discovery of its remains in peat-bogs and occasionally in graves and refuse-heaps associated with relics of Neolithic man, but also by historical evidence that boar-hunting was a farourite pursuit of our ancestors till the animal was exterminated, about the middle of the sixteenth century. As further proof of this statement, we might adduce the fact that the Celtic names, muc (pig) and torc (boar), enter largely into the composition of place-names, both in Scotland and Ireland: as Sliabh-na-muic, Ceann-tuirc, Loch-namuick, Sc.

The tusks of the wild boar have occasionally been utilised as cutting implements and ornaments, and, accordingly, they are not unfrequently met with among grave-goods in barrows of the Stone and Bronze Ages ; ${ }^{2}$ but otherwise its remains, neither in the wild nor tame condition, are of much archæological significance. Among the Gauls the figure of a boar was frequently placed on the helmets of their warriors, probably as an amulet-a practice which, whatever its object may have been, was continued in late Celtic times in Britain. Sir A. Wollaston Franks, in describing the beautiful bronze shield found in the river Witham, says: "The boar, of which the outline occurs on this shield, is a well-recognised Celtic symbol. M. de la Saussaye, in a valuable communication to the 'Revue Numismatique' for 1840 , p. 91 , has shown that this beast is to be found on the coins of every

1 British Fossil Mammals, pp. 426-431.

" British Barrows, p. 3S9; Ten Years' Diggings, pp. I3I, I69, 172. 
part of Gaul, as well as on the coins struck by the cognate races of Britain, Spain, Illyria, and Galatia. On English coins it is to be found on gold, silver, and copper; even on the coins of Cunobelin it is to be seen, though there refined and modified according to Roman taste." 1

According to Professor Rütimeyer, the Swiss lake-dwellers of the early Stone Age did not possess the tame pig, but only two races of wild swine, which might be called species-viz., the wild boar (Sus scrofa ferus) and the marsh pig (S. scrofa palustris). He thinks the marsh pig was first tamed, and afterwards the wild boar. But since the introduction of metals, remains of a domestic breed along with those of the wild species have been found on many of the lacustrine stations. The late Professor Strobel has noted both the wild and tame species among the animal remains on the Terremare, in Italy, ${ }^{2}$ those of the latter, however, being far more abundant than the former.

The remains of swine, so frequently found on the sites of crannogs, Romano-British villages, and other early habitations in this country, are those of domestic breeds.

\section{The Great Auk (Alca impennis).}

A few bones of the Great Auk were recognised by Sir R. Owen among a quantity of osseous remains, submitted to him for examination, from a refuse-heap in the "Harbour Mound at Keiss," in Caithness. Mr Samuel Laing, the explorer of that mound, thus describes the significance of the presence of the Great Auk among the former fauna of Caithness: "The most interesting fact is the discovery of the Alca impennis, which is now extinct in Europe, having but lately died out in Iceland, but said to survive in

1 Horæ Ferales, p. 185.

Lake-Dwellings of Europe, p. 274. 
Greenland. Its bones are frequent in the Danish Kjökkenmöddings, where they have been thought to imply great antiquity and a more glacial climate; but it is believed that they have never been found in any tumuli or deposits of a later date than those primeval middens. Hence their discovery in the Caithness middens affords an important link of connection with those of Denmark, and strengthens the evidence of high antiquity drawn from the rudeness of the implements." 1 Remains of this bird have also been notified by Mr Symington Grieve as being among the debris of a shell-mound in the island of Oronsay ${ }^{2}$ (see p. $5^{6}$ ).

The chronological value of these discoveries cannot, however, be very great, seeing that the bird is constantly referred to in the current historical annals down to the end of last century, and that a live specimen was caught, near Lochbroom, as late as $18.21 .^{3}$ Moreover, the osseous remains of the animals with which these few bones of the Auk were associated (only two or three individuals represented) do not carry us back to the chronological horizon of the people of the Danish Kjökkenmöddings, who, according to the late Professor Steenstrup, possessed only the dog in a state of domestication; whereas in the Keiss mound we find the Bos longifrois, horse, red-deer, goat, and pig.

Remains of the Great Auk have been found in considerable abundance both in the north and south of Ireland. Mr R. J. Ussher has recorded the discovery of its bones on the sites of Kitchen-middens on the coast of Co. Waterford in "The Irish Naturalist' (1897-99). With regard to his later finds, he thus writes: "These were all found strewn about on or

1 The Prehisloric Remains of Caithness, p. 50.

"Fur a most interesting account of the Great Auk, see Mr Grieve's book, 'The Great Auk or Garefow] : Its History, Archeology, and Remains,' 1855.

3 I'roc. Suc. A. Scot., vol. xiii. pp. 76-105. 
near the old surface where this cropped up, among the bones of domestic animals and fowls and of red-deer, of which many pieces of the antlers were also obtained. There were numerous burned stones, and charcoal in layers, and great quantities of shells of edible species, often very large, limpets, oysters, mussels, cockles, \&c. I have now seventeen bones of Alca impennis, which have either been determined by Dr Gadow or correspond with specimens that he has pronounced upon-eight coracoids, which he assigns to six individuals, five humeri, belonging to three individuals, one tibia, right and left metatarsals, and a portion of the pelvis. A right and a left humerus were found close together. In some of the bones the outer surface is well preserved, but in others it is much worn down, and the bones split from time and exposure. That my superficial searches among the sandhills, where but little of the old surface is now exposed, should have resulted in finding the remains of at least six Great Auks strewn about, suggests that these birds must have been used for food in some numbers. To obtain them, access was probably available to some breeding-place of the species on the neighbouring coast; so that when Professor Newton remarked that the Great Auk obtained near Waterford Harbour in 1834 may have been revisiting the home of its forefathers, he possibly described what took place."

$\mathrm{Mr}$ W. J. Knowles, in the same number of "The Irish Naturalist' (January I 899), records the finding of twentyfour bones of the Great Auk at Whitepark Bay, Co. Antrim. Besides other animal remains Mr Knowles informs us that "there were also associated with them flint-flakes, cores, hammer-stones, and flint-scrapers, together with edible molluscs."

Another bird, represented among the fauna of the Kjökkenmöddings - viz., the Capercailzie (Tetrao urogallus)-but now 
long extinct in Denmark, has for similar reasons been sometimes regarded as indicating great antiquity. This bird feeds principally on the buds of the pine, and its presence in Denmark, contemporary with the people of the Kjökkenmöddings, is explained by the existence at that time of extensive pine forests which supplied the bird's natural food. Doubtless its disappearance from the country was synchronous with the decay of the pine forests, which gave way to the subsequent oaks and beeches. But, nevertheless, the capercailzie continued an inhabitant of Scotland up to the beginning of the present century.

Remains of the reindeer are very rarely found in Denmark in the peat, but more frequently in the subjacent deposits. ${ }^{1}$ Among the fauna of the Kjökkenmöddings this animal is not represented. Hence it is probable that the reindeer left the country before man pushed his way along the fiords and lowlands of Denmark. But yet the animal survived in Scotland to the twelfth century.

\section{General Remarks.}

Of the other wild animals which were contemporary with prehistoric man in Britain, it is unnecessary to make more than a few passing remarks. The skull of a brown bear (Ursus arctos) has already been noticed as having been found in a peat-bog in Dumfriesshire (p. 90). Recently Sir F. T. Barry, M.P., found a bear's tooth in a broch at Keiss. ${ }^{2}$ This is a rare find in Scotland, but in the Swiss lake-dwellings perforated bears' teeth are not uncommon-one such from Polada, in Italy, is figured in my 'Lake-Dwellings of Europe' (fig. 68, No. 31). Remains of this animal have also been

${ }^{1}$ Congrès Inter. d'Arch. et d'Anth., 1869, p. 162.

2 I'roc. Soc. A. Lond., vol. xvii., and series, p. 191. 
recorded from Roman refuse-heaps at Colchester and in London, from Neolithic caves in North Wales, ${ }^{1}$ and from the Cambridgeshire Fens. ${ }^{2}$ As proof that the bear existed in Scotland during the Roman occupation of Britain, the following lines of Martial are often quoted :-

\footnotetext{
"Qualiter in Scythica religatus rupe Prometheus, Assiduum nimio pectore pavit avem, Nuda Caledonio sic pectora prebuit urso, Non falsa pendens in cruce Laureolus."
}

According to Pennant, the brown bear infested the mountainous parts of Scotland as late as 1057 ; but Professor BoydDawkins discredits this statement, finding no documentary evidence in support of it, and believes that the animal became extinct at an earlier period. ${ }^{3}$

Remains of the wolf (Lupus vulgaris), the fox (Vulpes vulgaris), and several species of dogs, have been found in the Brit-Welsh caves, associated with those of the domestic animals-horse, pig, and Celtic shorthorn. ${ }^{4} \mathrm{Mr}$ Bateman includes these three animals, and also the fallow-deer, among the fauna of the British Barrows. ${ }^{5}$ The last wolf in Britain is said to have been killed by Sir Ewen Cameron in 1680 ; but in Ireland wolves survived till at least 17 ro.

Among animals sometimes represented in the accumulations of food-refuse found in caves, which had afforded shelter to man, such as the MacArthur and Borness Caves, may be mentioned the badger (Meles taxus) and the otter (Lutra vulgaris), both of which still survive in various localities throughout Scotland.

Bones of the whale and seal have also been found among the débris of brochs and of other early habitations in the north

1 Cave-Hunting, pp. 13I, I66.

${ }^{3}$ Cave-Hunting, p. 75 .

5 Ten Years' Digging, p. 298.
2 British Fossil Mammals, p. Io5.

4 Ibid., p. 166. 
of Scotland and in the surrounding islands. These were utilised in the manufacture of vessels and implements, and for other purposes in the domestic life of the people.

On the classificatory value of the historic animals, Professor Boyd-Dawkins ${ }^{1}$ writes as follows: "The principal changes in the fauna of Great Britain during the historic age are the extinction of the bear, wolf, beaver, reindeer, and wild boar, and the introduction of the domestic fowl, pheasant, fallow-deer, ass, the domestic cat, the larger breed of oxen, and the common rat; and as this took place at different times, it is obvious that these animals enable us to ascertain the approximate date of the deposit in which their remains happen to occur. And for this purpose the following table may be consulted :-

Animals extinct.

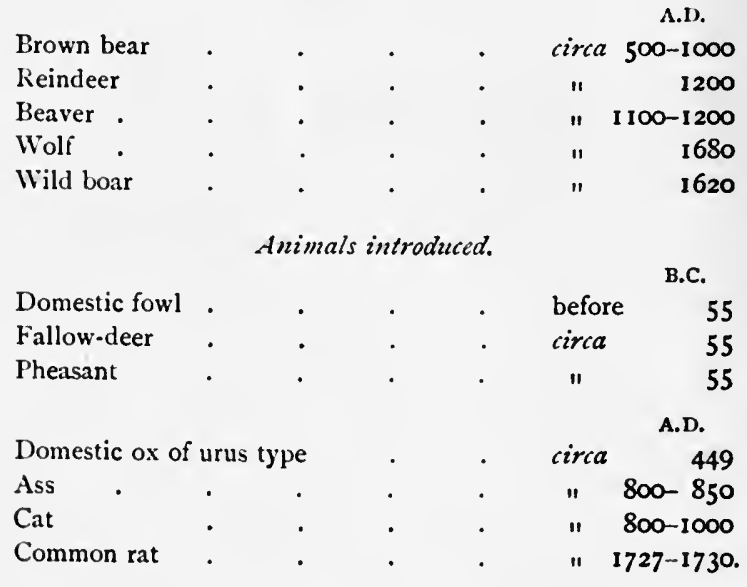

Domestic Animals.

As the ordinary domestic animals-ox, sheep, goat, horse, and $\operatorname{dog}$ - were in all probability importations by Neolithic

1 Cave-HIunting, p. 78. 
man into Europe, it is by no means an easy task to ascertain where and when their domestication first originated. In the old-world civilisations of the valleys of the Nile and Euphrates this important step in human progress was, even then, lost in the mists of antiquity.

Whether the domestic breeds of our modern cattle were derived from one or both of the two typical oxen, the Bos primigenius and the $B$. longifrons, is a matter of opinion. M. Dupont ${ }^{1}$ mentions the remains of a small ox among the fauna represented in the cave of Naulette, in the valley of the Lesse, which also includes those of the mammoth, rhinoceros, \&c. If these animals were really contemporary there is some reason for believing, with Sir Richard Owen, that the progenitor. of the Celtic shorthorn existed in. Europe as a wild animal before Neolithic man found his way thither. Since the very commencement of the Swiss lacustrine settlements their inhabitants were in possession of the small marsh cow; but later on new breeds of cattle were reared.

The domestic races of sheep, according to some authorities, have been derived from a common stock represented by the mouflon-now confined to the islands of Corsica and Sardinia-and the Armenian and Cyprian wild sheep. Others, however, consider it an open question whether they were derived from a single or several wild stocks. As to the origin of the domestic goat, there seems to be a consensus of opinion that it was derived from the Persian wild goat (Capra egagrus).

The horse (Equus caballus) had a wide range throughout the larger part of Europe, Asia Minor, and the regions around the Caspian Sea, during the Pleistocene period. Its fossilised remains, which indicate a middle-sized animal, have been

${ }^{1}$ L'Homme pendant les Ages de la Pierré, p. 9S. 
abundantly met with in caves and post-pliocene deposits of Western Europe. Sir Richard Owen, writing in 1846 , makes the following statement: "The best authenticated associations of bones of the extremities with jaws and teeth, clearly indicate that the fossil Horse had a larger head than the domesticated races; resembling in this respect the Wild Horses of Asia described by Pallas, and in the same degree approximating the Zebrine and Asinine groups." 1 It is very interesting to note that the drawings of the horse scratched on bones and horns in the reindeer caves of France and Switzerland corroborate in a singular degree the accuracy of this statement. The teeth and bones of the fossil horse are so like those of the existing species that even Cuvier failed to detect any difference, except size, by which he could distinguish the one from the other. The osseous remains of the horse are found in such prodigious numbers on the prehistoric camping-ground at Solutré, in the valley of the Rhone (see chap. xii. p. 462)-estimated at least at 40,000 individuals - that it has been surmised that the animals were kept in a state of domestication. But this opinion is controverted, on the ground that the $\mathrm{dog}$ is unrepresented in the osseous remains of this station, and without the assistance of this animal, it would be impossible to keep herds of horses and reindeer (also largely represented at Solutré) together. There seems, therefore, little doubt that the domestic horse was of the same breed as the wild animal which roamed during the Pleistocene period over Europe and Western Asia. But where, or when, its domestication was effected it would be hazardous to state. According to Egyptologists, the horse does not figure in pictorial representations of social life in the Nile valley till the 18 th dynasty, which dates, according to the most recent corrections, from 1587 to 1327 B.C., -

1 British Fossil Mammals, p. $3^{85}$. 
the general opinion being that it was introduced by the Shepherd Kings. ${ }^{1}$

Canon Greenwell records the finding of remains of the horse in several barrows; but these barrows were either of a late period, or their contents had been so disturbed that no chronological sequence could be drawn from them. Thus, a large barrow in the parish of Kirby Underdale contained Anglo-Saxon remains ; ${ }^{2}$ another, in the parish of Cowlam, had its contents so much disturbed that Canon Greenwell suggested that the "barrow was an ossuary" $;{ }^{3}$ and in a third they were associated with bones of the deer, goat or sheep, domestic dog, domestic pig, and two species of oxen. ${ }^{4}$ In a fourth group there were horses and chariots buried together, but from the most indubitable evidence of the associated relics these burials belonged to the "Late Celtic" period. ${ }^{5}$

Professor Rolleston thus comments on the rarity of the horse in the early Neolithic period: "As in the earlier piledwellings of Switzerland, so in the Stone-Age barrows of this country, the horse is less frequently found than from what we know of the discovery of its bones in cave-dwellings on the one hand, and in interments of later date than the Stone Age on the other, we should be inclined to expect. I have never found the bones or teeth of a horse in a long barrow, and I would remark that, whilst such bones are very likely to be introduced into such barrows in the way of secondary interments, I have not met with any exact record as to the finding of them in surroundings which left no doubt as to their being contemporaneous with the primary interments." 6

The general conclusion to which these observations point is that a middle-sized horse was introduced into the British

1 See Lenormant, 'Les Premières Civilisations,' vol. i. p. 300.
2 British Barrows, p. 136.
3 Ibid., p. 220.
4 Ibid., p. 262.
5 Ibid., p. 456.
6 Ibid., p. 736. 
Isles by Neolithic man. We have already quoted (p. 9) a passage from Tacitus to the effect that the Caledonians fought from chariots at the battle of Mons Graupius; consequently the horse must have been a domestic animal in North Britain prior to the Roman occupation. Perhaps the Shetland ponies of the present day may be regarded as the direct descendants of this first domesticated horse which, in the course of time, in obedience to the less favourable environments in which they have lived, have become more diminutive.

Although the dog is acknowledged on all hands to be the earliest animal which attached himself to man, there is no evidence to show that this friendly alliance dates further back than the Neolithic period. In Europe the oldest instance of its domestication is furnished by the Kjökkenmöddings of Denmark. This fact was established by the late Professor Steenstrup in a most interesting manner. Observing that all the cartilaginous and succulent portions of the mammalian bones found on the middens had been gnawed by a carnivorous animal, he concluded, from the completeness with which the practice had been carried on, "non seulement dans tous les amas mais dans toutes les parties des amas," that this animal had daily access to the food-refuse. 'The preponderance of the bones of the dog over those of other carnivorous animals left no doubt that this constant gnawing of the osseous remains was the work of a race of domestic dogs. ${ }^{1}$

Canine skeletons have rarely been found in the British barrows, - a fact which one would hardly expect, considering the warm attachment there has always been between this animal and man. Professor Rolleston, from one instance which came under his cognisance, determined the size of 
the animal to be about that of an ordinary sheep-dog, ${ }^{1}$ a result which harmonises with Professor Rütimeyer's conclusions with regard to the dog of the Swiss lake-dwellings. As to the origin of this early domestic dog in Europe, whether it was derived from the wolf, fox, or jackal, or from neither of them, naturalists are not yet agreed. Some regard the greyhound as derived from the Kaberu or Abyssinian wolf (Canis Simensis), an opinion which derives some support from the fact that the oldest dogs represented on the Egyptian monuments are of this description. On the other hand, an Assyrian monument, dated 640 B.c., shows the figure of a dog like that of a large mastiff.

$\mathrm{Mr}$ Darwin, who, as is well known, paid great attention to the domestication of animals, thus expresses his opinion of the descent of our domestic dogs: "Looking to the domestic dogs of the whole world, I have, after a laborious collection of all facts known, come to the conclusion that several wild species of Canidæ have been tamed, and that their blood, in some cases mingled together, flows in the veins of our domestic breeds." 2

Looking back on the concurrent phenomena of man's environments during the short time he has existed, even in such a secluded corner as Scotland, we can distinctly trace periods of growth and decay in the organic world. Coincident with climatic changes and alterations of sea and land, there were continuous modifications going on in the topographical features of the country, to all of which prehistoric man had to adapt himself. Yet, in these ever-changing scenes, few points can be fastened on as bringing any part of his career within the category of positive chronology. Beyond an occasional intermingling of his works with those of nature, such as was disclosed in the Oban cave and in

1 British Barrows, p. 736.

2 Origin of Species, p. 14 
the Carse of Stirling, we have rarely the means of correlating contemporary events. Should, however, the actual age of any such points of contact be determined by extraneous or collateral circumstances, it would be the key to the solution of many of the subsidiary chronological problems which so frequently disturb the equanimity of archæologists. Nothing has surprised me more, in the course of these investigations, than to find how few of the archæological remains, hitherto discovered on Scottish soil, can be assigned to a time much earlier than the Roman occupation. This remark, as we shall afterwards see, is especially applicable to inhabited sites indicating any kind of constructional features, such as crannogs, brochs, forts, earth-houses, \&c. 
CHAPTER V.

CULTURE AND CIVILISATION OF THE STONE AGE PEOPLE.

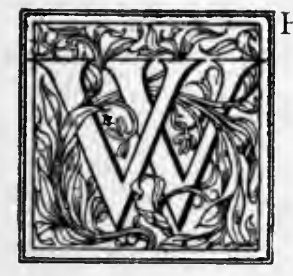

HEN man started on his career as an intelligent utiliser of nature's forces, he had recourse to methods and practices unique in the history of the organic world. By means of his special monopoly as a toolmaker, he manufactured a variety of implements, weapons, and tools, by the use of which he established a supremacy over all other animals. These inventions, being virtually the products of an intelligent mind, have one important characteristic which is of inestimable value in the study of archæology - viz., that they disclose the technical skill and teleological purpose of their manufacturers. In other words, the progressive phases of man's intelligence have been stereotyped in the material world by corresponding changes in his handicraft works. Hence, in the analysis of archæological remains-implements, weapons, ornaments, temples, tombs, houses, idols, \&c.-we have now the means of gaining some information regarding the intellectual and social condition of man during his past career on the globe.

The specialisation of the human hand is one of the most 
remarkable phenomena of organic evolution. Its efficiency as a prehensile and manipulative organ is due, primarily, to the freedon of the movements of the arm, the refinement of digital palpation, and the facility with which the thumb can be opposed to the other fingers so as to form a clasp or hook. But before the full import of this great engine of human civilisation can be appreciated, there is another element to be considered-viz., the objective tool or instrument which the hand grasps, without which the manipulative function of the latter would be shorn of half its value. The relation between the hand and the instrument is such that it may be plausibly asked whether the hand was adapted for the instrument, or the instrument for the hand. But however this may be, in their conjoined functional capacity the arm often becomes a handle, and the hand itself a mere pliant means of fixing the implement. The supplementary adjuncts to this special use of the hand are ingeniously adapted for a great variety of purposes. The various mechanical processes-cutting, sawing, scraping, boring, hammering, \&c. - are all effected by appropriate tools, such as the knife, axe, chisel, scraper, \&c. The mechanical efficiency of some of these implements is increased by the further interposition of an artificial handle of wood or some other material, as in the case of the ordinary axe-an adjustment which simply increases the leverage by adding to the length of the human arm; or, as in the case of the knife, which merely enables the hand to grasp it more firmly. In all hafted tools the hand-grasping, which was originally applied to the tool itself, is thus replaced by some sort of contrivance for binding the handle and it together; in which case the hand-grasping is more advantageously transferred to the handle. In the selection of materials for the manufacture of tools, as well as in the methods and contrivances by which 
they are adjusted, it must be acknowledged that prehistoric man has exercised an almost faultless judgment, as they invariably disclose a pre-eminent fitness for the special purpose for which they were intended.

When prehistoric man first entered the romantic glens and forests of North Britain, he was a skilled craftsman, and his life-drama had already been moulded on the fundamental principles of modern civilisation. As a thoughtful interpreter of the laws of nature, and a skilful manipulator of the economic materials around him, he appears to have been little inferior to his more refined descendants of the present day, although, of course, it cannot be maintained that his actual amount of knowledge was as great. But the difference is one of degree, and not of kind.

In this and the following chapter I shall treat of some of the archæological remains of the prehistoric period independently of the chronological element, except in so far as they may be defined by the sequence of the so-called three Ages of Stone, Bronze, and Iron. In regard to this doctrine, it is essential to have clear notions from the outset, as, whatever its critical and archæological value may be, it is undoubtedly applicable to Scotland. For its invention and application to prehistoric researches we are indebted to Scandinavian savants. Struck with the elegance and beauty of the stone implements, so profusely scattered over the land, they seized the idea-hitherto never seriously considered, though occasionally mooted, by writers in other countries-that there was a time when people were entirely ignorant of the use of metals, and had to depend exclusively on such tools as could be manufactured of stone, horn, wood, \&c., in the prosecution of their social industries and requirements. To this idea was linked another, which also seemed to be well founded - viz., that their earliest metal 
objects were made of a compound of copper and tin known as bronze. Iron was not known in the country till several centuries afterwards; but when it did become known, its superior qualities for cutting purposes gave it a preference over the former metal.

$\therefore$ With these remarks I proceed to inquire into the nature of the culture and civilisation of the early inhabitants of Scotland, so far as this may be deduced from the character and technic of the stray remains of their handiworks which, in defiance of the gnawing tooth of time, have survived to the present day. For convenience of description, and to prevent undue discursiveness, the subject will be treated under the three following heads: (I) The economic or raw materials; (2) The workshop and its tools; (3) The manner in which their handicraft products were applied to the exigencies of social and domestic life.

\section{The Raw Materials.}

The economic materials utilised by the Stone Age people in the manufacture of such articles as were indispensable to their simple mode of life consisted of different kinds of stones and minerals; horns, bones, teeth, shells, and skins of animals; wood-bark, reeds, and the prepared fibres of plants. Flint, on account of its hardness and peculiarity of flaking when struck with a smart blow, was chiefly used for cutting implements; but in Scotland, where the raw material is only sparingly found as nodules among travelled gravels, this industry was necessarily restricted to the manufacture of the smaller objects, such as knives, arrow-points, scrapers, borers, \&c., - the larger implements and tools being made of the more common stones found in the neighbourhood.

Although no prehistoric implements of jade or nephrite 
have been found in Scotland, the problems associated with their origin and prevalence throughout Central Europe are of so much importance, from an ethnological point of view, that, even in this sketch, some notice of them is desirable. Independent of the lake-dwelling finds, the number of jade axes known in Europe may be roughly estimated at 200 , about the half of which have been found in graves of the Stone Age in France, especially the dolmens of Brittany. Of the remaining half about eighty are from Western Germany, and the rest from various localities in Italy, Austria, and Greece. Seeing that jade could not be found in situ in Europe, the favourite theory for the origin of these implements was that they were imported by the Neolithic people in their westward journey from Asia. The discovery of a large number of celts and chisels in the Swiss lakedwellings has reopened the question as to the origin of jade implements. The stations in Lake Constance have alone yielded over rooo specimens-that of Maurach being the richest. In the latter station 349 tolerably well made and I 4 I badly made implements have been found, besides 154 chips and sawn portions varying from the size of a finger-nail to a few square inches. This proves that the lake-dwellers were in possession of the raw material; but, notwithstanding the most careful search, not a particle of jade has been yet found in situ in any part of Switzerland.

Jade, as known in Europe, may be classified into three varieties-nephrite, jadeite, and chloromelanite. From careful examination by Fischer, Meyer, and others, it appears that nephrite was greatly in excess of jadeite in the settlements of Lake Constance and its neighbourhood; but on moving westwards this inequality became gradually altered, till in France it was entirely reversed. Chloromelanite, on the other hand, though much rarer than either of the other 
two varieties, scems to have been more evenly distributed. Roundly speaking, we find in the whole of Europe from 300 to 400 worked objects of jadeite, 200 of chloromelanite, and as many as twice these numbers combined of nephrite.

A few isolated portions of jade have been found in Germany and Styria; and it is said that the mineral in small quantities has been detected in situ in the rocks of Silesia. A few chips have also been observed in the prehistoric caves of Mentone. Some thirteen small axes and chisels of green jade, and one of white jade, are recorded by Schliemann as having been found in the prehistoric cities of Troy. ${ }^{1}$ During a recent visit to Vancouver, $\mathrm{Mr}$ Hill Tout showed me in his private collection several polished masses. of jade, as large as a man's head, which had been found in glacial dibris some distance up the Frazer valley; also, a few small axes made of this material, as well as portions that had been sawn off, evidently in the course of working the mineral, which had been found on an old inhabited site in the same neighbourhood. Specimens of differently coloured jades may be seen in the Natural History Museum of Kensington from China, New Zealand, New Caledonia, India, \&c. One large water-worn mass, weighing I 56 lb., is from Battugol, Irkutsk, Asiatic Russia. Further references to the distribution of jade, together with a fuller notice of jade implements in Europe, will be found in 'The Lake-Dwellings of Europe,' p. 505, and 'Ilios,' p. 240.

The beautiful flakes and knives of obsidian found among the relics of the ancient Peruvians and Mexicans, as well as those which may still be seen in use among New Zealanders, American Indians, and other semi-civilised races prove how suitable this mineral is for cutting purposes. Though found in situ in several volcanic districts in Europe, 
implements made of it do not figure largely among prehistoric collections, probably owing to its rarity. No objects of obsidian have been found in Scotland, to my knowledge; and in the Continental museums their occurrence is rare. I have noted, however, a few dozen flakes in the Museum Ponti, on the Isola Virginia, from the "palafittes" of Lake Varese. Others have been collected on the sites of some primitive habitations in Hungary. ${ }^{1}$ The late Herr Fiala has recorded a few flakes and a beautifully worked arrowpoint from Debelobrdo and Sobunar, near Sarajevo. ${ }^{2}$ One knife is among the objects found on a lake-dwelling in the Attersee. $^{3}$ Dr Schliemann has noted the occurrence of knives and arrow-heads in several of his excavations, as many as thirty-five beautifully formed arrow-points having been found in the fourth sepulchre at Mycenæ. ${ }^{4}$ Nuclei of obsidian have also been found in Greece. ${ }^{5}$

Jet and its inferior varieties-brown or cannel coal and bituminous shales-were manufactured by the prehistoric inhabitants of Britain into a variety of ornaments, such as rings, pendants, necklaces, buttons, \&c. According to Pliny, ${ }^{6}$ gagates (now corrupted into jet) takes its name from Gages, the name of a river in Lycia, from the banks of which this substance was obtained. Bede, in his description of Britain (book i. chap. i.), states that "it has much and excellent jet, which is black and sparkling, glittering at the fire, and when heated, drives away serpents." The principal modern source of jet in this country is the vicinity of Whitby,

${ }^{1}$ Cat. de l'Exposition Préhistorique, Budapest, pp. 19, 24, 28, 34, 44, 86.

2 Wissenschaft. Mitt. aus Bosnien und der Hercegovina, vol. i. p. $4 \mathrm{~S}$, and vol. iv. pp. 53,54 .

${ }^{3}$ Lake-Dwellings of Europe, p. 163.

${ }^{4}$ Mycenæe and Tiryns, pp. 158, 272 ; Ilios, pp. 247, 445.

3 Perrot el Chipiez, Histoire de l'Art dans l'Antiquité, vol. vi. p. 127.

${ }^{6}$ Hist. Nat., xxxvi. 34 . 
in Yorkshire, where it is found mixed with beds of lignite in the Upper Lias. It is also largely found in France (Aude) and in Spain (Asturias), where it gives employment to a number of artisans, who manufacture it into beads, crosses, and other trinkets used in Roman Catholic countries. Jet, like amber, is electrical when rubbed, and hence it is called black amber by the German amber-diggers. Articles made of jet, or of the inferior shaies, were more abundantly used in prehistoric times in Scotland than those made of amber, probably because the raw material was more readily procured. Being easily worked, and capable of taking on a high polish, it admirably suited the requirements of the age. Its highest development to ornamental purposes appears to have been during the Bronze Age, as many of the plates, which formed the component parts of necklaces, are ornamented with designs which are considered characteristic of that period.

Amber, a fossil gum derived from an extinct coniferous tree, was an important substance in the prehistoric civilisation of Europe on account of its attractive appearance, and the facility with which it could be manufactured into ornaments. The Greeks and Romans set a high value on it, and used it as beads, pendants, and brooches. Pliny devotes a long chapter (book xxxvii. chap. II) to an account of it and "the many falsehoods that have been told about it." Homer refers to it in the line-

"The gold necklace hung with bits of amber." 1

Although doubtfully indigenous to Britain, pieces of amber are said to have been occasionally found washed up on its eastern shores, as at Buchan in Aberdeenshire, Queensferry on the Firth of. Forth, and along the coasts of Norfolk, Essex,

1 Odyssey, xv, 460 . 
and Sussex. Reference to the occurrence of amber in lignite beds in the counties of Londonderry and Tyrone, Ireland, is given by $\mathrm{Mr}$ G. Coffey. ${ }^{1}$ It has also been found in small quantities on the shores of Norway, Sweden, Sicily, and the Adriatic. But the chief source of its supply, both in ancient and modern times, is the south shore of the Baltic, especially between Königsberg and Memel, and the east coast of the island of Rügen. Its use in the British Isles during prehistoric times was almost exclusively confined to the manufacture of beads and pendants, a few examples of which have been recorded from English barrows of the Bronze Age ${ }^{2}$ and some ancient graves in Scotland. ${ }^{3}$ But during the Stone Age in Eastern Prussia it was put to more multifarious uses, not only beads and necklaces, but also buttons, studs, pendants, and rudely-formed human figures, having been found in the graves of that district. ${ }^{4}$ Ornaments of amber have been found in the Scottish and Irish crannogs, the lake-dwellings of Switzerland, the Terremare of Italy, and more especially among remains of the early Iron Age of South-Eastern Europe. The cemeteries of Glasinac and Jezerine, in Bosnia, Santa Lucia, at the head of the Adriatic Gulf, and Hallstatt in Austria, have yielded large numbers of beads and broochpendants of imported amber.

The granites, quartzites, porphyries, serpentines, greenstones, felstones, diorites, clay-slates, and indurated sandstones, of which the larger stone implements and weapons were usually made, are to a greater or less extent readily procurable in Scotland, either in situ or among ice-travelled débris.

1 Origins of Prehist. Ornament, p. 66.

2 British Barrows, p. 55 .

3 Proc. Soc. A. Scot., vol. xxvi. p. I 86.

4 See 'Der Bernsteinschmuck der Steinzeit,' by Richard Klebs, Königsberg, I $8 S_{2}$; also 'L'Ambra nella Storia e nella Geologia,' by A. Stoppani, Milano, I 886. 
The other substances made use of in the prehistoric workshop call for no special remarks. There appears to have been no lack of deer-horn in any part of Scotland; and of course bones, teeth, shells, skins, \&c., were to be had everywhere. Many of the organic materials are, however, so liable to decomposition that most of the articles made of them have long ago crumbled into dust. It is, consequently, very rare to find woollen fabrics, skins, bast, \&c., in burials, or on any of the inhabited sites, except the lake-dwellings. The fine mud and peaty deposits of the latter afforded the most favourable conditions for preserving such fragile objects as, from time to time, dropped into them from the hands of their occupiers. But these, and other remains of this kind, will be discussed later on under the category of worked objects.

\section{The WoRkSHOP AND ITS ToOLS.}

In describing the methods practised by prehistoric workmen in the stone industries of the period, we have sometimes not only to wander outside the Scottish area for archæological evidence, but also to be guided, to some extent, by the manner in which analogous objects have been manufactured in recent times by races who may still be regarded as living under a Stone-Age civilisation. Sir John Evans, in his usual exhaustive manner, has collected a mass of valuable information from both these sources. $^{1}$ He has, moreover, shown by practical experiments with his own hands that the simple appliances contained in a "kit of tools," such as can be proved to have been in the possession of the Stone-Age people, were capable of producing, in skilled hands, the effects assigned to them. As regards the fine chipping of flint, he has demonstrated that it could be produced both by skilfully directed blows of a stone hammer,

' Ancient Stone Implements, Sc., chap. ii. 
and by the application of steady pressure with a suitable implement made of some hard material, as the tyne of a reindeer horn. He admits, however, that, notwithstanding all his ingenious methods, there remains a residuum of manipulative skill to the credit of the Stone-Age operator which still baffles modern ingenuity. "I may, therefore, at once confess," he writes, "that though by the use of stag's horn the ordinary surface-chipping characteristic of ancient implements may be obtained, yet the method of producing the even fluting, like ripple-marks, by detaching parallel splinters uniform in size, and extending almost across the surface of a lance- or arrowhead, is at present a mystery to me, as is also the method by which the delicate ornamentation on the handles of Danish flint daggers was produced." 1

For a long time it was maintained by many antiquaries that round holes could not be bored through hard stones without the use of metallic instruments. But the discoveries on the sites of lake-dwellings have entirely disproved this assertion, as it is now conclusively shown that both the sawing and boring of all manner of stones could have been effected by properly adjusted instruments made of wood or horn, with the addition of a little sand applied in the same way as the modern lapidary uses emery. The late Dr Keller, experimenting with a thin wooden board and dry sand, proved that, by these means alone, he could saw through the hardest stone. Similarly with a wooden tube, or a piece of hollow horn, put into rotatory motion in alternate directions by means of a string bow, like the fire-drill of modern savages, he could bore perfectly round holes in stones. Soft wood was found to be more suitable than hard, as it took up more of the particles of sand into its tissues, thus acting like fine teeth in grinding the stone. That tubes of some kind were used

1 Ancient Stone Implements, \&c., chap. ii. p. $3^{8}$. 
for boring by the lake-dwellers is proved by the finding of hundreds of the cylindrical cores, which remained as refuse after the perforation had been completed. In the Archæological Museum of Lausanne I saw a tray full of these cores exhibited in one of the cases; and in the Museum at Zurich there may be seen a portion of a stone hammer, with the core still in its place, which had evidently been broken before the perforation was completed. ${ }^{1}$ This interesting relic was found on the station of Bauschanze. Another flat stone, just showing the commencement of a tubular perforation, may be seen in the Laibach Museum among the relics from one of the neighbouring lake-dwellings. Similar partially bored holes still retaining the cores may also be seen in the Museum of Stockholm and elsewhere. But it was not an essential part of the process of boring that the perforator should be a hollow tube, as a solid piece of wood, horn, or stone, could be used in the same way. Indeed, according to the evolutionary law of progress, I should say that the latter method preceded the former. In several instances I have seen evidence that the sawing or boring had been preceded by little pick marks, as if intended to guide the instrument in the initiatory stages of the operation.

Many of the Scottish specimens of perforated stone implements show that the boring had been performed from both sides, the two holes meeting near the middle, where on section they are seen to diminish in width (fig. 40). Such perforations would be readily accounted for by the rotatory motion of a cylindrical piece of wood, or a stone pestle, the funnel shape of the aperture being due to the gradual wasting of the borer by friction. Hollow tubes do not appear to have been used for boring holes in Scotland, or indeed within the British Isles, as, so far as my knowledge goes, no

\footnotetext{
${ }^{1}$ See Lake-1)wellings of Europe, fig. 184 , No. 6.
} 
such cores have been found among the antiquarian relics hitherto collected in these countries. I have seen one specimen, found in Scotland, in which the operation had just been begun, and it consisted of a conical depression on
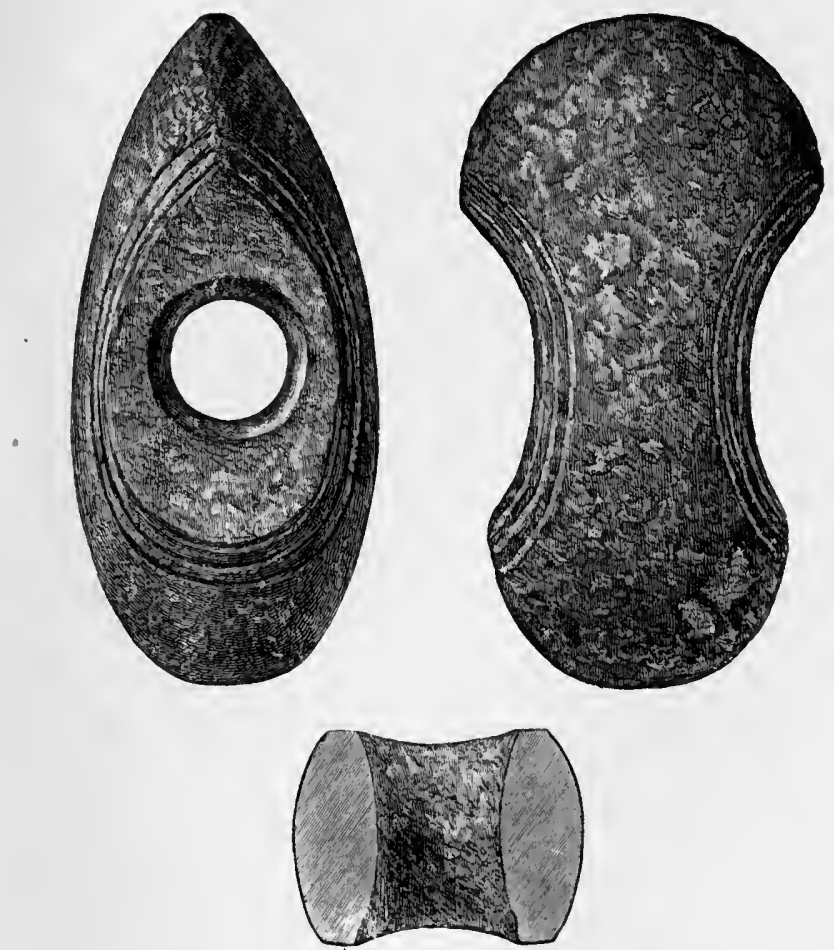

Fig. 40. - Axe-hammer found under an inverted urn on Chapelton Farm, W'est Kilbride $\left(\frac{2}{3}\right)$.

each side, apparently picked out with some sharp tool. Perhaps this first stage would be followed up by grinding with a stick and sand.

In the manufacture of flint implements from the raw material the operator proceeded to work the nodule from one of two points of view, according to the class of imple- 
ment required. To procure the flakes intended to serve as the groundwork of the smaller worked objects, such as knives, arrow-points, scrapers, $\&$., all his ingenuity was directed to the production of the suitable form of flake; and having exhausted the nodule's capacity in this respect, the remaining core was thrown away as useless. But if the operator's intention was to secure a large implement, say an axe or chisel, his attention was exclusively confined to reducing the nodule to the required shape, without any regard to the resulting flakes and splinters which, in this case, became waste products. The tools used in these operations were stone-anvils, hammer-stones of various sizes, and fabricators or flaking-tools made of flint, or perhaps of horn or bone.

Anvils have been found in Scotland in various localities, but more especially on the site of the flint factory at Skelmuir, in Aberdeenshire, where no less than nine specimens are known to have been found. ${ }^{1}$ They are generally made of quartzite, often from water-worn peebles, and show a number of small worked depressions on one or both surfaces (fig. 4I). Two anvil-stones from this factory, which were presented to the National Museum, in $\mathbf{1 8 9 7}$, by $\mathrm{Mr}$ John Rae, are thus described by Dr Anderson: "They are water-worn quartzose boulders, about 8 inches by 6 inches, and $21 / 2$ inches in thickness, strongly marked on both faces with a central pitted depression, surrounded by six or seven similar but smaller depressions, apparently produced by the wear resulting from the process of breaking flints upon then with hammer-stones, which are also abundantly found on the same site, amidst great quantities of splintered flint nodules." 2 One of these anvils and a hammer-stone from the same locality are represented on figs. $4 \mathrm{I}$ and 42 .

1 I'roc. Soc. A. Scot., vol. xiv. p. 314 ; vol. xvi. p. 13.

Ibid., vol. xxi. p. 135. 
Five other specimens purchased for the Museum are thus described: ${ }^{1}$ "Five anvil-stones of quartzite, found at Shelmuir, Aberdeenshire-viz., (I) with nine hollows on one face and six on the other; (2) with four hollows on each face; (3) with two hollows on one face and one on the other, and grooved on each side for a handle; (4) with three hollows on one face and two on the other, and the sides worn by use
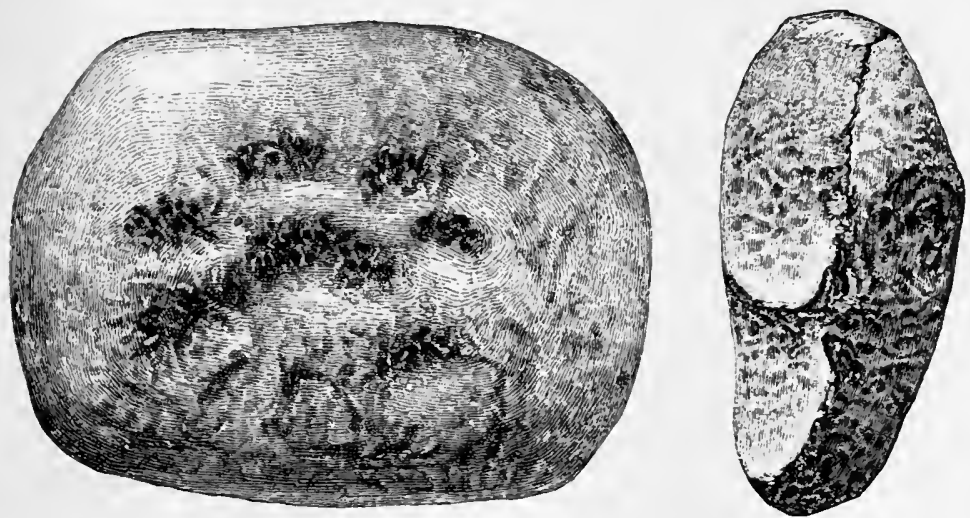

Figs, 4I, 42,-Stone anvil and hammer-stone from Skelmuir, Aberdeenshire (about $\frac{1}{3}$ ).

as a hammer-stone; (5) with a deep circular smoothed hollow on one face."

The stone hammers associated with the débris of flint factories are generally oblong quartzite pebbles showing markings of usage at one or both ends. Those found throughout the country, in fields or among the remains of human dwellings, vary greatly in size and configuration. They are often flat pebbles of a circular or oval shape, with marginal markings. Sometimes they present slight hollows on both faces, which go under the name of finger-marks (fig. 43). When perforated, so as to be used with a wooden handle,

1 Proc. Soc. A. Scot., vol. xxiv. p. 8. 
they display careful workmanship, with a symmetrical surface, often highly polished, and sometimes ornamented as shown in a remarkable specimen found at Corwen, in North Wales, and figured in the Proceedings of the Society of Antiquaries of Scotland, vol. vi. p. 43. But neither stone perforated hammers nor hammer-stones are peculiar to the Stone Age, as they are, especially the latter, abundantly found in the crannogs.

The so-called fabricators, or flaking tools, are made of flint, and worked into long narrow chisel-like objects with an
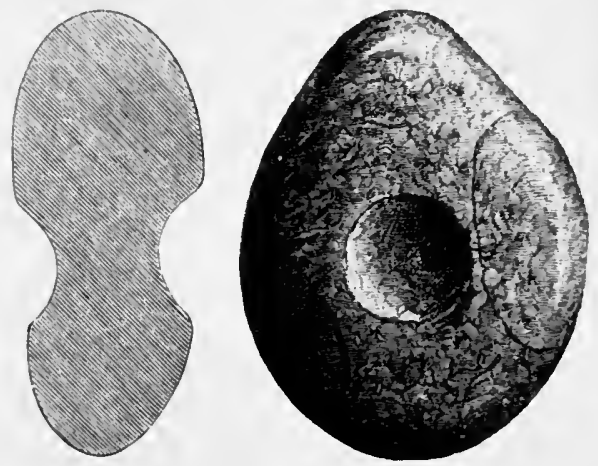

Fig. 43.-Hammer-stone, with circular depression on hoth surfaces, found on the farm of Balcraig, Ayrshire (1)

approach to a ridge on one or both surfaces, thus presenting a triangular or lozenge-shaped section across the middle. They are 4 to 5 inches in length, with rounded, or bluntly pointed, extremities. Such tools are by no means common in Scotland. 'Two have been found in Kincardineshire; ${ }^{1}$ one in the chambered cairn of Unstan in Orkney (fig. 44), associated with some beautifully worked flint arrow-heads and knives $;^{2}$ one from Strathspey $;^{3}$ three from Aberdeenshire ;

\footnotetext{
1 Proc. Soc. A. Scol., vol. xi. p. 25.

${ }^{3}$ Ibit, vol. xxiii. p. IS.

2 Ilbid, vol. xix. p. 351 .

4 Ibid., vol. xxvii. p. I1.
} 
and one from Roxburghshire. ${ }^{1}$ Similar implements have been found in England, especially in districts, such as Yorkshire, where flint is abundant; also in Scandinavia there are analogous forms which, though not recognised as flaking tools, could hardly have been used for any other purpose. I have not observed them elsewhere in Europe, but perhaps the tynes of deer-horns might have been used instead.

Another tool is the borer, or drill, used for making small perforations, such as the eye of a bone needle. Its characteristic feature is a sharp point worked on the tip of a flake (figs. 45 and 46). Such instruments are of great antiquity, as they were used in Palæolithic times both in England (Kent's cavern) and on the Continent (the reindeer caves of France and the rockshelter of the Schweizersbild). They are found among Neolithic remains all over Europe, though by no means numerously. Only three or four specimens have

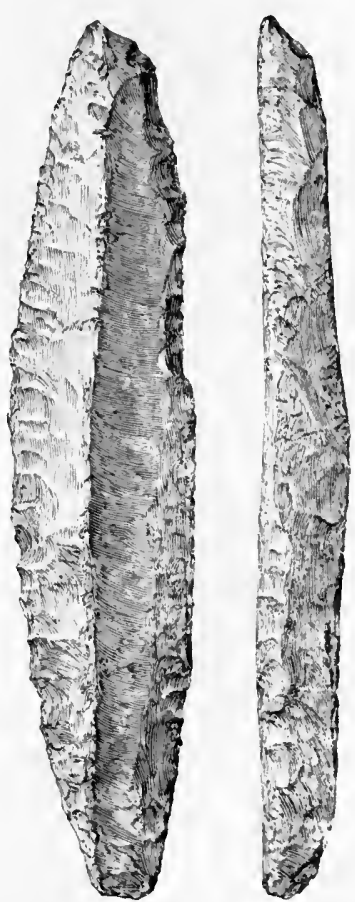

Fig. 44. - Fabricator of fint found in the chambered cairn of Unstan, Orkney (1). been found in Scotland-viz., one on the Culbin Sands, ${ }^{2}$ one in Roxburghshire, ${ }^{3}$ and the two here figured. ${ }^{*}$

As there is no sharp line of distinction between some of the

1 Proc. Soc. A. Scot, vol. xxviii. p. $33^{8}$.

2 Ibid., vol. xi. p. 546 .

${ }^{3}$ Ibid., vol. xxriii. p. 338 .

4 Col. Ayr and Gal. Arch. Association, vol. i. pp. $23,62$. 
tools of the workshop and other utilitarian implements, it may be as well to postpone further remarks on the mechanical skill of their manufacturers till after we have looked into the

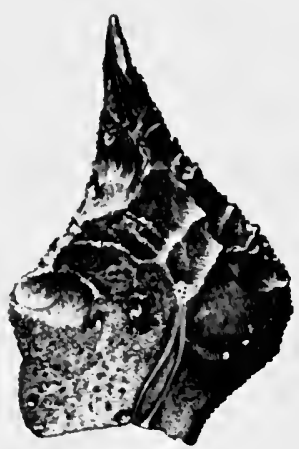

Fig. +5.-Flint drill found in the parish of Galston, fyrshire (1).

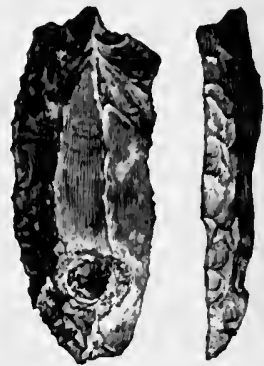

Fig. +5. - Flint drill, Tous, Old Luce, Wig. tononshire (t).

contents of the whole armoury with which Neolithic man fought the general battle of life.

\section{Implenents, Weapons, and Ornaments.}

To analyse and classify the multifarious relics of the Stone Age people collected on Scottish soil, in accordance with their specific forms and purposes, would greatly exceed the limits and scope of this work. I must, therefore, confine my remarks to a brief general survey of their structural features and functional uses in the social economy. The objects which thus fall to be noticed may be conveniently and simply classified as implements, weapons, and articles of apparel and ornament - comprising axes, adzes, chisels, hammers, knives, saws, gouges, scrapers, grinding-stones, \&c.; spearand arrow-heads, daggers, sling-stones, \&c. ; spindle whorls, loom weights, smoothers, cloth, buttons, beads, rings, \&c. 
I. Axes, Chisels, and Hammers.

Axes may be divided into two groups, according as they have or have not a haft-hole. The former are rarely made of flint, even in countries where this material is abundant,
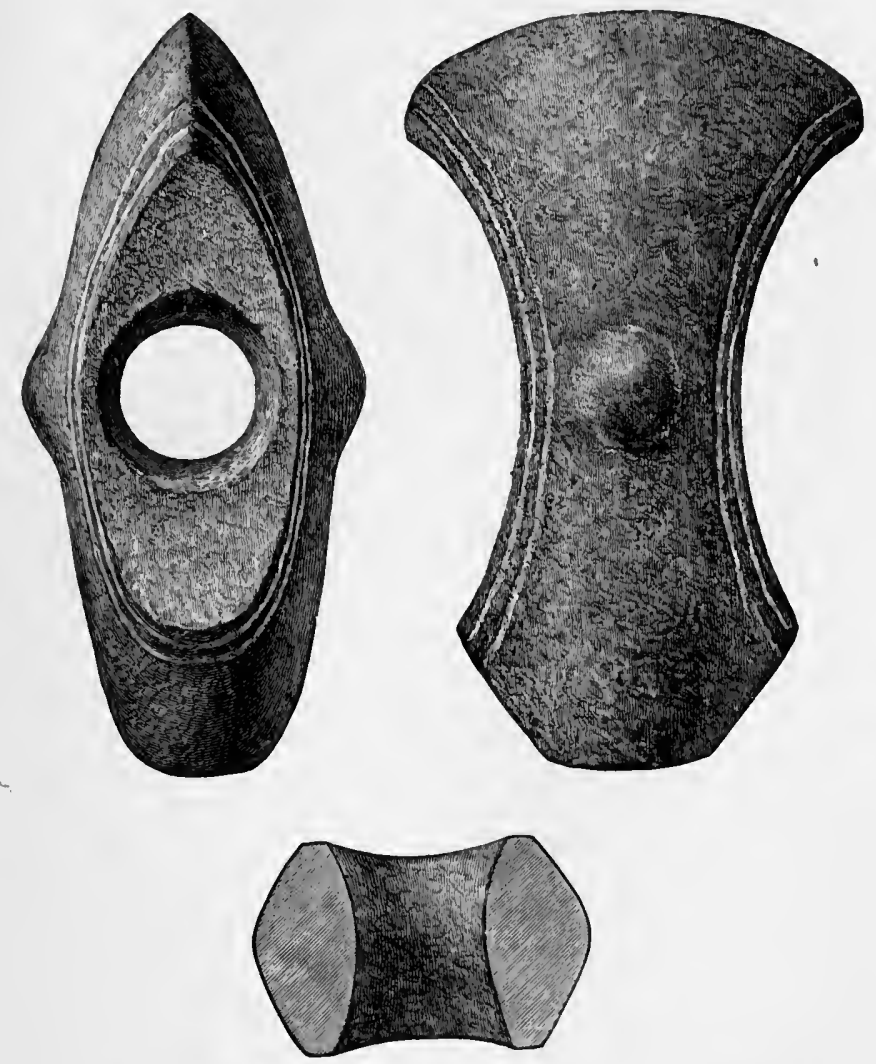

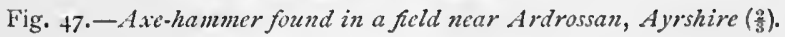

owing to the difficulty of perforating such a hard substance. They generally present one cutting edge running parallel to the axis of the handle, the other being blunt; and hence 
they are sometimes called axe-hammers. Some, however, have both ends brought to a cutting edge; white, on the other hand, implements of similar types have both ends blunt, in which case they fall into the category of stone hammers. All the axes in this group are worked with care, being nearly always polished, and sometimes ornamented with linear grooves along the margins of the perforated surfaces (fig. 47). They vary in size from a few inches to Io or I I inches in length. One fine example (fig. 48 ) was dug up in the stone circle of Crichie (see p. 316).

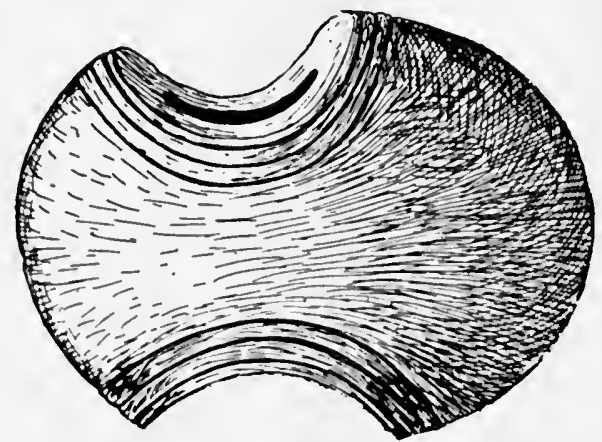

Fig. 48.- 4 .re-hammer found in the stone circle of Crichie, Aberdeenshire (t inches in length).

The stone hammer may be of any shape, but usually it is of an elongated or oval shape, with the perforation near, or in, the middle. The beautifully polished specimen here represented (fig. 49) was found, in 1873 , under a sepulchral cairn, and associated with an urn of the food-vessel type (fig. 50). ${ }^{1}$

The typical form of the unperforated axe, or celt, is that of a wedge with one end brought to a cutting edge, and the other bluntly pointed or more or less truncated (fig. $5^{\mathrm{I}}$ ). Specimens having both ends adapted for cutting are, how-

1 Proc. Soc. A. Scot., vol. xvii. p. 453. 
ever, occasionally met with. As a rule they have polished surfaces, with the exception of those made of flint, which are ground only at the cutting edge, though, even among these, some specimens may be seen which are beautifully polished all over. The members of this group vary so much in composition, finish, and dimensions that no two, among several hundreds in the National Museum, are exactly alike; but yet many of them have so many points of resemblance that certain types are recognised as peculiar to special areas

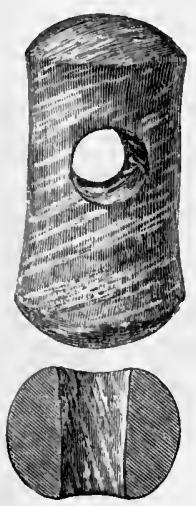

Fig. 49.-Stone hammer found with an urn in a cairn at Glenhead, near Doune $\left(\frac{1}{2}\right)$.

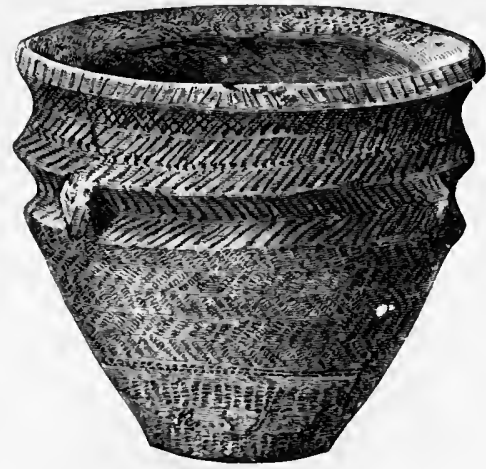

Fig. 50.-Urn found in a cairn at Glenhead (41/4 inches high).

-a fact no doubt due to fashion in local influences and customs. It is marvellous to what precision experts have carried the art of assorting these implements according to their provenances. In Scandinavia, owing to the abundance of flint in certain localities, we find specimens of very large dimensions made of this material, some being beautifully chipped and others finely polished.

In the Scottish National collection there are a few specimens which may be characterised as adzes, notably one from 
Ferny Brae, parish of Slains, Aberdeenshire. It is made of grey fint, "finely polished and of unique form, being triangular in section across the middle, and expanding slightly
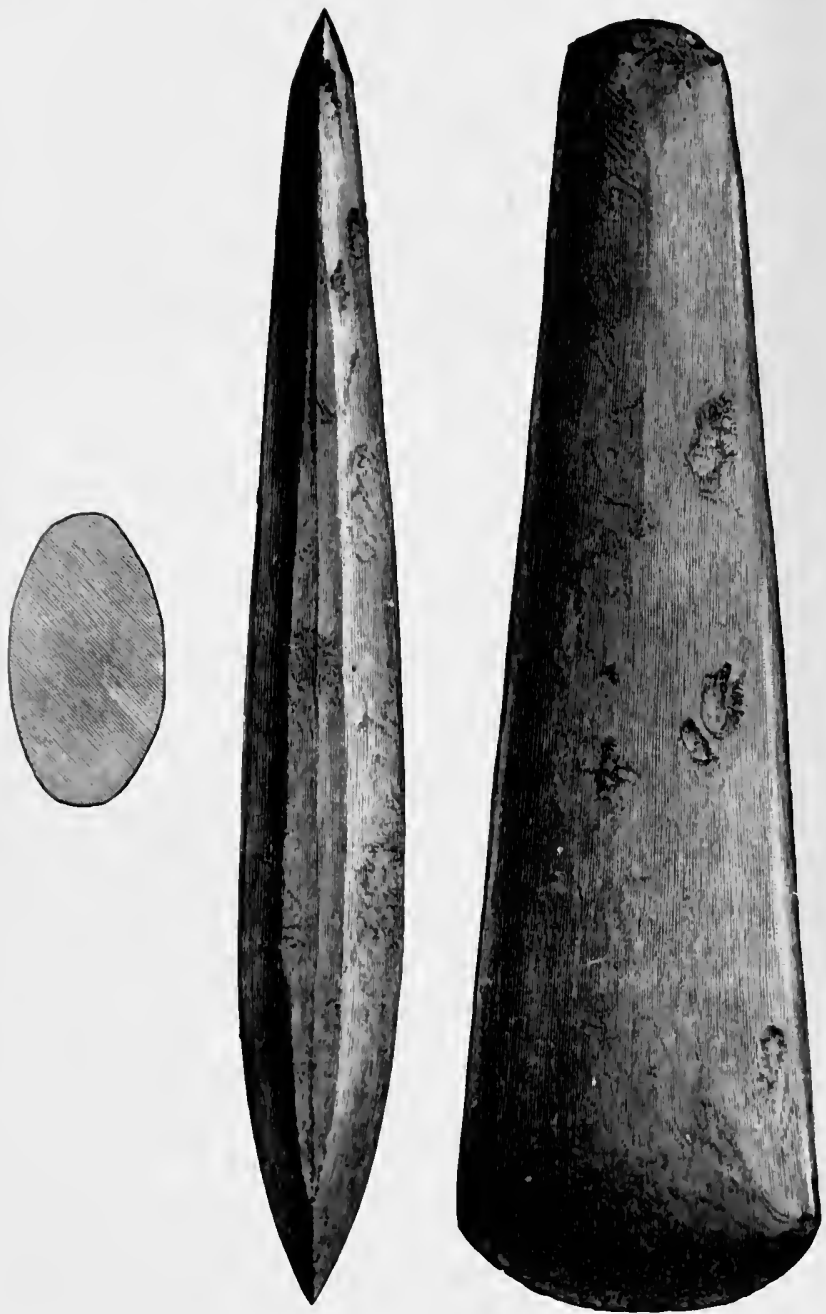

Fig. 51.- Sivne axe found while cutting a drain on the farm of Broanhill, Tarbolton (1). 
towards the two extremities. It is finished to a curved adze-like edge at both ends" (fig. 52). ${ }^{1}$ A few chisels are also to be noted, their characteristics being a short cutting edge and a long slender body.

Besides stone, bone and deer-horn have been utilised for making various kinds of implements, such as hammers, chisels, spatulæ, picks, \&c., numerous specimens of which have been recorded from crannogs, caves, kitchen-middens, brochs, \&c. They are not often found in graves, being in such positions liable to decay. Canon Greenwell, however, has met with a few horn implements in the Yorkshire barrows, two of which, a
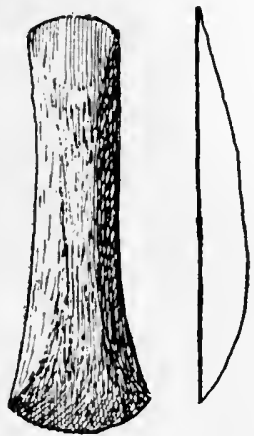

Fig. 52.-Polished celt of grey fint found at Ferney Brae, Slains, Aberdeenshire (7 inches in length). perforated hammer and a pick, are engraved as figs. 33 and 34 of his 'British Barrows.' Among the industrial remains from the Continental lake-dwellings, the Terremare of Italy, and the reindeer caves of France and Switzerland, implements of this class are very common. Picks of deer-horn were used by the prehistoric people of Britain in extracting flint from chalk pits, as at Grime's Graves near Brandon.?

The process of grinding and polishing stone implements appears to have been accomplished by the manual labour of rubbing them, either upon a fixed block of sandstone or with a portable hone. Specimens of these grinding-stones have been occasionally met with in Scotland, as shown in the accompanying illustrations (figs. 53 and 54); but in Denmark and Sweden large slabs, worn into elongated hollows

1 Proc. Soc. A. Scot., vol. x. p. 598.

2 Journ. Eth. Soc., N.S., vol. ii. p. 419. 
and grooves by the friction of the implements, are of frequent occurrence.

IIith regard to the methods of hafting the unperforated axes and chisels, we have, since the discovery of the Swiss

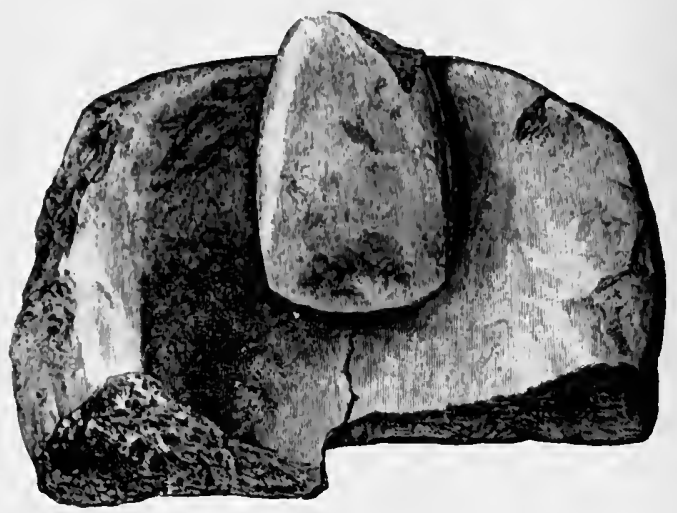

Fig. 53.- Whetstone with stune axe fonnd near the sandhills in Stoneykirk, IVigtownshire (1).

lake-dwellings, most satisfactory evidence as to how this was done. Remains of the actual handles have been very rarely found in Scotland - only two instances of the kind

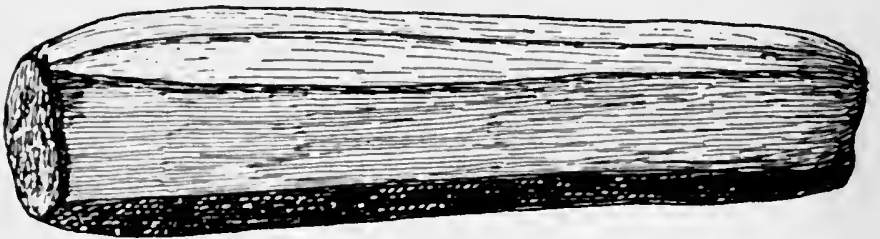

Fig. 54--Polygunal grinding-stone of quartsite found while excavating a irain on Lamberton. Ioor, Berwickshire (ł).

being known to me. One, consisting of a simple wooden handle with a hole into which the celt was inserted, was found by a man digging peats in the Solway Moss, at a depth of 6 feet (fig. 55 , No. 1 ). The other, found in a peat- 
bog in the island of Bute, and preserved in the Chapelhill Museum, Rothesay, was attached, with some sort of pitch, to a wooden handle now greatly decayed.

Among the relics from the Swiss lake-dwellings are numerous

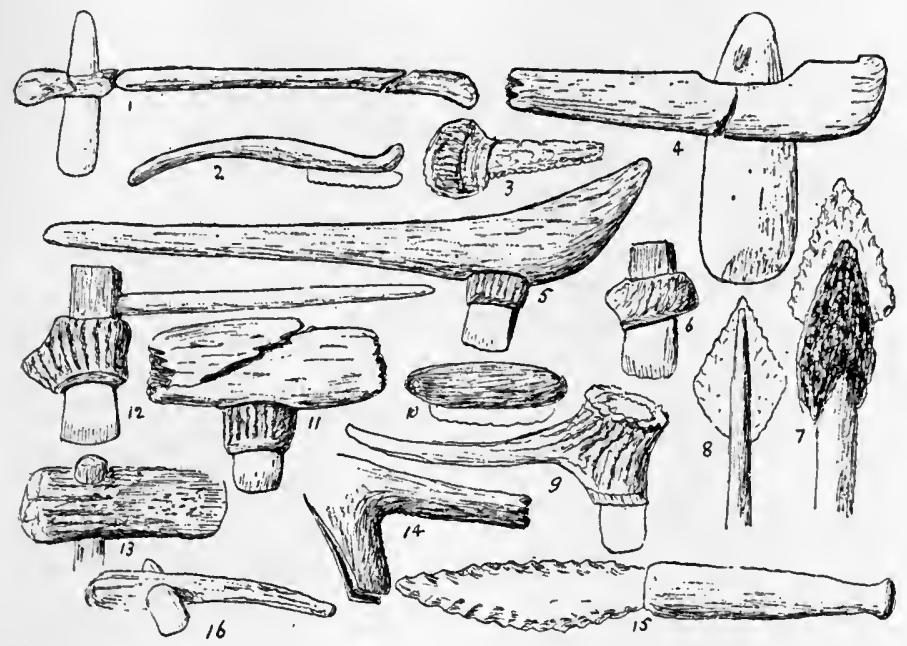

Fig. 55.-Various methods of mounting stone implements.

I, Stone axe from Solway 1 loss (Proc. Soc. A. Lond., vol. iv. p. ir2); 4 and 16 , 'Ancient Stone Implements, \&c.,' figs. 92 and $93 ; 8$, Arrow-head still in shaft from Fyvie (Proc. Soc. A. Scot., vol. xi. p. 509); all the rest from 'Lake-Dwellings of Europe.'

wooden objects, including the handles and horn fixtures for mounting stone axes. Specimens of a few of these are shown in the accompanying sketches (fig. 55).

2. Knives, Sazus, and Scrapers.

A flint flake, when suitably formed, is well adapted for cutting and scraping by a kind of sliding pressure, but when much used in this manner the edge becomes quickly blunted, and hence it was necessary to work up the flake by second- 
ary chipping. Sometimes this was done by grinding instead of chipping, but this variety of knife is much rarer in Scotland than the ordinary worked flakes. A few specimens of these trimmed flakes are represented in figs. 56-58. Those with ground edges and chipped surfaces, though few in number, have been recorded from such widely-separated districts as Caithness, Argyll, Aberdeen, Lanark, and Berwick. A very fine specimen of a ground-edged knife was found on the farm of Butterlaw, ${ }^{1}$ near Coldstream, and measures 4 inches
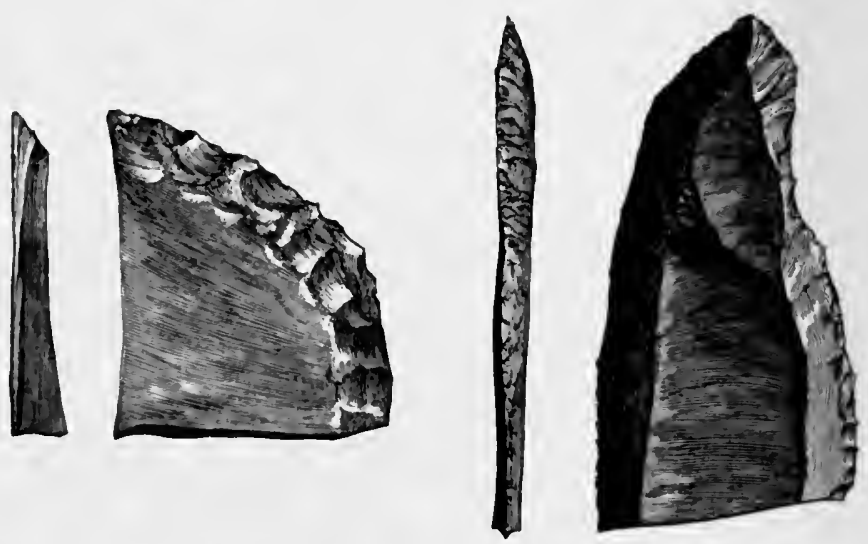

Figs. 56, 57.-Trimmed knives from Torrs, Old Luce, Wigtownshire ( $\left(\begin{array}{l}1 \\ 1\end{array}\right)$.

in length and $2 \frac{1}{2}$ inches in breadth, but only $1 / 4$ inch in thickness (fig. 59).

Canon Greenwell has figured a flint knife, with regard to which he writes as follows: "Aınongst the bones was deposited a flint knife, unburnt, $27 / 8$ inches long and $7 / 8$ inch wide, by far the most beautiful specimen I have yet met with; it is very delicately flaked over the whole of the convex surface, the edges being serrated with the greatest skill and regularity. It is another example of those implements which,

1 Proc. Soc. A. Scot., vol. xxviii. p. 324. 
when associated with interments after cremation, have been usually found to be themselves unburnt." 1

Originally the knife-flake and the saw were one and the same, but their specialisation into separate tools dates as far back as Palæolithic times, as we find saws among the relics of the reindeer caves of France and the rock-shelter of the Schweizersbild in Switzerland. ${ }^{2}$ In the earlier archæ-

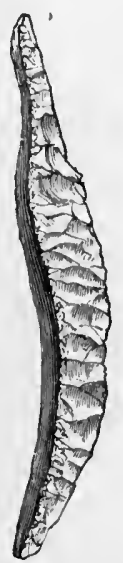

Fig. 58.-Trimmed flake, Mid Torrs, Old Luce (1).

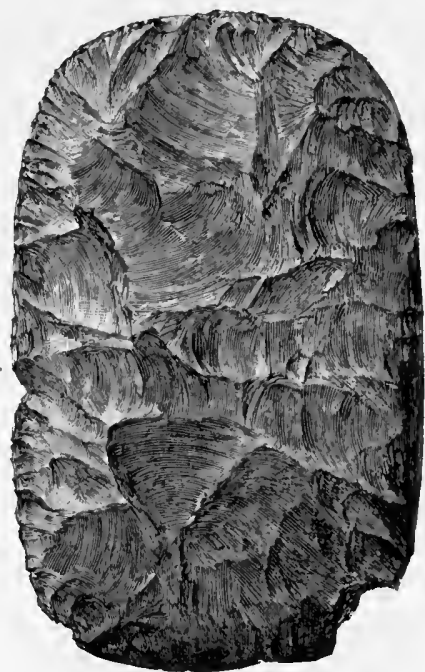

Fig. 59.-Ground-edged knife of fint found at Butterlaw (2).

ological works the term "saw" is indiscriminately applied to a knife-flake accidentally chipped by usage, as well as to one intentionally trimmed. The special characteristic of a saw is a cutting edge, with teeth so regularly formed that its function involves the necessity of a to-and-fro motion. Hence the knife described by Canon Greenwell in the above quotation might be regarded as a saw. True saws, though widely

1 British Barrows, p. 285.

2 Neue Denkschriften der allg. schw. Gesel., vol. xxxv., Pl. xi. 
distributed over Europe, are not abundantly to be seen in archrological museums. They have been found on the sites of lake-dwellings and other primitive habitations, and also in graves, but most frequently as stray objects in the surface soil. The flint saws in the Scottish National Museum (figs. 60-63) have been collected chiefly on the subsoil of the sand-dunes of Glenluce, Culbin, and Golspie. Their number now amounts to upwards of $\mathbf{r} 60$. They are usually made of flakes, but sometimes of chips, carefully trimmed so as to

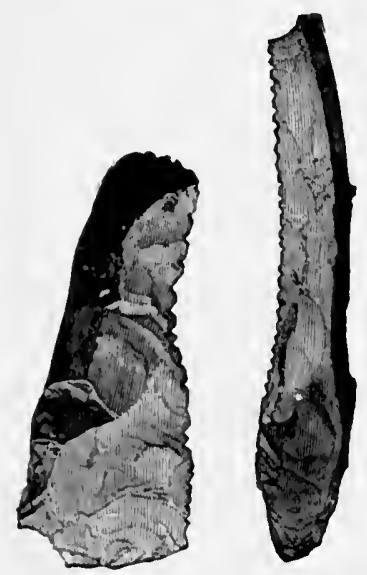

Figs. 60, 61,-Flint saws from Glenluce (1).
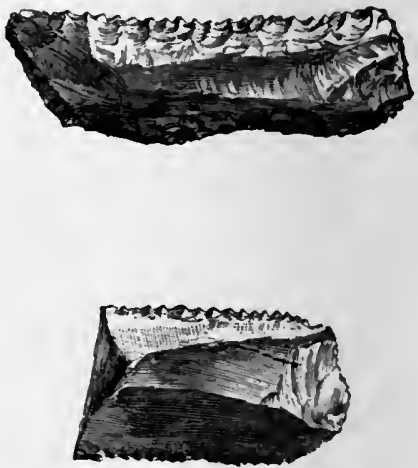

Figs. 62, 63.-Flint sazes from Culbin Sands (1).

present a series of regularly serrated teeth. Some are triangular on section and only one of the edges is serrated. Others, again, are serrated on both edges. The teeth in all the specimens found in Scotland are minute and fashioned with the utmost care and regularity. Along the edge of one specimen from Glenluce-a long, narrow, thickish flake$I$ counted thirty-five teeth over a length of $I 3 / 4$ inch; and along this edge there was to be seen a narrow band of glistening polish, scarcely broader than the length of the 
teeth. This feature has been observed on many of these saws without regard to their provenance.

Formerly it was a current opinion among archæologists that flint saws were not to be found in Ireland. That this opinion is erroneous is proved by $\mathrm{Mr}$ Knowles, who writes to me that he possesses numerous examples picked up among the débris of kitchen-middens on the sandhills. He states that in addition to flakes, "so serrated at the edge that a person at once comes to the conclusion that they had been
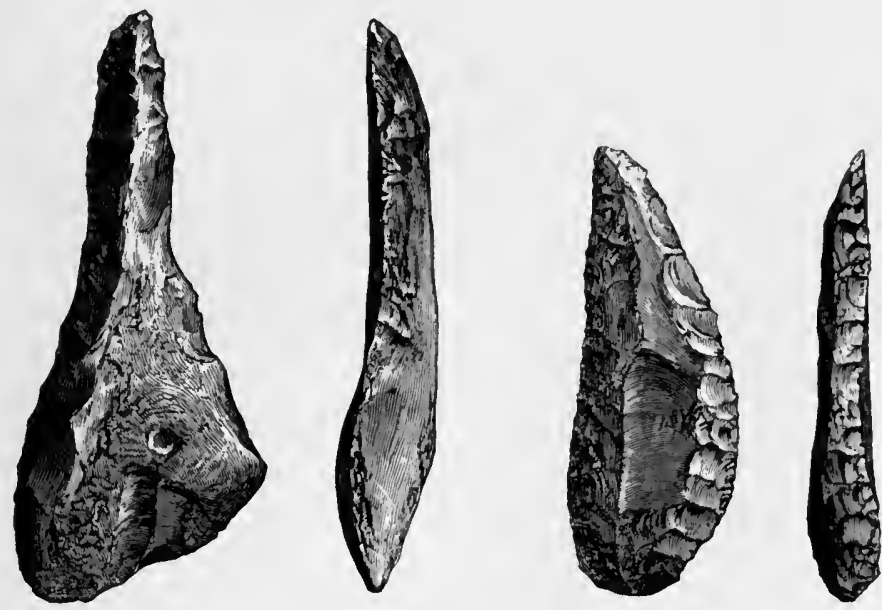

Figs. 64, 65.-Pointed fint scrapers, Torrs, Old Luce (1).

prepared for use as saws," there is another class of implements largely found in Ireland called "hollow scrapers," many of which must be regarded as true saws, as the teeth are regular and well defined. Mr Knowles has, recently, more particularly described these implements in a paper on "Irish Flint Saws" to the Royal Society of Antiquaries of Ireland (vol. iv., 5th series, p. 34I). For further notices of saws and their distribution in Europe I must refer my readers to 'Prehistoric Problems,' chap. viii. 
Among the remains of the ancient stone industry in this country the implement most largely represented is that known as the scraper, or "thumb flint" (figs. 64-67). It generally consists of a flake having the thick end worked into a semicircular edge slanting to its flat face, while the body or "neck" may be held between the fingers. But sometimes there is little or no neck, and the implement

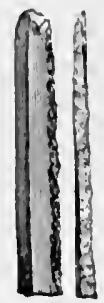

Fig. 66.-Slender scraper, Torrs, Old Luce (1).

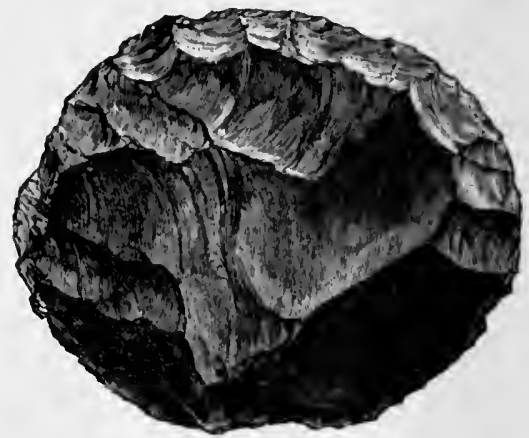

Fig. 67.-Horse-shoe scraper from the Crannog of Lochspouts, Ayrshire (1).

may be of a discoidal, circular, or horse-shoe shape; in which case it was necessary to have it mounted in some kind of handle to make it effective for any mechanical purpose. Some have a concave edge, and are known as "hollow scrapers"-a type of implement hitherto more frequently found in Ireland than in Scotland. The instruments used for boring have, of course, a sharp point, but otherwise they may be regarded as scrapers.

\section{Weapons.}

Arrows, spears, and javelins, being intended for piercing the tissues of the body (man or beast), naturally resemble each other in having a sharp point. Otherwise, they differ 
only in size and in the manner in which they are used. But whatever be the specific weapon,-arrow, spear, dagger, or javelin,-its efficiency demanded that the tip should be made of a harder substance than wood. For this purpose the best material was flint, although bone and horn were also used-especially for short hand-daggers, like those found in the lake-dwelling stations of Laibach, Mondsee, and others.

Arrow-points may be divided into tanged (figs. 68-70) and

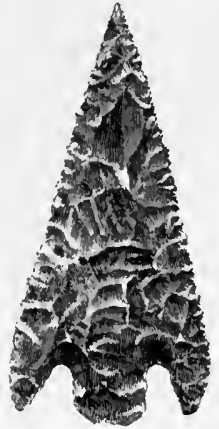

69

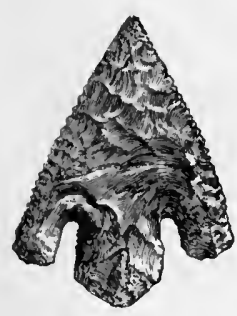

68

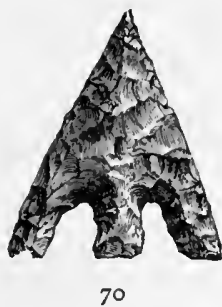

Figs. 68, 69, 70.-Tanged arrow-points of fint: 68 and 70 from Torrs, Old Luce, Wigtownshire; and 69 from Lanfine, Ayrshire (1).

untanged (figs. 7I-74), the latter being further subdivided according as they resemble a leaf, a lozenge, or a triangle-a division which is also applicable to spear-heads. The workmanship on some of those objects displays marvellous manipulation, especially in the execution of what is known as ripple-flaking.

Having secured the tip, the warrior or sportsman had to consider how it could be best attached to the shaft or handle. This was generally effected in the case of the arrow by inserting the lower end of the flint into a slit in the wood, and then tying it with a string. Among the lake-dwellers a kind of 
asphalt was used to keep the tip firmly in its position. These methods are illustrated in fig. 55, Nos. 7 and 8 .

It is perhaps unnecessary to say that the presence of

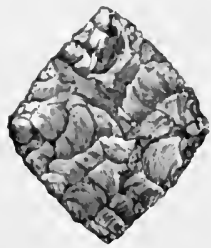

71
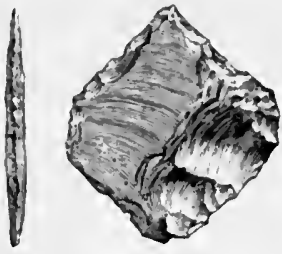

72

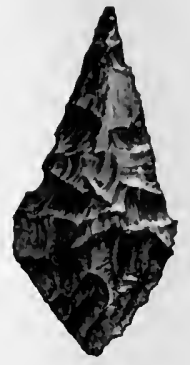

73

Figs. 71, 72, 73.-Losenge-and leaf-shaped arronv-heads, Old Luce,

IVigtownshire (t).

arrow-points implies the other necessary equipments of the archer-viz., the bow, the arrow-shaft, the quiver, and the bracer. Of the actual remains of the three former articles

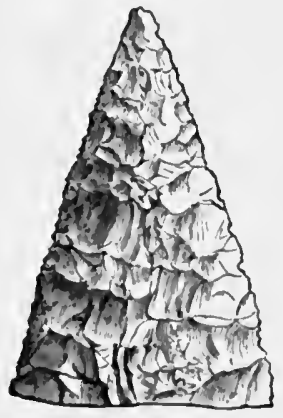

Fig. 74.-Triangular fint arrow-head, High Torrs, ll'igtonunshire (l). almost nothing has survived in this country to the present day, owing, no doubt, to their decay. But in the Swiss lake-dwellings several specimens of the bow have been found - as, for example, one from the station of Nidau in Lake Bienne, and another from Robenhausen, both being about 5 feet in length. The latter is made of yew; and shows the notch at both ends for the string. The bracer, supposed to be for protecting the wrist of the archer, being made of stone, and therefore not liable to decay, has been found in several localities in this country-generally in graves (figs. 75 and 76$)$. 
In Scotland, spear-heads, whether made of flint or of any other material, do not figure largely among its prehistoric relics. The few objects that may be so classified differ from the arrow-heads only in being a little larger, seldom exceeding 3 inches in length (fig. 77). In England we meet with a few large lanceolate, or leaf-shaped, flakes with elaborate workmanship, which, according to Sir John Evans, might have been used as daggers $;^{1}$ and in the Swiss lake-dwellings similar blades were either inserted into wooden handles, or had the butt-end covered over with twisted withes so as to afford a better grasp. ${ }^{2}$ No specimens of the beautifully formed daggers, having the blade and handle made of one
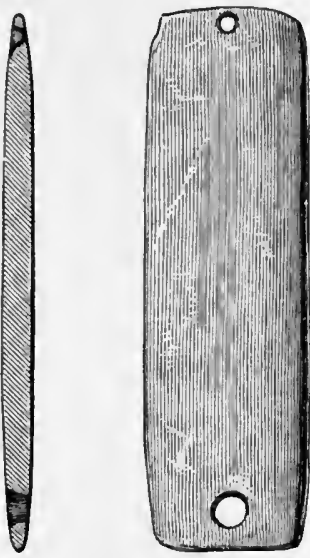

Fig. 75.-Bracer of stone found at Mid Torrs, Old Luce (1). piece of flint like those of the Scandinavian archæological area, have been found within the British Isles.

Barbed harpoons of an early type have already been noticed

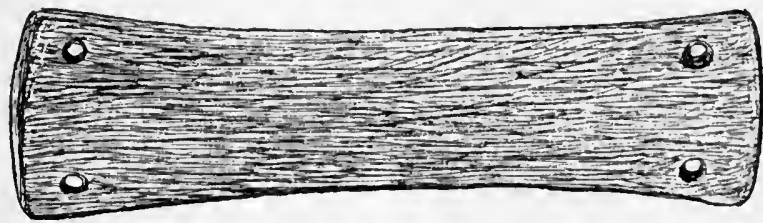

Fig. 76.-Polished bracer of felstone found with an urn at Fyrish, Evanton, Ross-shire $\left(\frac{2}{3}\right)$.

in the description of the MacArthur cave and rock-shelter at Oban, as also the perforated deer-horn chisels and picks

1 Ancient Stone Implements (figs. 264, 265).

2 Lake-Dwellings of Europe, fig. 8, Nos. 2 and 28. 
associated with the stranded whales in the Carse of Stirling. Sharp-pointed objects made of bone and horn, some of which may be regarded as daggers, have also been found in graves in this country, and more especially among crannog remains.

Among weapons may be noticed the so-called sling-stone, which may be a smooth pebble from the brook, or a flint nodule roughly chipped into a lenticular, discoidal, or globular

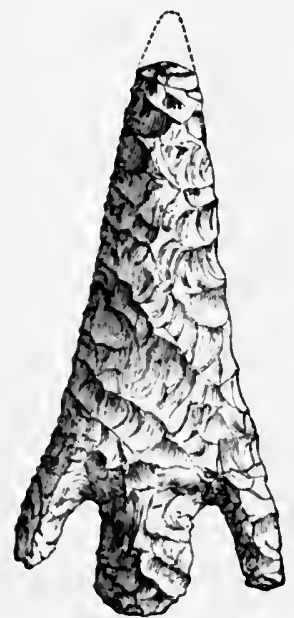

Fig. 77.-Jazelin-head, Machermore, Luce (s). shape. In the Wolds of Yorkshire these prepared flint nodules may be picked up in great numbers on ploughed fields, and elsewhere, as stray relics. It is, however, difficult to believe that all the objects so characterised were really used as sling-stones. The primary apparatus for projectiles was the hand itself, without the intervention of any mechanical appliances; and I cannot help thinking that many of the larger pebbles, so frequently found on ancient inhabited sites, were used in this manner.

Hundreds of ovate pellets of clay, generally not larger than a pigeon's egg, burnt and unburnt, have been found on the site of the lake-village of Glastonbury, which are regarded as sling-bolts, or perhaps fire-balls. Similar clay pellets have been recently dug up in considerable numbers on the site of Ardoch Camp, associated with Roman pottery and other Roman remains.

The remarkable series of ornamental stone balls found in Scotland-and only in Scotland-and supposed to have been attached to thongs and used as flail-like weapons, may here be noticed, though it is probable that they belong to a later period of Scottish civilisation than that now under 
review. They were first critically examined and described by Dr J. Alexander Smith, ${ }^{1}$ but since then their number has greatly increased. They vary in size from I inch to about $3 \mathrm{~T} / 2$ inches in diameter, and have their surfaces divided into four, six, or more symmetrical discs, or, sometimes, projecting knobs. The discs are generally ornamented by incised spirals, concentric circles, check patterns, \&c. Dr Joseph Anderson thus refers to their probable use: "In all their varieties of form, these objects present certain features which are sug-

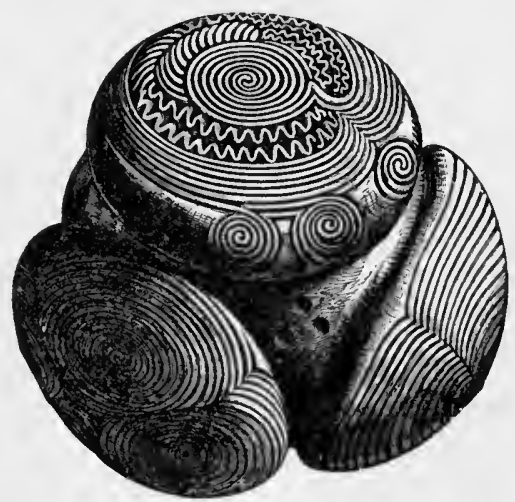

Fig. 78. - Stone ball ornamented with incised patterns found in digging a drain in the Glas Hill, Towie, Aberdeenshire (2).

gestive of a possible use as weapons. 'Their ornate character, their speciality of form, which renders them capable of being swung by thongs or bound to the end of a handle, and the fact that one example is pierced by a hole, are indications in this direction. Although there is no conclusive evidence of the fact, it is at least conceivable that they may have been mounted as mace-heads similar to those metal mace-heads with pyramidal projections which are found occasionally among the relics of the Iron Age, and con-

1 Proc. Soc. A. Scot., vol, xi. p. 29. 
tinued in use in the early Middle Ages, and similar, at least in appearance, to the mace-heads shown in the hands of unmounted men in the Bayeux Tapestry." 1 Some of these balls (fig. 78) are decorated with spiral ornamentation, which resembles that on metal work of the Bronze Age in Scandinavia and in the Danubian valley.

\section{Clothing and Ornaments.}

We have no knowledge of any phase of humanity in which the love of personal adornment does not play an important part in the life of the individual. The savage of the present day, who paints or tattoos his body and adorns it with shells, feathers, teeth, and trinkets made of the more gaudy materials at his disposal, may be accepted as typical of the Stone-Age men of Europe. Their ornaments consisted chiefly of beads, pendants, rings, bracelets, necklaces, \&c., made of jet, amber, bone, horn, teeth, \&c. Few, however, of such relics have been found in Scotland that can be identified as belonging to the Stone Age. Buttons made of jet are not uncommon among the contents of ancient graves. They are generally conical on the upper surface, and flat beneath, with a curved or V-shaped tunnel, both ends opening on the under surface, as shown in fig. 79 . On the 12 th December 1898 , three jet buttons, varying in size from $3 / 4$ inch to $I \frac{1}{4}$ inch in diameter, but of the usual conical form and perforated underneath, were exhibited at the Society of Antiquaries of Scotland as having been found in a cist with a cinerary urn at Keith Marischal, East Lothian. One found in a cist on Law Hill, Dundee, ${ }^{2}$ is quadrilateral in shape, with linear ornamentation on the back (fig. 80). Another, hemi-

1 Scotland in Pagan Times, p. 170.

2 Proc. Soc. A. Scot, vol. xxiv. p. 10. 
spherical in shape, is from Mid-Torrs, Glenluce. ${ }^{1}$ Three made of cannel coal, and found in a tumulus near Rothbury Northumberland, are described as circular, two inches in diameter, slightly conical on one surface and with the usual

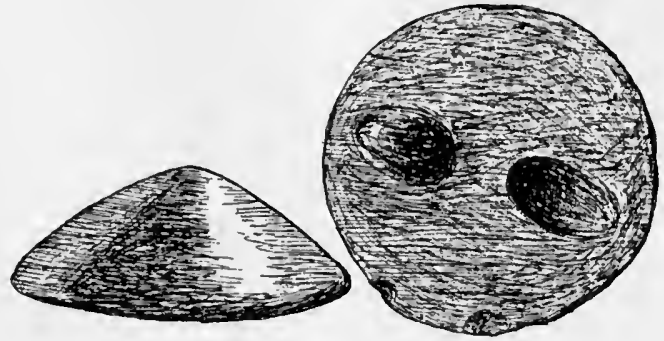

Fig. 79.-Set button, upper and under surfaces, found on Crawford Woor, Lanarkshire (3).

perforation on the other. Canon Greenwell has figured a number from the Yorkshire barrows, some of them being highly ornamented. Buttons of bone have also been found
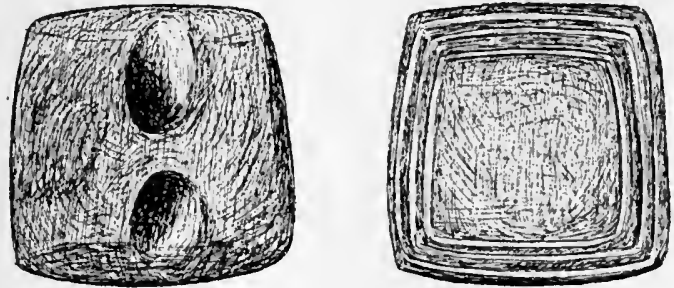

Fig. 80.-Back and front views of a jet button foumd in a cist at

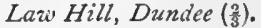

occasionally - one with two holes being from an urn at Murthly, Perthshire.

Of the more perishable works of the earliest inhabitants of Scotland very little, if anything, has reached our day. Of the spinning industry the spindle-whorl alone remains as evidence,

1 Proc. Soc. A. Scot., vol. xxx. p. 5. 
but, as it has also been used in all subsequent ages, even up to the present time, it possesses no chronological value. Fragments of woollen cloth, along with a skeleton, were found by a man cutting peats in a bog at Birsay, in Orkney. The body, that of a female, was in a sitting position, the top of the skull being 2 feet below the surface of the peat. "The portions of woollen fabric are of two or three different varicties of texture, the largest portions woven of thick and coarsely-spun yarn. The pieces are much patched, so much so as to suggest the dress of a vagrant rather than that of a person careful of appearances." 1

Portions of woollen cloth of four or five different textures are said to have been found in a cist at Greenigoe, parish of Orphir, Orkney, along with two beads, one of amber and the other of an opaque vitreous paste. ${ }^{2}$

A complete woollen hood, with a wide fringe, ${ }^{3}$ found in a moss in the parish of St Andrews, Orkney, is preserved in the National Museum; also fragments of cloth and a leather shoe said to have been found associated with human skeletons in a moss at Culrain, Ross-shire. ${ }^{4}$

Canon Greenwell has occasionally recorded the finding of remains of woollen and leather garments in British barrows, as, for example, in a coffin made of a hollow oak trunk, found in a barrow at Scale House, Craven. For a notice of this and similar tree-coffins in England and Denmark I would refer my readers to 'British Barrows,' p. 377.

Sir Daniel Wilson, ${ }^{5}$ in describing a garment procured by Dr Samuel Hibbert from some labourers who had found it, on the chance exposure of a stone cist, while excavating for railway work near Micklegate Bar, York, about the year 1838 ,

1 Proc. Soc. A. Scol., vol. xvi. p. 12.

3 Ibid., vol. xiv. p. 81.

2 Ibid., vol, xxiii. p. 123.

3 Prehistoric Annals, vol. i. p. 475.

4 Ibid., pp. $91,92$. 
thus writes: "This valuable relic-now in the Scottish Museum-appears to be a sleeve, or covering for the leg; and somewhat resembles the hose worn by south-country Scottish farmers, drawn over their ordinary dress as part of their riding-gear. It has been knitted; a process which doubtless preceded the art of weaving, probably by many centuries. The fabric is still strong, and, in careful keeping, may long suffice to illustrate the domestic manufactures of the ancient Briton. This is one of the examples to which reference has been made in a former chapter, as showing the source to which it is conceived the ornamental designs on early British pottery may be traceable; though the resemblance is less striking here than in some more imperfect specimens of such products of the primitive knittingneedle or loom. The accom-

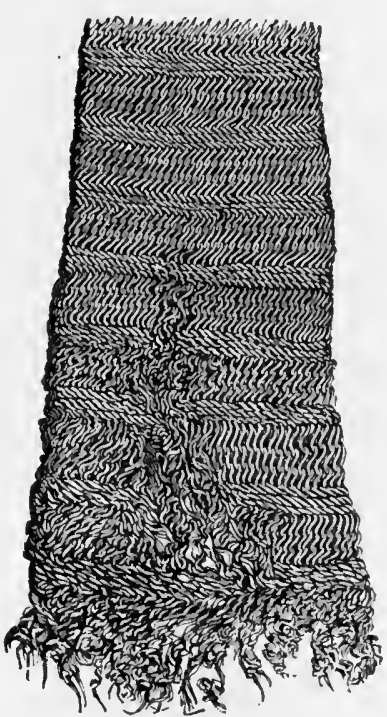

Fig. 8r.-Portion of knitted work found in a cist near Micklegate Bar, York. panying woodcut (fig. 8I), representing a portion of the knitted fabric, will enable the reader who is familiar with the style of ornamentation on the pottery of the tumuli to judge for himself how far this idea is justified by the correspondence traceable between them."

A human body, the mummy of which is now preserved in Dublin, was found in a bog 9 or 10 feet beneath the surface. "When first exhumed," writes Sir W. Wilde, "1 "the body was perfectly fresh, and enclosed in a dress not unlike

1 Beauties of the Boyne, p. 237. 
that in the description given of Gurth in 'Ivanhoe,' consisting of a tunic of cow-hide, apparently tanned, but with some remains of hair still preserved on the side worn next the skin. This dress is joined in the most accurate and beautiful manner, exhibiting an extraordinary perfection in the art of sewing. The hair on the head, which is both long and fine, is of a dark-brown colour, and the skull is compressed in a remarkable manner, owing to a portion of the earthy matter having been removed by the acid of the bog."

But for a more complete picture of the culture and civilisation of Neolithic man we must investigate the relics of the lake-dwellings of the Stone Age of Europe. In the station of Robenhausen we meet with a variety of woollen cloths, yarn, bast ropes, \&c., associated with spindle-whorls, loom-weights, and other objects used in spinning and weaving. In the Neolithic stations of Butmir, in Bosnia, ${ }^{1}$ and Laibach, in Styria, ${ }^{2}$ as well as in other localities throughout Europe, human' figurines have been found which are generally regarded as idols, thus showing that their inhabitants were guided to some extent by supernatural influences.

2 Rambles and Studies in Bosnia, p. 98, Pl. xiii.

" Lake-Dwellings of Europe, p. 532, fig. I95. 
CHAPTER VI.

PROGRESS IN CULTURE AND CIVILISATION DURING THE BRONZE AGE.

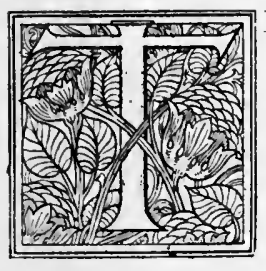

HE discovery of bronze, and its introduction into the simple arts and industries of the Stone Age people of Europe, may be said to have speedily revolutionised their whole system of social economy. Not only had all the primitive implements and weapons to be remodelled, in accordance with the principles of a metallic régime, but new industries and higher artistic aspirations were engendered which, by degrees, greatly modified the commercial and social aspects of life.

That this metallic innovation first found its way into Britain by means of cutting implements of bronze imported from abroad there can be little doubt, as the oldest metallic objects known-the small hand-daggers generally found in graveswere made of the best quality of bronze. Now, since a knowledge of this compound implies a previous acquaintance with its component elements, copper and tin, it follows that the progress in metallurgy had reached the stage of selecting the best combination of these metals for the manufacture of cut- 
ting tools, at the same time as, if not indeed before, the simple metals were known to the inhabitants of the British Isles. That this skill in the working of metals had not been acquired by the ancient nations on the shores of the Mediterranean without a long experience of the uncombined use and qualities of copper and tin, and of the various methods of hardening the former, was demonstrated by Dr Gladstone, F.R.S., at the meeting of the British Association held at Liverpool in $\mathrm{r} 896$. In a paper on "The Transition from pure Copper to Bronze made with Tin" he writes as follows: "The use of copper in Egypt can be traced from the fourth dynasty, when King Senefern captured the copper and turquoise mines of the Sinaitic peninsula. Tools made of this metal have been found not only in Egypt, belonging to the fourth, sixth, and twelfth dynasties, but also in Assyria, at Lachish in Palestine, Hissarlik in Asia Minor, and Naqada. Attempts were made to render this copper harder and stronger, and that in three ways. First, the admixture of a large quantity of suboxide of copper, or of its formation in the process of smelting, as seen in adzes from Egypt and Palestine, and perhaps Naqada. Second, the presence of a little arsenic or antimony, as shown in many tools from Kahun dating from the twelfth dynasty, and from the Sinaitic mines, as shown in a communication to the French Academy by Berthelot a few weeks since. Third, the admixture of a little tin, as at Kahun, the Sinaitic mines, and Cyprus, perhaps not exceeding I per cent. When, however, the superiority of tin, as the hardening material, came to be acknowledged, it was added in larger quantities, and formed the alloy known as bronze. Such proportions as 4 and 6 per cent occur in early specimens, as at Hissarlik; but subsequently about 10 per cent was usually employed. Tools of this composition are found not only in Egypt during 
the eighteenth dynasty, but in most countries, and for an immense variety of purposes." 1

The existence of a real Copper Age in Egypt, Cyprus, and other countries bordering on the Levant, as thus indicated by Dr Gladstone's researches, naturally prompts us to inquire if there had been a corresponding period in Europe when copper implements and tools had been in use before the invention of bronze. The late Von Pulszky, Drs Much and Gross, and, more recently, Professors Hampel and Montelius, have advocated the affirmative side of this problem, chiefly on the grounds that in Hungary, and on the sites of a few lake-dwellings, a large number of copper relics have been found; and, moreover, that in many countries the lowest type of metallic celt was made of copper in imitation of the stone celts previously in use. But none of these arguments are, in my opinion, applicable to Britain, as the simplest form of the bronze celt is precisely similar to the earliest copper celts. That copper was known in Europe prior to the knowledge of the art of converting it into bronze is likely enough; but as the pure metal was inferior to flint for cutting purposes, it produced no perceptible change on the social industries of the period. It was the art of hardening copper which first stirred up the slow channels of industrial progress in the ancient world and raised mankind to a higher mechanical platform. The finding of so many of these primitive copper celts throughout Europe is, no doubt, suggestive of a Copper period; but at the same time it must not be forgotten that flat axes of the best quality of bronze have also been found in circumstances which render it probable that they are as old as the former. Dr Montelius, one of the most recent advocates of this theory, figures in his brochure, 'Findet man in Schweden Ueberreste von einem

1 Brit. Association Report, 1896, p. 930. 
Kupperalter,' two metal celts, found together in a cultivated field at Pile, in Sweden, which could be used as an argument to prove that bronze was known and utilised in Sweden before copper. One of the celts is a large well-shaped implement, over 8 inches in length, with perpendicular borders and raised edges, and ornamented with a series of curved lines running across its surface. The other is smaller (6 inches in length) and has no raised border, nor indeed any specific character which in appearance would differentiate it from the most primitive type known. But the former is described as being made of copper, and the latter of bronze. The use of pure copper in the manufacture of some of the axes, even supposing that it had been so utilised before the introduction of bronze, could have lasted only a very short time in Western Europe-so short, indeed, that during its prevalence not a single progressive change or improvement is to be noted in respect of any specimen that can be shown to be older than the Bronze Age. No advocate of the Copper-Age theory holds that all the objects made of copper found in Hungary are actually earlier than the Bronze Age-many of them being similar in style and pattern to objects regarded as characteristic of that period. The existence of these Hungarian copper impiements, like the ornamented copper celt from Pile, must, therefore, be explained on other grounds than the chronological priority of the discovery of copper over bronze.

As soon as the metallurgic art had taken root among the prehistoric people of Scotland, they began to manufacture their cutting implements and weapons of bronze, modelling them, in the first instance, after the analogous objects of the Stone Age, or the imported metal specimens which already had passed through the stage of imitation in some outside area. I have elsewhere ${ }^{1}$ shown that a similar derivative

\footnotetext{
1 Prehistoric Problems, p. 330.
} 
connection can be traced between not only the flat axe, whether of bronze or copper, and the stone celt, but also between the knives, saws, sickles, daggers, \&c., of the two culture periods. By-and-by, however, all these objects underwent progressive modifications, probably in proportion as their makers had gained greater knowledge and experience in the art of working the metal. But as no remains of any kind of buildings, excepting sepulchres, have as yet been discovered on the Scottish area which can with certainty be assigned to either the Stone or Bronze Age, we are deprived of the best source of evidence regarding the evolutionary phases through which these objects passed in their transitions from stone into metal. The relics at our disposal have been for the most part discovered accidentally, either as concealed hoards or as stray objects in the soil. Such hoards have been found in various circumstances, as, for example, by peatcutters, and by workmen engaged in digging drains, foundations of houses, gravel-pits, \&c. The dredging for marl in lake-beds - an occupation which was very common at the beginning of this century - has brought to light some valuable antiquities. The plough has played no mean part in such discoveries; nor must we neglect to mention the services of the poacher, the mole, the rabbit, and other burrowing animals. Occasionally evidence of chronological sequence is to be derived from the contemporaneity of articles thus associated. Evolutionary changes, indicating progressive improvements in the various parts of a composite object, are sometimes of much value in this respect, as, for example, the development of the different parts of a fibula. Now it can be clearly demonstrated that the original safetypin occupies an intermediate stage between the primitive straight pin and the highly ornamental brooches of later times, such as were in use among the Celts, Saxons, and 
Scandinavians. The connection between such derivative objects is often obscure until all the intermediary links of a series are exhibited side by side. No better illustration of this can be given than Dr Hans Hildebrand's description of

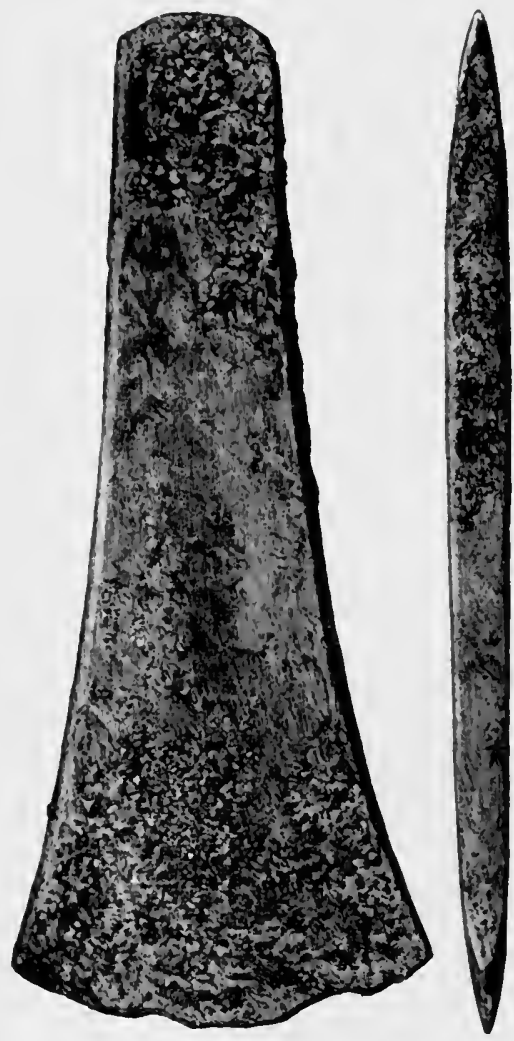

Fig. 82.-One of five bronse axes found at the "Maidens," Ayrshire (t).

the successive transformations which connect the Roman fibula with the boar's-head brooch of Scandinavia, so characteristic of Viking burials and hoards in this country. ${ }^{1}$

1 See Scandinavian Ar!s, pp. 22-30. 
1. Axes, Chisels, \&oc.

The division of axes into flat, flanged, winged, and socketed, not only sufficiently defines these implements, so far as any classification is necessary, but also describes the chronological order of their development. The flat celt (figs. 82 and 83 ) was the first to spread over Europe, and it is the form most com-
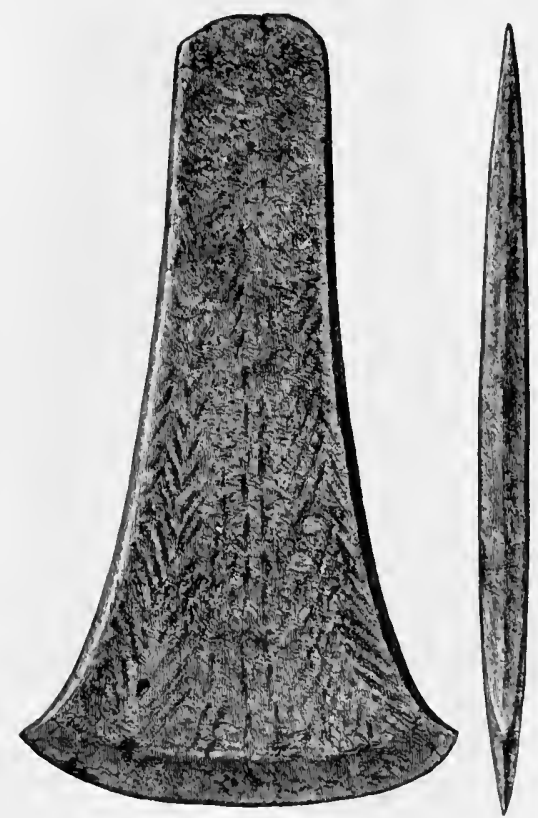

Fig. 83.-Bronze celt found on Bog Farm, near Kilwinning ( $\left.\frac{1}{2}\right)$.

monly met with in the British Isles. In the course of time, probably owing to improvements in the manner of hafting, the first alteration was made by raising a flange on each side; then these flanges became larger and curved inwards (fig. 84) until the two nearly met, thus forming two imperfect sockets, one on each side. Coincident with these 
changes a stop-ridge appears between the flanges, and a loop on one of the edges of the axe to fasten the handle more securely (fig. 85). Finally, we have the single socket, which is the culmination of previous adaptations, all of which now disappear or become merged into this more perfect mode of fastening the handle. Nothing remains to show these evolutionary stages except the direction of the socket and the

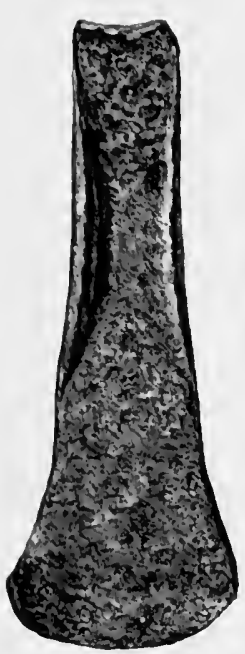

Fig. 84.-Bronze winged celt found near Largs $\left(\frac{1}{2}\right)$.

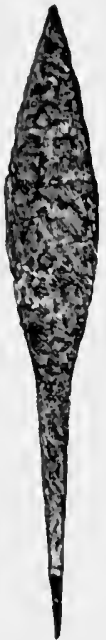

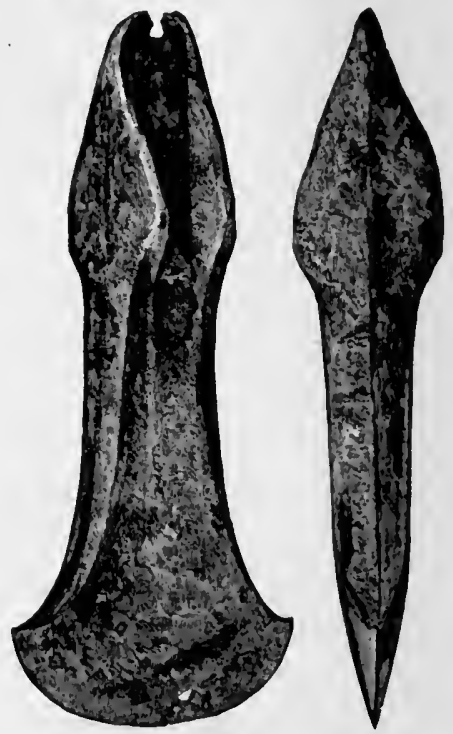

Fig. 85.-Bronse palstave found on the

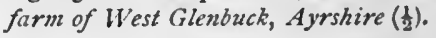

side loop (fig. 86). It is only in the Iron Age that we meet with the transverse socket, and even then the change seems to have been effected very gradually, as both in Hallstatt and La Tène the prevailing type of axe retained the vertical socket.

As to the methods of hafting these various forms of the implement, it may be observed that the first three types were inserted into slits in the wooden handle, and hence, when in 
use, the wood was apt to split; whereas the fourth had, instead, the handle inserted into the socket in one solid piece.

The flat axes vary greatly in size, from a few inches up to I $35 / 8$ inches in length, this latter being the largest known in Scotland. They were cast in open stone moulds, several

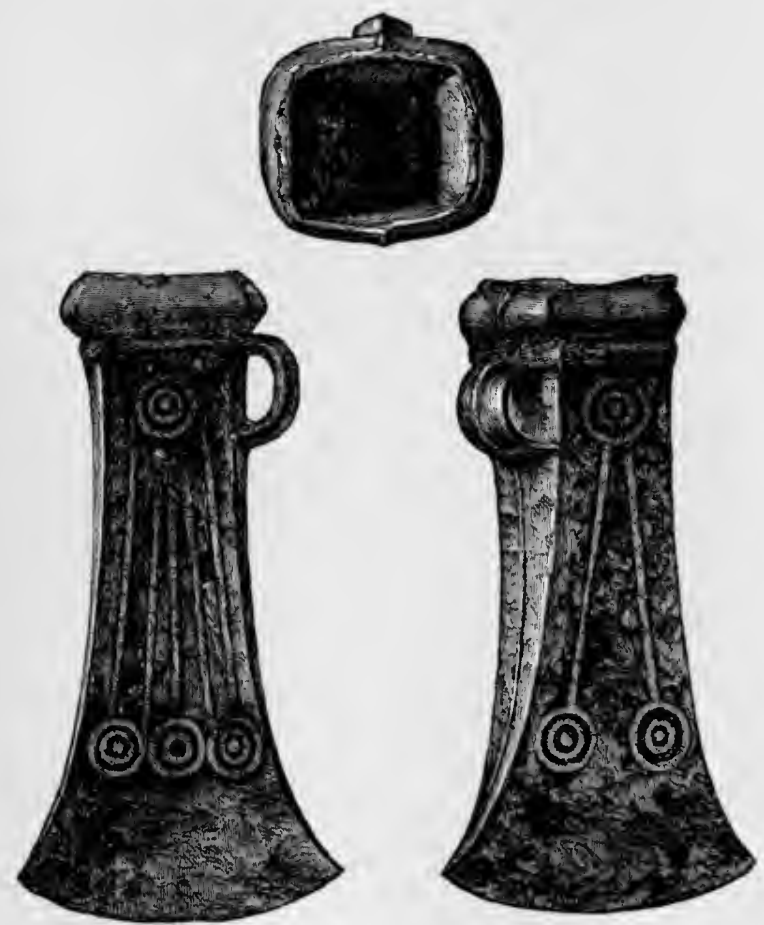

Fig. 86. - Socketed bronse axe-head found on the farm of Knock and Maize, Leszualt, Wigtownshire ( $\left.\frac{1}{2}\right)$.

specimens of which may be seen in the National Museum. The socketed axes are generally shorter than the intermediate flanged types, but they vary considerably both in size and in the shape of the blade. The bronze celt represented in fig. 87 , and included in the collection of antiquities presented by 
Sir Herbert Maxwell to the National Museum, is referred to by Sir Herbert as "a very delicate little article, and, so far as I have seen, there is none similar to it in any collection in Great Britain or on the Continent. Mr Evans assigns it to

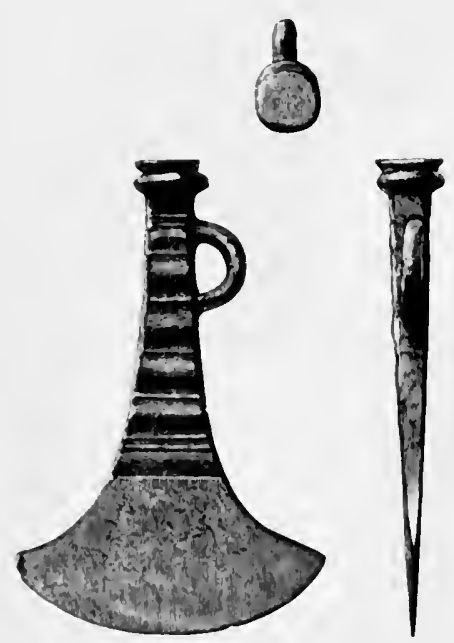

Fig. 87.-. Winiature ornament in the form of an axe-head found on the farm of Stelloch, Glasserton, Wigtown. shire (1). a late period of bronze manufacture, but it is difficult to say whether it has been intended for an ornament or for use as a small glyptic tool or chisel." 1

Chisels and gouges are generally socketed or tanged, and differ from the axes only in being elongated and more slender. The simplest form is a bar of metal sharpened at one end and blunt at the other so as to receive the blows of a hammer. When tanged there is usually a projecting rim or bar of the metal about its middle so as to act as a stop-ridge for the wooden handle.

So far as I know, no bronze hammer has yet been discovered on Scottish soil; but a few specimens of this most essential tool have been recorded from England and Ireland, all of which have a socket for the handle at one end. A few of these are figured by Sir John Evans. ${ }^{2}$ On the site of the lake-dwelling of Wollishofen, near Zürich, six hammers of this same type were among the remains dredged up, two of which, along with a bronze anvil from the same place, are

\footnotetext{
1 Iroc. Soc. A. Scot, vol. xxiii. p. 221.

2 Bronze Implements, \&c., p. 178.
} 
figured by me. ${ }^{1}$ It is remarkable that the principle of hafting the stone hammers and axes by a transverse perforation for the insertion of the wood-if these implements are really to be regarded as products of the Stone Age-should have been so thoroughly discontinued during the Bronze Age, while in the Iron Age, especially within the British Isles, even at a comparatively early period, the perpendicular socket was almost entirely superseded.

\section{Knives, Sazes, Sickles, and Razors.}

One of the most noteworthy facts in connection with the Bronze Age in Scotland is that neither knives, in the proper sense of the word, nor saws of bronze have as yet been discovered among its remains. The small hand-dagger with riveted handle, found occasionally in graves, may have served the purposes of a knife. The objects described by Sir John Evans as a knife is a dagger-like blade with a socket for the insertion of a handle; but specimens of these implements are rare in Scotland (fig. I00). In England they are more frequently met with; and in Ireland they are fairly abundant, not less than thirty-three having been recorded in Sir W. Wilde's catalogue. One of the Scottish specimens found at Kilgraston, Perthshire, is engraved by Sir John Evans, ${ }^{2}$ and another by Sir D. Wilson. ${ }^{3}$ Fragmentary specimens have been found at Clova and a few other localities. ${ }^{4}$

A flat bronze blade with a perforated tang, found in the lands of West Cairns, is figured and described by $\mathrm{Mr} \mathrm{M}^{\prime} \mathrm{Call}$ in his 'History and Antiquities of the Parish of Mid-Calder.'

1 Lake-Dwellings of Europe, fig. 4, Nos. 8, 18, and 21.

2 Bronze Implements, \&c., fig. 243.

3 Prehistoric Annals, vol. i. p. 390.

4 Proc. Soc. A. Scot., vol. xxvii. p. 12 ; vol. xxviii. p. 239. 
As may be seen from the accompanying outline (fig. 88) taken from $\mathrm{Mr}$ M'Call's illustration, this blade has sloping edges, a feature which gives it a unique character among the Bronze Age relics of Scotland. A few similar blades have been found in English barrows, one of which is figured by Sir John Evans. ${ }^{1}$ Daggers with a rivet-hole in the

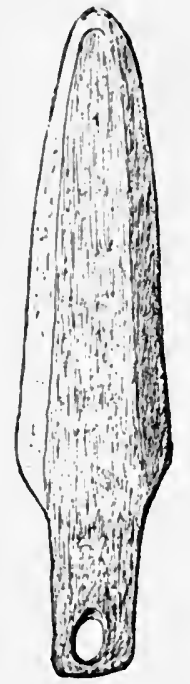

Fig. 88. - Bronze $k n i f c-b l a d c$ found in the parish of MidCalder ( (a).
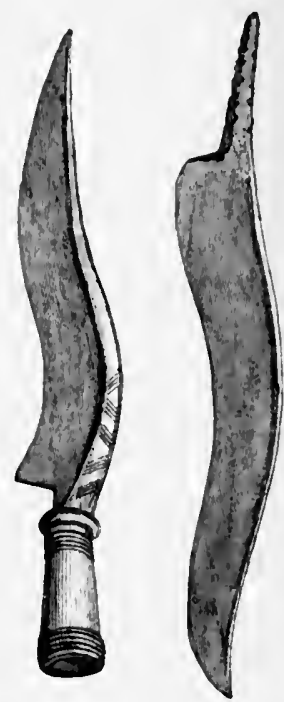

Fig. 89. - Tzuo large bronze knizes of rare forms (about $\frac{1}{6}$ ).

butt-end of the tang are known in Scotland, but they differ from the above in having a strongly marked mid-rib.

The paucity of these so-called knives, and the entire absence of the typical knife-blade, are in striking contrast to what we find on the Continent, especially in the Swiss lake-dwellings. There the knives are one-edged blades and extremely elegant in form, being always more or less curved, and frequently

1 Bronze Impleutents, p. 223. 
ornamented with parallel or wavy lines, concentric circles, dots, \&c. They were hafted either by a tang or socket, unless, as it sometimes happened, the blade and handle were cast together. In regard to their distribution over the lakedwelling area, it may be interesting to note that the socketed knives are very rare in eastern Switzerland, while in the west they are the rule and not the exception. Sir Daniel Wilson ${ }^{1}$ describes as bronze reapers two knives (fig. 89) of

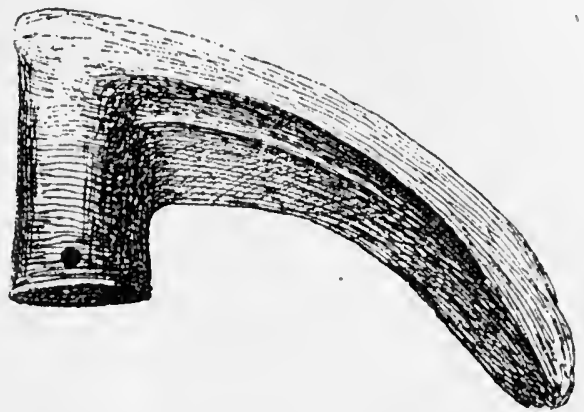

Fig. go.-Bronze sickle, parish of Dores, Inver. ness-shire ( $5 \frac{x}{4}$ inches in length).

the same characters as those from the lake-dwellings of the Bronze Age - one tanged and the other socketed. 'The former ( 14 inches in length) is stated to have been found on the farm of Moss-side, in the vicinity of Crossraguel Abbey, Ayrshire, and the latter was then in the collection of Sir John Clerk at Penicuik House.

I am not aware that a specimen of a bronze saw has yet been found within the British Isles, but among the remains of the Continental lake-dwellings and

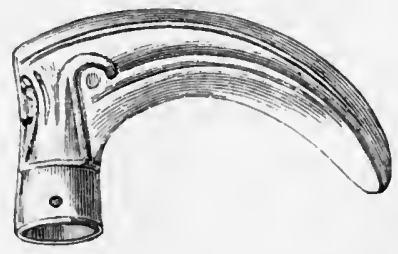
lïg. 91.-Bronse sickle found in Ireland (61/4 inches long). hoards saws are not unfrequently met with. One small file has been found in Lake Bourget. Sickles have been found in considerable numbers in England, Scotland, and Ireland. Those from the two latter countries (figs. 90 and $9 \mathrm{I}$ ) are all 
socketed-a statement which is also applicable to those from England, with the exception of one or two specimens from Somersetshire, which appear to have been imported, as they are of Continental types.

Implements supposed to have been used as razors have been discovered in England, Scotland, and Ireland. Three

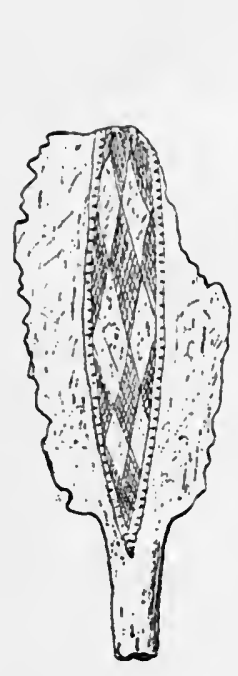

92

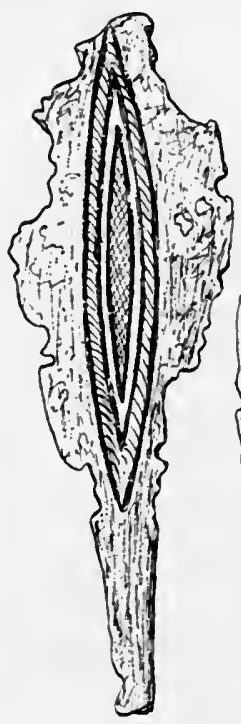

93

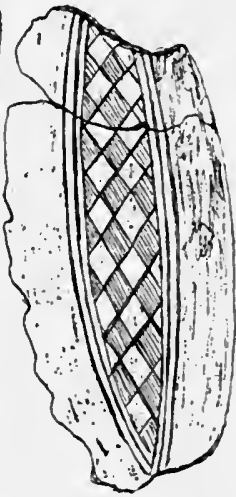

94

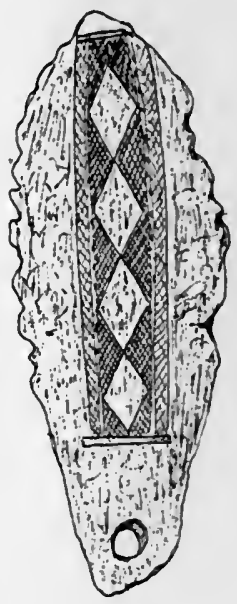

95

Figs. 92-95.-Scottish ornamented bronse blades (all $\frac{\text { qे }}{3}$ ).

92 found in a tumulus at Rogart, Sutherlandshire; 93 found in a cairn at Balblair, Creich, Sutherlandshire; 94 found in an urn at Magdalen Bridge, Mlusselburgb, MidLothian; 95 found with burnt bones at Shanwell, Milnathort, Kinross-shire. See Proc. Soc. A. Scot., vii. $475:$ x. $431-447$; xvi. 424 ; xix. 115 .

specimens (Pl. I. 3) are recorded as having been found in urns dug out of a tumulus at Bowerhouses, near Dunbar. Two specimens found in Sutherlandshire, one in a tumulus at Rogart, and the other in a large cinerary urn at Balblair, are ornamented as shown in figs. 92 and 93 . A similarly ornamented blade was among cremated bones in an urn found at Magdalen Bridge, near Musselburgh (fig. 94); and another (fig. 95) was associated with urn burials at Shanwell, 


\section{.}




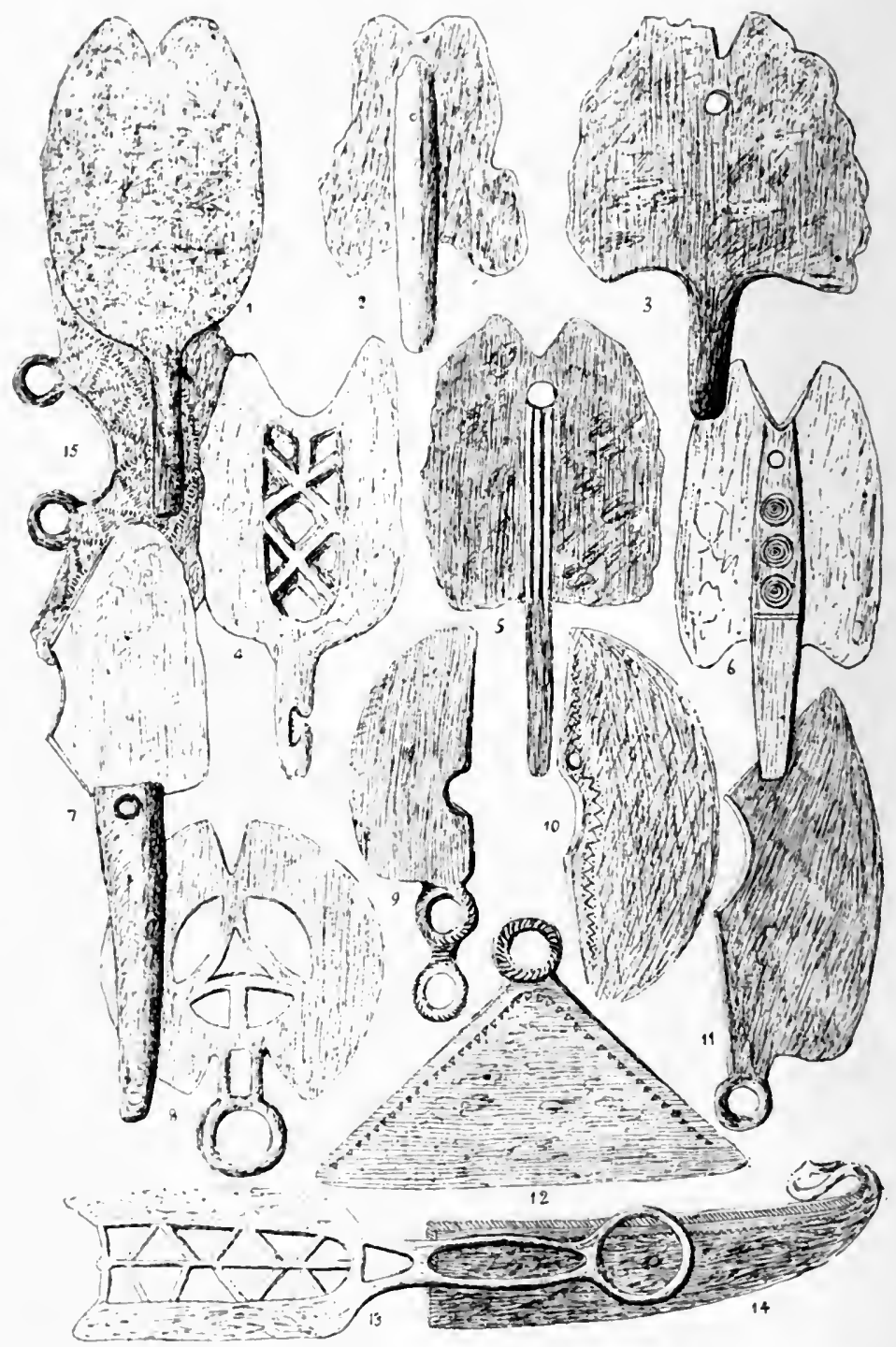

PIATE I.-FORMS OF RAZORS FOUND IN DIFFERENT PARTS OF EUROPE.-All 1/2. (For details see List of Illustrations.) 
Kinross-shire. All the Scottish specimens are tanged, with the exception of the one found at Kinleith, which has a loop at the end of a stem, corresponding to the tang in the others (fig. 39). The British specimens have all a family likeness, but do not differ materially from the Continental types, as represented in the lake-dwellings and the Terremare of Italy. ${ }^{1}$ For a number of various forms of razors from different parts of Europe, see Plate I.

\section{Weapons.}

Bronze daggers are usually of two kinds-viz. : (I) those with a thin, flat, triangular, or oval-shaped blade, and gener-

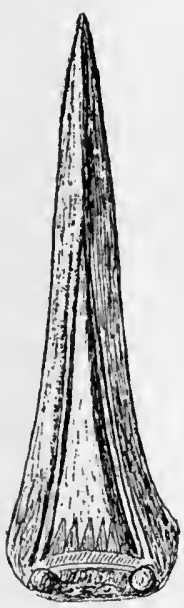

96

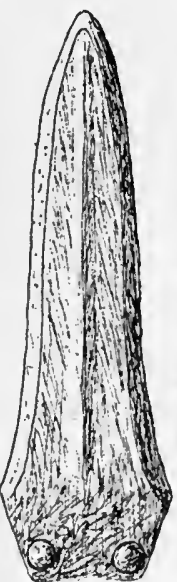

97

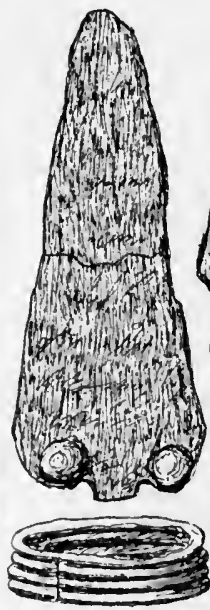

98

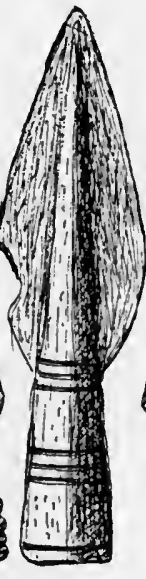

99

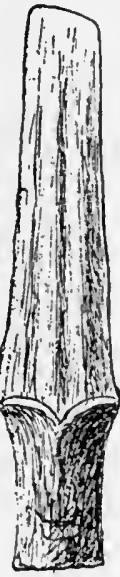

100

Figs. 96-100. - Scottish bronze weapons (all $\frac{1}{3}$ ).

96, Bronze blade found at Pitkaithley, Pertbshire; 97, Bronze dagger found near Gretna, Dumfriesshire ; 98 , Bronze dagger-blade and gold mounting of the hilt found in a cist in a cairn at Sketraw, Dunbar ; 99, Bronze socketed spear-head found near Forfar ; 100, Dagger-knife with oval socket and rivet-holes in side. See Proc. Soc. A. Scot., xvii. 8 ; xiv. 97 ; xxvii. 8 ; xvii. 95 ; xxiii. 16.

ally known as knife-daggers; and (2) those with a blade larger and heavier than the former, and having a thick mid-rib. As

${ }^{1}$ See figs. 63,83 , and 85 , 'Lake-Dwellings of Europe.' 
a rule, both varieties are hafted by rivets to a wooden or horn handle; but there are a few exceptions in which the tang takes the place of the rivets. For further illustrations and

Figs. 10I-105.-Bronze zueapons ( $\$$ ).

101, Spear-bead with side loops, locality unknown; 102, "Scyibe-shaped" blade found in Galloway; 103, "Scythe. staped" blade found in a moss on the farm of Whitleys, Stranraer; ro4, Spear-head from Barbullion, found jammed between two rocks; 105, Spear-head found near Denhead. Coupar-Angus. See Proc. Soc. A. Scot., vii. 423; xvií. $93 \cdot 98,200 \cdot 232$; xxiii. 224 .
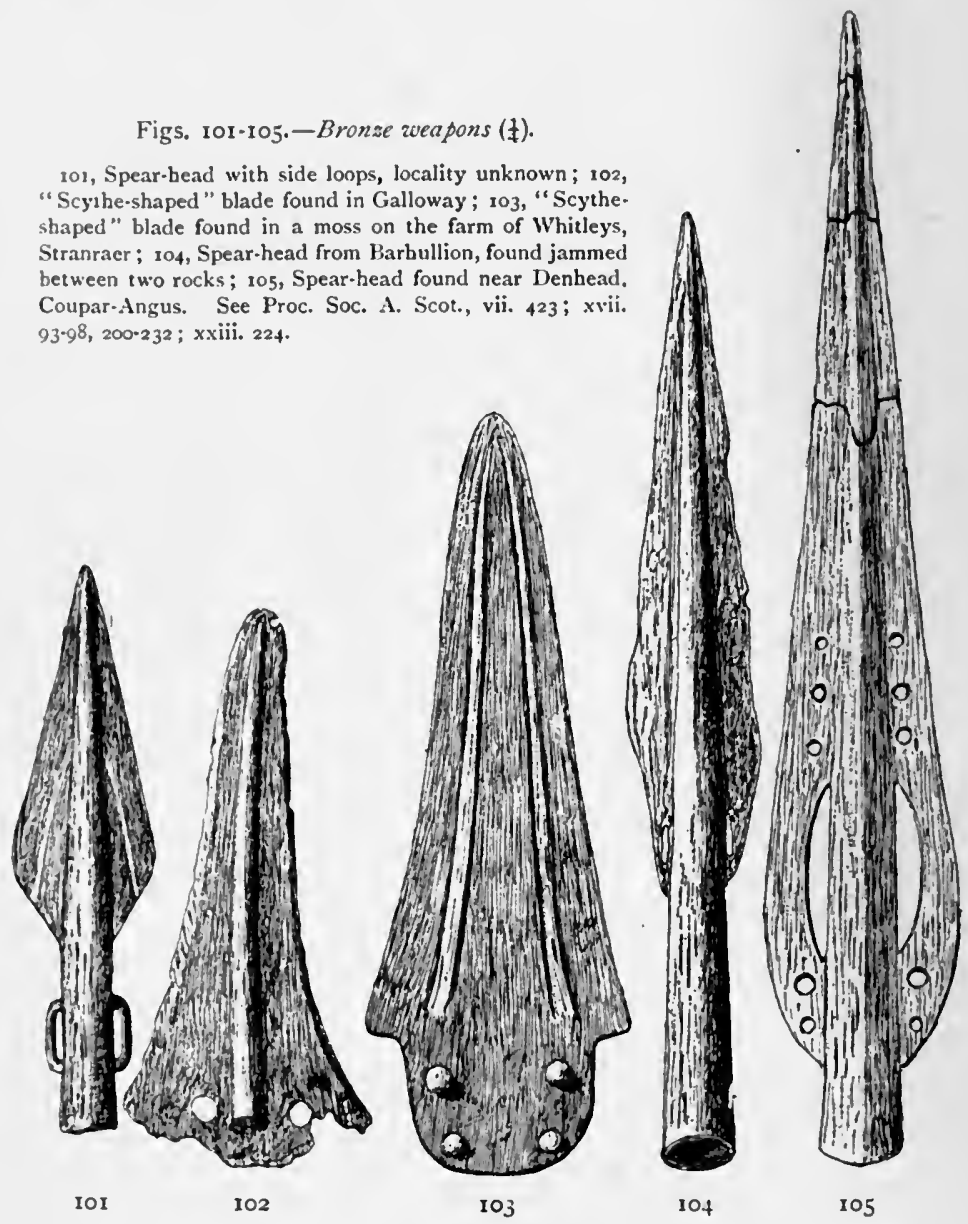

details of daggers, spear-heads, \&c., consult figs. 96-105. $\mathrm{Mr}$ A. Hutcheson has recently described a dagger-blade, along with fragments of others, apparently of the same type, in 
which a couple of notches have taken the place of the rivetholes (fig. 106). It was discovered in a cairn on the farm of Gilchorn, near Arbroath, associated with urns. ${ }^{1}$ The dagger represented by fig. 107, showing a large rivet-hole in the butt-end of the tang, is one of two specimens discovered on Scottish soil. It was found in Whitehaugh Moss, Ayrshire, at a depth of about 6 feet, and is described and figured by Dr James Macdonald. ${ }^{2}$ The other was found on the Crawford Priory estate, Fife, and is figured and described by the Hon. John Abercromby. ${ }^{3}$ These daggers, whether the blades were flat or ribbed, were sometimes ornamented as shown on figs. 96 and 107 .

Another class of weapon occasionally found in Scotland, and allied to the strongly ribbed dagger, is that which Sir W. Wilde calls the broad "scythe-shaped sword." It differs from the dagger in having the two edges unsymmetrical with the mid-rib-which is sometimes slightly curved-and also in being attached at right angles to the shaft, which gives it the appearance of a scythe. These weapons are largely found in Ireland, but sparingly in England and Scotland. One found in Galloway

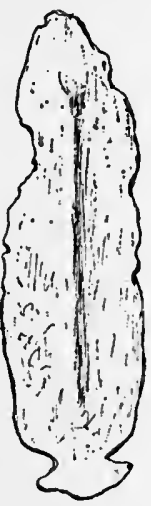

Fig. 106.-Knife or dagger-blade of bronze found at Gilchorn, near Arbroath $\left(\frac{2}{3}\right)$. is outlined in fig. 102, which sufficiently shows the peculiarities of this class of weapon.

Spear-heads are perhaps the most abundant of weapons of offence found among the relics of the Bronze Age in all countries. The Scottish examples are socketed, almost without an exception, and gracefully proportioned, but very

1 Proc. Soc. A. Scot., vol. xxv. p. 459.

2 Arch. and Hist. Collections of Ayr and IIigtown, vol. iv. p. 53.

3 Proc. Soc. A. Scot., vol, xxviii. p. 219. 


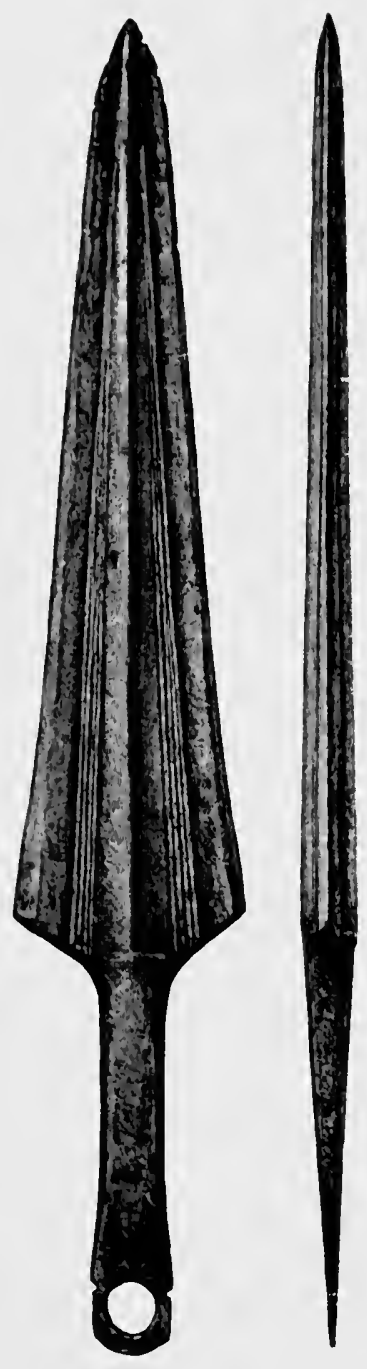

Fig. 107.-Tanged dagger or spear-head found in White-

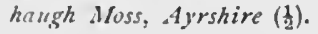

variable as regards dimensions. The larger specimens have sometimes a crescentic vacancy in the blades on each side of the socket, intended probably to lighten the weapon, as shown in that represented by fig. I05. Similar segmental apertures have been noted on the La Tène iron spear-heads. Another feature occasionally observed on the Scottish bronze spear-heads (common also in England and Ireland) was a loop on each side of the socket for the purpose of fixing the blade more firmly to the handle (fig. Ior). Stone moulds for casting the spear-heads have been found in Scotland, as well as in most countries of Europe.

The bronze swords found in Scotland are leaf-shaped blades with sharp points, and a flat projection at the hilt containing several rivet-holes, by means of which plates of bone, horn, or wood were fastened on each side so as to form a handle (figs. 108115). These weapons have no guard; and although both edges have been hammered out thin and sharpened by grinding-stones, they appear to have been better 
adapted for thrusting than for parrying or striking. The blades vary considerably in size, the largest in the National.

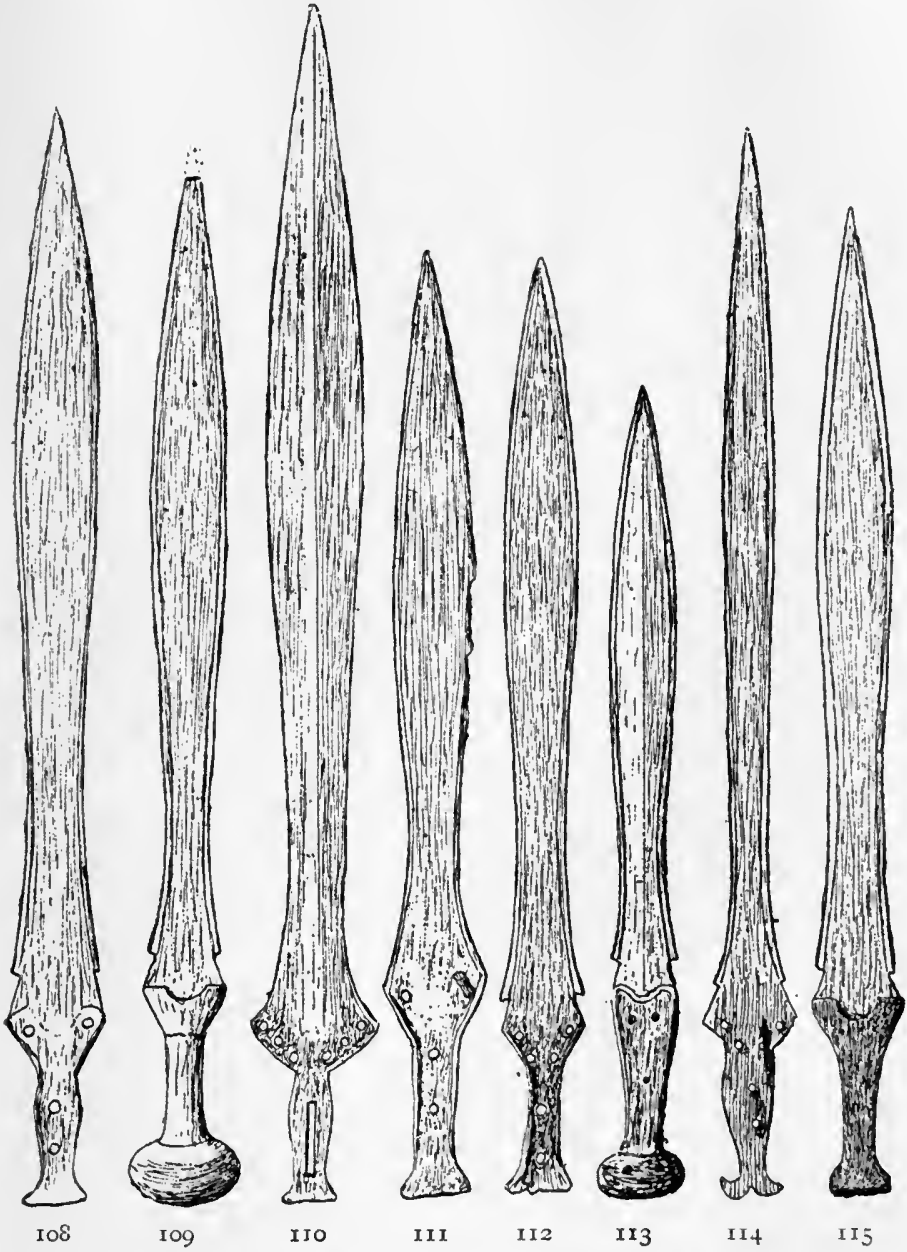

Figs. I08-I I 5. - Some Scottish sworl-blates of bronse (all $\left.\frac{1}{6}\right)$.

Museum being $30 \mathrm{x} / 2$ inches in length, while the smallest measures scarcely 20 inches. Sheaths of bronze, or wood 
with bronze mounting, were used to protect the blades, but of their remains in Scotland only a few of the bronze tips have been found. There is a considerable difference in the shape of the flat portion which formed the handle, as well as in the disposition of the rivet-holes, as shown in the illustrations.

Along with a number of flat-hilted sword-blades found in I 869, while workmen were engaged in digging the foundations of a house in Grosvenor Crescent, Edinburgh, was one (fig. I 3) which had the handle and pommel cast in bronze in the same mould as the blade. With regard to this sword Dr Joseph Anderson makes the following remarks : "It is a short sword, its whole length being only 20 inches. The blade is leaf-shaped, the hilt without a guard, but with a grip of 4 inches in length, terminating in a rounded pommel 2 inches diameter, and $1 / 4$ inch in height. The grip is $5 / 8$ inch thick, and $I$ inch in width at the centre, widening to $I / 8$ inch at its junction with the blade. A break in the pommel at one side reveals the fact that the core of hardened clay on which it was cast is still within it. Both hilt and pommel are pierced by holes, which at first sight suggest the rivet-holes in the handleplates of the swords from which the mountings of the grip are wanting. But the holes in this hilt do not pass through, and they are not opposite each other. Some other explanation of their purpose is therefore necessary. I have stated that the clay core on which the handle was cast is still within it. When the core was placed within the mould, it was necessary that it should be supported in its true position in the cavity of the mould, and this could not be more conveniently accomplished than by pins or projections which would leave corresponding holes in the casting of metal." 1

${ }^{1}$ Scotland in Pagan Times, p. 140. It is satisfactory to find that this sword is now in the National Museum, having been recently acquired by purchase. For the distribution of this variety of sword, see article by Dr Anderson (Proc. Soc. A. Scot., vol. xiii. p. 320). 
(

$$
\text { , }
$$




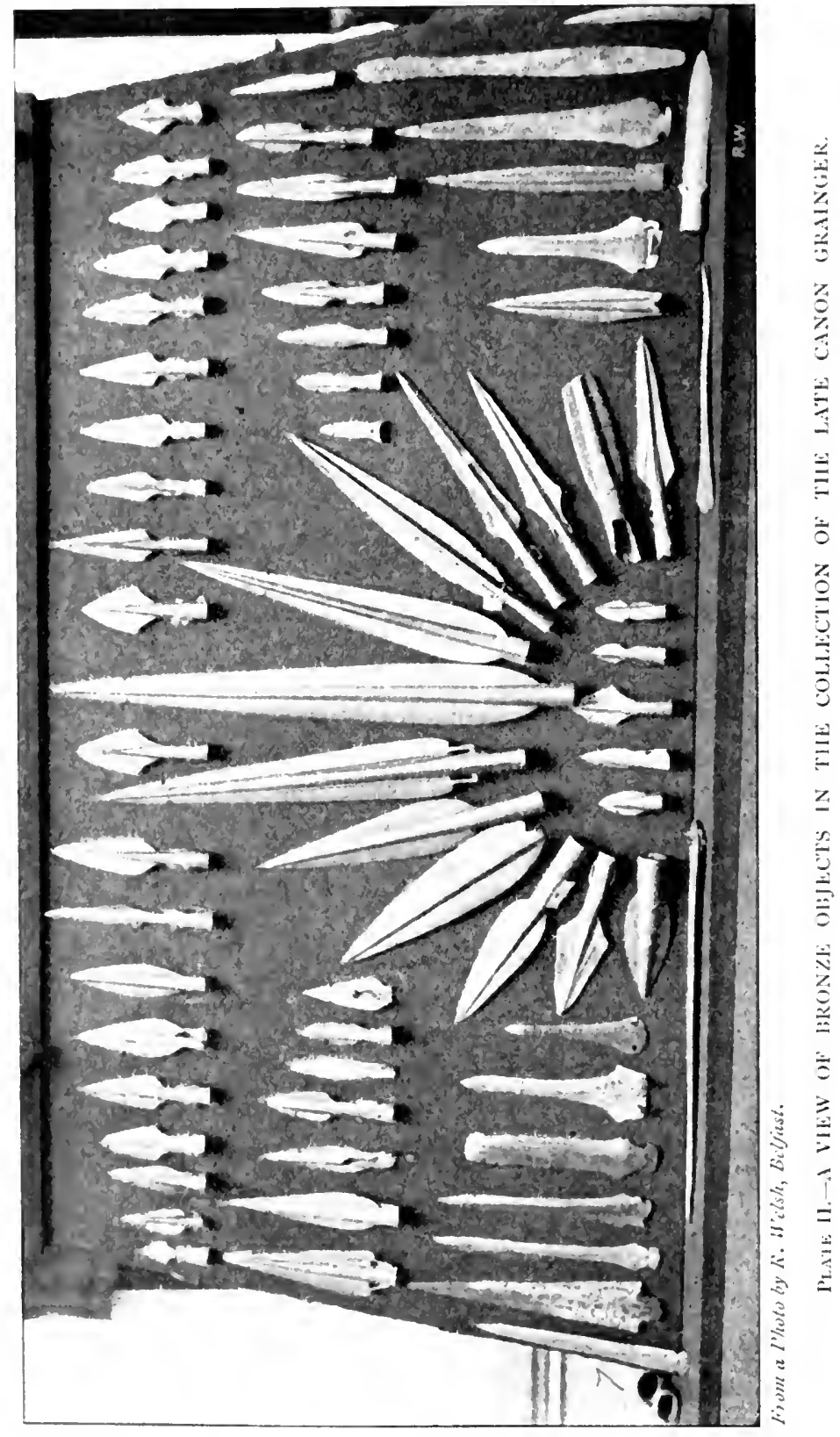




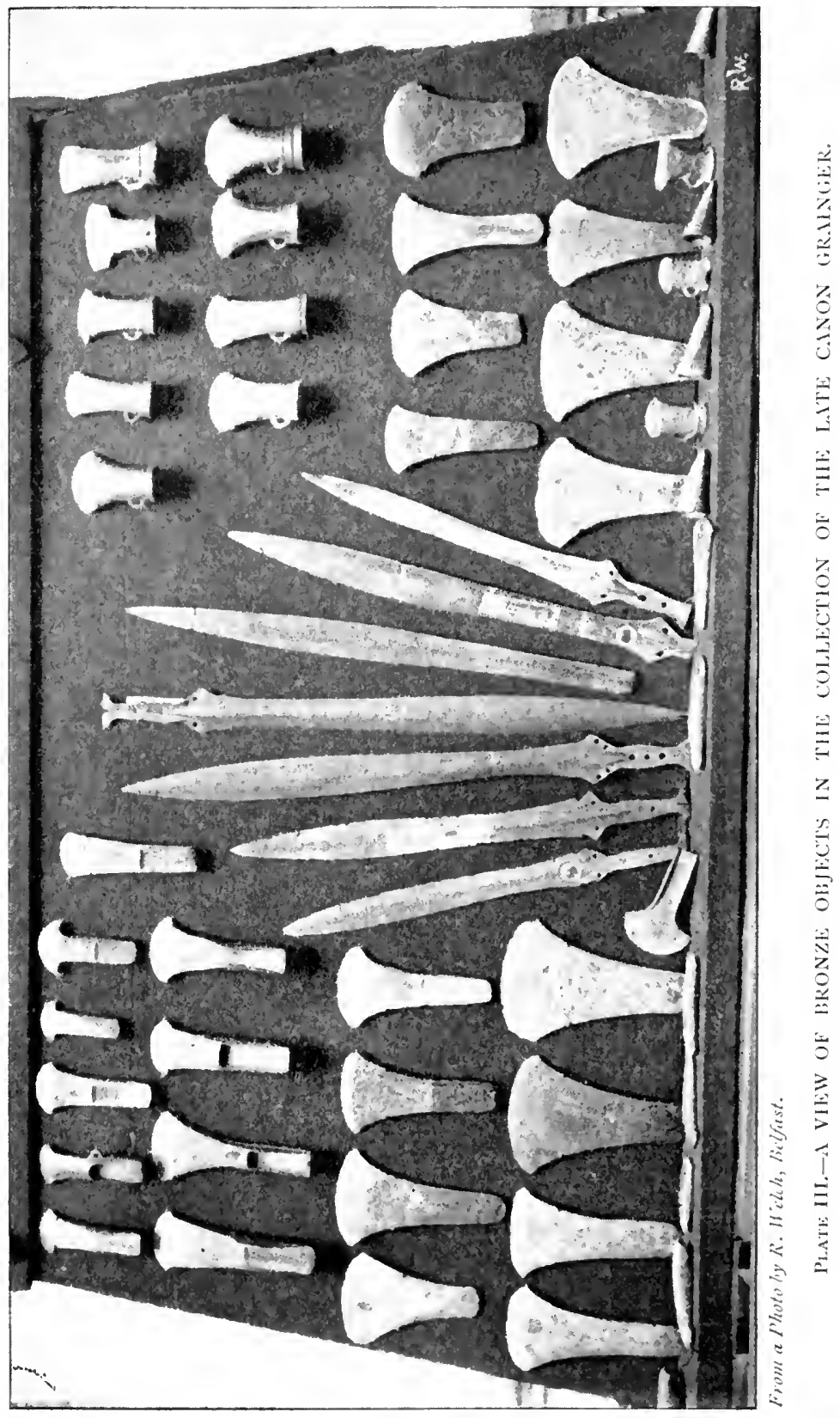



There is another rapier-shaped blade occasionally found in Scotland, the peculiarity of which is that it has no extension of the metal into the perishable material of the handle, but merely a flattened base to which the handle was attached by rivets like the knife-daggers (figs. I 6 and II 7). On Plates

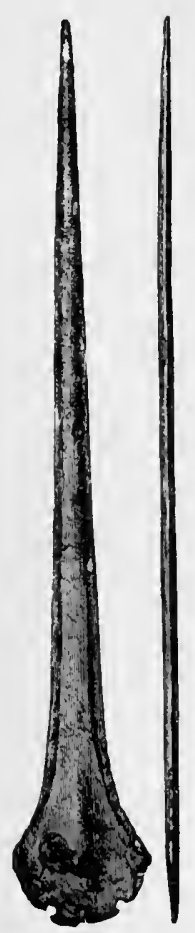

Fig. I 6. -Rapier-sword found in a peat moss, Kirkoswald, Ayrshire (1).

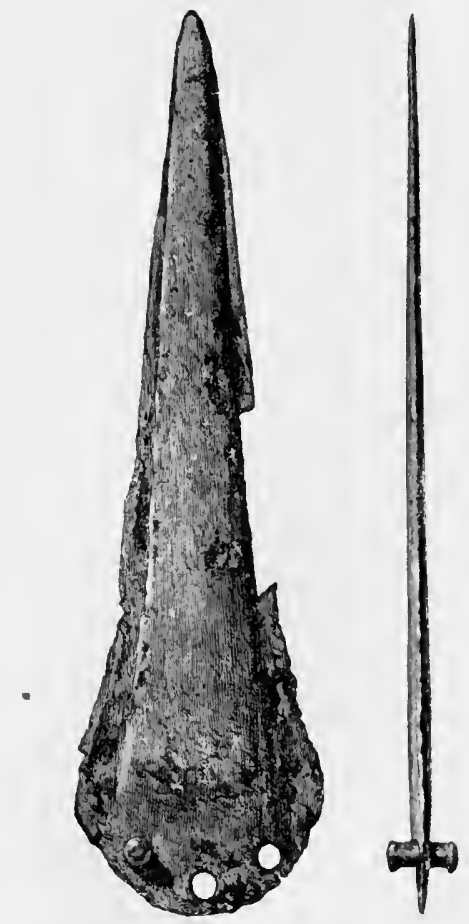

Fig. II7.-Dagger-blade found near Crossraguel Abbey (1).

II. and III. I have reproduced photographic illustrations of the principal objects of bronze included in the antiquarian collection (now in the Belfast Museum) of the late Canon Grainger, from which the characteristics of the various types of axes, swords, daggers, \&c., may be readily perceived. 

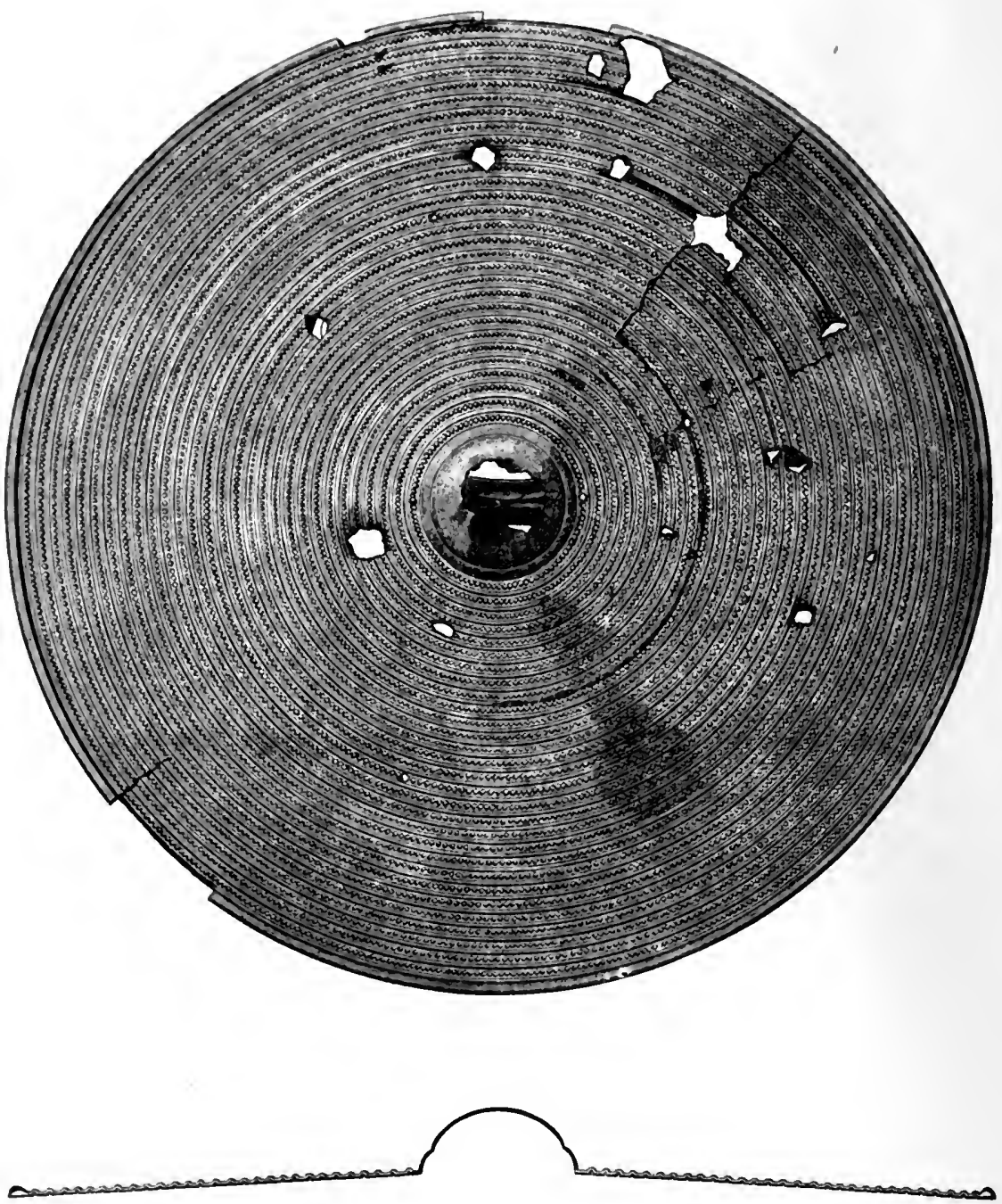

Fig. I18. - Bronze shichl found at Lugtonridge, near Beith. Front wicw and section (263:4 inches in diancter). 

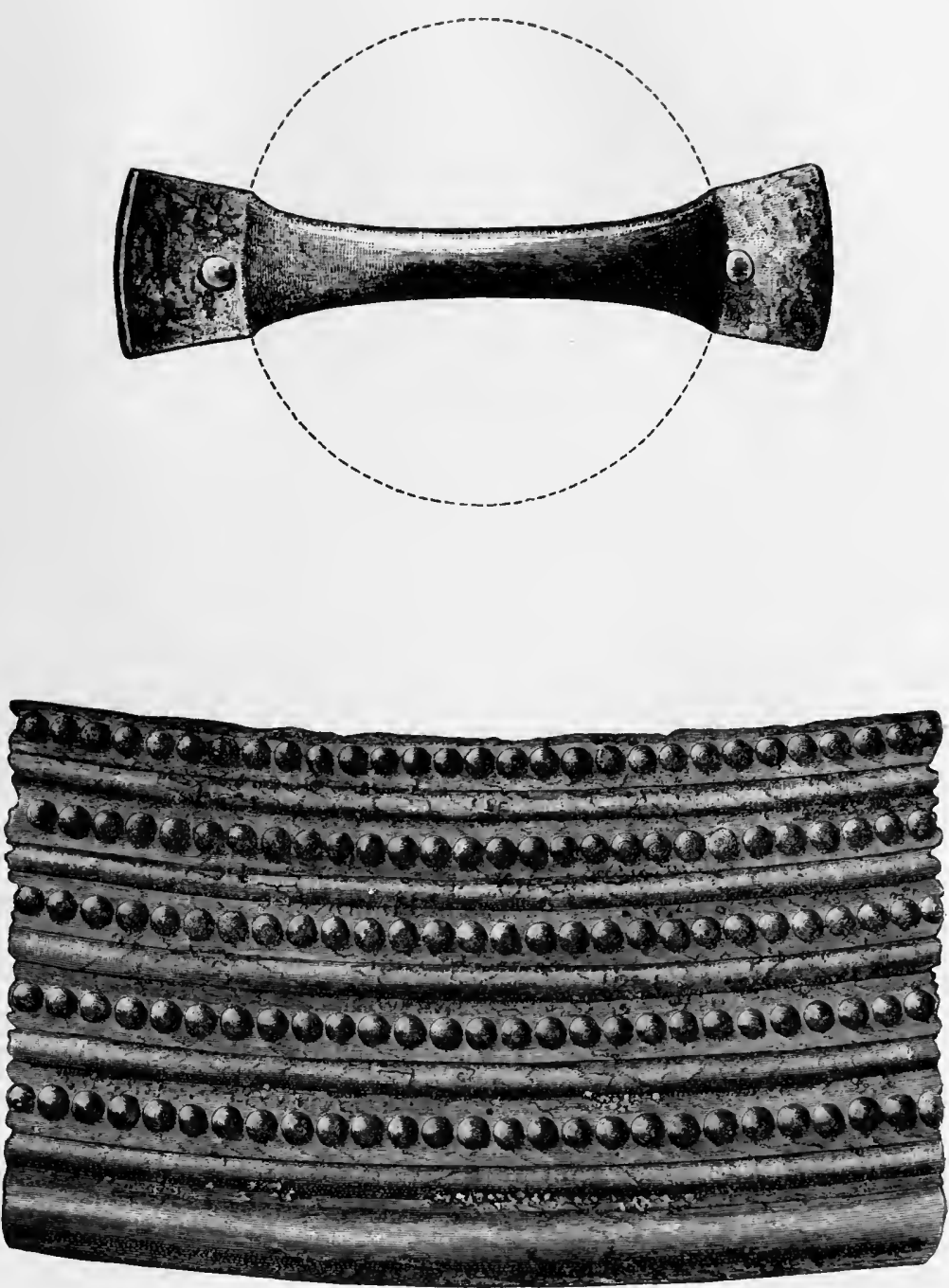

Figs. II9, I20.-Handle and part of the shield found at Lugtonridge. 
The most common type of shield found in the British Isles consists of a circular plate of thin bronze having a central boss about $3 \frac{1}{2}$ to $4 \frac{1}{2}$ inches in diameter, surrounded by a series of concentric raised rings with circles of small studs in repoussé between each. Two of these shields were discovered in a marshy place, near Yetholm, in 1837 , by labourers dig. ging a drain. They measure respectively $23 \mathrm{I} / 2$ and 24 inches in diameter, and in both specimens the handle was riveted across the hollow of the boss. A third shield of like character was ploughed up near the same place in 1870 .

In the year 1779 four or five bronze shields of the same type were discovered by peat-cutters at Lugtonridge, in the parish of Beith, Ayrshire, but of the entire hoard only one (figs. I 1 8-1 20) has been preserved.

Sir John Evans makes the following observations on the chronology of British shields: "The shields first in use in Britain were probably formed of perishable materials, such as wicker-work, wood, or hide, like those of many savage tribes of the present day; and it can only have been after a long acquaintance with the use of bronze that plates could have been produced of such size as those with which some of the ancient shields and bucklers found in this country were covered. They would appear, therefore, to belong to quite the close of the Bronze Age, if not to the transitional period when iron was coming into use. There are, indeed, several bronze coverings of shields of elongated form, such as those from the river Witham ('Horæ Fer.,' pl. xiv.) and from the Thames (ibid., pl. xv.), with decorations upon them, in which red enamel plays a part, that have been found associated with the iron swords of what Mr Franks has termed the Late Celtic Period. 'Those, however, which appear to have a better claim to a place in these pages are of a circular form." I

${ }^{1}$ Bronze Implements, \&c., p. 343. 
The use of war-trumpets among the Celtic races of Western Europe has been often referred to by classical authors, but only a few instruments which can be classed in this category have hitherto been found in Britain. In Ireland, however, they are more numerous, as we learn from Sir W. Wilde's Catalogue of the Museum of the Royal Irish Academy. These instruments were made either in a solid casting of bronze, or in sections by riveting tubes of sheetmetal together. The well-known large Danish trumpets are of this description. But besides the difference in their mode of manufacture, they may be classified into two varieties,

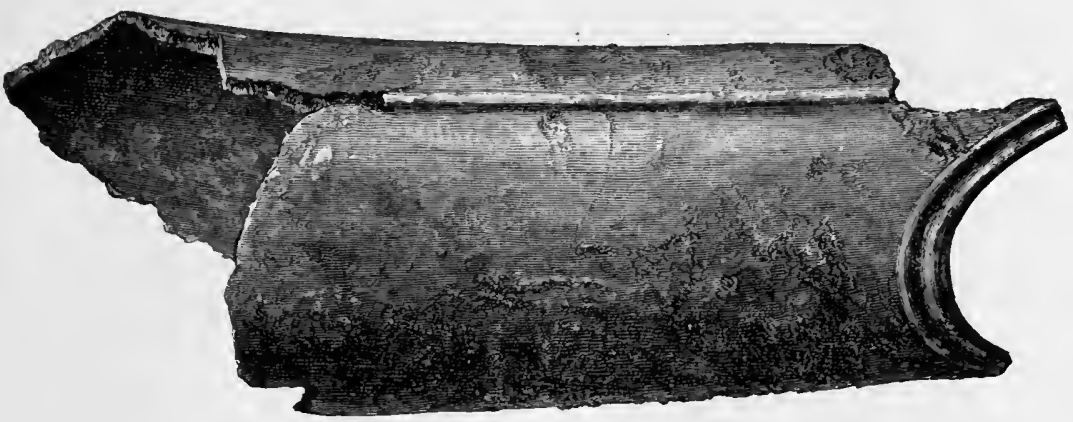

Fig. 121.-Portion of a side-blast trumpet found at Innermessan, Wigtownshire (1).

according as the aperture of blowing is at the end of the tube or at the side.

Among the objects in the collection of antiquities presented to the National Museum by Sir Herbert Maxwell, there is a portion of a bronze side-blast trumpet, showing the mouthpiece, which had been found at Innermessan, Wigtownshire (fig. I 2 I).

A bronze horn or trumpet (fig. I22) made in one solid casting (preserved in Caprington Castle) was found, some time prior to 1654 , on the estate of Coilsfield, in the parish of Tarbolton, Ayrshire. It measures 25 inches in length, 


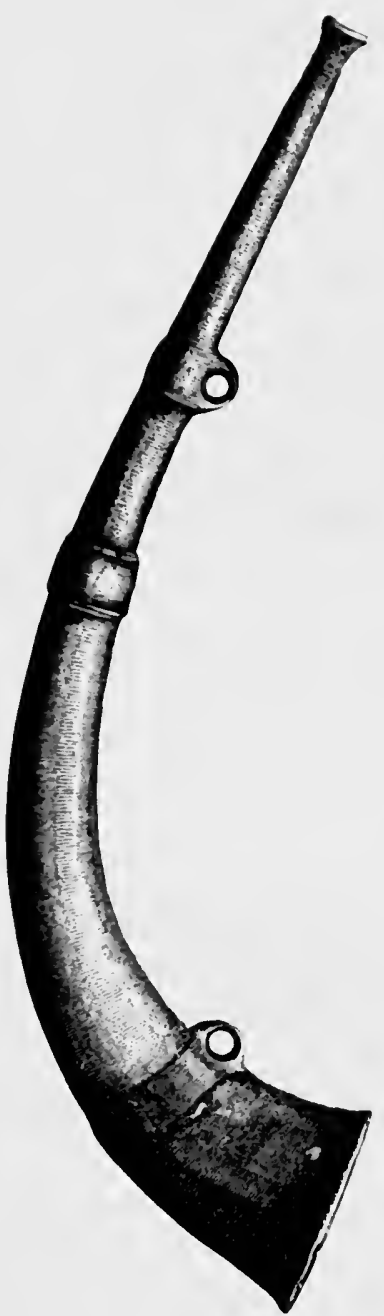

Fig. 122.-Bronse horn found at Coilsfield, Ayrshire (25 inches in length).

nearly 4 inches across the end aperture, and nearly 8 inches in circumference at the lowest band. ${ }^{1}$

It is probable that some of these trumpets belong to the early Iron Age; and this opinion is strengthened by the character of the ornamentation on the disc at the distal extremity of one of them (fig. I 23 ), which unmistakably shows Late Celtic work. In regard to this object Sir W. Wilde makes the following remarks : ${ }^{2}$ "In I 794 four brazen trumpets were found in a bog on the borders of Lough-na-Shade, near Armagh. One of these figured by Stuart, in his 'History of Armagh,' is the large riveted trumpet with a decorated disk, and central globular connecting portion, and which is joined with rivets; whereas all those previously noticed were cast. . . The decorated disk below, the details of the punched or hammered-up ornament on which are shown in the accompanying illustration (fig. I 23 ), measures $7 \mathrm{I} / 2$ inches across. Its style of decoration much resembles that of the large shield-iike plates represented by fig. 533, page 637 .

1 Proc. Soc. A. Scot., vol. xii. p. 565.

2 Catalogue, p. 625. 
Its present mode of attachment to the trumpet-mouth is evidently modern."

Besides the notices of these trumpets in the Academy's 'Catalogue,' in 'Ancient Bronze Implements,' \&c., and in 'Horre Ferales,' some additional notes and illustrations will be found in the 'Reliquary,' \&c., for April I 899, by Mr J. C. Prætorius and the Editor.

Arrow-heads made of bronze have not as yet been found in Scotland, and their existence in England and Ireland seems somewhat doubtful. ${ }^{1}$ But they are occasionally found among the remains of lake-dwellings in Central Europe, where they assume various forms, sometimes as miniature spear-heads with a tang or a socket,

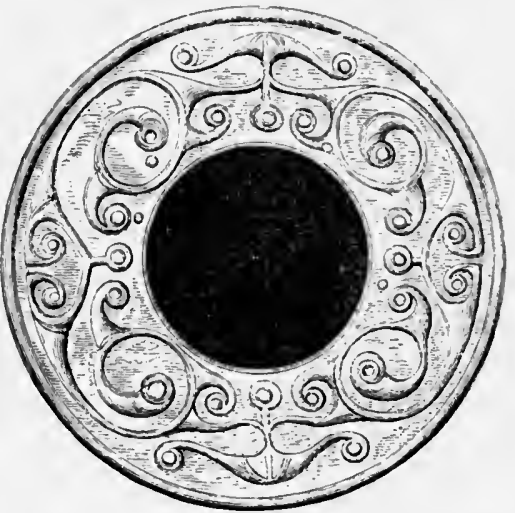
and sometimes as tri- Fig. 123.-Disc ornament of a bronze trumpet angular pieces of thin bronze. The latter found in an Irish bog $\left(7^{\frac{1}{2}}\right.$ inches in diameter).

contain two or more small holes by means of which they could be fastened to the stem with a string. In Southern Europe, Greece, and Egypt, a small triple-edged arrow-point was used, specimens of which may be seen in many of the Continental museums. Flint arrow-heads are so common in Bronze-Age burials that it is quite evident that the introduction of metal into general use did not supersede these weapons, so that they are not peculiar to the Stone Age.

3 Arch. Journal, vol. iii. p. 47 ; vol. vii. p. $2 S_{1}$; rol xiii. pp. 20, 27 ; vol. xxi. p. 90 ; vol. xxii. p. 69. 


\section{Objects of Toilet and Personal Ornament.}

That the use of bone and bronze pins survived in the British Isles to medieval times is amply proved by the discovery of numerous specimens on the sites of RomanoBritish towns, as well as among the débris and refuse-heaps of the Scottish and Irish crannogs. Hence it would be rash to infer that a bronze pin belongs to the Bronze Age, merely because it is made of bronze, unless its association with typical relics of the period would justify that conclusion. A slender bronze pin with a circular cup-shaped head was found in a moss in the island of Skye, associated with a leaf-shaped bronze sword and two socketed bronze spear-

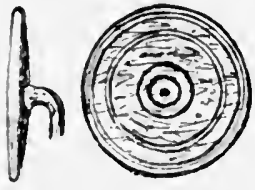

Figs. 124, 125.-Head of bronze pin axd button. like mounting found in Edinburgh (2). heads. ${ }^{1}$ Another pin (fig. I 24 ) having a flat circular head, ornamented with concentric circles, and bent over so as to bring the plane of the disc parallel with the stem, was found in the Grosvenor Crescent hoard already referred to. Two bronze pins with similar disc-shaped heads were found at Tarves, Aberdeenshire, associated with leaf-shaped swords and a scabbard-end of bronze. Specimens of the same type of pin, with the heads highly ornamented, have been found in Ireland and on the Continent. Small pins with round heads are not unfrequently found in urns among the cremated bones, and in graves after inhumation, having been used to fasten the clothing on the body previous to the interment. But they are often so much corroded that it is difficult to determine whether they were intended for 
pins or awls. Canon Greenwell found bone pins more common than bronze pins in the Bronze-Age barrows of Yorkshire. The bronze pins hitherto discovered within the British Isles are very inferior to those from the lakedwellings of Switzerland as regards size, variety of form, and beauty of ornamentation.

Buttons of bone and jet have already been described as relics of the Stone Age, but they are more commonly found among remains of the Bronze Age. A curious object of bronze, supposed to be a button, ${ }^{1}$ formed part of the Grosvenor hoard (fig. I 25). It is a hollow circular ring, I I $/ 4$ inch in diameter, having two loops on one side by which it could be attached to clothing. The common presentday button-viz., that of a disc, with a loop on one side -was also known in bronze. ${ }^{2}$

Needles of bone and bronze have been found in Scotland, but not often in circumstances which enable us to classify them as Bronze-Age relics. ${ }^{3}$ Both sewing and netting needles of bone are among the relics from the crannogs in Ayrshire. Combs of bronze have been found both in the Swiss lakedwellings and in the Terremare, but they are not among the relics of the Bronze Age hitherto collected in Scotland.

The knowledge of bronze gave a great impetus to the development of personal ornaments. Being an attractive metal to the eye, it was readily seized upon for the manufacture of armlets, necklaces, diadems, rings, pendants, earrings, \&c.

Of the Scottish armlets a few can be assigned to the Bronze Age, owing to their having been found in association with other relics of that period. Dr J. Alexander

1 Proc. Soc. A. Scot., vol. xiii. p. 322.

2 See Evans, 'Bronze Implements,' p. 400.

3 Proc. Soc. A. Scot., vol. xv. p. 273. 
Snith describes three bracelets, with fragments of others, found, along with a number of bronze objects (a celt with socket and loop, two spear-heads, and four broken bits of tin), by a man ploughing a mossy field at Wester Achtertyre, in Morayshire ${ }^{1}$ (fig. 126). Two penannular bronze armlets, tapering a little towards their extremities, were found, along with nine bronze celts, near the hill of Benachie, in Aberdeenshire. $^{2}$

Another armlet of thin beaten bronze was found, along with a necklace of beads and plates of jet, in a cist contain-

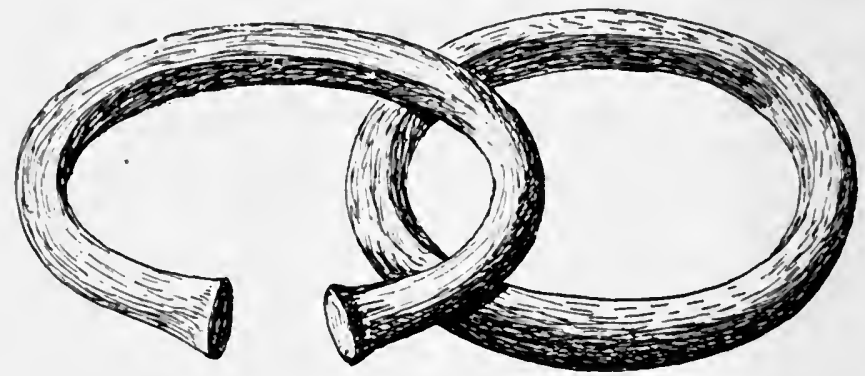

Fig. 126.-Bronze penannular armlet found at Achtertyre, ILrayshire $\left(\frac{2}{3}\right)$.

Fig. 127.-Bronze ring-armlet, one of a pair found with an urn at Kin. neff, Kincardineshire $\left(\frac{2}{3}\right)$.

ing an unburnt skeleton, at Melfort, $\operatorname{Argyleshire}^{3}$ (fig. 1 28). A penannular bracelet with expanded ends, and some plain rings, were part of a hoard found, near Killin, by a man trenching an uncultivated knowe. This hoard is described by $\mathrm{Mr}$ Charles Stewart. Besides the bracelet and rings it comprised the following objects: portion of the hilt-end of a small leaf-shaped sword; a socketed spear-head; two socketed celts; a socketed gouge; and a circular hollow ring, "similar to one found, with two spear-heads, at Inshoch, in Nairnshire, and to a smaller one found, with a bronze

1 Proc. Soc. A. Scot., rol. ix. p. 436.

2 Ibicl., p. 436, and rol. i. p. 13 S. 3 Ibid., vol. xix. p. 135. 
sword, in Edinburgh." 1 Dr Joseph Anderson describes two ring-armlets of solid bronze (fig. I 27 ) which were found by a man trenching ground near the Castle of Kinneff, in Kincardineshire, associated with a highly ornamented urn and a spear-head of bronze. Other armlets of the same type, also associated with burials, are recorded from the parish of Crawford, Lanarkshire, and from near Stobo Castle in Peeblesshire. $^{2}$

Another form of armlet is a penannular ring with cupshaped ends-a type more frequently met with in Ireland than in Scotland. One, described by Mr Jolly (fig. I 29), was found, along with a number of socketed celts and other bronze objects, 6 feet below the surface, by a man digging peats at Poolewe, Rossshire. $^{3}$ Bracelets of this type are more frequently made of gold. Sir Daniel Wilson 4 figures and describes a very fine example found by a

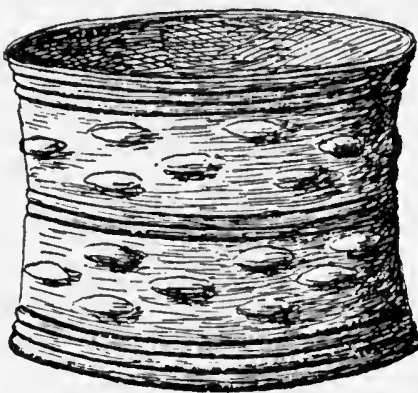

Fig. 128.-Bronse bracelet found in a cist at Melfort, Argyllshire ( $\left(\frac{2}{3}\right)$.

labourer while cutting peats in the parish of Cromdale, Inverness-shire (fig. I 30 ). Two gold armlets "were found in association with an interment of an unburnt body in connection with a group of burials at Alloa, of which the larger number were burials after cremation." The armlets lay on the top of a large flat stone, underneath which was an entire skeleton. ${ }^{5}$ Gold bracelets were generally made of

1 Proc. Soc. A. Scot., vol. xvi. p. 27.

2 Ibid., vol. xvii. p. 450 ; vol. ii. p. 277.

3 Ibid., vol. xiv. p. 47.

+ Prehistoric Annals, vol. i. p. 4 to.

3 Proc. Soc. A. Scot, vol. xvii. p. $44^{\$}$. 
solid rods, cylindrical or quadrilateral on section, with slightly enlarged or expanded extremities. Three penannular gold armlets, showing a quadrilateral section, were found together in Stonehill Wood, parish of Carmichael, Lanarkshire, and exhibited at a meeting of the Society of Antiquaries of London on the r 8 th April r864.

Another variety of the gold bracelets found in Scotland is a flat band twisted like a corkscrew, the ends passing gradually into hook-like knobs which can be made to clasp

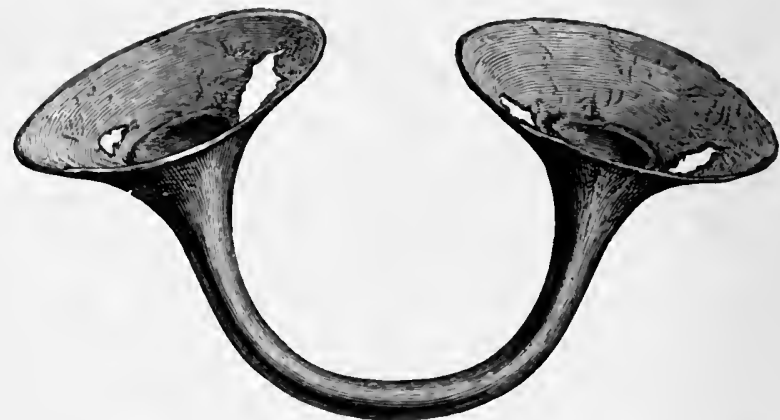

Fig. 129.-Bronze penannular ring with cup-shaped ends found in peat at Poolezve, Ross-shire (㞼).

each other. Specimens of this type are sometimes so large that they must have been used as torques for the neck. A hoard, consisting of four of these ornaments, was discovered in 1848 in loose earth at Lower Largo, in Fifeshire, and others have been found in several other places throughout Scotland. ${ }^{1}$

Of the many coiled bracelets or arm-bands, so common in Central Europe, none made of bronze has been found in Scotland, and only one of gold. This solitary specimen was found at Slateford, Mid-Lothian, in 1846 , during the construction of the Caledonian Railway. ${ }^{2}$ It is made of three

1 Proc. Soc. A. Scot., vol. xviii. p. 23 S.

2 Ibid., p. 239. 
rods of gold twisted together and uniting at the ends into one rod, which is then bent sharply back so as to form a long hook. Like many other valuable relics it found its way into the melting-pot, and only a model of it now remains (fig. I 3 I).

Penannular bracelets, with or without expanded ends, are common all over Europe. The large, hollow, and highly ornamented bracelets, so characteristic of the Swiss lakedwellings, are not represented in the British Isles.

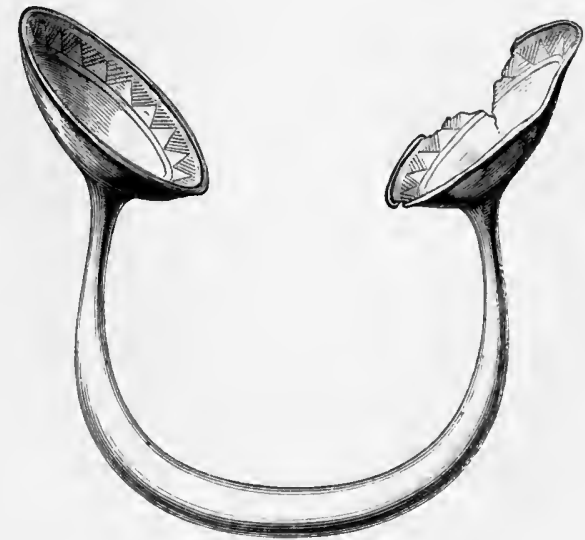

Fig. 130.-Gold armlet found in peat in the parish of Cromdale, Inverness-shire ( $\left.\frac{(2}{3}\right)$.

The torque or twisted neck - ring made of bronze, and found so largely in Central and Northern Europe, appears to be unknown both in Scotland and Ireland; but a few specimens have been found in the southern and western counties of England. Those which reverse the twist one or more times, and also those terminating in broad expansions or free spirals, are only to be found on the Continent. Upon the whole, torques are rare among the remains of the true Bronze Age in Europe, as only some half-dozen specimens have been collected on the sites of the lake-dwellings of 
Europe. These are all of one type, and adapted to hook at the back of the neck. ${ }^{1}$ The torques and spiral bracelets of this kind hitherto discovered in Scotland are made of gold, of which specimens have been recorded from Belhelvie, Aberdeenshire, ${ }^{2}$ Lower Largo, ${ }^{3}$ Moor of Rannoch ${ }^{4}$ (fig. 132), and parish of Urquhart, near Elgin. ${ }^{5}$

The Gaulish torques, so famous in Roman times, were not

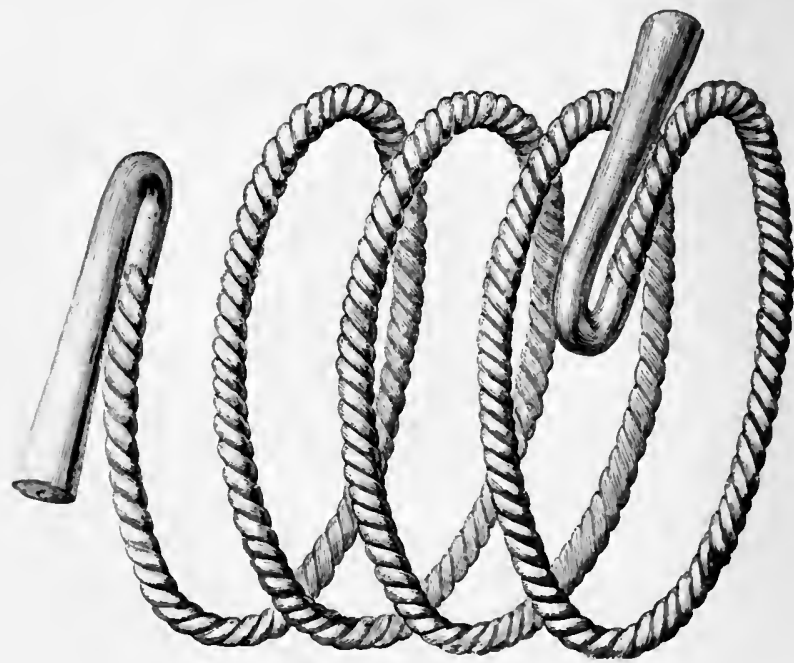

Fig. I3I.-Gold armlet found at Slateford, .Mid-Lothian (3).

of this type. They consisted of two symmetrical portions fastened at the back by a movable joint, the other ends terminating in an expanded bulb like some of the large penannular bracelets. Several portions of such torques have been found in the Oppidum La Tène, and so far they appear to be precisely similar to those represented on Roman

1 See 'Lake-Dwellings of Europe,' fig. 10, No. 3, fig. 63 , No. 19, and fig. 9 S, No. 9.

\footnotetext{
2 Proc. Soc. A. Scot., vol. xviii. p. 23\%.

3 Ibid., p. 234.

+ Ibid., p. 238 .

s Ibid., vol. ii. p. 530.
} 
statuary, such as the one on the neck of the Dying Gladiator, which is distinctly seen to be twisted spirally above the terminal bulbs.

Beads of glass, amber, and jet are only sparingly found among remains of the Bronze Age. Dr Joass states that a blue glass bead, ornamented with three volutes in yellow, was found in a cist, with burnt bones and small pieces of bronze, in the parish of Eddertoun, Ross-shire. ${ }^{1}$ In a cist at

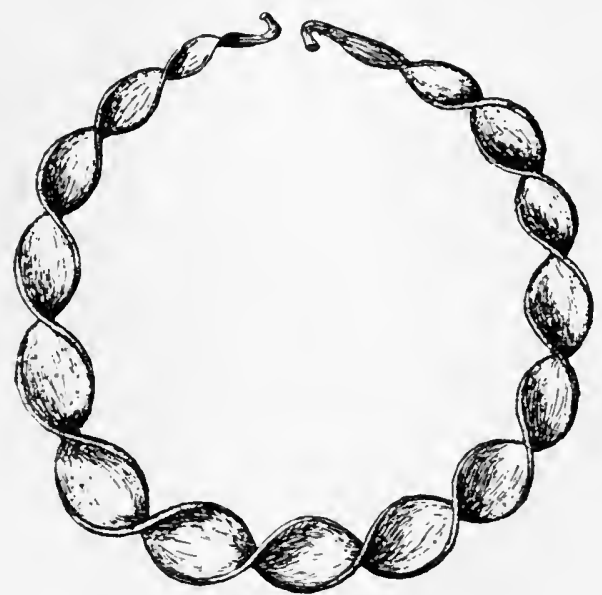

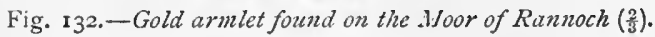

Moan, Harray, Orkney, eight amber and a large number of glass beads were associated with objects of the Iron Age. ${ }^{2}$

Glass beads are largely found on the Continent along with remains of the Early Iron Age, as, for example, the cemetery of Hallstatt. In the necropolis of Jezerine, in Bosnia, sereral hundreds of these beads-blue, yellow, white, and green in variously mixed patterns-have been recorded by the late Mr Radimsky. 3

Perhaps the most characteristic ornaments of the Bronze

1 Proc. Soc. A. Scot., vol. v. p. $3^{1} 3$.

2 Ibid., vol. xxi. p. 345 .

3 Rambles and Studies in Bosnia, \&c., p. 166. 
Age are those beautiful necklaces made by stringing together a combination of beads and plates of jet, the latter being generally ornamented with geometrical patterns of dots and

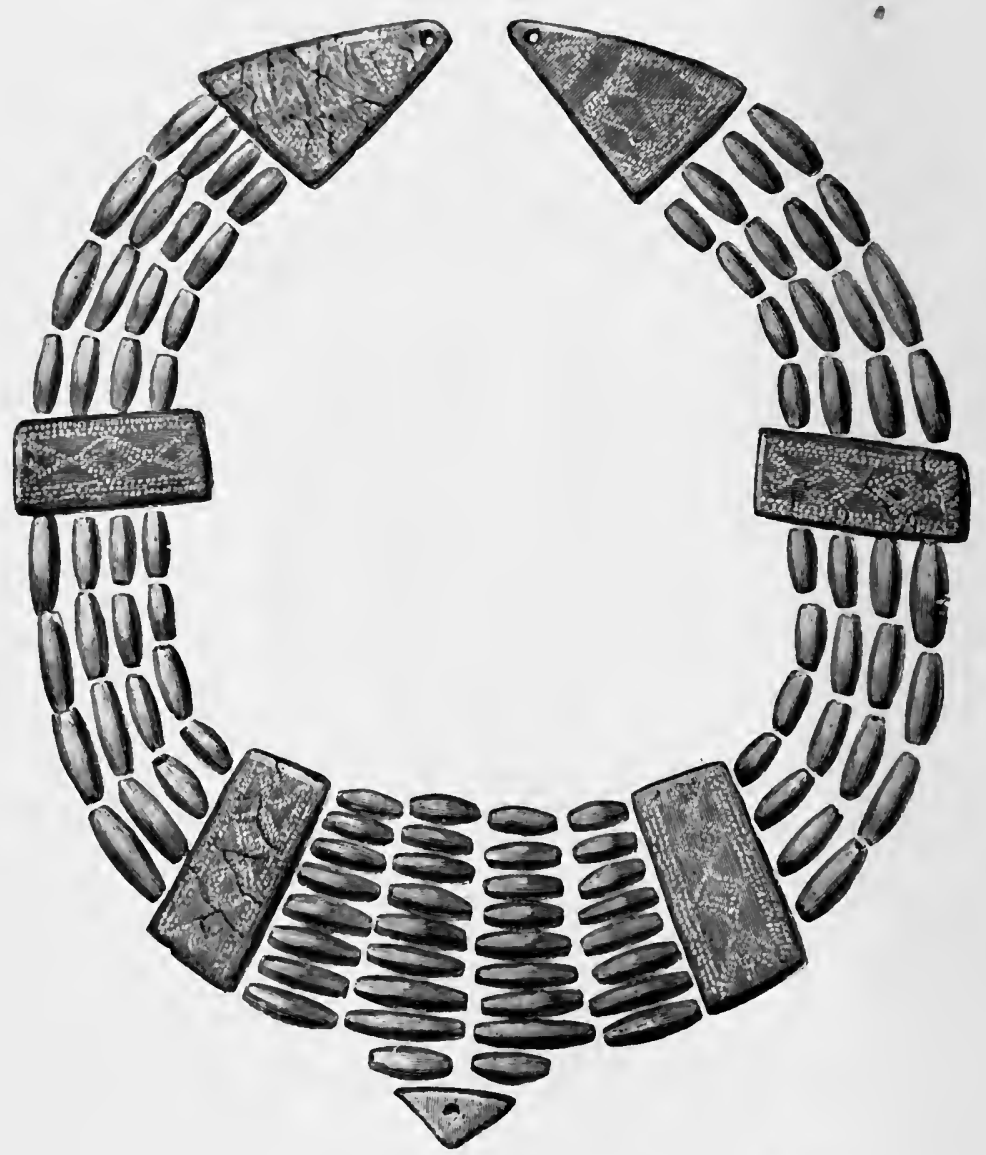

Fig. 133.-Necklace of jet beads and plates found in a cist at Mountstuart House, Bute.

lines. Several specimens of these handsome neck ornaments may be seen in the National Museum. The one here figured (fig. 133) was found at Mountstuart, Bute, in a cist of the 
Bronze Age, which also contained a piece of bronze, an urn (fig. I34), and a trepanned skull (fig. I35). Other jet necklaces have been discovered in the following localities in Scotland : Assynt, Ross-shire ; ${ }^{1}$ Torrish, Sutherlandshire $;^{2}$ Balgay, near Dundee ${ }^{3}$ Lunan Head, Forfar ; ${ }^{4}$ Balcalk, Tealing. ${ }^{5}$

Similar necklaces were also made of amber, as shown by the following discovery in Orkney. A large barrow, 30 feet in diameter and about II

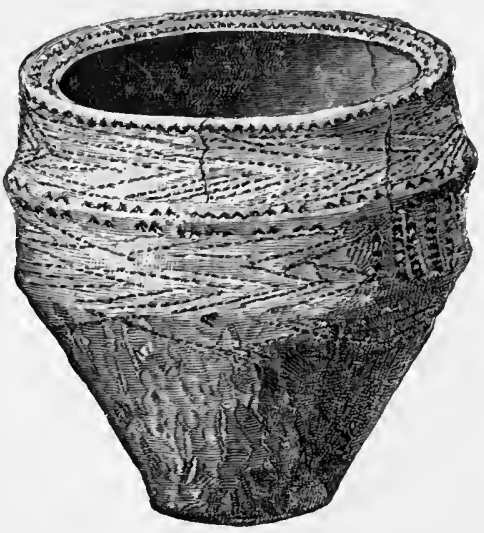

Fig. 134.-Urn from cist at Mountstuart, Bute (1). or 12 feet in height, was opened in $185^{8}$ at Huntiscarth.

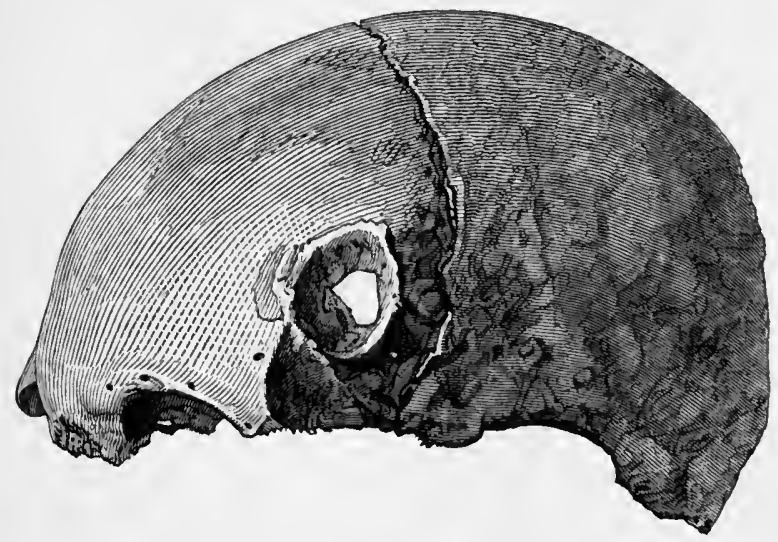

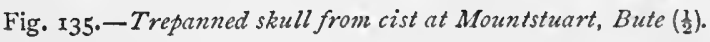

Near the centre, and some 5 feet from the surface, a large

1 Proc. Soc. A. Scot., vol. iii. p. 47.

3 Ibid., p. 412. $\quad$ Ibid., vol, xii. p. 296.
2 Ibid., vol. viii. p. 409.

5 Ibid., rol. xiv. p. 262. 
flagstone was exposed, which, on being removed, disclosed a stone cist, $21 / 2$ feet long, formed in the usual way of stones set on edge. On each side of the cist there were two upright stones, the tops of which reached within 2 feet of the summit of the mound. Some fragments of bones, supposed by the farmer to have been burnt, were found in the cist, together with the following ornaments, which lay at one corner on a flat stone: four discs of thin gold, each 3 inches in diameter, pierced in the centre with a round hole, and ornamented with a series of concentric circles and bands of zigzag and oblique lines in repoussé; a collection of rudely formed beads of amber - circular,

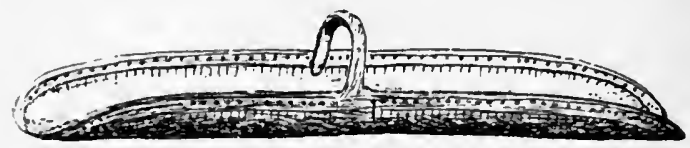

Fig. 136.-One of two gold earrings found in a stone cist at Orton, Morayshire $\left(\frac{1}{2}\right)$.

triangular, and curved-pierced with small holes like those of the jet necklaces. ${ }^{1}$

But the most remarkable objects of antiquity ever known in Scotland are a pair of gold ormaments, supposed to be earrings (fig. 1 36), which were found in a stone cist on a gravelly hillock at Orton, near Fochabers. The cist was exposed in the course of making the railway between Elgin and Keith, in the year 1863 , and the two ornaments lay one on either side of a "ridge of black dust," about a third from one end. Sir Noël Paton, who records this unique find, says: "The ornaments were retained by the navvies by whom they were discovered; but they ultimately came into possession of the daughters of the sub-contractor for that section of the line, by whom they were transferred to the hands of a jeweller

1 See coloured plate in the 'Proc. Snc. A. Scot.,' vol. iii. p. I 83. 
in Aberdeen, in exchange for certain objets de luxe of less obsolete fashion. From this person the one now before us was bought by Mr Walker, barely in time to save it from the melting-pot." 1

That these ornaments were earrings there seems no reason to doubt, as similar objects in bronze have been found in the Yorkshire barrows along with female skeletons. ${ }^{2}$

No fibulæ constructed on the safety-pin principle have hitherto, to my knowledge, been discovered within the British Isles which can be dated earlier than the Late Celtic period. The simplest forms of this type ${ }^{3}$ show clearly their evolutionary descent from the straight pin.

Canon Greenwell, whose experience in such matters is unrivalled, makes the following remarks on the subject of personal ornament as it affected the barrow folk: "Ornaments and objects of personal decoration are sometimes found associated with burials in the barrows. They are, however, much less frequently discovered than weapons and implements, and appear to be confined to those of women, at least in the barrows of the wolds. They accompany burials after cremation, as well as those by inhumation. When met with in association with a burnt body, in many cases they have not been burnt with it, but have been placed amongst the calcined bones, after they were collected from the funeral pile; and the same may be said of certain implements of flint. I have found three burnt bodies which had jet beads placed amongst the bones, and they showed by their perfect condition that they had never been subjected to the action of fire. It will give some idea of the rarity of ornaments when I state that out of the whole number of 379 burials, only ten possessed

1 Proc. Soc. A. Scot., vol. viii. p. 29.

2 British Barrows, fig. 47, p. 52.

${ }^{3}$ See Lake-Dwellings of Europe, fig. 64, Nos. 22.25. 
anything of the kind; and out of these, two, in barrows of Cowlam, belong to the Early Iron Age-a period later than that of the ordinary barrows, which are alone taken into consideration in these introductory remarks. The eight burials which had ornaments associated with them were as follows: One on Langton Wold, where a woman had been buried with a humble necklace consisting of a single jet bead, two shells, a piece of deer's tooth pierced, and the vertebræ of a fish, ' $A c$. One at Cowlam, where a woman was interred with two bronze earrings; and another on Goodmanham IVold, where what appear to have been two bronze earrings were found close to the head of a woman, one on each side of it. Two, each with a jet necklace, one being at Weaverthorpe, the other on Goodmanham Wold. One on Flixton Wold, where a young girl had four beads of bone, three of which were ornamented on each side; and a woman on Goodmanham Wold, with a pierced pig's-tooth. Besides these instances, there were found in a disturbed barrow at Helperthorpe two flat beads of jet, which had formed part of a necklace. They are ornamented with a pattern, consisting of minute punctured holes on the surface, and are similar to many which have been discovered in other parts of Britain, as in Wales, Derbyshire, Northumberland, and Scotland." 1

\section{Art of the Bronze Age.}

The elements of decoration used in the Bronze Age in Scotland, and indeed within the British Isles, so far as they have been disclosed on objects of metal, bone, jet, and pottery, consisted of a combination of incised or dotted lines arranged in herring-bone, chevron, saltire, cross, and other rectilinear patterns, so as to produce a variety of geo-

${ }^{1}$ British Barrows, p. 51. 
metrical figures. Circles, spirals, and curved lines also occur, but they are generally confined to stone-work. No representation of an organic or inanimate object has been discovered in Scotland, so far as I know, which can be assigned to the Stone or Bronze Age. With regard to sepulchral pottery, it may be observed that in addition to incisions in the soft clay, impressions were very often made by stamps. From an inspection of the decorated urns, of which there is such a splendid collection in the National Museum in Edinburgh, it will be readily observed that various kinds of stamps had been used by the potters of the period, such as a piece of wood or bone notched into dots, small triangles, squares, $\& c$, the teeth of a comb, twisted thongs in two or three plies, the finger-nail, \&c. These different patterns were generally arranged in horizontal bands round the body of the vessel, especially on its upper and middle parts, in such a varicty of ways that no two vessels have ever been found alike. A few socketed celts have been discovered, ${ }^{1}$ in different localities, which are decorated with concentric circles in relief, the incised pattern being in the mould; but otherwise, neither incised circles nor spirals are to be seen on the metal-work found either in England, Scotland, or Ireland-presenting in this respect a marked contrast to the bronze implements and weapons of the Scandinavian archæological area. A beautiful specimen of the socketed celt ornamented with concentric rings was found in a peat-moss on the farm of Knock and Maize, in the parish of Leswalt, Wigtownshire, and is now preserved in the cabinet of the Earl of Stair (fig. 86).

Of archaic sculpturing on stones and solid rock-surfaces in the form of cups, cup-and-rings, concentric circles, spirals, and irregular geometrical figures, there is no lack of examples in Scotland; but although much has been written on the

${ }^{1}$ Evans's Bronze Implements, figs. 137, 140, 142, and 144. 
subject, none of the theories advanced to explain their meaning has met with gencral acceptance. That they had a symbolic meaning in the religious conceptions of the people is evident from the frequency with which they are found on sepulchral monuments, but any interpretation hitherto advanced on the subject, beyond the general religious idea, seems to me to be pure conjecture. Readers interested in these mysterious memorials will find much solid matter in the writings of George Tate, ${ }^{1}$ Sir James Simpson, ${ }^{2}$ Charles $\mathrm{Rau}^{3}$ and George Coffey, ${ }^{4}$ as well as in a number of articles in different publications, references to which will be found in one or other of those works.

On analysing the various decorative elements in these lapidary sculpturings they readily fall to be classified as follows: (1) Simple cups. (2) Cup-and-rings. (3) Cup-andrings interrupted by gutter channels. (4) Concentric circles. (5) Semi-concentric circles. (6) Spirals. (7) Stars, wheels, and enclosed spaces. (8) Zigzag, wavy, or parallel lines.

I have represented on Plate IV. a few specimens of rocksculpturing, as depicted on some of the prehistoric monuments of Western Europe, which may be compared with those figured in the text on this important subject. The first 10 figures are mere diagrammatic illustrations, after the classification of Sir James Simpson. Some explanatory notes on the other figures will be found in the list of illustrations.

Nearly all these elements in one or more combinations are to be found on sepulchral or memorial stones in Scotland. Cups vary greatly in size, from about one to several inches in diameter, and from half an inch to about one and a half inch

${ }^{1}$ Sculptured Kocks of Northumberland, I 865.

2 Ancient Sculpturings of Cups and Concentric Rings, Sc., 1868.

${ }^{3}$ Contributions to N. American Ethnology, rol. v., 188 r.

Jour. R. Soc. Antiq. of Ireland, IS94-97. 

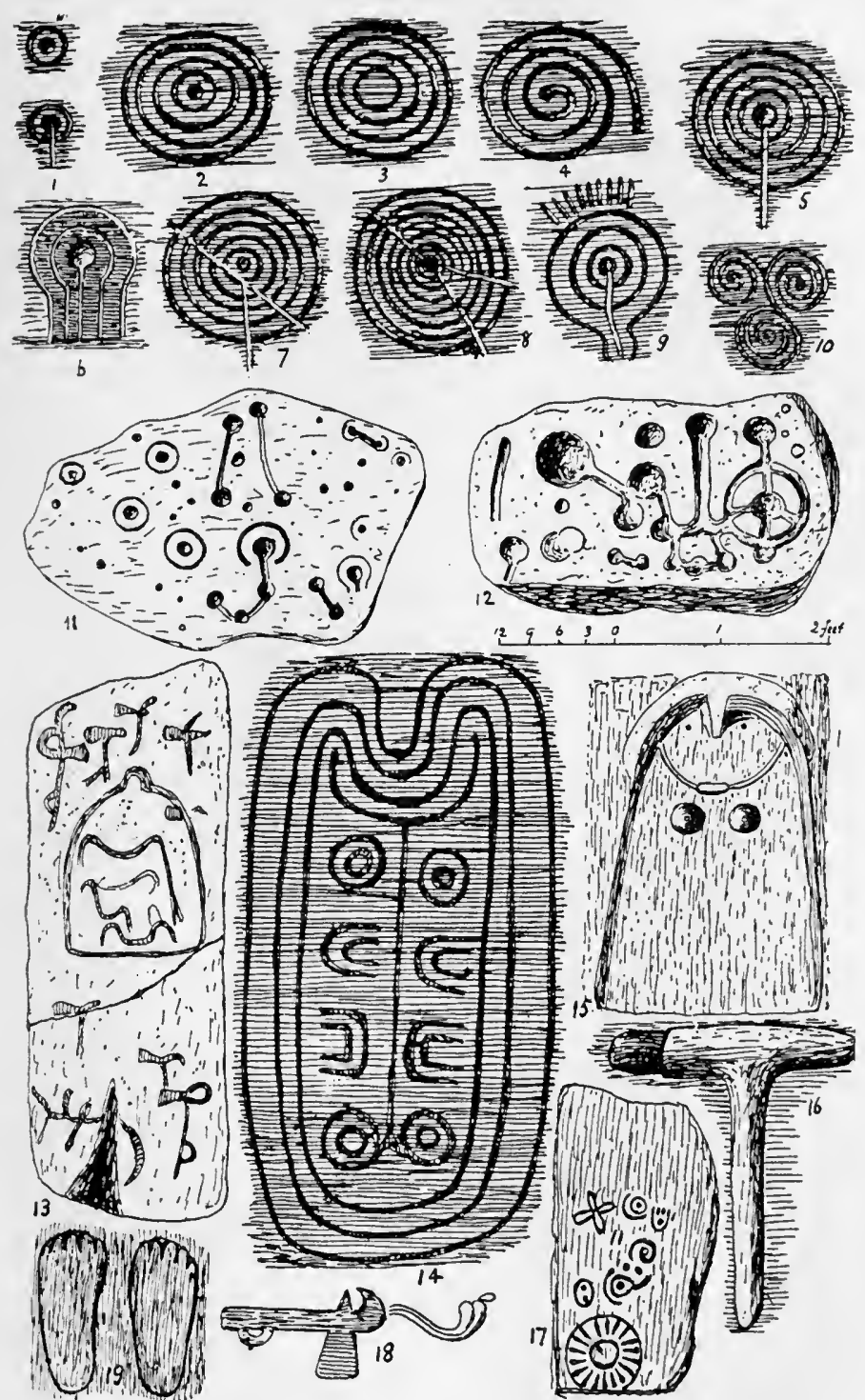

Plate IV.-VARIOUS FORMS OF PREHISTORIC ROCK-SCULPTURINGS

FOUND IN WESTERN EUROPE. (For details see List of Illustrations.) 

in depth. They occur sometimes singly, but generally in groups-often forming the only ornament on a stone-and occasionally in combination with some of the other forms above defined. Simple cups have a wide distribution in Western Europe, comprising Portugal, the British Isles, Denmark, Sweden, Germany, Austria, Switzerland, and France. On the same stone they may be seen in different sizes scattered irregularly over its surface, or in groups of threes and fours. Rings are not so deeply cut as cups, and they may be either complete circles or interrupted by grooves running from the centre cup to a distance beyond the outer circle. The radial grooves, or gutter-channels, are found occasionally to end in cups belonging to adjacent groups of cup-and-rings. It is noteworthy that the cup-and-ring with gutter-channels has not been found outside the British Isles. Both cup-and-rings and concentric circles have also a much more limited area of distribution than the simple cup; being, with one or two exceptions, limited to Sweden, Great Britain, and Ireland. The distribution of spirals, which is remarkable in many ways, has lately attracted much attention throughout Europe. The great development of this ornament in Mycenæ is now generally accepted by archæologists as the result of direct intercourse between Egypt and the shores and islands of the Ægean Sea, during the eighteenth dynasty (I $580-1320$ B.C.) From these regions there is reason to suppose that it spread into Europe by the Danube route. That this was the route by which the spiral ornament was introduced into Bavaria, North Germany, and Scandinavia, is proved by the fact that it is non-existent as an ornament on the bronze remains of North Italy, France, and Britain. Mr Coffey (loc. cit.) has recently advanced the theory that the spiral was copied in Ireland from bronze implements introduced into that country from Scandinavia, in consequence of commercial 
intercourse between the two countries, and that Ireland was the centre from which this ornament spread into the adjacent coasts of England and Scotland. He also adopts the theory, adrocated by Montelius and others, that concentric circles are

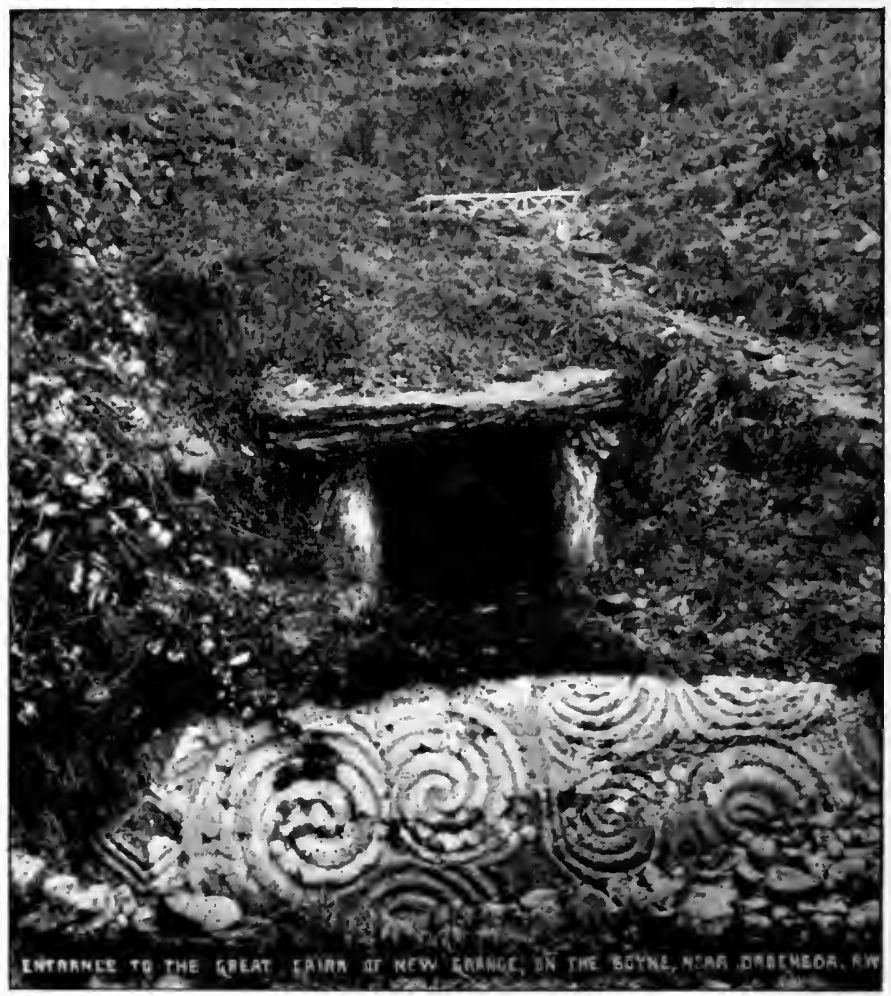

Fig. 137. - Stone with spirals at the entrance to the Great Cairn, . Vero Grange, Ireland. (From a photograph by $R$. Welch.)

debased spirals, and that, consequently, in countries where both spirals and concentric circles exist together, the latter are chronologically later than the former.

At New Grange beautiful spirals are to be seen both out- 
side, as on the stone immediately below the entrance passage to the chamber (fig. I37), and inside; but there are no concentric circles, or cups with spiral gutters. On the other hand, at Dowth and Loughcrew all these forms are common. From this, and other suggestive considerations, Mr Coffey thinks that the simple cup is the oldest symbol; next comes the spiral, which, by a process of degeneration, gives place to the concentric circles and cup-and-rings, with or without gutterchannels. But, however much of truth may be in these opinions, we have satisfactory evidence to show that the spiral

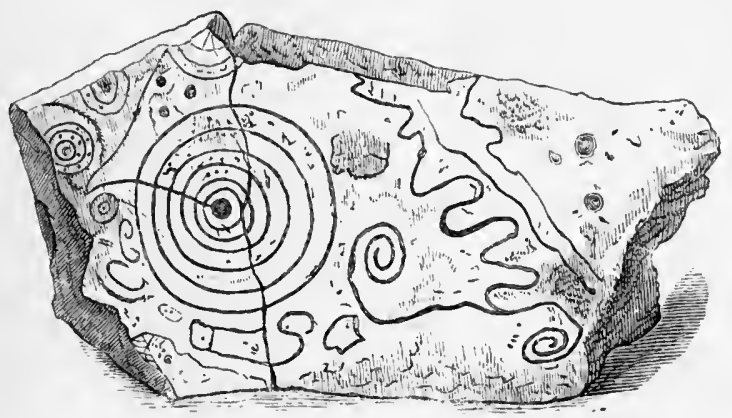

Fig. 138.-Cover-stone of a cist at Coilsfield, Ayrshire (about 5 feet in length).

was used in Scotland during the Bronze Age as an ornament on sepulchral slabs. It was found at Coilsfield, Ayrshire, on the cover-stone of a cist which contained portion of a cinerary urn $^{1}$ (fig. 1 38 ). Another cist with a cover, having its underside decorated in the same way as the one at Coilsfield, was exposed in the course of constructing a road which leads to Queensferry through the Craigiehall estate. ${ }^{2}$ A slab from a cist in Carnban, near the Crinan Canal, though not a coverstone, had five concentric lozenge-shaped sculptures. ${ }^{3}$ In I 87 I a cist near the village of Carnwath, Lanarkshire, was

1 Wilson's Prehistoric Annals, vol. i. p. $48 \mathrm{So}$.

2 Ibid., p. $4^{\$ 2}$.

${ }^{3}$ Simpson, loc. cit., p. 29, Pl. xiii. 
discovered, which contained an ornamental urn of the drinking-cup type, and which had the underside of its covering

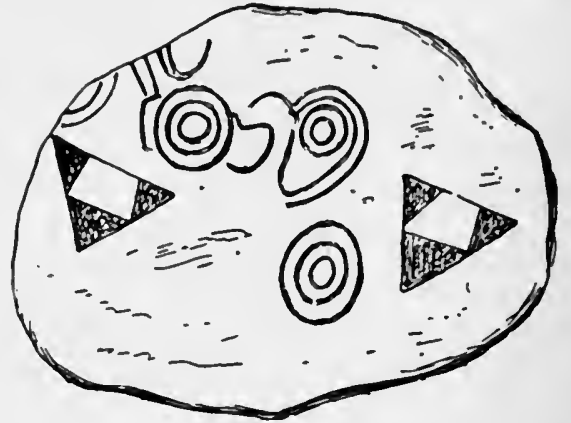

Fig. 139.-Cover of stone of cist at Carnwath ( 4 feet 3 inches long).

stone decorated with three groups of concentric circles and two triangular markings ${ }^{1}$ (fig. 139). Finally, in 1894, near

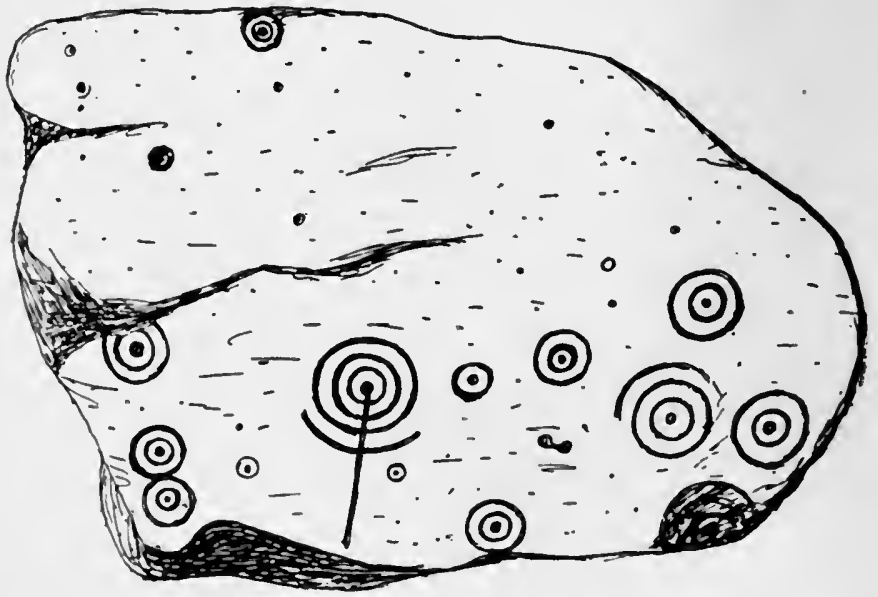

Fig. Ifo.-Sculptured stone at .Monsie Castle, Perthshire (6 feet 8 inches long).

or on the site of a stone circle in the vicinity of Tillicoultry - the stones having been removed for draining purposes some forty years previously-a cist covered with a large stone 1 Proc. Snc. A. Scot., vol. x. p. 62. 
was discovered which contained an urn of the food-vessel type with pierced ears. The sides and surface of this cover-

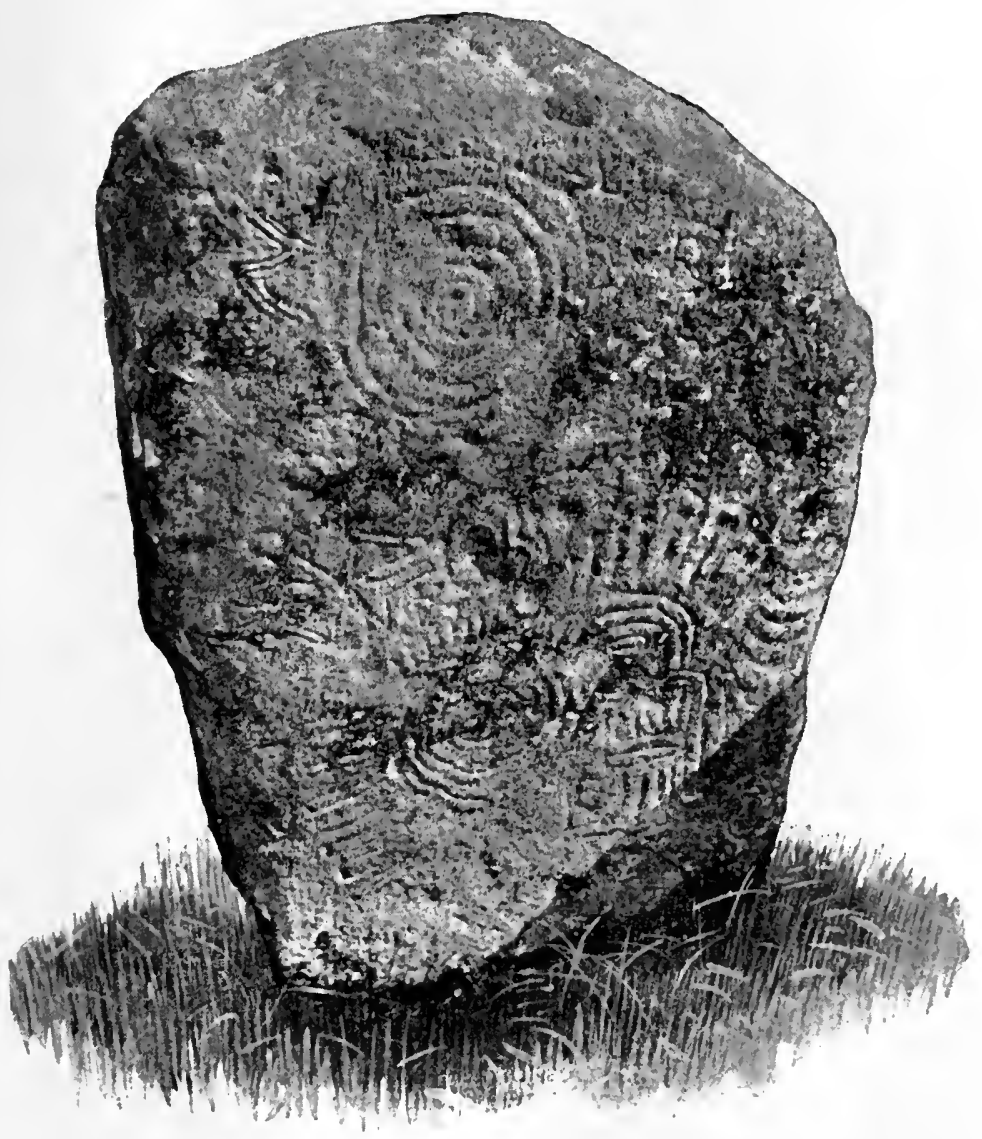

Fig. 141.-Stone in Knockmany Cairn, Co. Tyrone, Ireland (41/2 feet above ground). (From a photograph by $R$. Welch.)

stone were observed to have been sculptured with a series of concentric circles, spirals, and lines. ${ }^{1}$

A stone close to a small stone circle within the grounds of

1 Proc. Soc. A. Scot., vol. xxix. p. 193. 
Monzie Castle, Perthshire, shows a number of circles and cups. It is a whinstone boulder presenting a tolerably smooth surface sloping a little to one side. It measures 6 feet 8 inches in length and 5 feet in breadth; and the largest group measures 12 inches across, while its central cup is 3 inches in diameter. The following sketch (fig. 140),

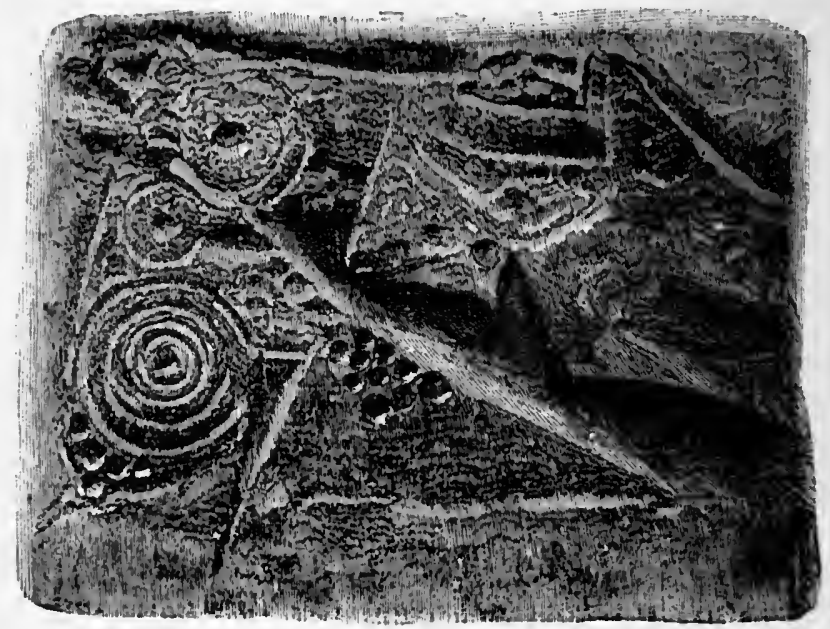

Fig. 142.-Cup-ntarked rock surface at High Banks, Kirkcudbrightshire.

taken on September 23, 1891, gives a general idea of the size and arrangements of the other markings. ${ }^{1}$

Fig. I 4 I represents a photographic view of cup-and-rings, $\& c$, on one of the stones of the ruined chamber in the demolished cairn of Knockmany, Co. Tyrone, recently described by $\mathrm{Mr}$ Cieorge Coffey: ${ }^{2}$

Cup-and-ring markings are often observed on exposed rock-

${ }^{1}$ For a list of the cup-marked stones of Scotland see the appendix to a paper by Mr Romilly Allen on "Some undescribed Stones with Cupmarkings in Scotland" in "Proc. of the Society of Antiquaries of Scotland,' February I3, ISS2.

${ }^{2}$ Joutn. R. Soc. Antiq. of Ireland, IS9S, p. 93. 
surfaces, such as those at Carnban, Auchenbreach, \&c., in the valley of the Crinan Canal, illustrated by Sir James Simpson (loc. cit., plates xxi., xxii., and xxiii.) Since the publication of this author's well-known monograph on the subject some curious examples have been described by $\mathrm{Mr}$ George Hamilton. ${ }^{1}$

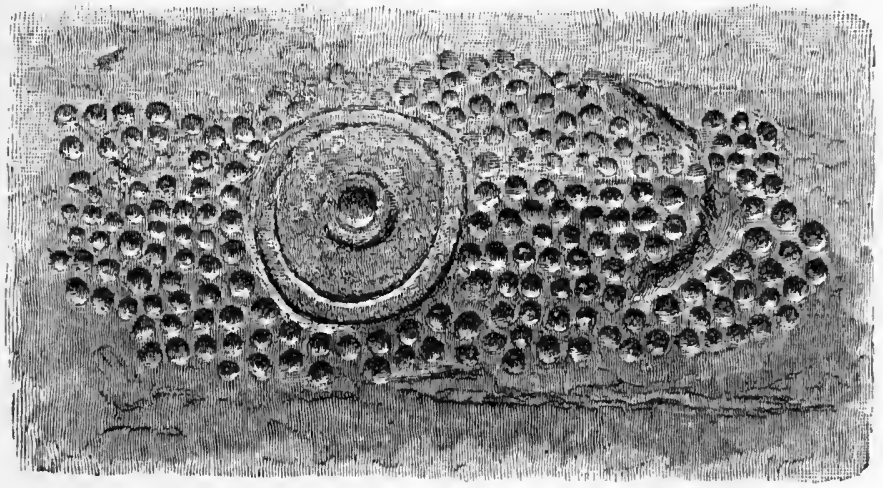

Fig. I43.-Cup-marked rock surface at High Banks, Kirkcudbrightshire.

They were discovered on the top of a glaciated knoll at High Banks, Kirkcudbrightshire, and having been for a long time protected by a natural covering of turf, they are unusually well preserved. Two of these groups are shown on figures 142 and I 43 .

1 Proc. Soc. A. Scot., vol. xxiii. p. 125. 


\section{CHAPTER VII.}

GENERAL PHENOMENA OF THE EARLY IRON AGELATE CELTIC PERIOD.

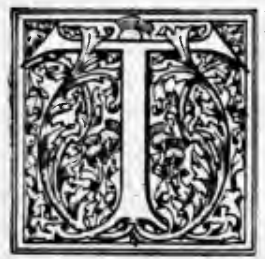

$\mathrm{HE}$ advantages of substituting iron for bronze in cutting implements would not be so apparent to people long conversant with the multifarious bronze objects already in use, as to induce them to make such an innovation per

saltum. Although, in the metallic state, iron is rarely found naturally, it must have been sufficiently common, as meteoric iron, to have attracted the attention of the Stone Age people who, from long practice, had an observant eye for all natural products, had they recognised in it properties superior to those of their ordinary stone materials. But, even should they have failed to discover the utilitarian value of meteoric iron, it is not likely that their successors, when they became skilled in the manufacture of bronze-involving the reduction of copper and tin ores-would remain ignorant of the method of smelting iron from some of its more common ores, such as bog ore and hamatite, both being readily recognised and widely distributed. Some archæologists, on these general grounds, maintain that iron was among the earliest known 
of the metals, although for various reasons it was the latest to come into general use. According to the late M. G. de Mortillet, ${ }^{1}$ iron was first discovered by some of the savage tribes in Africa, probably, as he suggests, from such an incident as a polished axe of hæmatite (a natural form of the ore abundant in Africa) having fallen into the fire-a degree of heat which would be sufficient to disclose its metallic basis. The same authority states his belief that the metal was known in Egypt some 7000 years ago; nay more, that it was with steel iniplements that the beautiful Egyptian statues of syenite and porphyry had been sculptured. He also holds to the frequently expressed opinion that bronze and iron (or steel) are represented on the wall-paintings of the Egyptian tombs by the colours red and blue; that the name $b a a$, by which iron is designated, occurs in the most ancient inscriptions; and that the actual metal has been found in the pyramids of the earliest dynasties. He agrees with M. Chabas and others in ascribing the restricted use of iron, in Egypt, to religious motives.

Bronze was, at all times, an expensive material, owing to the rarity of its ores, and the delay and difficulty of transporting it from foreign lands. During the initiatory stages of the competition between iron and bronze it is probable that the result of the struggle would depend on the comparative expense in the production of the respective metals, - the former, in the first instance, being possibly the dearer of the two. It cannot, however, be supposed that, in face of the abundance and wide distribution of iron ores, the economic problem would long stand in the way had there been no other difficulty to be surmounted. It seems to me that the real hindrance to the adoption of iron in the manufacture of cutting implements was the softness of the metal itself, as, until the

1 Formation de la Nation Française, 1897, p. 260. 
method of tempering it, by suddenly plunging it when heated into cold water, became known, implements and weapons made of it would be actually inferior to those of bronze. Polybius (book ii. c. 33) incidentally records a striking instance of the comparative uselessness of untempered blades. In describing the victory of Flaminius over the Insubres inhabiting Cisalpine Gaul (в.c. 224) he thus writes: "The Romans are thought to have shown uncommon skill in this battle; the Tribunes instructing the troops how they were to conduct themselves both collectively and individually. They had learned from former engagements that Gallic tribes were always most formidable at the first onslaught, before their courage was at all damped by a check; and that the swords with which they were furnished, as I have mentioned before; could only give one downward cut with any effect, but that after this the edges got so turned and the blade so bent, that unless they had time to straighten them with their foot against the ground, they could not deliver a second blow. The Tribunes accordingly gave out the spears of the Triarii, who are the last of the three ranks, to the first ranks, or Hastati; and ordering the men to use their swords only, after their spears were done with, they charged the Celts full in front. When the Celts had rendered their swords useless by the first blows delivered on the spears, the Romans closed with them, and rendered them quite helpless, by preventing them from raising their hands to strike with their swords, which is their peculiar and only stroke, because their blade has no point. The Romans, on the contrary, having excellent points to their swords, used them not to cut but to thrust; and by thus repeatedly hitting the breasts and faces of the enemy, they eventually killed the greater number of them." 1 
Those who deny the existence of a Bronze Age as distinct from that of Iron, are in the habit of accounting for the entire absence of iron relics in graves and early habitations by the theory that they have disappeared in consequence of the natural law of decomposition-it being well known that iron is more liable to oxidation than copper or bronze. But this is not an adequate explanation of the facts, as there are many natural conditions in which iron may for a long time resist atmospheric action. It is difficult to believe that steel implements, in such a dry climate as that of Egypt, could have been in use from the earliest times without having left some traces of their existence. Professor Flinders Petrie exhibited at the Loan Collection of the British Association at Liverpool, in 1896 , an interesting set of iron tools, including files and saws, which had been found in Egypt. They were catalogued as belonging to the seventh century B.C. ; but it was added that they were of Assyrian origin, as such tools were quite unknown in Egypt till later times.

Professor Rolleston, while advocating the view that the contents of the British barrows clearly prove the priority of bronze relics to those of iron, thus notices the oxidation theory: "It will be said by some in answer to this that iron is oxidisable and perishable in an eminent degree, and that it would disappear, whilst the bronze would remain This suggestion I will not characterise as one of the study as opposed to one of the Barrow, but as one of the laboratory, and the laboratory with its strong reagents supports it in a way that the slow and weak or wholly inert chemistry of the deep sand, or rubble, or gravel-filled grave does not. Of course, if you conceive a stream of water, acidulated even slightly with nitric acid, to pass constantly over an iron spearhead, there is no difficulty in estimating the time which will be necessary for the entire disappearance of an implement so 
tested. But no such agent is available in many, I might say most, Bronze Period graves. In some such graves you may find the objects they contain encrusted with a deposit of carbonate of lime, which would have protected an iron weapon of the Bronze Period if there had been any to protect; or you may find, as I am happy often to have seen, the bones in a capital state of preservation, and contrasting to great advantage with the corroded and "perished" bones of Saxons, whose iron weapons were, nevertheless, very present with them; or the grave itself may contain a considerable quantity of free carbonic acid, as other sunk wells do, and yet may be so dry from conditions of superjacent and subjacent rubble and soil as to have afforded no means for the removal of any results of any slight erosion which its contents might have suffered. The phenomena disclosed by the spade must be compared with those disclosed by the test-tube; and there is here a makro-as well as a mikro-chemistry." 1

Mr Engelhardt, in his work on the remarkable hoards of the Early Iron Age found at Thorsbjerg and Nydam, in south Jutland, makes the following remarks on the difference between these two peat-bogs as regards their corrosive action on iron: "Iron is almost entirely consumed by the water of this peat-bog [Thorsbjerg moss]. In many places vestiges of corroded iron were seen in the black peat, indicating that iron articles had been thrown in along with the others, but only very small fragments of iron objects had been preserved, and these were almost exclusively found in the upper layer, about a foot above the other remains. It is fortunate that the tannic acid of the Nydam moss has not this corrosive quality in the same degree as that of the

1 Trans. of the Bristol and Gloucestershire Arch. Soc., 1878 ; Reprint, p. 5 . 
Thorsbjerg moss. Numbers of iron weapons and implements of about the same period have been preserved in Nydam, and this deposit, in connection with that of Thorsbjerg, presents a vivid picture of the civilisation of the Early Iron period, in so far as it may be inferred from the remains of dress, weapons, household utensils, horse furniture, and shipbuilding." 1

Dr Schliemann also very pointedly directs attention to the total absence of iron remains in the prehistoric cities of Troy, while relics of copper and bronze were abundantly present. "Nothing," he writes, "could better testify to the great antiquity of the prehistoric ruins at Hissarlik and at Mycenæ, than the total absence of iron. It is true that Hesiod distinctly states that iron was discovered later than copper and tin, for, in speaking of the peoples who were ancient even in his day, he says that they used bronze, and not iron. But still, in order to show how old the knowledge of iron and steel was, he represents Gaea as making a sickle for Kronos of greyish glittering steel, and he gives to Herakles, besides armour of gold and greaves of bronze, a sword of iron and a helmet of steel." 2

We may therefore safely conclude that, had iron been in use to any great extent contemporaneously with the implements and weapons generally recognised as characteristic of the Bronze Age in Europe, we would, by this time, have found some archæological evidence of the fact. But there appears to be none. Whatever may have been the causes which kept this useful metal so long in the background, there are indications that, on its first introduction into Europe, it was a scarce commodity, as we find it used in small encrusted bands to decorate bronze objects. It was thus occasionally used among the Swiss lake-dwellers at the stations of Moer-

1 Denmark in the Early Iron Age, pp. 25, 26.

2 Ilios, p. 252. 
ingen, Cortaillod, Auvernier, and Corcelettes, to ornament bronze swords and bracelets. ${ }^{1}$ From these considerations it is evident that the mere knowledge of iron as a metal is not to be regarded as synonymous with its general introduction into the arts and industry of human civilisation.

The evolutionary stages through which the iron industry has passed, in its struggle for the mastery over bronze, may be regarded as only distantly connected with Scottish archæology, as there is ample evidence to show that a fully developed Iron Age obtained in Central Europe, long before the metal was utilised in the British Isles and other parts of northwestern Europe. But although these metallurgical changes were perfected outside the archæological area with which we are here specially concerned, it is incumbent on us to show whence these finished products of the Iron Age, or the skill which produced them, reached our shores.

The culture elements-industrial and warlike-to which one gets familiarised by a study of the archæological remains found at Hallstatt and La Tène, are the greatest landmarks in the history of early European civilisation. They radiated around these centres in successive waves from about the eighth to the second century B.C., and their influence ultimately became felt throughout the largest portion of Europe. La Tène civilisation, being a later development and geographically nearer to Britain, naturally affected the social organisation of the inhabitants of the British Isles more deeply than that of Hallstatt; but, however widely apart its products may'be found, whether in Illyricum or in Ireland, they disclose a remarkable similarity, apparently due to unity of origin. The repeated intrusion of the Gauls into the valley of the Po, some centuries before the Christian era, is attested

${ }^{1}$ For illustrations of some of these objects see 'Lake-Dwellings of Europe,' figs. 186, No. 6 , and 188 , No. 6. 
on the most explicit historical and traditional statements, but had history been altogether silent on these warlike episodes of the people who used La Tène weapons and armour, the archæological evidence alone would have been sufficient to establish their truth.

As the result of repeated peregrinations on the trail of the Iron Age in Europe, I have come to the conclusion that the introduction of iron into the British Isles was due to the continuance westwards of the advanced culture elements which successively flourished at Hallstatt and La Tène. To epitomise the evidence on which this opinion could be satisfactorily substantiated would necessitate a deviation into a wide field, involving not only a considerable amount of writing but also a large number of illustrations. Had there been space, a short account of the civilisation and social conditions which flourished respectively at these two centres of the early development of the iron industry would be pertinent to the object and scope of this book, and all the more so as there is no work in the English language which deals with the subject. Nor, indeed, with the exception of one or two special monographs on the Oppidum La Tène and the cemetery of Hallstatt, is there any Continental work, known to me, which gives a general description of these two civilisations, and their relation to each other; nor of the archæological remains found on the wider areas to which objects analogous to those of Hallstatt and $\mathrm{La}$ Tène extended. The works of MM. Bertrand and Reinach, ${ }^{1}$ Dr Hoernes, ${ }^{2}$ and Dr Undset ${ }^{3}$ may, however, be read with advantage on this subject.

${ }^{1}$ Les Celtes dans les Vallées du Pô et du Danube.

${ }^{2}$ Urgeschichte der Bildenden Kunst in Europa.

${ }^{3}$ Erstes Auftreten des Eisens in Nord-Europa. 


\section{LATE CELTIC PERIOD IN BRITAIN.}

We now come to the investigation of the early Iron Age in Britain, for it is not yet possible to eliminate Scotland from the wider area. The effect of the foreign influences emanating from Central Europe on the civilisation of these "barbarians in the ocean" was to develop a new school of art, which, though retaining the primary features of its Continental prototypes, presented so many deviations, both in design and execution, that it is now regarded as a third and final stage in the evolution of the Celtic art of Europe. Among the first to clearly define this remarkable group of antiquities in Britain was the late Sir A. W. Franks, who, as one of the editors of Kemble's 'Horæ Ferales,' named it "Late Celtic" - an expression which has since become common in archæological literature. His description of the principal objects in that group, so far as they were then known to him, is prefaced by the following remarks :-

"In the peculiar class of antiquities now to be considered, the British Islands stand unrivalled; a few ancient objects, analogous in design, may be found in various parts of the Continent, and more extended researches in local museums may bring many others to light, but the foreign contributions to this section are scanty when compared with those of our own country.

"The antiquities under consideration consist of shields, swords, and daggers, horse-furniture, personal ornaments, and a number of miscellaneous objects, some of iron, some of bronze, and frequently decorated with enamel. All these antiquities exhibit a style of decoration remarkable for its peculiar and varied forms, and testify to extraordinary skill in working metals." 1 
On finishing his descriptive details of the objects in question - the more perfect and highly decorated being delineated on seven plates of beautiful illustrations-he proceeds to show that their original owners could be no others than the Celts. By a process of analytical elimination he rejects the claims of the Romans, Saxons, and Danes, to be regarded as the owners and founders of this unique style of art. "We have, therefore," he writes, "only the Celtic races, or some branch of these races, to fall back upon. Moreover, the only designs at all similar, of which the origin is certain, are to be found in early Irish manuscripts; though there intermingled with patterns of a very different kind, and derived probably from a different country. For if we examine carefully the illuminations of Irish MSS., we shall observe that the designs are of two kinds: one composed of the singular wavy or trumpet patterns which occur also on these bronzes, but which, in the hands of the illuminator, become still more intricate and singular; the other exhibiting interlaced patterns of great variety both as to form and as to their component parts. The interlacings may possibly have been introduced with the Christian religion; in a simpler form we find them in Anglo-Saxon designs, and even occasionally in the later Roman mosaic pavements. They are seldom, however, combined with the wavy pattern in England, and then generally in the North of England, or in those places where the influence of the Scoti or Irish monks prevailed; we may name as an instance, the famous Gospel of St Cuthbert. Another peculiarity worthy of remark is the greater frequency of the trumpet patterns in the earlier MSS., and the gradual superseding of them by the interlaced patterns in the later MSS. and works of art." 1

In briefly noticing some of the Late Celtic remains found 1 Horæ Ferales, p. 184. 
within the British Isles, I shall first deal with the more isolated examples, with regard to which the circumstances of the discovery count for little, their archæological value being determined by some special features in their manufacture or style of ornamentation. Afterwards some of the more important objects found in association with collateral remains, such as the contents of graves, camps, hoards, \&c., will be considered. As most of the Late Celtic remains described in 'Horre Ferales' belong to the former category, it will be convenient to follow, as far as possible, the order of classification adopted in that work.

Shields.-Two entire shields and portions of six others are described in 'Horæ Ferales.' One of the entire specimens was found in the river Witham, and the other in the Thames. They are both oval or oblong in shape, and decorated with raised designs of Late Celtic character. The boss of the former contains five studs of red coral, and its surface is clearly defined with the stained space on which the figure of an "exaggerated" boar, with very long legs, had been riveted. The second is also ornamented with several groups of studs of red enamel. Some idea of the style of art and perfection of the workmanship on these shields may be gained from the accompanying pencil sketch of the specimen from the river Thames (Pl. V.) Of the other fragmentary portions two bosses are also from the Thames, three from Polden Hill (p. 247), and one from a barrow in Yorkshire. "These," writes Sir WV. Franks, "are the only remains of shields of the kind with which I am acquainted. It will be seen that they have not been found out of England; their form seems to have been oval, and they varied in length from 3 feet 9 inches to 2 feet 6 inches."

Every one interested in this class of antiquities should find an opportunity of inspecting these very remarkable re- 


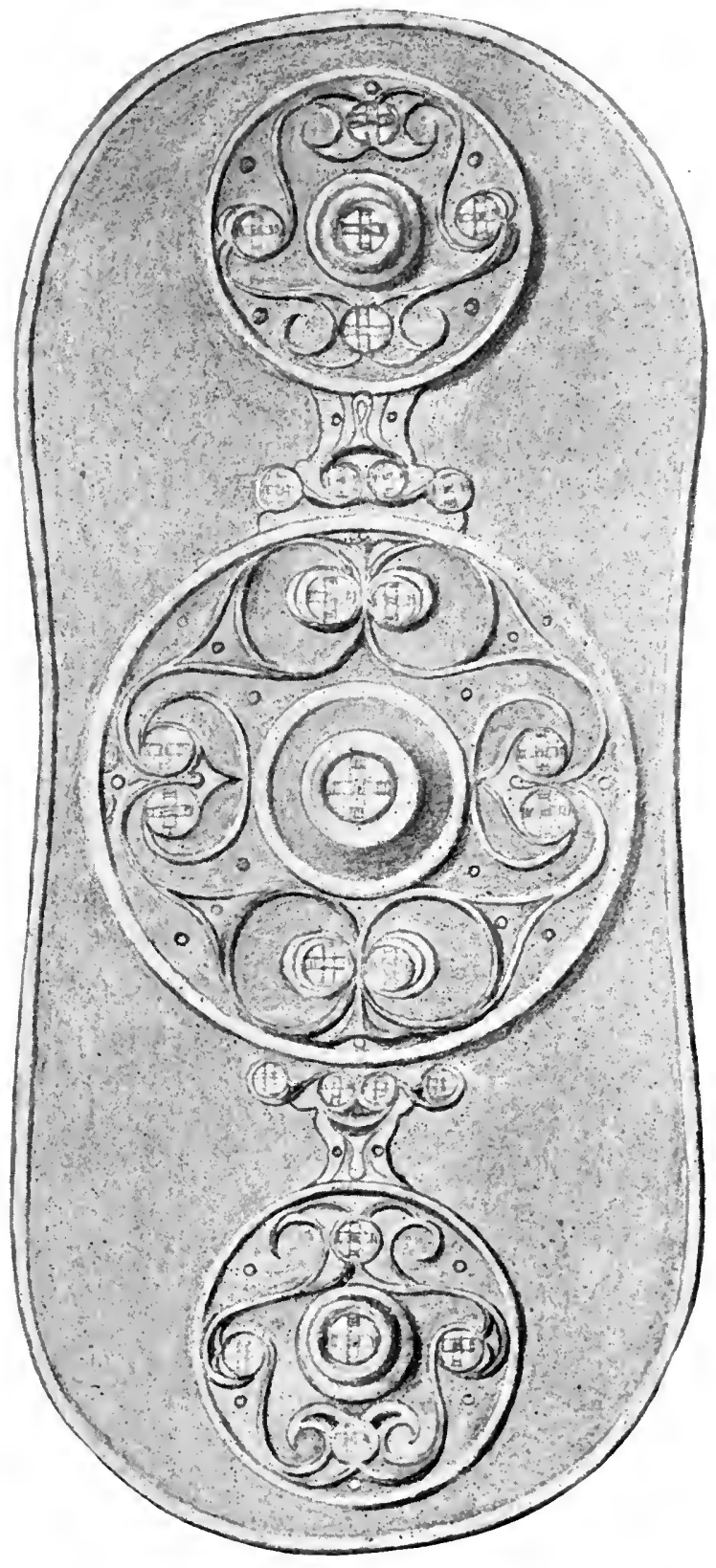

Plate V.-BRONZE SHIEld FOUND IN BED OF THAMES. British Museum (length 2 feet $6 \frac{1}{2}$ inches). 

mains, now preserved in the British Museum; or at least the coloured illustrations of them in 'Horæ Ferales,' pl. xiv.-xvi.

I may observe that the shields represented on the Gundestrup silver vase ${ }^{1}$ are oblong, while those on the bronze situlæ found in the Illyrico-Venetic province are either round, oval, or oblong. Various portions of shields have been found in Oppidum La Tène, including handles, bosses, and circular ornaments, generally of bronze, but sometimes of iron, which were fastened on the wooden framework of the shield. ${ }^{2}$

Helmets.-No British helmet earlier than Roman times was known to Sir W. Franks when he wrote his notes in I 863, and only one or two German specimens. He refers to one remarkable specimen, found in an ancient channel of the Seine, and figures a number from Greece and Italy. Since then, however, our knowledge of pre-Roman helmets in Europe has greatly increased. They have been found in Gaulish tumuli, in the cemeteries of Hallstatt, Watsch, Ambras, and other localities in the Illyrico-Venetic archæological area. A very remarkable helmet, found in a tomb at St Margarethen, was made of a kind of basket-work, over which there was a leathern covering. Outside the cap thus formed there were fastened six circular discs of bronze, surrounding a larger central disc which formed the summit, and from the middle of which an iron spike projected. It is now surmised that similar discs, many of which were formerly regarded as shield ornaments, were really parts of helmets of the same type as that at St Margarethen. A helmet of a decidedly Grecian character was found in one of the tumuli of Glasinac. ${ }^{3}$

1 See Sophus Müller : Nordiske Fortidsminder, 2 Hefte.

2 See group fig. S9 of the 'Lake-Dwellings of Europe.'

3 Rambles and Studies in Bosnia, s.c., fig. $3^{6}$. 
Some of the warriors figured on the famous situla from Bologna, Watsch, \&c., wear helmets. One scene represents two pugilists with a crested helmet between them, apparently the prize contested for. Actual specimens of these helmets have been found without a crest, and others with one or two crests. It may also be mentioned that the helmets on the mounted figures on the Gundestrup vase are ornamented by various devices, probably badges, such as a crescent, two horns, a boar, and a bird. The officer in command of the infantry has also a helmet crowned with the figure of a boar.

Two fragmentary portions of bronze found on Scottish soil, which are justly regarded as parts of helmets, have a close resemblance to those horned and boar-headed helmets figured on the Gundestrup vase. They are described by $\mathrm{Dr} J$. Alexander Smith in one of those exhaustive monographs by which he has so greatly enriched Scottish archæology. ${ }^{1}$ One of these objects (fig. 144) was found, about the year 1820 , in a morass, on the farm of Torrs, in the parish of Kelton, Kirkcudbrightshire, and, having passed into the possession of Sir Walter Scott, is still preserved at Abbotsford. It is made of thin beaten bronze like a mask, with eye-holes an inch in diameter, and two curved hollow horns rising from between them. The ornamentation on the body is in repousse, in the form of divergent spirals ending in volutes, \&c., all highly characteristic of Late Celtic work. The horns are also ornamented with " a continuous series of corresponding curvilinear lines and scrolls of finer character, the patterns being less prominent, and formed rather by their outline being depressed or indented in the metal."

The other analogous relic, which takes the shape of a boar's head, was found, at a depth of 6 feet, in mossy ground resting on the underlying clay; at Liechestown in the parish of Desk-

\footnotetext{
1 Proc. Soc. A. Scot, vol. vii. p. 334.
} 
ford, Banffshire. It was discovered about the year I 8 I 6 , and is now preserved in the Banff Museum. Though not so elaborately decorated as the former, it is clearly of the

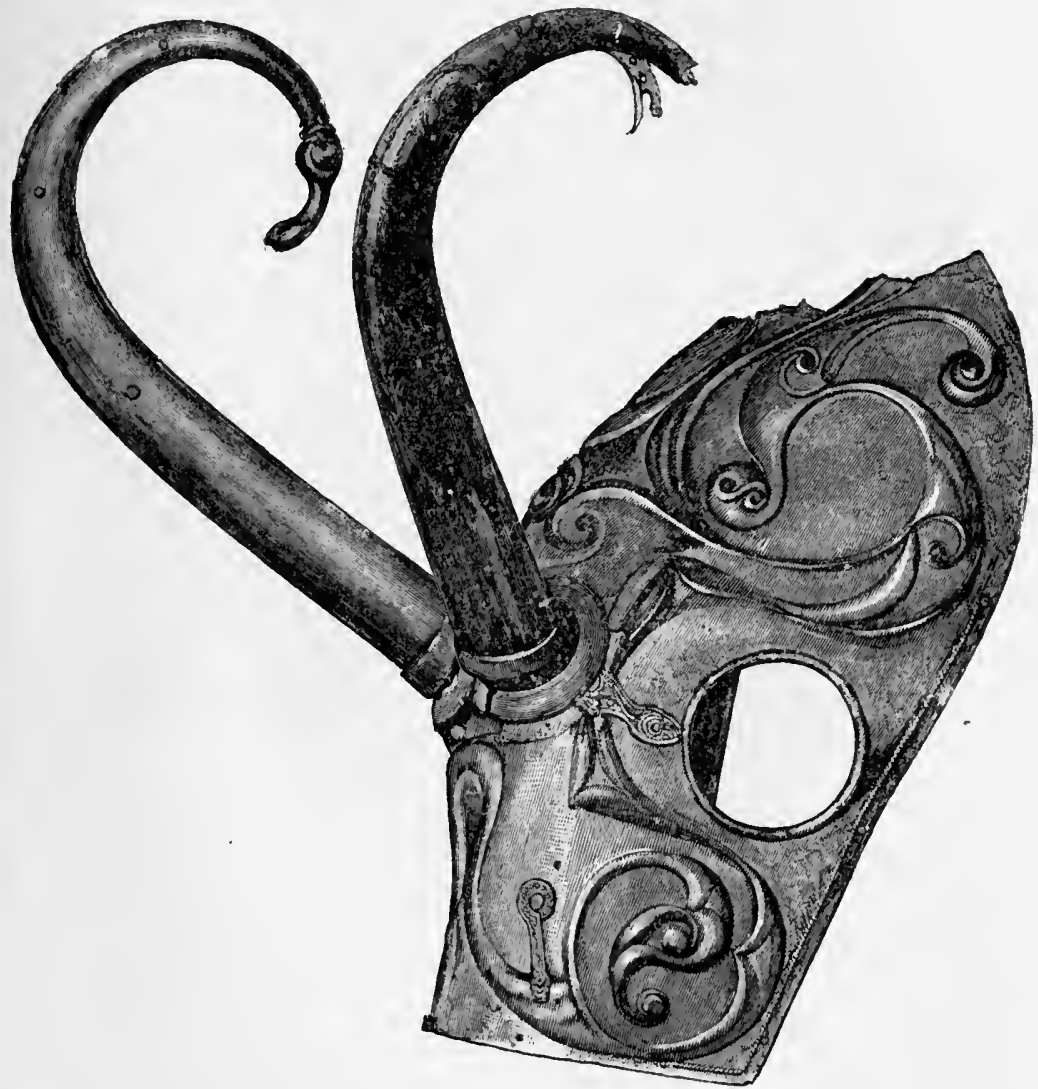

Fig. 144.-Bronse with horns found at Torrs, Kirkcudbrightshire (161/2 inches in greatest length).

same style of work, and probably of the same period. Dr Joseph Anderson illustrates his account of these objects in his Rhind lectures by a woodcut of a bronze plaque, found in Oland, representing two warriors with remarkably similar 
helmets. This plaque is one of four, with similar quaint figures, found in a cairn, and classified by Montelius as belonging to the third period of the Iron Age-i.e., seventh to eleventh centuries.

Mr Llewellynn Jewitt describes ${ }^{2}$ a remarkable grave at Barlaston, in Staffordshire, in which were a number of enamelled discs which he believed to have been portions of a helmet. Although this grave was regarded by the author as Anglo-Saxon, the ornamentation on some of the objects is so pronounced that there can be little doubt that it is Late Celtic work. The grave, which was 7 feet long by 2 feet wide, was partly cut out of the solid stone, and contained a basin-like cavity for the helmeted head. It was in this hollow that the relics now in question were found. "The fragments in the cavity," writes Mr Jewett, "consisted of several pieces of curved bronze, highly ornamented, which had probably, with other plain curved pieces, formed the framework of the helmet; some thin plates of bronze; a flat , ring of bronze, beautifully ornamented (fig. 434), which is conjectured to have been the top of the framework of the helmet; and three enamelled discs of a similar character to what have been elsewhere found, with hooks for suspension or attachment to leather or other substance. One of these is engraved, of its real size (fig. 435). The centre is of enamel mosaic work, ground down level with the metal, as in the old Chinese enamels." Similar relics (figs. 436, 437) were not unfrequently met with in other localities, as for instance in a barrow on Middleton Moor, Derbyshire, where they were associated with the iron umbo of a shield, and a thin vessel of bronze, which probably, according to Mr Jewett, formed portion of a helmet. ${ }^{3}$

1 Antiquités Suedoises, p. 150.

2 Grave-Mounds, p. $258 . \quad 3$ Ibid., p. 261. 
Swords.-Some twenty iron swords with bronze sheaths, or the bronze sheaths without the swords, are recorded in 'Horæe Ferales' as having been found in widely separated districts in Britain; also about an equal number of La Tène types, which are introduced for the purpose of comparison. The same author, writing in $1880,{ }^{1}$ states that to his knowledge the geographical distribution of these swords or their sheaths in England was as follows: Bed of the Thames, 8 ; Yorkshire, 5 ; Lincolnshire, 4 ; Dorsetshire, 2, besides fragments ; Hertfordshire, Cumberland, and Lancashire, I each. Since then a few more specimens have come to light, notably two in Hunsbury Camp, near Northampton (fig. 145), one in Ayrshire (fig. 146), and four in the bog of Lisnacroghera in Ireland (fig. I 47). The Hunsbury Camp and its relics will be described later on, but meantime the more perfect of the sword-sheaths may be noticed, as it is one of the most typical of the class yet known. It has already been figured and described by Sir Henry Dryden, ${ }^{2}$ along with the other remains found in the camp, and also by Mr C. H. Read. ${ }^{3}$ "This. beautiful specimen," writes Mr Read, "is formed of a thin bronze plate on one face, the other face being open, and provided only with transverse ornamented plates; the edge is of the usual character-that is, a rounded recurved plate, the two edges of which clasp the plates forming the face and back of the sheath. The end of the sheath is of thicker metal, and of the usual heart-shaped form which characterises other sheaths of the same period. Towards the lower part, 8 inches from the point, is a pair of ornamental bosses formed of curves and circles, resembling birds' heads. At the back of this part is an engraved plate with scrolls and circles, and two lower

1 Archreologia, vol. 45, pp. 25 1-266.

2 Associated Architectural Societies' Reports, vol. xviii.

3 Archrologia, vol. 52, p. 762 . 
bands, also engraved, which do not correspond with anything on the front. The upper end of the front of the sheath has an elegant pattern of scrolls and circles of the usual Late
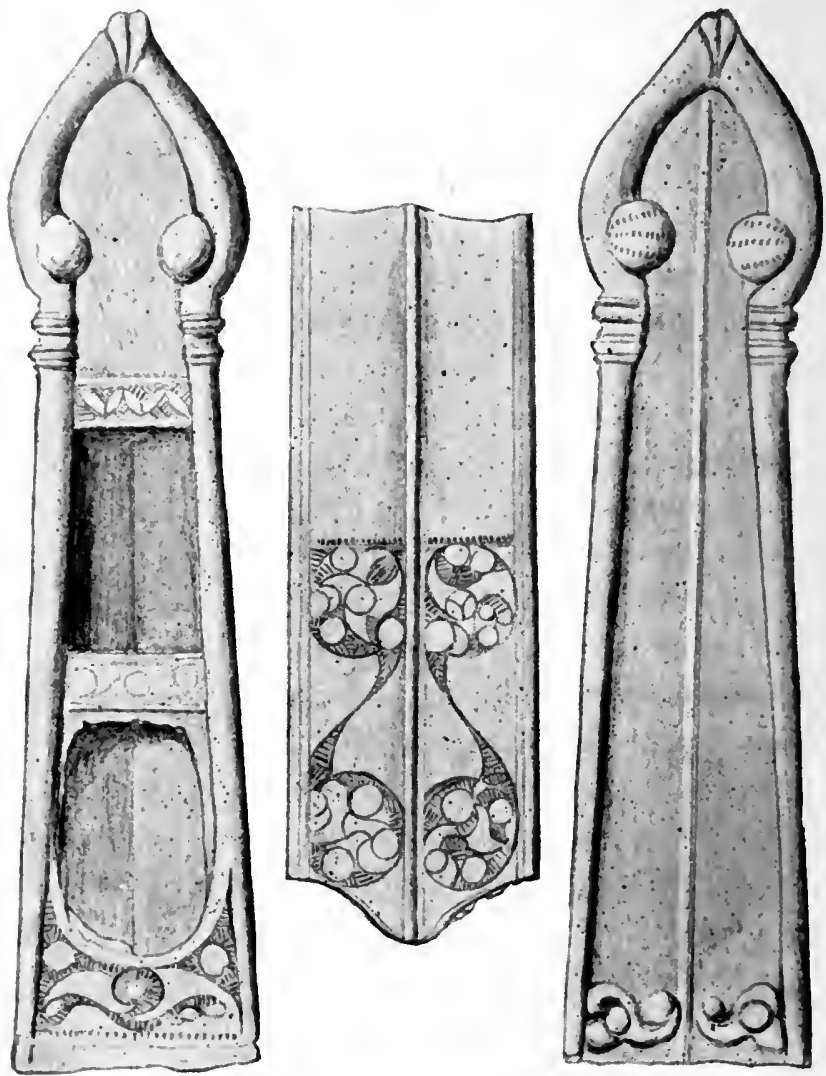

Fig. 1 $+5 .-B r o n z e$ sword-sheath found at Hunsbury Camp, Northampton $\left(\frac{1}{2}\right)$.

Celtic type, very like the engraved ornaments on the bronze mirror from St Keverne, in Cornwall. ${ }^{1}$ As a type, it is quite characteristic of Late Celtic work, and in no part has it any

${ }^{1}$ See fig. 174, p. 266. 
resemblance to, or connection with, the production of Saxon times, as has been suggested."

The Ayrshire specimen (fig. 146) was found many years ago in the course of draining, near Bargany House on the banks of the river Girvan, and presented to the Museum of St Andrews. Here I saw it in 1893 , and subsequently con-
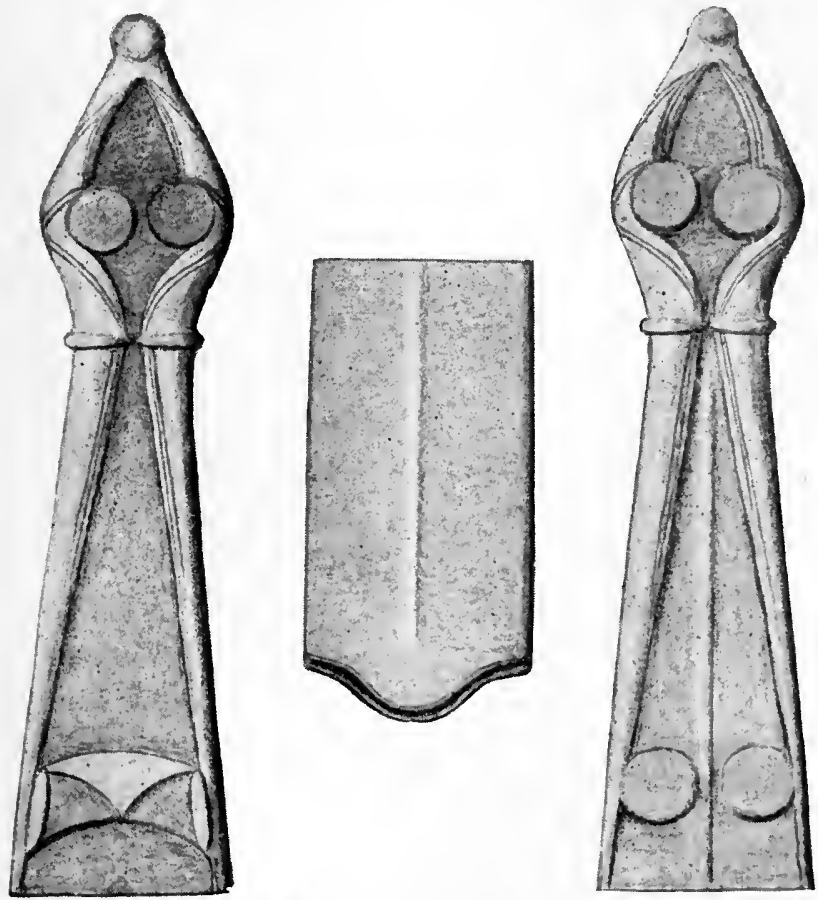

Fig. It6.-Bronze sword-sheath found in Ayrshire $\left(\frac{1}{2}\right)$.

tributed a description of it to the 'Archæological Collections of Ayrshire and Galloway' (vol. vii. p. 48, pl. i.) Although not decorated on its surface with the characteristic scrolls of spiral and curved spaces, like most others of its kind, it bears in all its structural details unmistakable evidence of belonging to the same class of work. It has an elegant form, slightly 
tapering towards the point, and measures 24 inches in length by I $3 / 4$ inch in breadth. It is made of two plates of bronze, one sufficiently large to be bent round at the margins so as to
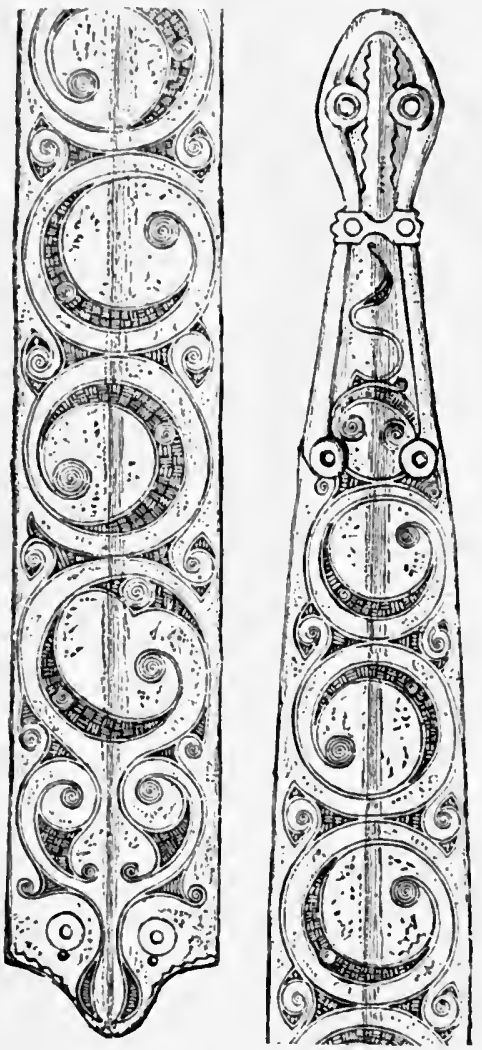

Fig. 147.-Bronse sword-sheath found in the bog of Lisnacroghera, Ireland $\left(\frac{1}{2}\right)$. overlap the other. The plates were then riveted and soldered together. The point is strengthened by a stout chape, from which a marginal moulding runs for several inches on both edges, and from which again an ornamental band extends across the body of the sheath.

The only other specimen of Late Celtic swordsheaths found in Scotland, known to me, is that in the National Museum in Edinburgh (fig. 148). There is no history of the circumstances in which this sheath was discovered, beyond an inscribed label to the effect that it was found on the Mortonhall estate, at the foot of the Pentland Hills. It measures $231 / 2$ inches in length by $1 \frac{1}{4}$ inch in breadth, and, according to Dr Joseph Anderson, "is formed of thin beaten bronze; the ornamental cup-shaped expansions at the lower end are solid castings, and the ornamental strap carrying the loop in front is fastened on with pins. The back of 
the sheath is a thin slip of bronze sliding in grooves in the inner margins of the two sides." 1

Another bronze sheath of this type was found by fishermen in the river Tweed, near the village of Carham, now preserved in the collection of Canon Greenwell. It is $2 \mathbf{I}$ inches long and $I 3 / 4$ inch broad. "It consists of the front of the sheath with a raised line in the centre, terminating in a triangle and with a solid end; of the back only the lower part remains, the rest having been probably made of leather." 2

A very fine iron sword, still in its bronze sheath, was found, in $\mathbf{I} 868$, in a barrow at Grimthorpe, associated with the bronze mountings of a wooden shield and a small disc decorated with raised trumpet-shaped ornaments-all of Late Celtic work. ${ }^{3}$ Near the same locality, at a place called Bugthorpe, a body was discovered with which an iron sword in a bronze sheath and an enamelled bronze brooch were associated. ${ }^{4}$

For additional illustrations of these swordsheaths in England, I would refer my readers to 'Horæ Ferales'; 'Collectanea Antiqua' (vol. iii. pl. xvi., and vol. iv. pl. xxxiii.); and 'Catalogue of Antiquities in Alnwick Castle.'

1 Scotland in Pagan Times, p. 120.

2 Archæologia, vol. 45, p. 256, pl. xvi.

3 Reliquary, vol. ix. p. 180; and Grave-Mounds, pp. 238,245 , and 263

4 British Barrows, p. jo.

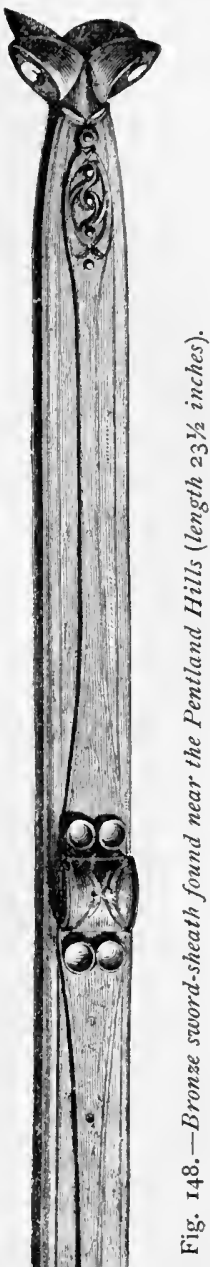


Daggers.-Of six specimens of iron daggers with bronze sheaths described by Sir W. Franks, five were found in the Thames and one in the Witham. This latter (fig. 149), one of two which still retained their bronze handles, is remark-

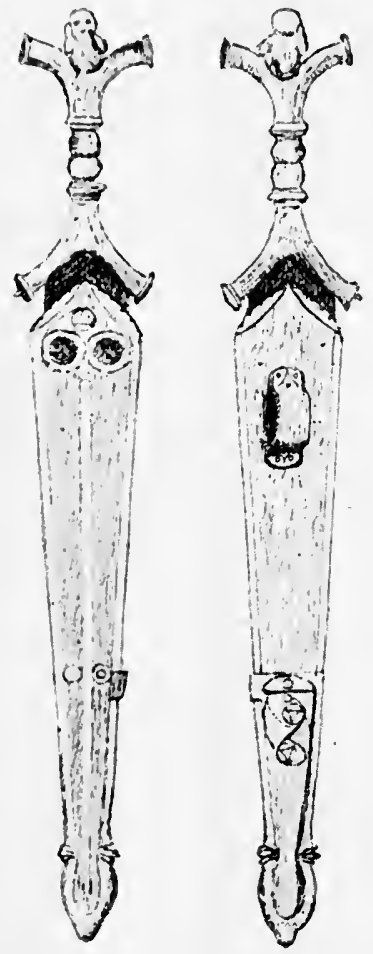

Fig. 149. - Iron dasser with bronse sheath found in the river Witham (1). able for the two horn-like projections on its hilt. Weapons with this type of handle have been found at Hallstatt and several places throughout Europe, extending in a narrow band from Bologna to the Pyrenees, but reaching northwards only to the southern limits of Belgic Gaul. MM. Bertrand and Reinach 1 enumerate no less than twentyfive localities within this area, chiefly graves after incineration, which have yielded one or more specimens. According to these eminent authorities, the horned weapons (ípées à antennes) are products of the proto-Celtic stratum which, chronologically, lies between the earlier megalithic chambers and the later Gaulish tumuli-both these, be it observed, being characterised by burials after the rites of inhumation. Their

bronze sheaths were constructed and ornamented after the fashion of those of the short swords of the period, with which the larger specimens are sometimes confounded.

One of the sheaths from the Thames, figured in 'Horæ 1 op. cit., p. 68. 
Ferales' (pl. xviii. fig. 3), and in the 'Archæological Journal' (vol. x. p. 259), has a strong resemblance to another found in the Thames, and figured in 'Archæologia' (vol. 54, p. 497).

Horse-trappings. - The mountings of horse-harness, rings, bridle-bits, \&c., are of much importance in illustrating the Late Celtic culture of Britain, more especially the art of enamelling, which is known historically to have been practised by the Celts of Western Europe. But as it would greatly exceed my limits to give a detailed résumé of the numerous discoveries of this kind which have been put on record, I must confine myself to a bare statement of a few of the more important.

At Polden Hill, near Bridgewater, the following objects were turned up by a man ploughing a field: three bosses of shields, fourteen bridle-bits, a nose ornament for a horse, a torque of iron with bronze wire, a large number of rings and ornamented plates of bronze, some being decorated with enamel. ${ }^{\text {I }}$

At Hagbourn Hill, Berkshire, several oblong pits were exposed at a depth of about 4 feet, and in one of them there was a circular excavation containing two bronze bridle-bits, some rings with bronze knobs on an iron plate, a bronze celt, and two javelin-heads. Two silver coins are also said to have been found with these objects. ${ }^{2}$

In a pit within the intrenchments at Stanwick, Yorkshire, at a depth of about 5 feet, were found bridle-bits, rings, plates, fragments of repoussé work, portions of iron chainmail, a sword-sheath, and other fragments having traces of enamel on them. Adjacent to these were the tyres of chariot wheels. ${ }^{3}$

On the opening of a barrow at Arras, Yorkshire, the

1 Archreologia, vol. 14, p. 90.

2 Ibid., vol. 16, p. 348.

3 Arch. Institute, York Vol, p. 10. 
following objects were found in a circular cist cut down to a depth of $I \frac{1}{2}$ foot in the chalky rock: two chariot wheels, one on each side of a human skeleton lying supine, the heads of two wild boars, and some horse bones, near which were two bridle-bits made of iron, and plated with bronze. The diameter of the wheel tyres was 2 feet

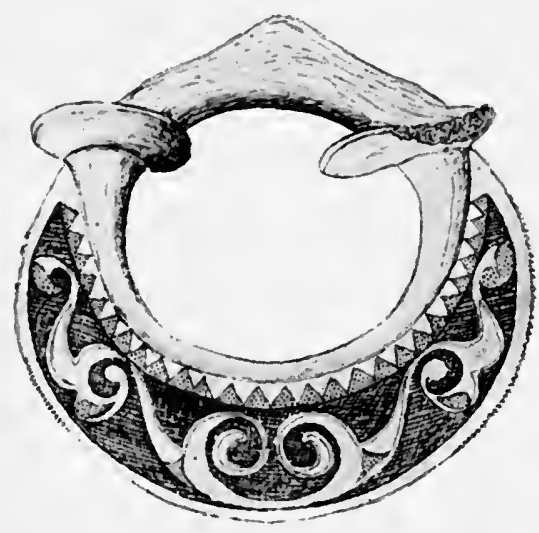

Fig. 150.-Enamelled ring, Westhall,

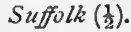

I I inches. Another barrow in the same group at Hessleskew contained the remains of wheels, a bridle-bit, a fibula, and other objects. $^{1}$

At Saham Toney, in Norfolk, five rings and two enamelled ornaments were discovered. ${ }^{2}$

At Westhall, near Halesworth, Suffolk, a number of rings, some being enamelled, were associated with "a bronze lamp of good Roman workmanship." 3

At Hamden Hill, Somersetshire, several human skeletons, tyres of wheels, lance- and arrow-heads of iron, and some bronze objects were found.*

As examples of the enamelling of these harness ornaments, I have given a couple of pen-and-ink sketches from the coloured illustrations in 'Horæ Ferales.' One (fig. I $5^{\circ}$ ), from Westhall in Suffolk, shows the enamelled portion darker, so as to bring out at a glance the elegant spiral scrolls. The other

\footnotetext{
1 Arch. Institute, York Vol., p. 26 ; and Crania Britannica, pl. vii.

- Norfolk Arch., vol. ii. p. 400.

3 Archeologia, vol. 36, p. 454 - Ibid., vol. 21, p. 39.
} 
(fig. I 5I) was found at Norton, also in Suffolk, and shows two coloured enamels, the small circles being bright yellow and the dark portion red.

These harness mountings, both with and without enamelling, are not unknown in Scotland. Sir Herbert Maxwell describes one specimen, found by a drainer at Auchendolly, Kirkcudbrightshire, which shows a design in yellow and red enamel, not unlike that from Westhall just

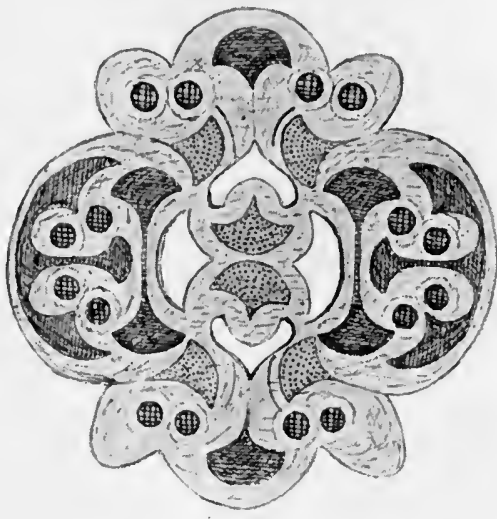

Fig. I5I.-Enamelled ornament for harness,

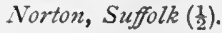
mentioned. ${ }^{1}$ A round button-like object, ornamented with a setting of red enamel, was found in the broch at Torwoodlee, associated with a bronze harness ring and some Roman pottery and glass. ${ }^{2}$ A circular ornament picked up on the exposed bed of the Loch of Dowalton (fig. I 52 ) has trumpet-shaped spaces which appear to have been filled with enamel.

Bridle-bits of Late Celtic workmanship have been recorded from various localities

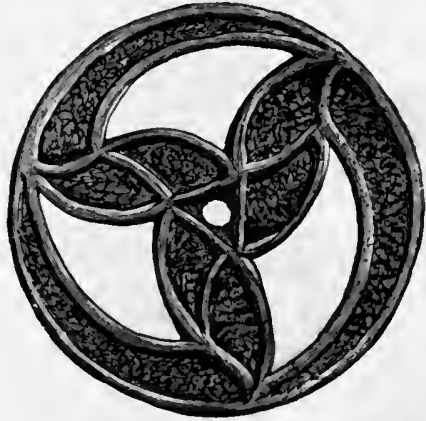

Fig. 152.-Ornament found in Loch of Dowalton (2 inches diameter). in Scotland and Ireland. One well-known specimen, found in a moss at Birrenswark (fig. I 53) more than a century
${ }^{1}$ Proc. Soc. A. Scot., vol. xx. p. 396.
2 Ibid., vol. xxvi, p. $8 \mathrm{r}$. 


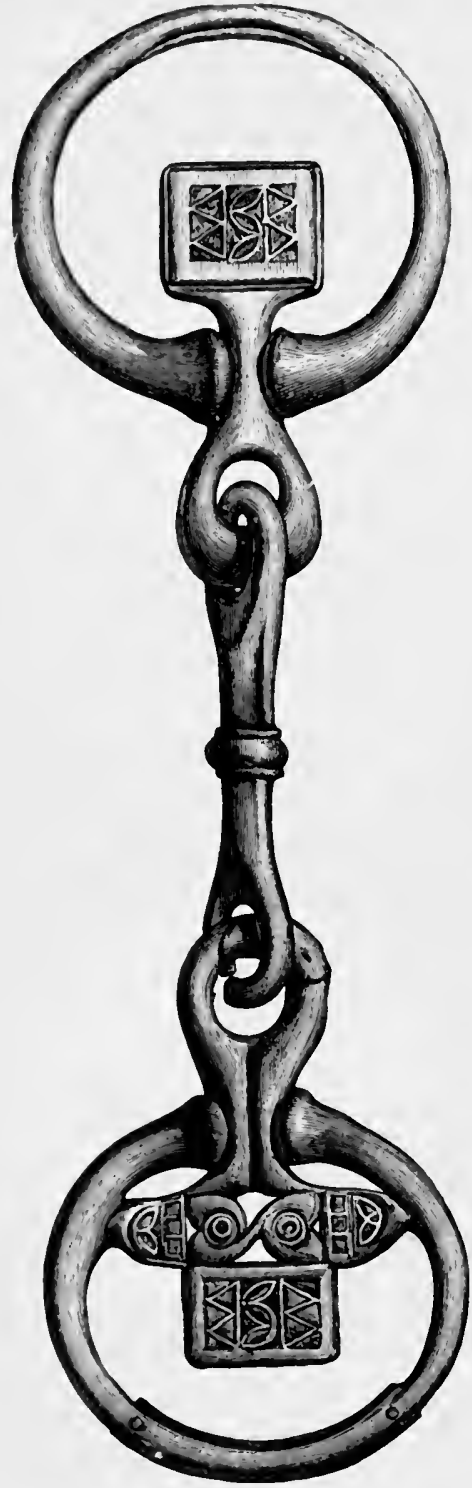

Fig. 153.-Bridle-bit found in a moss at Birrenswark, Dumfriesshire (63/4 inches in length). ago, and now preserved in the National Museum in Edinburgh, exhibits this style of art both in enamel and metal work. It is figured and described by Dr J. A. Smith, along with a couple of bronze rings from a cairn at Towie, Aberdeenshire. ${ }^{1}$

In the year 1737 two bridle-bits, rings, and other ornaments, apparently the harness furniture for a couple of horses, were found in a moss at Middlesby, Annandale. The find is described by Sir D. Wilson, ${ }^{2}$ who compares them with the analogous antiquities found at Stanwick, in Northumberland, with which "they are nearly identical in type." "The bridlebits," he remarks, "though plainer than the one found at Birrenswark, are of the same type, and one of them corresponds to it in the

1 Proc. Soc. A. Scot., vol. xr. p. 320 .

2 Prehistoric Ammals, vol. ii. p. 156. 
want of uniformity of the two rings: designed, as has been suggested, for use by the charioteer with a pair of horses, where the more ornamental ring would be worn on the outside, and fully exposed to view."

While discussing the subject of ancient enamelling, I may as well dispose of the few remaining specimens of this art found in Scotland. A hollow bronze disc, $I / 8$ inch in diameter, apparently some kind of mounting, having a central dot of yellow enamel surrounded by concentric circles in red enamel, was found by Dr Angus Smith while excavating in the vitrified fort of Dun Mac Uisneachan. ${ }^{1}$

Perhaps the finest specimen of enamelled work known to have been found in Scotland is a bronze cup, or patera, from Linlithgowshire, and described in the Proceedings of the Society of Antiquaries (vol. xix. p. 45). The form is that of an ordinary Roman patera in bronze, ornamented in enamel of blue, red, and green colours, and forming a combination of elegant patterns of a wreath, a floriated scroll, and bands with serrated edges. It carries a flat handle, $3 \mathrm{I} / 2$ inches in length, and the bowl measures $4 \frac{1}{2}$ inches in diameter and $2 \frac{1}{2}$ inches deep. Similar vessels have been found only in the Celtic area of Western Europe; and of three other specimens known to exist, two were found in England -one at Braughing, in East Herts, and the other at Bartlow, in Essex. The third specimen was dug up in a moss at Malbeck, in Denmark.

Personal Ornaments. - Torques of Late Celtic art, or fragments of them, are recorded in 'Horæ Ferales' as having been discovered in the following localities in England: a bronze torque formed of two portions united by iron tenons, one flat and the other composed of eleven wreathed beads, found in a stone quarry in the parish of Rochdale, Lancashire; another

1 Proc. Soc. A. Scot., vol. xix. p. 24 S. 
of a similar type was found between limestone flags on a moor above Embsay, near Skipton, Yorkshire; a portion of a bronze torque resembling the vertebræ of a fish is recorded from Perdeswell, near Worcester; a bronze torque weighing $2 \mathrm{lb}$. $121 / 2$ ounces, ornamented with wavy patterns and sockets for gems, found near Tower House, Wraxal, Somersetshire ; fragments of a bronze collar similar to the last-mentioned, found at Trenoweth, in Cornwall.

$A$ few torques of Late Celtic art have also been discovered in Scotland. A beautiful specimen of the Beaded Torque was found, enclosed in a bronze bowl, by a labourer while cutting turf in Lochar Moss, Dumfriesshire. As shown on figure 4, it consists of (I) a solid piece highly ornamented, and (2) fourteen ribbed beads, with a smaller bead separating each pair, like the vertebral bones of a fish. "The beads," writes Sir Daniel Wilson," "are disconnected, having apparently been strung upon a metal wire, as was the case in another example found in the neighbourhood of Worcester. A waved ornament chased along the outer edge of the solid piece seems to have been designed in imitation of a cord, - the last tradition, as it were, of the string with which the older necklace of shale or jet was secured. Altogether, this example of the class of neck ornaments styled Beaded Torcs furnishes an exceedingly interesting illustration of the development of initiative design, in contradistinction to the more simple and archaic funicular torc, which, though continued in use down to a late period, pertains to the epoch of primitive art."

Another torque of the same type, but in fragments, has been recently found on a crannog near the town of Lanark (fig. 154). The back portion, which was apparently an iron rod, is almost entirely decomposed, and only small fragments of it remain; but several of the beads, which are enveloped in

${ }^{1}$ Prehistoric Annals, vol. ii. p. 14 I. 
rust of iron and bronze, have been recovered. They were strung together by means of an iron wire which passed through a small rectangular hole in the centre of each bead.

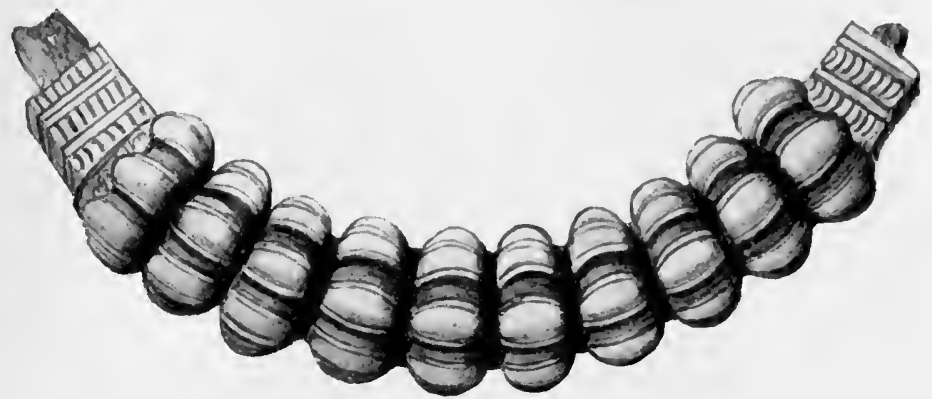

Fig. 154.-Portion of beaded torque found on the Hyndford Crannog (? $(3)$.

The ribbed beads have alternating with them thinner and smaller beads precisely similar to the Lochar moss specimen.

A bronze collar (fig. 155) was discovered in 1747, about 7 feet below the surface, while digging a well, at the east end of the village of Stitchel, in Roxburghshire. Its ornamentation, which is highly characteristic of Late Celtic art, is analogous to that on a bronze

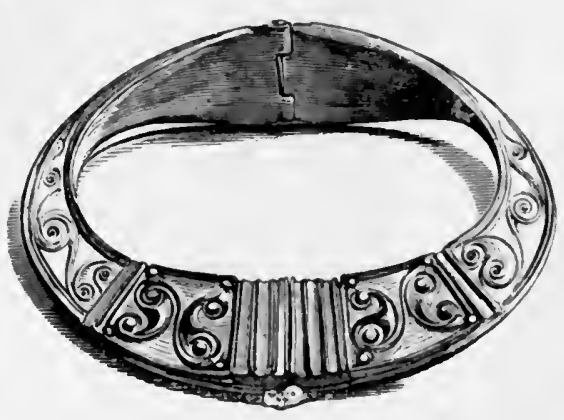

Fig. 155.-Bronze collar found near Stitchel, Roxburghshire (greatest diameter, 7 /3 inches). armlet found in I 826, near Plunton Castle, Kirkcudbrightshire (fig. 156 ). Both these relics open by means of a hinge and are closed by a pin clasp. ${ }^{1}$

Two massive bronze armlets, found on the farm of Pit-

1 Proc. Soc. A. Scot., vol. vii. pp. 348, 35 r. 
kelloney, near Muthill, Perthshire, and now in the British Museum, show a broad coiled pattern with oval medallions of red and yellow enamel at both ends. ${ }^{1}$

The Pitkelloney armlets belong to a type which is peculiar to Scotland, and of which many specimens have been found in different parts of the country. They consist of a solid casting of bronze, smooth on the inner surface and embossed on the outer by running scrolls in high relief. They are penannular and more or less oval in shape, with ends rounded, slightly expanded, and perforated with a circular opening for

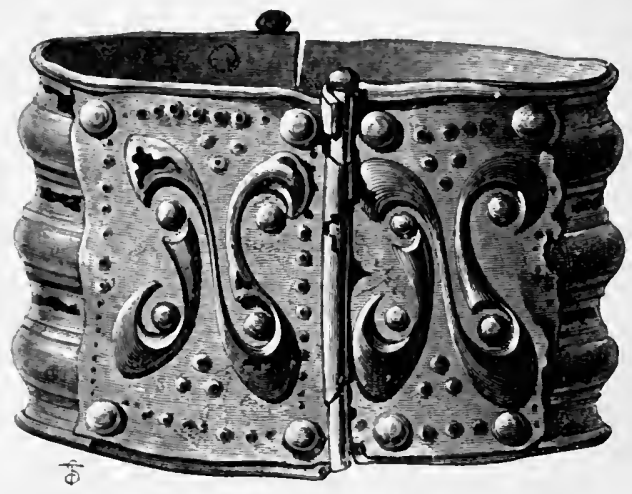

Fig. I56.-Bronse armlet found in the parish of Borgue, Kirkcudbright $\left(\frac{1}{1}\right)$.

an enamel disc. The decoration usually takes the form of three convex and parallel bands ornamented with trumpetshaped elevations, and connected by oblique ridges.

Dr J. A. Smith, who has written an elaborate account of these remarkable armlets, ${ }^{2}$ recognised some differences in their ornamental details sufficient to entitle him to classify them into two varieties, which he distinguishes as the "oval" and the "spiral" patterns. In the former the outer band is a continuous link which closely surrounds the central band,

${ }^{1}$ Archrologia, vol. 2S, p. 435.

2 I'roc. Soc. A. Scot., vol. xv. p. 316. 
except at the vacant end spaces (fig. 157). In the other "the design is a spiral starting from one side and passing round the opposite medallion, then recurved back and passing
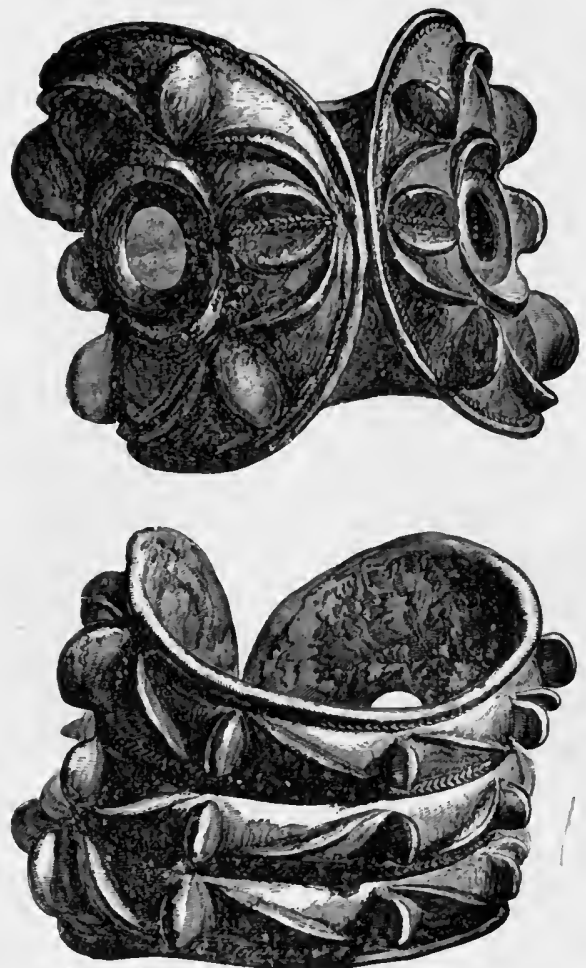

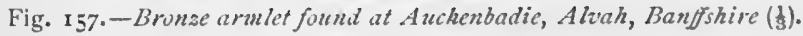

round the other medallion and then back again, and terminating as at the other end."

To the latter class the Pitkelloney specimens belong, as well as one of two reported to have been found many years ago at Bunrannoch, Perthshire. Another armlet of this variety was found by a man while digging a field near Seafield Tower, between Kinghorn and Kirkcaldy, in Fife (fig. 
I 58 ). To the same group also belong some fragments of an armlet preserved in the Perth Museum, as well as the only specimen discovered out of Scotland. This tatter was found near Newry, Co. Down, Ireland, by a man digging into a
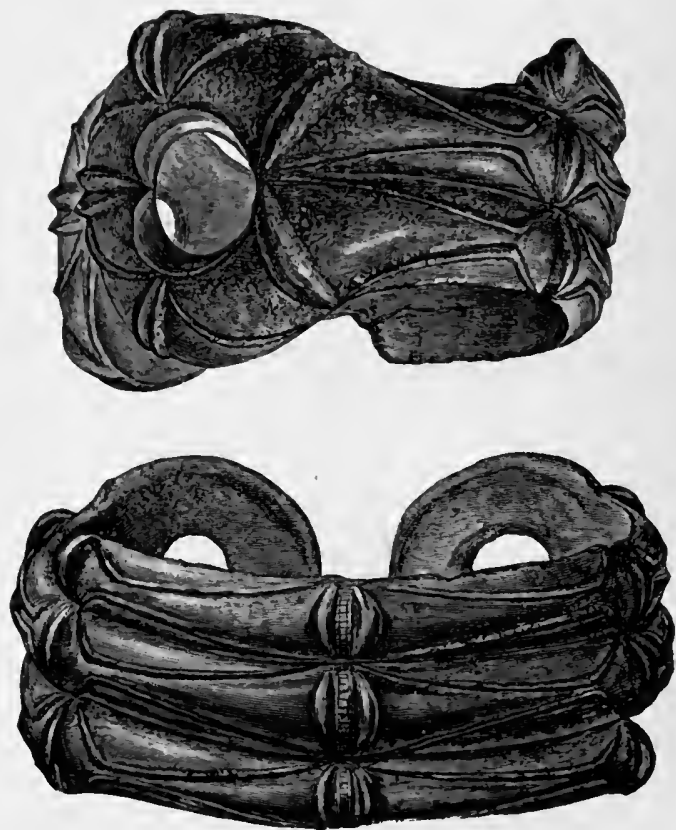

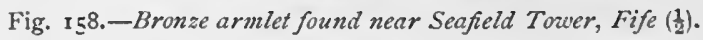

bank of earth, and is now in the Museum of the Royal Irish Academy.

Specimens of the oval pattern have been found in the following localities : a pair was discovered in an earth-house in the garden of Castle-Newe, Aberdeenshire (fig. I 59); one was ploughed up in a field on the farm of Mains of Auchenbadie (fig. I 57), parish of Alvah, Banffshire, and presented to the National Museum in 1864. A pair was found about 6 feet under the surface on the links of Drumside, parish of 
Belhelvie, Aberdeenshire. Three were found near Aboyne, while ploughing ground which apparently had not been before broken up. But perhaps the most important discovery was in 1876 . Mr Lindsay, the tenant of the farm of Stanhope, Peeblesshire, while searching for a rabbit beneath a
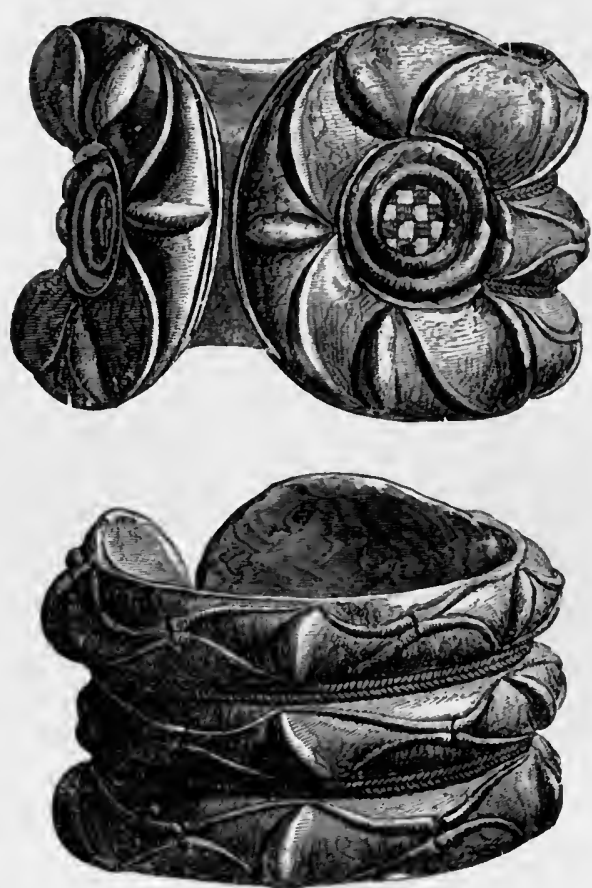

Fig. 159.-Bronze armlets found at Castle-Nenve, Aberdeenshire (5\%/4 inches in greatest diameter).

large flat stone, found an armlet, of the kind now under discussion, which is of special significance, inasmuch as it was associated with two other bronze relics--viz., a buckle and a Roman saucepan.

The spiral variety of these armlets is regarded as a transition link between the oval pattern and the spiral snake-like 
armlets, which are of the same style of art but showing a more decided zoomorphic character. A magnificent armlet of this latter class was picked up in 1827 on the Culbin sands. Another was found as long ago as 1732 at Pitalpin, near Dundee, but unfortunately no history of the discovery has been transmitted - a remark which applies to a third example now in the National Museum. With regard to a fourth, however, the circumstances of the discovery are most

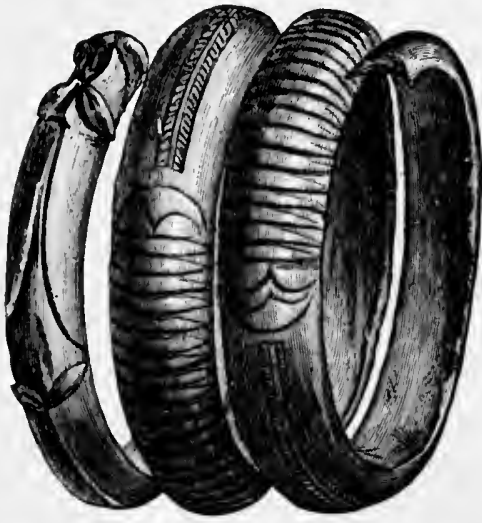

Fig. 160.-Bronse spiral armlet jound at Grange of Conan, near Arbroath (23/8 inches internal diameter). instructive (fig. I60). It was found in an earthhouse at Grange of Conan, near Arbroath, a fact which brings it on the chronological horizon of the massive bronze armlets, a pair of which, as already mentioned, was found in a similar underground dwelling at CastleNewe, Aberdeenshire. Dr J. A. Smith, in his description of the snake-like armlets, ${ }^{1}$ conmments on it thus: "It is of the same general form and style of ornament as the others, - a snake-like creature, terminating in zoomorphic or conventional style of head at each of its extremities, with well-marked transverse lines crossing the body, the rest being ornamented by a double cord pattern running along the centre of the spiral band, in a groove, towards the heads; where there are also longitudinal and stronger oblique and transverse projections or terminal ornaments." This specimen has one of the heads

1 Proc. Soc. A. Scot., vol. xv. p. 350. 
broken off, but in all other respects it has the special characters of the group. In the same locality were found the following objects: a bronze ring $3 \frac{1}{4}$ inches in diameter, a needle of bronze 2 inches long, some broken stone and earthen ressels, bones of animals, \&c. To this class may also be assigned the fine bracelet (fig. $16_{1}$ ) found at Barhullion, Wigtownshire, and included in the valuable collection of

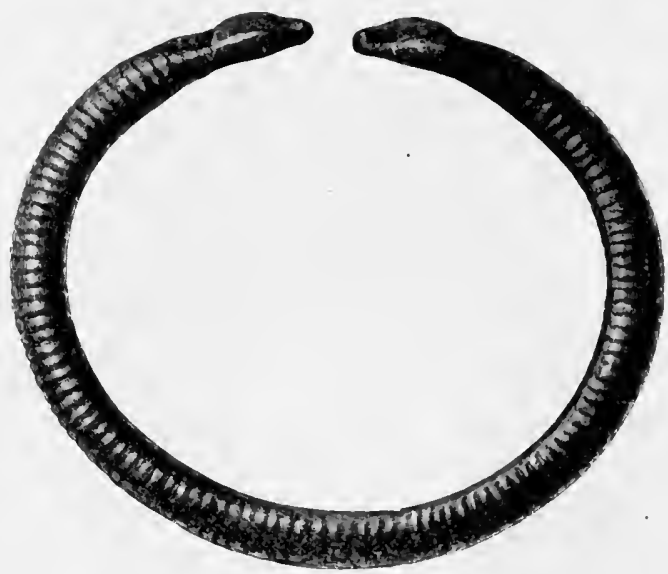

Fig. 161.-Snake-headed armlet from Barhullion, Wigtononshire (t).

antiquities presented to the National Museum by Sir Herbert Maxwell. ${ }^{1}$

Harp-shaped and other characteristic fibulæ of the Late Celtic period have been occasionally met with both in Britain and Ireland. Three from the latter country are engraved in 'Horre Ferales' (Pl. xxi. figs. I-3), and others in Wilde's Catalogue of the Royal Irish Academy; of which three specimens are here figured (figs. I62, I6 3 , and $16_{4}$ ). One fine example from a Yorkshire barrow, and associated with the remains of a chariot, is figured in 'Crania Britannica.' A

1 Proc. Soc. A. Scot., vol. xxiii. p. I51. 
few have been found in Scotland, and are now preserved in the National Collection-notably two from the valley of the Forth, one of which, found

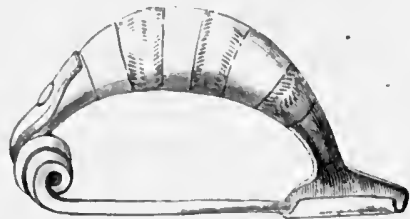

Fig. 162.-Bronze fibula found in lreland (t). near Falkirk (fig. I65), clearly discloses its relationship to Hallstatt types.

Some bowl-shaped bronze dishes were found in one of three graves after inhumation at Birdlip, near Bristol, ${ }^{1}$ which, judging from the objects associated with them, leave no doubt that they belong to this period. A bronze bowl, 9 inches in

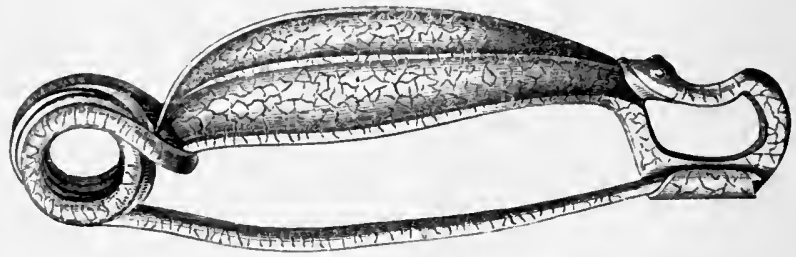

Fig. 163. - Bronze fibula with snake's head found in Ireland (1).

diameter, lay inverted over the face of a skeleton; and among the other contents of the cist were a smaller bowl of bronze,

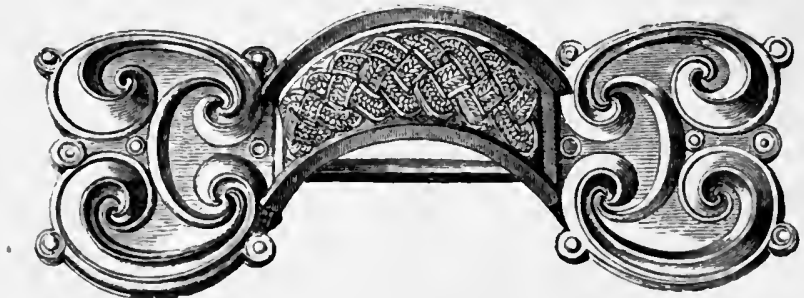

Fig. 164.-Bronze fibula found on crannog of Ardakillen, Ireland (1).

a mirror ornamented with characteristic Late Celtic designs, a harp-shaped fibula of silver plated with gold, a bracelet, a key-

1 Proc. Bristol and Gloucester Arch. Soc., vol. v. p. I37. 
handle, some beads of jet and amber, \&c. The smaller bowl is very similar to one found in the Glastonbury lake-village. In regard to the other bowl which is described as covering the face of the skeleton, it may be of interest to mention that similar instances of covering the head have been noticed in the tumuli of Glasinac in Bosnia. ${ }^{1}$

Late Celtic ornamentation has also been noticed on a series of spoon-like objects found in England and Ireland. A pair of these peculiar objects was found in excavating a quarry at Weston, near Bath; and another pair was disinterred in a railway cutting in the parish of Llanfair, Denbighshire. One

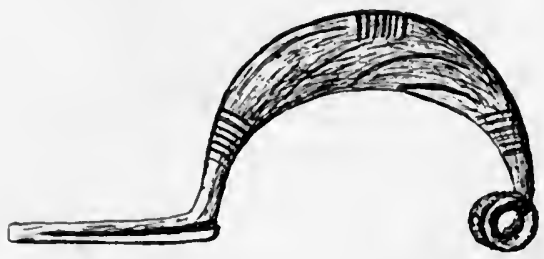

Fig. 165.-Bronae fibula found near Falkirk (?).

found in London is in the British Museum, two found near Cardigan are in the Ashmolean Museum, and two pairs are in the Museum of the Royal Irish Academy. These and others of the kind are described, and their purpose discussed, by $\mathrm{Mr}$ Albert Way ${ }^{2}$ and the Rev. E. L. Barnwell. ${ }^{3}$

Among sporadic finds of Late Celtic art may be noticed a curious ornament of bronze, with inlaid encrinite stem, found in Northamptonshire, and preserved in the Museum of Northampton (fig. I66). To the same period, but probably of earlier date, may be referred the bronze caldrons found especially in Scotland and Ireland. See figs. I-3, pp. 38-4o.

\footnotetext{
1 Rambles and Sudies in Bosnia, \&.c., p. 142 and fig. 37.

2 Arch. Journal, vol, xxvi. p. 52.

${ }^{3}$ Archrologia Cambrensis, vol, viii., 3 rd Series, p. 208, and vol. x. p. 57.
} 

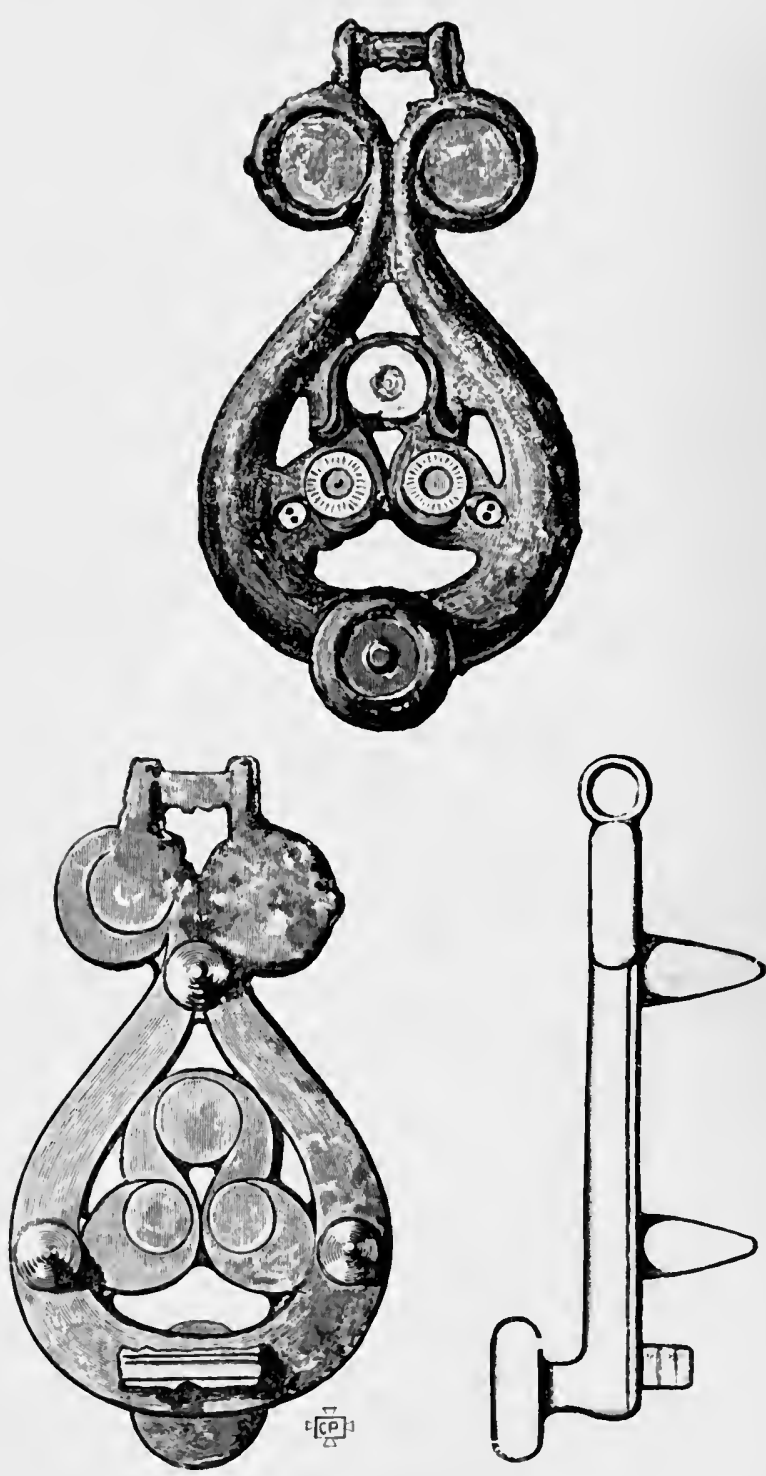

Fig. 166.-Front, back, and side views of a Late Celtic bronze ornament found in Northamptonshive (1). 


\section{Special Finds of the Late Celtic Period.}

Four parcels containing a number of bronze objects wrapped in cloth were turned up in draining a bog half a mile from the manse of Balmaclellan, Kirkcudbrightshire. The drains were from $2 \frac{1}{2}$ to 3 feet in depth, and the objects appear to have been found at the bottom of one of them, associated with an ornamental upper stone of a quernmill (fig. I 67). Among the bronze objects were a circular mirror (fig. I69), 8 inches in diameter, with a handle 3 inches long, and a

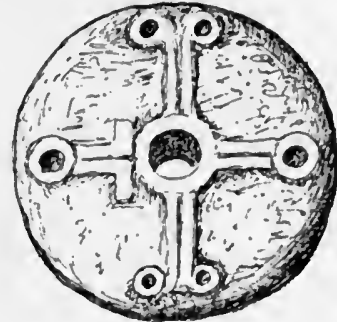

Fig. 167.-Upper stone of a yuern found at Balmaclel. lan, Kirkcudbrightshire (r inches in diameter). number of peculiarly shaped plaques. The lower end of the handle of the mirror contains three semilunar openings,
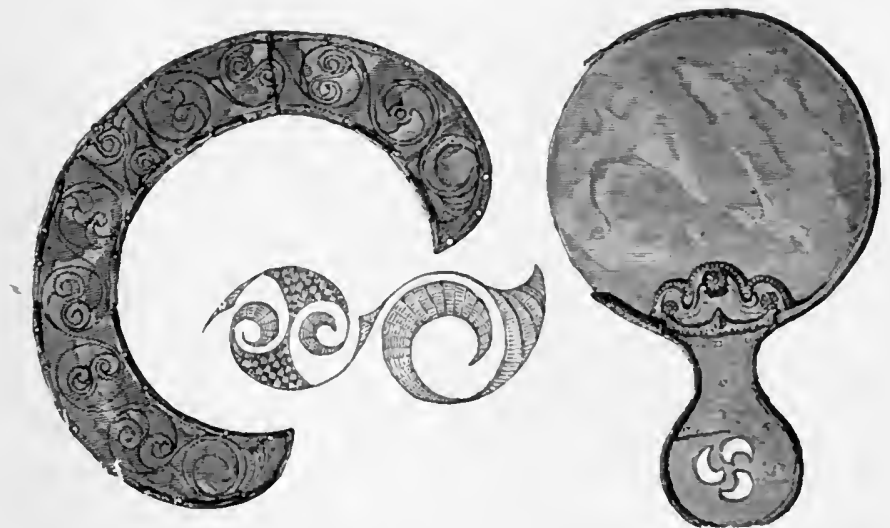

Figs. I68, 169.-Bronse mirror and crescent-shaped ormament, Balmaclellan.

and at its junction with the disc there is a highly ornamented plate (fig. I70). A large crescentic collar-shaped object, 2 inches wide, is decorated with incised scrolls of the 
usual Late Celtic patterns (fig. I68). Of the smaller plaques some are plain bands, others are triangular in shape, with

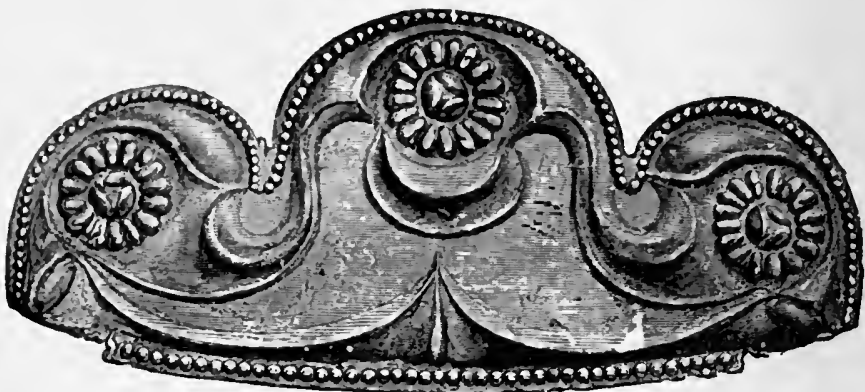

Fig. 170. - Ornamental plate of thin bronse at the junction of the handle to the mirror found at Balmaclellan $\left(\frac{1}{1}\right)$.

one straight and two concave sides, and they contain small holes as if they had been pinned on to something. ${ }^{1}$

A cemetery was investigated in 1865 at Mount Batten, near Plymouth, which yielded

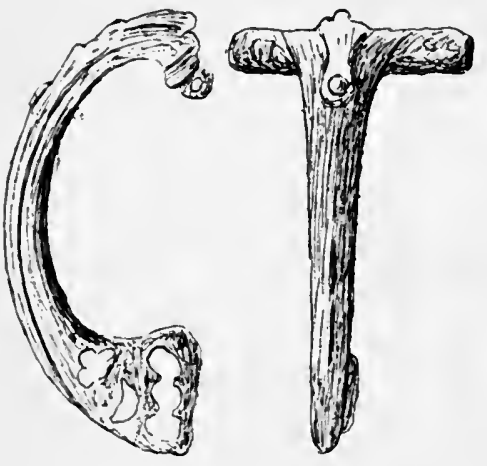

Fig. $17 \mathrm{x} .-$ Back and side vienus of a bronse fibula, Mount Batten, Plymouth ( $\left(\begin{array}{l}2 \\ 3\end{array}\right)$.
Late Celtic remains. The graves were dug to a depth of 4 to $4 \mathrm{I} / 2$ feet, threefourths of which had been excavated in the rock underlying the surface soil. Among the relics found in them were fragments of wheel-made pottery and of glass vessels, bronze ornaments - fibulæ (fig. I $7 \mathbf{r}$ ), armlets (fig. I 72 ), and rings - a pair of iron shears, an iron dagger in a bronze sheath, a bronze mirror 8 inches in diameter, and portions of the handles of other similar mirrors (fig. r 73). The 
back of the mirror had been decorated with engraved designs of spiral scrolls formed by diverging and converging lines, the spaces thus enclosed being filled with hatching. ${ }^{1}$

Another series of graves was encountered in the course of making a road at Trelan Bahow, in the parish of St Keverne, Cornwall, in which similar remains were discovered. In this case the graves were stone cists made of six slabs

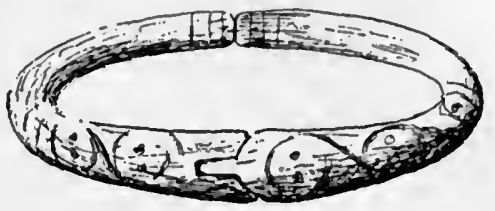

fig. 172.- Bronze armlet opening by a hinge, Mount Batten ( $\left.\frac{?}{3}\right)$. set on edge, one at each end and two on either side, and covered with large stones. In one of these cists a bronze mirror, some rings, fragments of fibulæ, beads of variegated
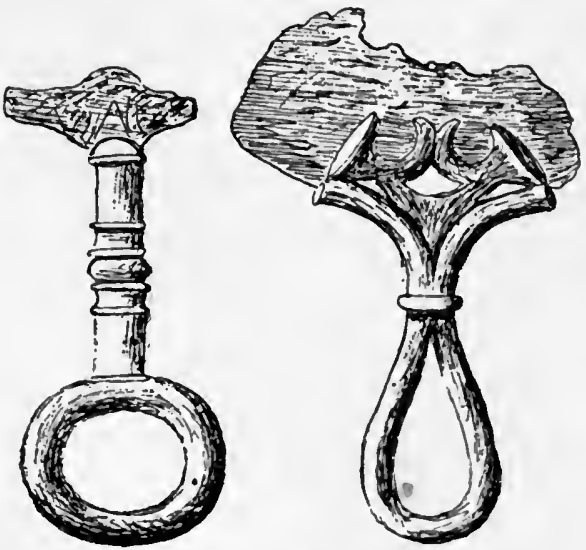

Fig. 173.-Handles of bronse mirrors, Mount Batten (3).

glass, and other ornaments were found. The mirror (6 inches in diameter) retains its handle, and is ornamented on the back with Late Celtic ornamentation of the same style as that on the other mirrors (fig. I 74). ${ }^{2}$

1 Archrologia, vol. 40, p. $500 . \quad 2$ Arch. Journal, vol. xxx. p. $26 S$. 
In 1894 , during excavations on the site of Esica-one of the camps on the Roman wall about half-way between Newcastle and Carlisle-two remarkable fibulæ were found among the rubbish accumulated within the western guard-chamber

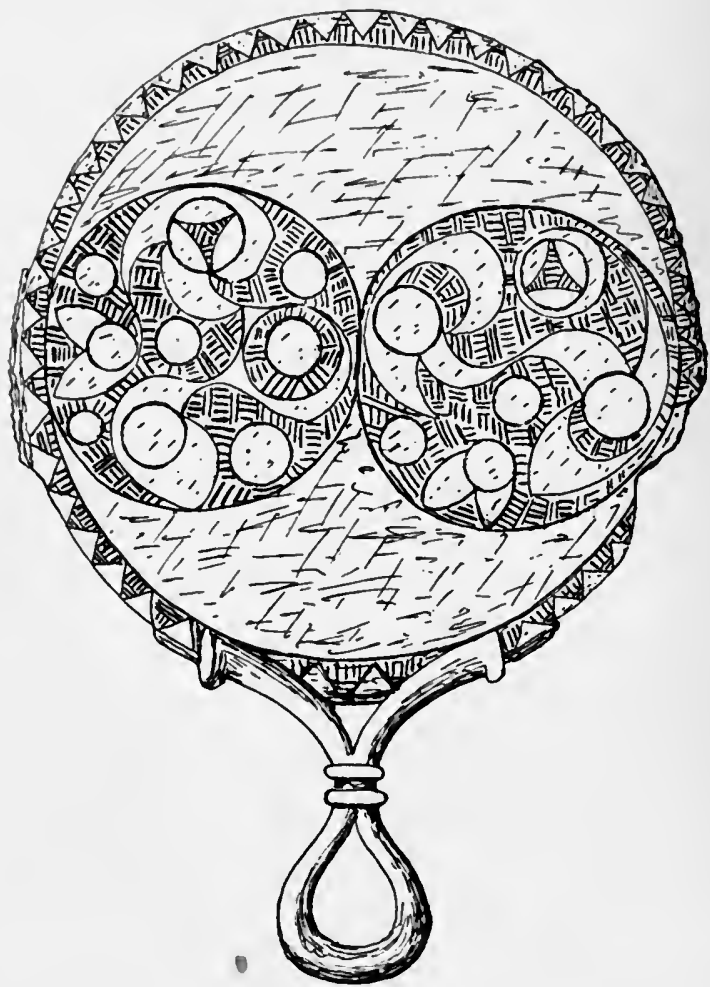

Fig. 174.-Bronse mirror from St Keverne, Cornwall (6 inches in diameter).

of the south gate, which Mr Arthur Evans claims to be products of Late Celtic work of the second century of our era. ${ }^{1}$

To the ready pen of the same author we are indebted for the description of another remarkable hoard found by

1 Archrologia, vol. 55, p. 179. 
a man ploughing near the sea on the north-west coast of Ireland. "The objects, which are all of gold, consist of a small boat with rowing benches and a place for a mast, miniature yards, oars, a grappling-iron, and other implements ; a bowl, apparently intended for suspension from four rings; two chains of very fine fabric; two twisted gold neck-rings, one of them broken; and a hollow gold collar with repoussé work designs, beyond question the most magnificent object of its kind ever discovered." This hoard Mr Evans assigns to the first century of our era." 1

Canon Greenwell ${ }^{2}$ explored a group of four barrows in the parish of Cowlam, Yorkshire, which proved to be of the Early Iron Age, and of about the same period as those previously opened at Arras and Hessleskew, already referred to. These graves and their contents are of extreme interest as showing the method of interment and general culture prevalent in Late Celtic times, of which hitherto no parallels have been found in Scotland. They contained uncremated bodies; and, associated with a female skeleton in one barrow, were a bronze armlet, a fibula, and seventy glass beads of a blue colour with a zigzag pattern in white. The original pin of the fibula, which seems to have been of bronze, had been replaced by an iron pin. In another barrow there was a beautiful armlet like those found at Arras. ${ }^{3}$ All these ornaments belong to types which are represented at Hallstatt or La Tène.

"There was nothing in these four barrows," writes $\mathrm{Mr}$ Greenwell, "to show that they belonged to a period different from that of the ordinary class, so many of which have been already described, except the glass beads, the fibula, and the armlets; the occurrence of the bones of the horse is also

1 Archrologia, vol. 55, p. 397 .

2 British Barrows, p. 20 .

3 See British Barrows, figs, $110-113$. 
unusual, though it has occasionally been met with in the barrows. The bodies were in the contracted position so universal throughout the burials of the wolds; the usual accompaniments of charcoal, flint chippings, and potsherds were found here also ; and, although the pottery was of a different ware from that of which the common cinerary urns, 'food vessels,' and 'drinking-cups' are made, yet $I$ have met with the same kind of hard, well-baked, dark-coloured, plain pottery in barrows of the ordinary kind. The holes, too, were like those which have been so often noticed, except that one had been made use of for lighting a large fire in, and that they contained more animal bones, potsherds, and chippings of flint than perhaps is common. Had the bodies occurred without the necklace, fibula, or armlets, I should not have hesitated the least about classing these four barrows with the other barrows in the immediate vicinity, which were of the time of Stone, or more probably of Bronze, and contained implements of flint and earthenware vessels of the ordinary round barrow type." I

In 1886 , in the course of removing the surface-earth above a gravel and sand pit at Aylesford in Kent, the following relics were discovered: a wooden pail or situla, with a bronze band ornamented with Late Celtic designs; a bronze jug anachố; a long-handled pan and two fibulæ, also of bronze, together with calcined bones and fragments of pottery. "These objects were discovered in what had been a round burial-pit, about $3 \frac{1}{2}$ feet deep, the sides and bottom of which had been coated with a kind of chalky compound. The bronze situla contained burnt bones and the fibula, the bronze vase and pan lying outside it, while around were the remains of several earthenware urns, some of which had been used as cineraries." The discovery, fortunately, came under the

${ }^{1}$ See British Barrows, p. 2 II. 
notice of Mr A. J. Evans, who, recognising the archæological importance of these objects, lost no time in making a full inquiry into the circumstances. The result of his researches was a comprehensive paper "On a Late Celtic Urn-Field at Aylesford," which appeared in $1890 .^{1}$ The conclusion to which Mr Evans comes, after a wide comparison of Continental ceramics, is that the Aylesford urns are "the derivatives of North Italian, and, in a marked degree, old Venetian prototypes."

The ornamentation on the upper of three bronze bands or hoops, which encircled the wooden staves of the pail, was almost identical with designs on sword-sheaths found in Oppidum La Tène, especially the famous one with three fantastic animals, like those so frequently represented on Gallic coins, and so well known to readers of lake-dwelling literature. ${ }^{2}$ The fibula (figs. I 75 and 176 ) were also La Tène types. Another relic found in one of the graves at Aylesford was a double-handled tankard, which, in its art and style of manufacture, can be precisely paralleled, not only with the pail above referred to, but with another tankard (fig. I 77) discovered in a cremation burial at Elveden, Essex. The bronze plates of the latter are ornamented with medallions in repoussé, containing triquetral designs of unmistakable Late Celtic art. But for further details of these remarkable discoveries I must refer readers to $\mathrm{Mr}$ Evans's elaborate article on the subject.

Hunsbury, or Danes' Camp, is situated about two miles south-west of the town of Northampton, on elevated ground commanding extensive views of the surrounding country. Close by it runs an ancient road or trackway connecting

1 Archreologia, vol. 52.

2 See Lee's 2nd ed. of Keller's Lake-Dwellings, Pl. cxxviii., No. 6 ; and Lake-Dwellings of Europe, fig. $\$_{7}$, No. 9. 
it with the camp at Arberry Hill, and othe: British camps. The camp is oval, or rather egg-shaped ( 560 feet by 445 feet), and covers about + acres of arable land, besides the "scarp,
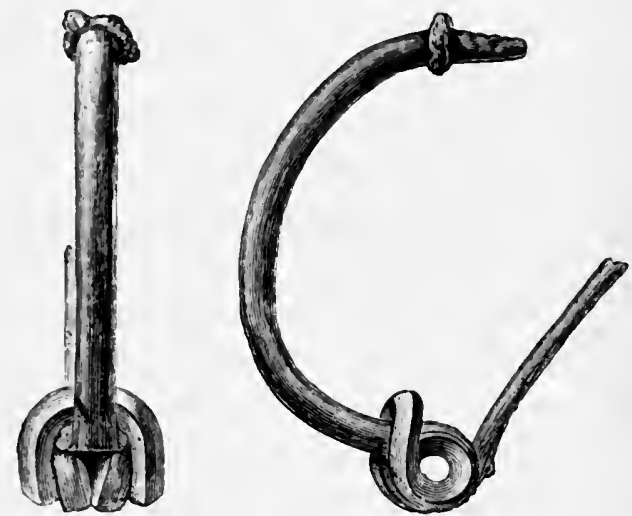

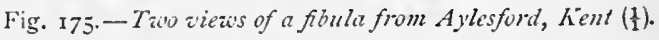

fosse, and counterscarp, which together occupy about $11 / 4$ acre." The ditch is 50 to 65 feet wide, and on an average I 5 feet deep, but it has got filled up to the extent of 5 feet

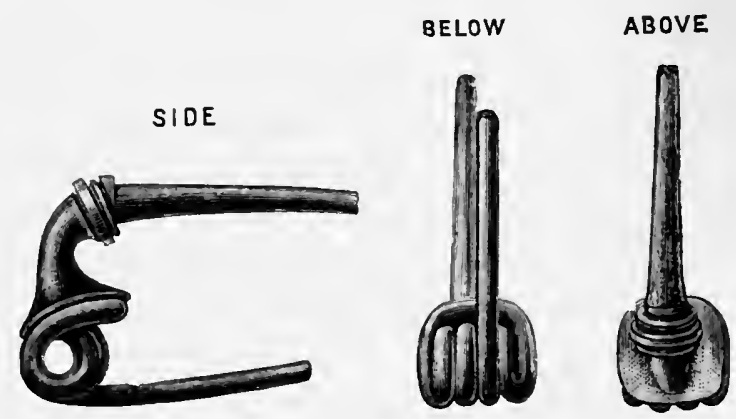

Fig. 176.-Fibula from urn-ficld at Aylesfort, Kent (1).

from its bottom. The dyke, which lies on the inner side of the ditch, looks loftier than it did previous to the excavations, as the ironstone bed, from 10 to 14 feet deep, has now been 
removed from its inner area. It was during this industrial operation that the antiquities hereafter referred to were discovered. Sir Henry Dryden, in his excellent account of these discoveries, with eight plates of illustrations, ${ }^{1}$ thus describes
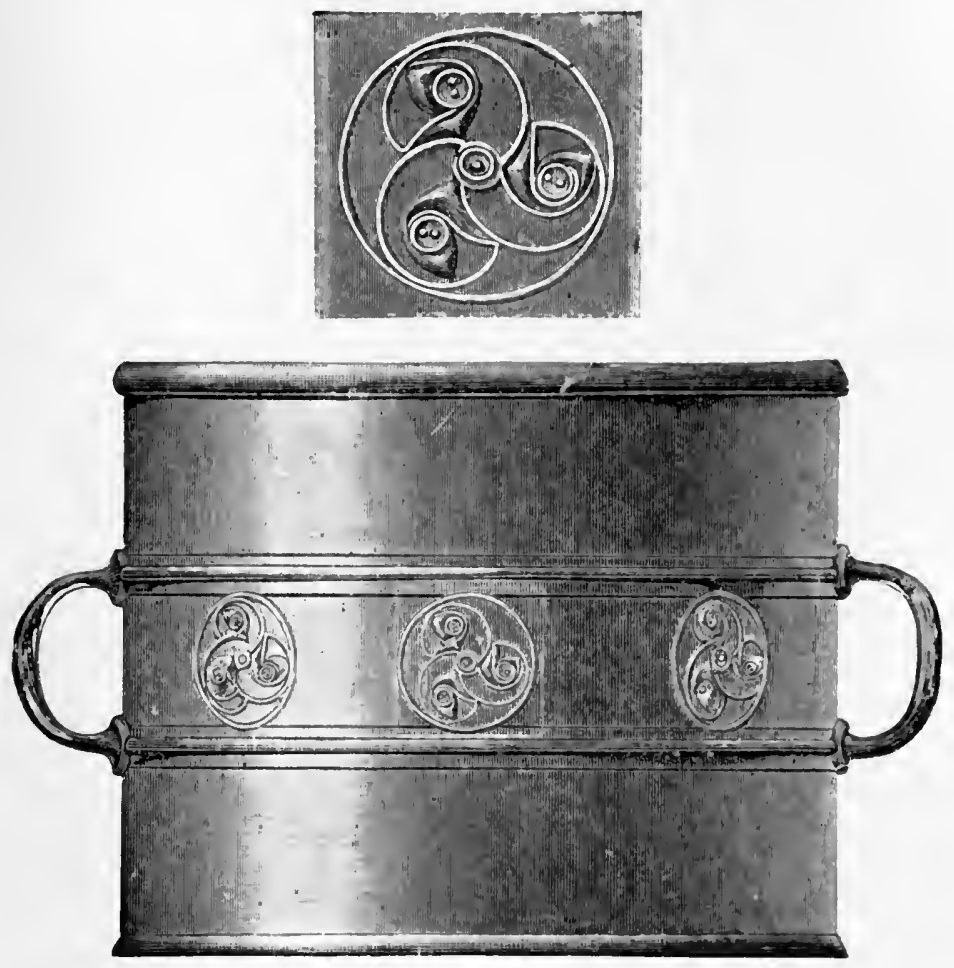

Fig. 177.-Tankard with bronse monting from Elidden, Esse.t (63/4 inche's in diameter $)$.

the circumstances under which the relics were found:-

"Over the whole area of the camp were found, at a few feet or yards apart, pits sunk to the bottom, or nearly to the bottom, of the 6 feet or 7 feet of soil. These pits varied from

1 Associated Arch. Soc. Reports, vol. xviii. pp. 53.6r. 
5 feet to $1 \circ$ feet in diameter, rudely circular in form, and nearly perpendicular as to their sides. They were distinguishable by being full of black mould. In them most of the remains hereafter described were found. In scarcely any instance did they penetrate the ironstone. In all there must have been over 300 of these pits. About six or seven of these pits were walled with small flat stones, chiefly limestone. The enclosed diameter of them was about 5 feet. These pits were evidently for the reception of refuse of various kinds. When a pit had

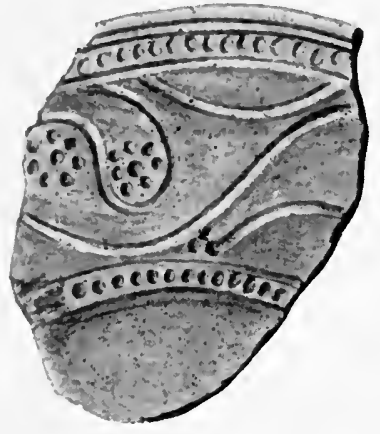

Fig. 178.-Fragment of pottery from Hunsbury Camp (about A). been used for a time it was filled up and another one made; so that only a small portion of those found were open at any one time.

"There is no reason to suppose that the remains found at Hunsbury differ widely in date from each other, and, if so, probably the occupiers were also the constructors of the camp. Unfortunately we have no coins for guides. The pottery is not decisive. The scabbards are of forms said to be Saxon, whilst the ornament is said to be Celtic."

For the privilege of inspecting these antiquities $I$ am indebted to the courtesy of Mr T. J. George, who freely exposed the objects I was interested in. In glancing over the collection, I found it contained fragments of pottery representing a large number of vessels of different forms and sizes-some fragments (fig. I 78 ) having a strong resemblance to Late Celtic pottery from the Glastonbury lake-village - portions of I 50 querns, some charred corn, a few glass beads, bronze fibulie and rings, spindle whorls, long-handled combs, clay 
supports, perforated loom weights and triangular bricks, sawn portions of deer-horn, bone and horn handles, \&c. (fig. I 79). A considerable quantity of bones was found, chiefly in the
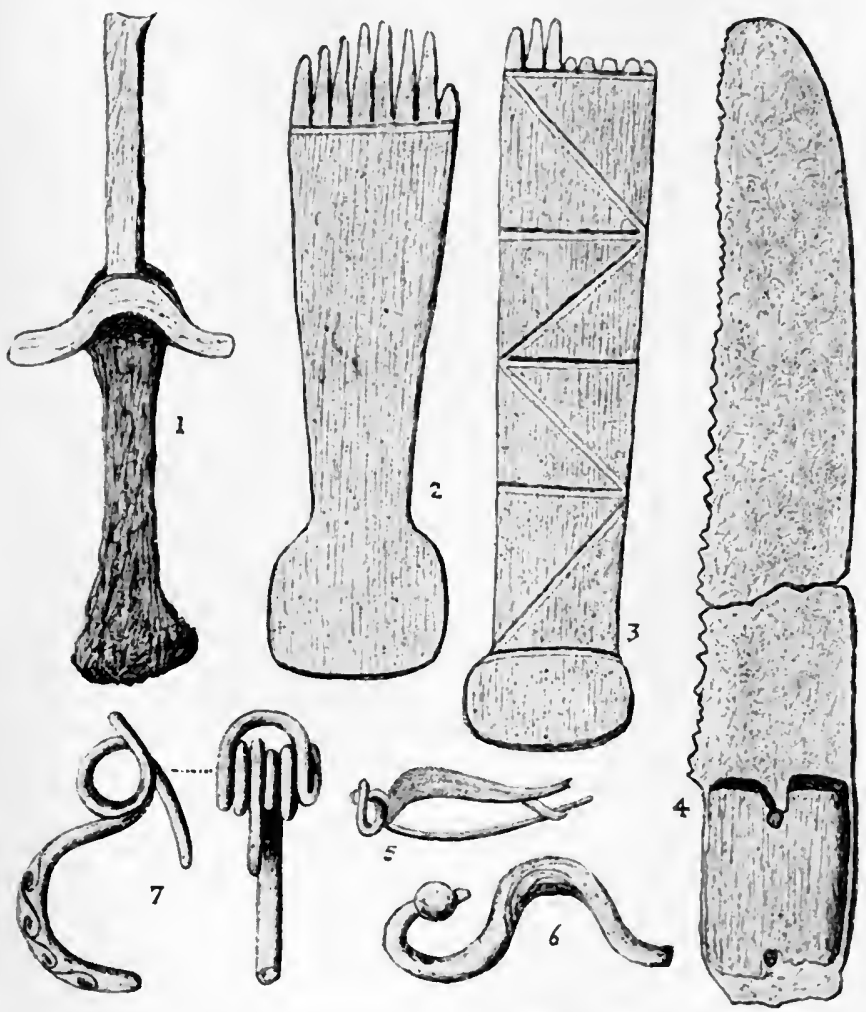

Fig. 179. - Various objects found in Hunsbury Camp, Northampton.

I, Iron dagger; 2 and 3 , Long-handled combs of bone; 4 , Iron saw with portion of handle; 5,6 , and 7 , Fibulie more or less fragmentary (all $\frac{1}{2}$ ).

pits, comprising those of human beings, shorthorn cattle, red and roe deer, goat, pig, and sheep.

Prior to the discovery of the remarkable relics at Lisnacroghera, there were only a few fragments of scabbards recognised in Ireland as belonging to weapons of Late Celtic 
work, among them being two chapes of sword-sheaths, one of which is said to have been found in County Galway. ${ }^{1}$ The relics of special interest from Lisnacroghera consist of four more or less perfect bronze sheaths, ornamented with characteristic Late Celtic designs (fig. I $47^{2}$ ); four iron swords, only one being in good condition (Pl. VI. No. I), $19 \frac{1}{2}$ inches long, and another still in its sheath; an iron spear-head $16 \mathrm{I} / 2$ inches long (No. 3); the bronze knobs

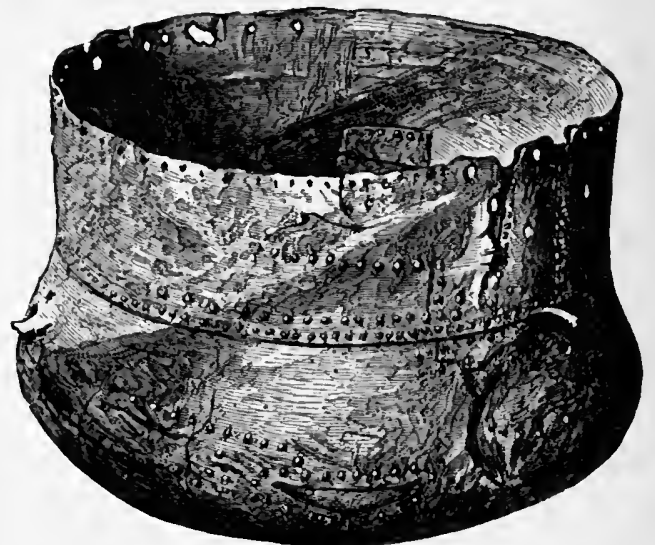

Fig. 180.-Bronze caldron found in Carlingwark Loch.

of seren or eight lance-shafts (Nos. 28, 29, 30) and their ferrules (Nos. 23, 24, 25); various bronze mountings, one ornamented with the triskele and another with the szuastika, supposed to be shield ornaments; also various beads and a coiled bracelet (No. I 5 ).

The only important hoard of the Iron Age as yet found in Scotland was a collection of implements and tools contained in a bronze caldron (fig. I 80 ), which was dredged up in 1866 from Carlingwark Loch, Kirkcudbrightshire. This caldron

'Horx Ferales, Pl. xvii.

2 For designs on the other sheaths, see 'Lake-Dwellings of Europe,' p. $3 \mathrm{SI}$. 

is of the same type as the caldrons previously noticed and. assigned to the late Celtic period, but its clouted appearance would suggest that it had been long in use. In it were found the following articles (fig. I8I): an adze, 7 inches in length
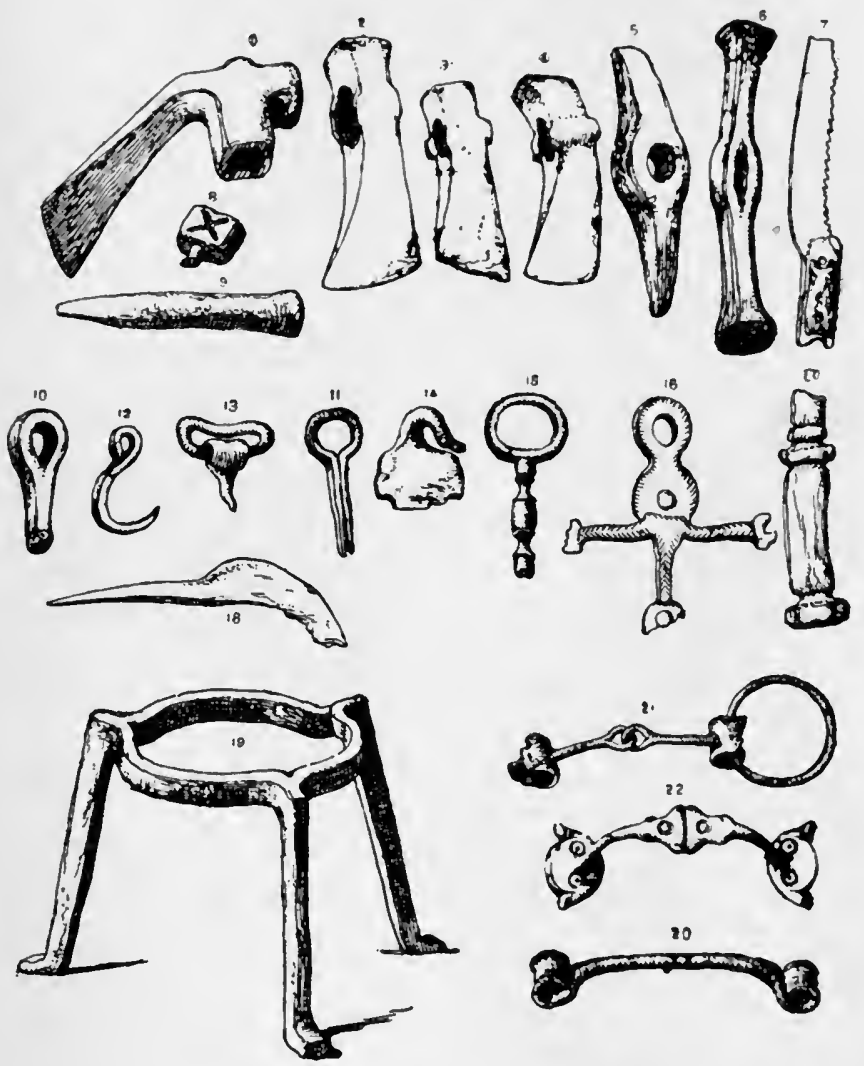

Fig. 181.-Objects in the caldron found in Carlingurark Loch.

(fig. I); three axe-heads, $4 \frac{1}{2}$ to $5 \frac{1}{2}$ inches in length (2, $3,4)$; four small picks or hammers from 6 to $7 \frac{1}{4}$ inches in length (5); a broken portion of a hammer-head, and another with flattened ends (6); portion of a small saw, $61 / 2$ 
inches in length, with part of the wooden handle still riveted to the iron (7); portion of a fine cut saw, $2 \mathrm{x} / 2$ inches long; nine portions of double-edged blades, with pointed extremities resembling sword-points; nails of various lengths, one with a square head and a cross marked on each side (8); a sinall chisel, 5 inches long, and portion of another; three punches about 5 inches in length (9); four split bats with eyes ( 10 and $\mathrm{I} \mathrm{I}$ ); two large holdfasts; six hooks, varying in size from $2 \mathrm{I} / 2$ to 5 inches in length (1 2); an iron buckle (I3); wo handles with loops, apparently of a bucket (14, I 5, and I6); wooden handle (17); an iron implement (18); an iron tripod (19); an iron frame with numerous bars like a gridiron, having two feet, the other two apparently awanting; five pieces of iron handles (20); a snaffle horse-bit, with check-ring 3 inches in diameter (21); a file, $93 / 4$ inches in length; and fragments of iron plates and hoops; portion of a bronze vessel, 4 inches in diameter and 3 inches in height; ornamented bronze handle (22); portions of chain-mail formed of small rings; portions of green glass-one piece, 3 by 2 inches, has in relief the letters $\mathrm{A}$ and $\mathrm{I}$, which may be a portion of M or some other letter. ${ }^{1}$

Among objects which do not readily fall under any system of classification may be mentioned an ornamental bronze ball (fig. 182 ) found in Lanarkshire. Its surface is divided into six discs, each of which is decorated by a spiral groove with a zoomorphic ending, and separated from each other by deeply hollowed grooves. This object is usually paralleled with the ornamented stone balls previously noticed.

In casting the eye over the distribution of Late Celtic remains, as shown in the previous sketch, the following deductions may be noted :-

I. The presence of querns and long-handled combs in ${ }^{1}$ Proc. Soc. A. Scot., vol. vii. p. 7. 
the Glastonbury lake-village and in the Hunsbury camp, associated with the debris of continued occupancy in which no characteristic Roman remains are found, points to a preRoman civilisation probably due to an immigration of Belgic or Gaulish tribes.

2. Such relics (querns and long-handled combs) are found in crannogs and brochs in North Britain associated with sporadic remains of both Late Celtic and Roman civilisations, thus indicating a later or post-Roman date.
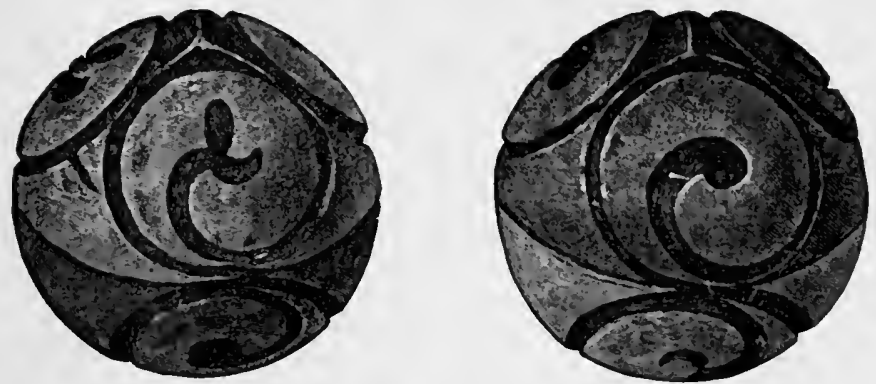

Fig. 182.-Bronze ball found at Walston, Lanarkshire (1).

3. Objects characteristic of the Late Celtic civilisation in Southern Britain, such as enamelled horse-trappings, articles of military equipments, mirrors, brooches, bracelets, and torques, are but sparingly found in Scotland and Ireland. And as no settlements or cemeteries of the period have been found in Britain farther north than Yorkshire, nor in any part of Ireland, it is suggested that the products of this special culture and civilisation spread to these regions by means of commercial and social intercourse, rather than by an immigration of a new race. 
CHAPTER VIII.

THE ABODES AND MEMORIALS OF THE DEAD.

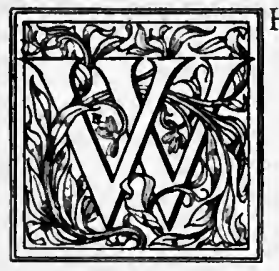

HEN man's thoughtfulness reached the stage of his being able to realise, by the power of reflection and experience, that physical death is the fate of all living things, nothing seems more natural than that he should come to regard the mysterious manifestations of his material surroundings as the work of the shadowy agents of an unseen world, the reality of which was so forcibly and frequently brought before him in dreams and other psychological phenomena. In the supernatural system thus conjured up, the momentous termination of his own earthly career became the central pivot of a religious cult which presaged the continuation of his spiritual existence-his alter Ego or ghost-in the world of spirits. The idea that death was a severance, for ever, of all social ties and friendships formed on earth would be, probably, more repugnant to Neolithic man than to some of the philosophical minds of the present day. To him, death seems to have been nothing more than the mere portal which conducted into the community of departed heroes and friends, and to which he looked forward, across the span 
of human life, with hopeful anticipations of a more perfect state of existence. When, and by what means, this higher phase of humanity, which led him on to the rails of religiosity, assumed the mastery over the mere animal propensities which he inherited from the organic world, are questions which it would be out of place here to discuss. But, whatever these influences and moulding agencies may have been, we have strong presumptive evidence for believing that when prehistoric man first appeared within the geographical limits of what is now called Scotland, he was in the true sense of the word a religious being. Already his belief in the supernatural and in his own future destinies had powerfully moulded his conduct in life. When a great man died we have reason to believe that his favourite wives, slaves, and pet animals were sacrificed on his grave so as to accompany him in his journey to the future world. His weapons, ornaments, and other cherished objects, as well as suitable viands for the journey, were laid in his tomb - all of which facts are incompatible with any other theory than that it was then the current opinion that life in the world beyond the grave varied little from that on earth. Consequently, in actual life the abodes of the dead came to be of far more importance than those of the living. In support of this we have the singular fact that whilst hundreds of the former are found scattered over Europe, there are but the faintest indications of the latter. The houses, generally built of such perishable materials as wood, turf, or clay, soon crumbled into dust. On the other hand, the tomb was constructed of the most durable materials, and placed on an eminence, so as to be seen from afar, and to be a lasting memorial among succeeding generations. Thus we see prehistoric man inspired with hopes and convictions which carried his mental vision beyond the affairs of this life. The grave was, therefore, to a large extent, a reflex of current 
civilisation, and, as a tribute of respect to the departed, there were occasionally deposited in it the choicest art products of the age. The most natural method of protecting the remains of the dead, and of commemorating their deeds while in life, was by rearing a mound of stones or earth over the grave. To this custom we owe some of the most striking and lasting monuments in the world's history-the pyramids of Egypt, the topes and dagobas of India, the mighty mounds of Silbury and New Grange, the megalithic circles of Stonehenge, Avebury, and other hoary monuments which are so abundantly found scattered on the outskirts of Western Europe from Scandinavia to Africa.

Sepulchral memorials are found under such varying conditions, as to structure and composition, that it is difficult to appropriate their physical characters as a basis of description. Another element which adds to the difficulty is the custom of cremation, which appears to have spread over the British Isles towards the close of its Stone Age, and to have initiated considerable changes in the manner of disposing of the dead. The body, reduced to a few handfuls of ashes and burnt bones, was sufficiently preserved in a clay urn, there being no longer any necessity for constructing great chambers. Hence sprung up a tendency to diminish the size of the abodes of the dead, even by those who still adhered to the earlier method of burial by inhumation. Some of the problems thus raised will be subsequently discussed. All I wish at present to emphasise is, that we have indisputable archæological evidence to show that, during the whole of the Bronze Age, both methods of disposing of the dead were practised within the British Isles apparently at the same time.

Burials may, therefore, be classified in various ways, as, for example, according to whether the body had, or had not, been cremated. The unburnt body was deposited, either within a 
chamber constructed of stones and covered by a cairn or mound, leaving a permanent passage for future access to the chamber; or in a stone cist, without an accessory passage, generally formed of slabs set on end, but only of dimensions sufficiently large to admit of the body in a doubled-up position, and then covered over with a mound of stones or earth; or in a wooden coffin formed out of the trunk of a tree, similar to a dug-out canoe; or simply in the bare earth, without any protecting envelope between it and the materials of the mound ; or, indeed, without a mound at all or any other external indications to mark the site.

On the other hand, when the body was cremated the remains were usually placed in an urn, and deposited sometimes in a chamber, sometimes in a cist, and sometimes in the bare earth. When no urn was used the incinerated remains were generally laid in a little heap, either in a chamber or on the floor of the tumulus.

The external form of the mound or barrow has also given rise to a number of qualifying epithets, such as long, round, oval, or bell-shaped barrow, \&c.

Burial mounds, it may be noted, are called cairns when their material consists of small stones, and barrows when it consists of earth; but not unfrequently both materials were used in combination-a small cairn being often inside the earthen mound. Sometimes the mound was surrounded by a ditch, or a stone circle, or both; and instances are on record in which one or both of these features were found within the area covered by the mound. Also an interment, whether by inhumation or cremation, may be found beneath the natural surface without any superincumbent mound, or any surface indications whatever. At other times, when the mound or cairn is absent, a standing stone, or a circle of stones, or a ditch, may indicate the site of a burial. 
The theory that long and round barrows contain respectively the remains of a long-headed and a round-headed race, which somehow has taken a singular hold on the minds of archæologists since Dr Thurnam's time, seems to me too fanciful to have much significance attached to it. The idea appears to be based on an observation which has been fairly well established as a fact-viz., that the skulls found in long barrows in England are those of a long-headed, or dolichocephalic, race (i.e., when the antero-posterior diameter stands to the transverse diameter in the proportion of about I 00 to 75 or less), which preceded a brachycephalic race (i.e., when these diameters are as 100 to 76 or more). But this is a mere coincidence arising from the structural characteristics of the grave, which, being generally a compound chamber, necessarily assumed an elongated form. These megalithic chambers could only be made of a certain breadth, not exceeding the length of stones available for covering them, and hence extension of the sepulchral chamber was most conveniently attained by adding to its length. The shape of the chamber generally determined the form of the barrow; but whatever that might be, the skulls were usually those of the long-headed race. In chambers with cremated burials there are, of course, no means of determining the craniological characters of the race. At any rate, the idea cannot for a moment be entertained that, in the construction of their sepulchral abodes, these people were in any way influenced by the shape of their heads, for in that case there would be no round barrows at all, as there is not, and never was, a human race with actually round heads. Nor is it a fact, as we shall afterwards see, that dolichocephalic and brachycephalic skulls are confined to long and round barrows respectively. The probability is that the constructors of dolmens and other chambered cairns, being the first on 
the field, continued their sepulchral methods after they were joined by other races practising different methods, such as cremation, and that consequently a certain amount of intermingling of the various systems took place.

As a rule the size of the mound, as well as the value of the grave-goods, was in proportion to the distinction of the individual. This deference to social position accounts for the occasional isolation of sepulchral memorials, some of which may be seen here and there on conspicuous eminences commanding extensive views of the surrounding neighbourhood. But, more frequently, cairns and mounds are found grouped together in the form of cemeteries, among which those representing persons of distinction may be recognised by their greater dimensions.

Thus, the concomitant circumstances through which we have to investigate the abodes of the dead are various, making it extremely difficult to trace any chronological sequence in their structural characteristics, independent of the character of the grave-goods. And this difficulty is increased by the overlapping of different customs of burial due to the persistence of old methods in some out-of-the-way localities. Before, therefore, proceeding further with the general discussion on sepulchral remains, it will be necessary to give a few descriptive details of the characteristic methods of burial found within the Scottish area.

In 187 I Dr Angus Smith ${ }^{1}$ explored a large chambered cairn on the farm of Achnacree, in the vicinity of Loch Etive. The cairn appeared to have been interfered with at some former time, when some of its stones had been removed and possibly an entrance to the chamber effected; but, as it then stood, it was nearly circular in form, and measured 75 feet in diameter and 15 feet in height. A hole was dug from the 1 Proc. Soc. A. Scot., vol. ix. p. 396. 
top until a large stone was reached, which proved to be one of the roofing stones, and thus an entrance was effected. The interior consisted of a passage, 28 feet long, 2 feet wide, and $31 / 2$ feet high, extending in a southward direction. Continuous and in line with this passage were three compartments, separated by walling, but connected by low doors. The first measured 6 feet in length, 4 feet in breadth, and 7 feet in height. Its lower part was constructed of massive slabs set on edge, and above this was dry-stone walling converging, on the beehive principle, till the diminished space ( 3 feet 4 inches by I foot 10 inches) was closed in by one large coverstone. The other two compartments were smaller, and

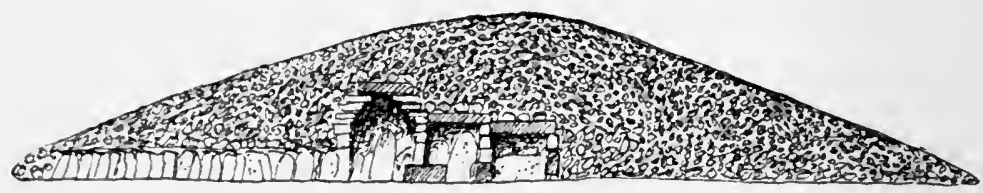

Fig. 183.-Section of the cairn of Achnacree ( 75 feet in diameter).

covered over by lintels, as shown in the accompanying section (fig. $18_{3}$ ). On the floor some fragments of urns and several groups of white pebbles were found. ${ }^{1}$ One urn was nearly entire, and measured 7 inches in diameter and 4 inches in depth. Its substance was hard, well baked, and of a darkish colour, and presented the peculiarity of having a wide mouth and a round bottom. Faint traces of perpendicular fluting were to be seen on its surface, but otherwise it had no ornamentation. These vertical scorings were more decided on some of the other fragments, all of which appear to be portions of vessels having round bottoms. One standingstone close by suggested that the cairn had originally been

1 On the occurrence of white pebbles in graves see a paper by Sir Arthur Mitchell (Proc. Soc. A. Scot., vol. xviii. p. 286). 
surrounded by a stone circle, and about 30 feet beyond there were traces of an encircling ditch.

A circumscribed district of Argyllshire, situated on the border of the Crinan Canal and including the parishes of Kilmartin and Kilmichael, is one of the richest in Scotland in prehistoric remains. Here are to be found several groups of standing stones, some bearing cup-marks and concentric circles; various rock-surfaces sculptured with similar symbols; numerous sepulchral cairns, stone circles, and cists with and without external mounds; a vitrified fort, \&c. In 1864 Canon Greenwell, the distinguished author of 'British Barrows,' explored several of the more prominent antiquities of this district, ${ }^{1}$ among them being a large and very remarkable cairn on Largie farm, situated about 300 yards north-east of one of the series of standing stones. Originally this cairn was very large, having a diameter of 134 feet; but the greater part of the stones had been removed for making drains and walls many years ago, during which three cists were partially laid bare. These cists had been constructed in the usual way, by slabs set on edge with a large stone cover, and placed at considerable distances from the centre. In one of them there was found a globular urn, highly ornamented over the whole of its surface, except the bottom, and measuring $33 / 4$ inches high, $41 / 2$ inches wide at the mouth, and $51 / 2$ inches at the middle; but there were no remains of the body, "which had, no doubt, been an unburnt one."

The chief interest of the investigation lay in a chamber, divided into four compartments, which occupied the centre of the cairn ; but whether or not it had an accessory passage was not ascertained, owing probably to its then dilapidated condition. It measured 19 feet in length, $33 / 4$ feet in breadth, and $9 \mathrm{I} / 2$ feet in height, and had its long axis directed nearly north

1 Proc. Soc. A. Scot., vol. vi. p. 336. 
and south. Its sides were made of large slabs of chlorite schist, with portions of walling of smaller stones, roofed over with long slabs. The south end was entirely closed with one large slab, but the north end had two upright stones placed transversely to the walls of the chamber, forming "a rude kind of portal." The two compartments next the supposed passage had been previously disturbed, as well as the third, which included among its contents some fragments of ornamental urns, " of the so-called 'drinking-cup' pattern," and several bones of unburnt bodies. The remaining compartment ( 6 feet 8 inches by 3 feet 9 inches) and its contents are thus described: "This compartment, like all the rest, was filled to a certain extent with a considerable quantity of stones and rubbish, which had fallen or been thrown in through holes in the roof since the mass of the cairn had been removed. On clearing this out we found a small cist placed in the southeast corner. This, which was $2 \mathrm{x} / 2$ feet long and 2 feet wide, was made of four stones, resting upon another flat one, and had once possessed a cover, which had been taken off, and which was lying by the side of the cist. We found nothing in it, the persons who first rifled the chamber having lifted the cover and thrown out the contents; but I think we may refer some unburnt bones and fragments of pottery, which were afterwards met with, to the burial in the small cist. . . To the north of the cist, and lying close to the side of the chamber, was an urn sadly broken and decayed, but of a very novel and peculiar type, both as regards its material and ornamentation (fig. I 84). It has a round bottom, from the centre of which run shallow and narrow flutings, reaching to the lip, which is broad and thick, and turns over with a convex surface, that also being fluted like the side. The ware is dark-coloured, almost black, like some of the Anglo-Saxon pottery, well worked and thin, with no 
broken stone amongst the clay, but apparently with a good deal of sand worked into it. It is $6 \mathrm{~J} / 4$ inches high, I $23 / 8$ inches wide at the mouth, the rim being $1 \mathrm{I} / 4$ inch wide. From the way in which this urn was deposited amongst the undisturbed layer of dark earthy matter and burnt bones, I cannot hesitate to attribute it to the primary interment, novel as its type is, and though it partakes much more of a late than of an early character. The introduction of the secondary interment and of the small cist had probably

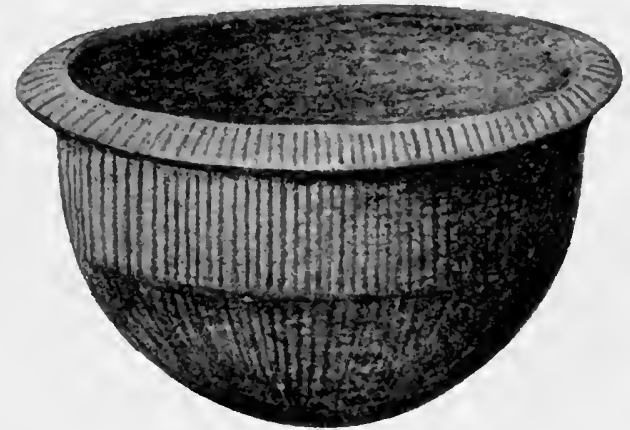

Fig. 184,-Urn from a chambered cairn at Largie, Kilmartin, Argyllshire (61/4 inches in height).

caused it to be broken, but it had certainly been deposited as a whole vessel at the time when the layer of dark matter was placed in the chamber." 1

In commenting on the archæological facts disclosed by the Largie cairn, Canon Greenwell thus expresses himself: "We learn from it that, in this part of Scotland, at all events, the earliest interments in the large megalithic chambers are of burnt bodies. The original and undisturbed layer, with burnt bones in it, at the bottom of the two most southern compartments-the only ones which contained any primary

1 Proc. Soc. A. Scot., vol. vi. p. 342. 
burials-proves this most distinctly. The examination of the similarly constructed chamber in a cairn at Kilchoan, by my friend the Rev. R. J. Mapleton, of which a detailed account is appended, has produced very strong corroborative evidence of this. The remains of unburnt bodies which were found in this chamber in the cairn at Largie farm, and also in that at Kilchoan, belong most unquestionably to a later, it may be to a considerably later, period than the deposits of burnt bones in the same chambers. These unburnt bodies belong most probably to the same period as that during which the corpse was frequently placed in a cist sunk below the surface of the ground, and where apparently no mound was ever raised over it. With these interments were buried beautifully made urns, and in some cases bronze daggers, and of such cists numerous examples have been found in the district."

Another cairn, explored by Canon Greenwell, on the glebe land of Kilmartin, measures $\mathrm{I} / 0$ feet in diameter and $13 \mathrm{I} / 2$ feet in height. It was made entirely of rolled stones, with occasional slabs of the schist of the neighbourhood, and contained within its area two concentric circles of standing-stones, the inner 27 feet, and the outer 37 feet in diameter-the latter being about 16 feet from the centre of the cairn. Within the central area there was a short cist composed of four slabs set on edge and a fifth lying over them as a cover. The interior of the cist was nearly filled with gravel, and in it were found a highly ornamented globular urn with four pierced ears, and a necklace of jet beads which lay above the urn; but all traces of the body had disappeared. This, however, was not the primary interment, but another cist formed in a hollow sunk in the ground in the centre of the cairn and lined with rounded boulders, and having a large slab of schist ( 9 feet by 4 feet 7 inches) for its cover. This cist, which was $71 / 2$ feet long, 3 feet wide, and 3 feet 
deep, was filled to within a foot of the cover with gravel. "At the south-west end was a flat stone laid across the cist about a foot from the bottom, and upon this was a quantity of black unctuous matter and charcoal. About a foot from this stone, on the south-east side, and 9 inches higher than it, was an urn, much broken and in part decayed, placed amongst the gravel. At the north-east end of the cist was a flat stone, similar to that at the opposite end. Upon it was a small, and below it a large, quantity of dark unctuous
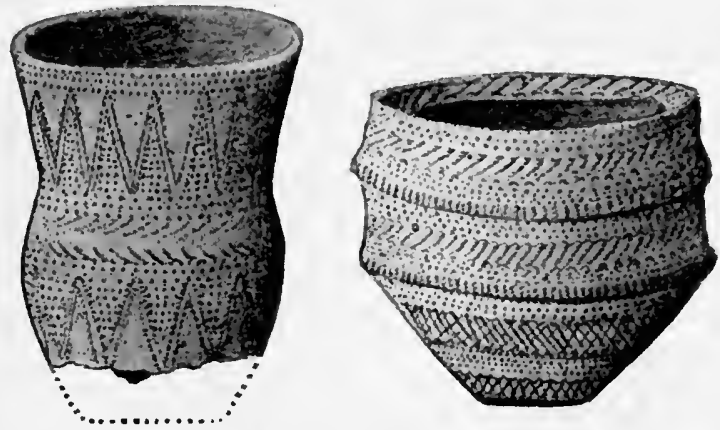

Figs. 185, 186.-Urns found in cists at Ballymenach and Kilmartin, Argyllshire (2).

matter. No trace of bone was found in the cist; the body, or bodies-for it is probable, from the separate masses of unctuous matter, that more than one were interred-had gone entirely to decay, leaving no further trace than the dark substance which was found upon and under the flat stones. The urn (fig. I 86) is one of a type similar to many of the Irish urns, and is very characteristic of those which have been found with unburnt bodies, and sometimes with bronze daggers, in this part of Scotland." 1

Another interesting exploration, conducted under the supervision of the same investigator, was that of the sepulchral

${ }^{1}$ Proc. Soc. A. Scot., vol. vi. p. $34^{\circ}$. 
circle at Ballymenach. This circle consists of an earthen mound with stones placed on it at intervals, and having a ditch within it. It measures 66 feet in diameter inside the ditch, and 95 feet to the outside of the mound, and has two entrances on opposite sides. Two cists were found within the circle, one south-east of the centre and the other nearer the centre. The former was a short cist formed of four side stones and a cover (previously removed), and contained some mixed sand and gravel, above which were the broken remains of an urn of the "drinking cup" type (fig. 185). The other cist was much larger, the side stones being 9 feet long. A portion of the cover had been broken off at some former period when the cist was probably rifled, as nothing was found in it.

Canon Greenwell suggests that facts disclosed by these investigations indicate that there was an early relationship between the people of Argyllshire and the neighbouring coast of Ireland. "The urns," he writes, "which occurred in the cairns and burial circles are, in shape, material, and style of ornament, very similar to those which have been found on the opposite coast of Ireland, and from this it may be inferred that the two countries were, in prehistoric times, occupied by the same race. That a constant intercourse was kept up between the two shores is evidenced by the Argyllshire implements, which are made from a chertose flint coming from Ireland. The identity of the people who inhabited the west of Scotland and the north-east of Ireland, in historic times, is certain, and that can scarcely have altogether arisen from the later Scotic occupation from Ireland, which was indeed only the migration of tribes to places already occupied by others related to them. This earlier and prehistoric relationship is quite borne out by the evidence which the burial mounds afford." 
We now pass on to another remarkable series of sepulchral cairns, whose special peculiarities were first clearly brought to light by Dr Joseph Anderson. ${ }^{1}$ An excellent résumé of these investigations is given in 'Scotland in Pagan Times,' pp. 229-268. The situation and general appearance of two of these cairns are thus described: "On the crest of a considerable eminence overlooking the south end of the loch of Yarhouse, on the estate of Thrumster, in Caithness, are two cairns of great magnitude within a short distance of each other. They are not circular, but elongated in form ; they lie across the crest of the hill from east to west; they diminish in breadth and height from east to west; and they have at both ends curved horn-like projections of their structure, falling gradually to the level of the ground."

The larger of the two cairns was 240 feet in length, and 12 feet in height at its east end, with a base configuration as outlined in the accompanying plan (fig. 187). The chamber, which was reached at the end of a short passage, was found to be small in proportion to the gigantic size of the cairn, being only 22 feet long by 6 feet wide. The roof had fallen in, but the side walls, to the height of 7 feet, still remained, and showed signs of convergence indicating a beehive structure. The ground-plan of the chamber was roughly quadrangular, and divided into three compartments by two pairs of divisional stones projecting from the side walls, and leaving a passage of about 2 feet between their edges. These divisional stones did not reach the roof. The most novel feature of the investigation was the discovery that the cairn had originally been constructed with a well-built double walling of dry stones along its entire perimeter. In some places the foundation stones only were

${ }^{1}$ Proc. Soc. A. Scot., vol. vi. p. 442, and rol. vii. p. 480 ; Memoirs of Anthrop. Soc. Lond., vol. ii. p. 226. 
in situ, but in others as much as 4 feet remained. No relics were found in the chamber, but its floor was a compact mass, about 5 inches thick, of "earthy clay, plentifully intermixed with ashes and charcoal of wood, and calcined bones, in a condition of extreme comminution. Although the amount of

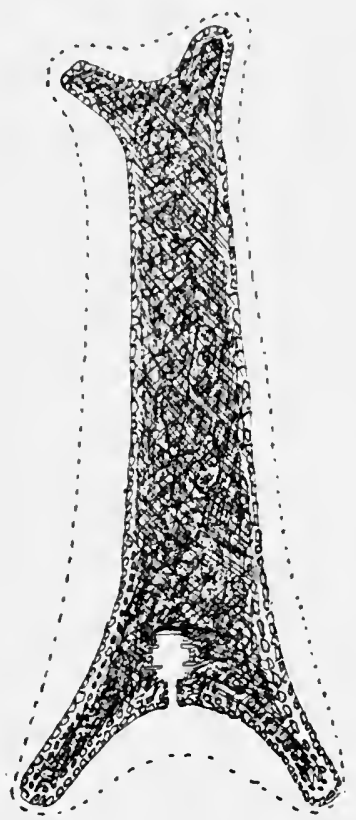

Fig. 187.-Ground-plan of cairn at Yarhouse $(2+0$ feet in length).

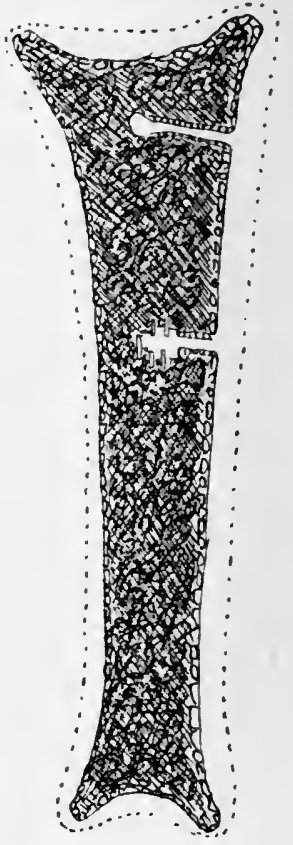

Fig. 188.-Ground-plan of cairn at Canster (195 feet in length).

bone-ash which entered into its composition was very large, no single fragment of bone was discovered exceeding an inch in length. The fragments that afforded definite indications, such as portions of teeth, jawbones, and phalanges, were unmistakably human in character. About a dozen chips of flint -mere chips, and mostly small - and two fragments of 
pottery, of a well-made, hard-baked, thin, and black paste, were all the manufactured relics that were obtained."

The second "horned cairn" was I 90 feet in length, and its structural details closely resembled those of the former. The chamber was divided, in its lower part, into three compartments, and covered over by one beehive roof, which, however, had collapsed. On the floor of the first compartment, to the left of the entrance, there was a cist, 4 feet 4 inches long, 20 inches wide, and 9 inches deep to the level of the floor. "At this level in the dark earthy clay which filled the interior of the cist there was a whitish layer of softened bones in a condition of extreme decay. In the east end of the cist were the fragments of an urn, ornamented with the parallel bands of impressions of a twisted cord, showing the fibrous texture of the strands. A necklace of small beads of lignite had been deposited with the urn, and by washing the clay removed from the cist seventy of these were recovered."

The floor in all the compartments consisted of clay, ashes, and charcoal with burnt bones, human and animal, forming a compact layer some 6 inches in depth, and on its surface there were some greatly decayed fragments of unburnt human bones and teeth. But no relics except the urn and the beads already mentioned were found.

Dr Anderson describes a third cairn, of the same character as the two at Yarhouse, on a ridge on the Moor of Camster, some three miles distant. It differed, however, from them in having two chambers with entrance passages on the south side as shown on fig. 188 . One of the passages terminated in a small beehive cell, the lower part of its walls being composed of five slabs set on edge. The floor consisted of two rough flagstones lying on the undisturbed subsoil, and neither above nor underneath them was there any trace of sepulchral deposits. The other chamber was 50 feet from the former. 
The entrance to it (some 4 feet high) was partly covered over by lintels and partly arched by the overlapping of the stones. The roof of the chamber had fallen in, but its construction appeared to be similar to those already described. The floor was also the same as at Yarhouse-a compact mass of clay, ashes, and burnt bones-human and animal. Among the loose layers on its surface were a few fragments of skulls and of other human bones, mingled with splintered bones of the horse, ox, deer, and swine.

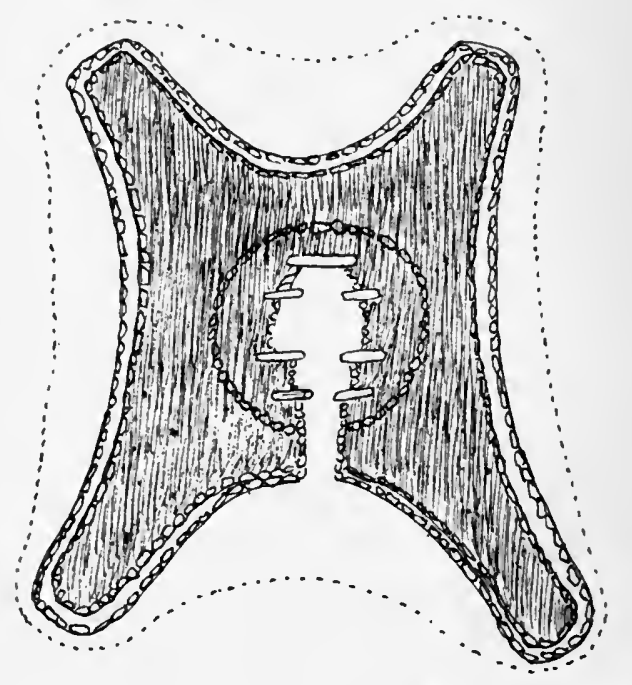

Fig. 189. - Ground-plan of cairn at Ormiegill (66 feet in length).

Another variety of the "horned" cairn presents the same characteristics in external form and internal structure as those at Yarhouse and Camster, with the exception that the body of the cairn is greatly shortened, as shown in fig. 189 , which represents the ground-plan of a chambered cairn at Ormiegill, near Ulbster. The contents of the chamber in this cairn are thus described: "On the floor of the chamber a quantity of unburnt bones of human beings and animals lay, mingled with 
the débris of the upper part of the cairn, with which the chamber was filled. The floor itself consisted of a layer of ashes fully a foot thick. A pavement of slabs had been laid in some parts of the chamber, and this layer of ashes extended both over and under the pavement. The natural subsoil beneath was in some places deeply pitted, the pits being filled with the same compacted layer of ashes and bones. The quantity of burnt bones in the ash-bed was very great. We recognised about thirty fragments of skulls, which, from their varying size and thickness, we judged to have been those of different individuals. The bones were very irregularly burned, some being merely charred in part of their length, and others completely calcined. Besides the human bones, there were a very large number of bones of animals, among which were those of the horse, the ox, the deer, the dog, the swine, and some leg and wing bones of fowls. Fragments of pottery, many of them indicating that they had been portions of roundbottomed ressels, made of a thin dark-coloured paste, hard and smooth, and without ornament, and a great quantity of chips and flakes of flint, were intermixed with the ash-bed throughout. In the central compartment of the chamber, embedded among the compacted ashes of the floor, there were found a finely polished hammer of grey granite, 4 inches in length, pierced with a hole for the handle; the point end of a finely finished flint knife, with a ground edge; an arrow-head of flint, triangular in form, but lop-sided, and hollowed at the base; an oval and pointed knife of flint formed from a flake trimmed to an edge all round; several flakes, serrated on one side, which seemed to have been used as saws; and a number of well-made scrapers of flint of the usual form. In the first compartment of the chamber another arrow-head of the same triangular form was found." 1

1 Scotland in Pagan Times, p. 244. 
The cairn of Get, near Bruan, which in form resembles that at Ormiegill, has only two chambers, but Dr Anderson draws attention to the curious and suggestive fact that "the divisional stones, which would have formed the partitions between the second and third compartments, are in their places; but, instead of being set across the floor as divisional stones, their faces are set flush with the walls, so that the second and third compartments are thrown into one." On the surface of the floor of the outer compartment, and on the right of the entrance, were four unburnt human skeletons, with the skulls lying close to the wall. The floor of the chamber was a mass of compacted ashes and bones fully $\mathrm{r} 8$ inches thick, both man and beast being represented-the latter comprising " horse, ox, dog, deer, swine, and probably the sheep or goat." Flint flakes and chips were found in abundance throughout the mass, as well as fragments of "pottery of a blackish colour, some of which retained indications of their having been portions of round-bottomed vessels, thin, hard-baked, well made, and mostly unornamented." Three small but finely worked leaf-shaped arrows were the only other articles found in the chamber.

A third variety of the chambered cairn differs from the two former varieties by not having the horned projections (fig. I 90), but the structure of the internal chamber remained much the same as already described. One of these cairnsviz., that at Bruan-disclosed a slight deviation which, as we shall afterwards see, became a highly specialised feature in another group. This was a small side-chamber, opening from the second or innermost compartment of the bipartite chamber, which was enclosed in this cairn (fig. I9I).

The district between Stromness and Kirkwall is particularly rich in the remains of primitive times, especially those of an imposing character, such as brochs, Picts' houses, chambered 



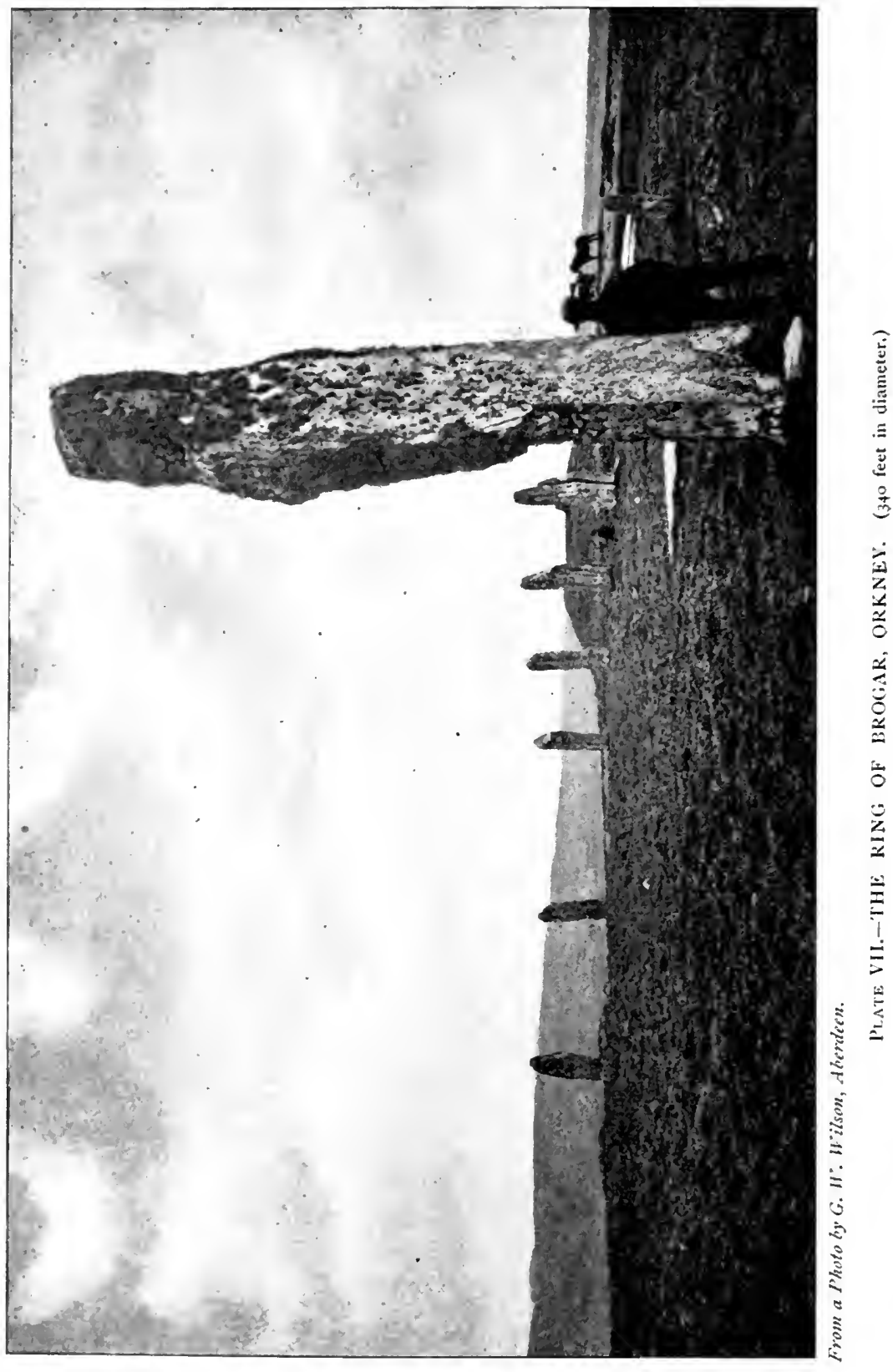


cairns, tumuli, stone circles, \&c., some of which may still be said to defy all efforts to fathom the secret of their origin and meaning. A few years ago I visited the locality, and in driving from the Picts' house of Skaill to Maeshowe, traversed lengthways the peninsula which separates the Lochs of Stennis and Harray. My first halt was at the Ring of Brogar (Pl. VII.), situated on a bleak moor about a quarter of a mile from the bridge which crosses the narrow strait connecting the two lochs. Of the great circle - for there are a few smaller ones and six or

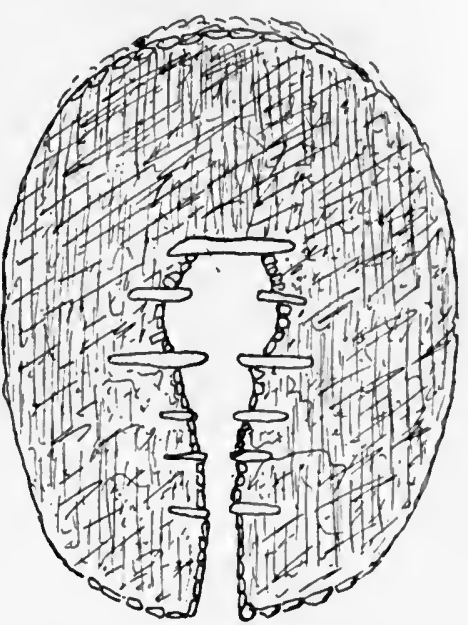

Fig. 19o.-Ground-plan of chambered cairn at Yarhouse (about 55 feet in length).

seven tumuli scattered over the district-only fourteen stones were standing and fifteen lying in the heather, out of the sixty which originally completed it. Some of the stones might be about ${ }_{5}$ feet high, but others do not rise above the surface more than 6 or 7 feet. Outside the line of the stones there is a ditch from 20 to 30 feet wide, and 6 feet deep. The area enclosed by the ditch measures r ro paces in diameter, and access to it is got by

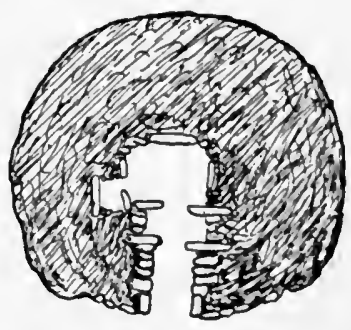

Fig. 191. - Ground-plan of chambered cairn at Bruan (about 40 fect diameter). two unexcavated portions of the ditch, like roads entering it on opposite sides. On the way to the bridge we pass a few 
standing stones and mounds, and immediately after crossing it there stands on the roadside a splendid monolith some I 7 feet high. About 150 yards farther on are three great monoliths-two standing and one fallen-near the ruins of a dilapidated dolmen, which appears to have been enclosed by the stone circle when in its original condition (Pl. VIII.) In a field, about a mile to the east of this ruined circle, at the base of low hills, rises the green grassy tumulus of Maeshowe (Pl. IX.)

From the account of the excavations conducted by $\mathrm{Mr}$ Farrer and other antiquaries in 1861,1 and from my own note-book, I have compiled the following short account of this remarkable monument. The mound, 92 feet in diameter and 36 feet in height, is surrounded by a trench 40 feet wide and 4 to 8 feet deep. During Mr Farrer's investigations, entrance to the interior was effected by driving a shaft from the top, till the chamber was reached through its previously fallen roof (fig. 193). When, or in what circumstances, the collapse of the roof had taken place it was impossible to say. When cleared, the chamber was found to be $15 \mathrm{ft}$. square and I 3 feet high to the top of the remaining walls. Behind three window-like openings, about $2 \mathrm{r} / 2$ feet square and 3 feet above the floor, one in each of the north, south, and east sides, are three small vaults or cells; the fourth side contained a symmetrical opening, but larger-viz., the inner end of the entrance passage. These cells vary a little in size, but they are all of the same height ( 3 feet), and have their back walls and roofs made of single slabs. The walls and roof of the chamber are made of large stones from the hard claystone of the neighbourhood, which, readily splintering into rectangular masses, present clean cut surfaces well adapted for building purposes. The roof was formed by the overlapping of each successive layer, and only

1 Proc. Soc. A. Scot., vol. v. p. 247. 


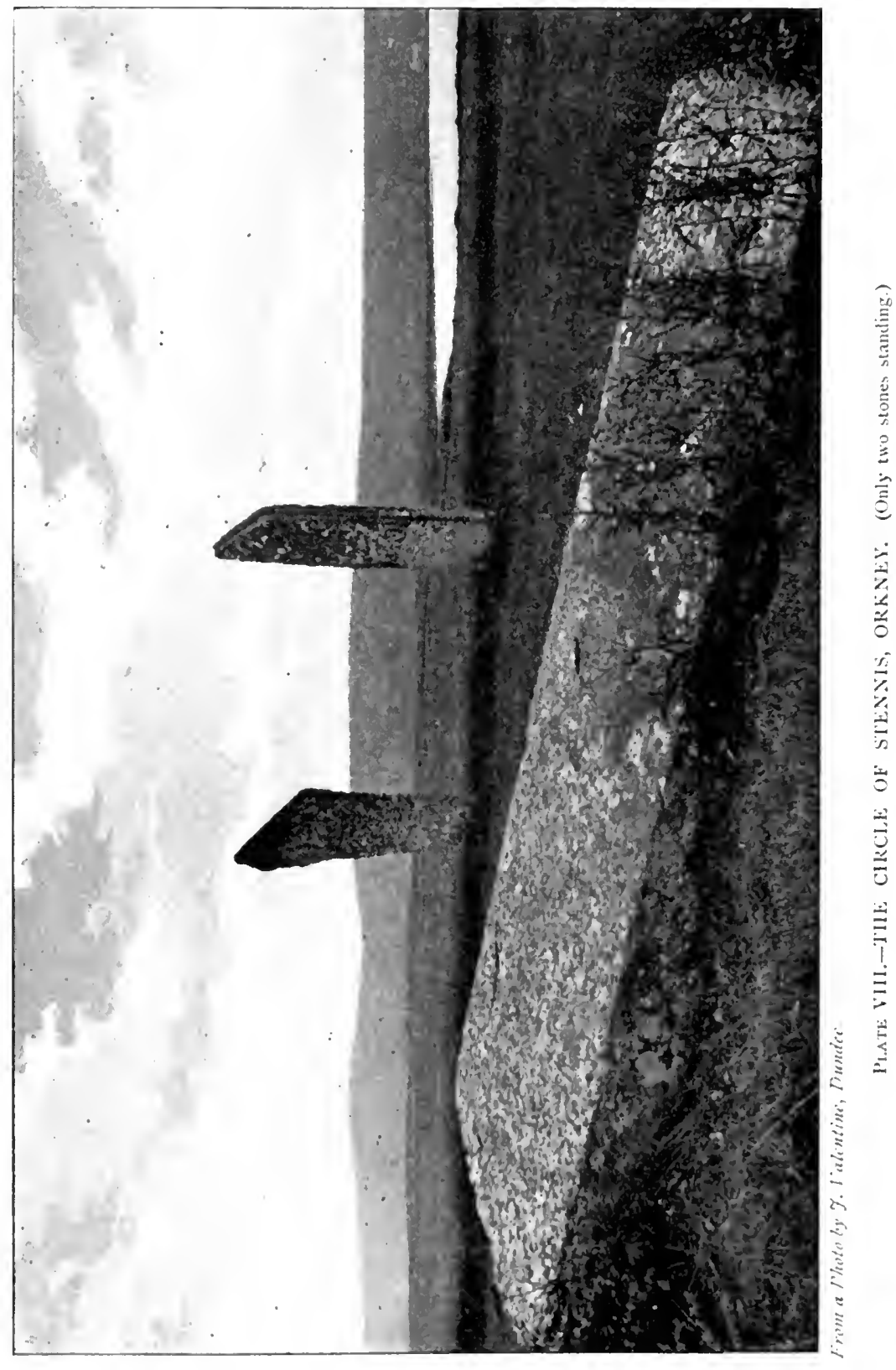





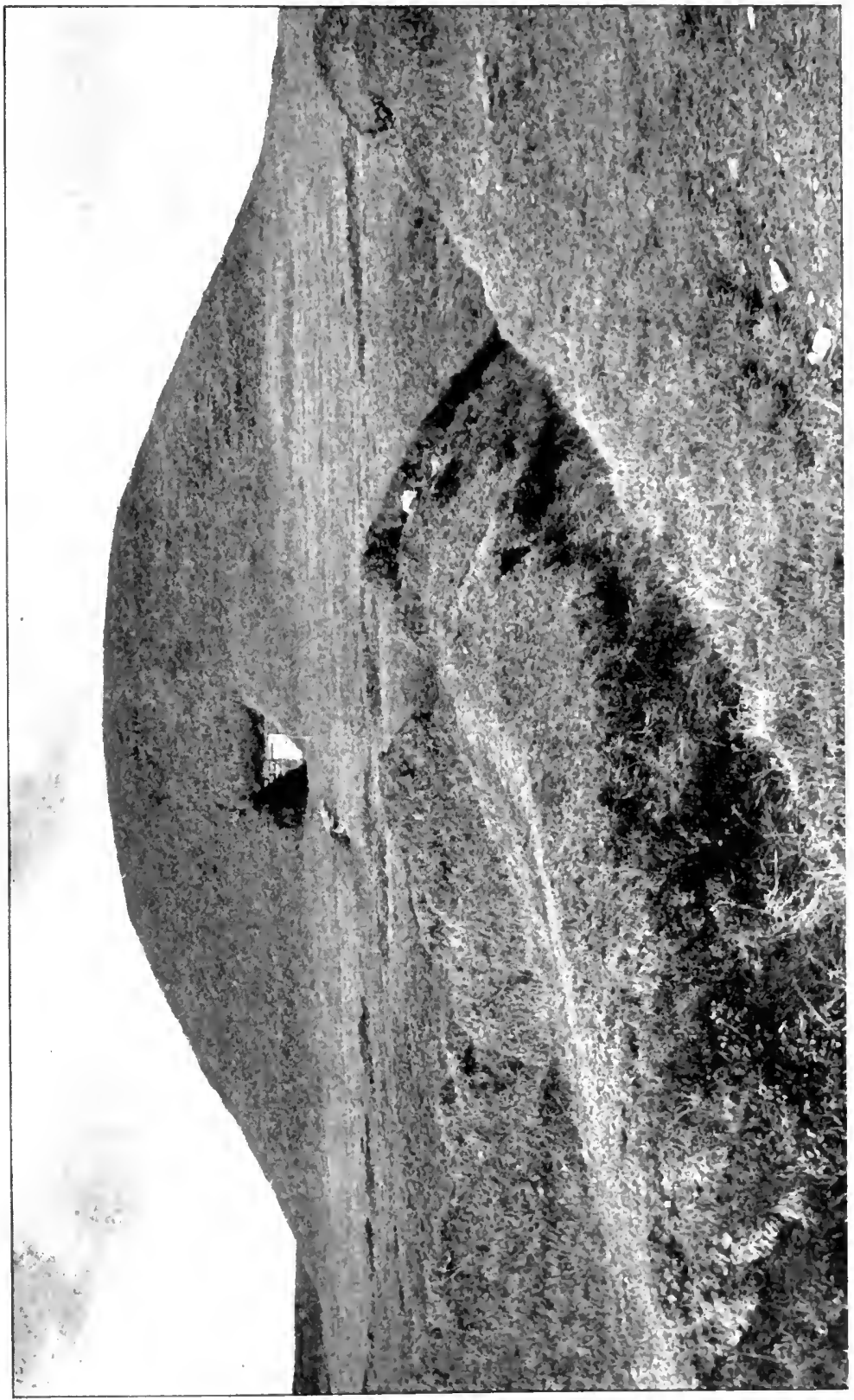

3
3
3
3 

differed from the beehive structures by having this convergence on two opposite sides-viz., north and south-the other two being continued perpendicularly, like the gables of a house. The four corners of the chamber were buttressed by tall slabs and some dry-stone walling, covering about 3 feet

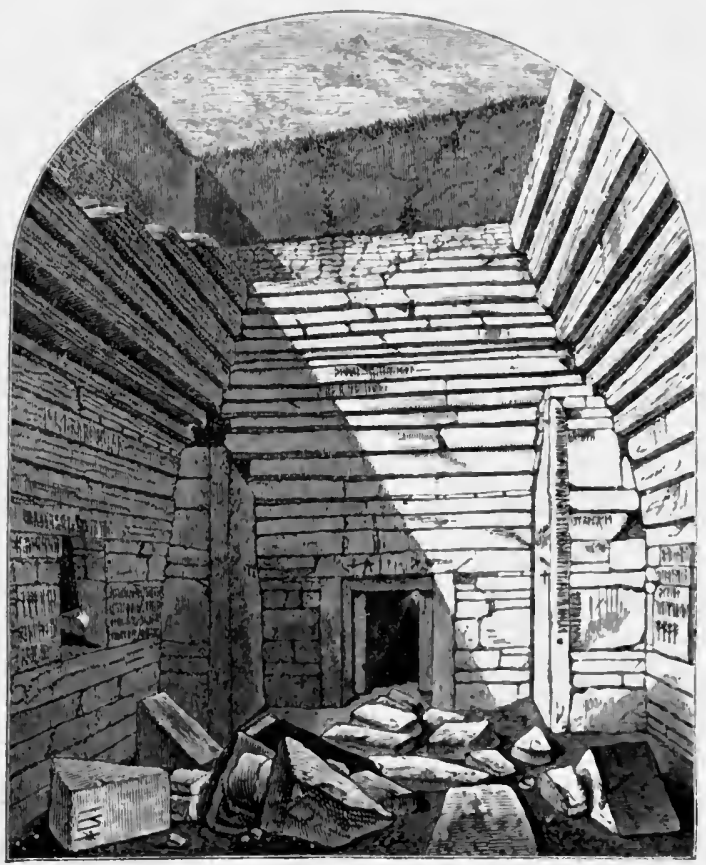

Fig. 192. - View of the central chamber in Maeshowe looking towards the entrance passage.

square at the base, and reaching to the commencement of the overlapping stones of the roof-peculiarities which are well seen in the accompanying illustration (fig. I92).

The entrance passage was 54 feet in length, and at its inner end measures 4 feet 8 inches in height and 3 feet 4 inches in width; but the space gradually diminishes till at 
the outer end it would probably be not more than 2 feet 4 inches square (the cover-stones in the outer half had fallen in). The sides of the passage are formed of huge flagstones with smooth even surfaces, one of them measuring over i 8 feet in length. See plan and section (fig. 193).

No sepulchral or industrial relics were found in the interior of Maeshowe, but there are indications in favour of the

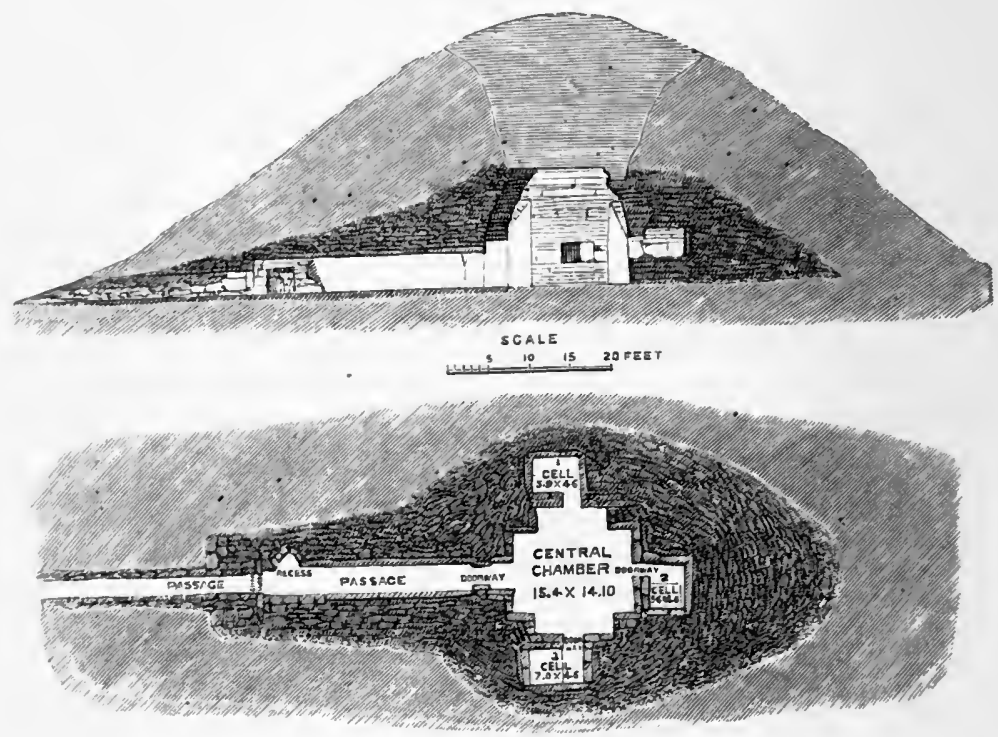

Fig. 193.-Ground-plan and section of Maeshowe.

common opinion that it had been previously rifled of its contents. One of the arguments in support of this is that on the walls there are some runic inscriptions dating back to the middle of the twelfth century. These inscriptions consist of names and short sentences, such as might be scribbled by a party of visitors. One inscription is of importance, as it specifically states that the "Orkahaug" was broken open by a party of Christian pilgrims on their way 
to Jerusalem, with the expectation of finding treasure; but that none was found, as it had been previously carried away. From this Professor Munch infers that the intruders were part of the expedition organised by Earl Rognvald when he made a pilgrimage to the Holy Land in II 52 A.D. But this episode has no bearing on the date of its construction. On one of the buttresses there is an engraving of a dragon and a serpent-knot of Scandinavian character (figs. I 94 and 195), which Dr Fergusson ${ }^{1}$ thinks were original decora-
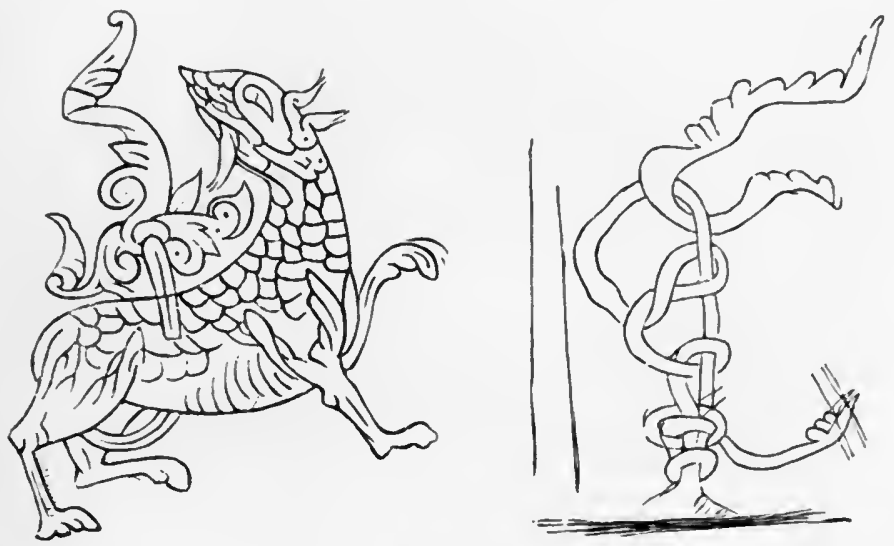

Figs. 194, 195.-Dragon and "Wurm-knot" engraved on a pillar in Maeshowe.

tions of the tomb, and hence he argues that Maeshowe is the work of Scandinavians who conquered the Orkney islands in the ninth century. If so, these northern invaders must have learned the art and plan of building it from the native inhabitants, as there never existed at any time in Scandinavian lands a structure of the peculiar character of Maeshowe. On the other hand, analogous structures are found within the British Isles-especially among the tumuli (fig. 196) of the great cemeteries on the banks of the Boyne, and at Lough-

1 Rude Stone Monuments, p. 245. 
crew, in Ireland. But without entering into the controversy as to the origin and purpose of Maeshowe, it can be readily shown that it differs only in some minor details from numerous other chambered cairns in the Orkneys. In its vicinity there are several examples which illustrate the developmental features and phases through which these chambers passed prior to the construction of Maeshowe.

The "knowe of Unstan," situated on a piece of land jutting out into the Loch of Stennis, a few hundred yards

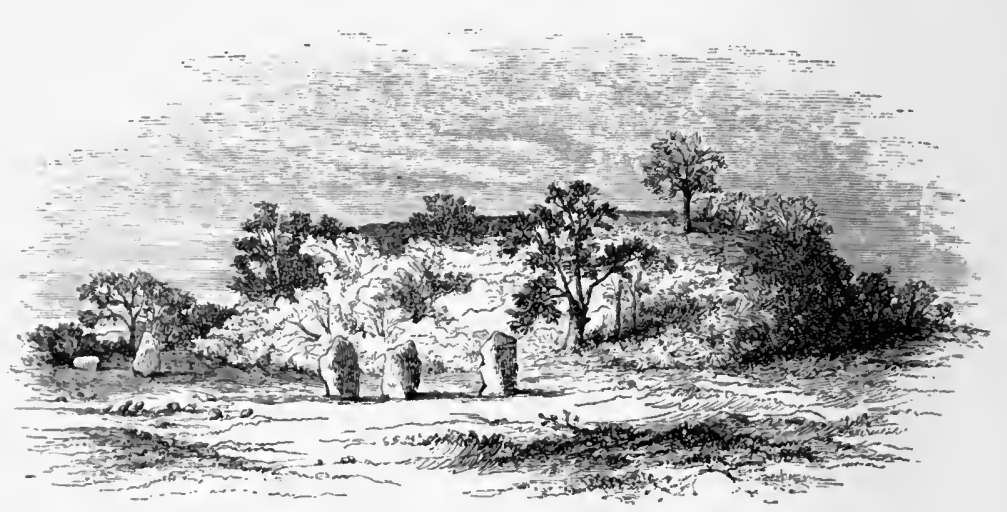

Fig. 196. - View of the great cairn at New Grange, Ireland.

to the north-east of the Bridge of Waithe, was excavated by Mr R. S. Clouston in the year I884, and yielded a most interesting collection of relics, besides disclosing structural features of importance. "The knowe," writes $\mathrm{Mr}$ Clouston," "prior to excavation, presented the same appearance as the usual Orkney tumulus, having an unbroken slope to the ground. This, however, is due to the slipping down of the stones of which the cairn is composed, as there is an external wall surrounding the whole structure, which, in the parts where we found it tolerably entire, was some

1 Proc. Soc. A. Scot, vol, xix. p. 341. 
feet in height, and built of larger stones than those used in the interior."

'The entrance passage, which was still partly covered, terminated in a chamber $2 \mathrm{I}$ feet long by 5 feet wide (over which the roof had fallen), divided into various compartments by large flagstones set on edge, as shown on the accompanying ground-plan (fig. I 97). The side compartment opening from the main chamber may be closely paralleled with that in the cairn of Bruan previously referred to. "Un-

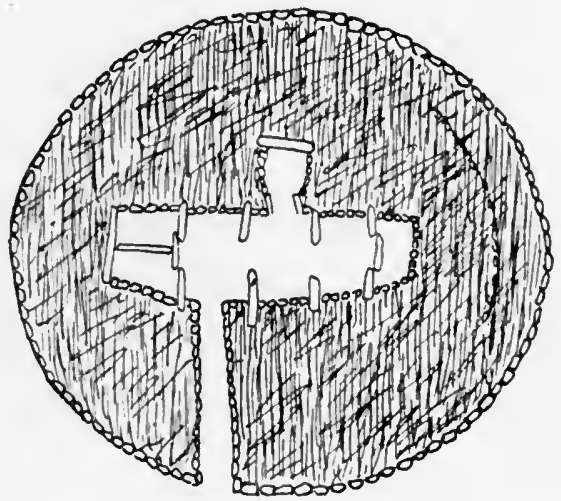

Fig. 197.-Crround-plan of chambered cairn at Unstan, Orkncy (about to feet in diameter).

like the rest of the building, with the exception of the passage, the roof is here entire, its height being 3 feet $61 / 2$ inches. A rude floor is made by a flagstone small enough to have been introduced after the chamber was completed, and supported on blocks of stone. There were two distinct burials here in the contracted posture, one of the skulls being the most complete of any of those found, though scarcely half remained."

Like the Caithness chambered cairns, burials took place here both by cremation and inhumation, and the facts point 
to cremation being first practised. "The whole structure," writes Mr Clouston, "is irregular in shape, none of the walls being quite straight, and the wall at one side of the dividing flagstone rarely coinciding with that of the other. At the side of the south-west flagstone in this compartment (second) there was a small space, not covered with white clay, and in this we found several fragments of different urns. A more striking instance of how the relics must have been scattered is the fact of a piece of pottery, found in the fourth compartment, fitting into an urn, the rest of which was dug up in this second compartment of the chamber. By far the greater portion of the relics found in the chamber were in this compartment. Overlying its clay floor was a stratum of black ashy or earthy matter, largely composed of charcoal, in which great quantities of pottery and several flint chips and flakes were found.

Several fragments of bones were found in the floor of this compartment, but none which showed any trace of burning. Curiously enough, however, the flints present indubitable indications of the action of fire. Upon the black stratum there were laid several burials in the contracted posture, as in the Caithness cairns."

The relics found scattered throughout the chambers consist of fragments of pottery, representing about thirty different shallow vessels, with round bottoms and wide mouths, and having the sides ornamented with scorings generally arranged into triangular spaces. With the exception of an oblong stone or "pounder," all the stone implements were of flintviz., a flaking tool ; four leaf-shaped arrow-points, and one with barbs and a stem; a finely finished scraper, and a knife with a ground edge.

On the farm of Quanterness, near Kirkwall, may still be seen another structure of the same type (fig. 198). It is 
close to the farm-house, and presents the appearance of a green mound, 128 feet in circumference, with, now, two openings leading to the interior. The central chamber measures $2 \mathrm{I} \mathrm{I} / 2$ feet long, $6 \mathrm{I} / 2$ feet wide, and I I 1 $/ 2$ feet high, and is closed in by a roof on the beehive plan. From this chamber there are 6 openings, about 2 feet square, two on each side and one at each end, which lead into corresponding cells, differing, however, from the analogous ones in

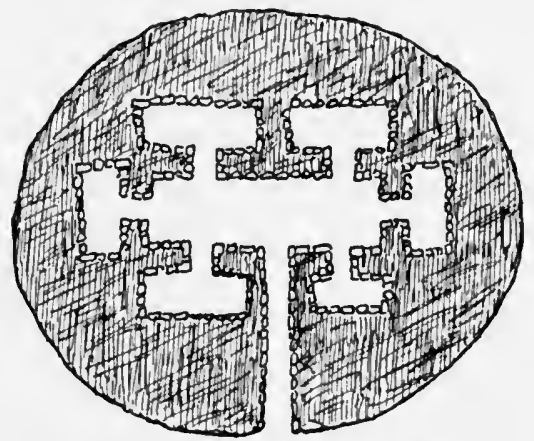

Fig. 198.-Ground-plan of chambered cairn at Quanterness, Orkney (40-50 feet in diameter).

Maeshowe, not only as regards number, but in being on the same level as the floor of the chamber, instead of being raised 3 feet above it as in the latter. The floor is described as being composed of dark earthy clay, containing fragments of unburnt bones both of man and beast; and in one of the cells there was found a human skeleton. ${ }^{1}$

Another underground structure, described as a "Pict's house," and situated on the other side of Wideford Hill, ${ }^{2}$ was explored by $\mathrm{Mr}$ George Petrie, in I 849 . The chamber was ro feet long, 5 feet broad, and $71 / 2$ feet high, and from it

1 Barry's History of Orkney.

${ }^{2}$ See Archrologia, vol, xxxiv., Pl. xv., p. 136 ; and Wilson's Prehistoric Annals, vol. i. p. 116. 
there were three lateral cells opening at irregular distances. The peculiarity of this structure is that there were no human bones found, but only those of domestic animals in great quantities-horse, cow, sheep, boar, \&c., and also some supposed to be those of deer. In the absence of any evidence of a sepulchral character it was regarded as an underground dwelling, and a connecting link between sepulchral cairns and such dwellings as the remarkable habitation at Skaill Bay, described at page 344 .

Other chambered structures are to be found in the Orkneys which present the same characters without evidence of having been used for sepulchral purposes. One is described by Captain Thomas, ${ }^{1}$ on the Holm of Papa Westray, which presented the appearance of a cairn, I I 5 feet long, 53 feet broad, and ro feet high. The internal arrangements consisted of a long chamber, entered by a passage, and surrounded by a dozen or so of small side cells averaging 4 or 5 feet in length, 3 feet wide, and from 3 to $5 \mathrm{t} / 2$ feet in height. There were no relics to indicate its age or purpose, but from its structural details-long entrance passage, central chamber, and lateral cells-it must be classified architecturally with the sepulchral chambered cairns.

Another sepulchral chamber at Quoyness, in the island of Sanday, was excavated by Mr Farrer and Mr Petrie, in $1867 .{ }^{2}$ The entrance passage was 24 feet long, 3 feet high, and 21 inches wide (slightly widening and increasing in height as it approached the chamber). The chamber was $121 / 2$ feet long and $5 \mathrm{I} / 2$ feet wide, with wall still standing to the height of I 2 feet, but the roof had fallen. Branching off it were six cells of an irregular oval shape. A bone dagger and two curiously shaped stone implements were found together along with unburnt human remains, including fragments of twelve ${ }^{1}$ Archæologia, vol. xxxiv. p. I27. 2 Proc. Soc. A. Scot., vol. vii. p. 398. 
or fifteen skulls, male and female, some being young persons. According to Dr Thurnam, to whom the bones were sent for examination, both long and short skulls were represented.

Before passing on I may observe that unburnt human remains have been found in another sepulchral cairn on Papa Westray. The chamber (fig. 199), I 2 feet long by 6 feet wide, was rendered tripartite by pairs of projecting flags set on edge and opposite to each other, but with a space between their edges. It was excavated by $\mathrm{Mr}$ Petrie in $1853,{ }^{1}$ and its contents are so remarkable that I give his description

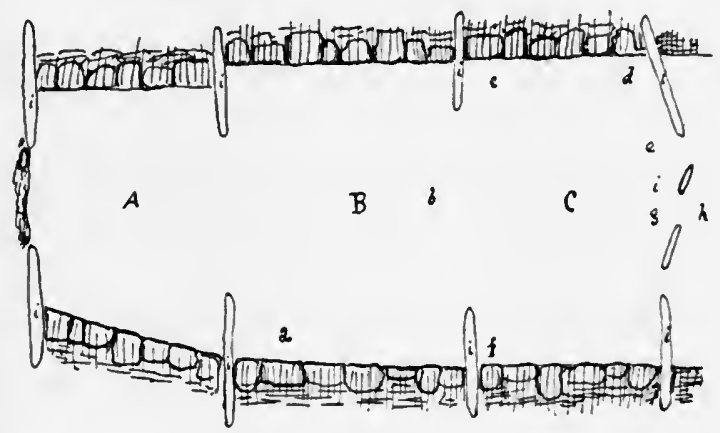

Fig. 199. -Ground-plan of chamber in sepulchral mound in Holm of Papa Westray, Orkney (12 feet long).

verbatim: "We commenced by digging in the compartment $\mathrm{A}$, and found it filled with stones and earth, mixed with animal remains, amongst which were fragments of deer's horns, the horn core of the ox, and a jawbone of the boar, together with portions of a human skull. In the compartment $\mathrm{B}$, the crowns and other portions of ten pairs of deer's horns were found lying on and between layers of stones, intermixed with bones of the ox, deer, sheep, \&c., the wing-bone of a swan, or other large bird, and the lower part of the bill of the curlew, with bones of various kinds of birds. And underneath

1 Proc. Soc. A. Scot., vol. ii. p. 62. 
a layer of deer's horns, and lying amongst others, part of a human skull face downwards was discovered at $a$. A human skull, or rather a part of one, was lying on its side at $b$, resting on a portion of a deer's horn. The face was towards the south-west. In the compartment $\mathrm{c}$, fragments of at least two pairs of deer's horns were found. The remains of a human skeleton lay at $c$, the ribs in tolerable order, not apparently having been previously disturbed; but no part of the skull was found except the lower jaw. The remains of another skeleton, without the skull, were found at $d$. Two skulls, one of them in good preservation, were found placed vertically at $e$, with the face towards the east. Another skull was lying on its side at $g$, with its face towards the backs of the two skulls at $e$. . . .

"The general appearance of the place, as far as it was opened, was that of an immense grave of double the ordinary dimensions, but divided into three compartments by the large upright flags or stones marked $i$, whose tops were above the surface of the mound. The sides of the grave were formed by stones built in the shape of rude walls, but how much of these may have been removed before we examined the place we could not even conjecture, as the whole mound was more or less covered with loose stones."

On the west coast of the island of Lewis, at the head of Loch Roag, there are four stone circles within about a mile of each other, all of which in the course of time had become deeply buried in peat-a fact which probably accounts for their preservation. In 1858 , under the instructions of Sir James Matheson, the largest, known as the Stone Circle of Callernish, was cleared of the peat which had accumulated on its site "down to a rough causewayed basement in which the stones were imbedded." The depth of peat averaged 5 feet, and in the course of its removal the workmen came upon 


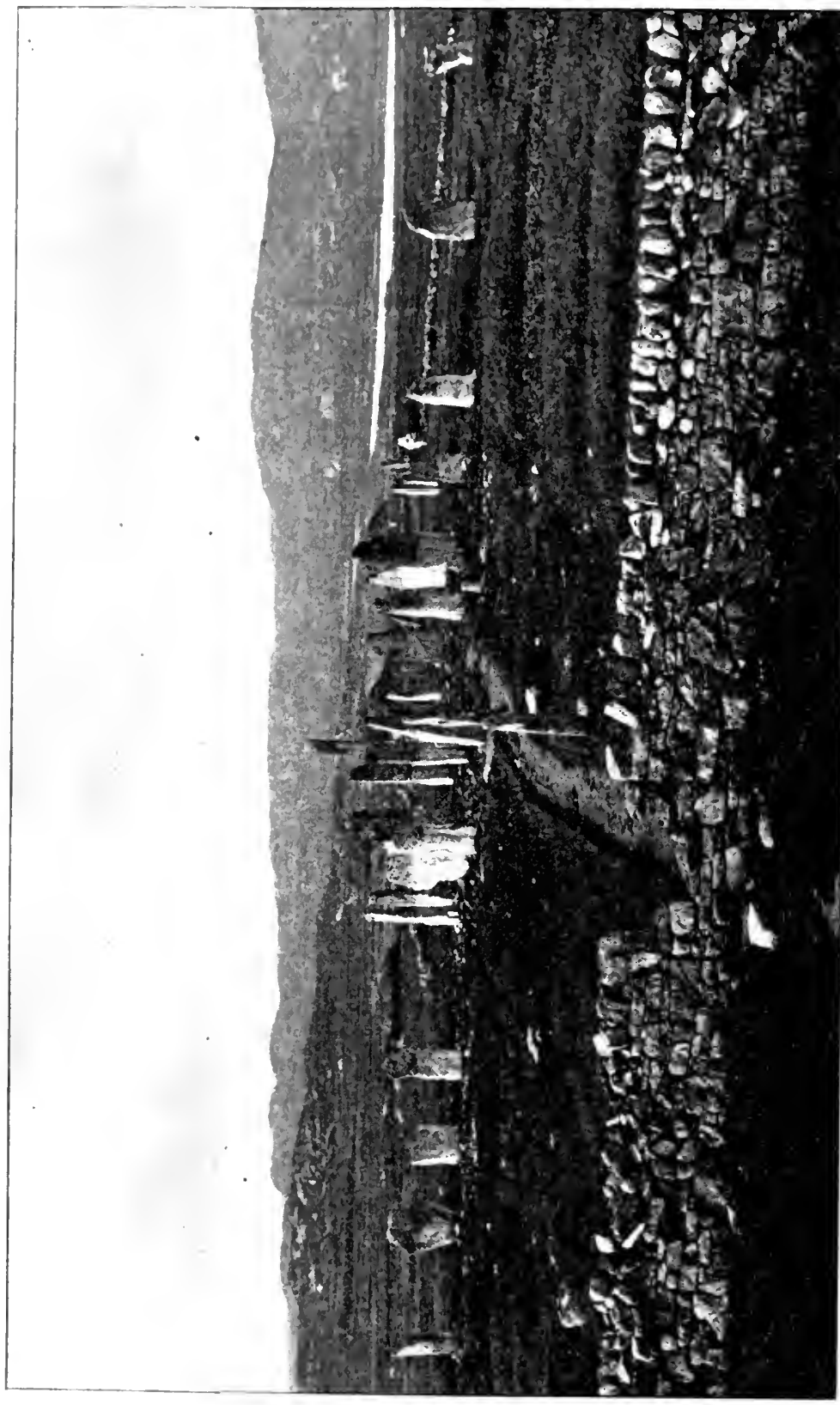

年

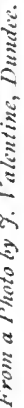


the ruins of a chambered cairn, occupying the space between the centre stone and the east side of the circle. It contained a bipartite chamber with a passage leading to its outside. Nothing was found in the chamber except some minute fragments of burnt human bones.

The accompanying view (Pl. X.) shows the general arrangement of the circle and its alignments. According to measurements, taken by $\mathrm{Mr}$ Kerr, clerk of works to Sir James Matheson, the following are their dimensions $:^{1}$ diameter of circle about 40 feet; length of west line 43 feet; length of east line 38 feet; length of south line 69 feet; length of avenue 270 feet ; breadth of avenue $\mathbf{2 7}$ feet; average height of stones 6 to 8 feet; height of centre stone 12 feet. To the height of the stones 5 feet must now be added to give their actual height after the removal of the peat. There are thirteen stones in the circle, including the centre one.

In I $884 \mathrm{Mr}$ James Fraser communicated to the Society of Antiquaries of Scotland ${ }^{2}$ a detailed account of the stone circles of Strathnairn and neighbourhood of Inverness, from which it appears that such remains, in various states of preservation, are found from the lower end of the strath to a point twenty-five miles farther up. There were twenty-five of these circles within the drainage area of the river Nairn, and twelve or fourteen between its western watershed and the river Ness. "Wherever the structures are sufficiently preserved," writes Mr Fraser, "they exhibit the following characteristics in common:-

I. "They consist of three concentric, or nearly concentric, rings of boulder-stones, or of flagstones, fixed on end in the ground, and without hewing or dressing of any kind.

2. "There is an outer ring of stones, varying from 60 to

1 Proc. Soc. A. Scot, vol. ii. p. $3^{83}$, and vol. iii. p. III.

2 Ibid., vol. xviii. p. 328. 
I 26 feet in diameter outside, and consisting of long stones, from nine to twelve in number, standing at nearly regular intervals, - the tallest being on the south side, and their size gradually diminishing towards the north.

3. "A smaller interior, and concentric, or nearly concentric, ring, varying from $3^{2}$ to 88 feet in diameter outside, made of smaller boulders (very few, if any, flags being used in this ring), the stones being set on end, close together, with a slight slope inwards, and with the best, or flattest and broadest, face outward. As in the outer ring, the large stones are on the south side, and the smaller stones to the north.

4. "A third, and still smaller, concentric ring, from $I 2$ to about 32 feet in diameter inside, and consisting of stones set on end, close together.

5. "They are all built on flat or low-lying ground, sometimes in a slight hollow or amphitheatre (with perhaps some not very decided exceptions on slight eminences)."

One part of the geographical area traversed by Mr Fraser is of special interest-viz., the plain of Clava, a flat "haugh" along the east bank of the Nairn, and near the battlefield of Culloden, because it contains within the distance of one mile the remains of eight cairns (two of which at least contained chambers) associated with stone circles. Besides the chambered cairns the surrounding district is studded with tumuli of various kinds, so that we may regard the Clava group as the remains of an important pagan cemetery.

One of the chambered cairns still remaining was opened about the year 1828 , under instructions from Mrs Campbell, Kilravock, the result of which is thus described by $\mathrm{Sir}$ Thomas Dick Lauder in his book on the 'Moray Floods': 1 "I received a most interesting communication from Miss Campbell, informing me that the fragments of two earthen ${ }^{1}$ Appendix vii., p. 338. 


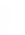




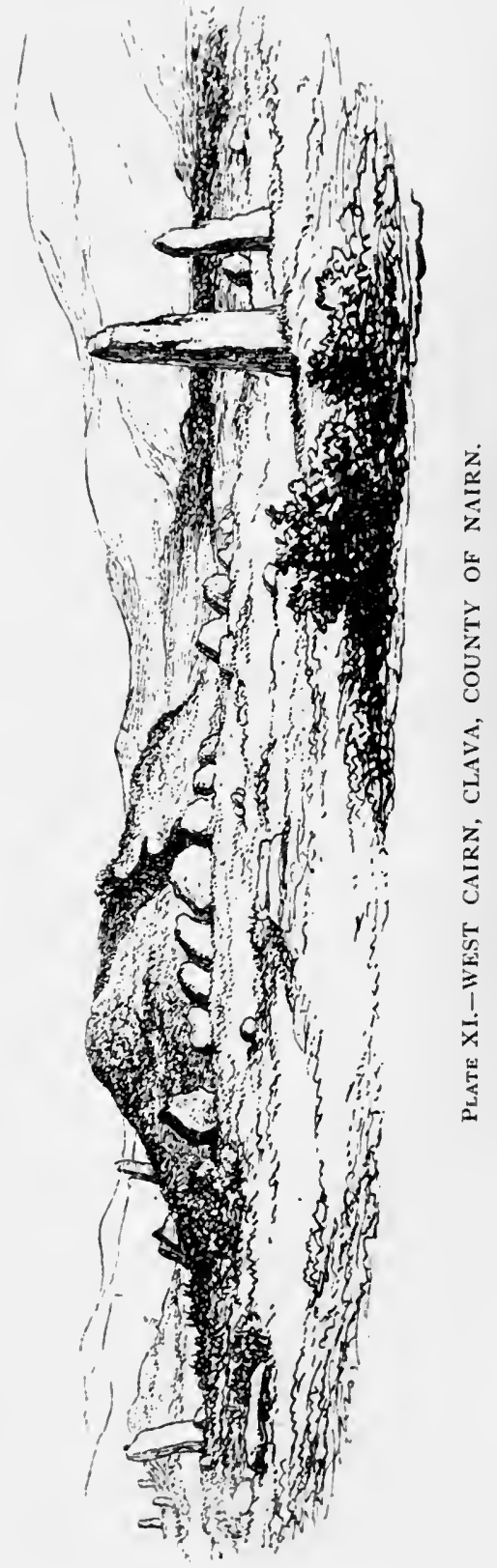




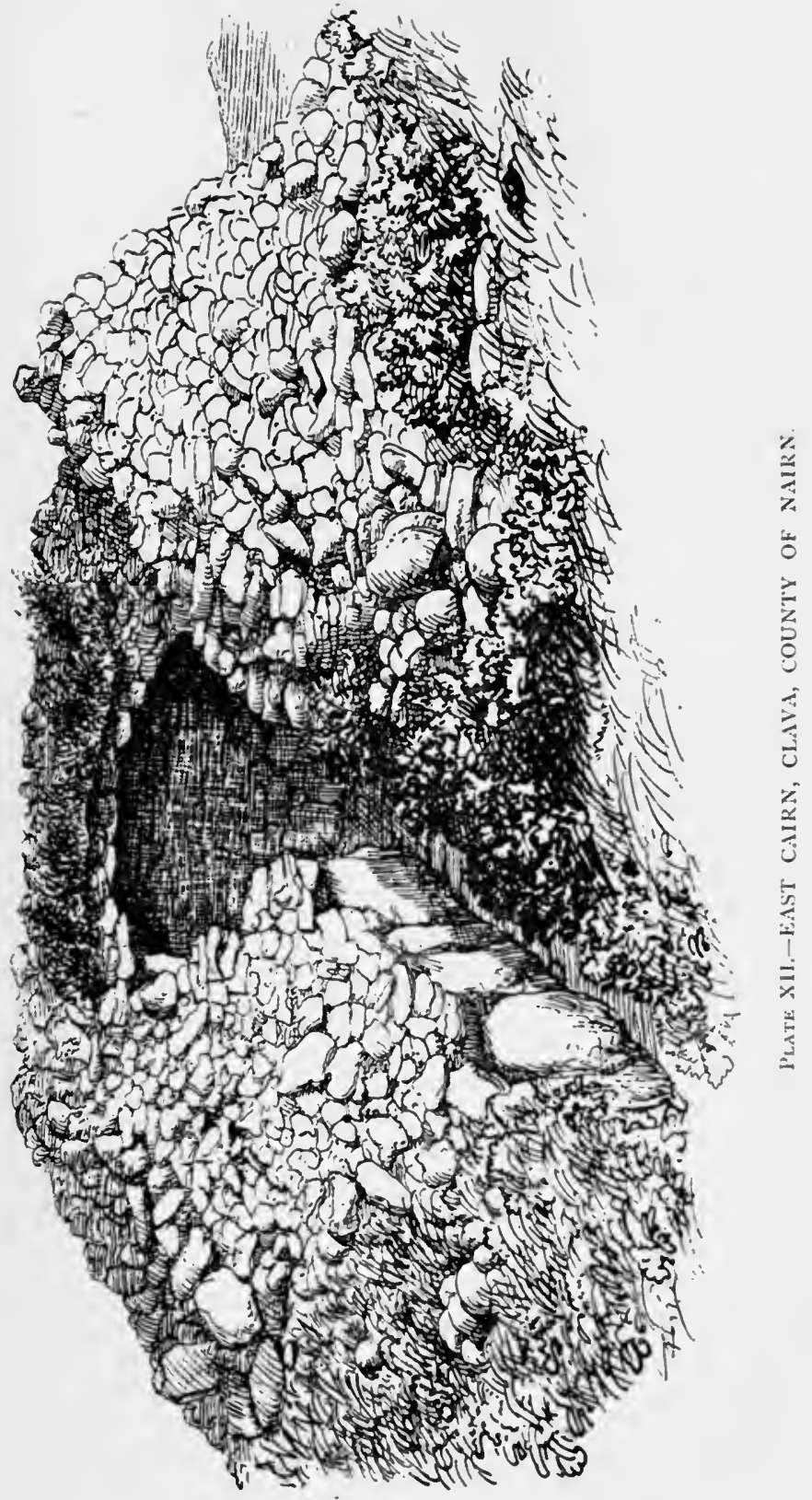



vases were found in the chamber in the interior of the Druidical circle opened at Clava by Mrs Campbell's orders. 'It was about 18 inches below the earth,' says Miss Campbell, speaking of the more perfect of the two, "exactly in the centre of the circle. It was found in a broken and very mutilated state, the whole body of the stones having lain upon it. A quantity of calcined bones were in it and about it, all of which we have. The clay is of the coarsest kind, and the vase is of the rudest make. It has, apparently, had no cover, but is rounded at the top like a garden-pot, which it resembles more than anything else. The bottom is flat, the inside very black from having been burned, the outside red; across the exterior of the bottom it measures $6 \mathrm{r} / 2$ inches, and across the interior exactly 5 inches, and the height, in its fractured state, is $4 \pi / 2$ inches. After clearing away the stones, the interior of the cairn was found to be composed of gravel, but the vase and bones were enclosed in a portion of clay quite distinct from the natural soil.'"

Cosmo Innes visited the locality in 1857 , and made two sketches of the Clava group-one showing the interior of this cairn-which are here reproduced (Pl. XI. and XII.)

The following dimensions of the cairn and its various adjuncts are taken from Mr Fraser's measurements. The outer ring is 108 feet in diameter, and consists of eleven stones, there being a vacant space for a twelfth. The intermediate ring, which forms the boundary of the cairn, is 53 feet in diameter. The inner ring (which forms the wall of the chamber) is $12 \frac{1}{2}$ feet in diameter (inside). It is built of more carefully selected stones (of which seven or eight feet still remained), and this wall supported the beehive roof of the chamber; but it would take four or five feet more to complete the dome. The passage, which lies at the southwest side, was about 18 feet in length, 2 feet wide at the 
outer end, 3 feet at the inner end, and about $4 \frac{1}{2}$ feet in height.

It will not be necessary to dwell at great length on the unchambered sepulchral cairns, as the interments are either in stone cists in the substance of the cairn or deposited in the earth beneath it. One of the most instructive of this category was at Collessie, in Fife, the investigation of which was superintended, and the results recorded, by Dr Joseph Anderson. ${ }^{1}$ The cairn was a mass of stones and boulders, $\mathbf{I} 20$ feet in diameter and 14 feet in height. A large central segment of the stones was cleared away down to the level of the ground, during which the following discoveries were made :-

I. Within a few feet of the margin there was exposed a portion of a circle of upright slabs which the explorers considered to be part of the original boundary of the cairn.

2. Within this ring the whole area of the cairn was covered with a layer of fine clay 1 to 3 inches thick, and on its surface were marks of fire in spaces several feet in diameter, with abundance of black ashes and wood charcoal. Charcoal was also found in the gravel beneath the layer of clay.

3. Near the centre of the cairn there was a stone cist $4 \frac{1}{2}$ feet by 3 feet, resting on the ground, and containing gravel, from which an urn of the drinking-cup type was extracted. The floor of the cist was paved with pebbles, and underneath this parement the soil was loose, and mixed with fragments of charcoal to a depth of 2 feet.

4. Some distance within the margin of the cairn, at a depth of 4 feet in the gravel, the remains of a cremated burial were found, among the bones of which lay a small bronze dagger-blade, and a gold fillet which had encircled the handle. 
5. A second deposit of burnt bones and a broken drinkingcup were found near the centre, at a depth of 6 feet in the earth.

A cairn on the farm of Gilchorn, near Arbroath, was explored by Mr Alexander Hutcheson, which yielded a bronze dagger (fig. I 06) and fragments of at least two others, associated with burials both by inhumation and cremation. ${ }^{1}$ On comparing the results of this investigation with those of the cairn at Newton of Collessie, Mr Hutcheson thus states the points of resemblance and difference: "The features in which they agree are-(I) the layer of clay underlying the site of the cairn ; (2) the appearance of wood ashes all over this surface ; (3) the existence of a cist of stone slabs containing an unburnt burial; and (4) the presence of cremated urn-burials associated with implements of bronze. On the other hand, the points in which they differ are as follows : (I) In the Collessie cairn the cist stood on the natural surface, in the Gilchorn mound the cist was sunk below the subsoil; (2) at Collessie, the burnt remains and the associated urns were found sunk in the subsoil, whereas at Gilchorn the urns rested on the subsoil."

Burials are often found in groups or cemeteries with or without stone cists.

A few years ago a cemetery, with and without urns, was discovered in a sand-pit at Kirkpark, near Musselburgh Station, in Mid-Lothian, the results of which have been described by the Rev. George Lowe and Dr Joseph Anderson. $^{2}$ The urns were merely buried in the sand, at a depth of from $3 \frac{1}{2}$ to 6 feet, along with burnt material which seemed to have been thrown into the graves when they were deposited. The urns were sometimes inverted; and some of them were full of burnt bones and others empty. One grave

${ }^{1}$ Proc. Soc. A. Scot., vol. xxv. p. 447. $\quad{ }^{2}$ Ibid., vol. xxviii. p. 62. 
contained no less than four (Nos. 6 to 9). No actual bronze was found, but in two instances the cremated bones were " extensively dyed, as it were, with a brilliant green colour," supposed to be due to the oxidation of bronze. Besides these graves there were some discoloured spaces which had the appearance of burial by inhumation. Mr Lowe adds that " in this same field many stone coffins containing bodies have been found at different times."

Dr Anderson, after giving a technical description of the urns from this cemetery, thus describes its general characteristics: "In its general character it closely resembles another cemetery also found in clearing away a natural deposit of sand at Magdalen Bridge, a little nearer the present sea-shore, and about a mile nearer Edinburgh, in which there were at least ten urns found, seven of which are now in the Museum, along with a small thin oval tanged bronze blade ${ }^{1}$ (fig. 94) found in one of them. The urns from the two cemeteries have much the same character, the ornamentation on two of those from the Kirkpark cemetery being composed of the same patterns distributed in the same way as that on two of the urns from Magdalen Bridge. In both cemeteries there was the same variety in the manner of burial, mostly after cremation."

Two cemeteries found on the estate of Pitreavie, near Dunfermline, and described by Henry Beveridge, Esq. of Pitreavie, ${ }^{2}$ present some features of special interest. One, near the summit of a gentle rising ground in cultivated lands, was without any evidence of a tumulus. There were seven cists nearly in a row within a space of 30 feet, but none of them was more than 12 inches below the surface. One had neither cover nor urn; another, without a cover, contained some handfuls of incinerated bones. Four cists contained
1 I'roc. Soc. A. Scot., vol. xvi. p. 424.
2 Ibid., vol. xx. p. 240. 
urns of the food-vessel type, measuring from $4 \frac{1}{2}$ to $53 / 4$ inches in height. Near one of the urns was found a small flint flake, and beside another a disc-shaped flint scraper.

The second cemetery was close to the north margin of Calais Muir, on the summit of a natural rising ground, and surmounted by an artificial tumulus, 40 feet in diameter and 4 feet in height. Near the centre of the tumulus was a cist covered by a large stone $2 \mathrm{r} / 2$ feet below the surface of the mound. In this cist was found an ornamented urn of the food-vessel type, 5 inches in height, which presents the peculiarity of being surrounded above the shoulder by a row of four projecting knobs perforated horizontally.

"Pursuing the excavation," writes Mr Beveridge, "around the central cist, ten other urns were recovered in a more or less imperfect condition; besides which were found numerous fragments of urns, and also several deposits of burned bones, as well as vegetable charcoal in considerable quantities. The urns lay at different points, but chiefly upon the west side of the cist, and at distances from the cist varying from 3 to 6 feet. These urns were all of the cinerary type ; they stood for the most part upon their bottoms, and were deposited at a level somewhat higher than that of the cist, thus suggesting a later date of interment. These urns were all more or less filled with incinerated bones and other remains of cremation. In one or two of the urns were observed pieces of calcined bone bearing traces of the peculiar green stain which always accompanies the presence of bronze; but although careful search was made, not the smallest fragment of bronze could be detected."

It has been established beyond doubt that most of the stone circles, as well as single standing stones, scattered more or less in groups over the country, so far as they have been subjected to practical investigation, are mere external ap- 
pendages of burials both by inhumation and cremation, but more commonly the latter. These interments are either in cists, urns, or grave-pits, differing in no respect from those under cairns or tumuli. This important generalisation was first clearly shown by a series of explorations made by $\mathrm{Mr} \mathrm{C}$. E. Dalrymple, the result of which is given in an Appendix to Dr Stuart's 'Sculptured Stones of Scotland.' $\mathrm{Mr}$ Dalrymple's investigations included a number of circles in the counties of Aberdeen and Kincardine-Crichie, Tuack, Sunhoney, "The Standing Stones of Rayne," Ardlair, Ardoyne, Auchorthie, \&c.

At Crichie the stone circle, which originally consisted of six stones, and one in the centre (fig. 200), was surrounded by a ditch except at two opposite points. Beneath the centre stone there was a pit, ${ }_{5}$ feet in diameter and 5 feet deep, filled with stones, under which was a cist with the remains of a skeleton. Burnt burials, with and without cinerary urns, were also exposed within the area, in one of which, among some burnt bones, close to a standing stone, was found a fine specimen of a perforated stone hammer (fig. 48).

At Tuack seven burials, all after cremation, were discovered within a circle which also originally consisted of six stones. The cremated remains were in pits, and in three instances inverted cinerary urns covered them. Fragments of a small bronze blade were found among the bones in one of the graves.

The publication of $\mathrm{Mr}$ Dalrymple's discoveries by $\mathrm{Dr}$ Stuart (1856) induced Dr James Bryce to undertake a similar investigation among the stone circles of Arran, especially those on Mauchrie Moor. One of this group, 15 yards in diameter, still retains in position three huge sandstone slabs 16 to 18 feet in height, but originally there would

1 See also Proc. Soc. A. Scot., vol. xviii. p. 319. 
be seven or eight stones in the circle. About the centre of the enclosed area, and 2 feet below the surface, the stone cover of a cist was exposed. This being raised with much difficulty, there was found an ornamented urn of the foodvessel type and four flint arrow-heads of rude construction.
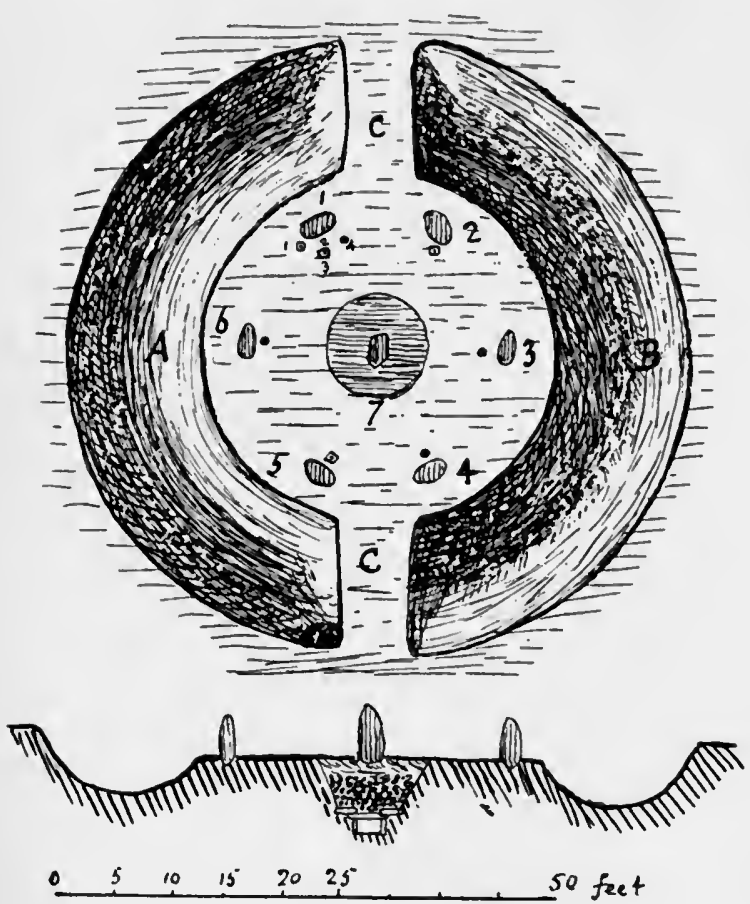

Fig. 200.-Ground-plan and section of stone circle at Crichie.

In another circle, $4 \frac{1}{2}$ feet from the surface, a cist was exposed which also contained an urn of a similar character and two rude flints. Analogous results were obtained in six or seven of the circles, but only in one instance was there any trace of metal discovered-viz., a portion of a pin or awl. All the burials thus examined within the. Mauchrie 
stone circles appear to have been after inhumation, as the two urns preserved are of the food-vessel type. ${ }^{1}$

Remnants of stone circles and "standing stones," often in groups of twos, threes, or more, sometimes arranged in lines or avenues, but more frequently as solitary hoary pillars, abound in almost every district of Scotland. Of such megalithic monuments history is almost silent, and the associations which still hover about them in local folk-lore are of little value in determining their origin or purpose. They are rough blocks or boulders from the natural rocks of the neighbourhood, probably selected because of their pillar-like forms. Only two of these unsculptured monuments bear inscriptions-viz., the Cat Stone, near Edinburgh, and the Newton Stone, in Garioch. Many of them, however, show cup-and-ring marks and other symbolical incised sculptures. That many of these megaliths are mere external settings of graves has been proved by actual investigation; whilst others, especially the solitary specimens, or menhirs, were no doubt intended to commemorate other important events, as indicated by the traditionary names assigned to some of them, such as Cat Stone, Hawk Stone, King's Stone, Tanist Stone, Stone of Odin, \&c. Such memorials are common in Scotland, and good examples must be familiar to visitors of the islands of Bute and Arran, and many of the more frequented Highland glens. Stone circles are numerous throughout the counties of Aberdeen, Perth, Kincardine, and Forfar; and they are also met with in the south-west of Scotland. As an illustration I reproduce from a photograph a view of the Stone circle of Auquhorthies near Inverury (Pl. XIII.)

Groups of upright stones arranged in rows, sometimes parallel, but more frequently converging at one end, occur within the Scottish area only in Caithness and Sutherland, but

1 Proc. Soc. A. Scot., vol. iv. p. 49, and vol. xvii. p. 458, figs. 19 and 20. 


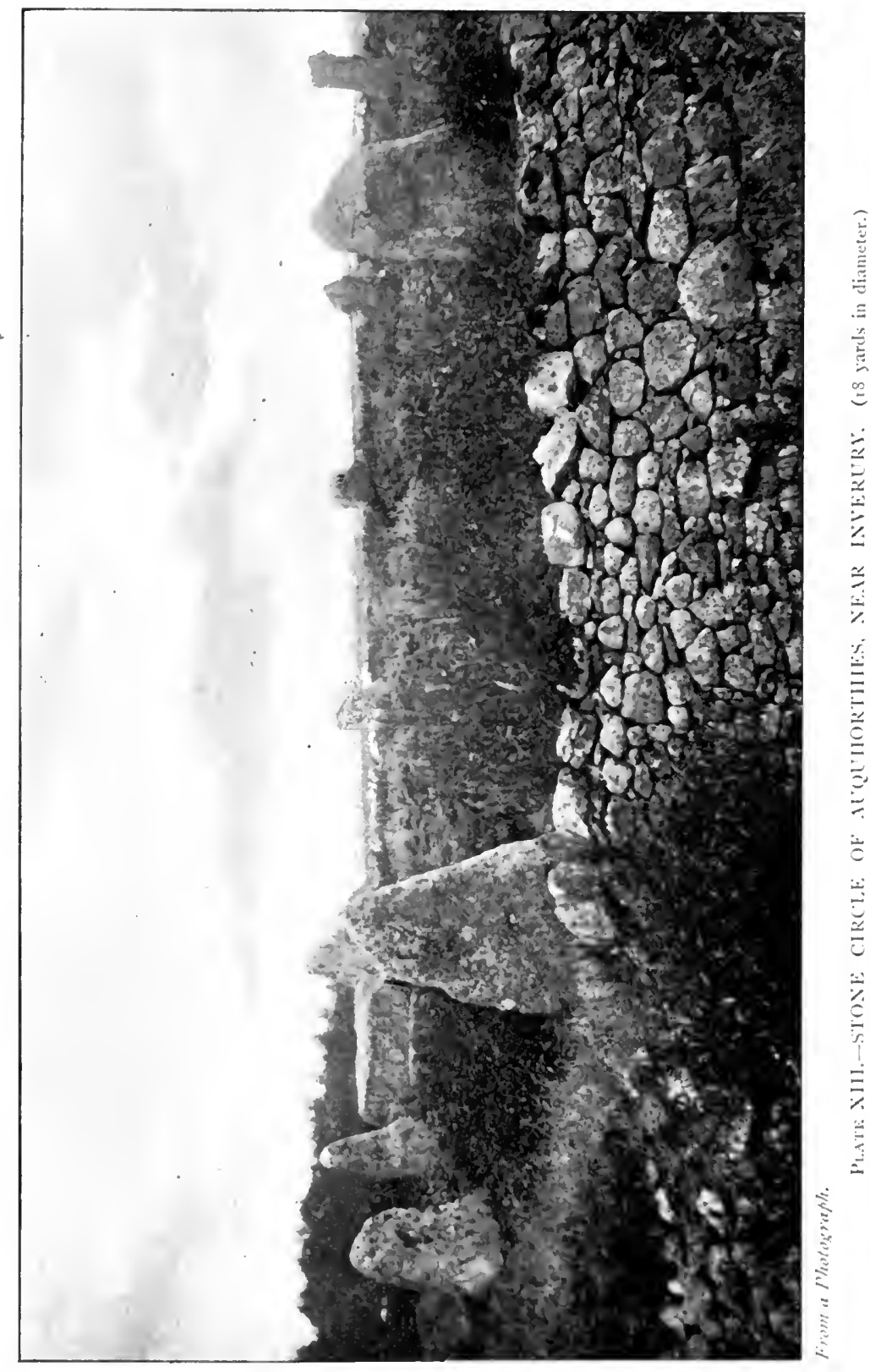





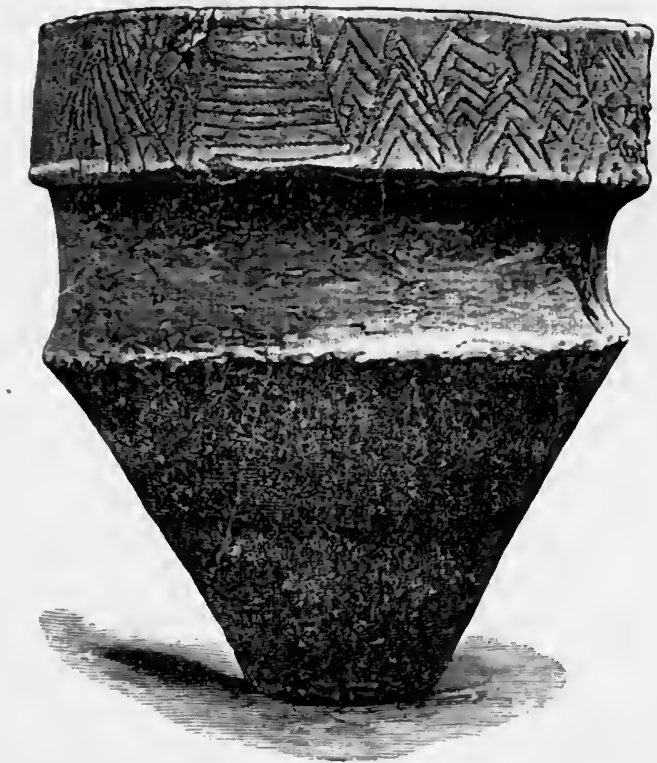

Fig. 2or.-Cinerary urn found at Moathill, Ochiltree, Ayrshire (1).

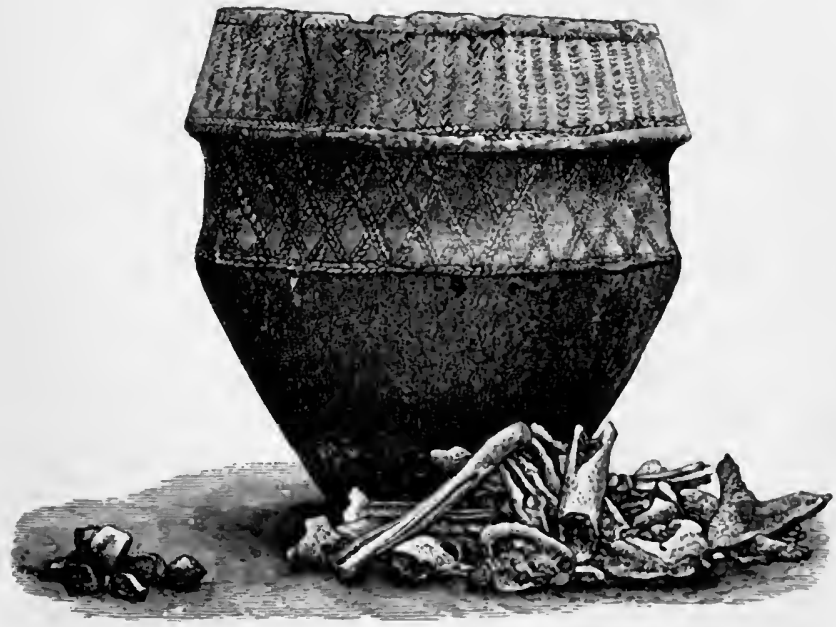

Fig. 202. - Cinerary urn found at Seamill, Ayrshire ( $\$$ ). 
analogous remains have been observed outside this area, as at Ashdown, in Berkshire, ${ }^{1}$ and especially at Carnac, in Brittany. The Caithness group, described by Dr Anderson ${ }^{2}$ and Sir Henry Dryden, ${ }^{3}$ are regarded by the former investigator as having sepulchral associations.

Before concluding our observations on sepulchral memorials, a few words must be said on the contents of the graves. The most common objects deposited with the dead were pottery, personal ornaments, and weapons.

The pottery consists of a variety of vessels, collectively called urns, but as they were deposited both with burnt and unburnt burials, it is manifest that they could not all have been used for cinerary purposes. Vessels associated with inhumed bodies are supposed to have originally contained food or drink, to supply the needs of the departed on the journey to the unseen world of spirits. Hence archæologists are in the habit of classifying them into "cinerary urns" (figs. $20 \mathrm{I}$ and 202), "food-vessels" (figs. 186, 203-205), and "drinkingcups" (figs. 185 and 206). Very small cup-shaped urns, often pierced with two or four holes on the sides, and generally found inside the large cinerary urn, are called "incense cups" (fig. 207). But there is no evidence to support this suggested use of them, and they are now more generally regarded as cinerary urns for infants.

Cinerary urns vary in size, form, and ornamentation, being from 10 to $18 \mathrm{I} / 2$ inches in height. They are coarsely made vessels, wide-mouthed and narrow-based, and having a broad overhanging rim to which the ornamentation is generally confined ; or they may be ornamented by transverse ridges as in fig. 208. They are found often inverted over the cremated remains, or in an upright position covered with a flat stone.

1 International Congress of Prehist. Arch., I868, p. 37.

2 Scotland in Pagan Times, p. 125. $\quad{ }^{3}$ Rude Stone Monuments, p. 529. 
The food-vessel, smaller, more globular, and more highly ornamented than the cinerary urn, is also wide-mouthed and

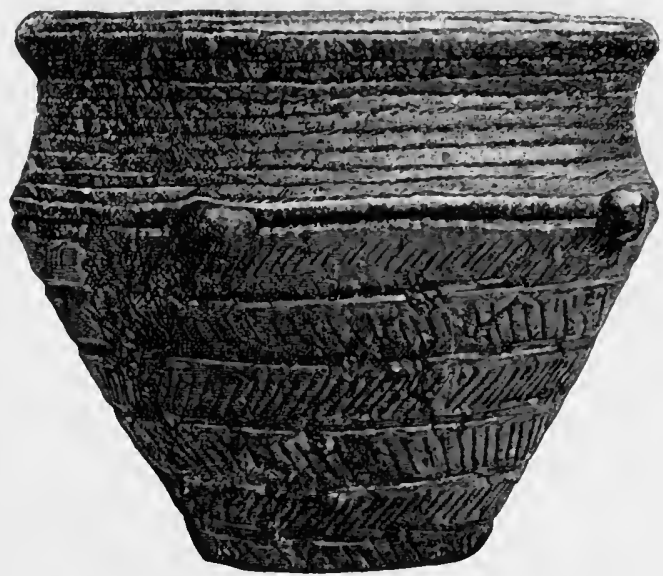

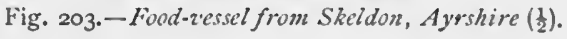

narrow-based. It is commonly found with an unburnt body, and generally placed near the head.

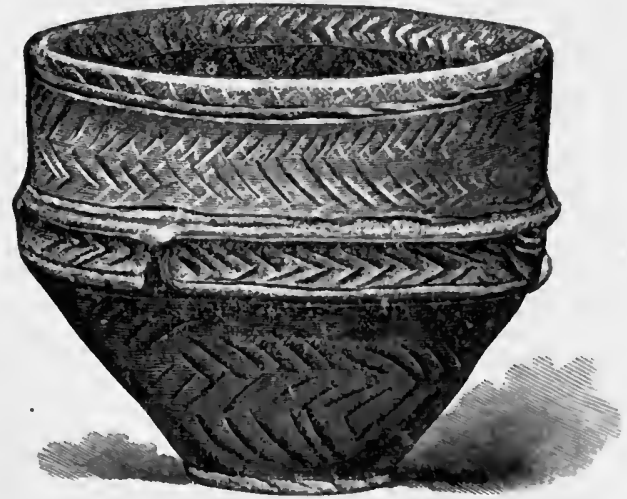

Fig. 204.-Food-zessel found in levelling a sandbank at Content, Ayrshire $\left(\frac{1}{2}\right)$.

Drinking-cups are tall, highly ornamented vessels, narrowing from the mouth to near the middle, then bulging out and 


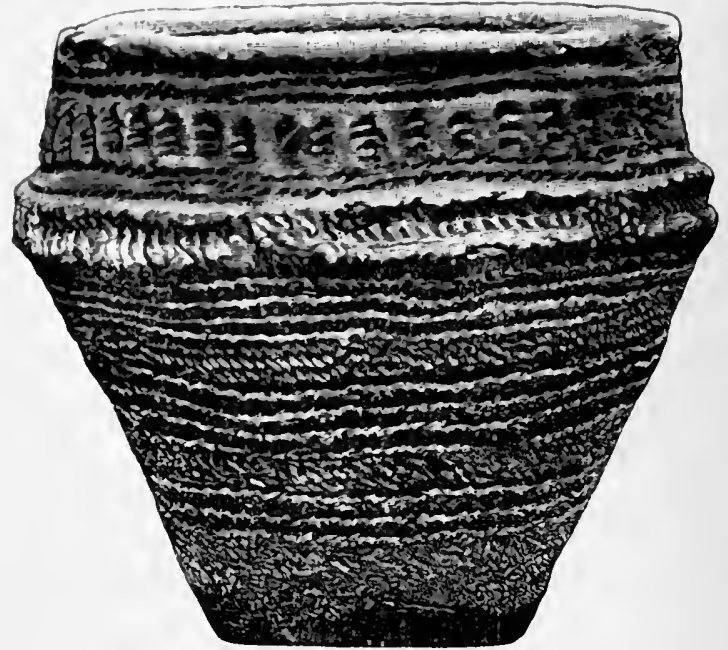

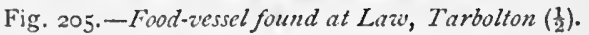

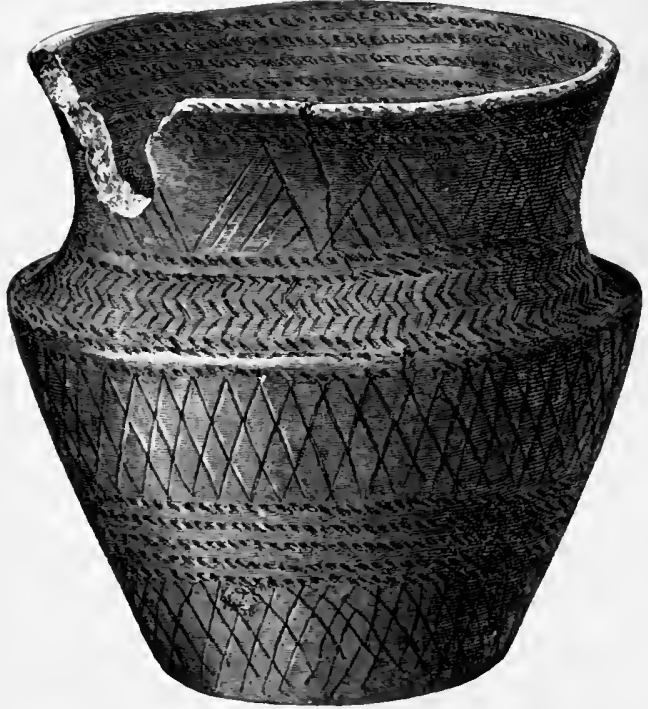

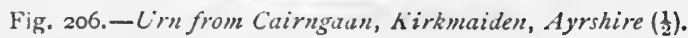


again narrowing at the base. A few specimens have been found with a handle like a jug. They are commonly associated with burials after inhumation-only two out of twenty-

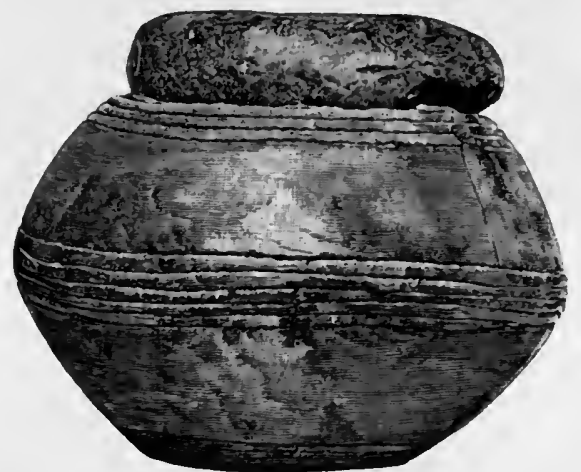

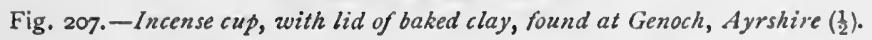

four having been found by Canon Greenwell in the woldbarrows with cremated burials.

The objects classified as personal ornaments found in these graves include buttons of jet, stone, or bone; pins of bone and bronze; necklaces made of plates and beads of jet. With regard to the latter, there are several instances in which the plates and scattered beads have been recovered and reconstructed so as to present the entire necklace. The plates are either tri. angular or trapezoidal, and often ornamented with incised or dotted lines arranged in groups of geo-

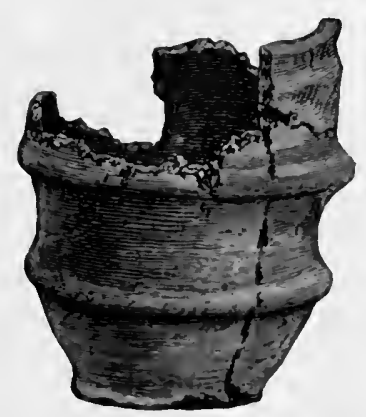

Fig. 208. - Urn found near Eglinton Castle, Ayrshire (7 inches in height). metrical figures. These relics are among the most interesting evidences of the culture of the Bronze-Age people which have come down to our day. (See fig. I33.) 
Ornaments of gold and bronze-rings, armlets, earrings, \&c. -are also not unfrequently met with; but those of amber, perforated teeth, and shells, are comparatively rare in the prehistoric burials of Scotland.

Among implements and weapons the most noteworthy are arrow-heads, knives, and scrapers of flint; wrist-guards (fig. 76 ), perforated stone-hammers (figs. 48 and 49), and whetstones; and small thin blades of bronze in the form of daggers and so-called razors attaclied to handles with rivets or tangs (figs. 92-95). Records of the finding of bronze axes of any kind, socketed spear-heads, and leaf-shaped swords, in association with sepulchral remains, are almost unknown not only within the Scottish area but within the British Isles.

Dr Anderson, who has reconstructed for our National Museum, often from the merest fragments, a typical collection of urns unsurpassed by that of any other country, thus refers to the contents of Scottish prehistoric burials of the Bronze Age: "We find the typical burials, of which these associated objects are characteristic, extending over the whole of the mainland of Scotland, and into many of its outlying isles. But we do not find-at least I have been unable to discover-any obvious or noticeable distinction between the forms or the workmanship of the different examples of the same classes of objects found in widely separated portions of the country. The urns from Ross-shire and Mull are as well made and as highly decorated as those from Mid-Lothian. The bronze blades and jet necklaces from Sutherlandshire are precisely like those from Forfarshire and Mid-Lothian. The gold ornaments from Banffshire are similar to those from the southern districts of Scotland. There may be among the various examples some that are finer and some that are ruder than others, but, taking them collectively, it is evident 
that the objects fashioned in these various materials usually exhibit shapeliness of form, fitness of purpose, and tastefulness of decoration." 1

In the above short review of the sepulchral phenomena prevalent in Scotland during prehistoric times, it will be observed that there is no mention of burials of the Early Iron Age. The reason for this is that archæologists have not yet found any mounds or graves in Scotland, with the exception of burials of the Viking period, which can with certainty be assigned to this period; and those explored in England have been already sufficiently described in the chapter dealing with the Late Celtic period. Considering the abundance of burials of the Early Iron Age throughout France, Germany, Austria, and Italy, it is somewhat remarkable that they should be so sparingly represented within the British Isles. The same remark is almost applicable to burials of the Stone Age. Although many graves have been examined which contained implements and weapons of stone and nothing of bronze, it does not follow that these graves were earlier than others in which bronze articles were found. It seems to me that the vast majority of the sepulchral memorials, hitherto explored within the Scottish area, date from the introduction of bronze and the custom of cremating the dead. Moreover, evidence is not wanting to suggest, if not to prove, that the same customs and civilisation continued to a much later period in North Britain than in the southern parts of the island. Some of the ordinary burials, whether after inhumation or cremation, which in all respects might be regarded as of the Bronze Age, may in reality be as late as the Roman occupation.

The following categorical notes on the relation between

1 Scotland in Pagan Times, p. 95. 
the various Scottish forms of burial and their analogues in Western Europe are noteworthy:-

I. The scries of chambered cairns, extending through the counties of Argyll, Inverness, Sutherland, and Caithness to

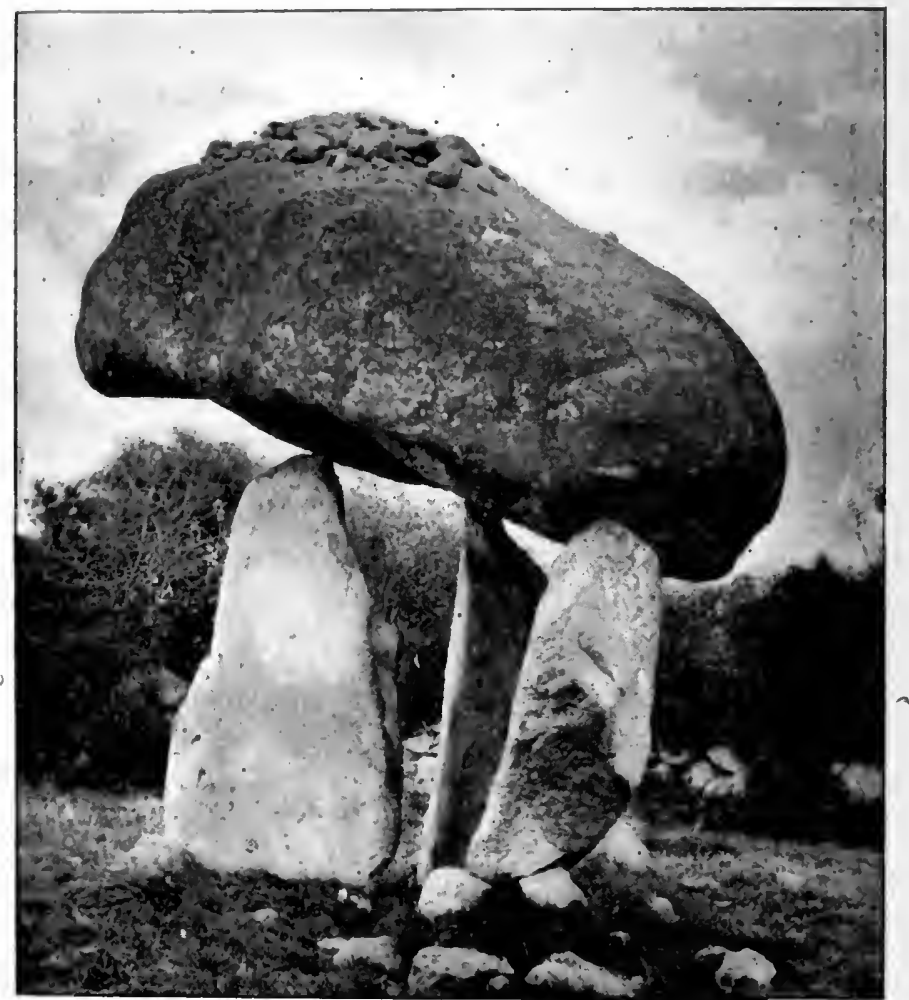

Fig. 209.-Dolmen at Ballymascanlan, Dunäalk (total height 12 feet). (From photograph by $R$. Welch.)

the Orkney Islands, do not cover a sufficiently wide area to entitle them to be regarded as the representatives of the Stone-Age burials of Scotland.

2. These same chambered cairns disclose a progressive 
amplification as regards structural details in the northern part of the area of their distribution; and in all of them from the very beginning both cremation and inhumation were practised by the people who constructed and owned them.

3. In the south-west of England (Gloucester, IVilts, Somer-

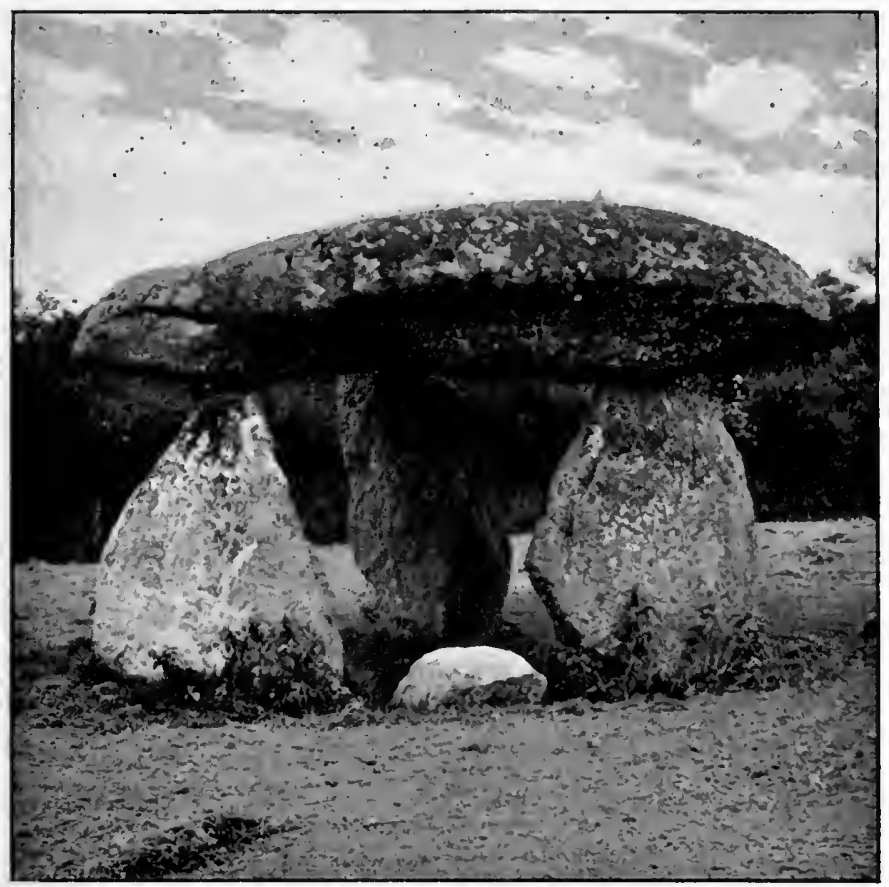

Fig. 210.-Spinsters' Rock, Chagford, Devonshire (supports 63/2 feet high). (From a photograph by Hudson.)

set, and some neighbouring localities) there are chambered cairns analogous to those in the Scottish area, including even "Horned Cairns," but in the former all the primary burials were by inhumation, and the skulls were those of a dolichocephalic race.

4. Sepulchral chambers with beehive roofs are met with 
in all parts of the British Isles, but they are not found in the Scandinavian archrological area, and only very rarely in France. Dr Fergusson, ${ }^{1}$ in describing the existence of two dolmens, associated with a circular chamber constructed on the beehive principle, in the long barrow called MoustoirCarnac, in Brittany, gives expression to the opinion that this method of construction is more modern than the simpler ceiling of single blocks, as was the custom in the earlier megalithic chambers. The beehive method of roofing was practised by the early inhabitants of Sardinia (Nurhags), Malta, Greece (tombs of Mycenæ), and Egypt (the Pyramids).

5. Dolmens - i.e., sepulchral monuments constructed of huge stones set on end and covered over with similar megaliths so as to form a chamber with, or without, an entrance passage - are rarely, if at all, met with in Scotland. But on the other hand, they abound in Ireland (fig. 209 and Pl. XIV.), England (fig. 2 ro), south of Sweden, Denmark, North Germany, the Drenthe, west of France, Spain, Portugal, and North Africa.

1 Rude Stone Monuments, p. 359. 


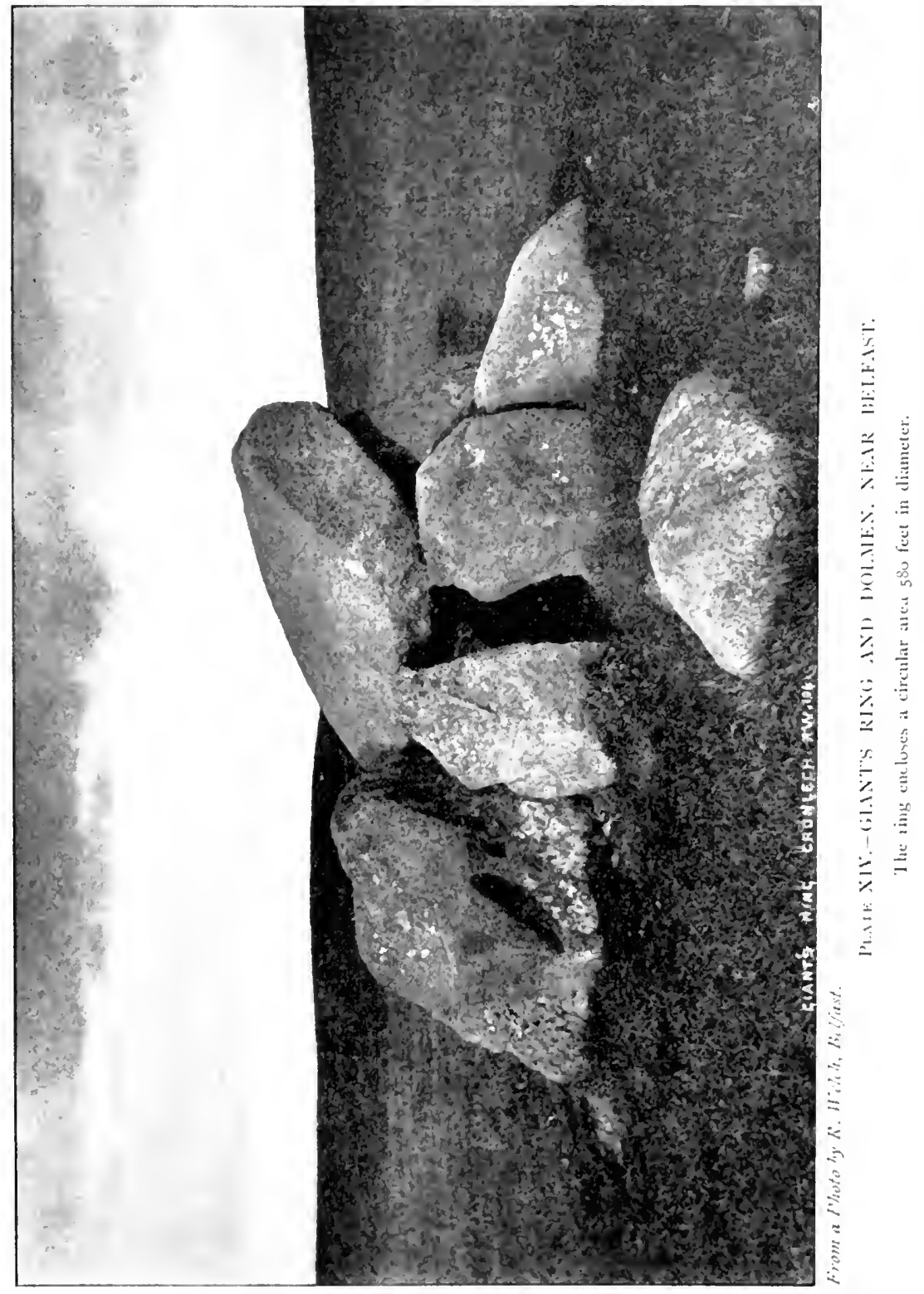





\section{CHAPTER IX.}

ABODES OF THE LIVING-SOCIAL LIFE.

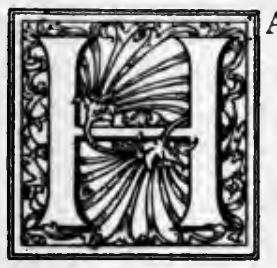

AVING in previous chapters discussed the mechanical skill of the prehistoric inhabitants of Scotland, as manifested in their stone and bronze industries, and expatiated on the strong evidence in support of the theory that they were greatly influenced in all their actions by religious principles, we now proceed to the consideration of the general phenomena of their domestic and social life. The first and paramount element in the attainment of domestic comfort is the dwellingplace, more especially in a country where the climate necessitates bodily clothing, shelter from a frequently inclement sky, and often a supply of artificial warmth. And on this point, also, I have to premise that the evidential materials within the Scottish area are so scanty and fragmentary that they have to be supplemented by foreign gleanings.

It was when dealing with the topographical modifications of the country due to changes in the relative level of sea and land that we caught the first glimpse of our prehistoric forefathers. We saw them hovering about the Carse of Stirling, when that stretch of now richly cultivated soil was the bed of 
a land-locked bay of no mean magnitude; at one time attacking and hashing up the carcasses of a number of stranded whales with instruments rudely fashioned of deer-horn, and at another feasting around extemporised hearths on the shore, on various edible molluscs which they had transported thither during the ebb-tide of the now vanished sea. Then again we had a peep of an interesting group of Troglodytes in a cave situated at the foot of a cliff in the present town of Oban, then washed by the Atlantic waves, but now over a hundred yards from the shore. From this place of abode these early colonists plied their avocations both by sea and land, culling from the products of each the ingredients of a substantial and varied meal. The accumulation of shells and broken bones in the form of a refuse-heap suggests a long sojourn in the cave, while the harpoons, bone chisels, and stone implements sufficiently attest the character and occupation of their owners. An inspection of the organic remains shows that they possessed some of the ordinary domestic animals, such as the dog, ox, and pig; and thus they combined with a pastoral occupation that of hunting and fishing. The absence of the sheep and horse from the fauna in this early period suggests that these animals were a later addition to the domestic animals of the neighbourhood.

We also noted some further evidence of the presence of an industrious population at this period (i.e., when the 25 -feet raised beach was being still laved by the tidal waves) in the canoes, stone implements, and camping-ground exposed in these ancient sea-margins along the shores of the Firths of Tay, Forth, Clyde, and Solway, localities now more or less inland. But with the exception of the Oban cave, and one or two rock-shelters, there is no reliable evidence to show what means they adopted to shelter themselves from the vicissitudes of a variable climate. The remains of pit- 
dwellings and hut-circles, so frequently chronicled by archæologists, afford few data for determining either the nature of these structures or the age to which they belonged, although it is quite probable that some of them may date to the incoming into Scotland of the earliest races.

At Spiennes, near the town of Mons, Belgium, may be seen, thickly scattered over a plateau of 50 or 60 acres, a large number of circular pits, 2 to 3 feet in diameter and 25 to 38 feet in depth. ${ }^{1}$ The chalk formation in this locality lies underneath quaternary and tertiary deposits, and these pits had been excavated by the Neolithic people for the purpose of extracting the flint nodules which it contains in great abundance. From the bottom of the shafts galleries were driven in all directions, until the whole district became actually riddled with subterranean passages. The shafts are now either fallen in or filled up with débris; but a few of them were cleared, and thus some interesting relics have come to light. The walls of the underground passages showed the marks of the flint and horn picks by means of which the chalk was excavated. In the vicinity of these pits MM. le Baron A. de Loë and E. de Munck have discovered the remains of flint-factories and dwelling-huts. ${ }^{2}$ 'These sites were in the form of circular depressions, 2 to 5 paces in diameter, but of no great depth. In the huts were found beds of charcoal, various kinds of implements of stone, horn, and bone, broken bones, land-shells, and other remains of food-refuse. The factories were distinguished from the huts merely by the quantity of flint-refuse and tools which they contained. The hammer-stones were round balls of hard sandstone-this substance being apparently preferable to a flint nodule. Flintmining on similar methods has also been carried on in Britain,

1 Congrès International, \&c., 1872 , p. 279.

${ }^{2}$ lbid., I $8 S 9$, p. 569. 
as at Grime's Graves, near Brandon, ${ }^{1}$ and at Cissbury Camp, near Worthing."

Foundations of dwelling-huts of a still earlier period have been discovered in several localities in Europe. The most important station of this kind is that at Campigny, near the picturesque village of Blangy (Seine Inférieure), France. The sites of these divellings were circular pits, excavated in quaternary gravels, and measuring a few yards in diameter and about 4 feet in deptl, which in the course of time became filled up, with débris and so preserved their contents. The industrial remains collected consist of hearths, remains of stone industry, and fragments of a coarse pottery. The pottery shows various kinds of vessels, some with perforated handles or ears, and others rudely ornamented with cross lines in quadrilateral spaces. Among the stone relics are small axes (tranchets), precisely similiar to those found in the Danish Kjökkenmöddings, knife-flakes, scrapers, \&c., but no polished objects. It would thus appear that the invention of pottery preceded that of the art of polishing the edges of cutting implements. There are also 2 few large flat sandstones showing marks of rubbing, as well as the smaller hand-rubbers, which are supposed to have been used for grinding grain and seeds. The number of hearths indicates communal life and a social organisation of some kind. As to the actual covering of these sites, or the kind of hut which these people constructed, there is no evidence. Campigny is chronologically on the same horizon as the rock-shelter of Mas-d'Azil, and to French archæologists it has supplied a name to the period of transition between Palæolithic and Neolithic times. ${ }^{3}$

Nor is the evidence to be gathered from collateral sources of a very precise character. Even as regards the actual habitations

${ }^{1}$ Eth. Soc. Journ., vol. ii.

2 Archæologia, vol. xlii.

'See 'Kerue Mensuelle,' r889, pp. 366-408. 
or huts of the lake-dwellers the details are meagre and fragmentary. The indications from this source consist of portions of clay-mouldings, hearth-stones, and a few special commodities of domestic life picked up on the sites of the lacustrine settlements. The faggot castings in clay suggest that the huts were made of small timbers and plastered over with puddled clay. Such impressions have been found on many stations; and it may be noted that they vary greatly in size, some showing merely a kind of wicker-work and others timbers of large dimensions. The clay-castings found on the Glastonbury lake-village are generally of the former character.

One important piece of evidence as to the kind of abodes constructed by the lake-dwellers of the Stone Age settlement of Schussenried, in the Federsee, came to light some years ago. This settlement had none of the signs of having been destroyed by fire, and it is supposed that its inhabitants voluntarily abandoned it on account of the growth of the surrounding peat. In this case it is probable that the huts would be allowed to fall into natural decay, but before this happened there was a chance that some part of the buildings would be overtaken by the moss, and so become, as it were, hermetically sealed up. That something like this actually occurred is now proved by the discovery of the foundations and portions of the walls of a cottage deeply buried in the moss. As soon as the discovery became known Mr Frank, the investigator of the settlement, had the ruins uncovered, and before the crumbling materials disappeared there was a plan of the building taken, which by his courtesy $I$ had an opportunity of inspecting. The structure was of an oblong rectangular form, about 33 feet long and 23 feet wide, and was divided by a partition into two chambers. On the south side there was a door, a little over 3 feet wide, which opened into one of the chambers. The other, or inner chamber, was 
somewhat larger, and had no communication with the outside, except through the former by means of a door in the partition. There were no relics found in this chamber, but in the outer there was a mass of stones which showed signs of having been a fireplace. The walls were constructed of split stems set upright, and their crevices plastered over with clay. The flooring in both chambers was composed of four layers of closely laid timbers separated by as many layers of clay. These repeated floorings may have been necessary from the gradual rise of the surrounding peat which ultimately drove the inhabitants away.

From the remains of the Scottish and Irish crannogs we also gather some reliable evidence as to the kind of dwellings that were in use during the early Iron Age. These were constructed of upright timbers placed side by side, the interstices being filled in with clay, like that at Schussenried, so that they may be regarded, to some extent, as direct survivals of structures previously in use. The Lochlee crannog had five distinct hearths superimposed one above the other, indicating successive, but intermittent, occupation. On the original platform, and at the same level as the lowest hearth, were the stumps of a wooden wall forming a rectangular enclosure 39 feet square. This enclosure was divided near its middle by a partition, and on the south side of the southern compartment were portions of two stout posts which had evidently formed a doorway. In front of this door and on the left side there was an immense refuse-heap, and a little beyond it, the remains of a gangway which stretched to the original shore of the lake.

Another crannog exposed in the bed of a drained loch in Argyllshire contained the wooden foundations of a circular dwelling-house which clearly showed the method of construction. In the centre of the artificial island there was the 
stump of a huge oak pile, and around it a series of flat horizontal beams, firmly fixed to the surface of the island and all pointing towards the centre. At the outer end of each beam there was a square-cut hole, apparently for receiving the end of an upright post. The distance between these holes and the centre was 8 or 9 feet, and that between the beams, at their outer extremities, 5 or 6 feet. That the uprights which stood in these holes had been connected with the central pile was obvious, but whether they converged towards it like the ribs of an umbrella, or rose perpendicularly to meet cross rafters, there was no evidence to show.

As early as 1833 Captain Mudge, R.N., described a wooden hut ${ }^{1}$ which had been exposed in the bog of Drumkilin, county Donegal. It consisted of a rectangularly shaped framework of oak beams, mortised at the corners, and measuring $\mathbf{2}$ feet square by 9 feet in height. It was open on one side, and about half-way up there was a horizontal flooring which divided it into an upper and a lower compartment. The base of the hut rested on a substratum of brushwood, a fact which subsequently led to the conjecture that it was the site of a crannog; and peat to the extent of 16 feet in depth had accumulated above its roof.

Remains of wooden structures, having some resemblance to the Drumkilin hut, were discovered in 1880 , in the Coal-bog, county Fermanagh, also on the site of a supposed crannog. Here, at a depth of $2 \mathrm{I}$ feet below the surface of the peat, an artificial mound was encountered, and upon it there was a wooden framework formed of rough beams with rudely executed mortises. This framework measured I I feet ro inches in length and 6 feet 3 inches in breadth, and associated with it were some stone implements and other objects of an archaic character. 
As to the materials which covered the roofs of these early huts we have but scanty data for forming an opinion. From discoveries made at Niederwyl, Mr Messikommer came to the conclusion that the roofs of the huts in that station had been covered with layers of straw and rushes. That thatch of some sort was generally used in proto-historic times in western Europe finds some corroboration in the statements of classical writers. Strabo asserts that the Belgæ lived " in great houses, arched, constructed of planks and wicker, and covered with a heavy thatched roof" (Book iv. chap. 4).

Owing to the perishable nature of the constructive materials of these wooden houses, we could not expect to find many traces of them now, except under such rare conditions as are occasionally supplied by lake-dwellings and peat-bogs. The supposition that wooden houses preceded the ordinary stone buildings in Scotland is also strengthened by the fact that the latter have been found only on the later crannogs.

\section{Beehive Huts.}

There is, however, a method of building huts with dry stones which claims a high antiquity, it being actually proved to have been practised in Ireland before the introduction of Christianity. This is the beehive hut (fig. 2 I I), which consists of a circular or oval building constructed of uncemented stones, and so arranged that each layer overlaps the one beneath it, till the opening becomes so small, at the apex, as to be closed in by one stone. Although these structures were comparatively rude within the British Isles, yet the architectural principle involved is capable of great development both in gracefulness of form and perfection of structure. The finest, and probably the oldest, examples known are the famous tombs of Mycenæ, especially that called the "Treasury of Atreus." 
In the simple form beehive houses appear to have been planned and laid out without any regard to symmetry, so that, when partially covered with earth or stones, an operation which was almost essential for the stability of the roof, they looked like a group of tumuli or cairns. These unicellular structures were not capable of attaining large dimensions, but by connecting them by means of passages, a many-roomed dwelling-house could be readily constructed.

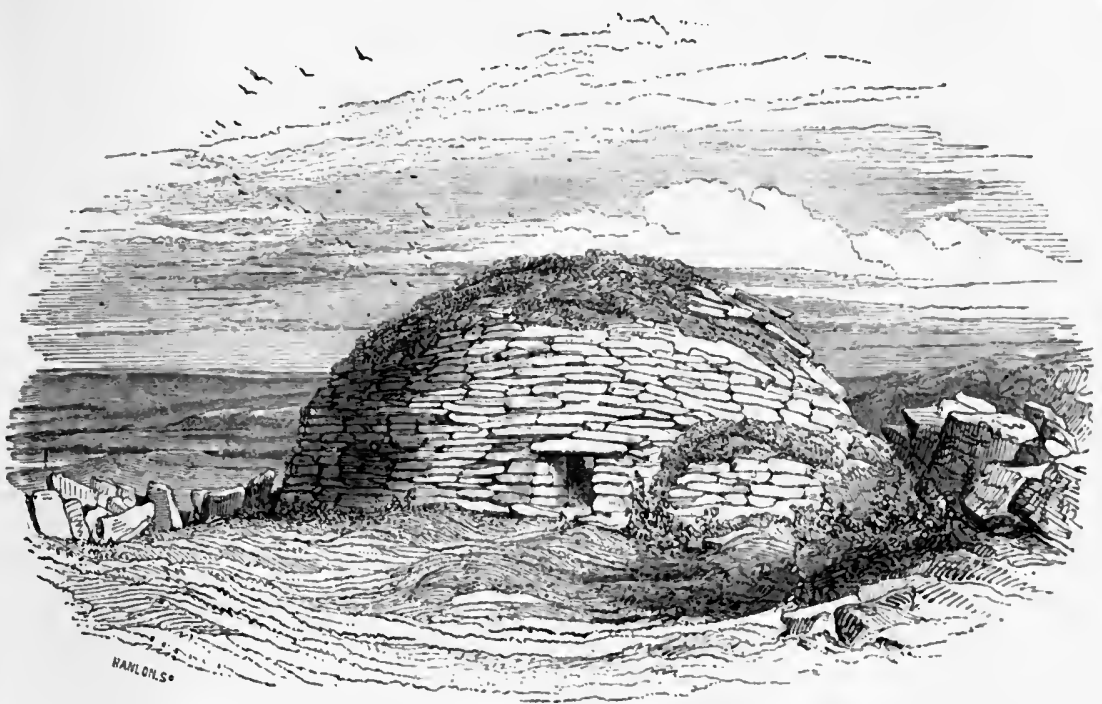

Fig. 211.-Clochan-na-Carraige, North Island, Aran.

Another method by which the dwelling could be enlarged disclosed no small amount of skill and architectural ingenuity. Thus, by surrounding a circular chamber with a gallery, leaving just the thickness of a wall between them, and having this wall interrupted by passages at regular intervals all round, a spacious compact building could be constructed. A specimen of this kind was discovered by Captain Thomas in South Uist, and is thus described by him: "On a small, 
flattish terrace, where the hill sloped steeply, an area had been cleared by digging away the bank, so that the wall of the house, for nearly half its circumference, was the side of the hill faced with stone; while the other side of the house, for it was almost gone, was built up from the ground. The interior of the house was circular and 28 feet in diameter. Within the area were pillars, or rather piers, formed of blocks of dry-stone masonry, raised distinct from the wall, and radiating from the centre of the house. These piers were about 4 feet high, 4 feet 6 inches long, and $I \frac{1}{2}$ foot to 2 feet broad; and there was a passage of from 1 foot to 2 feet in width between the wall and them. There were five piers remaining, and five more would complete the suite. These piers were evidently intended to lessen the space to be covered by overlapping; for while the breadth of the house is 28 feet, the central dome or beehive had, by this means, only 15 feet to span." 1

This remarkable house had attached to it a subterranean gallery or hypogeum, 14 feet long, which terminated in an underground beehive chamber of considerable size, as shown on the accompanying plan and sections (fig. 212).

From the investigations of Captain Thomas ${ }^{2}$ it would appear that beehive houses continued to be built and used down almost to the present day in the islands of Harris, Lewis, and St Kilda. Sir Arthur Mitchell, who has devoted a chapter to these primitive structures in his most interesting book, 'The Past in the Present,' thus writes: "When I had seen more of them, I came to the same conclusion as Captain Thomas, namely, that they represent an old form of divelling which is now dying out. No other conclusion, in fact, is possible. The time of the building of some of them has been well ascertained; one, for instance, was built by a

1 Proc. Soc. A. Scot., vol, vii. p. 166.

2 Ibid., vol. iii. p. 127, and vol. vii. p. 153. 
person who was alive in $185^{8}$, and there are people living who were born in them. They lave at one time been very common. Captain Thomas saw fifty or sixty in what he properly calls a limited area. They are not confined to Harris and the Lewis, but I believe are also found in the other islands of the Outer Hebrides, and they probably ex-

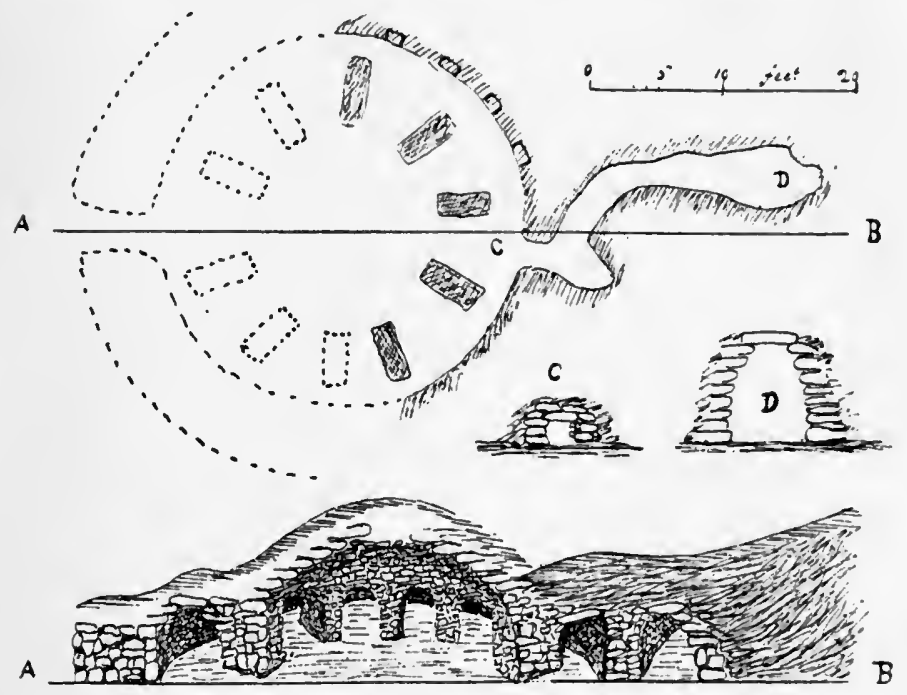

Fig. 212.-Ground-plan and section of beehize house (restored) on line A B, Huishinish, South Uist.

isted at no very distant time in Skye, in Mull, and in some of the west parishes of the mainland. Not more, however, than from twenty to thirty are now inhabited." I

In Ireland beehive huts, or cloghauns as they are there generally called, are very abundant, especially in stony districts, such as the Aran Isles and county Kerry. In June 1897 I had an opportunity, under the guidance of the 
Royal Society of Antiquaries of Ireland, of visiting the ruins of the "ancient city of Fahan," certainly one of the most extraordinary archaic remains I have ever seen. Proceeding westwards from the coastguard station on the slope of Mount Eagle, overlooking Dingle Bay, we reached Fahan, where may be seen "forts with three, four, two, and one huts, a group of seven huts and twelve detached cloghauns, a church, and four gallauns." Immediately to the south of this is the famous fort of Dunbeg, occupying a projecting headland, three-fourths of which require no defence, as it terminates in a precipitous cliff. On the landside it is protected by a massive stone wall and three earthen ramparts which stretch across the entire neck of the headland. There is a gate in the wall with a guard-chamber on each side, and in the court inside are the remains of a large beehive hut. The other forts on the slope of the hill consist of stone walls, Io to I 4 feet or more in thickness, enclosing groups of beehive huts. Some of these huts contained souterrains entered by trap-like doors from the floor.

One of the most interesting of these forts, Caher-Fada-anDoruis (the long fort of the doors), had been recently cleared out, and showed a triple-celled dwelling, the central one (the largest) measuring 18 feet in diameter. It was connected with the other two beehive huts by passages 8 feet in length. The entrance or outer door faced south-east, and communicated with the central chamber by an oblique passage, from which a flight of stone steps (in ruins) ran spirally to the roof. Another fort was a double-chambered cloghaun, which showed a small window-the only one in the Fahan group.

Two theories have been held as to the date of this remarkable settlement: ( $\mathrm{I}$ ) that it was a primitive pagan city, probably of the period of the Firbolgs (Du Noyer); and (2) 
that it was the abode of Christian monks (O'Curry). $\mathrm{Mr}$ Stewart Macalister, in his recent monograph on the subject, ${ }^{1}$ comes to the conclusion that it existed both in pagan and Christian times: "The clochán period of the settlement," he writes, "probably extends from a little before the introduction of Christianity into Corkaguiney, down to a comparatively recent date in the middle ages. The modern inhabitants are for the most part successors, not descendants, of the older stock; who probably died out, or else were gradually dispersed by political and religious troubles, or by the need of seeking other surroundings, more fertile if less sublime."

Remains of beehive huts are frequently found in the great stone forts on the west coast of Ireland, as, for example, the Black Fort and Dun Conor, in Aranmore. I have also observed similar hut-remains in a fort near Cahirciveen, which in construction is analogous to Staigue Fort in the same neighbourhood.

There can be no doubt, therefore, that beehive huts were erected by the pagan inhabitants of Ireland prior to the introduction of Christianity, and that the Christians merely adopted, in the construction of their cells, the architectural methods they found already in use. Fig. 2 I I illustrates a perfect specinen of a solitary cloghaun in the north island of Aran. It is called Clochan-na-Carraige, and measures 9 feet by $7 / 2$ feet and 8 feet in height. It is on this primitive type of building that the early church architecture, both in Ireland and Scotland, was founded. The series of monastic buildings on Skellig Michael-church, square, oratory, and beehive cells-present, even now, a striking example of the early Christian "Cashel." The oratory of Gallerus (fig. 213) illustrates the first stage in the development of the beehive

1 Trans. R. I. Acad., vol, xxxi. part vii. p. 334. 
structure into the subsequent church architecture of the Christian period.

On Eilean-na-Noimh (Island of Saints), one of the Garve-

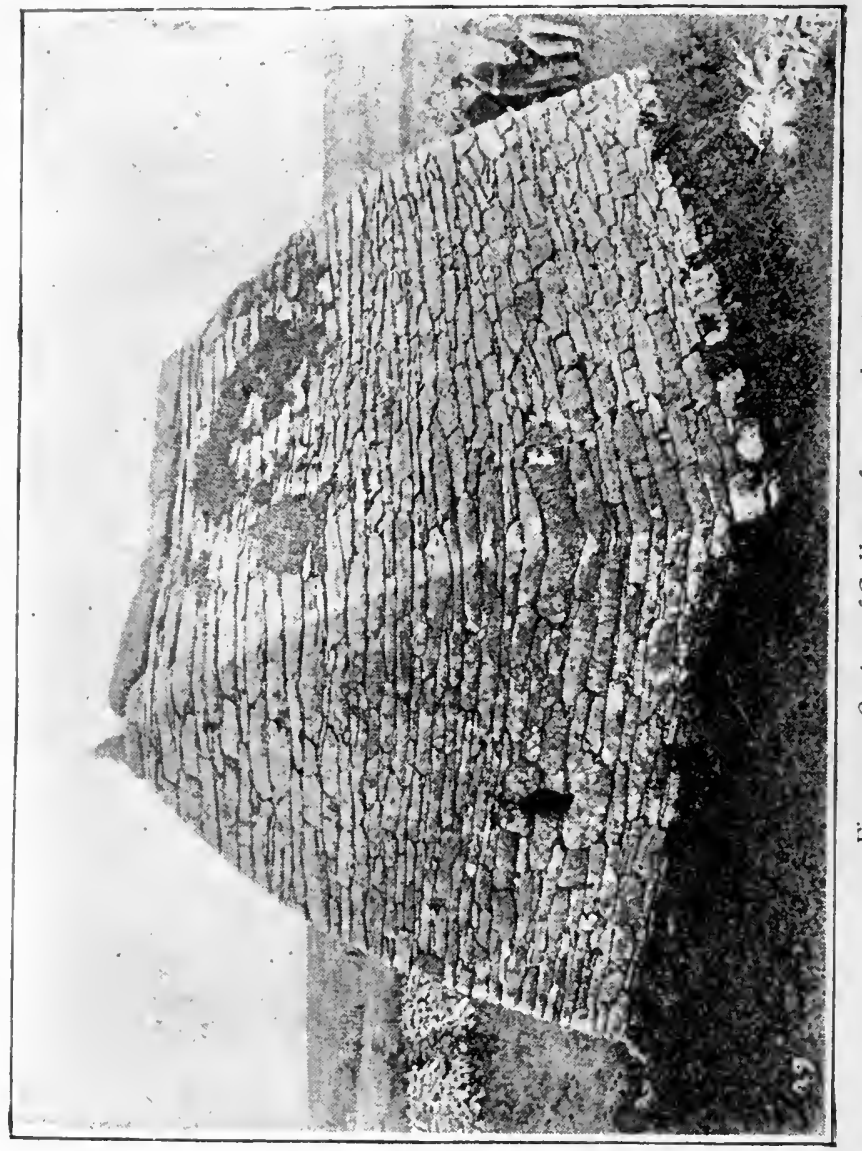

loch Isles, on the west coast of Argyllshire, there are two ruined beehive cells associated with a small church; but such remains are by no means numerous in Scotland. 


\section{Picts' Houses, Earth-houses, "Weems," \&oc.}

The comparative remoteness of North Britain and its associated islands renders these regions peculiarly favourable for the preservation of antiquities. The disturbing elements imported into the more southerly parts of Britain, in consequence of progressive waves of foreign civilisation, took a long time to reach these distant lands and islands. Hence we sometimes neet with the essential elements of an archaic civilisation surviving in these parts to a much later period than they did elsewhere. Of such survivals the so-called "Picts' houses" afford excellent illustrations. Dr Traill, in discoursing on these remains, thus writes: "The usual form of these buildings is that of a rectangular central chamber, with various passages leading into smaller chambers or cells; their shape, however, is variable, and one form in particular deserves some attention, as it differs so widely from the ordinary chambered tumuli that it appears to belong to a different period, and possibly may have been constructed by a different race. I allude to the circular towers, or 'brochs,' as they are commonly termed, the most characteristic example of which is the well-known tower of Mousa, in Shetland. . . . It has not yet been satisfactorily decided which of these very dissimilar types of architecture is the oldest. Both kinds are built of rough stone, without the aid of mortar or lime, and both seem to have been partially banked up on the outside with earth and turf, apparently with the object of excluding wind and rain. On this point, however, opinions differ; it is not always easy to determine how much of the earth and débris that surrounds these buildings is artificial, or how much is the effect of natural accumulation. In the case of Skerrabrae, however, we can speak with tolerable certainty, as enough of 
the outer wall is exposed to show us that earth had been heaped against the wall to the height of 6 or 8 feet, and the sloping bank thus formed had been coated over with a thin crust of clay. There was no clay on the wall itself, or between the stones of it, but only on the surface of the sloping embankment, and the deposit of earth above that, consisting of broken shells and vegetable mould, is, I believe, chiefly the result of drifting sand, with successive growths of vegetation on the top of it. It is remarkable that bones and horns of red-deer are generally found in both kinds of houses, and this circumstance is, I think, important in trying to arrive at some approximate date as to the age of these buildings; for, while we have undoubted evidence that these islands were formerly covered with forests abounding in deer and other wild animals, yet the writings of Cæsar, Diodorus Siculus, Solinus, and others, lead us to believe that at a time prior to the Christian era the forests had entirely disappeared, and we may justly conclude that the deer also had then ceased to exist. Assuming, therefore, as an established fact, that these early races of men were contemporaneous with the deer, we cannot bring them nearer to our own times than 2000 years; indeed, when we see how many links are wanting in the chain that connects them with our earliest recorded history, it is far more probable that we must assign to them an older date by some centuries." 1

One of the most instructive of the former class of divellings is that at Skerrabrae, referred to in the above quotation. It is situated on the south side of the bay of Skaill, in Orkney, and consists of a series of underground chambers connected by long winding passages. I visited these ruins during the summer of 1896 , and had the good fortune to have them explained to me by Mr Watt, who for many years has taken

${ }^{1}$ Proc. Soc. A. Scot., vol. vii. pp. $427,428$. 
a great interest in everything pertaining to this singular place. The explorations conducted by him from time to time have been so extensive that the exposed ruins look almost like a small village; nor was $\mathrm{Mr}$ Watt, even then, certain that its full extent had been exposed. Through his courtesy I had also an opportunity of examining the relics which for the most part are preserved at his private residence. Mr George Petrie, who first gave publicity to the existence of this remarkable dwelling, thus records its discovery: "About fifteen or sixteen years ago, the drift-sand, which had accumulated to a great height at a place called Skara, on the south side of the bay above named, was undermined and swept away by the wild waves of the Atlantic, and an immense 'kitchen-midden,' apparently of great antiquity, was exposed to view. It was at some points 15 or 16 feet high, and consisted chiefly of ashes thickly studded with bones, shells, pieces of horns of the ox and deer, and fragments of charred wood. The discovery was communicated to me by Mr William Watt, Skaill, who showed me various bone and stone implements which he had picked out of the mound, and informed me of the existence of the ruins of buildings at the same place. . . Mr Watt, afterwards, from time to time, collected a variety of stone and bone relics from the mound, and ascertained that a great mass of ruins lay buried there. $\mathrm{He}$ also came upon a stone kist or box containing about two dozen large oyster-shells, all perforated in the middle with a hole about an inch in diameter." 1

These structures, as now exposed, consist of four or five groups of chambers and cells, placed on both sides of a common gallery or passage which runs nearly parallel to the shore-line. The entrance to each group is by a secondary passage branching off to right or left from the main gallery.

1 Proc. Soc. A. Scot., vol. vii. pp. 201, 202. 
When discovered, all these chambers and passages were filled with sand and stones fallen from the roof, so that the labour of clearing them out was very great.

The first chamber, that on the left of the main entrance, was approached through a passage 12 feet long, $2 \mathrm{x} / 2$ feet wide at outer end, but widening to $33 / 4$ feet at inner end, and $31 / 2$ feet high. "About 8 feet from the entrance two jambs project slightly into the passage, and on the inner side of these, in the side walls, were bar holes, and extending across the passage with its ends in these holes a long stone was found, which had evidently been used as a bar to support or barricade a door." When the sand had been cleared out the chamber was found to measure II feet wide and about 2 I feet long, transversely to the line of the entrance passage. The walls were built of dry-stone masonry, 5 or 6 feet of which still remained. The floor was flagged and marked out into compartments by stones set on edge, varying in height from a few inches to $2 \mathrm{y} / 2$ feet. The hearth occupied the centre, and was clearly defined by stones placed rectangularly, and the space so enclosed contained ashes and burnt bones. On one side of the wall there was a small cell, 4 feet in diameter and 4 feet in height, the entrance to which was 2 feet 7 inches high and very narrow.

It would occupy too much space to describe the details of all the chambers, passages, and recesses. They were, however, all built on the same general plan. The roofs converged on the beehive principle, and there were also flags set on end which probably formed supporting pillars. In one place some large portions of whale ribs were found which, Mr Watt thought, had been used for this purpose.

$\mathrm{Mr}$ Petrie describes the following curious discovery in one of the chambers: "Beneath this wall a very thick rude clay urn was found. This discovery naturally suggests the ques- 
tion, When and why came the urn to be placed there? I am not sufficiently acquainted with the circumstances in which it was found to enable me to form any decided opinion as to the time when it was deposited on the spot in which it was discovered; but I think that it has been buried there either by the original occupiers of the building, or by those who at a later date seemed to have appropriated the dwelling, and made alterations and additions, including, apparently, the rude wall beneath which the urn was found." 1

With regard to a human skeleton reported to have been found in the sand inside one of the chambers, and about 3 feet above the fireplace, the same authority says: "The skull of the skeleton found in the chamber $\mathrm{L}$ is of a type with which $I$ an familiar. The forehead is rather low and receding, and the nasal bones are very high. In the last respect it closely resembles other skulls which I have obtained from ancient graves in Orkney, but the notch at the root of the nose is deeper than any of the skulls I have hitherto met."

Among the relics collected during a prolonged series of investigations the following may be noted: A few polished stone celts; stone cups, mortars, and one large stone with a cavity which might have been used for rubbing or pounding grain; a round stone ball ornamented with knobs, and another shaped like a ship's block; a few large vessels made of whalevertebræ, and a small piece of whalebone fashioned into a rude idol; a large assortment of pins, beads (over 1000), and a variety of implements made of bone, including pointers such as might have been used as daggers; also a few pronged implements of bone or red-deer horn precisely sinilar to those from the Mondsee, in Austria $;^{2}$ several implements made by

1 Proc. Soc. A. Scot., vol. vii. p. 206.

2 I ake-Dwellings of Europe, fig. 39, Nos. 9 and 12. 
perforating the articulating ends of the leg-bone of the sheep; a few teeth perforated and probably used as ornaments; some knives and cleavers of clay-slate; a few stone vessels containing red and white pigments, \&c.

Although not a trace of either bronze or iron has yet come to light, we should be disposed, judging from the character of these relics, to regard them as belonging to the Early Iron Age.

The underground buildings known as "eirde houses," weems, and sometimes as Picts' houses, have a wide distribution in Scotland, especially in the counties bordering on its eastern shore, and attain their greatest development in the district stretching between the Tay and the Moray Firth. They are generally met with as single chambers concealed below the level of the surface, but sometimes they occur in groups, as on the muir at Kildrummy, in Aberdeenshire, where nearly fifty have been discovered, extending over an area of less than a couple of square miles. They are long, low, narrow galleries, always more or less curved, and gradually expanding, both laterally and vertically, till, towards the inner extremity, they may measure as much as 1o or 12 feet in width and 6 or 7 in height. They are most frequently built of undressed dry stones, with convergent walls bearing heavy lintels; but occasionally the walls are made with flags set on end. The narrow entrance, probably concealed by a stone door, slopes down to the floor level of the chamber, but before reaching the latter there is sometimes a second door, often placed at the point where the direction is changed. Sometimes a passage branches off from one side of the gallery and leads to another chamber, usually of a circular or oval shape. These chambers are frequently roofed in a dome fashion, on the beehive principle, much in the same manner as those constructed in the walls of the brochs and in the chambered cairns. Though all built on a uniform plan, they vary greatly 
in dimensions, that at Tealing. Forfarshire, measuring 80 feet in length, 5 feet 8 inches in height, 2 feet 6 inches in width at entrance, and 8 feet 6 inches next the inner end; while the corresponding measurements of one at Kinord are only $2 \mathrm{I}$ feet, $I 1 / 2$ foot, 3 feet, and $2 \pi / 2$ feet.

The structure at Tealing is described under the name of a "Pict's house " by Mr Andrew Jervise, ${ }^{1}$ and is remarkable, not only for its size, but for the quantity and variety of relics found in it. A rough undressed boulder on the north side of the doorway was sculptured with cup-marks, and a cup with five concentric rings and a gutter-channel. Among the relics found scattered throughout the débris were the following: A piece of Samian ware, a bracelet, bronze rings, coarse pottery, ten querns (some broken), a number of whorls, stone cups, and an article made of iron slightly mixed with brass. On the surface, close to the entrance to the underground chamber, there was a macadamised circular space, 6 feet in diameter, with much ashes, probably a hearth or cooking-place.

It is the general opinion of archæologists that these subterranean chambers were associated with surface habitations, whose structural materials have disappeared through natural decay and changes due to the cultivation of the land. Striking evidence of such an association was observed in 1 859, at Cairn Conan, ${ }^{2}$ near Arbroath, Forfarshire. Here an underground structure (see plan and sections, fig. 214) presented the peculiarity of having, in addition to the usual long curved gallery, a circular beehive chamber attached to it by a low passage, and to which there was also a second entrance. About six or seven paces north of the underground gallery a circular space, 20 feet in diameter, and rudely paved with flagstones, was detected a few inches

1 Proc. Soc. A. Scot., vol. x. p. 287.

2 Ibid., vol. iii. p. 465 , and vol. iv. p. 492. 
beneath the surface soil. 'I'his, upon examination, was recognised as the site of a habitation of which, however, nothing then remained except the floor, and a few relics which its occupants had left behind them. These relics are important in supplying some clue to the age of the structures; for there seems to be no doubt that both the surface and underground remains were parts of the same homestead. Among them were the upper stone of a quern, two whorls

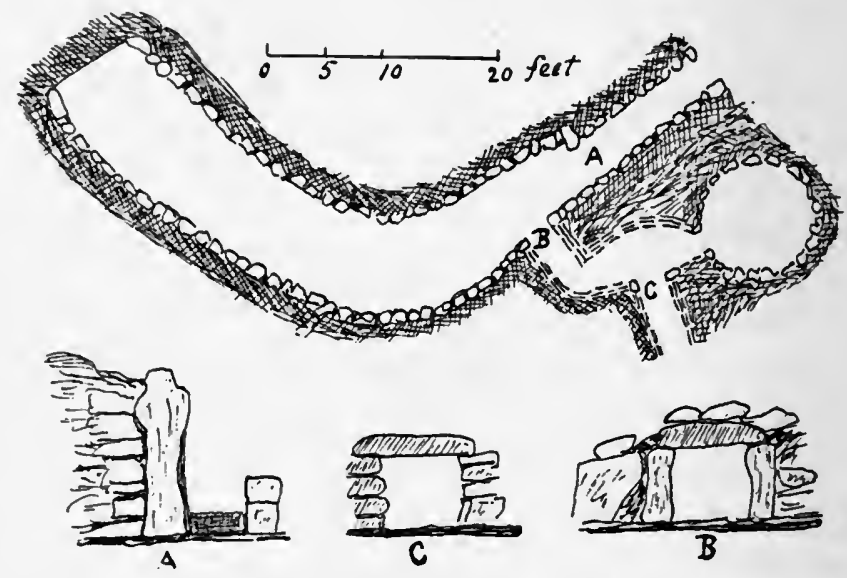

Fig. 214--Ground-plan and sections of earth-house at West Grange of Conan, Forfarshive.

of lead, a portion of a bronze ring, some rudely hollowed stones, and fragments of iron cutting implements. Those from the underground chambers comprised fragments of various kinds of pottery, some wheel-made, a bronze needle, part of a quern, horses' teeth, calcined bones, and a large spiral bracelet of the snake-like pattern-all of which point to Romano-British times.

Another interesting feature of this settlement was that, a few yards to the north-west of the underground chamber, a cluster of six full-length coffins, composed of rude stone slabs with 
stone covers, was discovered at no great depth in the soil. Some of the graves contained skulls and other portions of decayed bodies and a few coloured pebbles, but the only manufactured object was a portion of a ring of cannel coal. These graves were considered to have been the family burialground of the people who inhabited the adjacent dwellings.

Dr Stuart describes the "eirde" houses at Kildrummy as having been discovered "by the occurrence near the entrance of low foundations, which seem to have supported the frail summer- or daylight-houses of the early population." A similar association of surface and underground dwellings has been observed in several places elsewhere, as at Strathdonan, in Sutherlandshire, where two "eirde" houses were near a group of hut circles.

Earth-houses occur in the Scottish area singly or in groups of half-a-dozen or so, but rarely in such numbers as at Kildrummy. At Airlie, in Forfarshire, a group of five has been noted, but only one of them has been explored. Among its débris were found a bronze pin, charred wood, querns, and a piece of sandstone containing a cup-like hollow. An iron padlock was among the contents of one at Alvey, in Invernessshire. So far, therefore, as relics give indications of the age of these structures, they must be classified as belonging chiefly to the Early Iron Age. That many of them were utilised in post-Roman times is placed beyond doubt by the discovery of red Samian ware, as in those at Tealing and Fithie in Forfarshire, and Pitcur, near Coupar-Angus. Moreover, the investigation of one at Crichton Mains, Mid-Lothian, ${ }^{1}$ has revealed the fact that its walls contain stones dressed with diagonal and diamond markings, after the manner of Roman workmanship.

With regard to their distribution it may be observed that none have been found in Galloway, and only one in Berwick-

${ }^{1}$ Proc. Soc. A. Scol., vol. viii. p. 105. 
shire-viz., that near Broomhouse described by D. Milne Home, Esq. ${ }^{1}$ This earth-house is interesting as showing the peculiar curved shape so commonly met with in Scottish examples (fig. 2 I 5).

In Ireland underground chambers, generally known as "souterrains" or "coves," are to be found all over the country. In structure, and in the occurrence of side-cham-

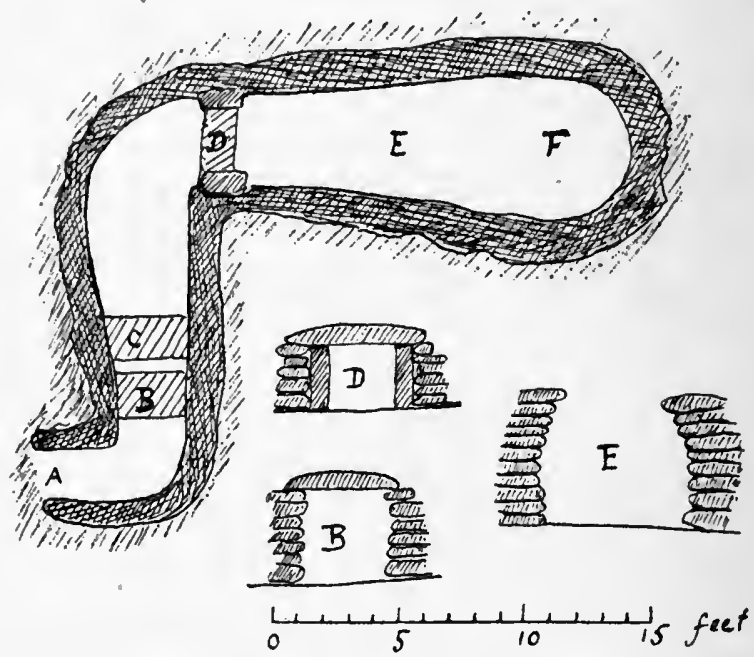

Fig. 215.-Ground-plan and sections of earth-house near Broomhouse, Bervickshire.

bers opening from the main passage at irregular distances, they are very similar to the Scottish examples, the only slight difference between them being in the extent of curvature of the main gallery, which appears to be less pronounced in the Irish souterrains. Although usually isolated, they sometimes occur in connection with the earthen forts or raths; differing in this respect also from the Scottish examples, among which only one instance is known inside a

1 Proc. Soc. A. Scot., vol. viii. p. 20. 
fort-viz.; that in the ancient fort known as Macbeth's Castle, on Dunsinane Hill. In the valley of Glenshesk, county Antrim, there is a good specimen of the souterrain locally called "Gobar Saer's Cave." It is situated on the hillside, about a mile and a half south of Ballycastle, and consists of two chambers, measuring respectively $3 \mathrm{I}$ and 24 feet in length. ${ }^{1}$

The only other locality in which subterranean dwellings, of the type now under consideration, are found is Cornwall -a district abounding in ancient British remains, such as beehive houses, dolmens, menhirs, stone circles, forts, \&c. A stay of a few days at Penzance enabled me to visit a number of these interesting remains with no other assistance than the 'Official Guide to Penzance.' The antiquarian notes in this little volume, being by $\mathrm{Mr} \mathrm{W}$. C. Borlase, are thoroughly to be depended on.

One excursion was in a north-west direction, occupying a circular journey of about fifteen miles. Following the Morvah road, we first came to "Lanyon Cromlech," a free standing dolmen with a cover-stone, 17 feet long by nearly 9 feet broad, and resting on three pillars 5 feet in height. But this was not its original height, as in the year 1815 the cover-stone fell and was broken, as well as one of its supports. The cover in its damaged condition was subsequently replaced, and the other two pillars were cut down to the same level as the broken one. In its original condition it is said that a man on horseback could ride under the cover-stone.

Turning to the left, we reached Chûn, where there is a group of remarkable antiquities, including a hill-castle, a dolmen, and an ancient British village. Chûn Castle is of an oval shape, 180 feet long by 170 feet broad, and differs from the ordinary hill-forts of the neighbourhood in being entirely built of stones in their rough state, but without any

1 Guide to Belfast, by the B. Nat. Field Club, p. 212. 
cement. It consists of two concentric ditches alternating with two walls. The inner wall is 20 feet thick, and before it was plundered of its stones in the last century "it was at least 10 feet in height." The entrance is on the west side, and the two gate-posts, each 5 feet in height, still remain. These are placed at the inner margin of the wall at a distance of only 6 feet, but this interval gradually widens to 12 feet at the outer margin of the wall. It is noteworthy that the corresponding gateway in the outer wall is not opposite to the former, but twelve paces to the south of it. The central area is partially occupied with ruins of dry-stone buildings which appear to have been divided into structural compartments. Chûn Castle is regarded by antiquaries as a connecting-link between the ancient British fort and the Norman castle.

The dolmen, whose stones are covered with a thick coating of lichens, stands in solitary grandeur about 250 yards to the west of the castle, and consists of a large cover supported on four pillar stones, enclosing a chamber 7 feet in height. A tumulus of earth and stones formerly covered these megaliths, and it was surrounded by a ring of stones set on edge.

A quarter of a mile to the east of the ruined castle is the site of the ancient British village of Bosullo, which appears to have been connected with the former by a paved way.

About a mile to the south there are the ruins of another ancient hut-village on the slopes of a hill at Bodinar, in which, "within the memory of man," there were beehive huts to be seen, but they are all now in ruins. However, I had the satisfaction of seeing one of the Cornwall beehive huts at Bosporthennis, now the only remaining specimen of a large British settlement. This consists of two chambers, one circular and the other rectangular. The former is $\mathbf{3}$ feet in diameter, and has no less than three small doors. The 
roof has unfortunately collapsed, but enough of the wall remains to show the converging system on which the dome was constructed. Connected with the beehive chamber by a low square door there is another chamber 9 feet long by 4 feet broad, which is regarded as a later appendage to the former.

The ancient British village of Chysauster, situated in the vicinity of the hill-fortress of Castle-an-dinas, has been partly cleared out, and in the course of these operations evidence of tin-smelting and fragments of Romano-British pottery were discovered. But without dwelling further on these ancient British remains, we must pass on to notice the characteristics of the subterranean dwellings which are associated with these villages.

A good specimen of them is the "Fogou" at Boleit, on the lower Buryan road, near the ruins of the ancient manor-house of Trewoof. It consists of a subterranean gallery 40 feet long, from which another chamber, at present about i 3 feet long, branches off, but whose full dimensions have not been ascertained. The convergent walls are of unhewn stones and covered with large granite slabs.

Another and still more interesting specimen is at Chapel Euny, parish of Sancreed, about four and a half miles from Penzance. Its main features consist of a gallery 60 feet in length, 6 feet wide, and from 6 to 7 feet high. At one end it gives access to the surface by a small trap-door closed by a stone, with holes in the sides apparently for barring it, and at the other there is a low passage 10 feet long which leads to a beehive chamber 16 feet in diameter. The floors of the gallery and chamber were paved with flagstones and provided with drains beneath the pavement. During the excavation of these underground structures evidence of tinsmelting and various relics were found, among the latter 
being whetstones, hammer-stones, various kinds of pottery, an iron spear-head, a "pot-hook," and a piece of red Samian ware. On the surface above these chambers there are the remains of a British hut-village - thus showing, like all the other examples in this district, a relationship between the surface and underground dwellings.

These subterranean dwellings, like their Irish analogues, do not manifest so strongly the single or, sometimes, double curvatures which are so constantly met with in the Scottish examples; but in all other respects they are so similar over the three special areas of their development, that they can hardly be accounted for except on the supposition of a unity of origin. The almost trivial differences manifested in their plan of construction can be readily explained by their geographical isolation, consequent on the occupation of Central Britain by foreign immigrants, and their continued occupancy after the old British associations became permanently broken up by the Roman occupation.

Outside the British Isles the beehive underground dwellings seem to be unknown, although the statement of Tacitus suggests the prevalence of such hiding-places among the Germans. In discussing the manners and customs of this people (chap. 16), he writes as follows: "They also dig subterraneous caves, and cover them over with a great quantity of dung. These they use as winter-retreats and granaries; for they preserve a moderate temperature ; and upon an invasion, when the open country is plundered, these recesses remain unviolated, either because the enemy is ignorant of them, or because he will not trouble himself with the search."

The special purposes thus assigned by Tacitus to underground retreats among the Germans, whatever may have been their mode of construction, are precisely those indicated by 
the results of the latest archæological investigations of the "eirde" houses, "souterrains," and "fogous" of the British Isles.

\section{Indications of Social and Industrial Life.}

The unequal distribution of the raw material used in the manufacture of stone implements, contrasted with the widespread use of the latter, suggests that a system of trading or barter was prevalent amongst the prehistoric people of Scotland. This view is supported by the occasional discovery of the remains of flint factories-anvils, hammers, fabricators, cores, splinters, chips, and other broken and disused materials. Remains of this character have been usually found on the indurated subsoil of sand-dunes, such as those at Culbin, Glenluce, and Irvine, and in localities where flint nodules abound in the natural graveis. At Skelmuir, already referred to, a remarkable hoard, consisting of thirty-four flints worked roughly to a leaf shape, was found concealed under a flat stone. They were evidently a consignment of unfinished goods possessing a certain commercial value, and it is possible that they were laid aside in concealment till such time as the warrior or huntsman had leisure to give them the final finishing touches; or, what is more probable, they might have been intended for transport to a locality where there was no natural supply of flint. Hoards of bronze objects, which are by no means uncommon, point to the same conclusion.

The principle of the division of labour, here dimly shadowed, is more forcibly indicated by the disposition and localisation of some of the materials found on the sites of lake-dwellings. From the uniformity with which grain, quantities of applecores, bundles of flax, yarn, cloth, \&c., were found strictly confined to separate areas at Wangen, Mr Löhle came to 
the conclusion that the difierent trades had been kept apart. At one of the stations in the Lake of Geneva, near the present town of that name, Dr Gosse fished up stone moulds together with a number of crucibles, ingots of bronze and tin, scoriæ, and other materials of the founder's art-all within an area of roo square yards. Other researches have proved a still wider generalisation, and it is probable that not only were the special trades kept apart in each village, but that some villages had already established a monopoly of certain industries. It is only on such a supposition that the extraordinary number of implements and chips of jade found at Maurach, and the equally striking predominance of flint refuse at Wallhausen, can be explained.

The late Mr Radimsky came to a similar conclusion with regard to the inhabitants of the Neolithic station of Butmir, in Bosnia. On dividing the seventeen different kinds of stone used in the manufacture of implements into two groups, according as they were, or were not, found in the vicinity of Butmir, he observed that all came under the first category, with the exception of the perforated hammers and two objects of gabbro, and that not a splinter or core of the foreign material of which the latter had been made had been detected on the station. Hence he inferred that the Butmirians manufactured the objects made from the rocks readily accessible to them, and imported, ready made, those represented by raw materials found only at a distance. ${ }^{1}$

But, indeed, the manipulative skill necessary to carry on these stone industries is suggestive of some kind of division of labour among the prehistoric folk, as the art could only be acquired by long experience and careful training.

I have already adduced evidence to show that the early immigrants into North Britain were hunters and pastoral

${ }^{1}$ Rambles and Studies in Bosnia, p. 107. 
farmers, who probably paid no attention to the cultivation of the land. It was only as the population increased, and permanent communities gradually took root in the glens and straths, that agriculture became the mainstay of their subsistence. From the investigations of Canon Greenwell it is proved that during the Early Bronze Age the people of the wolds of Yorkshire were possessed of domestic animals, cultivated grain, and manufactured cloth, pottery, and implements. But it was probably several centuries later before people, with an equivalent civilisation, brought the primeval forests and marshes of Scotland under cultivation. 'The testimony of classical authors might also be adduced in support of this view. Cæsar (Book v. chap. xiv) categorically states that most of the inland inhabitants of Britain did not sow corn, but lived on milk and flesh, and were clad with skins. The speech which Tacitus puts into the mouth of Galgacus on the eve of the battle of Mons Graupius contains the following: "For we have neither cultivated lands, nor mines, nor harbours, which can induce them to preserve us for our labours." In a sentence, however, almost immediately preceding this, the Caledonian chief is made to refer to the land and its yearly produce-apparently corn. Thus it would seem as if the inhabitants occupying the greater part of the country to the north of the Firths of Forth and Clyde were a purely pastoral people in the first century of the Christian era.

That the prehistoric people of Scotland were in the habit of using canoes on the lakes and firths which so abound in and around the country, is amply attested by the facts already recorded in chapter iii. Another kind of boat used by them was the currach (Celt. curach), or coracle, the invention of which must also be relegated to the remotest time of which we have any historical knowledge. It was made of a slender 
frame of wood, or basket - work, and covered with skins. Adamnan, in his Life of St Columba, describes long voyages made in skiffs of this description; and they are referred to by several of the classical authors. Pliny, ${ }^{1}$ writing of the inven-

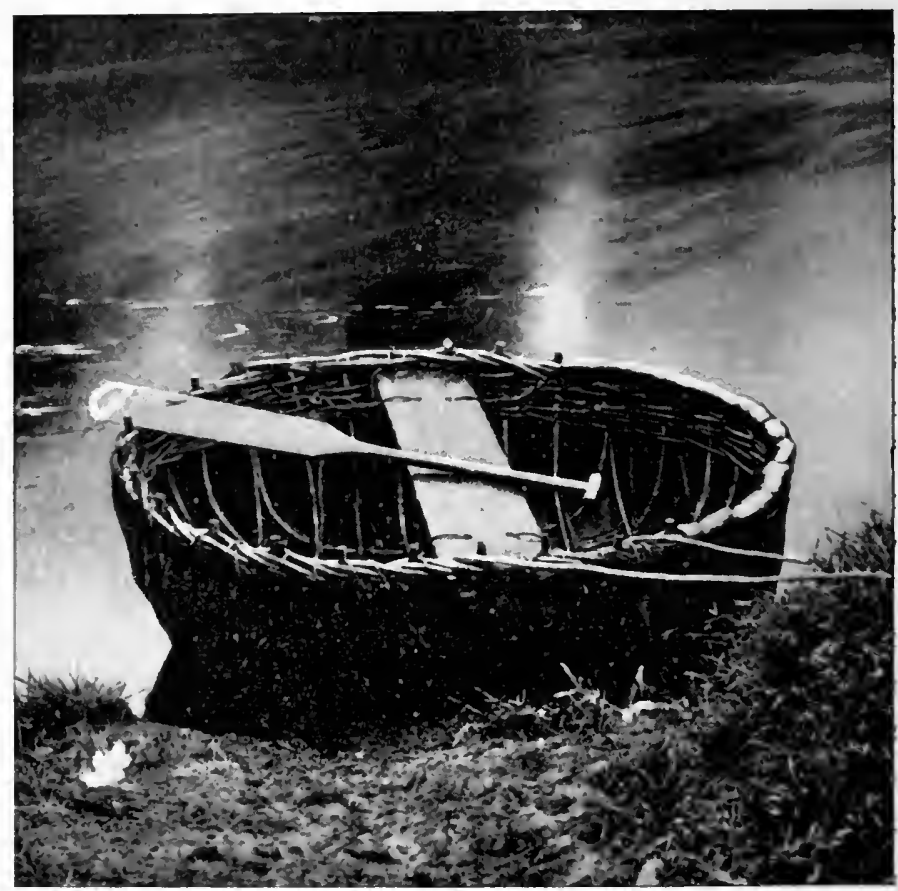

Fig. 216. - Currach or coracle used on the Boyne, Ireland. (From photograph by $R$. Welch.)

tion of ships, says: "Even at the present day they are made in the British ocean of wicker-work covered with hides." Currachs still continue to be used on many parts of the Irish coast-one recently seen at work on the river Boyne being here figured (fig. 216). Those now constructed by the people

${ }^{1}$ Nat. Hist., book vii. chap. 57 . 
of the Aran Isles, in the bay of Galway, are like ordinary rowboats, and covered with tarpauling instead of skins. Coracles are reported to have been employed on the river Spey at the end of last century.

But however far our gaze can penetrate the prehistoric arcana in search of evidence to elucidate the social life of our Scottish predecessors in the ages of stone and bronze, the story elicited is but an imperfect and fragmentary record. No structural habitation or building of these times, with the exception of the tomb, has ever been discovered, to my knowledge, within the Scottish area; so that in formulating general deductions we are largely dependent on the stray objects made of the more durable materials which have been gathered from the dustbins of time. Scarcely a particle of clothing-be it skin or woven stuff-has reached us across the long waste of forgotten ages, and yet the jet button, the bone or bronze pin, and other objects used for fastening the dress, unmistakably tell us that the prehistoric inhabitants of Scotland were not destitute of that essential commodity of life. On the other hand, if we judge of their social condition by that of their contemporaries, the lake-dwellers of the Stone-Age settlement at Robenhausen, who, by a mere coincidence of natural conditions, have bequeathed to us a great variety of woollen fabrics, plaited mattings of bast, and other fibrous materials, and a whole series of domestic utensils made of wood, we may legitimately infer that they were equally well equipped for the struggle of existence. In Scottish archæology the grave and its contents supply the most valuable evidential materials at our disposal. Here we find many objects which the hands of loving friends laid beside the body of the deceased-indicating by this very act social and religious traits which would do honour to the highest phases of modern civilisation. Mental conditions 
disclosing taste, refinement, and culture, are also traceable in the personal ornaments the people wore; and as to their skilled efficiency in handicraft manipulations, we have already seen that the evidence in support of this is overwhelming.

That the people of Scotland, from the earliest times, were governed by laws emanating from some central authority is suggested by various circumstances, as-the honour paid to persons of distinction on their demise, by the construction of tombs intended for perpetuity; the persistence of the same religious obsequies for many centuries; the indications of commercial intercourse with distant lands; the adoption of the principle of the division of labour in the prosecution of many of their industries; and the distribution of forts, camps, and other military remains throughout the country,-all of which, in my opinion, disclose a system of social organisation which contained within it the germs and main elements which are still paramount in European civilisation. 


\section{CHAPTER X.}

WORKS OF DEFENCE-FORTS, CAMPS, AND BROCHS.

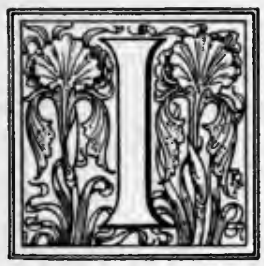

$\mathrm{T}$ is more than probable that during the earlier stages of human civilisation the uninhabited portions of the earth were gradually peopled by nomadic families of hunters who lived on wild fruits and the produce of the chase. Their daily avocations thus led them to penetrate farther and farther into the primeval forests, mountain recesses, and other haunts of wild animals. In these circumstances there can be no doubt that they found congenial homes in such caves and rock-shelters as they came across in their wayward wanderings. As evidence of the presence of these early colonists in Scotland, we have the remains of the Oban Troglodytes and the whale-hunters of the Carse of Stirling, already referred to. When, however, more settled communities began to arise, these natural retreats, even if always conveniently situated, would not suffice as means of defence, and hence the necessity of resorting to artificial methods of protection. The sites selected for this purpose, in the first place, would be those whose natural features facilitated their speedy conversion into places of strength and safety, such as rocky eminences with precipitous es- 
carpments, and promontories more or less surrounded by water or impenetrable bogs. For it must never be forgotten that, during the whole period of man's career on earth, the principal enemies with which all struggling communities had to contend were their fellow-creatures.

\section{Forts, Camps, Motes, \&c.}

Throughout nearly the whole of Scotland there are numerous remains of strongholds and works of defence in the form of (1) enclosures, of various sizes, fortified with ditches and ramparts of earth and stone; (2) mounds of earth, often terraced, and surrounded with a ditch or moat; (3) stone-built forts, generally situated on commanding eminences and defended by intrenchments. These different monuments are not uniformly distributed over the country, some parts being thickly crowded, while other parts are entirely destitute of them; nor is this irregularity in their distribution altogether accounted for by the disposition of land capable of cultivation, so that there is more than a surmise that the element of strategy had something to do with their erection. The hill-forts, being constructed of stones, have their materials still lying upon their sites (except in localities where the stones have been removed for agricultural improvements), so that their structural peculiarities are hidden under a mass of ruins. As a rule, their outlines and dimensions were determined by the contour of the summits of the hills on which they were built. If placed on the brink of a precipice, the assailable sides only were usually fortified with walls and ramparts. Those situated on the plateaux and lower grounds were almost invariably circular or oval. Some covered only a few yards in diameter, while others were of great extent, often occupying the whole top and flanks of a hill. 
From historical evidence we know that Scotland, since its occupation by the Romans, has been inhabited by various races-Picts, Scots, Danes, Anglo-Saxons, and Scandinavians -all of whom must have left some traces of their respective habits and customs. In no class of antiquities could such traces be more readily preserved than in forts, camps, battlefields, and the sites of warlike operations. But all these remains have become reduced in the course of time to a uniform state of dilapidation, so that from their external aspect it is now impossible to form a correct idea either of their original appearance or of the period to which they belonged. Careful excavations might, however, be the means of determining their origin by bringing to light stray relics of their inhabitants, or some special features in their structure.

In Scotland the large majority of forts are circular or oval, except where the local peculiarities of the site necessitated an irregular form. The Romans, however, were in the habit of making their camps square or rectangular, and were always guided in their construction by precise rules and measurements. Although the dimensions varied according to the number of men to be accommodated, the interior arrange. ments, and the relative proportions of the buildings, were generally the same. When an army took the field it never halted, even for a night, without throwing up an intrenchment consisting of a ditch and a rampart, the earth from the former being thrown inwards to form the latter, over which was then placed a palisade. This uniformity in the construction of the Roman camp has been of some service to archrologists, as it furnishes them with a prima facie clue to Roman camps as distinguished from those of native races. Thus, in Britain, all rectangular encampments are usually regarded as the work of the Romans. But, of course, this rule cannot be accepted as infallible, since the Romans themselves 
sometimes utilised native camps - a fact proved to have been of frequent occurrence in Illyricum, ${ }^{1}$ and even in Scotland there are indications that the hill-fort of Birrenswark, which has a very irregular perimeter, was occupied by the Romans.

After eliminating from the category of works of defence the artificial islands called crannogs, and the peculiar stone towers known as brochs, both of which, being constructions of a sui generis character, will be separately described, there remain in Scotland upwards of 1000 monuments which fall to be included in the list of prehistoric forts. Traditionally and locally they are known under various designations, often descriptive of some special feature in their structure or appearance, such as mote or moat, burh, dun, rath, lis, caer, \&c.-words whose etymology can be readily traced to one or other of the languages now, or formerly, spoken in the country. Many of them, being conspicuous objects in a landscape, have been visited, described, and illustrated in numerous articles and special works, the most important among the latter being those of Miss C. Maclagan ${ }^{2}$ and of Dr David Christison. ${ }^{3}$

The most natural division of the subject, and that which lends itself most conveniently for our present purpose, is into earth-works and stone-works; between which, however, there are no well-defined boundaries, as some are constructed of both materials. To throw up an intrenchment, as a ready means of defence, was not a monopoly of any people at any time; but it could only be most advantageously used in localities where wood for palisades was abundant. So common was the practice of palisading among the Romans,

1 Rambles and Studies in Bosnia, p. 365.

2 The Hill Forts and Stone Circles of Scolland, 1875 .

${ }^{3}$ Early Fortifications of Scotiand, 1898. 
that each soldier on the march carried a certain number of wooden stakes along with his intrenching tools. It is not likely, however, that stakes used in these intrenchments, owing to their liability to decay under the vicissitudes of a British clinuate, would survive to the present day; for it is only when wood is immersed in water, or embedded in bogs, that it is preserved for any length of time.

The numerous earthworks scattered over the country, chiefly in the south-western counties, vary greatly both in size and structure. They are usually called motes or moats, and moothills. But the latter, which are mere artificial mounds without any fortifications, may be at once eliminated from the category under discussion, as they do not appear to have much, if anything, to do with military works. They were places of meeting for the transaction of public business, the administration of justice, and the punishment of criminals. Whatever may be the origin of the word moothill, as used in the Lowlands of Scotland, its exact equivalent in Gaelic is dun a mhoid, from the word mod, a meeting or court. Moothill has also a parallel in the Tynwald Hill in the Isle of Man, which is still used on the occasion of the promulgation of new laws.

The mote consists of an artificial mound of earth, generally in the form of a truncated cone, flanked with terraces at lower levels and a circumambient ditch at its base. Adjacent to the mound there was often a court surrounded with an intrenchment. That these earthworks are the foundations of wooden fortresses and castles which, according to Chalmers, must be relegated "to the Scottish period when stone and lime were not much used in building," is rendered probable from collateral evidence, such as the illustration from the Bayeux Tapestry of the fortification of Dinan, reproduced by Dr Christison. ${ }^{2}$ These motes are found in considerable

$$
1 \text { op. cil., p. } 6 .
$$


numbers in various parts of England and Ireland. In Scotland their distribution is almost exclusively confined to the counties of Ayr, Wigtown, Kirkcudbright, ${ }^{1}$ and Dumfries -a fact which suggests their Irish origin, since they are very numerous on the opposite coast of Ireland. One of the most perfect motes I have ever seen is near the town of Ballymena, county Antrim.

Under the name motte or mothe such remains are abundant in France, as shown by the frequency with which these words enter into the composition of French place-names. M. G. de Mortillet ${ }^{2}$ gives a tabulated list of 167 , distributed over nearly the whole of France. According to him they dated from the fifth century, but they greatly increased in number in the middle ages. French archæologists have excavated many of their mottes, the results of which leave no doubt that they are the remains of habitations constructed for military purposes. Heaps of broken bones and other remains of food, together with Roman and medieval pottery, were invariably found in the excavations. In low-lying places the surrounding ditch, or ditches, contained water, so that they were veritable moated castles. The area of the distribution of motes extends into Belgium, Germany, and part of Austria.

But besides the motes there are other circular intrenchments, enclosing areas of different dimensions, which have no artificial mound-the essential characteristic of a mote-and between which and some of the stone forts there seems to be no difference except that the one is of earth and the other of stone. What kind of inner structures they possessed, or what was their special function, there is little evidence to show.

1 Mr F. R. Coles classifies the various fortifications in Kirkcudbright. shire as follows: Moles 27 , forts 34 , doons or doonhills 18 , doubiful and fragmentary 19. (Proc. Soc. A. Scot., vol. xxvii. p. 92.)

2 Revue Mensuelle, 1895, pp. 261 -283. 
Some of the hill-forts are among the grandest ruins of our country, reminding one of the giant's tales of olden times. Of this description the two Caterthuns, in the highlands of Forfarshire, are striking examples. The White Caterthun, occupying the southern spur of an isolated ridge, is of an oval form, and encloses a central area 470 feet long by 2 ro broad. Beyond this there is a succession of stone ramparts and ditches, surrounding the height at lower elevations, which gives the fortress the appearance of great strength. The Black Caterthun, occupying a rival eminence about a mile to the north, contains an inner enclosure measuring 280 feet by I 90 feet. The surrounding defences are nearly circular, and extend down the slopes in a series of concentric intrenchments of earth, but if they ever contained stones these have been removed long ago.

Another yery remarkable specimen is on the summit of the Barmekyne of Echt, a conical hill in Aberdeenshire. The inner enclosure, which was apparently reduced to a uniform level, is nearly circular, and measures about 300 feet in diameter. It is surrounded by five concentric ramparts of stone walls, with intervening trenches. Five entrances can still be traced, three on the south and two on the north. In their vicinity the walls appear to have been more strongly built, and so arranged as to have each a narrow opening (about 3 feet) commanded by the rampart immediately above it.

But perhaps the most striking of all the hill-forts is the East Fort on Bennachie, Aberdeenshire, which is perched on the top of a rugged granite hill, some 1400 feet above the plain. The summit consists of a small natural plateau roo feet long, 70 feet wide, and 70 feet high, which has its almost perpendicular sides strangely scarred into deep chasms. No artificial ruins are on the plateau itself, but at its base there 
are some remains of fortifications and round huts. It is not until we descend about $\mathrm{r} 20$ feet that the main rampart shows itself, stretching from cliff to cliff for 690 feet, with an average breadth of 24 feet. On a terrace continuous with a portion of this wall may be seen the ruins of some more round houses.

As a characteristic example of the pure earthworks, in the form, of a fortified camp on an elevation among cultivated lands, that on the Midhill Head, Mid-Iothian, described and measured ${ }^{1}$ by $\mathrm{Mr}$ W. Galloway, may be noted. Here are four earthen ramparts, still retaining a height of 4 or 5 feet, with intervening ditches, enclosing a central area 410 feet in length, from east to west, and 284 feet in breadth. There are three entrances to the interior, one at each end and another on the south side. Mr Galloway, who made a careful plan of this fortification, gives expression to the qpinion that its constructors had no theoretical considerations to guide them in determining its form beyond the natural conformation of the hill. "This strict adherence to the natural formation of the ground," he writes, "combined in several points with a careful adaptation of its special features, clearly indicates that to whomsoever, or to whatever period, the origin of the camp may be attributed, beyond the necessity of enclosing a given area on a selected site, with fortified lines, its constructors were guided by no more formal or preconceived principles of castrametation."

But however interesting and precise such superficial details may be, they add little to the kind of knowledge archæologists are mainly in search of. Hitherto the range in time of these structures and the racial affinities of their builders have been absolutely guesswork. As a more important part of the subject, I shall now select for description a few specimens

${ }^{1}$ Proc. Soc. A. Scot., vol. xiv. p. 254. 
which, owing to their having been subjected to a partial exploration in recent times, have yielded some evidence of chronological value.

Last summer I visited a fort, situated on a spur of the Ochil range, some 600 feet above the carse-lands, which was then being investigated under the auspices of the Society of Antiquaries. The fort occupies the summit of Castle Law Hill, overlooking the town of Abernethy, and commands an extensive view across the Firth of Tay and the lower reaches of the Earn. The defensive works consisted of a dry-stone wall, from 18 to 25 feet thick, having a well-built outer and inner facing, with rubble-work between, and enclosing an oval space, 136 feet in length and $5 \mathrm{r}$ in breadth. Portions of these walls, from 6 to 8 feet in height, remained in situ, but prior to the excavations they had been so completely buried in the débris that the surface had the appearance of a grassy knoll, over which a few trees found a congenial habitat. In one of the outer facings it was observed that the dry-built wall had been strengthened by logs of wood running both longitudinally and transversely: the wood, however, had completely decayed, and the row of empty spaces, some 2 feet apart, left by the transverse beams, looked like the port-holes of an old man-of-war. At a short distance along the most accessible part of the hill there was a dilapidated portion of an outer wall or tower; but, strange to say, there was no evidence of a gateway, which, if it existed, could only have been at this part of the fort.

Within the enclosed area the natural rock cropped up here and there, and the hollows were occupied with ashes, broken bones, \&c. In one place a circular rock cistern, 7 feet in diameter and 7 feet deep, was discovered, and among the rubbish cleared out of it there were numerous bones of the ox, the goat, and the pig, together with some blades of iron 
much corroded. The principal relics found in the course of the excavations are as follows: A bronze fibula of late $\mathrm{La}$ Tène type, remarkable as showing that the pin, with one coil attached to it, had been broken, but subsequently made serviceable by passing a bit of bronze wire through all the coils; so that, as found, it had the pin moving loosely on the inserted piece of bronze wire. In this form it might have been taken for one of those fibulæ of later times, so frequently associated with Roman and Romano-British remains (fig. 218 ). A spiral finger-ring of bronze (fig. 2 I 7). Portion of a bracelet of lignite; also a ring (fig. 219) and a polisher of the same material. Two stone lamps with nicks for the wick; a wellshaped stone axe (fig. 220 ), and a few rudely worked flints.

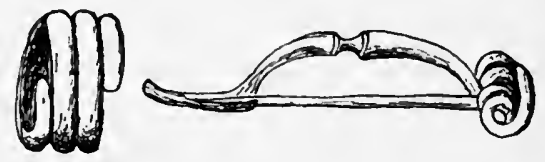

Figs. 217, 218.-Bronze finger-ring and fibula found in the fort at Abernethy (2).

Two portions of wooden dishes; a deer-horn handle; two pellets of burnt clay (supposed to be sling-bolts), like those found at Ardoch and the Glastonbury lake-village; a few fragments of hand-made pottery, like that of the cinerary urns.

The fort at Forgandenny, also situated on a commanding eminence, some 900 feet in height, was partially excavated during the summer of $\mathrm{I}^{8} 9^{2}$ by the late $\mathrm{Mr}$ E. Watson Bell. ${ }^{1}$ On the summit, beneath a grass-grown surface, excavations exposed the bases of two oval-shaped walls, an inner and an outer. The former was 18 feet thick and the latter $\mathbf{I}_{5}$ feet, and between them there was an intermediate zone, varying in breadth from 16 to 52 feet. The entire length of the fort is 456 feet, from east to west, and the breadth, from north to

${ }^{1}$ Proc. Soc. A. Scot., vol. xxvii. p. 16. 
south, I 90 feet. At the east end there was an entrance from a causewayed road into the intermediate zone, and from the south corner of the gateway a short wall ran across the latter to the inner wall, so that any one entering had always to turn to the right. There was no evidence of a gateway leading through the inner wall to the central enclosure, a feature which was also noticed in the Abernethy fort. The slope of the hill, especially on the south, was traversed by a number of ramparts and ditches in the usual manner.

In course of the excavations portions of the fort walls, from

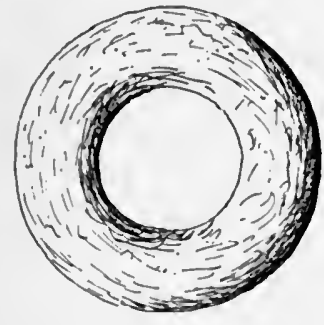

Fig. 219. - Ring of lignite, Abernethy fort $\left(\begin{array}{l}2 \\ 3\end{array}\right)$.

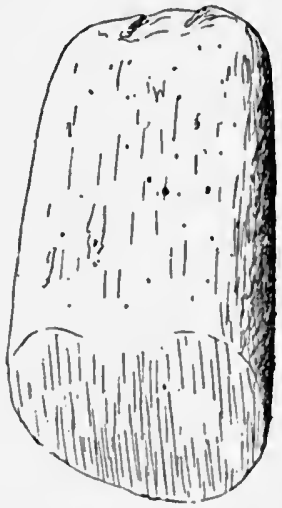

Fig. 220. - Stone axe,

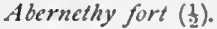

2 to 6 feet in height, were found in situ, showing inner and outer well-built facings with rubble-work in the interior. Some empty square holes, like those observed in the Abernethy fort, were supposed to have originally contained logs of wood. The relics found are a few whetstones and stone hammers, part of a jet bracelet, and a few fragments of coarse pottery. Bones of the ox (abundant), pig, and roe-deer were found along with charcoal and ashes.

The peculiarity presented by a wall, constructed of logs 
of oak alternating with layers of stone, was first noticed in this country by Dr James Macdonald, while conducting excavations at Burghead nearly forty years ago. This structural feature is thus described by $\mathrm{Dr}$ Macdonald: "The wall is built of unhewn stones, some of them of considerable size, carefully laid, but without mortar. It has only one face; but to strengthen it, beams of solid oak, still measuring from 6 to $\mathrm{r}_{2}$ feet in length, take here and there the place of stones; and similar beams, inserted endways, pass into the mass behind." I During the summer of $\mathrm{I} 89^{\circ} \mathrm{Mr} \mathrm{Hugh} \mathrm{W}$. Young, the present proprietor of Burghead, made some further explorations into the old walls of the fort. He penetrated the rampart, from where Dr Macdonald left off, till he reached the outer facing at no less a distance than 24 feet. "The two facing-walls," writes $\mathrm{Mr}$ Young, "are joined and strengthened by oak logs. The logs cannot be measured, as the state of decay is very great. Some of them I traced fully $\mathrm{r} 2$ feet into the rampart. These logs were joined across by oak planks and logs, riveted together by iron bolts," \&c. ${ }^{2}$

A similar method of constructing ramparts by stones and beams is described by Cæsar (book vii. c. 23) as peculiar to the Gauls-a statement the truth of which has been confirmed by the discovery, in modern times, of the actual woodwork in several of the ancient forts of France in the department of the Lot. ${ }^{3}$ The special advantages of the method are thus described in the Commentaries (loc. cit.): "This work, with respect to appearance and variety, is not unsightly, owing to the alternate rows of beams and stones, which preserve their order in right lines; and, besides, it possesses great advantages as regards utility and

\footnotetext{
1 J'roc. Soc. A. Scot., vol. iv. p. 350.

2 Ibid., vol. xxv. p. 436 .

${ }^{3}$ Congrès Arch. de France, I875, p. 427.
} 
the defence of cities; for the stone protects it from fire, and the wood from the battering-ram, since it [the wood] being mortised in the inside with rows of beams, generally 40 feet each in length, can neither be broken through nor torn asunder." These Gaulish methods of binding together loose stones and earth by means of mortised beams may be paralleled with those used by the crannog-builders for consolidating the composite materials of which the artificial islands were composed, as described on p. $43 \mathbf{I}$.

General Roy, in his 'Military Antiquities of the Romans in North Britain,' identified Burghead as the Ptoroton of the now discredited De Situ Britannia, which is described in that treatise as the capital of a Roman province of Vespasiana. For a review of this question, and of other interesting problems in connection with the history of Burghead and its remarkable promontory, I would refer my readers to an able article by Dr Macdonald, entitled "Burghead as the site of an Early Christian Church; with Notices of the Incised Bulls and the burning of the Clavie." 1 See also Sheriff Rampini's 'History of Moray and Nairn,' chap. i.

From behind the town of Ardrossan there extends northwestwards an elevated plateau, presenting towards the sea a steep escarpment, which overlooks a narrow strip of sandy soil lying between it and the sea-beach. The geologist at once recognises here an ancient sea-cliff, which in the course of time has become moulded into a succession of deep gullies, rounded knolls, and bluff headlands, around which nature has thrown a variegated garb of the richest vegetation. The tops of some of these commanding knolls have been converted into a series of forts, but as to the period of their occupancy, or the military exigencies that necessitated their erection, both history and tradition are silent.

${ }^{1}$ Trans. Glasgow Arch. Soc., vol. ii., N.S., pp. 63-115. 
One of these forts, situated on a grassy mound at Seamill, was explored in $\mathrm{r} 88 \mathrm{I},{ }^{1}$ the result of which may be thus epitomised: The oval contour of the mound supplied the design for the outlines of the ramparts, which on the sea-side consisted of two walls 5 or 6 feet thick. These walls, which were only a few feet apart, coalesced into one at the ends and on the north side. In their construction large undressed stones were used, without any cementing element, and the interstices were filled with smaller stones and earth. An ordinary partition wall along the shorter axis of the

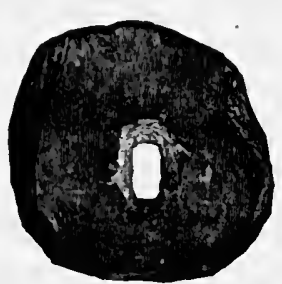

Fig. 221,-Spindle-whorl of cannel coal, Seamill fort, Ayrshire (f). enclosure divided it into two unequal compartments, the smaller of which, next a projecting ridge from the mainland, was found to have been partly paved with stones. The stuff lying over the area of this rude pavement was nearly all trenched over, in the course of which were found some charcoal and ashes, bones, horns, sea-shells, and all the following relics except the hammer-stone, which was dug up near the centre of the outer enclosure :-

Slone.-Hammer-stone of a flat oval pebble; globular ball artificially rounded with rubbing marks; two fragments of granite querns; a spindle whorl of cannel coal (fig. $22 \mathrm{r}$ ), and several other portions of this material showing cutting marks.

Bone.-A pointer made of a splinter of a leg bone 5 inches long; portion of bone perforated at each end and cut with a sharp instrument (fig. 222).

Iron.-Numerous portions, greatly oxidised, probably of blades and socketed spears or daggers.

Bronze or Brass. - A perforated bronze disc (fig. 223), and a wheel-like object attached to an ornamental stem (fig. 224 ).

1 Collections of the Ayr and Gal. Arch. Association, 1882, p. 59. 
Pottery and Glass.- Two small fragments of green glass, and a small bit of reddish pottery faintly showing three parallel lines.

Organic Remains.-Bones of ox, pig, sheep, and deer;

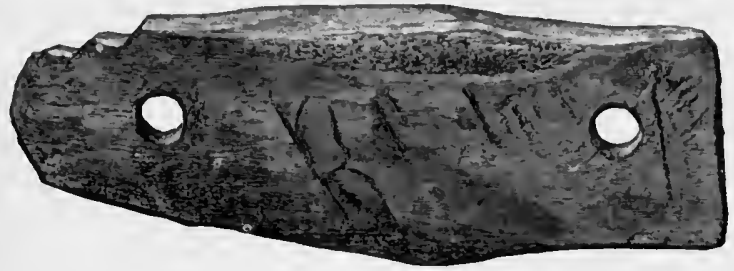

Fig. 222.-Bone implement, Seamill fort (1).

horns of the deer; and shells of several species of edible molluscs.

In 1827 Dr John Jamieson, in describing the fortifications on the top of the Laws, Forfarshire, says :-

"This fort consists of two walls of vitrified matter which surround the hill. The outer wall runs along its slope, and forms a kind of circle, although by no means perfect. . . The circumference of the outer wall, including the angular part, is, according to my measurement, 500 paces. .. The inner wall surrounds the summit of the hill, at the distance of several paces from the outer. This varies,

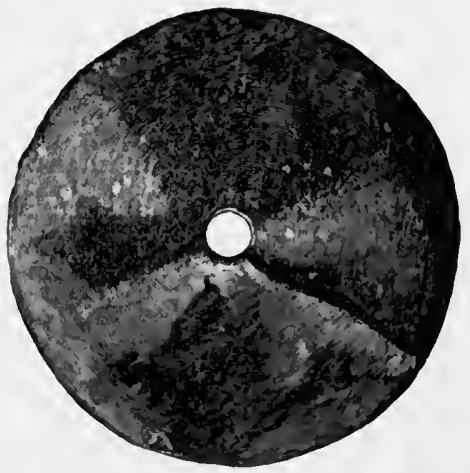

Fig. 223.-Bronze disc, Seamill fort (1). however, according to the nature of the ground. At the north-east comer, and round in that direction towards the north-west, are seen the foundations of several houses within 
the inner wall, which here seems to have formed the back wall to these houses. On the west side of the hill, the interstice between the two circular walls has been filled up

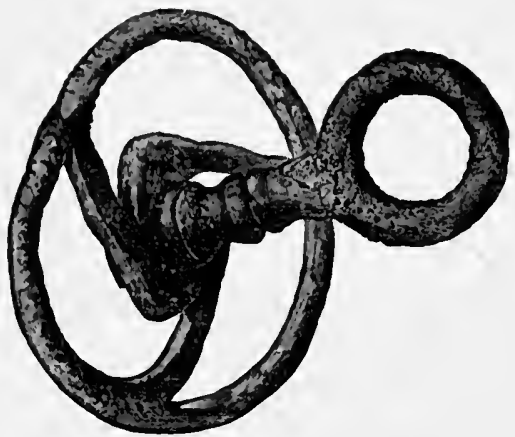

Fig. 224. - Bronze object, Seamill fort $\left(\begin{array}{l}(1) \\ 1\end{array}\right)$. by buildings of a small size. A wall runs nearly through the middle of the fort, extending from the south to the north side of the inner wall. The design of this has undoubtedly been to form a separation between the defenders and their cattle; for in the eastern division we ob-

serve no foundations of buildings, except a few on the wall itself. . . .

"Besides the gate formerly noticed, there seems to have been one on the west side. The vitrifaction here is as perfect as that of the fort of Finhaven, and assumes the very same appearance. Here, as well as there, the stones have been so completely fused, as in many places to seem as if they had been connected by some cement resembling melted ore; but this can be viewed only as the scoria forced from the stones themselves when in a state of fusion." 1

In 1859 , when these ancient structures were again examined by $\mathrm{Mr}$ James $\mathrm{Neish},{ }^{2}$ the fort was in a ruinous condition, owing to the removal of its stones for agricultural purposes, and no definite conclusions could be drawn from the remains then extant. Dr Stuart, in a supplementary note on $\mathrm{Mr}$ Neish's paper to the Society, thus writes: "I have twice

${ }^{1}$ Transaclions of the Royal Society of Literature, vol. ii. p. 274.

${ }^{2}$ Proc. Soc. A. Scot., vol. iii. p. 440. 
carefully examined the remains, and have found it difficult to form any feasible opinion as to their original shape, or to account for the arrangements of those walls which still remain. It seems obvious, however, from what we hear of the great quantities of stones which have been carried away from the hill, and the enormous masses of ruined walls still scattered over its top, that the buildings, when complete, must have been of great size and height."

$\mathrm{Mr}$ Neish collected a number of relics in the course of the excavations, most of which were subsequently sent to the National Museum in Edinburgh, ${ }^{1}$ among which the following may be noted :-

Stone.-Small cup, whorls and discs of sandstone, two flint chips, portions of vitrified sandstone with impressions of charred wood, stone with concentric circles.

Bone.-Double-edged comb and an implement with one end perforated.

Bronze.-Pin of a fibula, spiral finger-ring with four twists, a flat circular band of brass, an armlet with a pattern, and a copper coin.

Iron.- A small buckle, a pin with a ring-head, some large axes and an adze-head, portion of a single-edged sword, nails, needles, and fragments of implements.

Organic Remains. - Two bottles containing charred wheat and barley; a cowrie, and some land- and sea-shells; teeth of the horse, horn of a roebuck, and bones of domestic animals. Human remains were also found in stone cists, as well as elsewhere in the excavations.

One or two other excavated forts might be mentioned which have yielded a few relics, but their value, with regard to the question of chronology, is of no significance. I exclude the Dunbuie Fort, described by the late Mr Adam Millar, ${ }^{2}$

${ }^{1}$ Proc. Soc. A. Scot., vol. xvii. p. 300.

2 Ibid., vol. $x x x$. p. 291. 
because the strangely ornamented objects found in its débris appear to me not to be relics of any phase of Scottish civilisation. The presence of a couple of upper quern-stones among the relics vitiates the whole argument that this was a pre-Celtic fort of the Stone Age, as suggested by $\mathrm{Mr}$ Millar.

Forts perfectly analogous to the ordinary fortifications in Scotland are met with throughout the larger portion of Central and North-western Europe, and extend eastwards as far as the southern parts of Russia and the shores of the Black Sea. In Germany they are called Burgzülle or Rundzoalle, and are distinguished as Vorslavisch, Slavisch, and Spätslavisch-a distinction which has been suggested by the character of the pottery. Slavish pottery is always well burnt, and when it is decorated the ornamentation is in wavy lines running parallel to the rim-the well-known Wellenlinie. Wooden sub-structures are sometimes met with on the sites of the Burgwälle, especially in those situated in marshy localities, and also the remains of gangways in the form of a double row of the stumps of piles. The superstructures, of which nothing now remains, are supposed to have been of wood, agreeing in this respect with the motes of Scotland.

\section{Vitrified Forts.}

The variety of Hill-Forts known as "Vitrified Forts," on account of a peculiarity in their structure, has gathered around it an extraordinary amount of literature, chiefly of a controversial and speculative character. Mr John Williams started the discussion by the publication, in 1777 , of a work entitled, 'An Account of some Remarkable Ancient Ruins, lately discovered in the Highlands and Northern Parts of Scotland,' in which he enumerates six or seven vitrified 
forts around the head of the Moray Firth, and two in other districts (Finhaven and Bochastle).

In his account of the fort on Knock Farril he describes the whole wall as having been run together and vitrified into a solid mass by the action of fire. Writing generally of these forts, he says: "But what is most extraordinary, these walls have been vitrified, or run and compacted together by the force of fire, and that so effectually that most of the stones have been melted down, and any part of the stones not quite run to glass has been entirely enveloped by the vitrified matter; and in some places the vitrifaction has been so complete that the ruins appear now like vast masses of coarse glass or slag." Since Mr Williams's time nothing has been written or discovered which, to my mind, in the least impugns the correctness and scientific value of his observations. That he did not excavate the whole wall, or that he mentions in one place a few stones which were not included in the vitrifaction, cannot surely be advanced as sufficient evidence to discredit his general statement that the whole wall was "less or more vitrified." Would it be possible under the ordinary circumstances then available, whatever the process or object may have been, to vitrify the walls of a fort so thoroughly as to leave no portion or stone unaffected? The fact is that none of the forts, even those which disclose in the clearest manner that their vitrifaction was the work of design, has been completely vitrified.

The real problem at issue is to account for the vitrifaction which, to a greater or less extent, is, or rather was, to be seen on the surrounding walls of some fifty stone-built forts scattered throughout the northern and south-western districts of Scotland, and covering a broad band stretching from the shores of the Moray Firth to the counties of Argyll and Wigtown. Of the various hypotheses advanced to account for this phenomenon 
some may be at once ruled out of court, as, for example, that it is of volcanic origin, or that a liquid slag was poured like mortar between the stones when the fort was being built.

Looking at the problem from a practical point of view, the first observation to which I would direct attention is that the vitrifaction was effected by the external application of a great fire to the wall after it had been erected. Of the truth of this statement there can be no reasonable doubt. I have satisfied myself of its accuracy by a careful inspection of the more important vitrified forts in Scotland. On that at Carradale there is an uninterrupted portion of the eastern wall, extending for upwards of roo feet, which is absolutely consolidated for a depth of 3,4 , and 5 feet from the top. In one or two places where previous visitors had picked a hole right through the wall it was clearly seen that the vitrifaction was less in the lower and central parts, and disappeared altogether towards the base, which consisted of small, flat, and mostly water-worn stones. If this be so, the only point on which there is room for a difference of opinion is, whether the vitrifaction was due to incidental causes arising from the action of beacon-fires, \&c., or to fire kindled for the express purpose of fusing and thereby consolidating the materials of the wall. Present writers seem to range themselves as advocates of one or other of these alternative theories. For my own part, I see no reason for accepting either as a rigid dogma, to the exclusion of the other. Effects produced incidentally could be repeated designedly, so that vitrified forts may owe their peculiarity partly to the one and partly to the other. Nay more, it is even probable that it was the striking effect produced by beacon-fires on the wall which first suggested the idea of treating the entire wall in the same manner. At the same time, I hold firmly to the opinion that the vitri- 
faction in many of the forts examined by me was the work of design, the special object being to consolidate into a mass the small stones of which the walls are usually composed.

All trap-rocks are readily fused under a moderate heat without a flux; and with the addition of an alkali, such as might be supplied by wood-ashes or dried seaweeds, most of the ordinary stones could be converted into the puddingstone appearance and consistency presented by the walls of vitrified forts. Dr M'Culloch ${ }^{1}$ makes an important observation, to the effect that the stones readily fusible were selected and carried from a distance by the fortbuilders, and hence he justly argues "that they designed from the beginning to vitrify their walls." It is also noteworthy that vitrified walls are scarcely half as thick as those great stone walls with well-built double facings, such as we have seen in the forts of Burghead, Forgandenny, and Abernethy; so that, without some cementing element, the small stones of which they are composed could hardly be kept together or be of any use as a protective barrier. The economy in utilising collections of small stones by vitrifaction might also be an element in the construction of these forts, as the materials, being close at hand, could be easily carried to the tops of the hills on which they are generally situated.

As to the modus operandi by which vitrifaction was produced, the conclusion to which I came is, that the fire was laid over the entire wall, both sides and top being covered with the combustible materials. In a section of the wall at Beregonium, near Loch Etive, I noticed that, while the top and sides had a crust of vitrified materials over them, the interior was only partially affected. Some of the stones in the interior had large drops of slag adherent to them, ${ }^{1}$ Highlands and Western Isles of Scolland, vol. i. p. 292. 
evidently due to the trickling of the stuff while in a liquid state.

Mr John Honeyman ${ }^{1}$ has recorded some careful observations on the structure of the vitrified walls of several forts in the west of Scotland. In a portion of the walls at Rhufresean and Dunagoil he describes the vitrified mass as a wedge, the thin edge penetrating downwards through the interior of the wall ; and hence he forms a theory that the heat was applied to the top of the wall and not to the sides. But the facts he has recorded are, in my opinion, quite compatible with the supposition that the combustible materials were heaped both on the sides and top of the wall. If a flux were needed to produce vitrifaction it would be placed on the top of the wall, and here then fusion would first begin to take place, and so the liquid stuff, if in abundance, would readily flow down through the centre of the wall. I confess, however, that the phenomenon noted by Mr Honeyman has not come within my own experience, but, on the other hand, I have frequently noticed vitrifaction greatest at the sides and top, as at Carradale, already referred to. In regard to this fort, Dr Christison appears to have come to a similar conclusion, as he states that the masses are "much less vitrified below, particularly in the centre, than in the upper part." 2 This was clearly the case with the wall at Arka Unskel at Arisaig, described by Dr E. Hamilton, ${ }^{3}$ who also maintains that the fire was applied on all sides. "This is proved," he writes, "by the internal part of the wall being unvitrified, solely because the heat did not extend so far, leaving the stones in their original condition, or only partly agglutinated, and only not fnsed because unable to be affected by the fire applied externally." 4

1 Trans. Glasgow Arch. Soc., vol. ii. p. 29, and vol. i., N.S., p. 340.

2 Op. cit., p. 182. ${ }^{3}$ Arch. Journal, vol. xxvii. p. 227. \$Ibid., p. 241. 
Mr James Macdonald's excavations on the Tap o' Noth conclusively showed that in this case the vitrifaction was confined to the upper part of the wall. This is one of the largest of the vitrified forts in Scotland, being 345 feet long and 126 feet broad, and still shows great masses of vitrifaction here and there all along its circumference ; so that if the occurrence of beacon-fires is to be accepted as the incidental cause of this phenomenon, the fires must have been placed at regular intervals along the entire circuit of the wall. ${ }^{1}$

Eilean Buidhe (the yellow island), one of the Burnt Islands in the Kyles of Bute, has been long known as the site of a vitrified fort. $^{2}$ This fort, occupying the summit of the rocky islet, stands 21 feet above sea-level. According to the Rev. $\mathrm{Mr}$ Hewison, ${ }^{3}$ it is in the shape of a "complete circle, 67 feet in diameter from crest to crest of the ruined wall, which in many parts is quite levelled and overgrown with rough grass, through which the fragments of the vitrified work appear. At other points the wall is in good preservation, showing at the north-east a face 4 feet high and 5 feet thick, and also on the south-east a solid mass of vitrifaction over 5 feet thick." $\mathrm{Mr}$ Hewison directs attention to a remarkable feature of this fort -viz., "the apparent stances of four towers at the cardinal points of the compass," each 14 feet in diameter.

It is a very rare occurrence to find the wall vitrified to its base, and when this is the case the vitrifaction generally rests on the solid rock, as at Dùn Skeig and Craig Phadrick. On the other hand, at Dunagoil there was to be seen a few years ago a large portion of the vitrified wall reposing on a basis of loose stones-a fact which readily accounts for the large masses, some tons in weight, which now lie at the base of the

1 See Trans. Huntly Field Club, July 1887 .

2 Trans. Roy. Soc. of Edinburgh, vol. x. p. 79.

3 Proc. Soc. A. Scot., vol. xxvii. p. 292. 
Dun on its sea side. Large fragments may also be seen at the foot of Dùn Skeig, but in this case it requires some searching among the long heather to find them. At Dunideer the base of the sow-back hill on which the fort stood-for there is little of it now remaining-is strewn with pieces of slag, and, strange to say, some of them may be seen in the ruins of the old castle of stone and lime which had been subsequently built within the walls of the vitrified fort.

I have not observed any facts to indicate that, as regards the dimensions of the area enclosed, the vitrified differ from the non-vitrified forts. In this respect they are both alike in showing a wide range of variability, as may be gathered from the following notes:-

Carradale stands on a detached portion of a rocky promontory on the east side of Cantyre which, at high water, becomes an island. The surface, a small plateau some 70 feet above the sea-level, is almost entirely occupied by the fort, leaving little more than space to walk round it on the outside. Large portions of the walls, 3 to 5 feet thick and about the same in height, enclosing an oval space 60 paces in length and 26 in breadth, still remain in situ. Among the rocky débris at the base of the plateau, on the west side, I observed several portions of vitrified materials which had evidently fallen from the fort.

The fort of Dunagoil occupies the surface of a precipitous ridge of porphyritic trap, extending along the sea-shore at the south end of the island of Bute. This ridge, rising to the height of about roo feet, presents a perpendicular face on the north and west, an accessible slope on the east, and an uneven plateau on the top. It is only on the south side and east end that the remains of vitrified walls are now to be seen. The area thus fortified by walls and cliffs is about 90 paces in length, and varies in breadth from 26 yards at the west end 
to 12 yards at the east end, where there was an entrance. The wall followed the bow-shaped contour of the south margin of the ridge, and near its middle there was a short transverse wall dividing the enclosed space into two nearly equal divisions.

The vitrified fort of Dùn Skeig stands on the summit of a high conical hill on the south side of the entrance to Loch Tarbet. No position could be more suitable as a signalling station than this spot, as it commands extensive views both towards the mainland and the islands, including on clear days the north of Ireland. The ruins of the fort occupy the highest point of the hill, being only a few paces from the brink of the precipice. It has an oval shape, measuring 28 paces from east to west, and 18 from north to south. The vitrifaction would appear, from the traces still remaining, to have extended continuously along the entire wall. Here and there bits of slag might be seen resting on the natural rock, where it crops up, and others lying on a basis of loose stones. It was difficult to estimate with accuracy the original thickness of the wall, but, so far as I could judge, it would not be more than 6 to 8 feet. What its height may have been there is no evidence to show.

The famous vitrified fort which crowns the picturesque hill of Knock Farril, some two miles west of Dingwall, Ross-shire, overlooks the richly cultivated valley of Strathpeffer. My last visit to it was in the summer of 1896 . The summit is an elongated oval, some 200 paces in length by 40 in breadth, narrowing, however, at both ends. The remains of the walls of the fort are still considerable, enclosing a space 126 paces long by $3 \circ$ broad; but at the ends there are other remains of walls which, though now detached from the central division, were probably part of the original fort. Along the lines of these walls several masses of vitrified materials, two of them 
measuring about 9 feet in length, may still be seen cropping up through the greensward which clothes the summit.

Neither do the relics found on the sites of vitrified forts suggest that they differ chronologically from the ordinary forts. Dr Angus Smith, ${ }^{1}$ in the course of his excavations at Beregonium, found a single-edged dagger-blade of iron, so inches long, having a thick back and a tang for insertion into a handle; a finger-ring of bronze; and an enamelled disc of bronze ornamented with a series of concentric circles of red enamel of Late Celtic character. The structure on the top of the Laws in Forfarshire is the only other vitrified fort which has yielded relics, and, as already seen (p. 379), these do not carry us back beyond the Iron Age.

Outside the Scottish area the distribution of vitrified forts is somewhat remarkable. Four are stated, on the authority of Dr Petrie, to be in Londonderry ${ }^{2}$ and one in Cavan. ${ }^{3}$ I am not aware of their existence in England, unless we accept as such some calcined walls found in British camps at Bristol. In the vicinity of the Clifton Suspension Bridge there are, or rather were, three great intrenched forts occupying promontories on the precipitous cliffs on both sides of the Avon. One is at the Clifton end of the bridge, and the others- "Bower Walls" and "Stoke Leigh"-on the opposite side. It is stated $^{4}$ that when the ramparts of the Bower Walls were demolished the innermost, which stood 22 feet above its ditch, contained a central core of a hard material like cement. Quantities of a similar material may be seen on the remains of the Clifton fort near the end of the bridge. The calcification appeared to me to be the result of exposure of the materials of the wall to great heat; but the stones being lime-

1 Proc. Soc. A. Scot., vols. ix., x., xi., and xii.

2 Stokes's Life of Petrie, p. 223. 3 Trans. R. I. Acad., vol. xiii. p. 123.

* Proc. Somerset. Arch. Soc, vol. xv. p. 27. 
2 II 


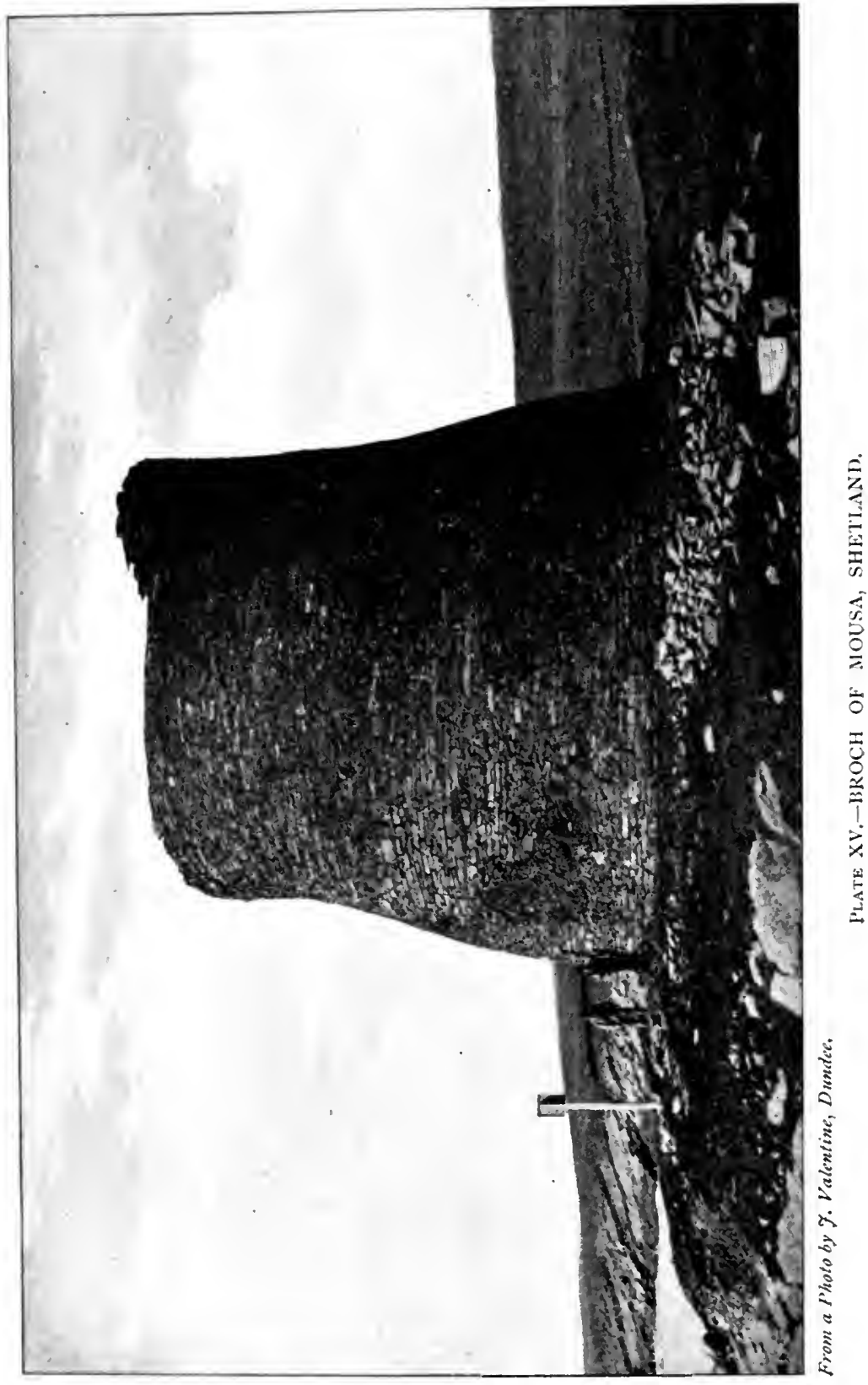


stone, the effect was a calcination rather than a vitrifaction. This phenomenon is worth looking into, as camps with similarly constructed walls have been described in France. ${ }^{1}$

Of the ordinary vitrified forts, several have been noticed in Brittany and Normandy, ${ }^{2}$ Saxony, Bohemia, Silesia, Thuringian Forest, and the Rhine district. ${ }^{3}$

\section{BROCHS.}

Like the vitrified forts, those massive tower-like buildings known as Brochs, and found nowhere else but in Scotland, have given rise to a considerable amount of controversial literature. Before they succumbed to the ravages of time, which have now reduced the great majority of them into an unrecognisable heap of ruins, some 400 might have been seen conspicuously dotting the more fertile lands along the shores and straths of the counties of Caithness, Sutherland, Ross, Inverness, Argyll, the islands of Orkney, Shetland, Bute, and some of the Hebrides. Outside this area only seven examples have as yet been recognised as true brochs-viz., two in Forfarshire, and one in each of the counties of Perth, Stirling, Mid-Lothian, Selkirk, and Berwick. The special characters of these remarkable buildings are so uniformly alike that, except in regard to a few minor differences-chiefly dimensions - it may be asserted, as literally true, that what applies to one applies to the whole-so much so, indeed, that it has been seriously maintained that they were all built at the same time and from one plan.

The most perfect now extant is the broch of Mousa (Pl. XV.), situated on a small island in Shetland. It is built

1 Camps vitrifiés et Camps calcinés. Barthélemy.

2 Mem. de la Soc. Antiq. de France, vol. xxxviii. p. $\mathbf{3}_{3}$.

${ }^{3}$ Lake-Dwellings of Europe, p. 332 ; Proc. Soc. A. Scot., vol. viii. p. 145. 
of dry-stone masonry, 50 feet in diameter and 45 feet high. At some distance it looks like a truncated cone, but closer inspection shows it to be a circular wall, 15 feet thick, and enclosing an open court 20 feet in diameter. The outside wall-face slants a little inwards from base to top, but the inner is nearly perpendicular. An entrance passage, 5 feet 3 inches high and 2 feet $I$ I inches wide, with jambs and lintels of flagstones, forming a kind of tunnel right through the wall, is the only access to the court. Four door-like openings may be seen in the wall facing the court near the ground-level, and about equidistant from each other. Three of these openings lead into oval-shaped beehive chambers, constructed in the solid wall and having their major axes in the direction of the curve of the wall. The other opens into a small recess from which a spiral stair made of undressed flagstones ascends to the top. On mounting the stair for about Io or I I feet we find that the surrounding wall, which up to this point is solid, with the exception of the beehive-chambers already referred to, now becomes split into two walls, leaving a vacancy, about 3 feet in breadth, between them. At successive intervals upwards this intermural space is bridged over with flagstones, thus dividing it into a series of galleries running round the entire building. The lower galleries are from 5 to 6 feet high, but as we ascend they diminish in height. The stair continues its spiral course to the top, intersecting these galleries, and thus gives access to them all. They are lighted from the interior by shallow openings, or windows, which look into the court. No access to any part of this curious structure can be got except by the passage on the ground-level, about the middle of which there is evidence to show that it had been protected by a stone door barred from within. In other brochs there is usually a guard-chamber on one or both sides of the entrance 
passage, constructed in the solid wall, after the manner of the beehive chambers.

Of the other brochs there are now only a few which show any considerable portion of their walls above the fallen débris, the rest looking like dilapidated tumuli or cairns. Sometimes, indeed, a cultivated hillock, over which the plough has regularly passed for centuries, conceals beneath it the well-defined foundations of a broch. Of their present ruined condition the broch at Ousdale, Caithness, excavated by $\mathrm{Mr}$ James Mackay ${ }^{1}$ in $189 \mathrm{r}$, furnishes a good example. The situation and general appearance of the ruins are thus described: "It stands on a prominent eminence near the confluence of the Ousdale and Borgue burns - one mile from the Ord of Caithness, four miles from Berriedale, and about 400 yards from the sea, commanding a good sweep of the latter. On one side it is protected by the steep precipice of the Borgue burn, and on the remaining sides by ramparts consisting of a well-built wall about 8 feet thick, and faced apparently with a dry ditch. The outworks surround the tower on three sides, and show signs of a second occupancy by a later and inferior race. The style of building of the hut-circles, of which the outworks are composed, is to a certain extent copied from that of the original broch in so far as the overlapping of the stones for the purpose of forming arches consist, and they were probably built with material taken from the tower after it had fallen into ruins.

"The broch presented the usual appearances of a grasscovered mound with stones cropping up over the surface. The entire diameter of the tower is 50 feet, and the diameter of the inner area or court 24 feet. The walls are 14 feet thick at the entrance, and 12 feet thick at the other side. The highest part of the wall remaining is 14 feet; and although

1 Proc. Soc. A. Scol., vol. xxvi. p. 351. 
this hardly shows sufficiently the traces of galleries, the presence of stairs shows their former existence. The inner court was completely filled up with stony detritus to a depth of 10 feet,
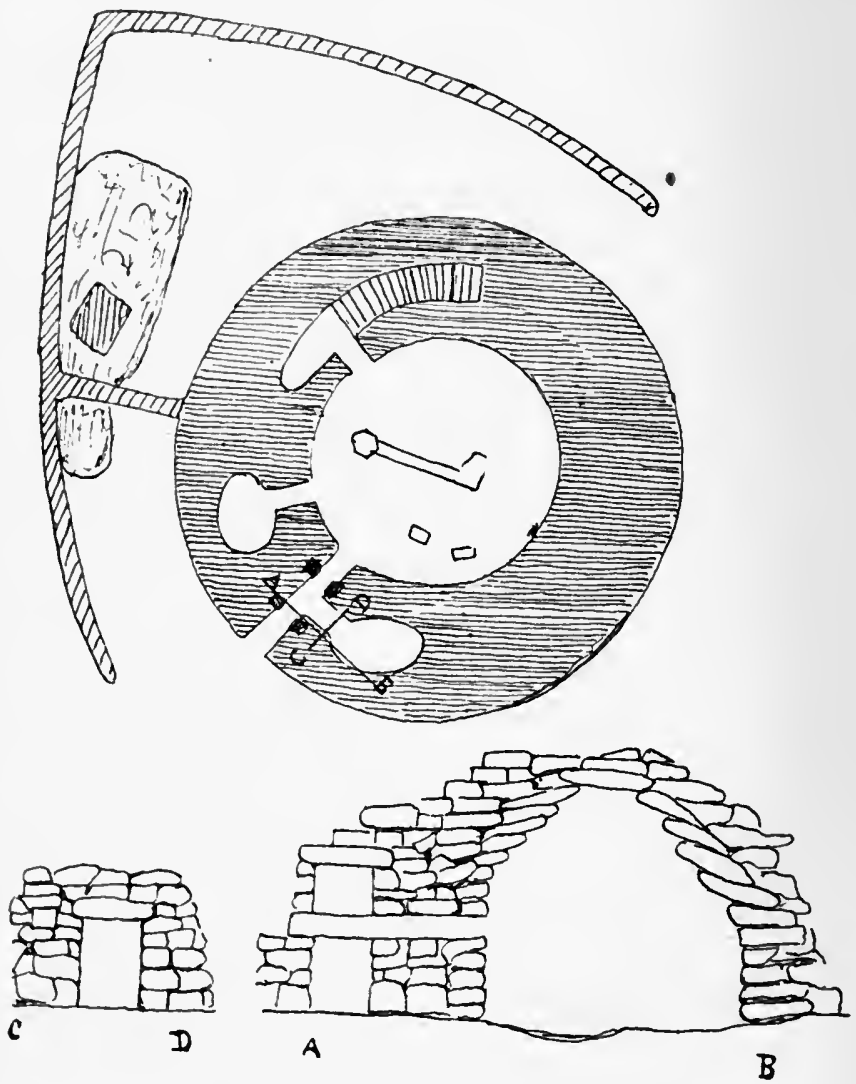

Fig. 225.-Ground-plan and sections of broch of Ousdale, Caithness.

and the remaining 4 feet consisted of charcoal and what appeared to be ashes of peat in alternate layers."

As will be seen from the plan and sections (fig. 225), the broch contained an entrance-passage, with wall-checks for 
two doors and a guard-chamber between them; a chamber in the wall entering from the court; and a third chamber from which the stair ascended. All these chambers were constructed with beehive roofs, and the doorways heavily linteled. In the guard-chamber "was found a cist, 2 feet square, covered over with a flag, and containing ashes, charcoal, and a dark unctuous clay. . . . At a height of 8 feet from the floor a scarcement or ledge, nearly a foot in width, ran round the entire inner court; but, unlike that in most brochs, it is undoubtedly part of the original building, and not a secondary construction." In clearing out the chamber at the foot of the stair a human skeleton was discovered, head downwards, roughly built in and covered with small stones and earth. Of the interior and its contents Mr Mackay gives the following account: "At about 4 feet above the real floor were found traces of a second occupation, probably after the tower may have been partly in ruins, several partitions of large slabs set on end being found at this level. The real floor of the central court consists of 2 feet of fine puddled clay laid on the natural bed. This floor was covered with layers of ashes and charcoal, which contained large quantities of animal bones, many half burnt, and some split for the purpose of extracting the marrow. Large quantities of shells of the limpet and periwinkle were also found, and a considerable quantity of wild-hazel nuts. The following articles were also found amongst the ashes on the floor and throughout the building: A damaged stone hatchet, with a slight groove round the centre; a granite mortar carefully hollowed out, the hollowing being $\mathrm{I}$ foot in diameter and 10 inches deep; several very rude mica-schist querns, some of which are broken; stone mullers; stone hammers or 'pounders,' generally much abraded at one end, and sometimes at both ; three mica-schist discs, eight inches in diameter, with holes two inches in diameter through the centre; several 
whorls in sandstone and steatite; a large quantity of fragments of very coarse hand-made pottery, fire baked, some composed of a layer of black clay inside and a layer of red outside,- the shapes appeared to be globularly bulging, with everted rims; part of a small cup of a finer blue clay, with flat bottom and slightly bulging sides; several specimens of whetstones; part of a wooden dish or scoop with everted rim, apparently about 5 inches in diameter and 2 inches in depth; a piece of polished lignite, which may have formed part of an armlet."

The animals represented by the osseous remains, as identified by Dr R. IV. Reid, Professor of Anatomy in the University of Aberdeen, were deer, ox, sheep, hare, and a large bird.

From historical evidence we know that many of these brochs were formerly much higher than they are now. Dun Carloway, on the west coast of the island of Lewis, is said to have been 40 feet high in the end of last century; and it is still, next to that of Mousa, the best preserved. Pennant describes the broch at Glenelg as being in his time (1776) $30 \mathrm{r} / 2$ feet high, and he adds that $71 / 2$ feet had just been removed. Mr Low, in his 'Tour through Orkney and Shetland' (r774), states that the "Pight's" castle at Burraness, in the island of Yell, was 20 feet, and that at Cullswick 23 feet, in height. The natural inference is that formerly they were all sufficiently lofty to prevent an attacking party from climbing over the walls.

As regards the structural peculiarities and special design of brochs, Dr Joseph Anderson, one of our most distinguished investigators of brochs, thus expresses himself: "The design of the whole structure and the arrangements of all its separate parts exhibit a careful and laborious adaptation of means and material to the two main objects of shelter and defence. The clever constructive idea of turning the house outside in as it were, placing its rooms within its walls, and turning all their 
windows towards the interior of the edifice, implies boldness of conception and fertility of resource. The height of the wall, which effectually secured the inmates against projectiles, also removed its essentially weak upper part beyond reach of assault, while the pressure of its mass knit the masonry of the lower part firmly together, and its thickness made it difficult to force an entrance by digging through it-if such a wall could be approached for this purpose when the whole of its upper materials were deadly missiles ready to the hands of the defenders. The door, securely fastened by its great bar, is too strong to be carried by a rush. Placed 4 feet or more within the passage, it can only be reached by one man at a time, and the narrowness of the passage prevents the use of long levers. In all probability the door itself is a slab of stone, and impervious to fire. But even if it is forced, and entrance gained to the interior court, the enemy finds himself as it were in the bottom of a well 30 to 40 feet in diameter, with walls 50 feet high, pierced on all sides by vertical ranges of windows, or loopholes, commanding every foot of the same space below, and rising to the number of twenty or more, immediately over the door which gives access to the galleries. In short, the concentration of effort towards the two main objects of space for shelter and complete security was never more strikingly exhibited, and no more admirable adaptation of materials so simple and common as undressed and un. cemented stone, for this double purpose, has ever been discovered or suggested." 1

Such being the structural characteristics of the brochs, we have now to glance at some of the minor differences and peculiarities observed in individual specimens. And, first, as regards the more constant characters there may be slight variations. For example, the entrance-passage may have

1 Scotland in Pagan Times, p. 203. 
one or two doors, one or two guard-chambers, or none at all. Thus in the broch of Glenelg, Inverness-shire, the entrancepassage, at 4 feet from its outer end, has large slabs set on end as door-checks, but from this point inwards it widens, the roof becomes more lofty, and on the south side there is a guard-chamber. In the broch of Kettleburn there are two guard-chambers, one on each side of the entrance-passage. The broch of Carn-liath, in Dunrobin Park, presents a more exceptional deviation from the rule in having no chambers in the wall entering from the ground-floor, but instead of them there were in the court area two underground chambers faced with flags.

The broch of Kintradwell is described by Dr Joass ${ }^{1}$ as having check-pieces fixed in the wall for two doors, the first 6 feet and the second 14 feet from the outer end of the entrance-passage, with a guard-chamber between them. Also at the side of the central area there was a well, 7 feet deep, with some stone steps leading down to near its bottom. On one of these steps a stone cup, 5 inches in diameter, was found, probably used as a drinking-cup. There were, however, some further peculiarities which, in the opinion of the explorer, formed no part of the original structure. Round the open court there had been constructed a wall, 8 feet high and I foot thick, the object of which was to supply a ledge or scarcement for supporting a wooden roof. Also, outsicle the broch proper, the ground was covered for a distance of 20 yards with a medley of the foundations of buildings of an inferior order of architecture. Among these ruins, at a depth of from 2 to $2 \mathrm{I} / 2$ feet from the surface, ten skeletons, in a much decayed condition, were discovered. Along with one of these skeletons there was an iron spear-head, and with another the blade of an iron dagger. Dr Joass considered

${ }^{2}$ Archreologia Scotica, vol. v. p. 95. 
these burials to be of a later date than either the broch or its secondary buildings.

Similarly, the broch of Yarhouse, excavated by Dr Joseph Anderson, had associated with it, both outside and inside, a mass of secondary buildings, among the ruins of which human skeletons were found. These Dr Anderson believed to have been buried after the broch and its outhouses had already succumbed to the ravages of time to the extent of becoming a grassy mound. Near one of the bodies lay a flat circular brooch of brass, bearing an inscription which identifies it with brooches of the twelfth and thirteenth centuries. There were casual interments during Christian times, but there is evidence which connects the custom with paganism as well. Dr Petrie describes a small cemetery of stone cists with burials after cremation, overlying the ruined broch of Okstrow in Orkney. ${ }^{1}$

Like that at Kintradwell, the broch of Yarhouse contained an interior wall built of inferior masonry against the original wall of the broch, and attached to it were remains of partitions. "These partitions," writes Dr Anderson," "were partly built, and partly formed of long slabs set on end. They rose to about 8 feet-the same height as the scarcement. The partitions and the iuner wall forming the scarcement were founded on an accumulation of rubbish largely mixed with ashes and food-refuse, which covered the original floor of the broch to the depth of 12 to 14 inches. They were therefore clearly secondary constructions, made to adapt the broch to the purpose of a secondary occupation." Similar proofs of later adaptations of the brochs to different conditions of life have been observed in many other instances, as at Burwick, Kettleburn, Lingrow, \&c.

Many of the brochs were built in positions evidently selected

${ }^{1}$ Arch. Scot., vol. v. p. 76. $\quad{ }^{2}$ Scolland in Pagan Times, p. 229. 
for natural strength, such as Cole's Castle, near Brora, Sutherlandshire, which occupies the top of an isolated eminence accessible only on one side. ${ }^{1}$ Others occupied promontories or small islands in lakes, such as the brochs of Snaburgh and Burraness, both in the island of Unst, in Shetland, which were protected by fortifications and ditches on the land side. The broch of Clikamin, at Lerwick (Pl. XVI.), though on an island, was fortified by a thick stone wall which completely surrounded the island. Inside this enclosure was the broch proper, strengthened in the usual way. The loch is now lowered and visitors can approach the ruins on foot, but it will take them some time to master the intricacy of the structure with its doors, passages, guard-chamber, vaults, \&c. The broch on Cockburn Law, known as Edenshall,-identified as such by the remains of a stair and beehive chambers in the thickness of the wall,-is important as being surrounded by a double rampart of earthworks in the ordinary manner of the British forts. The broch was one of the largest known, its wall being 7 feet thick and the area enclosed no less than $5^{6}$ feet in diameter. Outside the broch, but within the area defended by the earthworks, are numerous ruins of circular huts and other buildings, as shown on the accompanying plan (Pl. XVII.), taken from Mr John Turnbull's account of this remarkable stronghold. ${ }^{2}$

The relics collected on the sites of brochs are not less instructive than the buildings themselves, inasmuch as they disclose, with tolerable fulness, the culture and social condition of their occupants. On comparing the various collections derived from the very considerable number of excavations now recorded, they appear so marvellously alike that, with the exception of one or two stray objects from

\footnotetext{
1 Proc. Soc. A. Scot., vol. xv. p. 310.

${ }^{2}$ Proc. Berwickshire Nat. Club, I $879-8$ I.
} 


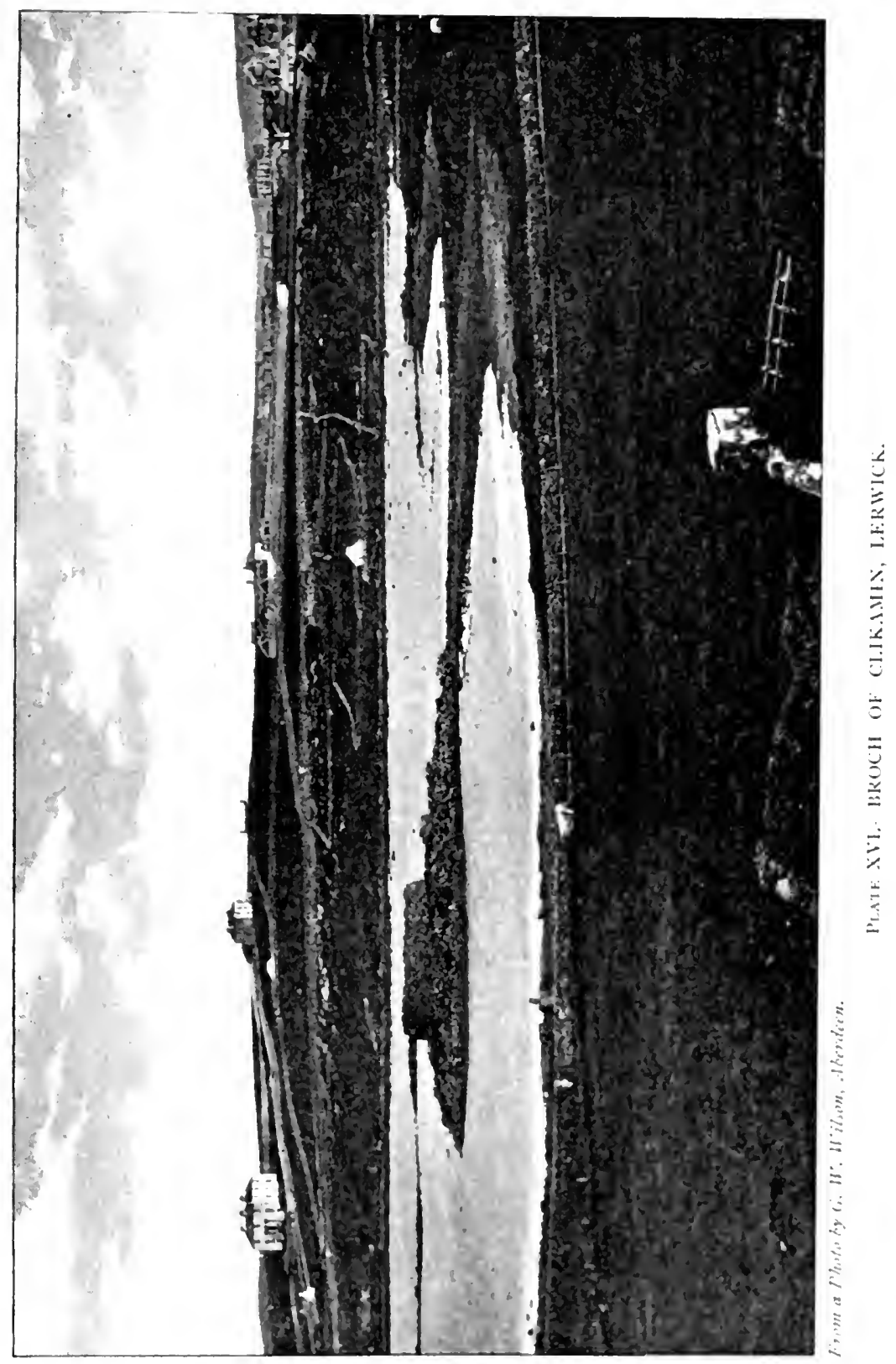





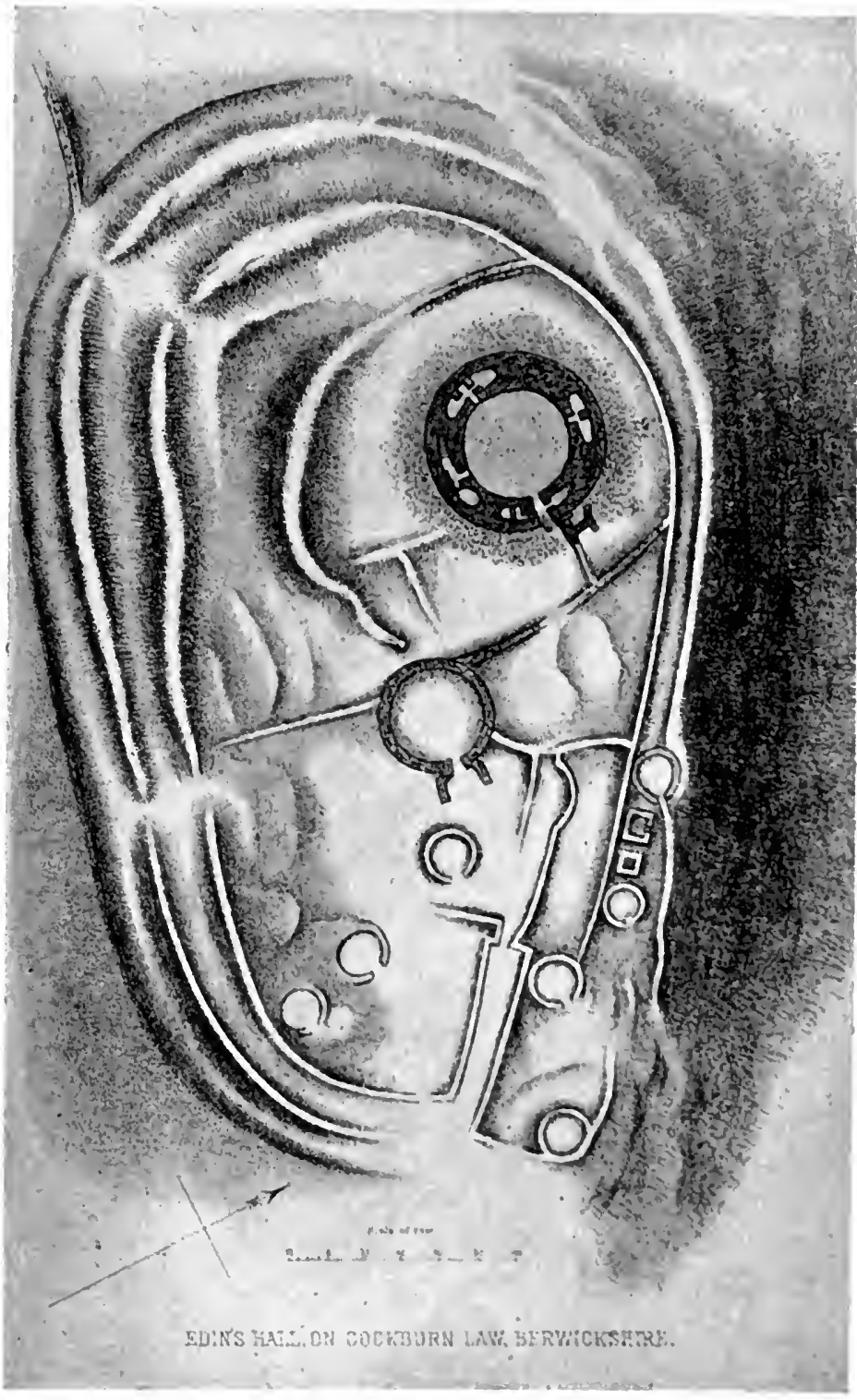

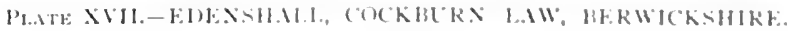



foreign cultures, they may be discussed as one homogeneous group. The following may be noted as the most common :-

Stone.-Querns, rubbers, hammer-stones, polishers ; oval or circular cups, mortars, pestles, whorls, discs, balls, whetstones ; vessels of steatite, \&c.

Horn and bone.-Pins, bodkins, buttons, knobs, longhandled combs supposed to have been used in weaving, toilet combs (fig. 226), needles; handles for knives and instruments are largely represented.

Bronze. - Objects of bronze are not numerous, being confined to pins, armlets, and buckle-like brooches.

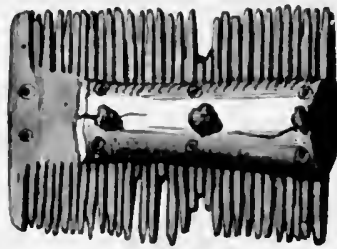

Fig. 226. - Bone comb from the Kinowe of Saverough, Orkney (1).

Iron.-Objects of iron are also sparingly represented, and they are generally so much corroded that it is difficult to identify them. As specific implements and weapons may be noted the knife, socketed chisel, spear, and dagger.

Pottery.-Fragments of pottery are common, showing a coarse unglazed ware in the form of globular vessels with everted rims.

The animals used as food by the inmates of the brochs are abundantly represented in the accumulated refuse-heaps found on almost all the sites hitherto explored. They are chiefly the following: Red- and roe-deer, ox, sheep, goat, pig, horse, dog, whale, seal, various kinds of fish, and the common edible molluscs.

Among the relics regarded as exceptional and special the following may be noted:-

1. In the broch of Carn-liath there were found rings of shale or lignite, some in the process of being manufactured; 
two plates of hammered brass; and a silver fibula of Roman type. ${ }^{1}$

2. At Kettleburn a pair of bronze tweezers, $4 \frac{T}{2}$ inches long and $13 / 4$ inch in breadth, elegantly manufactured and ornamented after Late Celtic style. ${ }^{2}$

3. The broch of Dunbeath, excavated by Mr T. Sinclair, contained chambers loftier than usual, and among the relics were an iron spear-head and a whetstone. A quantity of charred grain, bere, and oats was found on the floor. ${ }^{3}$

4. In one of the brochs in the parish of Harray an ornamental bronze knob (fig. 227) was found, which is of much

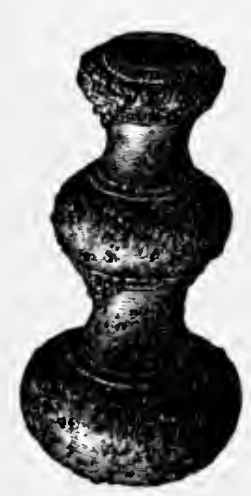

Fig. 227.-Bronze object found in a broch in

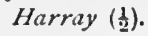
interest as being almost identical with a number of objects found on the crannog of Lisnacroghera ${ }^{4}$ (Pl. VI., Nos. 28-30).

5. Fragments of Samian ware were found in the brochs of Burray and Okstrow, as well as in one at Keiss, recently explored by Sir F. T. Barry; and four silver coins of the Roman Empire, in the outhouses of the broch of Lingrow.

6. The broch of Torwoodlee, Selkirkshire, recently investigated by $\mathrm{Mr}$ James Curle ${ }^{5}$ is remarkable for the preponderance of relics emanating from Roman civilisation found on its site. These include Samian pottery, glass vessels of well-known Roman types, armlets of opaque glass with enamel, a bronze disc with enamel, and some harness-rings in Late Celtic style of art.

'Arch. Scot., vol. v. pl. xvi.

${ }^{2}$ Proc. Soc. A. Scot., vol. i. p. 266.

${ }^{3}$ Arch. Scot., vol. v. p. 146.

'Proc. Soc. A. Scot., vol. vii. p. 103, and 'Lake-Dwellings of Europe,' p. 383 .

${ }^{5}$ Proc. Soc. A. Scot., vol. xxvi. p. 68. 
7. Among miscellaneous objects are a stone pebble with a hollow streak (fig. 228), supposed to be a strike-light, a clay mould for casting bronze pins (Lingrow), disc made of bone (Burrian), doubleedged combs like those from the Terp-mounds in Holland, a stone with two triangles crossed, the metatarsal bone of an ox with incised symbols of a crescent crossed with a V-shaped sceptre, a cross of Celtic

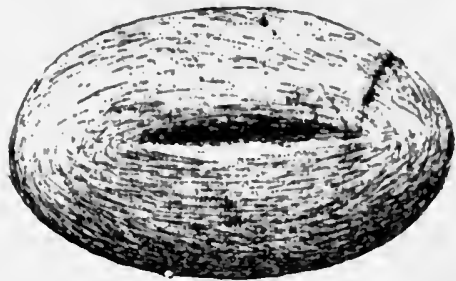

Fig. 228.-Quarti pebble from the broch of Kintraduell $\left(\frac{1}{2}\right)$. form, a fish, an ogham inscription, and a cup made of the vertebra of a whale.

This is but a meagre account of the archæological phenomena disclosed by the explorations of the Scottish brochs. The problem now to be considered is, Who were the people who constructed and inhabited them? Their geographical distribution coincides so fully with that of the roving Norsemen in their excursions to our shores, that in answer to the above question two possibilities are suggested: "Either they were erected by the Picts or Celtic races who inhabited these islands from the earliest times to which history and tradition ascend; or they were the work of the Norwegians who settled on the islands in or before the eighth century after Christ, and finally conquered and extirpated the Celtic inhabitants."

The problem at issue is fairly well set forth in the above statement by James Fergusson, F.R.S., who energetically defended the latter alternative, or Norwegian theory of the origin of the brochs, in a special treatise entitled 'The Brochs and the Rude Stone Monuments of the Orkney Islands' (London 1877). As Mr Fergusson's essay had to a large extent assumed a polemical character, mainly directed against 
the views of Dr Joseph Anderson, who held the other, or Celtic, theory of the origin of the brochs, the latter was constrained to take up the challenge. His reply will be found in the 'Proc. Soc. A. Scot.,' vol. xii. pp. 314-356. I cannot recall any scientific controversy that repays perusal better than these two essays; but even should I have space to summarise the arguments pro et con., it would be an injustice to my readers to deprive them of the full effect of the argumentative style and methods of two such able and competent controversialists. As I agree with Dr Anderson's views in this matter, it will suffice here to state, in a condensed form, the conclusions he arrived at in regard to the brochs, after a comprehensive survey of their structural characteristics, their geographical range, and their contents, with special reference to the questions of their origin and their relation to other antiquities in Northern Scotland. They are as follows :-

I. The brochs are allied by their structural characteristics to the Celtic and not to the Norwegian group of stone monuments, in which no instance of a vaulted chamber ever occurs.

2. Their geographical range and local distribution imply their native origin, and are incompatible with the theory that they were built by the Norwegians.

3. The Norwegian remains from graves of the Viking period in Scotland are wholly similar to the remains of the Viking period in Norway, and are thus easily distinguishable from the Celtic remains with which they are locally associated.

4. The general facies of the group of relics found in the brochs agrees completely with that of the group of relics of the post-Roman period of Celtic Scotland, and this is sufficient evidence that their occupants were not Norwegian.

Among the more recent investigations of brochs the most important are those conducted by Sir F. T. Barry, Bart., M.P., on his Keiss estate and elsewhere, in Caithness-no less than 
eight brochs having been excavated by him during the last few years, including the "Harbour Mound," partially explored by the late Mr Samuel Laing, M.P., and described in his 'Prehistoric Remains of Caithness ' ( 1866 ). A communication on the results of these excavations, by the explorer, was read at the Society of Antiquaries, London, on the 8th of June last; and its publication will be awaited with much interest, mainly to see if his discoveries have a tendency to shift backwards the chronological horizon usually assigned to these structures-as was the case with the remains found in the broch at Torwoodlee, which point to a period close on the Roman occupation of the district. The relics, some of which I recently saw at Keiss Castle, are generally of the same character as those already found on the sites of the northern brochs. Among them may be noted-long-handled combs, implements of deer-horn, pottery (including two small pieces of "Samian" ware), bone pins and a bone needle, whorls, whetstones, stone lamps, mortars and cups; also bones of the great auk, part of the antlers of the elk and reindeer, and the tooth of a bear (see p. 9r). The broch of Nybster was on a small promontory, with precipitous sides, jutting into the sea. Before excavations its site was a greensward with a ditch across its narrowest part. Parallel to this ditch there was a stone wall, 15 feet thick, containing an entrance passage with check-pieces for two doors, and on each side of its inner end were a few steps of a stair leading to the top of the wall. The broch, with its entrance facing the south, was immediately beyond this rampart, and in front of it were remains of outhouses which, unlike the generality of brochs, showed no indications of having been due to secondary occupation. Indeed all these structures appeared to me to have been the component parts of one original fortification. 


\title{
CHAPTER XI.
}

\author{
LAKE-DWELLINGS.
}

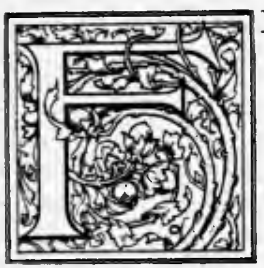

EW archæological subjects have excited more general interest in the scientific world than the discovery of the remains of those strange habitations known as Lake-dzuellings, the investigation of which has been steadily prosecuted throughout Europe for now close upon half a century. The comparative security afforded by natural islands could not fail to attract the notice of man from the very dawn of his reasoning faculties, and it is probable that he resorted to such means of protection as soon as he became acquainted with the buoyant properties of a log of wood, and utilised his experience by the invention of the dug-out canoe. From the natural to the artificial island was but a stage of transition which in course of time could be readily bridged over by his progress in mechanical skill. But whatever may have been the primary object of these structures, or the precise circumstances which led to their development, one thing is certain, that they continued for many centuries to be the characteristic abodes of the early inhabitants of Central Europe, in localities where the requisite conditions were 
to be found. The remarkable development of the system in Central Europe, during the Stone and Bronze Ages, seems to have come to a sudden end within prehistoric times; and, indeed, so completely had the custom fallen into desuetude that scarcely a trace of it has survived in the traditions or annals of those very countries in which lake-dwellings were most abundant. To have rescued so singular a phase of human civilisation from oblivion is one of the greatest triumphs of prehistoric archæology.

\section{Sketch of Lake-dzcelling Researches.}

The actual starting-point of lacustrine research may be dated to an incident which took place in Dublin upwards of half a century ago. It appears that early in the spring of 1839 curiosity was roused at the Museum of the Royal Irish Academy by the frequency of the visits of a local dealer offering for sale objects of a miscellaneous character, many of which were of rare antiquarian value. These objects were said to have been found in a peat-bog in the county of Meath, and their assortment in such a place seemed so strange to Dr Petrie that he resolved to visit the locality. Accordingly he and Surgeon Wilde (afterwards Sir W. Wilde) started in search of the mysterious find, and were conducted to the peat-bog of Lagore, near the village of Dunshaughlin. Here, within the boundaries of a drained lake and under a thick covering of peat, was an artificial mound then partially exposed by peat-cutters. This mound had been well known to bone collectors for upwards of ten years, during which time, it is said, they had dug out, and exported to a factory of bone-manure in Scotland, no less than 150 cart-loads of bones. The mound was of a circular shape, slightly raised above the surrounding plain, and measured 520 feet in cir- 
cumference. Along its margin were "upright posts of black oak, measuring from 6 to 8 feet in height; these were mortised into beams of a similar material, laid flat upon the marl and sand beneath the bog, and nearly 16 feet below the present surface. The upright posts were held together by connecting cross-beams, and fastened by large iron nails."

That the nature of this mound was correctly interpreted by Irish archæologists may be gathered from the abstract of Sir William Wilde's paper on the Lagore lake-dwelling or crannog in the 'Proceedings of the Irish Academy' for 1840 , from which the above extract is taken, as well as from the further discoveries which immediately followed on its publication-such as the crannogs in Roughan Lake, Lough Gur, Lake Monalty, Loch-na-Glack, Ballinderry, \&c.

But the most important subsequent discoveries were due to the workings of the Commission for the Arterial Drainage and Inland Navigation of Ireland, which brought to light no less than twenty-two crannogs throughout the counties of Roscommon, Leitrim, Cavan, and Monaghan. Reports of these crannogs by the engineers of the Board of Works, along with plans, maps, sections, and a large assortment of relics, were deposited at the time in the Museum of the Royal Irish Academy.

While these crannog investigations were thus steadily progressing in Ireland, an independent discovery was announced in Switzerland, which not only gave a new significance to the Irish discoveries, but almost immediately opened up one of the most prolific fields of prehistoric research which has ever come under the cognisance of archæologists. This discovery was indirectly due to the exceptional cold of the winter of 1853-54, which caused the water in Lake Zurich to sink to a lower level than any previously on record-being one foot 
lower than the celebrated mark on the stone of Stäfa, which preserves the record of a similar phenomenon in 1674 . In these circumstances two of the inhabitants of Ober-Meilen, whose vineyards came close upon the shore of the Lake, began to extend them by enclosing portions of the exposed shore with a stone wall, and filling in the space with mud, so as to bring its surface above the ordinary level of the water. In the course of these operations the workmen observed, protruding through the mud in the bed of the lake, portions of rotten posts, together with stone axes, flint implements, and other worked objects, which excited their curiosity. Mr Aeppli, the village schoolmaster, heard through his scholars of the curious things turned up in these diggings, and as soon as his day's duties were over he went to see the place. After inspecting some of the objects which the workmen had laid aside, Mr Aeppli 1 thus expressed himself to the interested bystanders: "Hier hat die Menschenhand gearbeitet, das sind Werkzeuge und Geräthe, die der Mensch einst gebraucht hat; ihre Form gehört menschlicher Thätigkeit an."

He then wrote a short account of what he had seen, and sent it to the Antiquarian Society at Zurich. Within four hours of the despatch of his epistle three representatives of the Society arrived at Ober-Meilen, among them being the President, Dr Ferdinand Keller.

After careful consideration of the facts, Dr Keller came to the conclusion that the piles had supported a platform upon which huts had been erected, and that, after a long period of occupancy, the entire structures were destroyed by a conflagration.

This important deduction, strengthened by the traditional stories of submerged cities long current among the fishing com-

${ }^{1}$ F. Staub, Die Pfahlbauten in den Schweizer-Seen, p. 8. 
munity, spread rapidly among the Swiss people, and produced an inmmediate army of explorers, who commenced a vigorous search for similar remains in this and the adjacent lakes. Guided partly by the recollection of previous finds, the significance of which became now apparent, and partly by the knowledge of local fishermen, who, from practical experience of disasters to their fishing-gear, could at once point to numberless fields of submerged woodwork, the efforts of these pioneer lacustreurs were speedily crowned with the greatest success. In the spring of the same year the famous station, known as the Steinberg at Nidau, was discovered, as well as many others in the Lakes of Bienne, Neuchâtel, and Geneva; so that before the report of the Ober-Meilen discovery could be published in the "Transactions of the Antiquarian Society of Zurich,' Dr Keller had equally interesting materials from other stations to record. This report, which appeared towards the close of $r 854$, under the title "Die Keltischen Pfahlbauten in den Schweizerseen," at once attracted the attention of archæologists throughout Europe.

The immediate outcome of the publicity thus given to the existence of an ancient lacustrine civilisation in Switzerland was a systematic search for similar antiquities throughout Europe. Nor was this search in vain, for within a few years analogous remains were found in many of the lakes and turbaries of France, Germany, Austria, and Italy; and more recently the area of their development has been extended to Bosnia, Greece, and Asia Minor, and probably other localities.

The merit of being the first to direct attention to Scottish crannogs belongs to Dr Joseph Robertson, who brought the subject before the Fellows of the Society of Antiquaries of Scotland in a paper read on December 14, r857. The facts adduced by Dr Robertson consisted chiefly of historic ref- 
erences to island-forts, and submerged wooden structures exposed, in the course of the drainage of loch and marshes, during the last, and the early part of this, century. Although this kind of evidence conclusively proved the existence of crannogs, it gave little information as to their nature and function in the social organisation of the times. The first great discovery which brought them on the field of practical research was made in the Loch of Dowalton, Wigtownshire, about thirty-five years ago. In order to drain the extensive meadows occupying the western portion of the Dowalton valley, the proprietor, Sir IVilliam Maxwell, Bart., conceived and successfully carried out a project of draining the loch by cutting a new outlet through the narrow lip of rock which, at a certain portion of its margin, was the only barrier between its waters and the lower ground beyond. This excavation was completed during the summer of 1863 , and, as the waters subsided, a group of five or six artificial islands gradually emerged, like a scene in fairyland, from the bosom of the lake. The antiquarian remains collected on these islands ultimately disclosed a picture of early Scottish civilisation hitherto unknown to historians or to archæologists. Sir Herbert Maxwell, to whom the event was especially exciting, on account of the bewilderment of the aquatic birds which were in the habit of frequenting the loch, and the tragic fate of its fish, gives the following reminiscence of the circumstances which led to the recognition of the true nature of the islands: "I remember when Lord Lovaine was taken down to see the drainage operations in 1863 , that the islands were then appearing above the subsiding waters. His lordship had, I think, just returned from Switzerland, where he had visited the lake-dwellings there. My father told me that he exclaimed, "Why, here are just the things I have been looking at in the Swiss lakes.'" 
In August of that year the late Duke of Northumberland, then Lord Lovaine, read a descriptive account of these crannogs at the Newcastle-upon-Tyne meeting of the British Association.

A couple of years later, Dr Stuart, Secretary of the Society of Antiquaries, visited Dowalton, and, owing to the more complete drainage of the loch, was enabled to examine the islands under more favourable conditions. The result of his labours was an elaborate paper to the Society, in which he

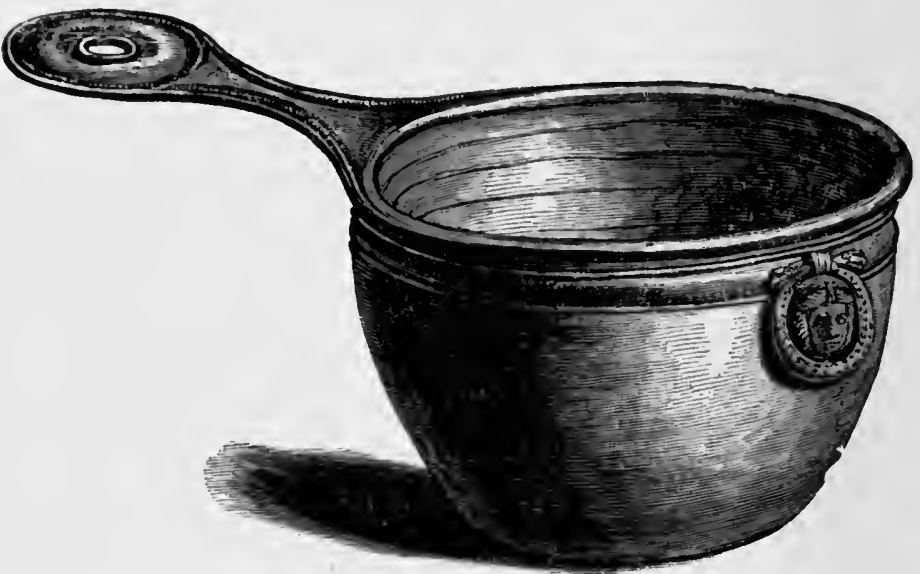

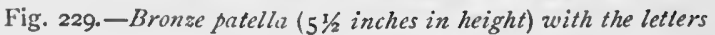
C I P I PO L I E I stamped on handle, Dowalton.

gave a detailed account of their structure and of the relics found on them; and to which he added all the facts he could glean from historical and other sources, including some of the contents of the unpublished paper of Dr Robertson.

Among the industrial remains collected on and around these islands were canoes, bronze dishes of Roman origin (fig. 229), bracelets and beads of glass (fig. 230), bronze brooches and other ornaments, crucibles and iron slag, perforated axe-heads and hammers of iron, fragments of 
Samian ware, querns, hammer-stones, a leather shoe stamped with a pattern (fig. 232), \&c., \&c. From the undoubted Roman element which characterised a considerable number of these relics, the habitable period of the Dowalton lake-

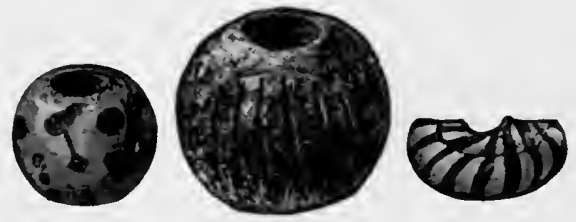

Fig. 230.-Beads of glass from Dowalton (1).

dwellings must be relegated back to the early centuries of the Christian era.

After the publication of Dr Stuart's paper in 1866 , little progress was made in the exploration of Scottish crannogs, although traces of them were occasionally noticed throughout the country, till the discovery and excavation of the Lochlee crannog in $1878-79$. This was the commencement of a series of explorations, conducted under the auspices of the Ayr and Galloway Archxological Association, which culminated in the excavation of no less than six typical crannogs through-

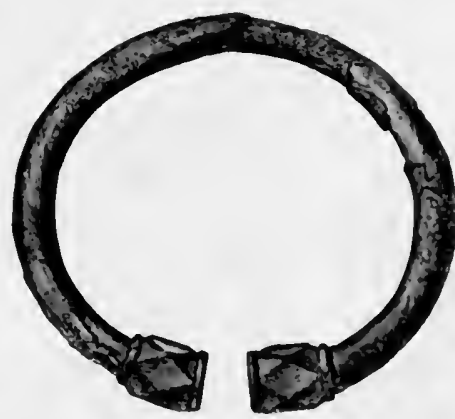

Fig. 231.-Bronse penannular brooch, Dowalton ( 1 ). out the counties of Ayr and Wigtown. From a careful consideration of the relics thus collected, there can be no ambiguity as to the testimony they afford of the peaceful occupation of their owners. Indeed, among a very large and varied assortment of objects indicating the prosecution of various industries, 
the warlike element is but feebly represented by a few iron daggers and spear-heads, one or two tips of the crossbow-bolt, and a quantity of so-called sling-stones. Among the rarer objects the following may be mentioned: Two spiral fingerrings of gold (fig. 233 ), and a crucible containing particles of

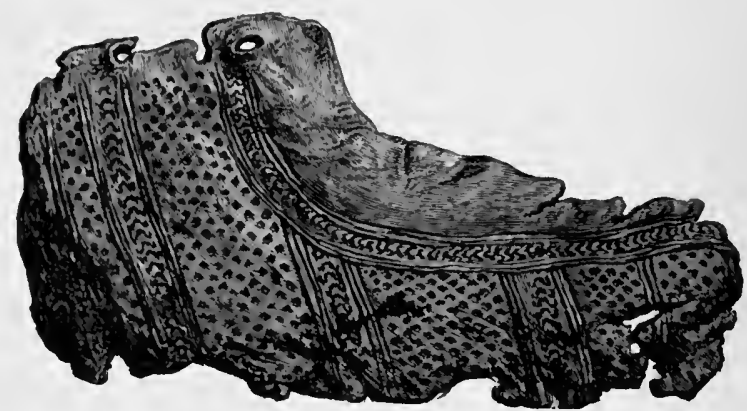

Fig. 232.-Portion of leather shoe (length 7 inches), Dowalton.

this metal; a gold coin of Saxon origin (fig. 234)-supposed to have been originally a forgery, as it was made up of two thin gold plates and a copper core; an amber-coloured bead of glass (fig. 235); two cup-marked stones, one of which has
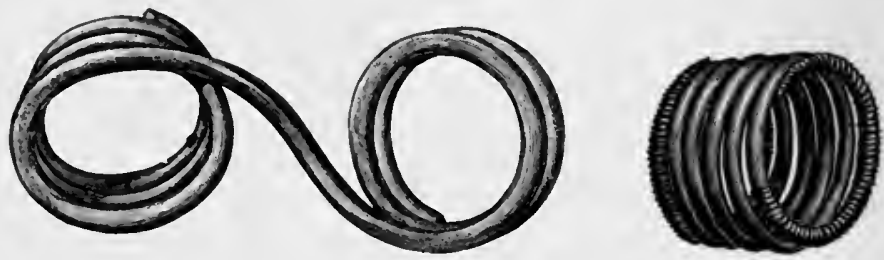

Fig. 233.-Tiwo spiral finger-rings of gold, Buston ( $\left.\frac{1}{1}\right)$.

the cup surrounded by two concentric circles (fig. 237); a pendant of jet in the form of a cross inscribed in a circle and ornamented with small incised circles (fig. 238 ); a conical object of rock-crystal highly polished and having some resemblance to the settings on early book-covers (fig. 236); a 
flat piece of ash-wood having both sides ornamented with an incised spiral pattern; a remarkable fringe-like apparatus made of the long stems of a moss (Polytrichum commune) (fig. 239); a bridle-bit, partly of iron and partly of bronze (fig. 240); several toilet combs (fig. 24I); fibula of Romano.

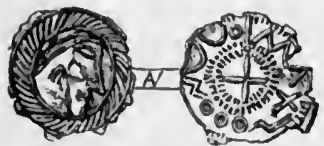

234

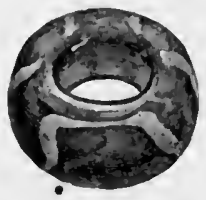

235

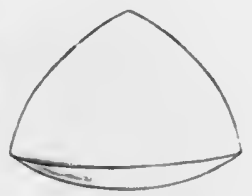

236

Fig. 234-235.-Gold coin (Buston), glass bead, and rock-crystal from Lochspouts (1).

British types (fig. 242); an ormament of bronze wire coiled into a double spiral (fig. 243), \&c.

Since the reports on these various investigations appeared in the Collections of the Association, only three genuine

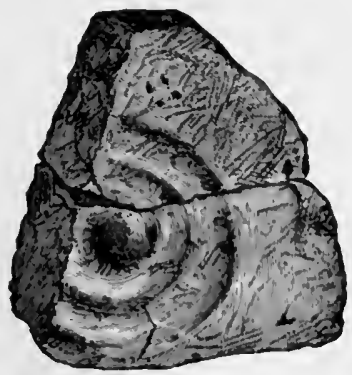

Fig. 237.-Stone with cup.andring markings, Lochlee $\left(\frac{1}{s}\right)$.

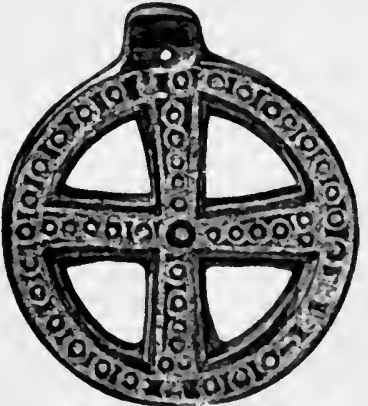

Fig. 238.-Jet ornament, Lach. spouts (t).

crannogs have been excavated in Scotland - viz., one in Lochan Dughaill, Argyllshire; one at Hyndford, near the town of Lanark; and a third-a stone crannog-in Ashgrove Loch, near Stevenston, Ayrshire. As these crannogs were investigated subsequent to the publication of $m y$ books on 
the Scottish crannogs (1882) and the Lake-dwellings of Europe (1890), I shall here give a short account of the archr-

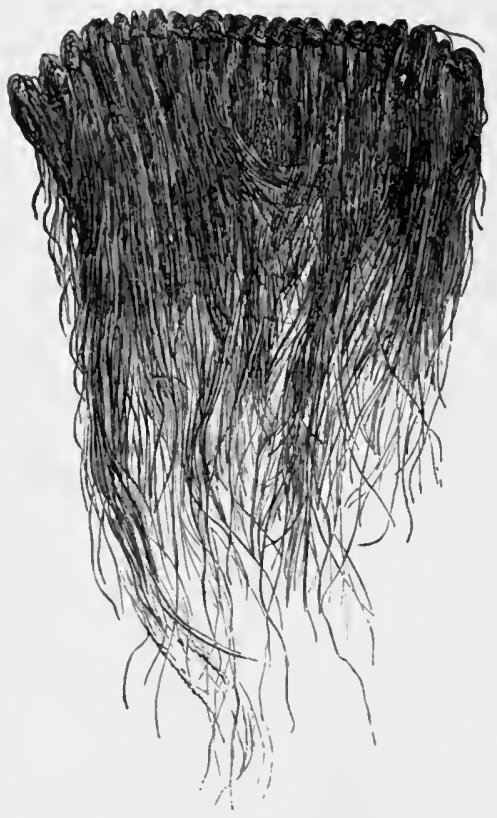

Fig. 239. - Fringe made from the stems of a moss (Polytrichum commune), Lochlee ( 3 ).

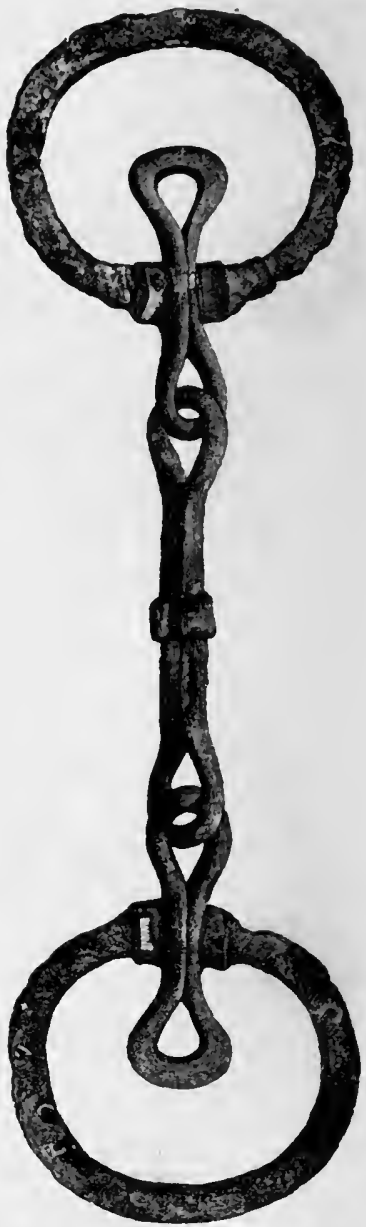

Fig. 240.-Bridle-bit of bronse and iron, Lochlee ( $\left.\frac{1}{2}\right)$.

ological results, by way of supplementing the information already before the public. 
The crannog of Lochan Dughaill ${ }^{1}$ is interesting, inasmuch as it revealed the foundation of a circular wooden house over

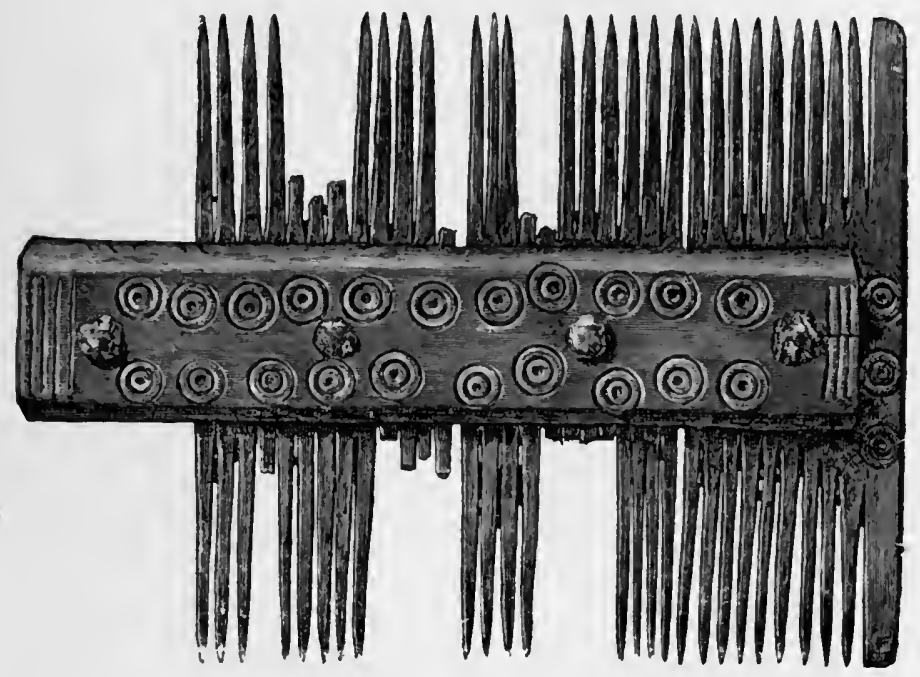

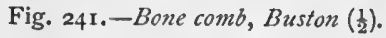

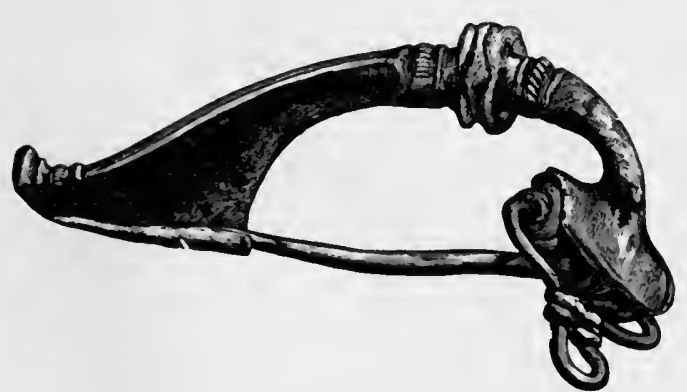

Fig. 242.-Bronze fibula, Lochlee (1).

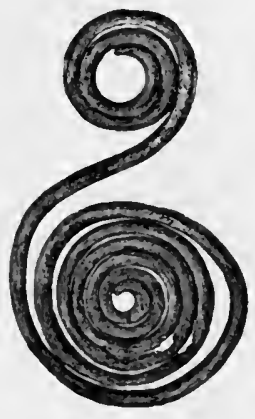

Fig. 243.-Bronse spiral ornament, Lochspouts (ł).

the artificial island, as already described (p. 334). The island consisted of timbers and brushwood, arranged in transverse

1 Proc. Soc. A. Scot, vol. xxvii. p. 211. 
layers to a depth of over 4 feet and surrounded by a circle of piles, whose surface formed an oval space, 49 feet long by 45 feet broad.

All the relics collected in the course of the investigation were found on the surface of the woodwork, and, though not numerous, they are of some archæological value. The following are the principal objects:-

A small flint scraper of prehistoric workmanship, which probably came from a grave of the Stone Age in the neighbourhood, was utilised by the crannog inhabitants as a strike-light (fig. 244).

A circular stone disc, $3 \frac{1}{2}$ inches in diameter, and rather more than an inch in thickness, having a central perforation half an inch in diameter.

Four sharpening stones made of a fine-grained sandstone, found in the primary rocks in the vicinity.

Five or six kidney-shaped polishers of a whitish quartz, 6 to 8 inches in length.

Half of a bracelet made of cannel coal, showing a diameter (internal) of $23 / 4$ inches.

Some fragments of glazed earthenware (wheel-made), found together, were reconstructed into a jar $6 \mathrm{I} / 2$ inches high (fig. 245).

Among the other relics may be mentioned-a projecting handle of the same kind of earthenware as the jar (fig. 246); a crucible $I 1 / 2$ inch in greatest diameter (fig. 247); and some portions of worked wood having round and square holes.

The Hyndford crannog, discovered and excavated by $\mathrm{Mr}$ Andrew Smith in 1898 , is situated about two miles east of the town of Lanark. Some twenty years ago the site of this dwelling was a small wooded island, but immediately prior to the excavations only the stumps of trees were to be seen 
dotting the surface of a grassy flat mound, some 70 or 80 feet in diameter. In winter, and during rainy weather, the mound was often completely surrounded by water, but in

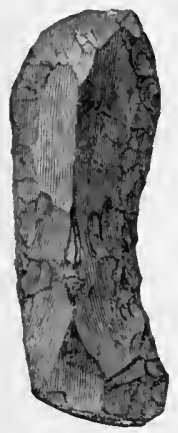

Fig. 244.-Flint scraper $\left(\frac{1}{2}\right)$.

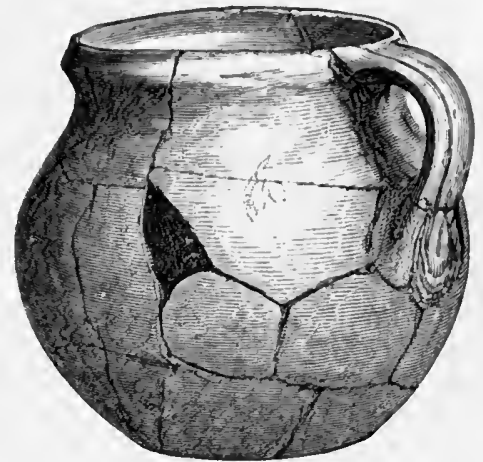

Fig. 245. - Jar of glazed earthenware (61/2 inches high).

summer-time there was only a large pond encompassing about three-fourths of its circumference, leaving a dry neck on the north-east side which connected it with the cultivated

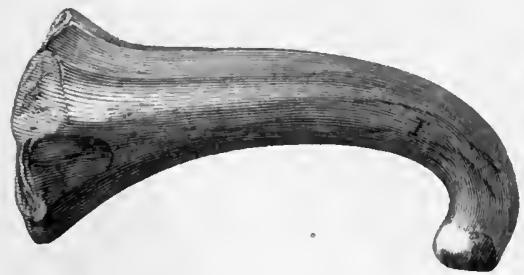

Fïg. 246.-Handlc of earthenware vessel. (t inches in length).

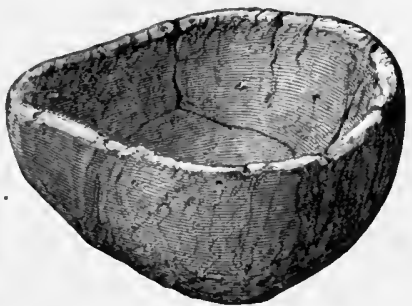

Fig. 247.-A crucible of clay (actual size).

land. The depth of the pond is very considerable close to the mound, and indeed it looks as if it had been intentionally deepened. The method of excavating adopted was to clear off the entire débris down to the original flooring of the 
dwelling, a depth of from $2 \frac{1}{2}$ to 3 feet. Underneath this there was a layer of much decayed brushwood mixed with the clayey silt on which it was originally laid. A circle of piles, having a diameter of about 49 feet, was exposed in the interior, the stumps of which projected some 2 feet above the flooring. They were irregularly set, as if two or three rows had been placed together, and it is probable that they formed part of a wooden house. Towards the centre of the circle of piles there were three fireplaces separated from each other by an interval of a few yards, each of which contained several superimposed hearths one above the other.

A large quantity of ashes, charcoal, and bones of animals - broken and sometimes burnt - was found throughout the débris, more especially on the south side, where there was an accumulation, suggestive of a kitchen-midden, occupying a space partly inside and partly outside the circle of piles. The relics, which were not localised in any way but scattered

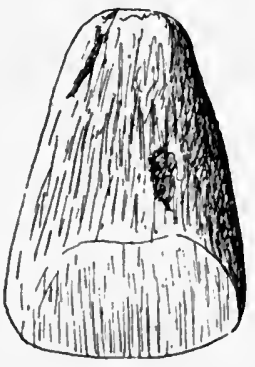

Fig. 248.-Stone axe from the Hyndford crannog ( $\left.\frac{1}{2}\right)$. throughout the whole ruins, are of special interest on account of the number of Roman remains among them. The following are the most important up to this date :-

Stone.-A neatly formed polished celt, 3 inches long (fig. 248), and a fragment of another specimen; a circular disc beautifully polished on both sides, 3 inches in diameter, and rather more than a quarter of an inch thick; another stone, 3 by $2 \frac{1}{2}$ inches, had the same characters as the former, but differed in being of a rectangular shape; four small and neatly formed sharpening stones; one whorl made of sandstone, 1 / $/ 8$ inch in diameter, and two of a light-yellowish shale, one of the latter having 
a circular groove near its margin (fig. 254); several portions of querns; a small mortar with traces of gold in it (fig. 252); portion of a stone cup (steatite) with a perforated handle (fig. 25 I) ; hammer-stones, pestles, perforated pieces of shale, \&c.

Bronze.-A spiral finger-ring of $3 \mathrm{~T} / 2$ coils (fig. 253); two rings $15 / 8$ inch in diameter; portions of small tubing, and a square rod or wire, 9 inches long; portion of a beaded torque (fig. I 54, p. 253).

Glass. - Three melon-shaped beads of different sizes (fig.
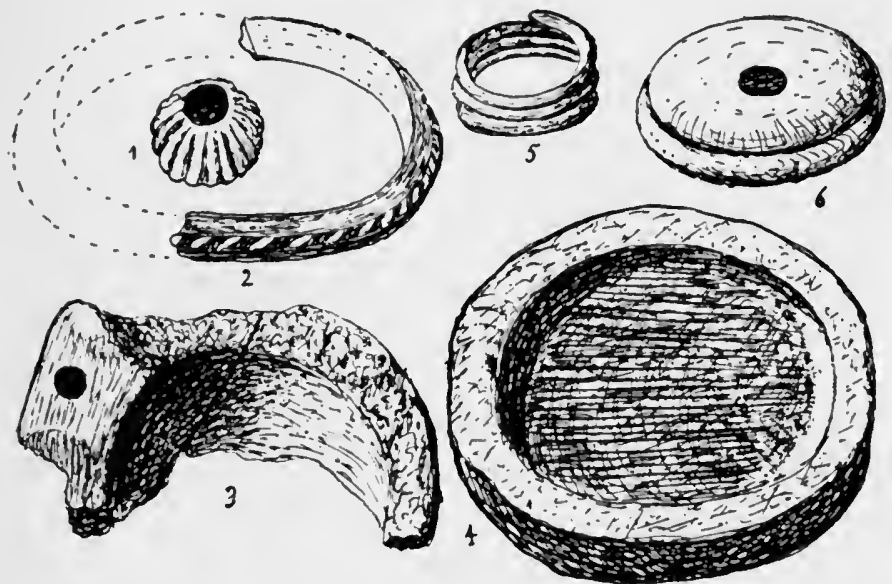

Figs. 249-254. - Various objects found in the Hyndford crannog.

t, Glass bead; 2, Glass bracelet; 3 , Portion of steatite cup (1) ; 4, Stone mortar; 5, Bronze finger-ring; 6 , Spindle-whorl of shale (all 2 with the exception of No. 3 ).

249), an elongated drop, and fragments of glass vessels; portions of five bracelets of different patterns (fig. 250).

Pottery.-Portions of at least six different vessels of red "Samian" ware, one with a pattern and figures; handles and portions of four vessels of the grey Roman pottery ; fragments of a very hard glazed ware of a bluish-green colour, indicating a vessel with a long wide neck, bulging in the middle, and ormamented with wavy lines. 
Lead.-A large mass weighing 13 lb. 9 oz., showing cuts on its surface, and another small portion.

Iron.-Axe- and hammer-heads and picks-one axe has imbedded in its corroded mass the tooth of a large ruminant; an iron collar, 6 inches in diameter, made of a flat band $I$ to $\mathrm{I} / \mathrm{z}$ inch broad; portions of iron slag.

Miscellaneous.-Portion of a remarkable mould like one found in Ayrshire; ${ }^{1}$ a small hemispherical object of red enamel about the size of the half 'of a large hazel-nut, showing a check pattern on its inner side.

The stone crannog in Ashgrove Loch, which was partially excavated by $\mathrm{Mr}$ John Smith, ${ }^{2}$ consisted of a circular stone wall enclosing a space of about 30 feet in diameter. Before its excavation it presented the appearance of a mound on the margin of the present loch, but in former times it would be within its boundaries. Trenches having been dug through the interior of this mound, $\mathrm{Mr}$ Smith came upon a built drain, covered with sandstone slabs, which he regarded as a water-tank. The wall, which on the land side had a thickness of 9 feet, but less than half this on the other, was placed upon a bed of brushwood, and built of "rough blocks of sandstone, and a few whinstones, laid in a mortar of tough yellow clay."

A causeway of rough blocks of sandstone slabs leading from this wall to the land was discovered about 2 feet beneath the present surface. The kitchen-midden was piled up outside the wall, and in it were found the following relics :-

I. A large number of bones, both entire and split, of red-deer, ox, pig, sheep, and goat.

1 Proc. Soc. A. Scot., vol. i. p. 45.

${ }^{2}$ Collections, Ayr and Gal. Arch. Association, vol. vii. p. 56; also 'Prehistoric Man in Ayrshire,' p. 48. 
2. Several chisels and knife-like objects, a wedge, a large needle perforated in the centre, a spoon, and a narrow needle-all of bone.

3. Several hammer-stones and a few smooth stones.

4. Bit of gas-coal with a round hole bored through it.

5. A pair of steel sheep-shears.

6. Numerous specimens of Littorina littorea.

"From the details given above," writes Mr Smith, "I think the history of the spot may be read thus: on top of a bluish clay-bed there had accumulated a bed of brown moss, possibly entirely from the decay of water-plants, I foot in thickness on the land side of the crannog, and 4 feet thick on the loch side. Then the position was occupied by man, who laid on top of the moss a layer of branches, and on this built a stone crannog, 43 feet in largest outside diameter, with a built water-tank under the floor, the interior of the dwelling being possibly divided into compartments, roughly paved, and carpeted with heather.

"All the deers' horns got were divested of the tines, except the brow one, and look remarkably like picks, and have possibly been used as such. Some of them are pretty well coated with vivianite.

"There are possibly remains of five other crannogs in the loch, but nothing has been done to explore them, and the place, when in its 'glory,' must have formed a very quaint little lake-village, the loch being nearly completely surrounded by rising ground."

The earlier evidence adduced in support of the existence of lake-dwellings south of the Scottish Border was in most instances too fragmentary to be of scientific value. Of this character were the structures in some of the Meres of Norfolk and Suffolk, described by Sir Charles Bunbury, Professor Newton, and the Rev. Harry Jones; also the reputed pile- 
structure in Cold Ash Common, Berks, noticed by Dr S. Palmẹr.

In 1866 General Pitt-Rivers communicated to the Anthropological Society of London a paper entitled "A Description of Certain Piles found near London Wall and Southwark, possibly the remains of Pile-Buildings." The author began by observing that his attention was directed to the locality by a short paragraph in the 'Times' of the 2oth October, stating that upwards of twenty cartloads of bones had been dug out of the excavations which were being made for the foundations of a wool warehouse. Here, in a bed of peat, 7 to 9 feet thick, intervening between the accumulated débris of modern London and a bed of gravel, the workmen came upon a number of wooden piles whose tips penetrated into the gravel. Scattered through this peat were numerous articles of human workmanship; also several kitchen-middens, containing the nondescript remains of human occupancy. The majority of the relics were of Roman origin, and included coins, tiles, pottery, and articles of dress. In addition to these there were others of ruder construction, made of bone and horn, such as knife-handles, spear-heads, a couple of bone skates, \&c.

In 1870 a circular island, near the shore of the Lake of Llangorse, Wales, was shown by the Rev. Mr Dumbleton to have been constructed after the manner of the stockaded islands or crannogs. In the course of the excavations, remains of a log-flooring, charcoal, food-refuse, \&c., were turned up, but among them there was no relic of sufficient character to give a clue to the period when the island was constructed or inhabited.

In 1880 the Drainage Commissioners of the Holderness found it necessary to deepen some of the drains in that lowlying district, and when this was being done Mr Thomas Boynton's attention was directed to some prepared woodwork, 
and bones of animals found in the stuff thrown out, which he regarded as evidence of a lake-dwelling. Such remains were observed at five different localities, two of which have since been more or less explored, with the result that there could be no doubt that they were the sites of human habitations, having some structural resemblance to the fascine lakedwellings of Switzerland. Some very curious implements made of the articulated ends of the long bones of some large bovine animals, a flint scraper, a stone axe, a bronze spearhead, and portions of two jet bracelets, are the chief relics recorded.

Indications of lake-dwellings, discovered on the banks of the Costa, near Pickering, Yorkshire, in 1893 , by Mr James Mitchelson, have been recently described by the Hon. Cecil Duncombe, F.G.S., at a neeting of the Anthropological Institute (vol. i., New Series, p. I50). As only a partial exploration of the locality has been made, the author refrains from formulating any positive conclusions on these discoveries. The evidence adduced in support of lacustrine habitations consists of rows of piles, suggesting gangways converging to one point where "water always rested or flowed in ancient times."

A section of the ground showed-superficial soil, 8 or 10 inches; stiff blue clay, 2 feet 6 inches; peat, 6 feet, resting on the Kimmeridge clay. A hole, 12 feet by 9 and 6 to 7 feet deep, was dug round some piles, and, near the bottom of the peat, relics of human occupancy were found, consisting of a cartful of animal bones and a quantity of broken pottery.

The animals represented were-man (at least four individuals); horse (small variety), numerous; ox (Bos longifrons), numerous; sheep (straight-horned), numerous; goat, one skull; pig (both wild and domesticated); wolf, fox, otter, beaver (one skull), voles, and birds. 
Portions of deer-horn showed marks of cutting, others were worked into rude implements, and one split portion contained five small perforations. The pottery was all handmade, formed of "coarse clay mixed with spar and small stones." Some fragments indicated vessels of large size, reminding Captain Duncombe of those found in the Holderness.

All these remains are, however, quite compatible with $\mathrm{Mr}$ C. H. Read's opinion that they must be assigned to the early Iron Age rather than to an earlier date. The absence of metals counts for very little in a mere preliminary investigation such as this has been; but enough has been disclosed to show the extreme interest of these early remains of Britisl lake-dwellings and the desirability of having the Costa site more fully explored.

These meagre records comprise nearly all the results of lacustrine research in England, with the exception of the Glastonbury lake-village discovered in the spring of 1892 by $\mathrm{Mr}$ Arthur Bulleid, and since excavated under his care. The site of this remarkable settlement occupies some three or four acres of a flat meadow, within the boundaries of what is supposed, on good grounds, to have been formerly a lake or marsh. Before excavations were begun all that the eye could discern, on the undisturbed surface, were sixty or seventy low mounds huddled in the corner of a field. These mounds were the débris of dwelling-huts, and the foundation on which they stood consisted of layers of brushwood and trees bound together, at least in some places, with mortised beams precisely similar to those of the crannogs. A strong palisading of piles and brushwood surrounded and protected the village. Its marginal boundary was very irregular, probably from the fact that enlargement continued to be made by the addition of huts projected from different parts of the original nucleus. 
The huts were circular or oval, and varied in size from 20 to 35 feet in diameter. Each hut contained a central hearth, sometimes neatly made of flat stones embedded in the clay flooring, but as subsidence, due to the compression and decay of the under-structures, progressed, the occupants superadded new floorings. These, on being repeated several times, showed on section a stratified appearance. In this way several hearths, five or six being not uncommon, were observed superimposed one above the other, precisely in the same manner as has been observed on the Lochlee crannog.

The objects collected form a large and varied assortment, made of stone, bone, horn, wood, bronze, iron, lead, glass,
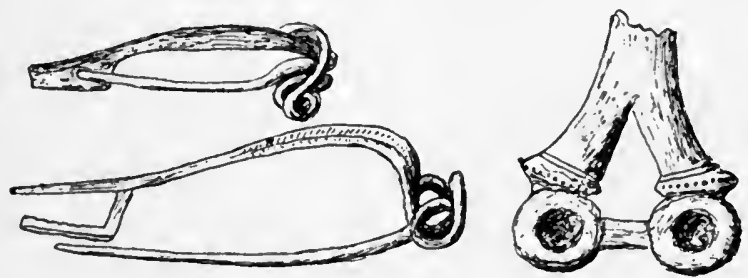

Figs. 255, 256.-Two fibulce and portion of handle of bronse mirror from Glastonbury lake-village $\left(\frac{2}{3}\right)$.

amber, and pottery, besides the osseous remains of man and the ordinary domestic and wild animals. These remains illustrate, with rare and singular completeness, the life-history of the community-its social industries, culture, and civilisation. Many of the relics exhibit the special characteristics of Late Celtic art; nor does it appear that they have been influenced in any way by Roman civilisation, so that this feature alone gives to the Glastonbury lake-village an exceptional importance among the lacustrine researches hitherto prosecuted within the British Isles.

Among the bronze objects are many fibulæ of La Tène types (fig. 255), spiral finger-rings, penannular brooches, 
portions of mirrors (fig. 256), and an elegant bowl. Of bone or horn we have needles, pins, handles of instruments, longhandled combs, some of the latter being decorated. The pottery consists of various vases and dishes, some showing devices of unmistakably Late Celtic character; iron weapons and implements, generally much corroded; a fine specimen of a saw, still retaining its wooden handle, is of the same character as that found on Hunsbury camp, and figured on page 273 . A leaden weight, shaped like a cheese, and weighing 4 ounces 229 grains, is the only thing which betrays a suspicion of Roman origin. Among the objects of wood are-a canoe, the framework of a loom, a decorated stave of a bucket, part of the axle and nave of a wheel with a couple of spokes in their place, and a ladder; querns, loom weights, crucibles, thousands of sling-bolts, made of clay both burnt and unburnt, \&c.

\section{Structure of Lake-dzuellings.}

The preliminary problem which had to be solved before lacustrine habitation became possible was to construct a level platform, sufficiently elevated above the water to be beyond the action of the waves, on which dwelling-huts could be erected. This had been effected in one or other of the three following ways :-

r. By driving long piles of wood into the bed of the lake, leaving their tops projecting at a uniform height above the water, and placing over them transverse beams, so as to form a platform capable of supporting such buildings as were considered necessary for the domestic comfort of their inhabitants. The dwellings so constructed are called Pile-structures or Piledicellings, Pfahlbauten, Palafittes, \&c. This was the method most commonly adopted in Switzerland, Austria, Savoy, and North Italy. 
2. A second method was to construct a series of rectangular basements of wood in close proximity to each other, each basement having its sides formed by a succession of horizontal beams lying one above the other like the logs in a Swiss châlet, and overlapping at the four corners. These compartments measured only a few yards in diameter. Their lowest beams rested on the bed of the lake, and when the requisite height above the water was attained, the usual platform was laid across, and so the empty spaces underneath became covered over. This plan, selected probably with the object of saving material, is analogous to the columnar and vaulted foundations of modern buildings. It appears to have been adopted chiefly by the founders of the sporadic lakedwellings of the Iron Age. Characteristic examples have been investigated in Lake Paladru, France, and in the lakes of Persanzig, Arys, Daber, and others, in Germany.

3. The third method was by constructing an artificial island of timbers, laid in layers transversely to each other, and generally mixed with stones and earth, so as to afford a substantial basis for a building which could be used as a habitation, or as a fort. This was the method almost invariably practised by the inhabitants of the British Isles, and the ruins of such habitations are now frequently met with in the form of submerged, or partially submerged, islands known as crannogs.

As regards the pile-structures proper, everything-huts, platforms, and piles, except their submerged lower ends-has disappeared ages ago, either by natural decay or by the accident of a conflagration. Such a catastrophe was by no means an uncommon occurrence among the Swiss lacustrine villages; but, strange to say, it was, from an archæological point of view, the most fortunate termination these structures could have had. In the hurry and scrimmage of a conflagration not only did many articles of value drop into the 
lake, but some of the most perishable commodities-such as grain, fruits, bread, cloth, \&c. -and, what is not the least interesting, portions of the clay mouldings of the hut walls, were first charred before they dropped into the subjacent mud, and thus became less liable to decomposition.

When we consider the number and extent of the lakevillages which formerly clustered along the sheltered bays in the larger lakes of Switzerland, we begin to realise the labour involved in their construction. One of the BronzeAge stations at Morges, in the Lake of Geneva, was I 200 feet long by 150 feet broad; and the whole of this area was thickly studded with the stumps of the piles which had supported the huts. Mr Löhle, the explorer of Wangen, a station of the pure Stone Age in Lake Constance, estimated the number of piles used in its construction at 40,000 or 50,000. Dr von Fellenberg calculated, by counting the number of piles in one or two selected spots, that the entire number required for the Bronze-Age settlement at Möringen could not have been less than I0,000. A more striking and realistic phenomenon has rarely come before archæologists than that which the stations of Möringen and Lattringen presented, shortly after the Lake of Bienne became affected by the results of the Correction des eaux du Jura-an operation which lowered its surface from 6 to 8 feet. Photographic illustrations of their sites, taken in 1876 , show quite a forest of black-looking stumps rising a few feet above the muddy bottom, which then for the first time became exposed to view. A similar sight was witnessed a few years later (the autumn of I884), at Cortaillod, in Lake Neuchâtel, and it made such an impression on the minds of the country-people that they flocked in crowds to behold the novel spectacle. The recently emerged piles, as positive evidence of human habitation, could not be gainsaid, more especially as relic-hunters 
were finding a rich harvest among the débris in the surrounding mud. The pile-structures which became embedded in peat are, however, still better preserved, as may be seen from the accompanying illustration (fig. 257), taken from a freshly excavated portion of the celebrated station of Robenhausen.

Contemporary with these pile-dwellings there existed throughout the same regions of Central Europe other lake-dwellings

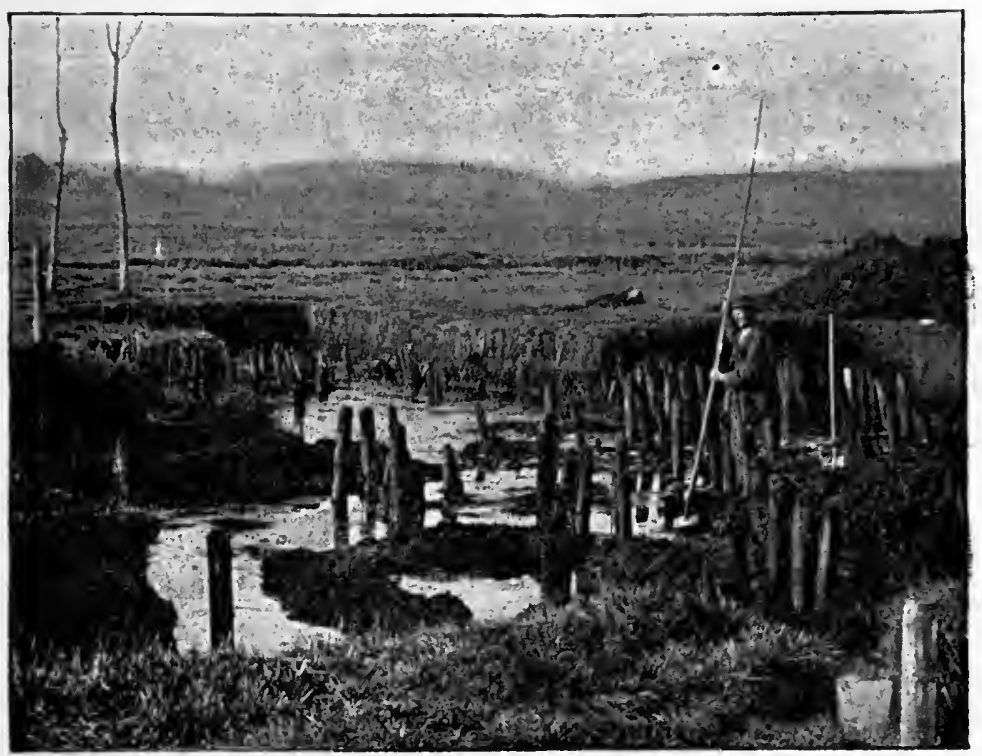

Fig. 257.-View of piles exposed on peat at Robenkausen, Suitzerland.

which, instead of platforms on tall piles, had solid substructures composed of layers of timbers alternating with beds of clay. Such structures are commonly met with in the smaller lakes, and their remains are now generally buried in peat. Characteristic specimens of this class have been investigated at Wauwyl, Niederwyl, and Schussenried. Examples of the artificial island or crannog have also occasionally 
been met with on the Continent. In this category are to be reckoned a prettily wooded island in the Iaake of Inkwyl, near Soleure; also one in Lake of Nussbaumen, which measured I 10 by 60 feet, and a third in the Arrasch See, in Livonia, which belonged to the Iron Age.

But it was within the British Isles that the artificial islands acquired their greatest development, some 300 having been recorded and more or less investigated, of which considerably more than two-thirds are in Ireland. The most precise information as regards their structure, however, has been furnished by one or two of the Scottish examples, notably those of Lochlee and Buston, in the county of Ayr.

The construction of a crannog must have been a gigantic piece of work, requiring in many cases the services of the whole village community. In a lake containing soft and yielding sediment it is manifest that any heavy substances, such as stones or earth, would be inadmissible, owing to their weight, so that logs of wood, provided there was an abundant supply at hand, would be the best and cheapest material that could be used. The plan adopted seems to have been to make first a floating raft of stems of trees, brushwood, bracken, heather, \&c., mingled with stones and earth, until the mass grounded. When this was effected the entire mass was pinned together and surrounded by circles of piles, firmly united by horizontal beams with mortise-holes to receive the uprights. These horizontal beams were arranged in two ways. One set ran along the circumference, and bound together all the uprights in the same circle, while others took a radial direction and connected each circle together. Sometimes the latter were long enough to embrace three circles. The external ends of the radial beams were occasionally observed to be continuous, with additional strengthening materials - wooden 
props, large stones, \&c.-which appeared also to act as a breakwater. On one side of the Lochlee crannog there was a large accumulation of brushwood outside the stockade. The mechanical skill displayed in the construction was specially directed to give stability to the island, and to prevent superincumbent pressure from causing the general mass to bulge outwards.

The internal composition of the Lochlee island was carefully ascertained by cutting a large rectangular hole near its centre, which was carried down till the original silt of the lake was reached-a depth of 10 feet from the primary floor of the dwelling-house, or about 16 feet from the surface of the mound. The result of this was to show that the solid mass was composed of the unbarked stems of various kinds of trees, from 6 to $\mathbf{x} 2$ inches in diameter, laid in transverse layers over each other. At the very bottom a large trunk, 44 inches in diameter, was encountered, between which and the lake sediment there were only a few hazel twigs. Interspersed among this woodwork, and stretching beyond the limits of the cutting, were prepared oak-beams pinned at their ends to others of the same kind, as well as, here and there, to the ordinary rough logs. This arrangement probably extended to the marginal stockades, and so formed a strong binding framework to the whole island. One pin, some 3 or 4 inches in diameter, penetrated through no less than four beams in successive layers, and terminated ultimately in a large trunk, 13 inches in diameter. One of these oak-beams measured 8 feet 3 inches in length and ro inches in breadth; and the holes in it were 5 feet apart. Another terminated in a small round projection or tenon, which evidently fitted into a mortised hole in an adjacent beam.

Some of the artificial islands have been constructed of dry 
stones with, or without, a wooden foundation, and numerous examples of them have been recorded both in Ireland and in Scotland. According to $\mathrm{Mr}$ Kinahan, the largest and most characteristic stone crannog in Ireland is Hag's Castle, Lough Mask, county Mayo. In Scotland, a specimen in the White Loch of Ravenstone, Wigtownshire, explored some years ago by the late Lord Borthwick, under my supervision, had the appearance of a mound of stones with a level surface 80 feet square. On the surface there were ruins of stone buildings, but on excavating a hole near the centre, to a depth of 6 or 7 feet, we came on a foundation of large beams and trunks of trees. ${ }^{1}$

Many, if not all, of the lacustrine villages of Central Europe were connected with the shore by means of one or more gangways, supported by a double row of piles, and varying in length and breadth according to the situation and requirements of each village. Dr Gross informs us that the bridge leading to the Bronze-Age settlement at Möringen was about 200 yards in length, and from 10 to 12 feet in width; while that to the Stone-Age station in the same locality was considerably shorter, and only 5 to 8 feet wide. The extent of the space occupied by piles at Robenhausen was about 3 acres, and the nearest point of the old lake-shore was some 2000 paces distant; but yet it would seem, from traces of piles found in the peat, that a bridge at one time traversed the whole of this distance. Remains of similar approaches have been frequently observed in connection with the sporadic dwellings in the outlying districts of Europe. Dr Conwentz ${ }^{2}$ has recently shown that, in prehistoric and early medieval times, wooden roads and bridges had been constructed in North Germany across bogs and marshes, the

${ }^{1}$ Collections of Ayr and Gal. Arch. Association, vol. v. p. 121.

${ }^{2}$ Die Moorbrïcken im Thal der Sorge, 1897. 
remains of which are at the present time occasionally met with buried in peat and other superficial accumulations.

Access was had to the Scottish and Irish crannogs by various means. Some had moles or stone-causeways, the existence of which in some instances only became known upon the drainage of the lake. Hence it has been conjectured that these approaches might have been always submerged, and so supplied, on emergencies, a secret means of communication with the shore. This idea was suggested by the tortuous direction which many of them assumed, as, for example, the causeway discovered after the drainage of the Loch of Sanquhar, which had a zigzag direction, and so could only be waded by persons intimately acquainted with its windings. Others were approached by a wooden gangway, the evidence of which in some cases still exists in the form of a double row of piles. Both at Lochlee and Lochspouts it was ascertained that these piles were tightly embraced at their lower extremities by a curiously constructed network of horizontal beams, spreading from one line of uprights to the other. As these structures were buried from 3 to 7 feet beneath the lake-bed, my first impression was that they might have been used, like the submerged stone causeways, as a concealed means of communicating with the shore. To test this suggestion, I caused a special excavation to be made along the line of a gangway at the Miller's Cairn, in Loch Dowalton. After digging through 3 feet of hardened mud we came upon a stratum of fine, blue, and extremely tenacious clay. The pointed stakes, which penetrated into this clay only a few inches, here met with a firm resistance. It then occurred to me that the ingenious arrangement of the wooden beams at the crannogs of Lochlee and Lochspouts served merely the same end as the blue clay at the Miller's Cairn, and that they were to be found only 
in localities where there was a great depth of mud incapable of affording a sufficient basis of resistance to the piles. It is curious to note the ingenuity and variety of means by which such difficulties were overcome.

In addition to the ordinary lake-dwellings, or palafittes, there is to be found, in the eastern part of the Po Valley, another class of ancient habitations known as terremare, which are so closely allied to the former that they may be regarded as land palafittes. They date from the Bronze Age, being apparently a development of the lacustrine system; and although long known as the source of many interesting antiquities, it was only after the lake-dwelling researches came into vogue that their real nature was recognised. Nearly one hundred of these mounds have now been more or less investigated, with the result that there can no longer be any doubt that they are the sites of ancient villages constructed on piles, and fortified by an earthen dyke and a ditch. In their construction one uniform plan was adopted. Having selected a suitable site, always four-sided and orientated, but of course varying in size according to the requirements of the community, the constructors proceeded to surround it with a ditch, the excavated material being thrown up in the form of a dyke on the inner side. The area thus enclosed was then thickly planted with stakes, the tops of which were brought to a common level, and over them a wooden platform was laid. On this platform cottages made of light timbers and clay were erected. Thus, in a very simple manner, was constructed a fortified village, access to which was secured by one or more wooden bridges spanning the surrounding ditch. The vacant space beneath the common platform became a convenient receptacle for all sorts of refuse, including lost and worn-out objects of industry. When in the course of time this space became filled up, the terramaricoli, in order to avoid the labour of having to remove 
the débris which would otherwise accumulate around them, adopted the ingenious method of constructing a brand-new platform above the former. It seems that a preliminary step to the carrying out of this project was to set fire to the entire village, thus at one coup getting clear of all sanitary difficulties as well as of a number of uninvited guests. Having thus started with a clean bill of health, they elevated the dyke to the requisite height, and planted stakes, as formerly, for the support of the new platform and huts-the stakes in this case penetrating only into the accumulated rubbish of the former village. This mode of procedure appears to have been repeated over and over again, until in the course of ages the successive deposits accumulated to a height of 15 or 20 feet.

\section{Marine Duellings.}

Before the construction of the great sea-dykes in Holland, nearly the whole of West Friesland would have been in that hybrid condition described by Pliny, in which it was difficult to say whether it belonged to sea or land ("dubiumque terræ sit, an pars maris"). "Here," says this writer, "a wretched race is found, inhabiting either the more elevated spots of land, or else eminences artificially constructed, and of a height to which they know by experience that the highest tides will never reach. Here they pitch their cabins; and when the waves cover the surrounding country far and wide, like so many mariners on board ship are they," \&c. At the present time this region is richly cultivated, and looks as if it were a dead level, and it is only on close inspection that certain elevations of considerable extent, called terpen, scattered irregularly over the country, can be detected. It is on such elevations that villages and churches are generally built, and, till they accidentally attracted the attention of agriculturists within 
recent years, no one seemed to have thought anything about their origin. They are now proved to have been originally constructed as pile-dwellings, precisely similar to the terremare, and are probably the actual mounds seen and described by Pliny. They might therefore be more appropriately designated as marine dwellings.

Like the terremare of Italy, the terpen are largely excavated on account of their rich ammoniacal deposits, which are used by agriculturists as guano. The industrial remains found in the course of these operations are of a very miscellaneous character, and give a vivid picture of the civilisation of their inhabitants from Roman times down to the twelfth century. Among the relics I noticed such objects as the shells of eggs (hen and goose), some of which were unbroken, a flute made of the shank-bone of an animal, large casks, canoes, loomweights, toilet-combs, iron bridle-bits, beads of glass and amber, Anglo-Saxon, Byzantine, and Roman coins, bronze pots, pottery, \&c., \&c.

Traces of marine pile-structures are also said to have been found in the Bay of Wismar, North Germany. ${ }^{1}$

The only remains suggestive of ancient habitations known to me within the tidal shores of the British Isles are-(I) a cairn of stones on a substratum of wood near the island of Eriska, at the mouth of Loch Crerar; (2) the Black Cairn, in the Beauly Firth; (3) some stumps of piles in Ardmore Bay, county Waterford; and (4) a curious wooden structure recently discovered at Dumbuck within the tidal area of the Clyde.

The Eriska mound, which was dry at low water but submerged at spring-tides to the extent of 5 feet, was found on examination to be composed of clay and stones resting on a foundation of logs of wood. The mound was circular in form,

1 Lake-Dwellings of Europe, p. 31 . 
about 60 feet in diameter, and in digging a trench through it, ashes, charcoal, and the broken bones of domestic animals (ox and sheep) were turned up as evidence of human occupancy. ${ }^{1}$

The Black Cairn, which is situated about 400 yards within the flood-mark of the Beauly Firth, and nearly opposite to Red Castle, is also said to be constructed on a foundation of large beams. Miss C. Maclagan ${ }^{2}$ thus refers to it: "We visited it at low water of the lowest tide of the year, and believe it to be a crannog greatly resembling one in the neighbouring 'Loch of the Clans,' but resting on larger, stronger piles. Our boatmen declared they had often drawn out of it beams 9 or ro feet long and 3 feet broad, fresh and fit for use. They had great difficulty in pulling them out, which they did by fixing their anchors in a $\log$ or pile. Tradition says that as late as I 745 the place was an island, and a refuge to which some of Prince Charles Edward's defeated adherents fled after the battle of Culloden."

The "submarine crannog" at Ardmore, discovered by $\mathrm{Mr}$ R. J. Ussher, ${ }^{3}$ covers an oval space about $r o o$ feet in diameter, and contains piles in a stratum of peat. The present submarine position of these remains may be reasonably accounted for on the strength of the evidence that a submergence of the land, since Neolithic times, has taken place along the southern shores of England and Ireland, while, during the corresponding period, the very opposite change has been proved to have occurred in Scotland and the north of Ireland. ${ }^{4}$ For further references to marine dwellings see 'Lake-Dwellings of Europe,' pp. 3 1 r, 389, 443, 573, and 574 .

The so-called crannog at Dumbuck is situated between high- and low-water marks, and at full tide its site is covered to a depth of at least 3 feet. Before it was subjected to the

\footnotetext{
1 Proc. Soc. A. Scot., vol. xix. p. 192.

${ }^{3}$ Proc. R. I. Acad., vol. ii., 2nd series.

${ }^{2}$ Hill Forts, \&c., p. 89.

- Arch. Journal, Sept. 1898.
} 
recent excavations conducted by $\mathrm{Mr}$ W. A. Donnelly, its discoverer, I counted the tops of twenty-seven piles of oak, some 5 or 8 inches in diameter, cropping up through the mud in the form of a circle 56 feet in diameter. The area thus defined was occupied by three layers of timbers - apparently the trunks of small trees from the forest-laid transversely one above the other. The surface of this log-pavement was not lower than that of the surrounding mud, so that a little scraping with a small hand-shovel was sufficient to reveal its extension over the entire area of the circle, with the exception of a few yards in the centre, which were then occupied by a heap of stones. On the removal of these stones it was ascertained that the woodwork did not extend over the entire area, but left a circular portion, about 2 yards in diameter, in the centre free. Another unique feature of this structure was a ring of horizontal woodwork, some 8 or ro feet outside the circle of piles, the intervening space being destitute of wood; so that this zone, when cleared of the mud, looked like a canal separating the circle of piles, with its enclosed wooden flooring, from the outer ring of woodwork. In short, the woodwork was arranged in two concentric rings, the inner being, however, much broader than the outer. The southeast portion of this unpaved zone contained a refuse-heap of ashes, charcoal, and broken bones, some of the latter being calcined. Among the bones, Dr Traquair, F.R.S., has identified those of the ox, sheep, pig, deer, and roe, also some teeth of the horse. Several portions of the antlers of deer had marks of cutting and sawing implements on them.

Near the outer margin of the outer ring of woodwork, on its north-east side, there was found a single-tree canoe, 33 feet long, 4 feet wide, and about $\mathrm{I} / 2$ foot deep, embedded in mud just of sufficient depth to cover it. On the north-west border of the central ring of woodwork there was exposed a 
massive beam of oak, some $x_{5}$ feet long, which contained in its middle two-thirds 5 slanting apertures, cut out of the solid, like the steps of a stair.

The whole area occupied with these wooden structures was strewn over with stones which, judging from their localised grouping and the entire absence of stones in the surrounding muddy deposits, must have been carried there by the hand of man. One thing is quite evident, that the surface of the exposed woodwork was not at any time the habitable level, as it is covered every twelve hours by upwards of 3 feet of water. Nor was there any evidence whatever to suggest that it was a habitation supported on piles, analogous to the pile-structures (Pfahlbauten) of the Stone and Bronze Ages of Central Europe. The most probable explanation of the curious set of phenomena here disclosed is, that the woodwork was the foundation of a superstructure of stones, built sufficiently high to be above the action of the tides and waves, over which there had been placed some kind of habitation; but whether it was a crannog, fort, or watch-tower, still remains sub judice. The unique arrangement of the woodwork at once suggests that the central building was in the form of a round, hollow tower, with very thick walls, like the brochs, and that outside this there had been a circular wall or breakwater which had the outer ring of woodwork for its foundation. Why, when, or by whom the stones were removed there is no evidence to show; but were I to make a suggestion it would be that the stone causeway, now laid along the bank of the recently made canal which stretches from a point close to the "crannog" to the railway, accounts for a large number of them. The site of the building and its substructures of wood now alone remain to puzzle antiquaries. Similar wooden basements are very common among the stone-crannogs of Scotland and Ireland, as already explained. 
The most mysterious outcome of the Dumbuck investigations is that relics, entirely new to Scottish archæology, but almost identical with those recorded as having been found on the adjoining hill-fort of Dunbuie, have also been found among the débris of this marine site-some in the refuse-heap, some in the canoe, and others in the empty central space. The account of the Dunbuie fort and its extraordinary relics having already been published as evidence of a Neolithic and pre-Celtic civilisation ${ }^{1}$ (not, however, without a protest on the part of a few antiquaries), the same theories have appeared in current literature with regard to the Dumbuck crannog. In dissociating myself from these theories, which I regard as utterly untenable, I have elsewhere given expression ${ }^{2}$ to the opinion that these strangelooking objects, both from Dumbuck and Dunbuie, do not belong to any known phase of Scottish civilisation, and most certainly not to the Neolithic period. The statement that a wooden structure-unquestionably showing the marks of metal tools, and exposed on the surface of recent river deposits-is a Neolithic monument, is a palpable contradiction in terms. To look for Neolithic remains in this locality, one would not go to the superficial deposits within the present tidal area of the Clyde, but rather to those which formed its shelving shore in those earlier times. On the supposition that a crannog, or any other analogous structure, had been constructed in the Stone Age, near the line of low-water mark, its site would be now, doubtless, many hundreds of yards inland, and buried some 8 to 12 feet beneath the cultivated land of the present day. The section of the sedimentary deposits on this site, so far as I can gather from Mr Donnelly's statements, shows " a bed of loam on which the timbers of the structure rest; then a bed of silt which is filled up with brushwood under the ${ }^{1}$ Proc. Soc. A. Scot., vol. xxx. p. 291. $\quad 2$ Glasgow Herald, 7 th Jan. 1899. 


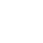




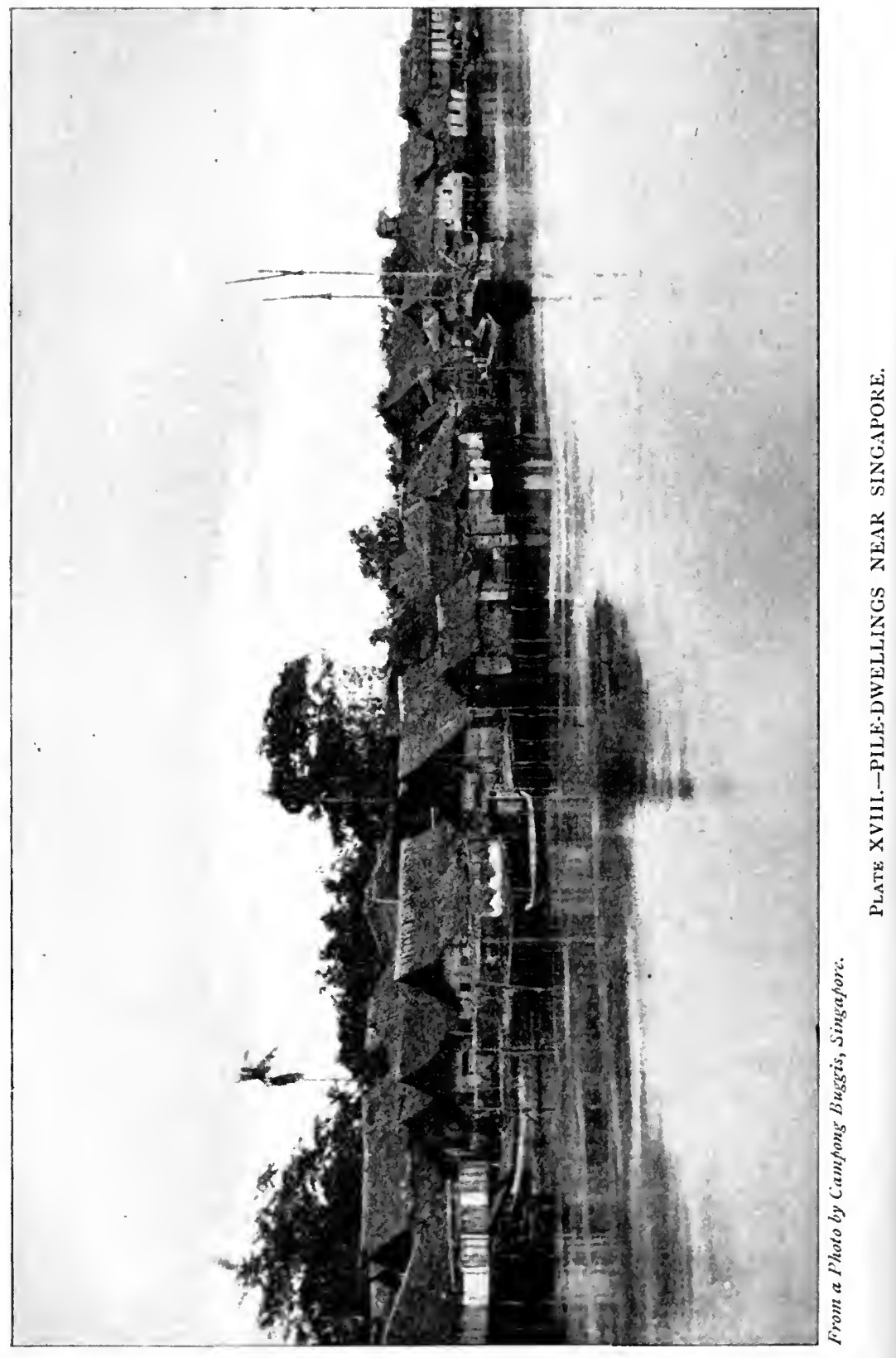


timbers"; then layers of sand and gravel; and finally the blue glacial clay into which the tips of the piles penetrated. These facts are probably correct, and harmonise with the geological phenomena of the locality. The alluvial deposits which have accumulated during, and since, Neolithic times in the shallows of Dumbuck, have encroached on the water in the form of a wedge, the thin edge being next low-water mark. The increase of mud around the wooden structure, since it was laid, is probably less than a foot in depth.

Among the genuine relics found at Dumbuck may be mentioned portions of deer-horn sawn across, a quern, some pointed implements of bone like those found in the Lochlee crannog, and illustrated by fig. 79 in 'Ancient Scottish Lake-Dwellings,' and a few polishers of stone-all of which unmistakably indicate the medieval character of this curious structure. The quern, or hand-mill, was not known in Europe, either in the Stone or Bronze Age, and none prior to Roman times has been found in North Britain. The shale and slate images and weapons, the perforated stone-pendants, oystershells, and other objects, ornamented with cup-marks, concentric circles, \&c., would be as much out of place as surviving remnants of the prehistoric civilisation of Scotland in Romano-British times, as they are now.

Pile-dwellings are still common in many parts of the world, as in the Gulf of Venezuela, in South America, and on the shores of nearly all the islands in the East Indies-Borneo, New Guinea, Celebes, \&c. At Singapore I saw several pilevillages situated on the charming little bays which are to be met with in that neighbourhood. When the tide is full no more picturesque sight could be imagined than one of these villages, as may be seen from the accompanying photographic view of one of them.

(Pl. XVIII.) 
CHAPTER XII.

ETHNOLOGY.

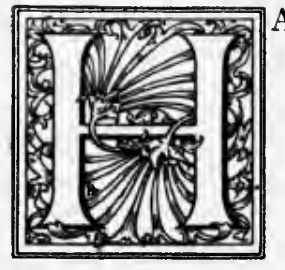

AVING in previous chapters discussed the general civilisation of the prehistoric inhabitants of Scotland, we now come to examine their physical characteristics, as disclosed by such fragmentary remains of their bodies as have survived to the present day, and the relation of these characters to those of foreign contemporaries, with the view of gathering some information regarding the part of the world from which our ancestors came, and the branch of the human family to which they belonged.

One of the most important facts inculcated by the science of anthropology is that racial characteristics are more persistent than the superficial varnish supplied by a sudden alteration in social environments, such as occurs when one nation conquers and governs another. In this way the interval of a few generations might suffice to bring about a complete change in the language and culture of a people; but such influences do not so readily affect the organic elements which determine the physiognomy, the stature, the conformation and proportions of the body, and the colour 
of the skin, hair, and eyes. In support of this doctrine I might refer to the oft-quoted observation that the physical peculiarities of the old-world races of the Nile valley, as depicted on Egyptian tombs, have not materially altered during the last five thousand years. Applying these principles, even should they have to be greatly modified by the results of cross-breeding, to the inhabitants of the British Isles, we should naturally expect those of the present day to preserve some of the typical characteristics of their prehistoric forefathers. Although, in this case, we have no pictorial representations of the ancient Britons as a standard of comparison, there is still extant a remarkable description of them, which for our purpose is equally good. In his Life of Agricola, the Roman historian Tacitus thus writes: "Who were the first inhabitants of Britain, whether indigenous or immigrants, is a question involved in the obscurity usual among barbarians. Their temperament of body is various, whence deductions are formed of their different origin. Thus, the ruddy hair and large limbs of the Caledonians point out a German derivation. The swarthy complexion and curled hair of the Silures, together with their situation opposite to Spain, render it probable that a colony of the ancient Iberi possessed themselves of that territory. They who are nearest Gaul resemble the inhabitants of that country, whether from the duration of hereditary influence, or whether it be that when lands jut forward in opposite directions climate gives the same condition of body to the inhabitants of both. On a general survey, however, it appears probable that the Gauls originally took possession of the neighbouring coast. The sacred rites and superstitions of these people are discernible among the Britons. The languages of the two nations do not greatly differ. The same audacity in provoking danger and irresolution in facing it when present is observable in 
both. The Britons, however, display more ferocity, not being yet softened by a long peace; for it appears from history that the Gauls were once renowned in war, till, losing their valour with their liberty, languor and indolence entered amongst them. The same change has also taken place among those of the Britons who have been long subdued; but the rest continue such as the Gauls formerly were" (chap. xi.)

The above statement $I$ regard as a valuable landmark in British ethnology, as it discloses, at the very dawn of the historic period, the existence of two extremely different types of people in different parts of Britain. Although the evidence on which the historian assigns the one (Caledonians) to a German and the other (Silures) to a Spanish origin may not satisfy modern criticism, it does not follow that his conclusions are erroneous.

With regard to the early ethnology of Western Europe, I have elsewhere ${ }^{1}$ attempted to establish the truth of the two following propositions: (I) that during the Quaternary period only dolichocephalic crania have been met with; and (2) that the first appearance of a brachycephalic people on the scene was contemporary with the rudimentary development of the Neolithic civilisation of Europe. My concluding words on the subject were as follows: "From the amalgamation of these varied races the highly mixed populations of modern Europe can be readily accounted for; but whether the brachycephalic people have been evolved from the older dolichocephalic types still remains a controverted problem. To my mind the glimpses which both archæology and human palæontology have given us of the career of man in Europe agree in support of the hypothesis that two peoples, long and widely separated, had come into contact in Southern France, and perhaps elsewhere, at the

1 Prehistoric Problems, p. 160. 
close of the Reindeer period. Of these the dolichocephalic were the oldest, and probably the direct representatives of Palæolithic man."

When these words were written there was no occasion to pursue the subject through Neolithic times, my task being then restricted to the remains of Palæolithic man, but now it forms the starting-point of our inquiry. Considering the rapidity with which craniological researches have advanced within recent years, and the large amount of materials now available for discussion, it will be necessary in this sketch to dispense as much as possible with technical and anatomical details, and to confine ourselves chiefly to results which we consider to be well founded on facts.

\section{Craniology.}

The first to make a definite statement based on anatomical data with regard to the prehistoric inhabitants of Scotland was Sir Daniel Wilson, who, as early as $185^{\circ}$, read a paper at the British Association on "The Existence of Primitive Races in Scotland prior to the Celtæ." Writing in 1863 , he makes the following remarks: "The results of my first investigations into the physical characteristics of the earliest races of North Britain appeared to me sufficient to establish the fact that the Aryan nations, on their arrival, found the country in the occupation of allophylian races, by whom the wilds of Europe had already been reclaimed in part for the use of man. Still further, I was led to conceivecontrary to the conclusions of Continental investigators of the same evidence in relation to Northern Europe - that the earliest Scottish, and indeed British, race differed entirely from that of Scandinavia, as defined by Professor Nilsson and others, being characterised by the markedly 
elongated and narrow cranium, tapering equally towards the forehead and occiput, already referred to here under the
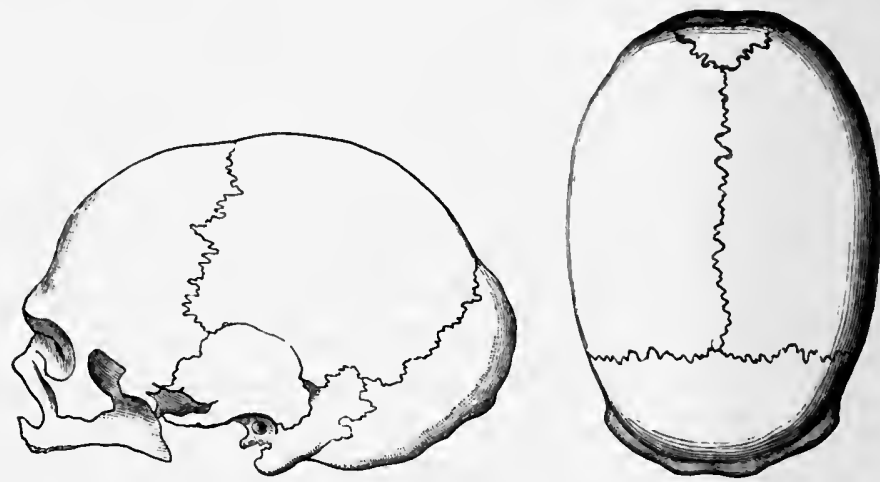

Fig. 258.-Two views of a skull from a cairn at Nether Urquhart, Fifeshire.

name of kumbecephalic or boat-shaped skull. It is a form by no means peculiar to Britain." 1 As illustrations of the
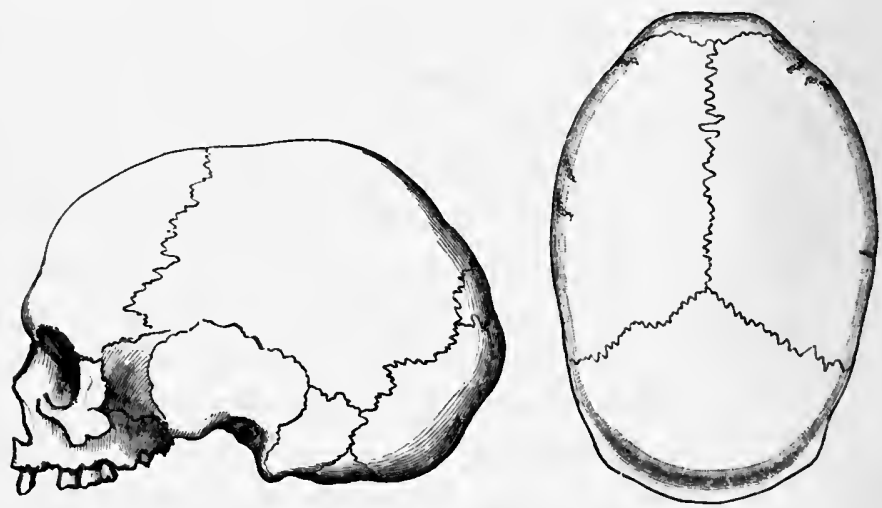

Fig. 259. - Two views of a skull from a stone cist at Cockensie, East Lothian.

kumbecephalic skull, Sir Daniel figures two crania (figs. $25^{8}$ and 259), both from the National Museum of

1 Prehistoric Annals, 2nd ed., vol. i. p. 249. 
Antiquities in Edinburgh. One of these was "obtained from a cist discovered under a large cairn at Nether Urquhart, Fifeshire"; and the other from one of a "group of short stone cists, opened at Cockenzie, East Lothian." The cephalic index of the former is 70.7 , and of the latter $75 \cdot 7$.

With regard to Professor Nilsson's views on the priority of a brachycephalic race in Scandinavia, it may be mentioned that he subsequently abandoned them, as at p. I 2 I of the third edition (1868) of his 'Primitive Inhabitants of Scandinavia' we find the following statement: "Some isolated brachycephalous crania have been occasionally found in our stone sepulchres; but it may be taken for granted that the people who constructed these sepulchres belonged to one of the dolichocephalous races which still inhabit the greater part of the country." Sir Daniel Wilson associated the British dolichocephalic race with the constructors of the chambered barrows in the south-west of England, and maintained that they were succeeded by a brachycephalic people, "among whom apparently the simple arts of the Stone period still prevailed; though in their later barrows, weapons and implements of bronze indicate their acquisition of the metallurgic art." Both these races he regarded as pre-Celtic. But, however this may be, it was inferred, from the data then collected, that during the later portion of the Neolithic period in Scotland there existed two races, differing widely from each other in physique, and especially in the form of the skull, the earlier of the two being dolichocephalic and the other brachycephalic. The tendency of subsequent investigations has been not only to confirm the truth of this hypothesis, but to extend its application to much wider areas, embracing the whole of Western Europe, as will be shown in the sequel. 
Through the researches of Bateman, ${ }^{1}$ Thurnam and Davis, ${ }^{2}$ Busk, ${ }^{3}$ and others, archæologists have been long conversant with the great generalisation that the human crania from the chambered cairns of Wiltshire, Somerset, Gloucester, and some adjacent localities were, as a rule, dolichocephalic. The occasional presence of a brachycephalic skull in some of these cairns was easily explained on the supposition that the short-headed people appeared on the scene while their predecessors were still practising these methods of sepulture. The co-existence of these two types of crania in the round barrows of the Bronze Age goes far to support this view.

The ethnological doctrine thus formulated has been greatly strengthened by the researches of Canon Greenwell among British barrows, and the masterly monograph of Dr Rolleston on the prehistoric crania thus collected. In a couple of preliminary sentences Dr Rolleston puts the result of his craniological investigations in a very striking light: "A craniographer with Canon Greenwell's series before his eyes in a coup-d'ail view would be impressed with the fact that out of the series, two sets, the one by its length typically illustrative of the dolichocephalic, the other by its breadth as typically illustrative of the brachycephalic form of skull, could at once be selected, even by a person devoid of any special anatomical knowledge. An antiquary similarly inspecting this series with a knowledge of its archæological history would, if he separated it into two groups, the one containing all the skulls of the Stone and Bone Age, the other containing all those of the Bronze period, perceive that, while the latter group comprised both dolichocephalic and brachycephalic crania, and in

${ }^{1}$ Ten Years' Diggings, \&c.

${ }^{2}$ Crania Britannica; Mem. Anthrop. Soc., vols. i. and iii.

3 Journ. Ethnol. Soc. Lond., 2nd Series, vol. vi. 
very nearly equal proportions, none but dolichocephalic skulls were to be found in any set of skulls from the barrows of the premetallic period." 1

According to Dr 'Thurnam's cranial statistics, the range of the cephalic index in sixty-seven skulls from long barrows was $6_{3}$ to 79 , and in seventy from round barrows 74 to 89 . There was thus no dolichocephalic skull (i.e., one with a cephalic index less than 74 ) in a round barrow, and no brachycephalic skull in a long barrow. It was on this evidence that the famous aphorism, "Long barrows, long skulls; round barrows, round skulls," was founded. Later researches have, however, entirely disproved the idea that long skulls were confined to long barrows, for of the four typical long skulls from Canon Greenwell's collection of crania from the Yorkshire barrows, specially selected by Dr Rolleston for description and illustration, three were taken out of round barrows. But the really important part of the aphorism-viz., that short skulls are not found in the earlier long barrows-has been confirmed by all subsequent researches. "It is undoubtedly an important fact," writes Dr Rolleston, "that in no skull from any long barrow, that is to say, in no skull undoubtedly of the Stone Age, examined by us, has the breadth been found to bear so high a relation as that of $80: 100$ of the length; for this alone would suffice to show that Retzius's classification of skulls into two great divisions of dolichocephalic and brachycephalic cannot, ever when taken to connote merely the strictest geometrical proportions, be summarily set aside as an artificial one." 2 .

Dr Thurnam gives the mean height of the dolichocephalic men of the long barrows at 5 feet 5.4 inches, and that of the brachycephalic men of the round barrows at 5 feet 8.4 inches. As Dr Rolleston's measurements are practically in accordance
1 British Barrows, p. 627.
2 Ibid., p. 637. 
with those of Dr Thurnam, we may accept it as a fact that the former were less in stature than the latter by about 3 inches. "To this I would add," writes Dr Rolleston," " that whilst this very striking difference is brought out by taking the average length of the two sets of femora, a simple inspection of the two sets of bones puts them into even sharper contrast. The longer femora very often are also the stronger in a most marked degree, and amongst them are to be seen bones with muscular ridges, and processes indicating the possession by their owners of strength far exceeding that usually observable in the skeletons of the earlier race. In like manner other bones indicate unmistakably that the earlier was also the feebler folk as a whole, though humeri and femora are forthcoming from long barrows which show that men of great muscular power, even if not of great stature, were not wanting amongst the British tribes of the long-barrow period. In some cases the muscular ridges on the long-barrow bones are so well developed on comparatively ill-developed shafts as to suggest the idea of a poorly or only intermittently well-fed population which was constantly worked hardly. The large size of the deltoid ridge on some small humeri has suggested the perhaps fanciful hypothesis that the owners of such bones had been employed in lifting the stones of the huge barrows in which they were found entombed. The linea aspera on the femora of the British long-barrows examined by me never attains the enormous development which caused Professor Busk and Dr Falconer to call the femora from the Genista Cave at Gibraltar 'carinate,' and which has suggested the name 'fémur à colonne' to Broca and Topinard, for similar femora from early sepultures. In the absence of this peculiarity, as also of the fluting of the fibula and of the sabre-shape of the tibia which are found to accompany it, 
these skeletons contrast with many of the probably earlier skeletons described by the authors just referred to."

The truth of these general conclusions has been more recently confirmed by the results of Dr Garson's careful description of seven skeletons found in a round barrow (Howe Hill Barrow) in Yorkshire. ${ }^{1}$ The average height of these skeletons was calculated to be 5 feet 5.4 inches. One of them was remarkable for its size, being, according to the lowest computation, 6 feet 3 inches, a height which corresponds precisely to the tallest long-barrow skeleton in 'Crania Britannica.' The cephalic index varied from 65.5 to 79.6, or an average of 74.7. "The skulls," says Dr Garson, "are in all respects similar to those of long-barrow specimens which have passed through my hands from different parts of the kingdom, but I have never examined a series of skulls in which there were such a large proportion of hyper-dolichocephalic specimens."

I may observe that the Howe Hill Barrow was explored by Mr J. R. Mortimer, whose experience in this kind of investigation is so well known. It measured 125 feet in diameter, 47 feet across its summit, and 22 feet in height. Inside the mound there was a central core, not, however, corresponding with its present centre, in which the primary interments were found. The portion outside this core contained mixed relics -British, Roman, and Anglo-Saxon-and may therefore be regarded as an addition to the mound in later times. "This inner mound," continues Dr Garson, "consisted of two layers, in the outer of which were found seven deposits of burnt bones, with flint and bone implements and a piece of a foodvase. In the inner or core of the barrow were numerous cremated deposits extending to half its thickness, but fewer in number below that. Towards the base line of the barrow and

${ }^{1}$ Journ. Anth. Institute, vol. xxii. p. 8. 
in the central grave we have the skeletons placed in different directions, chiefly lying on one or other side, with the limbs drawn up towards the body. With them were found flint implements carefully manufactured, worked flints, and flakes, bone pins-some of which were burnt. With the primary interment at the bottom of the grave was a semi-globular vase of Kimmeridge clay, but no cinerary urns were anywhere found. The animal remains found in connection with the skeletons were those of fox (identified as such by Mr Newton), ox, deer, boar, and beaver. . . . From these data I think we have undoubtedly to deal with the remains of a Neolithic people, interred in an age before metal had been introduced among them."

In Scotland some interesting discoveries of human remains have been made in the caves at Oban, which have been exposed from time to time along the foot of the cliff overhanging the ancient raised sea-beach, on which part of the town is built. These have been carefully examined and described by Sir William Turner. ${ }^{1}$ Evidence of human occupation was found in four caves, consisting of a few flint scrapers and flakes, stone and bone implements, food-refuse, $\& c .$, all apparently of the same character as the relics found in the MacArthur Cave already described (p. 46). In one of these caves some fragments of pottery were found which Dr Joseph Anderson regards as resembling "in all their characteristics the cinerary urns of the late Neolithic period and of the Bronze Age."

Among the human remains, besides those from the MacArthur cave, there was only one skull, that of a child, sufficiently preserved to admit of correct measurements being taken. The cephalic indices of these three crania were ascertained to be 75.4 (A) and 70.2 (B) for the two adults,

1 Proc. Soc. A. Scot., vol. xxix. p. 410. 
and 77.8 for the child. With regard to the physical characters of these cave-dwellers, of whom portions of about fifteen skeletons were here represented, Sir William makes some valuable observations. The skulls $A$ and $B$ "prove them to have been people with well-developed crania, dolichocephalic in form and proportions. . . The great capacity of the skull B (figs. 260-262), which, in its uninjured state, had doubtless been capable of containing not less than

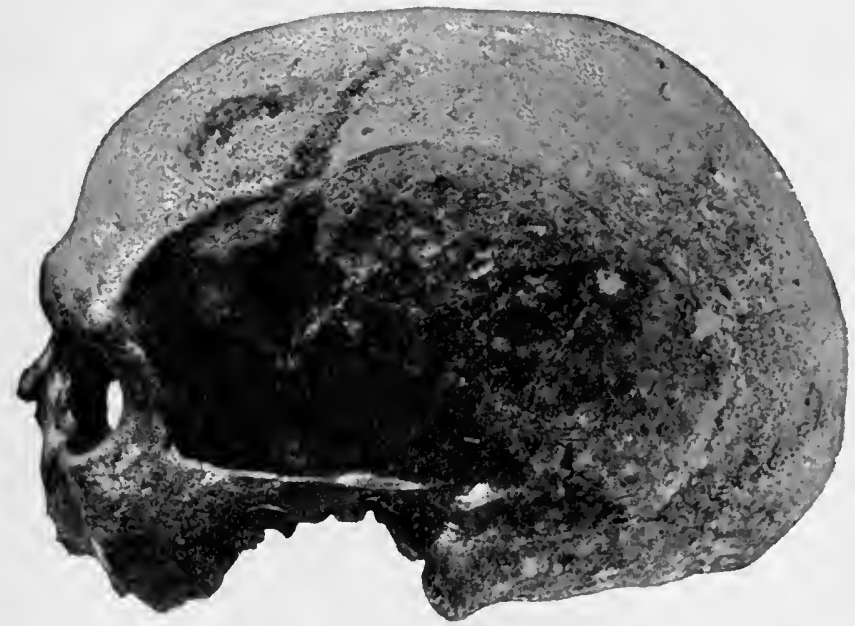

Fig. 260.-Profile view of skull B, MacA rthur Cave, Oban.

I 730 c.c. of water, places it on a level with some of the most capacious skulls of modern Scotsmen which I have measured." The tibia of one skeleton at least were platycnemic, and one of the thigh bones was platymeric. As no thigh bone was entire, the data for determining the stature were unfortunately imperfect, but from the available materials, such as they were, the height of one was calculated to be about 5 feet 5 inches. Of course there is one objection to the validity of general conclusions drawn from the sepulchral 
remains being applied to the Oban cave-dwellers, because we are not certain that they were the same people. In the MacArthur Cave the human remains were clearly subsequent to the time when the Troglodytes made it their home; but in the other cares this relationship has not been noted.

Sir William Turner has for many years devoted great

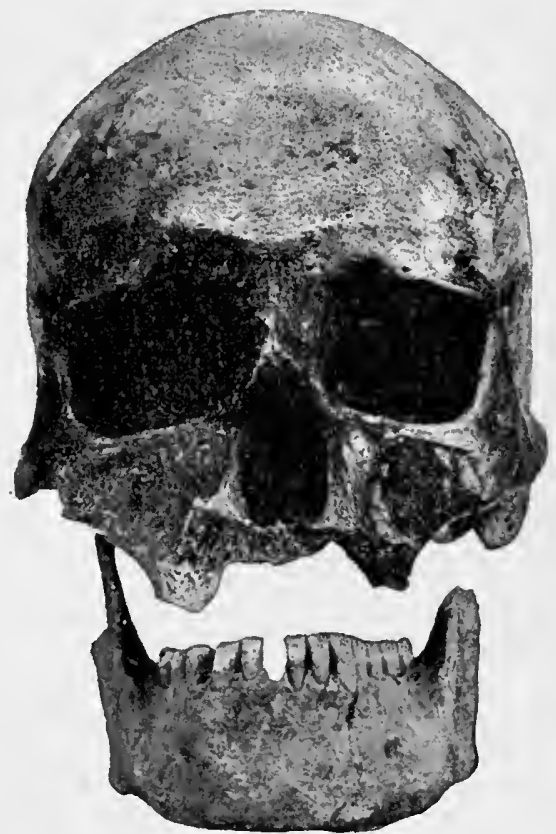

Fig. 26r.-Facial view of skull B.

attention to Scottish anthropology, and most of the human remains found in prehistoric graves, \&c., have passed through his hands. I am fortunate, therefore, in having in his recent Royal Institution lecture (March 26, I 897) the following summary of his observations on the prehistoric craniology of Scotland :-

"As similar physical conditions prevailed both in England 
and Scotland during the polished Stone and Bronze periods, there is a strong presumption that the two races had, in succession to each other, migrated from South to North Britain. Unfortunately very few skulls have been preserved which can with certainty be ascribed to Neolithic man in Scotland, but those that have been examined from Papa IVestray, the cairn

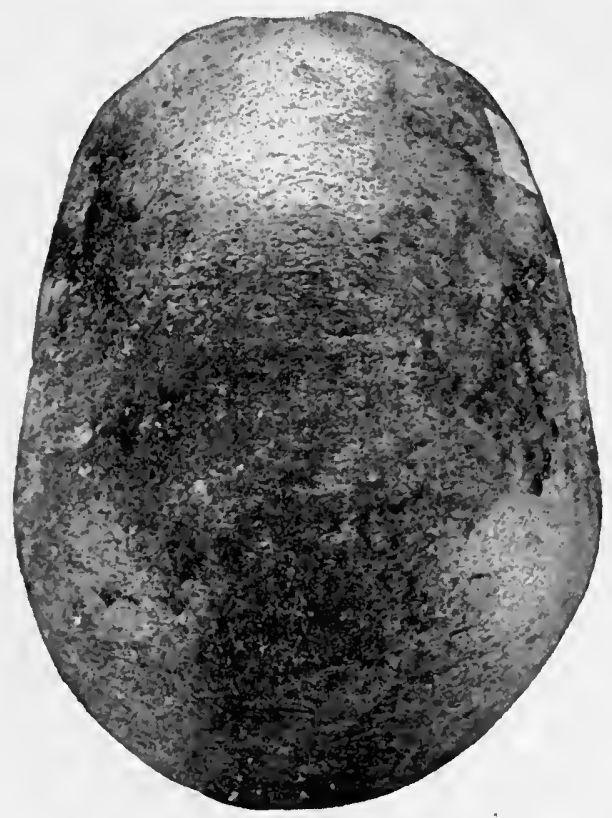

Fig. 262.-Vertex view of skull $B$.

of Get, and Oban, are dolichocephalic, and doubtless of the same race as the builders of the English long barrows.

"Seventeen skulls from interments belonging to the Bronze period have been examined by the author. The mean lengthbreadth index of twelve was 8 r.4, and the highest index was 88.6. In each skull the height was less than the breadth. In the other five specimens the mean index was 74 ; the 
majority, therefore, were brachycephalic. In only one specimen was the jaw prognathic: the nose was almost always long and narrow; the upper border of the orbit was, as a rule, thickened, and the height of the orbit was materially less than the width. The capacity of the cranium in three men ranged from I 380 to I 555 c.c., the mean being 1462 c.c. In stature the Bronze men were somewhat taller than Neolithic men. The thigh-bones of the Bronze-Age skeletons gave a mean platymeric index 75.1, materially below the average of 81.8 obtained by Dr Hepburn from measurements of the femora of modern Scots. The tibiæ of the same skeletons gave a mean platycnemic index 68.3-intermediate, therefore, between their Neolithic predecessors and the present inhabitants of Britain. Many of the tibiæ also possessed a retroverted direction of the head of the bone; but the plane of the condylar articular surfaces was not thereby affected, so that the backward direction of the head exercised no adverse influence on the assumption of the erect attitude."

An opinion to the effect that two similar races existed in Ireland, apparently simultaneously, was promulgated by Sir W. Wilde in 1844 , and republished in 1851.1 Though not then based on definite anatomical data, this opinion has since been more or less confirmed by various writers, among them being the authors of 'Crania Britannica' and Professor Huxley. The latter, after placing on record the specific points of some Irish skulls which he saw in the Museum of the Royal Irish Academy and in the collection of Trinity College, Dublin, thus sums up his remarks : "Sir IV. Wilde speaks of long-headed, dark, Irish (Firbolgs) west of the Shannon, and of a more globular-headed, light-haired stock north-east of that river. But I imagine that by 'globularheaded' Sir W. Wilde means only that the people in question

${ }^{1}$ Beauties of the Boyne, second edition. 
have broader heads than the others-not that there was any really brachycephalic stock in Ireland. At any rate, Sir William claims the Uley Barrow skull as that of a 'fellowcountryman,' and the cephalic index of this skull is only $7 \mathbf{I}$. And, according to Dr J. B. Davis, the mean cephalic index of fourteen male skulls from the old Abbeys of Mayo, Galway, Avonmore, and Kerry, is 75 ; that of thirty-two living men in Kerry being 77.6." 1

"As the evidence stands at present, I am fully disposed to identify the ancient population of Ireland with the 'longbarrow' and 'river-bed' elements of the population of England, and with the long-headed, or 'kumbecephalic' inhabitants of Scotland; and to believe that the 'roundbarrow,' or Belgic, element of the Britannic people never colonised Ireland in sufficient numbers to make its presence ethnically felt." 2

Subsequent writers, though in perfect accordance on the main problem, have slightly diverged in their nomenclature. Professor Rolleston thus defines his position: "It will be convenient to begin by saying that I should speak of the crania of the long-barrow period, not as belonging to the 'Iberian,' as it is becoming the fashion to style them, but as belonging to the 'Silurian' type; and the brachycephalic crania of the round barrow I should similarly speak of, not as belonging to a 'Ligurian' but to the "Cimbric' type." 3 On the other hand, Professor Boyd-Dawkins adopts the term 'Iberian' as applicable to the dolichocephalic skulls of the Neolithic tombs of Britain, and regards their owners as a branch of the ancient Iberians, of which the existing Basques are a remnant. ${ }^{*}$

${ }^{1}$ Crania Brit., Decade vi.

2 Prehistoric Remains in Caithness, p. 127.

${ }^{3}$ British Barrows, p. 630 . Early Man in Britain, p. 315. 
Many anthropologists have directed attention to the survival of these two primary types of crania among the inhabitants of the British Isles, although mongrels, hybrids, and intermediate skull-forms have largely increased owing to intermarriages, a better supply of food, and other modifying influences. Dr Beddoe has shown ${ }^{1}$ that there is still a blackhaired race in the west of England which, in their physical characteristics, corresponds with the description given by Tacitus of the Silures, and that they are shorter in stature and feebler in development than the fair races, while their skull-forms remain dolichocephalic.

Turning now to the prehistoric remains of Western Europe, we find the same duality of long and short skull-forms recorded by the most competent anthropologists. The celebrated Swedish anatomist Professor Retzius, finding that modern Scandinavians were a long-headed people, and that one or two skulls, found in graves of the Stone Age, were brachycephalic, propounded the theory that the original inhabitants of Scandinavia (autochthones) were a brachycephalic race, and that the dolichocephalic element was introduced into these lands by the Indo-Europeans or Aryans. This was the view to which Sir Daniel Wilson objected, as already mentioned, when advocated by Professor Nilsson. A vigorous effort was made at the time to apply this theory to the whole of Western Europe, but soon objections to it appeared from all quarters. At last, in $\mathbf{1 8 6 5}$, Professor von Düben announced a discovery in Sweden which gave the final coup de grâce to Retzius's views, and brought the Scandinavian peninsula into line with the rest of Western Europe. This discovery was due to the investigation of a dolmen at Lutra, near Falköping, which contained 145 interments associated with grave-goods unmistakably of the

1 Mem. Anth. Soc., vol. ii. p. 350. 
Stone Age. Among the osseous remains in this dolmen there were thirteen entire skulls, and seven sufficiently perfect to furnish data for ascertaining the cephalic index. Of these twenty crania all but one were dolichocephalic, with an average cephalic index of $74.14 \cdot{ }^{1}$ Subsequently Von Düben announced at the International Congress of Archæology in I 874 that out of a hundred crania, found in graves of the Stone Age in Denmark and Sweden, examined by him, there were only twelve brachycephalic (five being from Denmark) showing a cephalic index of 84.2. In their anatomical characters they greatly resembled the present skull-forms of the Laplanders, but he hesitated to identify the prehistoric race with that people.

According to Professor Huxley, ${ }^{2}$ the ancient inhabitants of Switzerland, North Germany, and Scandinavia were almost wholly dolichocephalic, but the south-west Germans were less so. At the present time, 75 per cent of the modern Swiss and 85 per cent of the south-west Germans are brachycephalic, while among the Scandinavians few of the latter tyfe are now to be met with. Hence it would appear that since the dawn of modern European civilisation, dolichocephaly has increased and brachycephaly has diminished with the latitude.

The earliest inhabitants of the Iberian peninsula were also dolichocephalic. The crania discovered in the prehistoric caves at Gibraltar, without reckoning one of the Canstatt type, supposed to be palæolithic, have been shown by $\mathrm{Mr}$ Busk to be not only of this character, but identical with those of the Basques, and similar to a series of crania taken from various caverns and dolmens in Andalusia. ${ }^{3}$ Opinions

1 Congrès Internat., Paris, 1867, p. 380.

2 Loc. cit., p. 112.

3 International Congress, Norwich, p. 164. 
tending in the same direction had already been expressed by other British anthropologists, as may be seen from the following remarks by Professor Huxley : ${ }^{1}$ -

"But, if it be true, as I believe it is, that close craniological affinities unite the Hiberno-British long-heads on the one hand with the Scandinavians, is it not equally true that as close affinities connect the dolichocephali of our islands with a southern type? On this point I must again quote $\mathrm{Dr}$ Thurnam: 'During the last summer $I$ had the advantage of examining the series of sixty Basque skulls, lately added to the collection of the Anthropological Society of Paris. I was at once struck with their great resemblance to the dolichocephalic skulls from the long barrows of this country, and this impression was much confirmed by the perusal of the two memoirs on these skulls by M. P. Broca, so rich in details necessary for the comparison before us.'

"And Dr Thurnam is evidently inclined to carry on this line of affinity to the ancient Iberians and Phœnicians. I am by no means disposed to stop even here. The same form of skull appears in the 'type grossier' of the ancient Egyptian : I suspect it will be found in the inhabitants of Southern Hindustan; and it is finally traceable to Australia, the natives of which country, as I have already pointed out, in the largely developed probole, the wall-sidedness, pentagonal norma occipitalis, prognathism, and strong brow-ridges, and even in the remarkable vertical depression exhibited by some extreme forms of their skulls, come nearest to the ancient long skulls of Europe."

The Kjökkenmöddings near the villages of Salvaterra and Mugem, in the valley of the Tagus, Portugal, were described by MM. C. Ribeiro and F. de Paula e Oliveira at the Lisbon meeting of the International Congress of Anthropology and 
Prehistoric Archæology in 1880 . It had been ascertained, in the course of some extensive excavations, that the people who amassed these shell-heaps lived in the earliest Neolithic period; but the most interesting feature of the investigations was the discovery of upwards of a hundred interments at various depths in the débris. It does not appear that any grave-goods had been associated with them, and the relics collected were of a very rude and primitive character. The osseous remains were much decayed, and the skulls distorted, probably by the pressure of the débris; enough, however, remained to show that they represented two races - one dolichocephalic and the other brachycephalic. Some of the crania were at once recognised by $M$. de Quatrefages, and other anthropologists present at the Congress, as belonging to the types of Cromagnon and Furfooz. Of the latter, only two specimens were in the series, all the others being dolichocephalic. One of the former showed a very high cephalic index (86.90), and the latter varied from 7 I.I I to $75.5^{6}$. From the slender character of the bones in general, these primitive fishermen of Mugem were judged to have been of small stature.

On examining a series of skulls found in sepulchral caverns, dolmens, and other burial-places of the Neolithic Age, the same duality of type was observed as in those from the kitchen-middens of Mugem, in all of which dolichocephaly still retained its predominance. Characteristic specimens of both long and short skulls were also recognised in a collection from the dolmen of Licêa, the caverns of Casa da Moura, Monte Junto, and Carvalhal. Only one series of skulls-viz., those from the caverns of Cascaes-were exclusively dolichocephalic, with an average cephalic index of 74 .

It is, however, in France and Belgium that craniological deductions bearing on the Neolithic races of Western Europe 
have attained their highest significance; and hence it becomes necessary to review the anthropological materials within this area more in detail than those already commented upon.

In 1868 the skeletons of three men, a woman, and a child were discovered in the rock-shelter of Cromagnon, in the valley of the Vézère, Dordogne. These skulls were all dolichocephalic, but one of them, known as that of the "old man of Cromagnon," was remarkable for its size and fine proportions, having, according to Broca, a capacity of 1590 c.c. (96.99 inches), and a cephalic index of 73.6. This rockshelter had for a long time been a rendezvous for reindeerhunters, who left evidence of their visits in a mass of accumulated débris. It seems, however, that these human remains were not embedded in this débris, but lay on the surface in a recess under the overhanging rock, and that, at the time of their deposition, this recess had been concealed by heaping up a portion of the palæolithic rubbish which had previously accumulated on the site. It would thus appear to have been an interment which, possibly, had been made long after the reindeer-hunters ceased their visits to the locality. Hence there is a diversity of opinion as to the chronological horizon of the Cromagnon skull, some regarding it as Palæolithic and others as Neolithic. Similar mistakes have often occurred, more especially in the earlier stages of anthropological research. One well-known instance is the Grotte d'Aurignac, which, though long accepted as a sepulchral cavern of the Palæolithic period, is now regarded as Neolithic. Skulls of the Cromagnon type found on the great station of Solutré have also been described by MM. Ferry and Arcelin, ${ }^{1}$ and the authors of 'Crania Ethnica,' as relics of the Quaternary period, but now the larger portion of

1 International Congress, \&c., Norwich, p. 319. 
them are shown to be Neolithic. ${ }^{1}$ Among eighteen crania from this station the cephalic index ranges from 68.3 to 88.3 , and of these, thirteen are below 80 and five above it. I cannot help thinking, therefore, that Solutré, like Mas-d'Azil, the Grotte de Reilhac, the hut habitations at Campigny, the rockshelter of Schweizersbild, as well as many others, belongs to a transition period which connected the Palæolithic and Neolithic civilisations; so that we can hardly doubt that there has been a direct continuance of human life in Europe from the first appearance of Palæolithic man up to the present day.

One of the most useful of recent contributions to prehistoric craniology is a statistical list drawn up by M. Philippe Salmon $^{2}$ of the Neolithic crania of Gaul, recorded up to 1895 , giving the localities and circumstances in which they were found, the names of the anthropologists who measured and described them, and the sources of their publication. The cephalic indices are arranged under three columns according as they are dolichocephalic ( 76 or under), mesaticephalic ( 76 to 80 ), or brachycephalic (80 and upwards). The number of stations thus tabulated is 140 , consisting of sepulchral caverns (4I), dolmens, tumuli, \&c., together with a few sporadic finds in the soil. The total number of skulls measured is 688, being 397 long, I 45 medium, and 146 short, or $57.7,21.1$, and 21.2 per cent for the three different grades into which they were classified. In looking carefully into the various details of these crania some striking results are brought out, the importance of which can hardly be overrated. Thus there are some large stations, especially among the sepulchral caverns, which contained only dolichocephalic crania, while others seemed to have been restricted to brachycephalic types. A large majority of them, however, included

1 Revue Mensuelle, I894, p. 113.

2 Ibid., I895, p. 155. 
long, intermediate, and short types of skulls in various proportions. The two most remarkable stations which contained only long skulls are the caverns of l'Homme Mort and Baumes-Chaudes, both situated in the department of Lozère. The details of their exploration and osseous contents have been recorded by Drs Broca and Prunières.

In the cavern of l'Homme Mort there were nineteen skulls sufficiently well preserved to furnish the necessary measurements. Of these the cephalic indices of seventeen varied from 68.2 up to 76.7 , and the other two were 78.5 and 78.8. There were, therefore, no brachycephalic skulls at all in this sepulchre, so that the race appeared to have been comparatively pure. It may also be mentioned that some of the crania had been trepanned-a feature which, though at first overlooked, subsequently became the subject of much interest to anthropologists. The animal remains were those of the Neolithic epoch, but among them were none of the reindeer, horse, ox, or stag. Among the relics were a lancehead and a portion of a polished stone axe. Drs Broca and Prunières were of opinion that the individuals whose remains had been consigned to this ossuary belonged to an intermediate race, who flourished in the transition period between the Palæolithic and Neolithic civilisations, and thus became connecting links between the people of the reindeer caves and the dolmens.

The crania recorded from the station known as BaumesChaudes were found in two natural caverns distinct from each other, but opening on a common terrace. They contained a vast collection of human bones, representing some 300 individuals; but both were regarded by the investigators as the continuation of the same family burying-place, which, indeed, had not been altogether abandoned till the beginning of the Bronze Age, as one of the skeletons in the upper 
deposits had beside it a bronze dagger. In one of these caverns only chipped flints, rude implements of horn, \&c., were discovered; but in the other there were a few arrowpoints, a bead, some roundlets of deer-horn, \&c., which suggested some progress in culture. The crania measured and classified in M. Salmon's list from the Baumes-Chaudes ossuary amount to thirty-five, and all of them are dolichocephalic, the indices varying from 64.3 to 76 .1. The average height of this race was calculated to be $1.6 \mathrm{I}^{\mathrm{m} . \text {. }}$ or about 5 feet $3 \frac{\mathrm{T}}{2}$ inches. As examples of further sepulchres of this unmixed race the following may be mentioned : the cavern of Avigny (Seine-et-Marne), the Baoussé-Roussé caves at Mentone, the cavern of Cravanche (Haut-Rhin), the dolmen of "la Justice" (Seine-et-Oise), \&c.

On the other hand, in the cavern of Tertre-Guerin (Seineet-Marne) only two skulls were found, and they were of a highly brachycephalic type, with cephalic indices of 86.6 and 91. In striking contrast to the preceding caves, the archrological remains in this sepulchre comprised polished stone celts, with and without horn-casings, together with various other relics indicating an advanced Neolithic civilisation. The people here represented would appear, from the characters of the bones, to have been strong and muscular. Only a few of the leg-bones were platycnemic, the olecranon fossa of the humerus was pierced in the proportion of $\mathbf{2 4}$ per cent, and the face was prognathous. They also practised trepanning, as a portion of an aged man's skull contained a round, highly bevelled aperture which bore evidence of having been made while the individual was in life.

As examples of sepulchral caverns in which brachycephalic crania formed the majority, a series of caverns at Hastière in Belgium may be mentioned. Of thirty-three skulls from this locality measured by Professor Houzé, six were dolicho- 
cephalic ( $7 \times 6$ to 76.9$)$, eleven mesaticephalic, and sixteen brachycephalic (80 to 88.4 ).

Artificial caves used for sepulchral purposes have also been discovered in several departments of France-more especially those with chalky formations, as the Marne district. Here, upwards of a dozen stations, each containing a number of artificial caves excavated in the flanks of low hillocks, have been most successfully explored by Baron de Baye. Among some hundreds of interments, over I 20 crania, including various trepanned specimens and cranial amulets, have been collected, and are now preserved in the Château de Baye. Associated with them were a number of implements, weapons, and ornaments of Neolithic types-such as stone axes and their handles, arrow-points (some chisel-shaped), flint knives, bone pointers, polishers, beads and pendants of amber, bone, stone (one of callaïs, like those in the tumuli of Brittany), fossil shells, teeth, \&c. Of the crania, forty-four were submitted to Dr Broca for examination, and are thus classified: dolichocephalic (71.6 to 76.7) fifteen, mesaticephalic seventeen, and brachycephalic (80 to 85.7) twelve. Dr Broca recognised in these human remains the products of the union of two races analogous to those of Furfooz and Cromagnon - the latter having already been identified by him as of the same type as the dolichocephalic people of l'Homme Mort and Baumes-Chaudes.

I may observe that the interesting caves of Petit-Morin ${ }^{1}$ are supposed to have been constructed in imitation of the dolmens, as they were preceded by an entrance passage and occasionally a vestibule, from which a low door, closed with a stone slab, led to the sepulchral chamber. Baron de Baye thinks that some of them had been used as habitations for the living, before being appropriated to the dead,

${ }^{1}$ L'Archéologie préhistolique, par le Baron de Baye, 1888. 
as they had sometimes niches and shelves cut out of the solid chalk walls, on which various industrial relics had been deposited. A rudely executed human figure with a birdlike nose, two eyes, a necklet and breasts, together with the form of a stone axe in its handle, were sculptured in relief on the wall of the vestibule of one of the larger caves. This cave appeared to have been much frequented, as the threshold was greatly trodden down by the feet of visitors. M. Cartailhac explains this peculiarity by supposing that it was a place for temporarily depositing the dead before being transferred to their final resting-place. All these caves contained abundance of relics characteristic of an advanced Neolithic civilisation without any trace of metals, and the surrounding neighbourhood is rich in flint objects of that period.

From a careful study of the geographical distribution of the 140 Neolithic stations annotated by M. Salmon some interesting deductions have been drawn, among which the following may be noted : ${ }^{1}$ -

r. The departments to the south-west of a line drawn from Normandy to the sources of the Garonne are those least affected by the brachycephali; and it is remarkable that the area thus circumscribed virtually coincides with that of the dolmens and megalithic monuments of France.

2. To the north-east of this line the brachycephali and mesaticephali are in greatest abundance at two points, thus indicating that they entered the country by two routes-viz., one via Belgium, and the other via Savoy, the Alps, and the Danube.

3. The steady increase in the numbers of mesaticephalic crania found in the later Neolithic stations up to the Bronze Age, when, of course, the innovation of cremation puts a stop

1 See articles by M. Georges Hervé, Revue Mensuelle, I894, pp. 105, 393. 
to all such craniological researches, is accounted for on the hypothesis that a brachycephalic race, or races, hailing from Eastern regions, socially amalgamated with the indigenous population of Western Europe.

Dr Verneau, who has spent some years investigating the anthropology of the Canary Islands, has traced the Cromagnon race through Spain, Algiers, and Morocco to the Guanches of these Atlantic islands. $\mathrm{He}$ finds that this people retained their racial purity, amidst a Stone-Age civilisation, up to the fourteenth century, when, in the course of their struggle for freedom against the Spanish and Portuguese, they became extinct as a separate race. Sir William Dawson, in a paper on "The Physical Characteristics and Affinities of the Guanches," associates the Guanches with the Neolithic people of Western Europe, "the men of the Polished Stone and early Bronze Ages, of the long barrows and cromlechs, and of the Swiss lake habitations, as well as with the Iberian races of France and Spain and the Berbers of North Africa. The crania of those races, as tabulated by Quatrefages, are those which most nearly approach to our specimens from the Canaries, and their arts and habits and state of civilisation in early times are also those which afford the best terms of comparison." Of ten skulls of this race from the island of Teneriffe, in the Redpath Museum, Montreal, the average cephalic index was 76.4 , and that of one specimen from the Canaries 75.8-figures which show a considerable amount of intercrossing since the Reindeer period in France.

At the dawn of the Neolithic period there were thus two well-defined races - dolichocephali and brachycephaliinhabiting Western Europe, not, however, isolated, but mixed in different proportions in different localities. The former were well built, but somewhat short in stature compared with nodern Europeans generally. They occupied the western 
shores of the Mediterranean, from which they radiated to the Canaries, the British Isles, Sweden, North Germany, and Central Europe. Eastwards, on the south of the Mediterranean, they embraced the ancient Lybians and probably the Neolithic Egyptians (the New Race of Dr Flinders Petrie). According to Professor Sergi, ${ }^{1}$ these dolichocephali occupied Italy prior to the incoming of the Celts and Etruscans. Also Professor Bogdanow, in a paper contributed to the International Congress of Archæology held at Moscow in 1892, maintains that the most ancient race in Central Russia was dolichocephalic. The results of a series of careful measurements of crania collected from the Kourganes (tumuli) showed that long, short, and intermediate were in the proportions of 47,14 , and 39 per cent.

These dolichocephali in France varied considerably in size. The mean height of the men of the cavern of l'Homme Mort was 5 feet $3 \frac{1}{2}$ inches, that of the old man of Cromagnon 5 feet I I $1 / 2$ inches, and that of one of the skeletons from the Baoussé-Roussé caverns at Mentone a little over 6 feet. Of course these measurements are only approximations, and other anthropologists give them at a little less. ${ }^{2}$ They had the following general characters : the skull dolichocephalic ; large, well-developed forehead, and somewhat prominent eyebrows; the limb-bones indicated great strength, being thick and solid, with strongly marked muscular impressions; the tibia was generally platycnemic, the fibula grooved, and the femur showed a prominent linea aspera.

The brachycephali were also short, some of the typical specimens of the "race of Furfooz" being little over 5 feet. The skull was broad and the face long, with well-marked prognathism. The flattening of the tibia (platycnemism) was

1 Monist, vol. viii. p. 161.

2 Formation de la Nation Française, p. 319. 
less pronounced than in the long-headed race, but the olecranon fossa was frequently pierced. Towards the end of the Neolithic period these anatomical characters (which are regarded as indicating a low type) became less frequent. Thus out of twenty tibix, or shin-bones, from the artificial caverns of Petit-Morin only four were platycnemic, of sixteen fibula only six retained the special groove, and of twenty femora only five had a well-marked linea aspera.

How many different races occupied European lands at the commencement of the Neolithic period it is difficult to determine. According to Professor Kollmann there were at least four types to start with, a number which he arrives at by dividing the dolichocephali and brachycephali each into two varieties of long-faced and short-faced ${ }^{1}$ - types which he recognises among the population of Europe at the present time. In order therefore to follow with some degree of intelligence the development of civilisation which followed the amalgamation of these primary Neolithic races, we have to consider various collateral sources of information.

The contact of these different races was, in the first place, by land routes, and the first important result was to spread a knowledge of agriculture and of a few domestic animals among the autochthones of Western Europe, who, owing to a change of climate, had now lost the reindeer and other big game on which their livelihood depended.

\section{General Anthropological Data.}

But craniology, though a most suggestive and valuable guide in racial investigation, is not alone sufficient to determine the ethnical problems which now crowd the Neolithic horizon. Skeletons do not reveal to us anything of the 
colour of the skin, hair, or eyes of the individuals who owned them; nor of the language they spoke, nor of the religious ceremonies they enacted, nor of the implements, weapons, ornaments, and clothing, by means of which they fulfilled their destinies in the organic world. Yet, on all these problems, important information has been gathered. Through successive generations these Neolithic races have transmitted their physical characteristics to the inhabitants of the present day, probably with little change as regards the colour of the hair and eyes. But the puzzling fact is that we find fair and dark dolichocephali, as well as fair and dark brachycephali. If, as has sometimes been assumed, the Troglodytes of the Reindeer period of France are correctly represented by the Esquimaux of the present day, who are small and dark, it may be fairly inferred that the former were also small and dark; but among the early dolichocephali of Central Europe there have been found skeletons of men over six feet in height. Had we positive evidence that these exceptionally tall men were fair-haired, many of the anthropological difficulties now surrounding the prehistoric ethnology of Europe would be entirely removed, as the more modern Gauls, with their great stature and blond appearance, could be thus readily accounted for.

Of the marvellous results of linguistic research, which carries us back through the flotsam and jetsam of a common Aryan language to a remote past, I cannot here give even a meagre sketch. Since the days when the common belief was that the dispersion of mankind was due to the confusion of language at the tower of Babel many theories as to the origin of the Aryans, their primitive home, religion, and civilisation, have been propounded and abandoned. Professor Max Müller, discrediting the Mount Ararat hypothesis of Blumenbach and Cuvier, has traced this mythical people to 
"the sources of the Oxus and Jaxartes, the highest elevation of Central Asia." Subsequently, after some lively controversies, based on the phonetic laws of speech and the detection of loan words, Professor Penka and other philologists have transferred the origin of the Aryan languages into Europe, fixing on the Scandinavian peninsula as the exact locality of their primary development. Canon Isaac Taylor maintains, both on anthropological and linguistic grounds, that the Aryans were "an improved race of Finns," and so he places their primitive home somewhere in Lithuania. Their social condition he thus describes: "It appears, therefore, that prior to the separation of the Aryan and Finnic races they were acquainted with copper and probably with gold, but their tools were chiefly of horn or stone. They sheltered themselves in huts, and were clad in skins, but there is no evidence that they possessed the art of weaving. They knew how to kindle fire; they could count up to ten, possibly up to a hundred. They had personal names, while family relationship and marriage were fully recognised. They were acquainted with the sea, and may have been able to cross lakes or rivers in canoes made of hollow trees. They caught salmon and used salt, and gathered bitter herbs for food, or more probably for condiment. It does not appear certain that they grew grain or were acquainted with the rudiments of agriculture, the name of the Finnic plough, kar, the crooked branch of a tree, being only doubtfully connected with the Aryan plough. They collected honey, from which they produced an intoxicating drink, and made a sort of soft cheese, like curds. They possessed herds of domesticated animals, which were tended by herdsmen, and were kept in fenced enclosures. These animals were probably goats, swine, reindeer, and geese, and possibly oxen; but the dog, the sheep, and the horse 
seem to have been as yet untamed." 1 As the starting-point of Neolithic civilisation this is surely primitive enough, but yet it is quite in accordance with archæological evidence.

That philologists have established some kind of radical connection between the Indo-European languages, mythology, and religion is undoubted; but how this bond of brotherhood has been acquired, whether by migratory races, or successive waves of civilisation emanating from one or more common centres, seems to me to be still sub judice. However this may be, the social and intellectual influences which were introduced or developed in Central Europe ultimately led to extensive migrations towards the less inhabited portions of Europe, and these carried with them the rudiments of progressive civilisations. Besides the primary land routes, the discovery of the means of intercourse by distant sea voyages soon disseminated the germs of the earlier civilisations of the eastern seaboard lands of the Mediterranean to various points on the European coast. Even then, and for many centuries later, the British Isles and the entire Atlantic coast of Europe were terre incognita, yet we are certain that the Celtic language, which was then spreading over these regions, emanated from the same fountain-head as Greek and Latin.

But, among the collateral materials bearing on the lifehistory of prehistoric man, those which directly or indirectly spring from his religious beliefs are the most important. A vague fear of the potency of the unseen powers of nature led to the belief in spirits and in a future life, in which the disembodied spirit after death continued its existence. These ideas naturally engendered great reverence for the dead, and the earliest evidence of religiosity shows itself in the inhumation of the dead body, accompanied by such objects as were

2 Journ. Anth. Institute, vol. xvii. p. 269. 
supposed to be useful on the journey to the unseen world. The evolutionary stages from simple inhumation to incineration involved, however, a considerable interval of time, during which there is evidence to show that funereal rites of various kinds were performed in Western Europe which disclose a progressiveness in religious ideas. The culmination of these rites was the process of cremating the body, so as to liberate the spirit more quickly from its earthly abode. The practice of depositing the dead body in a mortuary till the flesh was decomposed, and then burying the bones, seems to have been by no means uncommon in France. This is evident from the disconnected manner in which the bones were placed in their final resting-place, but yet they were often systematically arranged in layers one above the other, and separated by beds of ashes or flat stones. For these and other curious customs in the cult of the dead, as well as for various methods of hastening the natural process of removing the flesh from the bones, I refer my readers to $M$. Cartailhac's excellent work, 'La France Préhistorique.' That cremation was at first merely used as an adjunct in the later stages of natural decomposition is highly probable ; and hence it may be argued that it had its development on French territory. It is, however, generally regarded by archæologists as the product of a religious custom which emanated from Eastern lands. But where it originated is involved in as much mystery as the Aryan question itself. During the Stone Age inhumation appears to have been practised all over Europe, with the exception of a few localities, mainly in France, which show traces of cremation. In Petit-Morin several of the sepulchral chambers contained bodies that had been cremated, and among the pottery there were two vases with calcined human bones. More singular still, there were a few human skulls stuffed with the bones of apparently young 
children. $^{1}$ Besides the sculptured goddesses, trepanned skulls, and cranial amulets, it appears that the stone axe was an object of worship in these caves. During the Bronze Age cremation was more common than inhumation in the east of Europe, and this ascendancy was kept up in the early Iron Age ; but in the West, inhumation, with a few local exceptions, was always the predominant custom. In the early Roman period cremation was the rule, both at Rome and in the Roman provinces, but later inhumation was restored. The introduction of Christianity into Western Europe caused cremation to disappear, but it lingered among the Saxons, Slavs, North Germans, and Scandinavians till the early Middle Ages. (For prehistoric trepanning see 'Preh. Problems,' c. v.)

In Scandinavia, according to Montelius, ${ }^{2}$ Worsaae, and others, cremation came into use only in the second Bronze Age. M. Worsaae thus refers to the introduction of the custom: "The mere influence of culture from the south or the east, without any accompanying influx of population, would hardly have induced the warlike occupants of the North to change their funeral customs in every respect, and to such an extent. Naturally the old-fashioned interment of the unburnt body must have continued simultaneously with the more modern cremation. But that the latter custom at last generally prevailed is evident from the fact that in the grave-mounds smaller graves with burnt bodies are commonly deposited in the upper part of the mound, while the larger graves with unburnt bodies are found below. Independent graves with burnt bodies are, moreover, found throughout the North in great numbers. Comparatively speaking, the graves from the later Bronze Age are far more numerous in the Baltic lands and in Denmark than in the rest of Europe." 3

1 Archéologie préhistorique, p. 120.

2 La Suède préhistorique, p. 41.

${ }^{3}$ Danish Arts, p. 79. 
According to Professor Boyd-Dawkins, cremation was introduced into Britain simultaneously with a knowledge of bronze. "The invasion of Britain by the bronze-using Celtic tribes," he writes, "is marked by a striking change in the customs of burial, which probably is the sign of the introduction of a new faith. In the Neolithic age the dead were interred surrounded by the implements, weapons, and ornaments for use in the future life. In the Bronze age the dead were burned, - were purified by being passed through the fire, along with their possessions. Cremation, however, did not altogether abolish the older practice of inhumation. It is evident that both were carried on simultaneously, from the researches of Thurnam in the south of England, Bateman in Derbyshire, and Greenwell in the northern counties. The one may have been connected, as Dr Fred. Wiberg suggests, with the worship of fire, and the other may have been employed by the descendants of the Neolithic Britons from the force of habit, and from its cheapness by the poorer classes." 1

The following remarks by Canon Greenwell on the relative frequency with which these different modes of interment were practised by the Yorkshire barrow-builders are the most authoritative records we have on the subject: "As marking the relative general proportion of burnt to unburnt bodies in the barrows I have opened on the wolds, it may suffice to mention that out of 379 burials, only 78 were after cremation, whilst $30 \mathrm{I}$ were by inhumation, which gives nearly $2 \mathrm{I}$ per cent for burials of burnt bodies. And to show that in the wold-barrows bronze is by no means more commonly found with burnt bodies than with unburnt, out of fourteen instances where I have discovered bronze articles associated with an interment, it was only in two that the body had been burnt. The proportion, therefore, is that about 4 per cent 
of unburnt bodies, and about $2 \mathrm{x} / 2$ per cent of burnt bodies, had articles of bronze accompanying them. This question partly resolves itself into another, whether, in the main, the round barrows of the wolds belong to a time before the introduction of bronze. As the subject will be considered more at length in the sequel, it is sufficient to remark here that I see nothing to imply that they are the burial-places of a people unacquainted with bronze, and my own impression is that, as a rule, they date from a time after its introduction." 1

But, according to the same authority, these burial customs varied in different localities. For example, the extensive investigations of $\mathrm{Mr}$ Atkinson in Cleveland, and a series of barrows near Castle Howard, yielded nothing but burnt bodies. "In Derbyshire the proportion is slightly in favour of unburnt bodies; in Wiltshire burnt bodies are as three to one unburnt; in Dorsetshire as four to one; and in Cornwall cremation appears to have been by far the most common usage. In the counties of Denbigh, Merioneth, and Caernarvon, cremation seems to have been almost universal. In Northumberland I have disinterred $7 \mathrm{I}$ bodies, and of these 45 were after cremation and 26 by inhumation." 2

As regards Bronze Age burials in Scotland, Sir W. Turner, in his lecture at the Royal Institution, writes as follows : "From an analysis of $\mathrm{r} 44$ localities in Scotland of burials which may be associated with the Bronze Age, and which included about 400 distinct interments, it would appear that in $5 \mathrm{I}$ of these localities the bodies had all been cremated; in 60 they had been buried in stone cists; in 15 the same mound or cemetery furnished examples of both kinds of sepulchre; and in the rest the kind of interment was not precisely recorded."

That cremation was a foreign importation into the British

${ }^{1}$ British Barrows, p. 19.

2 Ibid., p. 21. 
Isles cannot be gainsaid. When once introduced it seems to have spread among their entire habitable portions with wonderful celerity-a fact which suggests its religious character. If the date of this remarkable movement could be definitely ascertained, it would present the nearest approach to a chronological datum line that can be found among the different elements which the successive waves of Continental civilisation have washed to our shores. Its progress from Central Europe westwards was so rapid that it overtook, and passed by the way, many of the slower influences which were travelling in the same direction. Thus when the people of the round barrows of Yorkshire lived, both cremation and the bronze industry had already extended to that part of Britain, for, as we have just seen, Canon Greenwell regarded the round barrows, whether they included burials after inhumation or cremation, or with or without bronze objects, as of the same age. Indeed, so far as available evidence has been adduced, it would appear that the only sepulchral remains, proved to have been older than the custom of cremation, are the chambered cairns in the south-west of England. When, however, the analogous cairns of Argyllshire, Caithness, and the Orkney Islands were constructed, the religious wave had already enveloped North Britain. Hence, though generally destitute of bronze relics, these structures were really contemporary with the Bronze Age burials elsewhere in Britain. The same thing has occurred in several localities in France. Thus M. du Châtellier has shown that, out of 145 tombs of the Stone Age in Brittany, 20 contained inhumed and 72 cremated bodies, while 31 were associated with charcoal, and $\mathbf{2 2}$ were of an indefinite character. Finistère alone yielded 58 burnt out of 69 interments. ${ }^{1}$ The explanation of these and other similar instances

1 La France préhistorique, p. 272. 
is that in out-of-the-way localities, such as the western shores of Brittany and the Highlands of Scotland, the Stone-Age civilisation lingered longer than in those situated on the main routes of commercial intercourse. It was about the middle of the Bronze Age (some five or six centuries B.c.) that cremation was adopted in Sweden, but as the route by which bronze entered that part of Europe was by the Danube, and therefore different from that by which it reached Britain, there can be no chronological comparison between these events in the two countries.

\section{General Conclusions.}

Such is a brief statement, for it is too meagre to be called a review, of the different aspects and channels through which the early ethnology of the British Isles has to be investigated. The latest researches in anthropology, archæology, religiosity, and linguistic science are requisitioned to throw their flash-light on the ways and means by which our prehistoric forefathers foregathered in various contingents of different degrees of civilisation on our primeval shores. But notwithstanding the abundance of materials which has accumulated around these diversified standpoints, and the conspicuous talent of many of the investigators who have entered on this fascinating field of research, the conclusions hitherto formulated on the subject are still far from being satisfactory. When, however, we find distinct currents, though only discernible through mere waifs and strays, all tending in the same direction, we are encouraged to feel some degree of confidence that in following them we are not led by an ignis fatuus.

It may therefore serve some useful purpose to state more precisely and categorically how the general results at which we have arrived in regard to Western Europe become appli- 
cable to the prehistoric inhabitants of the British Isles, so far as they are known to us at the time of the Roman occupation.

In early Neolithic times the southern parts of Britain and Ireland were peopled by immigrants from the adjacent Continent, commencing probably when there was a direct land communication between the latter and Britain. The physical characteristics of these invaders were - short stature, strong muscular frames, dark hair and eyes, and dolichocephalic heads. They were a religious people, as even then they buried their dead, the chiefs and persons of social distinction being consigned to great chambered cairns and dolmens, which formed family burying-places for several generations. The subsequent incomers would carry with them further elements of progressive civilisation, as well as whatever changes in their personal physique became developed through the crossing of the different races.

The next great landmark in the peopling of these islands of which we have evidence was the appearance of a brachycephalic and somewhat taller race, who brought with them a knowledge of bronze. This metal was, however, only sparingly used, the objects known in the earliest period being confined to small hand-daggers, pins, and a few trinkets. Almost coincident with this great event in the progress of British civilisation came the remarkable religious movement which manifested itself in the sepulchral rite of cremation. There can be no doubt that these innovations were due to the stream of immigrants to our shores, but from what particular localities we are unable to say. They appear to have been cross-breeds which had sprung up somewhere in Central Europe, and formed the van of the so-called Aryans, generally known to us under the name of Celts. The physical characteristics, especially the complexion, of these early 
Celts have been long a matter of controversy-some regarding them as dark and others as fair. So far as I can judge they belonged to the fair stock, and had more or less red or yellow hair. Having conquered the previous inhabitants, they amalgamated with them and ultimately spread over Ireland and Scotland, where their characteristic sepulchral remains are largely to be found. Meantime, the chambered cairns had been gradually discontinued, and inhumation in short cists or urn burials, with or without mounds and other external indications, had taken their place. In Ireland, however, it would appear that these sepulchral innovations had made slower progress than in Britain, for when the inhabitants of the north of this island began to cross over into Scotland to the adjacent shores of Argyll, they still adhered to the system of burial by chambered cairns, notwithstanding that cremation was then a common practice over the larger portion of Scotland.

The third wave of westward civilisation, which carried with it new elements of culture and industry, was that known in this country as "Late Celtic," corresponding to the "Marnian," or "La Tène," period of Continental antiquaries. Chronologically, this period is roundly defined by the three, or perhaps four, centuries immediately preceding the Christian era. The main body of immigrants of this movement were not the same as those of the Bronze Age, as they belonged to the "Galli," or Gauls of classical authors, and probably the Belgæ of Cæsar. They do not appear to have extended their authority over the whole of Britain, as the north and west of Scotland, as well as parts of Wales and Cornwall, were unaffected by them; nor did they occupy Ireland. But the art and industrial elements which they introduced found much favour among the inhabitants, and spread to Ireland and Scotland, where they took deep and permanent root. As 
special memorials of their presence in Britain we have a number of cemeteries (Aylesford urn burials, a cairn at Mold, Flintshire, the Yorkshire tumuli, \&c.), the Hunsbury Camp, and the lake-village of Glastonbury. The special characteristics of this art have already been described, and need not be further referred to here; but for the physical character of these invaders we are on the terra firma of history, as both Germans and Gauls are depicted by ancient writers as being tall and fair-skinned, with large limbs, blue eyes, and reddishyellow hair. Strabo (v. 2), in referring to the Britons, says that they were "taller than the Kelts, with hair less yellow, and slighter in their persons." Cæsar (v. I 2) states that the maritime portion of Britain was inhabited by those who had passed over from the country of the Belgæ for the purpose of plunder and making war (see p. 5). The farthest north of the Late Celtic tumuli hitherto discovered in Britain were in Yorkshire, so that these Belgic immigrants will scarcely account for the existence of the red-haired Caledonians, who, in the judgment of Tacitus, were more like the Germans than the southern fair people. Hence the Caledonians of that historian must have belonged to the earlier Celts, or have entered the country as a colony from German lands. One of the Late Celtic skulls found in a tumulus at Arras in Yorkshire, described and figured by Dr Thurnam, has a cephalic index of 73.7. As this is regarded as a typical specimen, we have to note the remarkable fact that, while the early Celts were brachycephalic, the late Celts were dolichocephalic.

Looking at these general deductions from the linguistic point of view, we find that at the time of the Roman conquest there were two main dialects spoken in the British Isles-viz., Gaelic and Cymric-both being branches of a common Celtic language which had its home in Central Europe. The former survives in the modern Gaelic of the Highlands of Scot- 
land, the Manx in the Isle of Man, and the Irish, which still lingers in some of the western counties of Ireland. The latter is represented by modern Welsh, the ancient Cornish (now extinct), and the Breton, still spoken in parts of Brittany. Gaelic was introduced into Britain about the same time as bronze, whence it spread, along with the Celtic invaders, into Ireland. It was followed, in the course of some centuries, by the Cymric, a branch of the same speech, and then the language of the Gauls of history, but greatly modified by the intermixture of races and the wandering tendencies of the Celtic tribes on the Continent. The immigrants of this second invasion called themselves Brythons, and as we have seen that they were the introducers of the Late Celtic art, they may be associated with the development of the early Iron Age in Britain. Professor Rhys, taking advantage of the accident in Celtic phonology which led them to substitute a $p$ in words in which their predecessors used a $q$, characterises the two, in accordance with this shibboleth, as Q Celts (Goidels) and $\mathrm{P}$ Celts (Brythons).

As to the speech of the indigenous, or Iberian, inhabitants with whom the first Celtic invaders (Goidels) came into direct contact there is little known. Professor Rhys and other philologists profess to see its fossil remains in a few nonAryan words. ${ }^{1}$ That a non-Celtic language was prevalent among the common people in the vicinity of Inverness, in the sixth century A.D., has often been suggested by the fact recorded by Adamnan - viz., that Columba, while on his mission to Brude, King of the Picts, addressed the natives by means of an interpreter. The Picts are also included by Bede among the five British nations (Angles, Brythons, Scotti, Picts, and Latins) in whose languages Christianity was taught in his time. I do not, however, think that on such evidence

1 See Proc. Soc. A. Scot., vol. xxxii. pp. 324-398. 
we can regard the Pictish language as the lineal descendant of the pre-Celtic, or Euskarian, which, in the time of Cæsar, was spoken in Aquitaine and Spain, and is still represented by the modern Basque. That the Pictish language had been considerably modified by the pre-Celtic speech there can be little doubt. But the difference between the Celtic speech of Columba and that of the northern Picts may be only dialectical-the mere accumulated accretions and modifications of one common speech acquired while moving in different paths and different environments. Columba's mothertongue reached him by a circuitous route through Ireland, while the Pictish came direct through Britain, so that after such a long separation, representing many centuries, we need not wonder that the two languages were not interchangeable when they met in the Highlands of Scotland, though at the starting-point they may have been the same.

When North Britain was invaded during the first century of the Christian era by the Roman legions the country was inhabited by a mixed population, among whom the Caledonians attracted attention on account of their tall stature and reddish appearance. Brythons were pushing northwards, Norsemen had probably even then found a permanent footing on its eastern shores, and Goidelic immigrants from Ireland had for centuries kept up intercourse with its western islands and mainland. Thus the dawn of our history reveals the fact that three different streams of immigrants had then reached the shores of North Britain. It took some time, however, for these peoples and their various culture elements to make much progress northwards; and as each succeeding wave travelled faster than its predecessor, it is probable that the duration of the pre-Roman periods in these out-of-theway regions was considerably shorter than in the southern parts of the island. This view partly accounts for the inter- 
mingling of relics usually regarded as characteristic of the three ages of Stone, Bronze, and Iron, which is so frequently to be met with in the north of Scotland and in Ireland. If Tacitus is correct in his assertion that at the battle of Mons Graupius the Caledonians were provided with long swords, short targets, and armed chariots, it is quite clear that they were then in the early Iron Age, and that Gaulish influence had already reached them through the Brythons. Although metallurgy and all its appurtenances had been an exotic growth, it is proved, from the frequency with which moulds and casting materials have turned up, that the bronze industry was carried on throughout various parts of the country.

To describe the influence of Roman and Anglo-Saxon civilisation in moulding the subsequent destinies of the Scottish people lies within the sphere of the historian: I shall not, therefore, encroach on materials which will be, more or less, utilised by other writers of the series to which this volume may be regarded as an introduction. For the same reason, antiquities referred to in the Scottish annals have not been discussed in these prehistoric sketches, with the exception of works of defence and lake-dwellings, which, in their general aspects and associations, are more allied to the prehistoric than to the historic materials.

Ireland seems to have been peopled by the same races as Britain, as, from the earliest period of which we have any knowledge, it contained $\mathbf{a}$ dark and a fair stock. Its language was that of the Goidels-the first Celtic invaders -and it continued unaffected by the Cymric and all subsequent linguistic elements till superseded in comparatively recent times by the Teutonic tongue.

On comparing the present population of Western Europe with the earlier races, notwithstanding the extensive changes due to the spread of civilisation, the greater intercourse 
between nations, the intrusion of the Teutons into Britain, and political dislocations, the dark and fair people still retain relatively the same geographical distribution as in proto-historic times. The fair folk cluster around the German Ocean and eastwards along the shores of the Baltic to Asia, while the dark occupy a more southern zone on both sides of the Mediterranean. All statistics go to prove that the tendency has been to increase the number of people with intermediate skull-forms (mesaticephali), a fact which may be partly explained by the intercrossing of the original brachycephali and partly by the steady advancement of brain-matter.

The greatest difficulty in all these anthropological researches is to account for the origin of the blond element among the earlier races. According to Professor Huxley, the fair whites (Xanthochroi) and dark whites (Melanochroi) of Britain are distributed now very much the same as they were in the time of Tacitus. From these and other facts he formulated the following conclusions: "(I) That the Melanochroi and Xanthochroi are two separate races in the biological sense of the word race; (2) that they have had the same general distribution as at present from the earliest times of which any record exists on the continent of Europe; (3) that the population of the British Islands is derived from them, and from them only." 1

There is one feature of the ethnological question which, being of a practical character, cannot fail to interest those who think they can distinguish, through the gossamer of language and tradition, the blood and civilisation of the various races who have, from time to time, found a permanent home within the British Isles. Perhaps few anthropologists have ever seriously considered the slender grounds 
on which the term "Celtic" is applied in modern times to sections of the population of these islands. If the linguistic fragments still extant are to be taken as evidence of the distribution of Celtic influence, they would restrict the latter to the very same geographical areas which the racial evidence marks out as non-Aryan or pre-Celtic. No greater contrast between existing races is to be found than between the present inhabitants of the Aran Isles, in Galway Bay, and those of County Kerry, in Ireland. They are probably the purest breeds of the Xanthochroi and Melanochroi to be found in Western Europe, but yet they are both within the modern "Celtic Fringe." The truth is, that between language and race there is no permanent alliance. Many of the most sentimental and patriotic Scotsmen of the present day are Teutons by blood, while still more have pre-Celtic blood coursing in their veins; and the same may be said of Irishmen. And what a picture of mistaken identity do so many Englishmen present when, with the physical qualities of low stature, long heads, and dark eyes, they boast of their Teutonic origin! To console readers who may not find themselves labelled by nature among any of the original types which enter into our common nationality - neither dark nor fair, long nor short, dolichocephalic nor brachycephalic-but among the larger category of welldeveloped mongrels, let me assure them that no special combination of racial characters has ever yet been proved to have a monopoly of intellectuality and virtue. 



\section{N D E X.}

Abercromby, the Hon. John, on bronze dagger from Crawford Priory, 193.

Aberdeenshire, fabricators found in, 152.

Abernethy, fort on Castle Law Hill, $37 \mathrm{r}$-remains found at, $37^{2}$.

Aboyne, bronze armlets found near, 257.

Adams, Mr A. Leith, on Irish elk, I02.

Adzes of the Stone Age, 157 .

Asica, fibulæe of Late Celtic Period found on site of, 266.

Agricola, invasion of Scotland, 7 et seq. - battle of Mons Graupius, 9withdraws south of Firths of Forth and Clyde, $1 \mathrm{x}$-recalled to Rome, $i b$.

Agriculture the mainstay of prehistoric peoples, 359.

Airleywight, Pertbshire, head and horns of the elk found at, $94 \mathrm{et} \mathrm{seq.}$

Airlie, Forfarshire, earth-houses at, 35 I.

Aiton, Mr, quotation from 'Treatise on the Origin, Qualities, and Cultivation of Moss Earth ' by, 3I.

Allen, Mr J. Romilly, on cup-marked stones, $224 \mathrm{fn}$.

Alloa, two gold armlets found at, 207.

Alvah, Banffshire, bronze armlet found in, 256.

Alvey, Inverness-shire, earth-house at, 351.

Amber, its use in the Stone Age, 144.

Anderson, Dr Joseph, his discussion of the MacArthur Cave, 52-account of the investigations at Caisteal-nanGillean, 56 - animal remains in broch at Yarhouse, 89 - remains of large ox found at Keiss by, 115 - stone anvils described by,
I50 - his conclusions regarding brochs, 402 - references to 'Scotland in Pagan Times' by, 89 fn., 171 et seq., 196, 291, 294 et seq., 324 et seq., 394, 397.

Anvils, stone, finds of, 150.

Arborescent Age, 22 et seq. - arborescent growths, 27 et seq.

Arbroath, dagger-blade of Bronze Age found near, 193 .

Ardmore, "submarine crannog" at, 437.

Ardoch, camp of, suggested as Agricola's headquarters, 9 .

Ardrossan, forts near, 375-rockshelter at, 8r.

Argyllshire, remains of circular dwell. ing-liouse on crannog in, 334.

Armlets of Bronze Age, 205 et seq. penannular ring with cup-shaped ends, 207.

Arras, Yorkshire, chariot-wheels, \&c., found in cist at, 247.

Arrow-heads of the Bronze Age, 203arrow-points of Stone Age, I67 et seq.

Art of the Bronze Age, $216 \mathrm{et} \mathrm{seq.}$

Ashgrove Loch, stone crannog in, 420 -relics found in, ib. et seq.

Ashkirk, Roxburghshire, stag's lıead found at, 108-horns of urus found on Synton estate, 11 I.

Ass, approximate date of introduction into scotland of, 130 .

Assynt, Ross-shire, jet necklace of Bronze Age found at, 213.

Athol, skull of urus found near, 113.

Aucherıdolly, Kirkcudbrightshire, enamelled harness mounting found at, 249.

Auk, Great, in prehistoric times, $125^{-}$ 128. 
Auquhorthies, near Inverury, stone circle of, 318.

Axes, of the Stone Age, 155 et seg.unperforated axe, 156 et seq.method of hafting, $\times 60-$ of the Bronze Age, 183 et seq.

Aylesford, Kent, relics of Late Celtic Period discovered at, 268.

Ayrshire, renuains of beaver found in, 122 - bronze sword - sheath found near Bargany House, 243 .

Badger in prehistoric tines, 129.

Balblair, Sutherlandshire, bronze razor found at, roo.

Balcalk, Tealing, jet necklace of Bronze Age found at, $23_{3}$.

Bald, Mr Robert, on skeleton of whale found at Airthrey, 6o.

Balgay, near Dundee, jet necklace of Bronze Age found at, 213.

Ballymenach, stone circle at, 290.

Ballynamintra, Co. Waterford, bones of Irish elk found in the cave of, ro2.

Balmaclellan, Kirkcudbrightshire, find of Late Celtic Period at, 263.

Baoussé-Roussé caverns at Mentone, 469.

Barhullion, Wigtownshire, snakeheaded armlet found at, 259.

Barmekyne of Echt, Aberdeenshire, hill-fort on the, 369 .

Barnwell, Rev. E. L., on Late Celtic ornilments, $26 \mathrm{r}$.

Barri, Giraldus de, reference to beaver in 'Itinerarium Cambrize' by, I22.

Barry, Sir F. T., M.P., discovery at Keiss of reindeer horn, $9 x-$ part of antler of elk, 99-of bear's tooth, 128 - reference to excavation of brochs at Keiss, 403 .

Bateman, Mr, reference to 'Vestiges' by, $x$ r9-references to 'Ten Years' Diggings' by, xr9, x24 fn., 129, $44^{8}$.

Beach, 25-feet raised, theory of Sir Archibald Geikie and others, 37suggested cause of, 45 .

Beads of glass, amber, and jet of the Bronze Age, $2 x \mathrm{x}$.

Bear, brown, in prehistoric times, $x_{28}$ et seq. - approximate date of extinction in Scotland of, $x_{3}$.

Beattie, Mr W., on cave at North Esk, 79.

Beauly Firth, the Black Cairn in, 437 .

Beaver, in prehistoric times, 120.123approximate date of extinction in Scotland of, 130.

Beddoe, Dr, on Silures, $45^{8}$.

Beehive huts, 336 et seq. - on Skellig
Michael, $34 \mathrm{I}$-at Eilean-na-Noimh, $3+2$.

Beith, Ayrshire, bronze shield found at Lugtonridge, 200.

Belhelvie, Aberdeenshire, remains of urns found at, $1 \times 5$-torque found at, 210-bronze armlet found in, 257.

Bellenden, reference to beavers in his 'Croniklis of Scotland,' 123.

Bennachie, Aberdeenshire, bronze arnılets and celts found near, 206-East Fort on, 369 .

Bertrand and Reinach, MM., references to 'Les Celtes dans les Vallées du Pó et du Danube' by, $233,246$.

Beveridge, Henry, Esq., on burials at Pitreavie, 314.

Birdlip, near Bristol, bowl - shaped bronze dishes found at, 260.

Birrenswark, bridle-bit found at, 249 .

Birsay, Orkney, clothing of female skeleton found in peat-bog at, 174 .

Blair Drummond Moss, 37-renaains of Celtic shorthorn found in, $x \times 9$.

Boar, wild, in prehistoric times, 123125-approximate date of extinction in Scotland of, 130 .

Boethius, reference to beavers in his 'Scot. Hist.,' 123.

Bone used for making implements in Stone Age, 159.

Borer or drill used by Stone Age people, $\mathbf{r} 53$.

Borgue, Kirkcudbright, bronze armlet found in, 253 .

Borness Cave in Kirkcudbrightshire, 79-Celtic shorthorn found in, $x \times 8$.

Bower, heads of urus found in bog in the parish of, $x \times 6$.

Bowl-shaped bronze dishes of the Late Celtic Period, 260.

Boyd-Dawkins, Professor, quoted, 90 -on the urus, rog-on the Celtic shorthorn, $1 \times 6$ et seq.-references to 'Cave-Hunting ' by, 129 fns., 130 -reference to 'Early Man in Britain' by, 457,476 .

Boynton, Mr Thomas, on lake-dwellings in the Holderness, 422.

Bracelets of Bronze Age, 206.

Brechin, part of horn of an elk found in Trinity Muir, 93 .

Breckigo, Loch of, remains of urus, \&c., found in, $\mathrm{r}_{\mathbf{5}} \mathrm{5}$.

Bridgewater, Devon, Celtic shorthorn found in peat near, $x$ rg.

Bridle-bits of Late Celtic Period, 249 et seq.

Britain, becomes known to the Greeks, 2-visit of Pytheas establishes the overland trade-route, 3-Roman 
invasion, ib. et seq.-Cæesar's ac. count of the country and people, 4 et seq. - Strabo's account of manners and customs of Britons, $5 e t$ seq.-reference by Diodorus Siculus, 6 - religion of the Britons, 12 population prior to the Roman invasion, 14 -account of the inhabitants and country by Roman writers, 42 et seq.

Broadsword traced to pre-Roman times, 10.

Broca on Neolithic skulls, $4^{62}$ et seq.

Brochs, only found in Scotland, 389 - Mousa, ib. et seq.-Ousdale, $39 \mathrm{I}$ et seg. - their structure and design, 394 et seq. - relics found on sites of, 398 et seq. - their builders and inhabitants, 401 et seq.

Brodie, Rev. J., on horns of elk found at Marlee, 94 .

Brogar, Ring of, 297.

Bronze Age, sea-level in, 40-cemetery of, at Magdalen Bridge, $i b$. - find in Duddingston Loch, 93-progress in culture and civilisation during the, 177 et seq. - art of, 216 et seg.

Bryce, Dr James, on stone circles in Arran, 316.

Bryson, Mr A., on cave at North Esk, 79.

Buchanan, Mr John, on the Clyde canoes, 70.

Bugthorpe, iron sword, \&c., found at, 245.

Bunrannoch, Perthshire, armlets found at, 255 .

Burghead, remains of Celtic shorthorn, \&c., found at, 118-Dr Macdonald's account of the wall of fort at, $374-$ further details by Mr Hugh W. Young, $i b$.

Burial customs of prehistoric man, 279 et seq. - cairns and barrows, 281.

Burraness, broch of, 398 .

Burray, broch of, 400 .

Butmir, Bosnia, remains of ox, urus, \&c., found at, 119-stone objects at, $35^{8}$.

Buttons, of Bronze Age, 205-of the Stone Age, 172 et seq.

Cæesar, Julius, invades Britain, 3 et seg.--account of the trees found in Britain, 43-on the uri of the Hercynian forest, 109 - describes the Gaulish method of constructing ramparts by stones and beans, 374 .

Caher-Fada-an-Doruis, 340.

Cairn of Achnacree, 283-at Largie, 285-at Kilchoan, 288-at Kilmartin, $i b$. - horned cairns of Caithness, 29r et seq. -Maeshowe, 298 et seg.-at Unstan, 302-at Quanterness, 304 - at Wideford, 305-at Papa Westray and Quoyness, 306 et seq. -at Clava, 3 ro-at Collessie, 312-at Gilchorn, 313-general remarks, 326 et seq.

Cairn Conan, near Arbroath, Forfarshire, edith-house at, 349 .

Caisteal-nan-Gillean, exploration of, 56.

Caithness, horned cairns in, 291 et seg.

Caldron, bronze, description of one found in Kincardine Moss, 37 et seg.--one found in West of Scot. land, $3^{8}$-one found at Cardross, $i b$. - one found in Carlingwark Loch, 274.

Caledonians, the, I4-describer by Tacitus, 443.

Caledonii, 12.

Callernish, stone circle of, 308 et seq.

Cambridgeshire Fen, remains of brown bear found in, 129.

Campbeltown, discovery of urns and flint instruments in, $73 \mathrm{et} \mathrm{seq.}$

Campigny, hut dwellings at, 332 .

Cannibalism in the Neolithic Age, 82.

Canoes, finding of, in Carse-lands, 66 et seq. - in the basin of the Clyde, 70 et seq.-used by prehistoric people in Scotland, 359.

Capercailzie, the, in Denmark and Scotland, 127 et seq.

Carham, bronze sword-sheath found in the Tweed at, 245 .

Carlingwark Loch, Kirkcudbrightshire, relics of Iron Age found at, 274 et seq.

Carmichael, Lanarkshire, three pen. annular gold armlets found in parish of, 208.

Carnban, near Crinan Canal, slab with concentric lozenge-shaped sculptures found at, 22 r.

Carn-liath, broch of, 396, 399 .

Carnwath, Lanarkshire, ornamented cover-stone of cist, \&.c., found at, 221.

Carradale, vitrified fort at, 386 .

Carse of Stirling, 36 - implements associated with the skeletons of whales in, 57 et seq. - other relics of man found in, 65 et seq. - perforatcd deer-horn chisels and picks found in, 169 .

Cartailhac, M., references to ' $\mathrm{La}$ France Préhistorique' by, 474, 478. 
Carthaginians, trading expeditions of, I.

Cassiterides, or Tin Islands, location of, I et seq.

Castle-Newe, Aberdeenshire, bronze armlets found at, $256,258$.

Cat, approximate date of introduction into Scotland of, 130.

Caterthuns, the, Forfarshire, 369.

Cattle, moder $n$, origin of, 131 .

Caves, Borness, in Kirkcudbrightshire, 79-near the mouth of the North Esk, ib.

"Celtic Fringe," the, 487.

Celtic Period in Britain, Late, 234 et seq.

Celtic shorthorn in prehistoric times, 116-120.

Celts, bronze, found at the " Maidens," 77 -the celt or unperforated axe, 156 et seq.-method of hafting, 160.

Chambers, Mr Robert, quotation from 'Ancient Sea-Margins' by, 72.

Chisels, of the Stone Age, 159-nethod of hafting unperforated chisels, 160 - of the Bronze Age, 186.

Christison, Dr David, reference to 'Early Fortifications of Scotland ' by, 366.

Cill-Trölla Broch, pieces of reindeer horns found in, 87 -Celtic shorthorn found in broch of, 118 .

Clava, cairn and stone circles of, 310 et seq.

Cleaven Dyke suggested as Agricola's headquarters, 9 .

Clerk, Sir John, quotation from ' Reli. quiæ Galeanæ' by, 3r, 66.

Clikamin, Lerwick, broch of, 398 .

Climatic features of prehistoric Scotland, 20 et seq.-change from an arctic to a temperate climate, 25clinatic conditions at the period of the Roman occupation, 36, 42 et seq.

Cloonfinlough, horns of Irish elk found in the crannog of, 102.

Close-y-Garey, Isle of Man, skeleton of Irish elk found at, $\mathrm{IO}_{4}$ et seq.

Clothing of the Stone Age, 172 et seg.

Clouston, Mr R. S., on cairn of Unstan, 302.

Clyde, canoes found in basin of, 70 et seq.- - reindeer horns found on north bank, 89 -remains of urus found on north bank, I12.

Coal-bog, wooden hut in, 335 .

Coffey, Mr G., reference to Origins of Prehistoric Ornament' by, 145 - on decoration of the Bronze Age in Ireland, 219 et seq.

Coilstield, Ayrshire, spiral decoration on cover-stone of a cist, found at, 221.
Colchester, remains of brown bear found at, 129.

Coldingham, Berwickshire, palmated horn found at, 96.

Coldstream, flint knife found near, 162.

Cole's Castle, near Brora, Sutherlandshire, 398.

Collessie, Fife, sepulchral cairn at, 3 I2.

Coracle, description of, $359 \mathrm{et}$ seq.

Cornwall, earth-houses and other remains in, 353 et seq.

Cowden Burn, remains of urus found in, 112.

Cowlam, Yorkshire, remains of Late Celtic Period found at, 267.

Craigton, Linlithgowshire, reindeer horns found in marl-pit near, 89.

Cramond, skeleton of elk found on the farm of Greycrook, 93.

Crannogs, evidence of kind of dwellings in early Iron Age, 334-Irish crannogs, 406-Scottish crannogs, 408 et seq. - relics found in, 412 et seq. - construction of, 430 et seq.

Crawford Moor, Lanarkshire, jet button found on, 173-bronze armlets found at, 207.

Cree, the, trees found in, 42 -ancient forest of, 69 et seg.

Cremation, spread of, in Britain towards close of Stone Age, 280-inhumation and, 474-481.

Crichie, Aberdeenshire, axe-hammer found in stone circle of, 156 -stone circle at, $3 \mathbf{I} 6$.

Croftamie, Dumbartonshire, portion of reindeer horn found at, 90 .

Crofthead, Renfrewshire, remains of Irish elk, urus, \&c., found near, 104. 112.

Cromagnon, prehistoric skulls at, 462 .

Cromdale, Inverness-shire, gold armlet found at, 207.

Croy, oaks and firs found in a moss at, 30.

Culbin Sands, borer found on, $153-$ flint saws from, 164-bronze armlet found on the, 258 .

Culrain, Ross-shire, fragments of cloth and leather shoe found at, 174 .

Culzean hoard, 40 - discovery of bronze celts near, 77 .

Curle, Mr James, on broch of Torwoodlee, 400.

Currach. See Coracle.

Daggers, of Bronze Age, 19l et seq.of the Late Celtic Period, 246 et seq.

Dalrymple, Mr C. E., reference to Appendix to Stuart's 'Sculptured 
Stones of Scotland' by, 316-stone circle at Crichie, $i b$.

Darwin, Mr, reference to 'Origin of Species' by, 135.

Dawson, Sir W., on Guanches, 468.

Deskford, Banffshire, fragment of bronze helmet found at, 238 .

Dick, Sir Alexander, of Prestonfield, his find of Bronze Age, in Dudding. ston Loch, 93.

Dio Cassius, description of the Caledonians, 43.

Dog, the, in prehistoric times, 134 et seq.

Dolmens rarely met with in Scotland, 328 -distribution of, $i b$.

Domestic animals in prehistoric times, 130-136.

Dowalton, Loch of, Wigtownshire, remains of Celtic shorthorn, \&c., found in crannogs in, II7-ornament found in, 249-account of the crannogs, 409 et seq.-relics found at, 4ro et seq.

Drem, skull of Celtic shorthorn found at Balgone, 1 rg.

Drill or borer used by Stone Age people, 153 .

Drinking-cups found in graves, $32 \pi$.

Druids, I2 et seq.

Druimvargie, rock-shelter of, 54 et seq.

Drumcrief, finding of oaks in moss at, 3 I.

Drumkilin Bog, wooden hut in, 335 .

Drummond, Mr H. H., on whale remains, 6r.

Dryden, Sir Henry, on Hunsbury Camp, 24I, 269 et seq.

Düben, Prof, von, on skulls in Sweden, $45^{8}$.

Duddingston Loch, remains of Bronze Age found in, 93 .

Dumbuck, crannog at, 4.37 et seq.relics found at, 440 et seq.

Dumfries, finding of animal remains on the Shaw property, 90 .

Dumfriesshire, remains of urus, bear, and reindeer found in, 90, III skull of brown bear found in, 128 .

Dunagoil, vitrified fort at, $385 \mathrm{et} \mathrm{seq}$.

Dunbar, bronze razor found at Bowerhouses, near, 190.

Dunbeath, broch of, 400 .

Dunbuie Fort, 379-relics found at, 440.

Duncombe, Hon. Cecil, on lacustrine remains on the banks of the Costa, 423.

Dundee, jet button found on Law Hill, 172.

Dunfermline, cemeteries found on Pitreavie estate, $314 \mathrm{et}$ seq.
Dun Mac Uisneachan, enamelled bronze disc found on vitrified fort of, $25 \mathrm{I}$.

Dùn Skeig, vitrified fort of, $3^{87}$.

Dupont, M., reference to 'L'Homme pendant les Ages de la Pierre'by, $131 \mathrm{fn}$.

Earrings, gold, found at Orton, near Fochabers, 214.

Eddertoun, Ross-shire, blue glass bead of Bronze Age found at, 2 II.

Edenshall, Cockburn Law, 398.

Edinburgh, stag's head found in the Meadows, ro8-sword-blades, \&c., of Bronze Age found at Grosvenor Crescent, 196, 204, 205-the Cat Stone, near, 3 18.

Edrom, skeleton of beaver found in Middlestot's Bog, I 22.

Eilean Buidhe, vitrified fort on, 385 .

Eilean-na-Noimh, Garveloch Isles, beehive cells on, 342 .

Eirdc houses, 343 et seq.

Elk, the, in prehistoric times, 91-99.

Embsay, near Skipton, Yorkshire, bronze torque found at, 252.

Enamelled ornaments found in Scotland, 249.25x.

Engelhardt, Mr, quotation from ' Den mark in the Early Iron Age' by, 230.

England, remains of elk found in, 99 -remains of Celtic shorthorn found in eastern counties, II6.

Eriska, mound at, 436 .

Ethnology, 442 et seq.- description of ancient Britons by Tacitus, 443dolichocephalic and brachycephalic crania, 444- modern research in craniology, 445 et seq. - dual type of skull found in Portugal, 460 et seq. - French rescarch in prehistoric craniology, 46I et seq.-dolichocephali and brachycephali, 468 et seq. - general anthropological data, 470 ct seq.-linguistic research and the Aryans, 47 I et seq.- - religiosity and funereal rites, $473 \mathrm{et}$ seg. - cremation and the Bronze Age in Britain, 476 et seq. - general conclusions, 479 et seq. -inhabitants of Britain in Neolithic times, 480 - the Celts, $i b$. - in. nugration of the Gauls bringing late Celtic art, $48 \mathrm{r}$ et seq. - the Calcdonians, $482-t$ two dialects spoken at the time of the Roman conquest, $i b$. the speech of the Iberians, 483Prof. Huxley on dark whites and fair whites, 486.

Evans, Sir John, reference to 'Ancient Stone Implements' by, 146 et seq.; 
r69-reference to 'Bronze Implements ' by, 186-188, 200, 205, 217.

Evans, Mr A. J., reference to ' On a Late Celtic Urn-Field at Aylesford, by, 269-fibulae at Esica, 266-gold ornaments in Ireland, 267.

Fabricators or flaking tools, description of, I 52 .

Fahan, ancient city of, 340 .

Falkirk, canoe found in Carse of, 66canoe found near, 67 -bronze fibula found near, 260.

Fallow-deer, approximate date of introduction into Scotland of, 130 .

Farrer, Mr, on Maeshowe, 298 chamber at Quoyness, 306.

Fauna, of the post-glacial period, 21, 25-of prehistoric times, 84 et seq. reindeer, 86-9I-elk, 9r-99-gigantic Irish deer, 100-105-red-deer and roe-deer, I05-108-urus, I08-I16Celtic shorthorn, I 6 -120-beaver, I20-123-wild boar, 123-125-Great Auk, 125-128-general remarks, 128 r3o-domestic animals, 130-136.

Fergusson, Dr, reference to 'Rude Stone Monuments' by, 301, 328reference to "The Brochs and the Rude Stone Monuments of the Orkney Islands' by, 40r.

Fibulæe of the Late Celtic Period, 259 et seq.

Fife, dagger of Bronze Age found on Crawford Priory estate, 193.

File of Bronze Age, 189.

Fir found in peat-bogs up to 3000 feet above sea-level, 36 .

Flaking tools or fabricators, I 52.

Flanders Moss, bronze caldron found in, 38.

Fleming, Dr, reference to 'History of British Mammals' by, r 12.

Flint implements found at Millknowe, 74 et seq. - use of flint in the Stone Age, r40-flint factories discovered near Mons, Belgium, 331-similar discoveries in England, $i b$. - renıins of factories in Scotland, 357.

Flora of post-glacial period, 21 .

Food vessels found in graves, 321 .

Forests, disappearance of the, since prehistoric times, 42-Romans charged with their destruction, 43-south of Scotland well wooded after the Saxon language replaced the Celtic, 44- scarcity of wood in medieval times, ib.

Forfarshire, head and horns of an elk found in a marl-pit, 94.

Forgandenny, fort at, 372 .

Forts, classification and distribution of,
364 -earth-works and stone-works, 366 et seq. -motes, 367 et seq. - hill. forts, 369 et seq. - analogous forts in Europe, 380-vitrified forts, $i b$. et seq.-suggested means of vitrification, $3^{82}$ et seq.-vitrified forts outside Scotland, 388 et seg.

Fowl, domestic, approximate date of introduction into Scotland of, 130.

Fox in prehistoric times, 129.

Franks, Sir A. Wollaston, quotations from 'Hora Ferales' edited by, 124,234 et seq.

Fraser, Mr James, on circles of Clava, 309 et $\mathrm{seg}$.

Friarton, Perth, canoe found at, 67 .

Furfooz, brachycephalic race of, 469 .

Fyrish, Evanton, Ross-shire, bracer found at, 169 .

Fyvie, arrow-head found at, $16 \mathbf{r}$.

Galloway, skull of urus found in, III.

Galloway, Mr William, his exploration of Caisteal-nan-Gillean, $56-$ other excavations in Oronsay, 57description of fortified camp on Midhill Head, 370.

Galston, Ayrshire, borer found in parish of, I54.

Garioch, the Newton Stone in, 318.

Garson, Dr, on Yorkshire barrows, 451 .

Geikie, Sir Archibald, his theory of the 25-feet raised beach, 37 .

Geikie, Prof. James, references to 'Great Ice Age' by, 23, 42-his 'Prehistoric Europe' quoted, 24his description of a canoe found at Friarton, Perth, 67-account of remains of urus found in Cowden Burn, I 12.

"Ghcgan Rock," near Seacliff, East Lothian, and account of early habitation on, 79 et seq.-relics found there, $80-$ Celtic shorthorn found in kitchen-midden on, 118.

Gilchorn, near Arbroath, cairn at, $3{ }^{1} 3$.

Glacial period, 20 et seq.-parallelism between glacial epochs and landsubmergences, 45 .

Gladstone. Dr, quotation from paper on "The Transition from pure Copper to Bronze made with Tin" by, 178 .

Glasgow, remains of urus found in, II2.

Glastonbury Lake village, remains of beaver, \&c., found on, I2I-account of, 424 et seq.-relics found at, 425 et seq.

Glenelg, Inverness-shire, broch at, 396. 
Glenluce, flint saws from, 164-jet button found at Mid-Torrs, 173.

Golspie, flint saws found at, 164 .

Gouges of the Bronze Age, 186.

Grange of Conan, near Arbroath, bronze spiral armlet found at, $25^{8}$.

Graves, contents of prehistoric, $320 \mathrm{et}$ seq.

Gray, $\operatorname{Mr}$ Alexander, on raised beach at Campbeltown, 73.

Gray, Rev. George, on Irish elk in Ayrshire, 103.

Greeks, their discovery of Britain, 2.

Greenwell, Canon, references to 'British Barrows' by, 119, 121, $124 \mathrm{fn}$., $133,145,159,162,173,174,215$, 267,476 et seq. - on cairns and stone circles in Argyllshire, 285 et seq.

Grieve, Mr Symington, his exploration of Caisteal-nan-Gillean, 56-remains of the Great Auk found in Oronsay, 126-references to 'The Great Auk or Garefowl' by, 56, $126 \mathrm{fn}$.

Grime's Graves, flint-mining at, 332.

Grimthorpe, iron sword, \&c., found in a barrow at, 245 .

Gundestrup vase, 238 .

Hadrian's wall, $\mathbf{I r}$.

Hagbourn Hill, Berkshire, bronze bridle-bits, \&c., found at, 247 .

Hamden Hill, Somersetshire, tyres of wheels, \&c., found at, 248 .

Hamilton, Dr E., on vitrified forts, $3^{84}$.

Hamilton, Mr George, on sculptured rock-surfaces at High Banks, 225.

Hammers, stone, description of, 151 et seq., 156- of the Bronze Age, 186.

Hardy, Mr James, on elk remains, 96.

Harray, Orkney, amber and glass beads, with objects of Iron Age, found at, 211 -broch in, 400 .

Hatfield Moss, 32 et seq.

Hebrides, Outer, existence of bogwood in, 35 .

Helmets of Late Celtic Period, 237 et seq.

Herodian, account of the Caledonians by, 43 .

Hewison, Rev. Mr, on vitrified forts, 385.

Hibbert, Dr, on reindeer in Caithness, 86.

High Banks, Kirkcudbrightshire, cupinarked rock surfaces at, 225.

Hildebrand, Dr Hans, reference to 'Scandinavian Arts' by, 182.

Hilgay, Norfolk, bones of beaver, \&c., found at, r21.

Himilco, the voyage of, 2.
Hoare, Sir R. Colt, reference to 'Ancient Wilts' by, Irg.

Hoerness, Dr, reference to 'Urgeschichte der Bildenden Kunst in Europa' by, 233.

Holderness, Yorkshire, rénıains of beaver found at, 121-crannog discovered in, 422.

Honeyman, Mr John, observations on vitrified forts by, $3^{84}$.

Horn, use of, in making implements in Stone Age, 159.

Horse, the, in prehistoric times, 131 134-horse-trappings, \&c., of Late Celtic Period, 247 et seq.

Howden, Dr, on cave at North Esk, 79.

Howe Hill Barrow, Yorkshire, 451.

Hunsbury, or Dane's Camp, near Northampton, relics of Late Celtic Period found at, 24I et seq., 269 et seq.

Huntiscarth, Orkney, amber necklaces found at, 2 r 3 .

Hutcheson, Mr A., on dagger-blades, 192-on the cairns of Gilchorn and Collessie, $3^{1} 3$.

Huts of prehistoric date discovered on the Continent, $33 \mathrm{I}$ et seq. - Stone Age settlement of Schussenried, 333 et seq. - dwellings of early Iron Age, 334 et seq. - discoveries in Ireland. 335 et seq.-beehive huts, 336 et seq.

Huxley, Prof., on prehistoric skulls, 456, 459, 460-fair whites and dark whites, 486.

Hyndford crannog, near Lanark, ${ }_{41} 6$ et seq. - relics found at, $418 \mathrm{et} \mathrm{seq}$.

Ice Age, 20 et seq.

Implements of bone and horn, found in MacArthur's Cave, 48 et seq. in rock-shelter at Oban, $55-$ at Caisteal-nan-Gillean, 56 - of deerhorn in the Carse of Stirling, 57 et seg. - of the Stone Age, I55 et seq.-process of polishing, I59 et seq. - found in graves, 324 .

Industrial life of prehistoric people, 357 et seq.

Innermessan, Wigtownshirc, bronze trumpet found at, 2or.

Innes, Cosmo, his 'Sketches of Early Scottish History' quoted, $4.4-$ on Clava circles, $3 \mathbf{I I}$.

Inveravon, finding of sea-shells at, 65 et seq.

Inverness, stone circles near, 309.

Ireland, remains of elk found in, $99-$ remains of Celtic shorthorn found in, 116, 119-flint saws found in, 
165-remains of wooden buts found in, 335 et seq.-bechive huts in, 339 et seq. - earth-houses in, 352 .

Irish deer, gigantic, in prehistoric times, roo-105.

Iron Age, 226 et seq.

Jade, its use in the Stone Age, 140 et seq.

Jamieson, Dr John, on fortifications on the Laws, 377 .

Jardine, Sir W., on animal remains from a peat.bog, 90 .

Jedburgh, skull of urus found near, III.

Jervise, Mr Andrew, on "Picts' house" at Tealing, 349 .

Jet, its use in the Stone Agc in Scotland, I43 et seq.

Jewitt, Mr Llewellynn, reference to 'Grave-Mounds' by, 240.

Joass, Dr, on animal remains near Tain, 86-at Kintradwell, I I5-on glass beads, $2 \mathrm{rr}$ - reference to ' $\mathrm{Ar}$ chreologia Scotica' by, 396.

Jolly, Mr W., on bronze armlet found at Poolewe, 207.

Keiss, Caithness, portion of reindeer horns found at, 88, 9r - part of antler of elk found at, 99-remains of large ox found at, II $_{5}$ - Celtic shorthorn found at, 118 -bones of the Great Auk found in the Harbour Mound, 125 - bear's tooth found in broch at, 128 - excavation of eight brochs by Sir F. T. Barry, 402-relics found, 403 .

Keith Marischal, East Lothian, jet button found at, 172 .

Keller, Dr, his experiments in cutting and boring stones, 147 .

Kelton, Kirkcudbrightshire, bronze with horns found in, 238 .

Kemble's 'Horæ Ferales' quoted, 234 et seq.

Kettleburn, Celtic shorthorn found at, $x$ r8-broch at, 396, 400 .

Kilbarchan, description of a moss at, $3^{r}$.

Kilchoan, cairn at, 288.

Kildrummy, Aberdeenshire, " Picts' houses" at, 348 .

Killin, bronze bracelet and rings, \&c., found near, 206.

Kilmartin, cairn on glebe-lands of, 288.

Kilmaurs, Ayrshire, reindeer horns found at, 90 .

Kinahan, Mr G. H., on Irish elk, IO2.
Kincardine Moss, bronze caldron found in, 37 .

Kincardineshire, finds of fabricators in, ${ }^{52}$-bronze armlets found near the Castle of Kinneff, 207.

Kinleith, near Edinburgh, bones of ox and dog, \&c., found at, 118 et seq. bronze blade found at, rgr.

Kintradwell, find of animal remains at, Ir5-broch of, 396.

Kirkcudbrightshire, skull of urus found in, III.

Kirkpark, near Musselburgh, cemetery with and without urns at, 313 .

Kirkurd, horns of elk found in, 99 .

Kitchen-middens, at Inveravon, 66in Denmark, 134-at Salvaterra, Portugal, 46o.

Klebs, Richard, reference to 'Der Bernsteinschmuck der Steinzeit' by, $145 \mathrm{fn}$.

Knives, flint, 16r et seq. - of the Bronze Age, 187 .

Knock Farril, vitrified fort at, $3^{81}$, $3^{87}$.

Knockmany, Co. Tyrone, sculptured stone found in cairn, 224 .

Knowles, Mr W. J., on Great Auk, 127-on flint saws, 165 .

Kollmann, Prof., on primitive races, 470.

Kourganes, Neolithic remains in, 469.

Lagore, near Dunshaughlin, Ireland, lake-dwelling at, 405 et seq.

Laibach, in Carniola, remains of beaver found at, raI.

Laidlay, Mr J. W., description of early habitation on the "Ghegan Rock," 79.

Laing, Mr Samuel, on harbour mound at Keiss, 88-urus, Ir6-great auk, r25-reference to "Prehistoric $\mathbf{R e}$ mains of Caithness' by, ib. et seq., 403. 457 .

Lake-deposits, stratigraphical succession of, 26.

Lake-dwellings, $404 \mathrm{et}$ seq. - sketch of lacustrine research, $405 \mathrm{et} \mathrm{seq}$. - Lagore, 405-Ober-Meilen, 406 et seq. -other discoveries in Europe, 408 - Loch of Dowalton, 409 et seq. crannogs in Ayr and Wigtown, 4II -lake-dwellings in England, 42I et seq. - structure of lake-dwellings, 426 et seq. - pile-structures, 427 et seq.-crannogs, 430 et seq.-terremare, 434 et seq.-marine dwellings, 435 et seq.-modern piledwellings, 441 .

Lamberton Moor, Berwickshire, grinding-stone found on, 160 . 
Lanark, skeleton of urus found in the parish of, 112 -beaded torque found near, 252.

Lanarkshire, ornamental bronze ball found in, 276.

Lanfine, Ayrshire, arrow-point from, 167.

Largie Farm, Argyllshire, cairn at, 285 et seq.

Largo, Lower, Fifeshire, four gold bracelets found at, 208 - torque found at, 2 ro.

Late Celtic Period in Britain, 234 et seq.

Lauder, Sir Thomas Dick, reference to 'Moray Floods' by, 3 ro.

Laws, the, Forfarshire, fortifications on, 377 et seq. - relics found at, 379 .

'Leges Wallicæ,' reference to beaver in, 122.

Lenormant, reference to 'Les Premières Civilisations' by, $\mathrm{r}_{33} \mathrm{fn}$.

Leswalt, Wigtownshire, ornamented socketed celt found in, $18_{5}, 217$.

Lewis, stone circles on, 308.

Lilliesleaf, skulls of uri seen near, II I.

Lingrow, broch of, 400 .

Linguistic research and Aryan language, 471.

Linlithgowshire, enamelled bronze cup or patere found in, 251 .

Linton Loch, Roxburghshire, remains of urus, \&c., found in, III.

Lisnacroghera, relics of Late Celtic Period found at, 274 .

Llangorse, Lake of, Wales, crannog at, 422.

Lochan Dughaill, crannog at, 334 , 4 I5-relics found at, 416 .

Lochar Moss, 36 -beaded torque found in, 40, 252-description of, 67-Rev. James Laurie's account of, 68.

Loch Etive, exploration of cairn near, 283 et seq.

Lochlee crannog, fragments of reindeer horns found in, 90-remains of Celtic shorthorn, \&c., found in, II7 -evidence of kind of dwelling at, 334 - discovery of, $4 \mathrm{II}$ - construction of, $43 \mathrm{x}$.

Lochspouts, Ayrshire, scraper from crannog of, $\mathbf{x} \in 6$.

London, remains of brown bear found in, 129-remains of pile-buildings found near London Wall and Southwark, 422.

Loughrea, head of Irish elk found in, 102.

Low, George, quotation from 'Tour thro' Orkney and Shetland' by, 35 .

Lowe, Rev. George, on cemetery at Kirkpark, 3r3.
Lowson, Mr W., on Bronze-Age cemetery, 40.

Lunan Head, Forfar, jet necklace of Bronze Age found at, 213.

Lyell, Sir Charles, on marl-deposits, 26- 'Antiquity of Man' referred to, $28 \mathrm{fn}$.

Macalister, Mr Stewart, on ruins of Fahan, 34r.

MacArthur Cave, Oban, discovery of, 46 -contents of the cave, 47 et seq. description of bone and horn iniplements, 48 et seg. - animal remains, 49 et seq. - discussion of the cave, 52 et seq. - Celtic shorthorn found in, 118.

M'Call, Mr, reference to 'History and Antiquities of the Parish of Mid-Calder,' 187.

$M^{\prime}$ Culloch, Dr, reference to ' Highlands and Western Isles of Scotland' by, 383 .

Macdonald, Dr, reference to "Burghead as the site of an Early Christian Church " by, 375 .

Macdonald, Mr James, excavations on Tap o' Noth, 385 .

Mackay, Mr James, on broch of Ousdale, 39r.

Maclagan, Miss C., reference to 'The Hill Forts and Stone Circles of Scot. land ' by, 366 .

Maate, r2.

Maeshowe, tumulus of, $298 \mathrm{et} \mathrm{seq.}$

Magdalen Bridge, near Musselburgh, cemetery at, 3 I 4 .

"Maidens," the, discovery of bronze celts at, 77 .

Mapleton, Rev. R. J., on cairns in Argyllshire, 288.

Marine dwellings in Holland, 435analogous rentains in Scotland, 436 et seq.

Marlee, Joch of, Perthshire, animal remains found in, $89-a$ pair of elk's horns found at, 94-remains of beaver found in, $\mathbf{1 2 2}$.

Mauchrie Moor, Arran, stone circles on, 316 et seq.

Maxwell, Sir Herbert, reference to 'Dumfries and Galloway' by, 7-on miniature bronze axe, 186 - wartrumpets, 201.

Maxwell, W. H., reference to 'Hillside and Border Sketches ' by, 96.

Maybole, remains of Irish elk found in the parish of, 103 -skull of urus found in, Irz.

Melfort, Argyllshire, bronze armlet, \&c., found at, 206.

Mid.Calder, bronze knife-blade found in . parish of, 187 . 
Middlesby, Annandale, bridle-bits, \&ic., found at, 250 .

Midhill Head, Mid-Lothian, fortified camp on, 370 .

Millknowe, flint implements found in beach shingle at, 74 et seg.

Millport, fossil Trochus lineatus found in raised beach strata of, $8 \mathrm{r}$.

Mitchell, Sir Arthur, his 'The Past in the Present' referred to, 6 , 338-his obscrvations on the forest of Cree, 42, 69 .

Molyneux, Dr, on Irish elk, roo.

Montelius, Dr, reference to 'Findet man in Schweden Ueberreste von einem Kupferalter' by, I79.

Monzie Castle, Perthshire, sculptured stone found at, 22.4.

Moosseedorfsee, settlement of, 25 .

Moothills, 367 .

Morayshire, bronze objeets found at Wester Achtertyre, 206.

Morbhaich Mor, 'Tain, find of animal remains at, 86, 119.

Morris, Mr David B., on whale remains near Stirling, 62 et seq.

Mortillet, M. G. de, reference to 'Formation de la Nation Française' by, 227.

Mortimer, Mr J. R., on Howe Hill barrow, $45 \mathrm{I}$.

Mosses, finding of trees in, $30 \mathrm{et} \mathrm{seq.}$

Motes, 367 et seq.

Moulin, Perthshire, skull of urus found near, 114 .

Mount Batten, Late Celtic ornaments at, 264 .

Mountstuart, Bute, necklace of Bronze Age, and other remains, found at, 212.

Mousa, Shetland, broch of, $3^{89}$ et seq.

Munro, Robert, references to 'Ancient Scottish Lake-Dwellings' by, 90 , I08, 4I4, 44I-references to 'LakeDwellings of Europe' by, 39, I21, $125,128,1_{42}, x_{43}$ fn., $4^{8}$ fn., $1_{75}$, 187, 2 Io fn., 232 fn., 237 fn., 347 fn., 414, 437-references to 'Prehistoric Problems' by, 55 fn., 165 , $\mathrm{r} 8 \mathrm{o}, 444 \mathrm{fn}$. - references to 'Rambles and Studies in Bosnia' by, I19, 121 , 175 fn., 237 fn., 26 I fn., $35^{8}$ fn., 366 fn.

Murthly, Perthshire, bone button found at, 173 .

Musselburgh, cemetery of Bronze Age at, 40-bronze blade found at Magdalen Bridge, near, rgo.

Muthil, remains of uri found near Drummond Castle, ir5.

Muthill, Perthshire, two bronze armlets found near, 253 .
Necklaces of Bronze Age, 212.

Needles of bone and bronze, 205.

Neish, Mr James, on fortifications on the Laws, $3-8$ et seq.

Neolithic man, first appearance of, in Britain, 83-domestic animals of, 84 .

Newburgh, Fifeshire, skull of urus found at, 112.

Newbury, Berkshire, bones of beaver, \&c., found at, 121 .

Newry, Co. Down, Ireland, bronze armilet found near, 256.

Newstead, Roxburghshire, remains of Celtic shorthorn found at Roman station at, I 18.

Niederwyl, huts at, 336 .

Nilsson, Professor, quotation from 'Primitive Inhabitants of Scandinavia' by, 447.

Northamptonshire, Late Celtic bronze ornament found in, $26 \mathrm{r}$.

North Esk, cave near mouth of, 79 .

Norton, Suffolk, enamelled ornament for harness found at, 249.

Oakwood, Selkirkshire, skull and horns of elk found at, 97 .

Oban, MacArthur Cave at, 46-54discovery of rock-shelter at, 54 et seq. - contents of the shell-heap at, 55 -barbed harpoons found at, 169 .

Obsidian, use of, in the Stone Age, $\mathbf{I}_{42}$ et seq.

Okstrow, broch of, 400 .

Old Luce, javelin-head found at Machermore, x7o.

'Orkneyinga Saga,' reference to, 86.

Orkney Islands, decayed timber found in peat-bogs, 34 et seq.

Ornaments, of the Stone Age, 172 et seq. - of Bronze Age, 204 et seq.found in graves, 323 .

Oronsay, finding of bone harpoons and implements of bone and stone at Caisteal-nan-Gillean, 56.

Orphir, Orkney, portions of woollen cloth found in cist at Greenigoe, 174.

Orton, near Fochabers, gold earrings found at, 214 .

Otter in prehistoric times, r2c.

Ousdale, Caithness, broch at, $39 \mathrm{r}$ et seq.

Owen, Sir Richard, references to 'British Fossil Manimals' by, 89 fn., 10 r, 106, 109, I 13, I 16, i 19 et seq., 124, 129 fn., 132.

Ox, domestic, of urus type, approximate date of introduction into Scotland of, 130 .

Papa Westray, Orkwey, sepulchral cairn at, 306, 307 et seq. 
Paton, Sir Noel, on gold earrings, $2 \tau_{4}$.

Paulinus, attack of, on Isle of Mona, I3.

Peach, Mr B. N., on kitchen-middens at Inveravon, 66 .

Peat-bogs, 29 et seq.

Peeblesshire, bronze armlet found near Stobo Castle, 207-bronze armler, \&c., found on farm of Stanhope, 257.

Pennant's 'Tour' quoted, 68-'History of Quadrupeds' referred to, 89 -on broch at Glenelg, 394 .

Pentland Hills, mammalian bones found at Green Craig, 90-bronze sword-sheath found near, 244.

Perdeswell, near Worcester, bronze torque found at, 252.

Perrot et Chipiez, reference to ' $\mathrm{His}$ toire de l'Art dans l'Antiquite' by, $143 \mathrm{fn}$.

Personal ornaments of the Late Celtic Period, 25I et seg.

Petit-Morin, Neolithic remains at, 466.

Petrie, Mr George, on sepulchral cairns, 305, 307 .

Pheasant, approximate date of introduction into Scotland of, 130 .

Phocæeans found Massilia, 2.

Phœenicians, colonies of, I-did not trade for tin with Britain, 2.

Physical features of Scotland in prehistoric times, 19.

Pickering, Yorkshire, indications of lake-dwellings found on the banks of the Costa, near, $423 \mathrm{et}$ seq.

Picts, their first appearance in history, 12.

Picts' houses, 343 et seq.

Piette, M., on the rock-shelter of Masd'Azil, 55.

Pins of the Bronze Age, 204.

Pitalpin, near Dundee, bronze arnlet found near, 258.

Pitkelloney armlets, $254 \mathrm{et} \mathrm{seq.}$

Pitt-Rivers, General, on pile-dwellings at London Wall, 422.

Pliny's 'Natural History' referred to, 108,435 - on wild oxen, 108.

Plymouth, find of Late Celtic Period at Mount Batten, near, 264.

Polden Hill, near Bridgewater, bosses of shields, bridle-bits, \&c., found at, 247.

Polishing stone implements, process of, 159 et seq.

Poolewe, Ross-shire, penannular ring found at, 207.

Pratorius, Mr J. C., on bronze trumpets, 203.

Pytheas, the voyage of, 3 .
Quanterness, near Kirkwall, chambered cairn at, 30.4 .

Queensferry, cover-stone of cist, with spiral decoration, found near, $22 \mathrm{I}$.

Quoyness, sepulchral chamber at, 306.

Raesgill, Lanarkshire, fragment of reindeer horn found at, 89 .

Rampini, Sheriff, reference to ' $\mathrm{His}$ tory of Moray and Nairn' by, 375 .

Rannoch, Moor of, torque found at, 210.

Rat, common, approximate date of introduction into Scotland of, 130.

Rau, Charles, reference to 'Contributions to N. American Ethnology" by, 218 .

Razors of the Bronze Age, rgo.

Rend, Mr C. H., on sword-sheath from Hunsbury, 24I.

Red-deer in prehistoric times, 105 Ior.

Reindeer, remains of, found in Scotland, 86-91-remains rarely found in Denmark in peat, 128-approximate date of extinction of, 130 .

Relative level of land and sea, 22 et seq.

Religion of the Britons, 12 et seq.

Retzius, Prof., on Scandinavian skulls, 458.

Rhys, Prof., on pre-Celtic people of Britain, 483 .

Robenhausen, remains of urus found at, Iog-civilisation of lake-dwellers at, $36 \mathrm{r}$.

Rochdale, Lancashire, bronze torque found in, $25 \mathrm{r}$.

Rock-shelter at Ardrossan, 8r.

Roe-deer in prehistoric times, $105-108$.

Rogart, Sutherlandshire, bronze razor found at, 190.

Rolleston, Professor, quotation from article "On the Iron, Bronze, and Stone Ages," 1o-reference to 'British Barrows' by, 133, 134, 448 et seq., 457 - on the oxidation theory as accounting for the disappearance of iron relics, 229.

Romans, their invasion of Scotland, 7 et seq.-Dattle of Mons Graupius, 9 - Hadrian's wall, I I-march of the Emperor Severus through Scotland, ib. et seq. - destruction of British forests by, 43 .

Ross-shire, reindeer horn found in the peat-bogs of, 90 .

Rousay, reindeer horn found in, 90.

Roxburghshire, fabricator found in, 153-borer found in, $i b$.

Roy, General, on the position of Agricola's headquarters, 9-reference to 
'Military Antiquities of the Romans in North Britain' by, 375.

Ritimeyer, Professor, on the wild swine possessed by Swiss lakedwellers of the Stone Age, 125-on the dogs of the Swiss lake-dwellings, I35.

Saham Toney, Norfolk, rings, \&c., of Iate Celtic Period found at, 248.

St Andrews, Orkncy, complete woollen hood found in a moss in parish of, I74.

St Keverne, Cornwall, objects of Late Celtic Period found at, 265.

Salmon, M. Philippe, on Neolithic crania of Gaul, 463-general conclusions on, 467 .

Saws, flint, $16_{3}$ et seq. - of the Bronze Age, 189 .

Schliemann, reference to 'Ilios' by, 140, 143, 23I-reference to 'Mycenæ and Tiryns ' by, $143 \mathrm{fn}$.

Schussenried, dwelling of Stone Age at, 333 .

Schweizersbild, rock-shelter at, $8_{3}$, 463.

Scotland, Agricola's invasion of, 7 et seq. - battle of Mons Graupius, 9physical features in prehistoric times, I6-climatic and topographical features, 20 et seq-first appearance of Scots in history, 12.

Scraper or "thumb flint," I66.

Seafield Tower, Fife, bronze armlets found near, 255 .

Seal, remains of, found in brocbs, \&c., 129.

Sea-level, in Bronze Age, 40-in Roman times, $4 \mathbf{I}$-alterations in relative level of sea and land since appearance of man in Scotland, 45 et seq. - -argument from finding of canoes in Clyde basin, 71-evidence from sanddunes, raised beaches, \&c., 73 et seq.

Seamill, Ayrshire, fort at, 376 -relics found at, ib. et seq.

Selkirkshire, remains of urus, stag, \&.c., found in, 97 et seq. - head of urus found in, Iro.

Sergi, Prof., on dolichocephalic races prior to Celts and Etruscans, 469.

Severus, Emperor, march of, to Moray Firth, II.

Shanwell, Kinross-shire, bronze blade found at, I9o.

Sheep, domestic, origin of, $13 \mathrm{r}$.

Shetland Islands, decayed timbers found in peat-bogs, 34 et seq.

Shewalton Moor, evidence of encamp. ment at, 76 .
Shields of Bronze Age, 200-of Late Celtic Period, 236 et seq.

Sickles of the Bronze Age, 189.

Silures, the, 14-description of, by Tacitus, 443.

Simpson, Mr James, on animal remains in Oban Cave, 49-at Green Craig, 90.

Simpson, Sir James, reference to 'Ancient Sculpturings of Cups and Concentric Rings, \&c.,' by, 218, 221, 225.

Sinclair, Mr T., on broch of Dun. beath, 400 .

Singapore, pile-dwellings at, $44 \mathrm{r}$.

Skaill, underground house of, Orkney, horns of large ox found in, 16.

Skelmuir, Aberdeenshire, stone anvils found at, 150,151 -hoard of flints found at, 357 .

Skene, Dr, on the position of Agricola's headquarters, 9 .

Skerrabrae, Orkney, "Picts' houses" at, $344 \mathrm{et}$ seq.

Skye, bronze pin found in, 204 .

Slains, Aberdeenshire, celt found at Ferney Brae, 158.

Slateford, Mid-Lothian, coiled gold bracelet found at, 208 .

Sling-stones, 170.

Smith, Dr Angus, on Dun Mac Uisneachan, 25I-on cairn of Achnacree, 283.

Smith, Dr J. Alexander, on the reindeer, 86-elk, 9r et seq.-red-deer, I08 et seq.-urus, III-stone balls, I7r et seq.-Dronze helmets, 238 et seq. - bronze armlets, 254 et seq.

Smilh, Rev. Fred., on palæolithic remains in Scotland, 20.

Sinith, Mr John, reference to 'Prehistoric Man in Ayrshire' by, 420 fn. - on rock-shelter at Ardrossan, $8 \mathrm{x}$-on beaver, 122 .

Smith's 'Newer Pliocene Geology' referred to, 70 .

Snaburgh, broch of, 398 .

Sobunar, near Sarajevo in Bosnia, reinains of beaver found at, I2r.

Social life of prehistoric inhabitants of Britain, 329 et seq.

Solutré, remains of horse, \&c., on prehistoric camping-ground at, 132, 462.

Solway Moss, stone axe from, $16 \mathrm{r}$.

Spear-heads, of Stone Age, I6g et seq. - of Bronze Age, 193 et seq.

Spiennes, pit-dwellings and flint-factories at, 331 .

Spindle-whorl, I73.

Spoon-like objects of Late Celtic Period, 26r. 
Standing stones, 318.

Stanwick, Yorkshire, bridle-bits, \&c., found at, 247.

Staub, F., reference to 'Die Pfahl. bauten in den Schweizer-Seen' by, $407 \mathrm{fn}$.

Steenstrup, Prof., on domestication of the dog, 134.

Stewart, Mr Charles, on bronze hoard at Killin, 206.

Stitchel, Roxburghshire, bronze collar found near, 253.

Stone Age : the raw materials used by the people, 140-146-their workshop and its tools, 146.154-method of chipping, 146 et seq. - method of boring, 147 et seq. - tools used in the manufacture of flint instruments, 150 et seq.-implements, weapons, and ornaments, 154-176- process of polishing stone implements, 159 et seq.

Stone balls, 170 et seq.

Stone circle, at Ballymenach, $290-$ Ring of Brogar, 297-in Kincardine and Aberdeen, $3^{16-a t}$ Mauchrie Moor, Arran, ib.-Auquhorthies, 318.

Stoneykirk, Wigtownshire, whetstone and stone axe found in, 160.

Stoppani, A., reference to 'L'Ambra nella Storia e nella Geologia' by, $145 \mathrm{fn}$.

Strath Halladale, horns of elk and red-deer found in, 95 et seq.

Strathnairn, stone circles of, 309.

Strathspey, fabricator found at, 152 .

Strobel, Prof,, on swine in the Terremare, 125.

Stuart, Dr, on earth-houses, 351 -on the fortifications on the Laws, 378 -on crannogs in Loch Dowalton, 4 ro.

Sword-sheaths, Hunsbury, 24I-Ayrshire, 243-Lisnacroghera, 244Pentland Hills, ib. - river Tweed, and elsewhere, 245.

Swords, of Bronze Age, 194 et seq.rapier-shaped blade, 197 - scytheshaped, I93 - of the Late Celtic Period, $24 \mathrm{I}$ et seq.

Switzerland, lake-dwellings in, 428 .

Tacitus, his 'Life of Agricola ' quoted, 8-reference to Druids quoted from 'Annals,' 13 - on underground dwellings, 356 .

Tap o' Noth, vitrified fort on, $3^{85}$.

Tarbolton, Ayrshirc, stone axe found at, 158 -bronze horn found at, $20 \mathrm{r}$.

Tarves, Aherdeenshire, bronze pins found at, 204 .
Tate, George, reference to 'Sculptured Rocks of Northumberland ' by, 218.

Tealing, Forfarshire, "Pict's house" at, 349 .

Terpen, structure of, 435-described by Pliny, $i b$.

Terremare, structure of, 434 .

Thames, antiquities found in, 236 , 246.

Thomas, Captain, on beehive huts, $33^{8}$.

Thurnam and Davis, reference to 'Crania Britannia' by, $44^{8}, 457$.

Tillicoultry, sculptured cover-stone of cist found at, 223 .

Tools used by people of Stone Age, 146-154.

Topographical features of prehistoric Scotland, 22 et seq.-main outlines remain unaltered, 26.

Torque, beaded, found in Lochar Moss, 40-torque or twisted neckring of the Bronze Age, 209-torques of Late Celtic Period, 251-in Hyndford crannog, 253.

Torrs, Old Luce, Wigtownshire, borer found at, 154-flint knives from, 162 - scraper found at, I66-arrowpoints from, 167,168 -bracer found at, 169 .

Torwoodlee, Selkirkshire, enamelled ornament, \&c., found at, 249 broch at, 400 .

Towie, Aberdeenshire, stone ball found at, $17 \mathrm{r}$.

Trenoweth, Cornwall, fragment of bronze collar found at, 252 .

Trepanned skull from grave at Mountstuart, Bute, $2 \mathbf{r}_{3}$.

Trumpets of Bronze Age, 20I et seq.

Tuack, stone circle at, 316 .

Tumulus of Maeshowe, 298 et seq.

'Turnbull, Mr John, on Edenshall, 398.

Turner, Sir William, his report on the human remains in the MacArthur Cave, 47 - his discussion of the implements associated with the skeletons of whales in Carse of Stirling, 57 et seq. - summary of his observations on the prehistoric craniology of Scotland, 454 ct seg.

Uhlmann, Dr, on shell-marl, 25.

Uist, North, roots of trees found in peat-bogs in, 29.

Uist, South, remains of beehive huts found in, $338 \mathrm{et} \mathrm{seq}$.

Underground dwellings, 343-at Skerrabrac, 344 -in Aberdeenshire, 348 -in Forfarshire, $349-$ not found in 
Galloway, 351-in Ireland, 352-in Cornwall, 353-in Germany, 356.

Undset, Dr, reference to 'Erstes Auftreten des Eisens in NordEuropa' by, 233.

Unstan, Orkncy, fabricator found at, 152 - chambered cairn at, 302 et seg.

Urns. cinerary, found in graves, 320 .

Urquhart, near Elgin, torque found nt, 2 ro.

Urus, in prehistoric times, 108-116.

Ussher, Mr R. J., on Irish elk, IO2great auk, 126-on a submarine crannog, 437.

Vernenu, Dr, on the Gaunches, 468.

Victoria Cave, Yorkshire, harpoon found in, 57 .

Vitrified forts, $3^{80}$ et seq.

Wales, North, remains of brown bear found in, 129.

Walston, ornamented bronze ball found at, 277 .

Warne, $\mathrm{Mr}$, reference to 'Celtic Tumuli of Dorset' by, rig.

Wauwyl, remains of urus found at, 109.

Way, Mr Albert, on Late Celtic ornaments, 26r.

Weapons, of the Stone Age, I66 et seg. - of Bronze Age, rg1 et seq. - found in graves, 324 .

Weems, 343 et seg.

Westhall, near Halesworth, Suffolk, rings and bronze lamp found at, 248.

Whales, remains of, found in brochs, \&.c., $129-$ stranded in Carse of Stirling, 26, 57-65.

Whitburn, harpoon found at, 57 .
Whitehaugh Moss, Ayrshire, dagger of Bronze Age found in, 193 .

Whitmuirhall, discovery of five skulls of uri at, rio.

Whitrig Bog, Berwickshire, account of skull and horns of elk found in, 91 et seq.-portion of skull of urus found in, IrI.

Wideford Hill, "Pict's house" at, 305.

Wigtownshire, horns of elk found in, 99.

Wilde, Sir W., reference to ' Beauties of the Boyne' by, 174, 456-on wartrumpets, 202 - on early races in Ireland, 456 .

Williams, Mr John, reference to 'An Account of some Remarkable Ancient Ruins, \&c.' by, 380 .

Willie Struther's Loch, Roxbırghshire, skull of elk found at, 97 .

Wilson, Sir Daniel, his 'Prehistoric Annals of Scotland ' referred to, $67,71,174,187,189,207,221$, 250, 252, 305 fn., 445 et seq.

Witham, daggers of Late Celtic Period found in, 246 .

Wolf, in prehistoric times. 129-approximate date of extinction in Scotland of, r 30 .

Wraxal, Somersetshire, bronze torque found at, 252.

Yarhouse, tynes found at, 89-Celtic shorthorn found at, 118-broch of, 397.

Yarrow, remains of urus and deer found in, 98.

Yctholm, bronze shield found near, 200.

Yorkshire, remains of beaver found in, 121. 
RECENTLY PUBLISHED.

\section{PREHISTORIC PROBLEMS.}

Demy $8 v 0$, pp. xix-371, mofusely illustrated, price 10s. net.

Contents. - 1. Rise and Progress of Anthropologr. 2. On the relation between the Erect Posture and the Physical and Intellect tual Development of Man. 3. Notes on "Fossil Man." 4. On Intermedinry Links between Man and the Lower Animals. 5. Prehistoric Trepanning and Cranial Amulets. 6. Otter and Beaver Traps. 7. Bune Skates. 8. Prehistoric Saws and Sickles.

"One of the most interesting essays in this book is that dealing with the inportance of the assumption of the erect posture as a factor in the plyysical and intellectual development of man. Dr I unro is a strong advocate of the enornous advantage which man lerived from the attainment of the erect posture, and the consequent differentiation of the limbs into hands and feet; in other words, the releasing of the fore-limbs from locomotive duties, so that they might become the servants of the brain in other directions, and thus assist the development of mental qualities."-Natural Science.

"Not merely is the above theory important, by rendering the process of physical evolution as applied to the luman body and brain more conceivable than it otlerwise would be, but it is still further valuable as furnishing an entirely new standard, by means of which 'transition forms,' should remains of such appear, may be classified. It thins vindicates, with no uncertain sound, the entirely human character of the men of Neanderthal and Spy, and this in spite of certain slight but distinct approaches to the simian type ; while, on the otlier hand, it is able to point to the contrasted characters of sknll and thigh bone shown by the remains of the strange nondeseript from Java, called by its founder, Dr Dubois, Pithecanthropus firectus, as being precisely those which a genuine 'missing link' might be trusted to display."-The Quarterly Review.

"His 'Notes on Fossil Man' are a model of careful examination of a diflicult problem...... We recommend to those who would sec what pertinacity and patience are needed to solve an apparently simple problem iu archaology, the study of two essays on otter aud beaver traps and bone skates."-The Times.

"There is no need to further emphasise the fact that Dr Mumro has produced a book which, though designed for the general reader, contains a good deal of new matter, and is a serious contribution to several important aspects of archæology." - Nature.

"Dr Munro is one of the few original investigators who possess the happy knack of presenting the results of their inquiries in a popular form...... The author has given ns a learned and useful work, and withal a very readable one. The different objects described are earefully illustrated."-Antiquary.

"We are convinced Dr Mnuro's book will meet with many readers, and will prove to be a new stimulant for the study of man."-Internationales Archiv fiur Ethnograpleie.

"The prime value of Dr Munro's book lies in the fact that his object has heen, not to formulate any fanciful theories and speculations, but to put before his readers clearly and fully all the available data. This lie has done with complete success, and there has been no such valuable contribution of recent years towards the furtherance of the science of anthropology.".-. Iberdeen Free Press.

WILLIAM BLACKWOOD \& SONS, EDINBURG AND LONDON. 


\title{
RAMBLES AND STUUDIES IN BOSNIA- HERZEGOVINA AND DALMATIA.
}

\author{
SECOND EDITION, REVISED AND ENLARGED.
}

Demy $8 v 0$, profusely illustrated, price 12s. 6d. net. [In the Press.

This edition will include, besides some additional matter throughout the text, a new chapter on the "Civilisation of Hallstatt and La Tene." Notwithstanding the importance of these two landmarks in the evolution of the iron industry in Europe, there is no work in the English language which gives a general idea of the archæological phenomena with which they are associated. This desirleratum in archaolorical literature came forcibly before the author while writing 'Prehistoric Scotland,' and hence this effort to remove, to some extent, the deficiency -for it is a remarkable fact that a knowledge of the subject-matter of this chapter is as essential for the elucidation of the Early Iron Age of the north-western regions of the Balkan peninsula as it is for that of the British Isles. The archaological part of the work contains a description of the remarkable remains found on the Neolithic station of Butmir, and in the cemeteries of Glasinac and Jezerine, together with an account of the Proceedings of the Special Congress invited by the Government to discuss the place of these remains in the prehistoric civilisation of Europe.

\section{EXTRACTS FROM REVIEWS OF THE FIRST EDITION.}

"No surer guide to the archæology of this almost virgin soil could be wished for than Dr Munro, and his patient and lueid explanation is profusely supplemented by excellent plates and euts in the text."-Pall Mall Gazette.

"Every page of the book has something of interest in it, and from the vivid and lucid style of the author the reader may, when he closes it, almost inagine he has himself traversed the wooded glens and rugged depths so clearly depicted to him." - Belfast News-Letter.

"The author has produced a book which will become.a necessity to all students of the history and antiquities of Bosnia - Herzegovina and Dalmatia." - The Graphic.

"Sketch-maps and many illustrations heighten the interest of this fascinating monograph."-Evening Standard.

"IIr Munro has, indeed, produced a book wortly of the subject and of his own reputation, a work of unending interest to archrologists, and one witl considerable attraction as a picture of scenery and a record of travel."-Notes and Queries.

"We specially commend chapters ix. and $x$. to all persons interested in the details of a bygone civilisation, containing as they do a masterly summary of the subject. The figure ornamentation of men and animals in the cemeterics commonly assigned to the Bogomiles, and representing the ehase, the battlefield, the dance, and other idyllic scenes, are of peculiar signification."-Daily News.

"But, apart fron these matters, the book is a mine of information about a most interesting region, which, though now easily accessible to Western Europeans, has as yet been little visited."-Guardian.

"L'auteur tout en aborlant avec sa haute compétence les questions scientifiques, lleerit d'une maniere charmante son voyage."-Revue Mensuelle.

WILLIAM BLACKWOOD \& SONS, Edinburgir axd Losmon. 
9145 
